
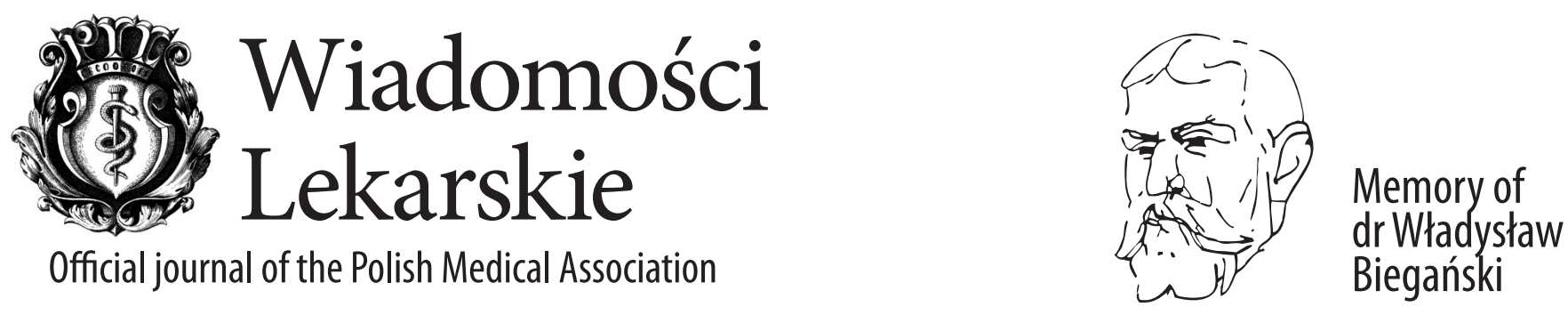
Wiadomości Lekarskie is abstracted and indexed in: PUBMED/MEDLINE, SCOPUS, EMBASE, INDEX COPERNICUS, POLISH MINISTRY OF EDUCATION AND SCIENCE, POLISH MEDICAL BIBLIOGRAPHY

\section{Copyright: @ ALUNA Publishing House.}

Articles published on-line and available in open access are published under Creative Common Attribution-Non Commercial-No Derivatives 4.0 International (CC BY-NC-ND 4.0) allowing to download articles and share them with others as long as they credit the authors and the pu-

blisher, but without permission to change them in any way or use them commercially.

\section{Wiadomości Lekarskie monthly journal}

You can order the subscription for the journal from Wydawnictwo Aluna by: prenumerata@wydawnictwo-aluna.pl

Wydawnictwo Aluna

Z.M. Przesmyckiego 29

05-510 Konstancin-Jeziorna

Poland

Place a written order first.

If you need, ask for an invoice.

Payment should be done to the following account of the Publisher:

account number for Polish customers (PLN):

82194010763010740700000000

Credit Agricole Bank Polska S. A., SWIFT: AGRIPLPR

account number for foreign customers (EURO):

57249000050000460076043035

Alior Bank S. A.: SWIFT: ALBPPLPW

Subscription of twelve consecutive issues (1-12):

Customers in Poland: 360 PLN/year

Customers from other countries: $320 \mathrm{EURO} /$ year 


\section{2: Wiadomości Lekarskie}

Editor in-Chief:

Prof. Władysław Pierzchała

\section{Deputy Editor in-Chief:}

Prof. Aleksander Sieroń

Editors of the issue:

Prof. Vitalii M. Pashkov

Prof. Vladyslava S. Batyrgareieva

\section{Statistical Editor:}

Dr Lesia Rudenko
Managing Editor:

Agnieszka Rosa - amarosa@wp.pl

International Editorial Office:

Lesia Rudenko (editor) - I.rudenko@wydawnictwo-aluna.pl Nina Radchenko (editor's assistant)

- n.radchenko@wydawnictwo-aluna.pl

Polish Medical Association (Polskie Towarzystwo Lekarskie): Prof. Waldemar Kostewicz - President PTL

Prof. Jerzy Woy-Wojciechowski - Honorary President PTL

\section{International Editorial Board - in-Chief:}

Marek Rudnicki

Chicago, USA

\section{International Editorial Board - Members:}

Kris Bankiewicz

Christopher Bara

Krzysztof Bielecki

Zana Bumbuliene

Ryszarda Chazan

Stanislav Czudek

Jacek Dubiel

Zbigniew Gasior

Andrzej Gładysz

Nataliya Gutorova

Marek Hartleb

Roman Jaeschke

Andrzej Jakubowiak

Oleksandr Katrushov

Peter Konturek

Jerzy Korewicki

Jan Kotarski
San Francisco, USA

Hannover, Germany

Warsaw, Poland

Vilnius, Lithuania

Warsaw, Poland

Ostrava, Czech Republic

Cracow, Poland

Katowice, Poland

Wroclaw, Poland

Kharkiv, Ukraine

Katowice, Poland

Hamilton, Canada

Chicago, USA

Poltava, Ukraine

Saalfeld, Germany

Warsaw, Poland

Lublin, Poland
George Krol

Krzysztof Łabuzek

Henryk Majchrzak

Ewa Małecka-Tendera

Stella Nowicki

Alfred Patyk

Palmira Petrova

Krystyna Pierzchała

Tadeusz Płusa

Waldemar Priebe

Maria Siemionow

Vladyslav Smiianov

Tomasz Szczepański

Andrzej Witek

Zbigniew Wszolek

Vyacheslav Zhdan

Jan Zejda
New York, USA

Katowice, Poland

Katowice, Poland

Katowice, Poland

Memphis, USA

Gottingen, Germany

Yakutsk, Russia

Katowice, Poland

Warsaw, Poland

Houston, USA

Chicago, USA

Sumy, Ukraine

Katowice, Poland

Katowice, Poland

Jacksonville, USA

Poltava, Ukraine

Katowice, Poland
Distribution and Subscriptions:

Bartosz Guterman prenumerata@wydawnictwo-aluna.pl Graphic design / production:

Grzegorz Sztank

\section{Publisher:}

ALUNA Publishing House

ul. Przesmyckiego 29, www.red-studio.eu
05-510 Konstancin - Jeziorna www.wydawnictwo-aluna.pl www.wiadomoscilekarskie.pl www.wiadlek.pl 


\section{FOR AUTHORS}

1. The monthly "Wiadomości Lekarskie" Journal is the official journal of the Polish Medical Association. Original studies, review papers as well as case reports are published.

2. In 2022, the cost of publishing the manuscript is PLN 1,500 plus 23\% VAT. From 2022, the publication costs for foreign authors amount to EUR 450, of which EUR 50 is payable with the submission of the article (includes the costs of review, anti-plagiarism system, English language level assessment, checking the compliance of the manuscript with the regulations of the publishing house, etc.), and the remaining EUR 400 - after accepting the article for publication. Thanks to obtaining funding for authors from Ukraine, the cost of publication for Ukrainian authors is EUR 350 . EUR 50 is payable together with the submission of the article, and EUR 300 - after accepting the article for publication. The publisher issues invoices. If the first author of the manuscript is a member of the Editorial Board, we do not charge a fee for printing the manuscript. Membership of the Polish Medical Association with documented paid membership fees for the last 3 years is also the exempt from publication fee.

3. Only papers in English are accepted for publication. The editors can help in finding the right person for translation or proofreading.

4. Papers should be sent to the editor via the editorial panel (Editorial System), available on the journal's website at https://www.wiadlek.pl. In order to submit an article, free registration in the system is necessary. After registration, the author should follow the instructions on the computer screen.

5. All editorial work is under control and using the editorial panel. This applies in particular to sending manuscripts, correspondence between the editor and author and the review process. In special cases, the editor may agree to contact outside the panel, especially in case of technical problems.

6. Acceptable formats for individual elements of the article are as follows:

A) Content of the article - doc, docx, rtf, odt.

B) Tables - doc, docx, rtf, odt

C) Figures - JPG, GIF, TIF, PNG with a resolution of at least $300 \mathrm{dpi}$

D) Captions for figures and tables.

These elements are sent to the editor separately using the editorial panel. References and article metadata such as titles, keywords, abstracts etc. are supplemented by the author manually in the editorial panel in appropriate places.

7. The volume of original papers - including figures and references - must not exceed 21,600 characters (12 pages of typescript), and review papers - up to 28,800 characters (16 pages).

8. The original manuscript should have the following structure: Introduction, Aims, Material and methods, Results, Discussion and Conclusions which cannot be a summary of the manuscript.

9. When using abbreviations, it is necessary to provide the full wording at the first time they are used.

10. In experimental manuscripts in which studies on humans or animals have been carried out, as well as in clinical studies, information about obtaining the consent of the Ethics Committee should be included.

11. The Editorial Board follow the principles contained in the Helsinki Declaration as well as in the Interdisciplinary Principles and Guidelines for the Use of Animals in Research, Testing and Education, published by the New York Academy of Sciences Ad Hoc Committee on Animal Research. All papers relating to animals or humans must comply with ethical principles set out by the Ethics Committee.

12. The abstract should contain $150-250$ words. Abstracts of original, both clinical and experimental, papers should have the following structure: Aims, Material and methods, Results, Conclusions. Do not use abbreviations in the title or the abstract. The abstract is pasted or rewritten by the authors into the appropriate field in the application form in the editorial panel.

13. Keywords (3-5) should be given according to MeSH (Medical Subject Headings Index Medicus catalogs - http://www.nim.nih.gov.mesh/MBrower.html). Keywords cannot be a repetition of the title of the manuscript.

14. Illustrative material may be black and white or color photographs, clearly contrasting or drawings carefully made on a white background. With the exception of selected issues, the Journal is printed in shades of gray (black and white illustrations).

15. The content of the figures, if present (e.g. on the charts), should also be in English

16. Links to all tables and figures (round brackets) as well as references (square brackets) the author must place in the text of the article.
17. Only references to which the author refers in the text should be included in the list of references ordered by citation. There should be no more than 30 items in original papers and no more than 40 items in review papers. Each item should contain: last names of all authors, first letters of first names, the title of the manuscript, the abbreviation of the journal title (according to Index Medicus), year, number, start and end page. For book items, please provide: author's (authors') last name, first letter of the first name, chapter title, book title, publisher, place and year of publication. It is allowed to cite websites with the URL and date of use of the article, and if possible the last names of the authors. Each literature item should have a reference in the text of the manuscript placed in square brackets, e.g. [1], [3-6]. Items should be organized as presented in Annex 1 to these Regulations.

18. When submitting the article to the editor, the authors encloses a statement that the work was not published or submitted for publication in another journal and that they take full responsibility for its content, and the information that may indicate a conflict of interest, such as:

1. financial dependencies (employment, paid expertise, consulting, ownership of shares, fees),

2. personal dependencies,

3. academic and other competition that may affect the substantive side of the work,

4. sponsorship of all or part of the research at the stage of design, collection, analysis and interpretation of data, or report writing.

19. The authors in the editorial panel define their contribution to the formation of scientific work according to the following key:

A - Work concept and design

B - Data collection and analysis

C - Responsibility for statistical analysis

D - Writing the article

E-Critical review

F- Final approval of the article.

20. In the editorial panel along with the affiliation, the author also gives her or his ORCID number.

21. The Journal is reviewed in double, blind review mode. The submitted papers are evaluated by two independent reviewers and then qualified for publishing by the Editor-in-Chief. Reviews are anonymous. The authors receive critical reviews with a request to correct the manuscript or with a decision not to qualify it for publishing. The procedure for reviewing articles is in line with the recommendations of the Ministry of Science and Higher Education contained in the paper "Good practices in review procedures in science" (Warsaw 2011). Detailed rules for dealing with improper publishing practices are in line with COPE guidelines. The publishing review rules are in the Review Rules section.

22. Each manuscript is subject to verification in the anti-plagiarism system.

23. Manuscripts are sent for the author's approval. The author's corrections should be sent within the time limit indicated in the system. No response within the given deadline is tantamount to the author's acceptance of the submitted material. In special cases, it is possible to set dates individually.

24. Acceptance of the manuscript for publishing means the transfer of copyright to the Aluna Publishing House (Aluna Anna Łuczyńska, NIP 5251624918).

25. Articles published on-line and available in open access are published under Creative Common Attribution-Non Commercial-No Derivatives 4.0 International (CC BY-NC-ND 4.0) allowing to download articles and share them with others as long as they credit the authors and the publisher, but without permission to change them in any way or use them commercially.

26. The authors receive a free PDF of the issue in which their mansucript is enclosed, and on request - a printed copy. The printed copy is sent to the address indicated by the authors as the correspondence address.

27. Manuscripts not concordant with the above instructions will be returned to be corrected.

28. The editors do not return papers which have not been commissioned.

29. The editors take no responsibility for the contents of the advertisements. 


\section{CONTENTS}

\section{ORIGINAL ARTICLES}

Nataliya Gutorova, Vitalii Pashkov, Tetyana Kaganovska

ENSURING THE CITIZENS'RIGHTS AND FREEDOMS IN CASE OF COVID-19 VACCINATIO IN THE PUBLIC HEALTH SYSTEM

Vladyslava S. Batyrgareieva, Sabriie S. Shramko, Olena M. Samoilova

MORTALITY AND INJURY IN UKRAINE AS A RESULT OF TRAFFIC ACCIDENTS IN MEASURING OF PUBLIC HEALTH:

TOTHE ANALYSIS OF SOCIAL-LEGAL AND CRIMINOLOGICAL PROBLEM

Tetiana 0. Mykhailichenko, Oksana P. Horpyniuk, Victor Yu. Rak

MEDICAL CONFIDENTIALITY DISCLOSURE IN CONDITIONS OF EPIDEMIC THREATS

Valery F. Obolentsev, Oleh M. Hutsa, Dmytro B. Yelchaninov

AUTOMATED DECISION-MAKING SUPPORT SYSTEM FOR QUALIFICATION OF CRIMINAL OFFENSES AS AN ELEMENT OF HUMAN RIGHTS HEALTH PROTECTION SYSTEMS

Natalia 0. Antoniuk

FORMS OF CRIMINAL LIABILITY IN CASE OF DEATH OF THE PATIENT

Kateryna V. Latysh, Yevhenia E. Demidova

CORRUPTION OFFENCES IN MEDICATIONS CIRCULATION: INVESTIGATION PROBLEMS

Oleksandr K. Marin, Iryna Z. Sen

CORRUPTION BETWEEN DOCTORS AND PHARMACISTS: CRIMINAL LAW PROBLEMS OF COUNTERACTION

Olha I. Denkovych, Viktor I. Markin, Snizhana V. Shevchenko

PENALIZATION OF NON-COMPLIANCE WITH THE COVID-19VACCINATION: TO BE OR NOT TO BE?

Pavlo S. Berzin, Ivan S. Demchenko, Anzhela B. Berzina

THE PROBLEMS OF DEFINITION OF THE ABETTING IN THE COMISSION OF THE OFFENCES INVOLVING THREATS TO PUBLIC HEALTH (PART 1 OF ARTICLE 9

OF THE COUNCIL OF EUROPE CONVENTION ON THE COUNTERFEITING OF MEDICAL PRODUCTS AND SIMILAR CRIMES INVOLVING THREATS TO PUBLIC HEALTH)

Oleksandra G. Yanovska, Alyona V. Chugaevska, Mykhailo S. Ivanov

CARGOCULTISM OF PSYCHIATRIC CARE IN CUSTODY

Vladyslava S. Batyrgareieva, Alina V. Kalinina, Kateryna O. Poltava

VICTIMOLOGICAL RISKS FOR ROAD USERS AS AN ELEMENT OF PUBLIC HEALTH

Volodymyr V. lemelianenko, Alesia V. Gornostay, Olena V. Yevdokimova

DEPRIVATION OF REPRODUCTIVE RIGHT OF SEX OFFENDERS: SOCIAL OPINION AND LEGISLATIVE REGULATION

Olga I. Tyshchenko, Ivan A. Titko

PRESUMPTION OF MENTAL HEALTH VS FORENSIC PSYCHIATRIC EXAMINATION REPORT: MEDICAL AND LEGAL ASPECT

\section{REVIEW ARTICLES}

Borys V. Babin, Andrii M. Chvaliuk, Olexiy V. Plotnikov

EPIDEMIOLOGIC ACTIVITIES IN THE MODERN CRIMEA: HUMANITARIAN CHALLENGES AND POSSIBLE SOLUTIONS

Viktor M. Shevchuk, Ihor V. Parfylo, Mykyta 0. Sokolenko

FALSIFICATION OF MEDICINES AND DISTRIBUTION OF FALSIFIED MEDICINES IN UKRAINE: CRIMINALISTIC MEANS OF DETECTION AND COUNTERACTION

Yevdokiia J. Streltsova, Yevgen L. Streltsov, Eduard E. Kuzmin

THE EVOLVING IDEA OF"HEALTH"IN THE LEGAL LANDSCAPE: AN ATTEMPT TO IDENTIFY CRITICAL ASPECTS

Tetiana L. Syroid, Lina 0. Fomina

INTERNATIONAL LEGAL FRAMEWORK FOR PUBLIC HEALTH: FROM ITS ORIGINS TO THE PRESENT DAY

Viacheslav I. Borysov, Maxim G. Kolodyazhny, Daryna P. Yevtieieva

COVID-19 PANDEMIC CONSEQUENCES: CLASSIFICATION ISSUES

Serhiy S. Vitvitskyi, Marianna I. Liubchenko, Oleksii 0. Liubchenko

COVID 19-RELATED STIGMATIZATION: A HUMAN RIGHTS-BASED APPROACH 
Viktor V. Horodovenko, Larysa G. Udovyka, Tatiana 0. Shekhovtsova

VACCINATION IN THE SYSTEM OF HUMAN RIGHTS AND OBLIGATIONS: IMPACT OF THE COVID-19 PANDEMIC

Mariya G. Shul'ha, Anatoliy V. Mazur, lurii V. Georgiievskyi

IMPACT OF EPIDEMIOLOGICAL SITUATION ON RESPECT FOR HUMAN RIGHTS AND FREEDOMS: INFORMATIONAL ASPECT

Marija V. Mendzhul, Viktoriia V. Nadon, Zhanna 0. Rekova

PROTECTION OF THE RIGHTS OF CHILDREN BORN BY SURROGATE MOTHERS DURING THE COVID-19 PANDEMIC

Roman I. Tashian

THE INVALIDITY OF CONTRACTS IN THE FIELD OF MEDICAL SERVICES AS A WAY TO PROTECT THE RIGHTS OF THE PATIENT

Oksana M. Ponomarenko, Yuriy A. Ponomarenko, Kateryna Yu. Ponomarenko

LEGAL REGULATION OF THE "BIOLOGICAL" PROTECTION OF MARRIAGE AND FAMILY: ISSUES OF BALANCING BETWEEN THE RIGHT TO MEDICAL SECRET

AND THE RIGHT TO CONSCIOUS MARRIAGE

Roman A. Maydanyk, Kateryna V. Moskalenko

CERTAIN LIMITATIONS IN REPRODUCTIVE RIGHTS`S EXERCISING (CASES OF CHINA AND AUSTRIA)

Viktoriia V. Nadon, Marija V. Mendzhul, Olga I. Kotlyar

LEGAL BASIS FOR THE USE OF ASSISTED REPRODUCTIVE TECHNOLOGIES: A COMPARATIVE ANALYSIS OF THE LEGISLATION OF UKRAINE AND EUROPEAN STATES

Olena V. Moskalenko, Nataliia 0. Melnychuk, Denys 0. Novikov

ENSURING PHYSICAL AND MENTAL HEALTH OF ATHLETES BY THE LABOR LAW

Oksana P. Kuchynska, Yulia V. Tsyganyuk, Serhiy 0. Shulgin

CONSIDERATION OF STATE OF HUMAN HEALTH DURING APPLYING RESTRICTIVE MEASURES

Andriy M. Orlean, Inna V. Berdnik, Mykhailo S. Puzyrov

INTERNATIONAL- LEGAL REGULATION OF TRANSPLANTATION IN THE SYSTEM OF PREVENTION OF ILLEGAL TRADE IN ORGANS, TISSUES AND CELLS

Inga Kudeikina, Marina Loseviča, Nataliya 0. Gutorova

LEGAL AND PRACTICAL PROBLEMS OF USE OF ARTIFICIAL INTELLIGENCE-BASED ROBOTS IN FORENSIC PSYCHIATRY

Oleksandr M. Drozdov, Oksana V. Lazukova, Serhiy 0. Shulgin

SEARCH AND REMOVAL OF PROHIBITED ITEMS FROM THE HUMAN BODY: MEDICAL- PROCEDURAL ASPECT

Tetiana A. Pavlenko, Viktoriia A. Mozghova

UKRAINE'S DRUG POLICY ON PSYCHOLOGICAL DISORDERS AND BEHAVIOR DUE TO THE USE OF PSYCHOACTIVE SUBSTANCES: PROSPECTS FOR DEVELOPMENT

Natalia M. Kvit, Sibilla B. Buletsa, Vasyl V. Kopcha

RESEARCH USE OF HUMAN IN VITRO EMBRYOS: LEGAL BOUNDARIES

Natalia D. Kogut

ENVIRONMENTAL HEALTH LEGAL REGULATION AS A PREREQUISITE FOR PREVENTIVE MEDICINE

Olena M. Batyhina, Bogdan V. Derevyanko, Tetiana V. Khailova

FOOD SECURITY AS A GUARANTEE OF THE REALIZATION OF THE RIGHT TO HUMAN HEALTH

Alla K. Sokolova, Maryna K. Cherkashyna

LEGAL ASPECTS OF USING NATURAL RESOURCES FOR HEALTH AND RECREATIONAL PURPOSES TO ENSURE HUMAN RIGHT TO HEALTH CARE

Viktoriia V. Haltsova, Sergiy 0. Kharytonov, Oleksii 0. Bondarenko

DIVULGENCE OF CONFIDENTIALITY OF ADOPTION: CRIMINAL LEGAL AND MEDICAL ASPECTS

Volodymyr V. Shablystyi, Dmytro 0. Anisimov

DOPING AS A GLOBAL PROBLEM OF THE 21ST CENTURY ON ACCOUNT OF ITS ILLEGAL INFLUENCE ON THE RESULTS OF OFFICIAL SPORTS COMPETITIONS

Yana 0. Hryhorenko, Oleksandr G. Kushnirenko, Oleksandr I. Shkuropatskyi

THE EXPERIENCE OF LEGAL AND ORGANISATIONAL ARRANGEMENTS FOR MILITARY MEDICAL ACTIVITIES IN THE DEFENCE FORCES (USING FRANCE,

GERMANY AND UKRAINE AS EXAMPLES)

Olena I. Antoniuk, Ivan I. Vyshnyvetskyy

RESEARCH STUDY OF MEDICINES USING THE HUMAN BODY AFTER HIS/HER DEATH

Nataliia M. Akhtyrska, Yuriy V. Grodetskiy

THE RIGHT TO LIFE FROM THE POINT OFVIEW OF PERSONAL AUTONOMY IN DECISION-MAKING ON EUTHANASIA (REVIEW OF THE ECHR PRACTICE

AND THE LEGISLATION OF SELECTED COUNTRIES) 


\title{
ENSURING THE CITIZENS' RIGHTS AND FREEDOMS IN CASE OF COVID-19 VACCINATIO IN THE PUBLIC HEALTH SYSTEM
}

DOI: 10.36740/WLek202111201

\author{
Nataliya Gutorova', Vitalii Pashkov', Tetyana Kaganovska² \\ ${ }^{1}$ ACADEMICIAN STASHIS SCIENTIFIC RESEARCH INSTITUTE FOR THE STUDY OF CRIME PROBLEMS, KHARKIV, UKRAINE \\ 2V. N. KARAZIN KHARKIV NATIONAL UNIVERSITY, UKRAINE
}

\begin{abstract}
The aim: To study the legal and regulatory framework for ensuring the right to health of patients depending on the legal status of coronavirus vaccines in different countries as an essential element influencing the right to public health and other rights of citizens.

Materials and methods: In this paper, we study the legal norms and scientific positions on the above issue using generalized information from scientific journals that use scientific methods from a medical and legal point of view. This article is based on dialectical, comparative, analytical, synthetic, and complex research methods. Using the above methods, we studied the attitudes of different categories of citizens to vaccination against coronavirus disease through questionnaires on the following issues: attitudes to vaccination in general; motivation for vaccination, in case of consent to vaccination; reasons for refusal of vaccination. The case-law of the European Court of Human Rights on vaccination and ensuring the rights of citizens to health care was also analyzed.

Results: Proper legal regulation of the right to health depending on the legal status of the vaccines is important in order to implement restrictive measures to combat COVID-19 and, accordingly, to prevent the possible spread of a pandemic in the public health system.

Conclusions: Ensuring the right to health and applying restrictive measures to prevent the spread of a pandemic is an essential element of the public health system. However, the question of the legal status of vaccines is crucial to prevent the spread of the disease. That is, it is essential to go through all the stages of clinical trials for the vaccines used. Their safety and effectiveness and proving the fact that the harm of vaccination is much less than the harm of the spread of coronavirus disease. In the process of ensuring the right to health, including by making compulsory vaccination against COVID-19, legal framework and practice are critical components that aim to minimize the potential hazards that threaten the health and lives of the population.
\end{abstract}

KEY WORDS: right to health, coronavirus disease, pandemic, vaccination, public health, clinical trials

Wiad Lek. 2021;74(11 p.2):2863-2869

\section{INTRODUCTION}

The COVID-19 pandemic has become the most severe test for the health of the world's population and health care systems. Coronavirus disease has caused the premature death of millions of people worldwide, and many patients suffer from the clinical effects of coronavirus, including a condition called "postcoronavirus syndrome", namely when a combination of disorders in several body systems leads to persistent deterioration of health. I [1]. However, when it comes to ensuring the protection of patients' rights in the context of coronavirus disease, some jurists first consider this issue through the prism of avoiding compulsory vaccination or in the context of violating the right to informed consent. And this is despite the negative consequences of coronavirus disease. These negative consequences, in addition to premature death and the "postcoronavirus syndrome", should be accompanied by inequality and injustice, which have a detrimental effect on the state of society, as well as an increased adverse impact on the most vulnerable categories of the population.

In addition, the declaration of a pandemic by the World Health Organization [2] was the basis for the adoption of a number of legal acts aimed at regulating various spheres of society. In such circumstances, the rights and freedoms of citizens are restricted, and measures are taken to prevent the spread of new forms of COVID-19. As a result, all countries, one after another, faced with a pandemic were forced to introduce so-called "non-medical anti-epidemic measures" along with the mobilization of the health care system, both at the state and regional level. The purpose of such measures is to prevent the spread of the epidemic by reducing people-to-people contacts. In addition, since the beginning of the pandemic in different countries worldwide, the development of a vaccine against this infection has started due to the fact that, according to WHO experts, vaccination is the only effective way to overcome the COVID-19 pandemic [3]. At the same time, the development of vaccines was accompanied by competition (not always fair) with incorrect mutual accusations regarding the side effects of such vaccines.

Since 2020, more than 170 types of coronavirus vaccines have been developed in various countries worldwide [4]. The best known are vaccines from Pfizer / BioNTech, Oxford / AstraZeneca, Johnson \& Johnson, Sanofi / GSK, 
CureVac, Moderna [5], and Chinese coronavirus vaccines CanSinoBio and Sinovac [6].

It is clear that the issue of compulsory patients vaccination can be considered through the prism of many ECtHR decisions using the principle of proportionality, according to which such a natural right as the right to health outweighs all other human rights, including the right to work and employment, education, freedom of movement, etc. . However, not in this case.

It is a matter of the legal status of vaccines used worldwide against coronavirus disease. To date, none of the vaccines have undergone complete clinical trials. That is those patients who have consented to vaccination against coronavirus disease simultaneously participate in a clinical trial without receiving any information.

That is why many questions arise: are these vaccines really effective against coronavirus? Will the vaccination procedure be mandatory for all, and how can its refusal affect the restriction of certain citizens' rights and freedoms?

It should be noted that most scientific studies on vaccination and immunization of the population were about common, well-known diseases and time-tested vaccines $[7 ; 8 ; 9 ; 10 ; 11]$. That is, those that have passed complete clinical trials and had the appropriate effectiveness.

\section{THE AIM}

To study the legal and regulatory framework for ensuring the right to health of patients depending on the legal status of coronavirus vaccines in different countries as an important element influencing the right to public health and other rights of citizens.

\section{MATERIALS AND METHODS}

In this paper, we study the legal norms and scientific positions on the above issue using generalized information from scientific journals that use scientific methods from a medical and legal point of view. This article is based on dialectical, comparative, analytical, synthetic, and complex research methods. Using the above methods, we studied the attitudes of different categories of citizens to vaccination against coronavirus disease through questionnaires on the following issues: attitudes to vaccination in general; motivation for vaccination, in case of consent to vaccination; reasons for refusal of vaccination. The case-law of the European Court of Human Rights on vaccination and ensuring the rights of citizens to health care was also analyzed.

\section{RESULTS AND DISCUSSION}

1. General characteristics of ways to combat coronavirus disease. Any state aims to ensure such an element of national security as ensuring the right to health and other citizens' rights and freedoms, including timely response to any threats to the health of citizens as an element of national security. That is why the governments of most countries after the WHO declared a state of the pandemic followed the tried and tested path and introduced largescale vaccination.

In addition, at the 71st session of the WHO Regional Committee for Europe (RC71), it was proposed to develop, in line with the WHO Global Plan of Action for Vaccines until 2030, and to adopt a global policy on pandemic vaccination, which should set out rights and the responsibilities of all actors, including those who fund and conduct the research needed to develop and evaluate vaccines, those who are responsible for products licensing, those who deal with intellectual property issues, and those who must ensure that vaccines are available to the needy and vaccination by medical workers of the leading edge. This new policy should find a way to achieve the immediate goal of public health - to ensure a high level of protection against a particular disease. However, manufacturers should not be deprived of incentives to invest in research and development on other relevant issues [12].

Before proceeding, we have to find out what vaccination is. According to the $\mathrm{WHO}$, vaccination is a simple, safe, and effective way to protect against harmful diseases before you come across them. It uses your body's natural defenses to increase resistance to certain infections and strengthen the immune system [13]. In addition, vaccines train the immune system to produce antibodies, as it does when exposed to the disease. However, because vaccines contain only killed or attenuated forms of microbes, such as viruses or bacteria, they do not cause disease and do not put you at risk of complications [13].

We can conclude that vaccination is a guarantee of immunization and is quite capable of protecting against disease. But this statement is undoubtful when it comes to any other well-known diseases other than coronavirus disease.

2. Legal status of COVID-19 vaccine-candidates. As of June 3, 2021, the WHO has assessed that the following vaccines against COVID-19 meet the necessary safety and efficacy criteria: AstraZeneca / Oxford; Johnson and Johnson; Modern; Pfizer / BionTech; Sinopharm; Sons of Biotech [3]. It has been a short time since the WHO declared the pandemic, particularly since March 12, 2000, and sometime later, several types of vaccines have been developed and introduced.

However, it is interesting to note that the vaccine-candidate usually goes through three phases of development before being approved by regulatory authorities. After successful completion of testing and licensing of the product, a fourth phase study, also called post-marketing surveillance studies, is carried out to continue monitoring the vaccine for safety and efficacy among the population $[14 ; 15 ; 16 ; 17]$. In total, the development of one vaccine takes about $10-15$ years (not including practical monitoring after the production stage) [18]. These stages of the study were reflected in the Decision of the Council of the Eurasian Economic Commission dated 03.11.2016 № 78 «On the Rules of registration and examination of medicinal products for medical use» [19].

However, in accordance with Commission Regulation (EC) No 507/2006 of June 29, 2003 [20], «conditional mar- 
keting authorizations» are granted in order to ensure the right to health. Although the data on which the conclusion on the conditional marketing authorization is based may be less complete, the risk-benefit balance set out in Article 1 (28a) of Directive 2001/83 / EC [21] should be positive. In addition, the public health benefits of the immediate marketing of an appropriate medicinal product should outweigh the risk of using new dosage forms that have not undergone complete clinical trials [22].

Conditional marketing authorizations differ from marketing authorizations granted in exceptional circumstances under Article 14 (8) of Regulation (EU) No 726/2004 [23]. In the case of a conditional marketing authorization, the authorization is issued before all clinical trial data are available. However, authorization is not intended to remain a condition for an indefinite period. Instead, as soon as the missing data are provided, it should be possible to replace them with a non-conditional sales authorization, i.e., not subject to a specific obligation. In contrast, it is usually impossible to compile a complete dossier on a marketing authorization issued in exceptional circumstances.

According to the European Medicines Agency (EMA), current marketing authorizations are valid for one year and may be rejected [24].

EMA website provides information on the granting of a conditional marketing authorization for the Pfizer / BioNTech vaccine on December 21,2020. This authorization was provided in the interests of healthcare, as medicines meet unmet medical needs and the benefits of immediate availability outweigh the risks of less comprehensive data than is usually required. Later, on January 6, 2021, the vaccine of Moderna Biotech Spain, S.L. received a conditional permit for sale.

For any medicinal product, if new data show that the benefits of the medicinal product no longer outweigh the risks, the EMA may take regulatory measures, such as suspension or revocation of the marketing authorization [25].

EU legislation is considered to guarantee the approval of vaccines only after a scientific assessment has shown that their overall benefits outweigh the risks. The benefits of legalized vaccines, from the point of view of the European Medicines Agency (EMA), in protecting people from COVID-19 are far greater than any side effects or potential risks from their use [26].

US legislation regarding the admission to the use of coronavirus vaccines is similar.

Thus, under the Federal Food, Drug, and Cosmetic Act, [27] the FDA may allow the use of unapproved medical products in emergencies to diagnose, treat, or prevent serious or life-threatening illnesses when there are no adequate, approved, and available alternatives. The FDA has clarified that "emergency use permit» means what its name implies: a medical device receives a special permit from the FDA for use in an emergency - but it does not have full approval [28].

For example, Pfizer will have to apply separately for a full vaccine license. According to FDA rules, this is the so-called «compassionate use», namely access for a patient with a life-threatening condition for treatment outside of clinical trials, when there are no comparable or satisfactory alternative treatment options. The legal basis for expanded access was the Seventh Amendment to Declaration Under the Public Readiness and Emergency Preparedness Act for Medical Countermeasures Against COVID-19 [29].

That is, in this case, both in the EU and in the US, we are not talking about full-fledged clinical trials, following all the necessary procedures. In fact, all patients who agreed to be vaccinated against coronavirus disease were essential participants in a medical trial.

3. Characteristics of possible citizens' rights and freedoms violations in the general vaccination of the population.

It is unfortunate, but the governments of some countries are forcing citizens to participate in such an experiment, which in essence must be voluntary. This is done by restricting certain rights and freedoms of citizens. However, the restriction of rights may occur in the interests of the state and society and is primarily due to the need to respect the same rights and freedoms of others, as well as the need for the proper functioning of society and the state. The problem of rights and freedoms restriction can be considered from two points of view: when restrictions are related to exceptional circumstances, the extraordinary situation in society and the state, which should be directly prescribed by the laws of the country; in other cases, when restrictions on the individual's rights and freedoms are caused by the need to avoid violating the rights and freedoms of others [30].

Thus, more and more information is coming from the EU and the US about different ways of forcing citizens to get vaccinated. This is done by threatening to dismiss various categories of workers without paying wages.

For example, since September 2021, about 3,000 health workers in France have been fired for not being vaccinated against Covid-19. Greece has introduced new testing requirements and attendance restrictions for people who have not been vaccinated against COVID-19. Measures include requiring unvaccinated workers to be tested weekly or twice a week and providing access to certain indoor facilities only to those who have been vaccinated or have a certificate confirming that they have recovered from COVID-19 over the past six months [32]. In addition, healthcare workers in Greece who have not suffered the coronavirus disease in the last six months and refuse to be vaccinated are sent on unpaid leave.

In Italy, as of April, 2021 medical workers were obliged to be vaccinated under the threat of dismissal, and as of 15.10.2021, all citizens, except pensioners and the unemployed, must have a Green Pass.

In the United States, federal anti-discrimination laws do not prohibit employers from requiring all employees who physically visit the workplace to be vaccinated against COVID-19. However, employers who encourage or require vaccination must comply with the Americans with Disabilities Act (ADA) [35], Section VII of the Civil Rights Act 1964 [36]. As a result, many companies view mandatory COVID-19 vaccination as a condition of employment. 
Many labor lawyers believe that an employer can force employees to be vaccinated under law, and if they fail to do so, the employer can fire them. [37]

In the United Kingdom, the Government has passed an act of compulsory vaccination against COVID-19 for nursing home workers. In addition, consultations are currently underway to extend such requirements to health and social care workers [38].

In order to address the issue of minimizing restrictions on the movement of citizens, Regulation (EC) 2021/953 of the European Parliament and of the Council of 14.06.2021 EU COVID certificate) was issued to facilitate free movement during the COVID-19 pandemic." This document is intended to promote the application of the principles of proportionality and non-discrimination in relation to restrictions on free movement during the COVID-19 pandemic while ensuring a high level of public health protection [39]. However, in our opinion, the main task of this resolution is the legalization of digital vaccination passports.

Meanwhile, the Universal Declaration of Human Rights (Article 29, part 2) [40] stipulates that in exercising their rights and freedoms, everyone should be subject only to such limitations that are prescribed exclusively by law to ensure the proper recognition and respect of the rights and freedoms of others, ensuring fair demands for morality, public order, and general well-being in a democratic society.

Although it is necessary to consider the balance of individual rights and the interests of society, however, it is clear that forcing one to participate in a medical experiment is an illegal act. Primarily if coercion is associated with blatant discrimination, intrusion into private life, or the imposition of restrictions that make it difficult for a person to earn a living. However, refusal of such vaccination with reference to an unwillingness to participate in a medical experiment and trial of a vaccine that has not passed a complete cycle of clinical trials is possible but is considered unpromising to protect human rights in national courts.

4. Analysis of the survey on the attitude of the population to vaccination against coronavirus disease.

In order to establish the attitude of different categories of citizens to vaccination against coronavirus disease, a survey was conducted on the following issues: attitude to vaccination in general; motivation for vaccination, in case of consent to vaccination; reasons for refusal of vaccination.

One thousand one hundred respondents took part, and the survey found that: 1) 60 percent of citizens aged 18 to 30 do not consider it necessary to be vaccinated at all, but 50 percent of citizens in this group said they would be vaccinated to avoid restrictions on free movement, including to other countries. Moreover, these categories of citizens are ready to be vaccinated only with defined vaccines; 2 ) among citizens aged 31 to 55, 59 percent are ready to be vaccinated, including 40 percent - in order to avoid possible restrictions on rights and freedoms, namely, the right to work, employment and the right to free movement; 3 ) Among citizens aged 56 and over, 60 percent are ready to be vaccinated, and only 15 percent of them, in addition to avoiding negative health consequences, aim, to also avoiding restrictions on the right to free movement.

In many cases, the motivation for vaccination against coronavirus disease among the citizens of Ukraine is to avoid restrictions on certain rights and freedoms, most to avoid the restriction of the right to free movement to other countries.

In the survey, we discovered a desire to be vaccinated with specified vaccines that are not directly related to the effectiveness of vaccines and their health impact but are grounded on the recognition of such vaccines in most countries and thus the possibility to travel.

This fact was of interest, and we discovered that, for example, in Germany, according to the Robert Koch Institute, only the following vaccines are recognized: BioNTech / Pfizer, AstraZeneca, Moderna, and Johnson \& Johnson [41]. We want to pay attention to the fact that WHO has assessed and recognized, in addition to the above, those vaccines that meet the necessary safety and efficacy criteria: Sinopharm; Sinovac Biotech [3]. Furthermore, under the COVAX program [42], most low-income countries receive, in most cases, namely Sinopharm and Sinovac Biotech.

Thus, patients vaccinated with the "wrong vaccine" still lose the right to free movement to certain countries.

That is why PACE under the Resolution 2361 [43] encourage countries to cooperate to ensure equal access to Covid-19 vaccines and to avoid "vaccine nationalism".

5. Analisys of international acts and ECtHR case-law on vaccination in general.

It should also be borne in mind that there is distrust of COVID-19 vaccines worldwide today. One of the reasons for this mistrust is the spread of false information about vaccination in the media and social networks. For example, the American Red Cross [44] was forced to refute the information spread on social networks that the vaccinated could not be blood donors. There are also many other myths that have been refuted.

Despite the many informed sources that offer citizens to be vaccinated, there is still a large number of people that refuse vaccination. Indeed, there are some legal points used by lawyers who protect the rights of their clients. For example, it may be: 1) Art. 1, 8, 9 of the Nuremberg Code of 1947 [45];2) paragraph 16 of the Helsinki Declaration of the World Medical Association on the ethical principles of clinical trials [46]; 3) Art. 6, section 1, section 3 of the Universal Declaration on Bioethics and Human Rights [47]; 4) p. 7.3.1. and 7.3.2. of PACE Resolutions 2361 of 2021 "Vaccines against COVID-19: ethical, legal and practical considerations" [48], etc.

The case-law of the European Court of Human Rights on compulsory vaccination is very interesting. For example, in case 47621/13 "CASE OF VAVŘIČKA AND OTHERS v. THE CZECH REPUBLIC" the Court ruled that the parents were legitimately administratively punished for refusing to vaccinate their children. [49]

According to the plot of the case, several families from the Czech Republic have filed a lawsuit against the man- 
datory vaccination of children "against nine diseases well known to medical science." The plaintiffs were convinced that the refusal of kindergartens to accept unvaccinated children was illegal, but the Court did not agree with them, and on April 8, 2021, the Grand Chamber of the Court made a final decision. Proponents of coronavirus vaccination believe that this decision may set a precedent for vaccination against COVID-19.

Although, in our opinion, this decision cannot be a precedent because the case concerns known diseases that have always been included in vaccination plans for children according to the WHO recommendation [50].

Another case directly concerns the issue of compulsory vaccination against coronavirus disease. Thus, the ECtHR decided to reject the request for interim measures submitted by the French fire brigade in the case of Abgrall and 671 Others v. France (application no. 41950/21) concerning French legislation on vaccination requirements against COVID-19 [51]. The Court concluded that such requirements do not fall under Art. 39 of the ECtHR Regulation.

The case concerns French legislation (Law № 2021-1040 of 05.08.2021 on the management of the public health crisis), which, inter alia, establishes compulsory vaccination for specific categories of people and a ban on work for those non-compliant with such a requirement for vaccination, together with cessation in the payment of their wages. The applicants to the ECtHR, 672 full-time and voluntary members of the French Departmental Fire and Emergency Services (SDIS), considered that these provisions were contrary to the right to respect for private and family life under Articles 2 and 8 of the European Convention on Human Rights [52]. It should be noted that relevant law that was challenged in the ECtHR applies not only to firefighters and rescuers but also to teachers and health workers.

In this case, it can be argued that the ECtHR avoided considering the merits of the case.

\section{CONCLUSIONS}

Ensuring the right to health and applying restrictive measures to prevent the spread of a pandemic is an essential element in the public health system. However, the question of the legal status of vaccines is crucial to prevent the spread of the disease. That is, it is vital to go through all the stages of clinical trials for the vaccines used. Their safety and effectiveness and proving the fact that the harm of vaccination is much less than the harm of the spread of coronavirus disease. In the process of ensuring the right to health, including by making compulsory vaccination against COVID-19, the legal framework and practice are essential components that aim to minimize the potential hazards that threaten the health and lives of the population.

In the context of the spread of coronavirus disease, the system of protecting the rights of patients, both in protecting the right to health and ensuring other rights and freedoms, does not work. Compulsory vaccination with drugs that have not undergone complete clinical trials is widespread. The admission of such vaccines to the health care market is based on assumptions about the possible proportionality of health damage when using untested vaccines and without vaccination. There is a violation of certain citizens' rights and freedoms regardless of whether the patient is vaccinated. Countries ignore WHO decisions to allow the use of a specific list of vaccines. Some countries have their own list of recognized vaccines. As a result, there are risks of restricting the right of free movement of citizens.

There is no coordination of public health services in terms of disease control. In such circumstances, the ECtHR did not rule on the merits of the case. Against this background, in some countries, private law entities independently at their own discretion depending on whether a citizen is vaccinated or not, make decisions related to the employment of citizens, dismissal from work, admission to study, and so on.

\section{REFERENCES}

1. Drawing light from the pandemic A NEW STRATEGY FOR HEALTH AND SUSTAINABLE DEVELOPMENT. REPORT Drawing light from the pandemic A NEW STRATEGY FOR HEALTH AND SUSTAINABLE DEVELOPMENT September 2021. Available from: https://www.euro.who.int/_data/ assets/pdf_file/0015/511701/Pan-European-Commission-healthsustainable-development-eng.pdf

2. WHO announces COVID-19 outbreak a pandemic. Available from: https://www.euro.who.int/en/health-topics/health-emergencies/ coronavirus-covid-19/news/news/2020/3/who-announces-covid-19outbreak-a-pandemic

3. WHO. COVID-19 advice for the public: Getting vaccinated. Available from: https:/www.who.int/emergencies/diseases/novel-coronavirus-2019/ covid-19-vaccines/advice

4. COVAX explained. 3 September - by Dr Seth Berkley, CEO of Gavi, the Vaccine Alliance. Available from: https://www.gavi.org/vaccineswork/ covax-explained

5. Belgian secretary of state accidentally reveals EU vaccine prices. Available from: https://www.politico.eu/article/belgian-secretary-of-stateaccidentally-reveals-eu-vaccine-prices/?fbclid=IwAR30XidyWIhE56i LmdQkszF_JE0t3G5BLRKIOCIkRIv8QfxNDfgL-_ADbal

6. China slips in COVID-19 vaccine race on doubts over effectiveness. Available from: https://asia.nikkei.com/Spotlight/Coronavirus/Chinaslips-in-COVID-19-vaccine-race-on-doubts-over-effectiveness

7. Pashkov V.M. Istoriya vakcinaciï: pravovij nigilizm ta medichnij... SHCHotizhnevik APTEKA. 2018; 12: 10

8. Zaporozhec' T. M. Antivakcinal'na kampaniya, vivchennya mifiv pro shkodu vakcinaciï. Medsestrinstvo. 2011;2: 21 - 25

9. A. Danyliv, T. Stepurko, I. Gryga et al. Is there a place for the patient in the Ukrainian health care system? Patient payment policies and investment priorities in health care in Ukraine / Society and Economy. 2012;34 (2):273-291

10. PashkovV.,Gutorova N. Imunoprofilaktikav mekhanizmizabezpechennya ta zahisti prava na zdorov'ya. Pravo Ukraïni. 2020;3: 61 - 84

11. Pashkov V., Golovanova I., Olefir A. The impact of the legal regime of intellectual property protection in the pharmaceutical market. Wiad Lek. 2016; 3:582-586

12. WHO. COVID-19: Latest updates. Available from: https://us4.campaignarchive.com/?u=bb832ff4c9f8efad547ffcf69\&id=b5148e77d8

13. WHO. Vaccines and immunization: What is vaccination? Available from: https://www.who.int/news-room/q-a-detail/vaccines-andimmunization-what-is-vaccination 
14. KSingh, SMehta. The clinical development process for a novel preventive vaccine: An overview. J Postgrad Med. Jan-Mar 2016;62(1):4 -11. Available from: https://pubmed.ncbi.nlm.nih.gov/26732191/

15. WHOTechnical Report. Annex 1:WHO Guidelines on Clinical Evaluation of Vaccines: Regulatory Expectations. World Health Organization. 2004:36 - 96. Available from: https://www.who.int/biologicals/BS2287_ Clinical_guidelines_final_LINE_NOs_20_July_2016.pdf 3

16. Hudgens MG, Gilbert PB, Self SG. Endpoints in vaccine trials. Stat Methods Med Res. 2004;13:89 - 114. Available from: https://journals. sagepub.com/doi/10.1191/0962280204sm356ra

17. Collins H. Vaccine development: From concept to licensed product. In: Kahn P, editor. AIDS Vaccine Handbook: Global Perspectives. 2nd ed. AIDS Vaccine Advocacy Coalition (AVAC); 2005: 37 - 4.

18. N. F. Nikityuk i dr. Osnovnye podhody k organizacii i provedeniyu klinicheskih isledovanij vakcinnyh preparatov: nauchnoe izdanie. Medicinskij al'manah. 2012;3:51 - 54

19. Assembly debate on 27 January 2021 (5th Sitting) (see Doc. 15212, report of the Committee on Social Affairs, Health and Sustainable Development, rapporteur: Ms Jennifer De Temmerman). Text adopted by the Assembly on 27 January 2021 (5th Sitting). Covid-19 vaccines: ethical, legal and practical considerations. Resolution 2361 (2021). Available from: https://pace.coe.int/en/files/29004/html

20. EUR-Lex. Commission Regulation (EC) No 507/2006 of 29 March 2006 on the conditional marketing authorisation for medicinal products for human use falling within the scope of Regulation (EC) No 726/2004 of the European Parliament and of the Council (Text with EEA relevance). Available from: https://eur-lex.europa.eu/legal-content/EN/ TXT/?uri=celex\%3A32006R0507

21. EUR-Lex. Directive 2001/83/EC of the European Parliament and of the Council of 6 November 2001 on the Community code relating to medicinal products for human use. Available from: https://eur-lex. europa.eu/legal-content/en/ALL/?uri=CELEX\%3A32001L0083

22. EMA. Conditional marketing authorization. Available from: https:// www.ema.europa.eu/en/human-regulatory/marketing-authorisation/ conditional-marketing-authorisation

23. EUR-Lex. Regulation (EC) No 726/2004 of the European Parliament and of the Council of 31 March 2004 laying down Community procedures for the authorisation and supervision of medicinal products for human and veterinary use and establishing a European Medicines Agency (Text with EEA relevance). URL: https://eur-lex.europa.eu/legal-content/EN/ TXT/?uri=celex\%3A32004R0726

24. EMA.COVID-19vaccines: development, evaluation, approval and monitoring. Available from: https://www.ema.europa.eu/en/human-regulatory/ overview/public-health-threats/coronavirus-disease-covid-19/treatmentsvaccines/vaccines-covid-19/covid-19-vaccines-development-evaluationapproval-monitoring\#scientific-evaluation-and-approval-section

25. European Medicines Agency. Human regulatory. Conditional marketing authorisation. Available from: https://www.ema.europa.eu/en/ human-regulatory/marketing-authorisation/conditional-marketingauthorisation\#use-during-covid-19-pandemic-(new)-section

26. European Medicines Agency. Human regulatory. Robustregulatory framework and scientific expertise in the EU. URL: https://www.ema.europa.eu/en/ human-regulatory/overview/public-health-threats/coronavirus-diseasecovid-19/treatments-vaccines/covid-19-vaccines-development-evaluationapproval-monitoring\#scientific-evaluation-and-approval-section

27. FDA. Federal Food, Drug, and Cosmetic Act (FD\&C Act). Available from: https://www.fda.gov/regulatory-information/laws-enforced-fda/ federal-food-drug-and-cosmetic-act-fdc-act
28. FDA issues emergency use authorization for Pfizer/BioNTech Covid-19 vaccine. By Jacqueline Howard, CNN Updated 0840 GMT (1640 HKT) December 12, 2020. Available from: https://edition.cnn. com/2020/12/11/health/covid-vaccine-fda-eua/index.html?utm_ medium=social\&utm_content=2020-12-12T02\%3A44\%3A51\&utm_ term=link\&utm_source $=$ twcnnbrk

29. PREP Act Guidance. Seventh Amendment to Declaration Under the Public Readiness and Emergency Preparedness Act for Medical Countermeasures Against COVID-19. Available from: https://www. phe.gov/Preparedness/legal/prepact/Pages/PREP-Act-Guidance.aspx

30. ECHR. Cases opinions matters. Ukrainian aspect. Available from: https://www.echr.com.ua/vakcinaciya-vid-covid-19-pravoveob\%D2\%91runtuvannya-vidmovi-i-zaxist-vid-podalsho\%D1\%97diskriminaci\%D1\%97/

31. BBC. NEWS. Covid-19: France suspends 3,000 unvaccinated health workers. Available from: https://www.bbc.com/news/world-europe58581682?piano-modal

32. AP NEWS. Greece announces new restrictions for those not vaccinated. Available from: https://apnews.com/article/europe-business-healthgreece-coronavirus-pandemic-9656434341e8db7aa36fd73a2cbbb50c

33. EURONEWS. Italy first in Europe to require all employees to have COVID health pass. Available from: https://www.euronews.com/2021/09/16/ italy-set-to-be-first-in-europe-to-require-all-employees-to-havecovid-health-pass

34. EMPLOYMENT LAW. By Allen Smith, J.D., and Lisa Nagele-Piazza, J.D. Employers React to Workers Who Refuse Vaccination as COVID-19 Cases Rise. Available from: https://www.shrm.org/resourcesandtools/ legal-and-compliance/employment-law/pages/if-workers-refuse-acovid-19-vaccination.aspx

35. ADA.gov. Introduction to the ADA. Available from: https://www.ada. gov/ada_intro.htm

36. Office of the Assistant Secretary for Administration \& Management. Legal Highlight: The Civil Rights Act of 1964. Available from: https:// www.dol.gov/agencies/oasam/civil-rights-center/statutes/civil-rightsact-of-1964

37. Dermatology Times. In this month's Legal Eagle column, David J. Goldberg, MD, JD, explores the legality of terminating an employee for refusing a COVID-19 vaccine. Dermatology Times, April 2021 (Vol. 42, No. 4), Volume 42, Issue 4. Available from: https://www.dermatologytimes. com/view/covid-19-vaccine-refusal-grounds-for-termination-

38. Practical Law. COVID-19: employment implications of vaccination by Practical Law Employment. Available from: https://uk.practicallaw. thomsonreuters.com/w-029-5946?transitionType=Default\&contextD ata $=($ sc.Default $) \&$ firstPage $=$ true

39. Official Journal of the European Union. REGULATION (EU) 2021/953 OF THE EUROPEAN PARLIAMENT AND OF THE COUNCIL. of 14 June 2021 on a framework for the issuance, verification and acceptance of interoperable COVID-19 vaccination, test and recovery certificates (EU Digital COVID (ertificate) to facilitate free movement during the COVID-19 pandemic (Text with EEA relevance). Available from: https://eur-lex.europa.eu/ legal-content/EN/TXT/HTML/?uri=CELEX:32021R0953\&rid=2

40. United Nations. Universal Declaration of Human Rights. Available from: https://www.un.org/en/about-us/universal-declaration-of-human-rights

41. Robert Koch Institut. COVID-19 in Deutschlandю RKI: vaccines approved in Germany will protect against severe course of COVID-19. Available from: https://www.rki.de/DE/Home/homepage_node.html

42. GAVI. COVAX explained. Available from: https://www.gavi.org/ vaccineswork/covax-explained 
43. Parliamentary Assembly of the Council of Europe. Covid-19 vaccines: ethical, legal and practical considerationsю Resolution 2361 (2021). Available from: https://pace.coe.int/en/files/29004/html

44. American Red Cross. Answers to Common Questions About COVID-19 Vaccines and Blood, Platelet or Plasma Donation Eligibility. Available from: https://www.redcross.org/about-us/news-and-events/ news/2021/answers-to-common-questions-about-covid-19-vaccinesand-blood-platelet-plasma-donation-eligibility.html

45. BRITISH MEDICAL JOURNAL No 7070 Volume 313: Page 1448, 7 December 1996. The Nuremberg Code (1947). Available from: https:// media.tghn.org/medialibrary/2011/04/BMJ_No_7070_Volume_313_ The_Nuremberg_Code.pdf

46. World Medical Association. WMA DECLARATION OF HELSINKI - ETHICAL PRINCIPLES FOR MEDICAL RESEARCH INVOLVING HUMAN SUBJECTS. Available from: https://www.wma.net/policies-post/wma-declarationof-helsinki-ethical-principles-for-medical-research-involving-humansubjects/

47. UNESCO. Universal Declaration on Bioethics and Human Rights. Available from: https://en.unesco.org/themes/ethics-science-and-technology/ bioethics-and-human-rights

48. Parliamentary Assembly of the Council of Europe. Covid-19 vaccines: ethical, legal and practical considerationsю Resolution 2361 (2021). Available from:

https://pace.coe.int/en/files/29004/html

49. EUROPEAN COURT OF HUMAN RIGHTS. GRAND CHAMBER. CASE OF VAVŘIČKA AND OTHERS v. THE CZECH REPUBLIC (Applications nos. 47621/13 and 5 others). JUDGMENT. Available from: https://hudoc. echr.coe.int/fre\#\{\%22itemid\%22:[\%22001-209039\%22]\}

50. Recommended Routine Immunizations for Children - WHO. Available from: https://www.who.int/immunization/policy/Immunization_ routine_table2.pdf?ua=1

51. ECtHR rejects request for interim suspension of French conditional vaccination rules for COVID-19. Available from: https://eulawlive.com/ ecthr-rejects-request-for-interim-suspension-of-french-conditionalvaccination-rules-for-covid-19/
52. European Convention on Human Rights. Available from: https://www. echr.coe.int/Pages/home.aspx?p=basictexts\&c

\section{ORCID and contributioship:}

Nataliya O. Gutorova: 0000-0003-2485-0651 ${ }^{\text {A, E, F }}$

Vitalii M. Pashkov: 0000-0001-9489-7768

Tetyana Ye. Kaganovska: 0000-0002-4427-2038 ${ }^{D, E, F}$

\section{Conflict of interests:}

The Authors declare no conflict of interests.

\section{CORRESPONDING AUTHOR Vitalii M. Pashkov \\ Academician Stashis Scientific Research Institute For The Study Of Crime Problems, Kharkiv, Ukraine tel: +380666931651 \\ e-mail: v.pashkov26.06@ukr.net}

Received: 18.08.2021

Accepted: 15.10 .2021

A - Work concept and design, B - Data collection and analysis, C - Responsibility for statistical analysis, D - Writing the article, $\mathbf{E}$ - Critical review, $\mathbf{F}$ - Final approval of the article 


\title{
MORTALITY AND INJURY IN UKRAINE AS A RESULT OF TRAFFIC ACCIDENTS IN MEASURING OF PUBLIC HEALTH: TO THE ANALYSIS OF SOCIAL- LEGAL AND CRIMINOLOGICAL PROBLEM
}

DOI: 10.36740/WLek202111202

\author{
Vladyslava S. Batyrgareieva, Sabriie S. Shramko, Olena M. Samoilova \\ ACADEMICIAN STASHIS SCIENTIFIC RESEARCH INSTITUTE FOR THE STUDY OF CRIME PROBLEMS OF THE NATIONAL ACADEMY OF LAW SCIENCES OF \\ UKRAINE, KHARKIV, UKRAINE
}

\begin{abstract}
The aim: Based on the statistics study of the consequences of road accidents for human potential of Ukraine and quantitative indicators of criminal offenses in the field of road safety for the period 2016-2021, as well as assessing the risks to public health of Ukrainian society to carry out socio-legal and criminological analysis of the problem and identify key areas of the national approach to the implementation of the tasks of the Second Decade of Action to ensure road safety (2021-2030).

Materials and methods: The study is based on the results of a survey of ordinary citizens of Ukraine on the state of road safety on the roads of Ukraine; information posted on the WHO website for 2009-2020; statistical reports of Ukrainian law enforcement agencies, specialized literature on law, etc. The methodological basis of the research is dialectical, comparative, logical, analytical, synthetic, statistical, and concrete-sociological research methods.

Results: In Ukraine, among adolescents and young people at the age of 15-24, the first and main cause of death from external circumstances is death in an accident. Among young people aged 25-29 years, this is the second leading cause of death (after suicide). Every third child, being in the status of passengers, dies due to the fault of relatives and friends. One-third of all victims are pedestrians. It is estimated that Ukraine lost more than USD 308 million in GDP as a result of the deaths of road accident victims in 2020. Conclusions: In Ukraine, road accidents are a significant cause of death and disability due to external circumstances, and therefore pose a threat to the public health of the population. The death and disability of people as a result of road accidents cause huge material and human losses to Ukraine. An unsatisfactory state of legal awareness of Ukrainian citizens is a direct threat to public health and a source of the perpetuation of the generally unfavorable trend with the level of criminally punished violations of traffic rules. An important task of the Ukrainian state is to create a service of emergency specialized care according to world standards of so-called disaster medicine.
\end{abstract}

KEY WORDS: road injuries, disabilities, road deaths, road safety, years of life lost in Ukraine

Wiad Lek. 2021;74(11 p.2):2870-2876

\section{INTRODUCTION}

The annual increase in the vehicle fleet and the constant intensification and complication of traffic in Ukraine determine the fact that traffic accidents, including criminal offenses, are becoming a real disaster. And although the roots of this problem, which even acquires the character of an epidemic [1], are largely common to any country in which complex technical systems, devices, mechanisms, devices, etc. are designed to move people, goods, etc., however, the international community is concerned about the high rate of road deaths and injuries, especially in those regions of the world where the situation is close to critical. Therefore, the international community pays considerable attention to finding the most effective ways to gradually reduce offenses with serious consequences in the field of traffic. This is highlighted in UN General Assembly Resolution "Improving Road Safety Worldwide” № 74/299 of 31 August 2020, which states in paragraph 3 that in 2021-2030 the goal is to reduce mortality and injuries as a result of a road accident.

In Ukraine, the unsatisfactory state of road safety, as a result of which road accidents are a visible cause of death and disability, is a serious problem in maintaining the public health of the country's population, becoming a threat on a national scale. Therefore, it is not in vain that the analysis of bills submitted and registered in recent years in the legislative body of Ukraine shows that among the priority areas of criminal law policy of the state such areas as, in particular, ensuring life and health on the roads by strengthening criminal liability for violations road safety and transport operation. At the same time, in order to reduce the level of accidents in Ukraine and the severity of road accidents' consequences, the State Program for Improving Road Safety in Ukraine until 2020 [2] and the Strategy for Improving Road Safety in Ukraine for 2020 was adopted. [3]. Starting from 2021, Ukraine has a Strategy to increase the level of road safety in Ukraine until 2024 [4].

Nevertheless, the rates of accidents, deaths, injuries, delinquency, and socio-economic costs associated, firstly, with prejudice and, secondly, with the elimination of these phenomena, continue to deteriorate due to an ineffective response system to those threats which permanently lead to a statement of the crisis in this area. 


\section{THE AIM}

Based on an in-depth study of the consequences of road accidents as a threat to the preservation of human potential of Ukraine, quantitative indicators of criminal offenses in the field of road safety for the period 2016-2021, as well as assessing the risks of leaving the situation unchanged criminological analysis of the problem in order to identify key areas of the national approach to the implementation of the Second Decade of Road Safety (2021-2030) by the UN General Assembly Resolution "Improving road safety worldwide” № 74/299 of 31 August 2020

\section{MATERIALS AND METHODS}

The study was conducted in the second half of 2020 - first half of 2021 and is based on the survey's results of ordinary citizens of Ukraine on the state of road safety; information posted on the WHO website for 2009-2021; statistical reports of Ukrainian law enforcement agencies, specialized literature on law and others. The study is based on dialectical, comparative, logical, analytical, synthetic, statistical, and sociological research methods used to present various indicators that characterize the level of road injuries and deaths, as well as to visualize the damage to the national economy. The obtained empirical material was processed using, in particular, the tools of descriptive statistics, as well as methods of potential demography. The calculations were done using Microsoft Excel 2016 and Microsoft Word 2016.

\section{RESULTS}

Every 23 seconds in the world one person (!) dies in an accident [5]. Road traffic injuries are currently the leading cause of death for children and young adults at the age of 5-29 years [6, p. 3]. In this regard, the situation of road injuries in Ukraine should be defined as critical, because, in addition to the fact that in our country the first and main cause of death of adolescents and young people at the age of 15-24 is death in road accidents [7], in addition, every third a child among the victims of an accident dies while in the status of passengers. This means that most often the cause of their death is the fault of relatives and friends. In some other age categories, accidents also occupy leading positions among unnatural causes of death or deaths from external causes. Thus, among young people at the age of $25-29$, this is the second leading cause of death [7].

It is interesting to trace the dynamics of road traffic injuries according to the $\mathrm{WHO}$, which covers the period from 2009 to the present. Thus, in terms of deaths due to road traffic injuries in Europe in 2009, the top ten countries in this area were nine post-Soviet countries, among which Ukraine ranked fifth, behind Kazakhstan, Russia, Kyrgyzstan, and Lithuania. [8, p. 23]. Thus, if the countries of Northern Europe were characterized by one of the lowest mortality rates in the region and the world (on average 5.7 per 100, 000 people), the average accident mortality rate in the above countries was almost four times higher (21.8 per 100,000 people). It was highest in Kazakhstan (30.6 per 100,000 people), followed by Russia (25.2 per 100,000 people), Kyrgyzstan (22.8 per 100,000 people), Lithuania (22.4 per 100,000 people) and Ukraine (21.4 per 100,000 people) [8, p. 12]. In 2018-2019, the WHO noted a significant reduction in mortality on European roads. However, as before, Ukraine ranks sixth among dysfunctional countries, behind Armenia, Georgia, Kazakhstan, Moldova, and Russia [9]. At the same time, if we compare the indicators of human losses during road accidents in Ukraine and the average in the European Union per 100,000 people in 2019, in these countries this figure is 5 deaths, while in Ukraine the war reaches 12.9 people per 100,000 people $[10,11]$. A purely Ukrainian problem today is the frequent deaths of road accident victims at improperly equipped railway crossings. As a result, the WHO describes the situation in these countries as very unfavorable.

If it has resorted to specific losses of road accidents in terms of public health, every year in Ukraine there are about 160-170 such cases, in which 24-27 thousand people suffer. Thus, in 2019 , a total of 160,675 such cases were recorded. At the same time, 26,052 accidents were not without fatalities and/or injuries (3,454 people died and 32,736 were injured). Pedestrians made up one-third of the deaths. 168,107 road accidents were registered during 2020 . Of these, 26,140 road accidents were with fatalities and injuries. (3,541 and 31,974 people, respectively) [12] However, according to the analysis of the National Police, the main types of non-compliance with traffic rules in Ukraine have remained unchanged for years, leading to mortality and injuries, such as violation of maneuvering rules - $22 \%$, speeding - $34 \%$, non-compliance with the distance $-8 \%$, violation of the intersection rules, pedestrian crossings $-8 \%$, violation of pedestrian crossings' rules $-6 \%$, driving while intoxicated up to $4 \%$, etc. [4]. In total, they accumulate for more than $80 \%$ of accidents.

The authors of the paper conducted a survey of the population of Ukraine on the state of compliance with traffic rules found that more than a quarter of respondents (25.7\%) during 2016 - the first half of 2021 were involved in road accidents, often in the status of a driver (54.2\%) or passenger $(16.7 \%)$.

Given the significant proportion of accidents involving passengers, the survey asked about the use of seat belts by such road users in a vehicle. The fact that $20.4 \%$ of people use such means of security from time to time is threatening, and $7.5 \%$ do not use it at all. Such behavior is evidence of a lack of legal awareness, which even borders on legal nihilism, manifestations of which are especially dangerous in situations when in a vehicle there is also a child next to such an adult. Such reckless behavior probably has its explanation, if we compare this respondents' answer about the importance of legal awareness of citizens in road safety. Thus, $72.1 \%$ emphasized that the role of legal awareness is the most important for road safety. However, $19.9 \%$ of respondents noted that its role in this process is insignificant; another $8 \%$ believe that legal awareness does not matter at all. In our opinion, without a doubt, the unsatisfactory level of legal awareness correlates with the general state 
of road safety in Ukraine and is a significant socio-legal problem, the existence of which in the Ukrainian state is a direct threat to public health and a constant source of deterioration maintaining an unfavorable trend with the level of criminally punishable violations of traffic rules.

In this regard, it is interesting to analyze the risks that, in the opinion of the respondents, including those with insufficient legal awareness, threaten them when they are in the status of road users. Among these are speeding (72.1\%); driving while intoxicated (72.7\%); violation of the rules of the intersection, pedestrian crossings (51.3\%); violation of maneuvering rules (49.3\%); distractions for drivers (mobile devices, road advertising, etc.) (40.7\%); fake driver's licenses (19.3\%); failure to ensure the safety of passengers of the vehicle (4.7\%), etc. In this regard, we should agree with the opinion that most of these reasons are related to the disregard of drivers and other road users of the established traffic rules [13, p. 132]. In exchange, this situation on the roads leads to the need to analyze the level of traffic crime in Ukraine.

Analysis of criminal law statistics of motor vehicle crimes shows a huge jump in these offenses in 2014 (by $113.13 \%$ compared to the previous year) (from 11,589 to 24,700 crimes). In 2016, their number reached a maximum of 26,170 . In 2017, there is a decrease in them $(2018-17,485$; 2019 - 17,210; 2020 - 15,795). At the same time, 20-22\% of victims die as a result of these offenses [14].

Returning to the results of our survey regarding the respondents' assessment of the situation of possible risks that may threaten them on the roads, it is very surprising that none of the respondents mentioned the quality of pre-hospital care in case of an accident, as well as the state of medical care and social assistance in the event of disability due to an accident or loss of a breadwinner. According to experts, the cost of medical care and rehabilitation is so significant that the damage to society can reach $3 \%$ of gross domestic product $[15 ; 16]$. Together in the literature, it has been repeatedly emphasized that it is essential to provide access to immediate health services due to a threat to health or life and to provide specialist rehabilitation for road accidents casualties in the post-accident phase $[1 ; 20 ; 21]$.

This aspect is especially important because in Ukraine many road accident victims die due to the lack of medical staff skills to provide emergency care according to the standards of so-called disaster medicine. This situation is a reflection of the state of social, legal, and moral-psychological anomie of Ukrainian society, in connection with which this problem attracts the attention of the public, scientific community, and the state and forces the state to take permanent measures to protect road users. It is aimed, in particular, at the Strategy to increase road safety in Ukraine until 2024, which aims to reduce high mortality, injuries, material costs due to accidents by at least $30 \%$ by 2024 , reducing the severity of their consequences for road users and reducing socio-economic costs; and introducing an effective road safety management system to protect the lives and health of the population.

Similarly, none of the respondents considers as a risk for themselves and other cases of leaving victims without assistance from the perpetrators of the accident. However, criminal law statistics show that during 2019, under Article 135 of the Criminal Code (Leaving in danger), 221 proceedings were initiated, in $2020-217$. Moreover, the vast majority of these criminally punishable offenses are related to leaving the driver, injured in an accident, without the necessary assistance.

The phenomenon of road injuries must be analyzed not only in retrospect but also given the huge socio-economic damage caused to society due to premature mortality of employable people who died or became disabled as an accident's result. Damage to human resources from accidents has its own dimension, its own price. This "price" can be determined based on a universal international system of calculating the years of lost potential life due to premature death (Years of Potential Life Lost, hereinafter - YPLL [22, pp. 3-33]) and non-compliance with society and the state in the form of domestic gross product (hereinafter - GDP).

By the way, this system of calculations has proved itself well in determining the corresponding losses from premature death due to suicidal behavior, drug use, and any accidents. Concerning road accidents, the WHO states that relevant information on losses in monetary terms is not provided to Ukraine [8, p. 156], although in fairness it should be noted that Ukraine refers to the calculations of the World Bank, according to which the socio-economic losses of our country from road traffic injuries are estimated at almost 70 billion UAH per year, which is about $2 \%$ of GDP [23]. Therefore, to clarify these data using the YPLL method, we will determine at least the losses for the state and society from the deaths of road accident victims in 2020.

Our calculations showed that the total number of YPLLs for men who died in road accidents in Ukraine in 2020 is $73,660.82$ years, and the working-age $-68,158.5$. As for women, the corresponding figures are $24,378.4$ and $14,518.5$ years, respectively. In general, the quantity of YPLLs for men and women killed in road accidents in Ukraine is 98,039.22, and amount of working years is 82,677 (Table I).

The volume of the gross domestic product due to the premature death of road accident victims was determined by calculating the number of years under retirement age and the value of annual income per capita. In 2020, the value of the latter indicator was 3,725.6 USD per person [17]. Our calculations show that if there were no premature death, then during the relevant part of working life, men who died in road accidents only in 2020 could produce a gross domestic product in the amount of $253,931,308$ USD. In turn, the shortfall of the state and society's GDP due to the death of women in road accidents (during their working life) reaches 54,224,245.2 USD. And in total, these losses for Ukraine from death in 2020 in road accidents of all persons are equal 308155553 USD (Table II).

To this should be added the costs borne by the state and society due to the need to maintain the disabled, orphans, elderly parents left without care, cost of burial, treatment, social rehabilitation and prosthetics, and so on. We empha- 


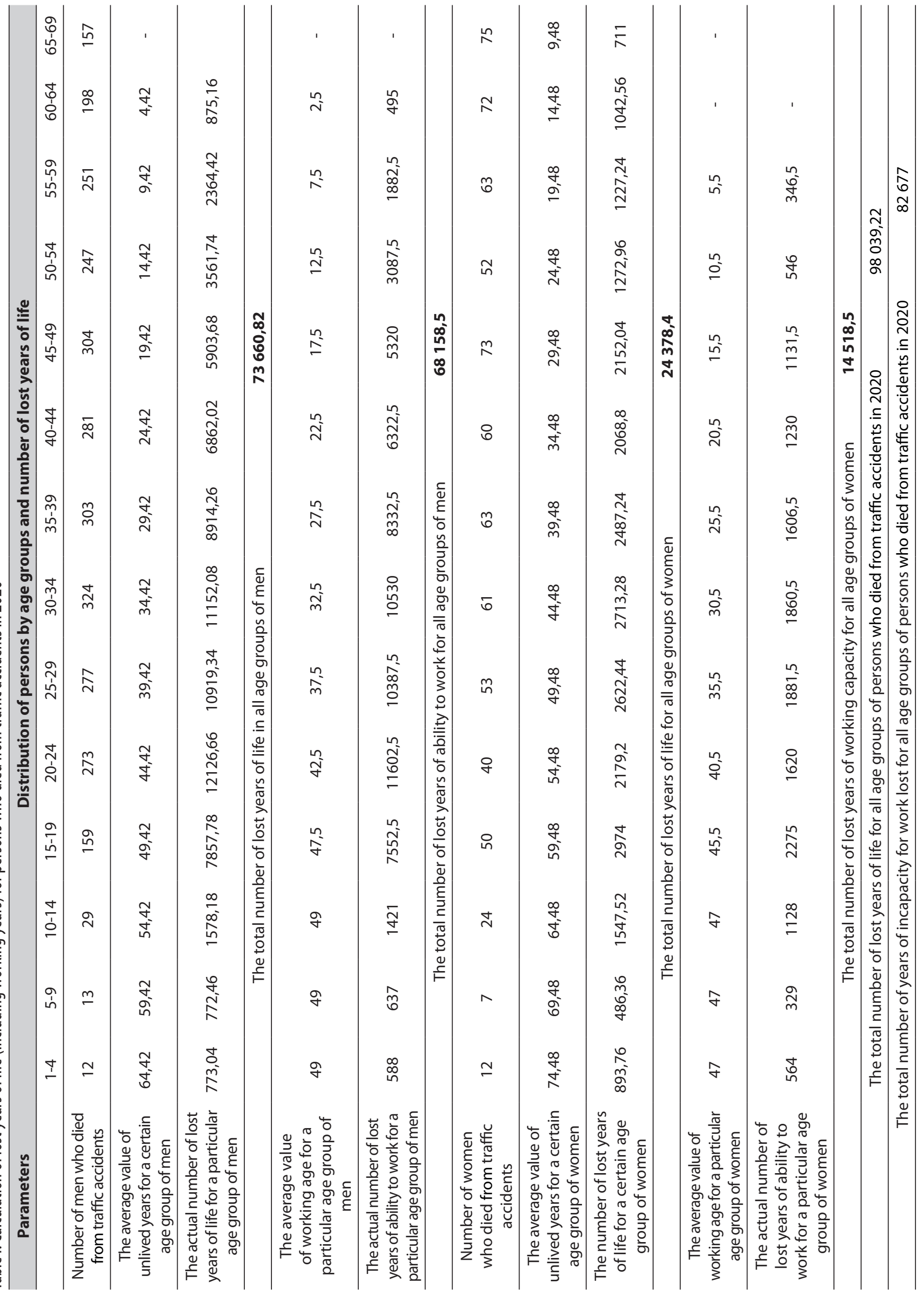




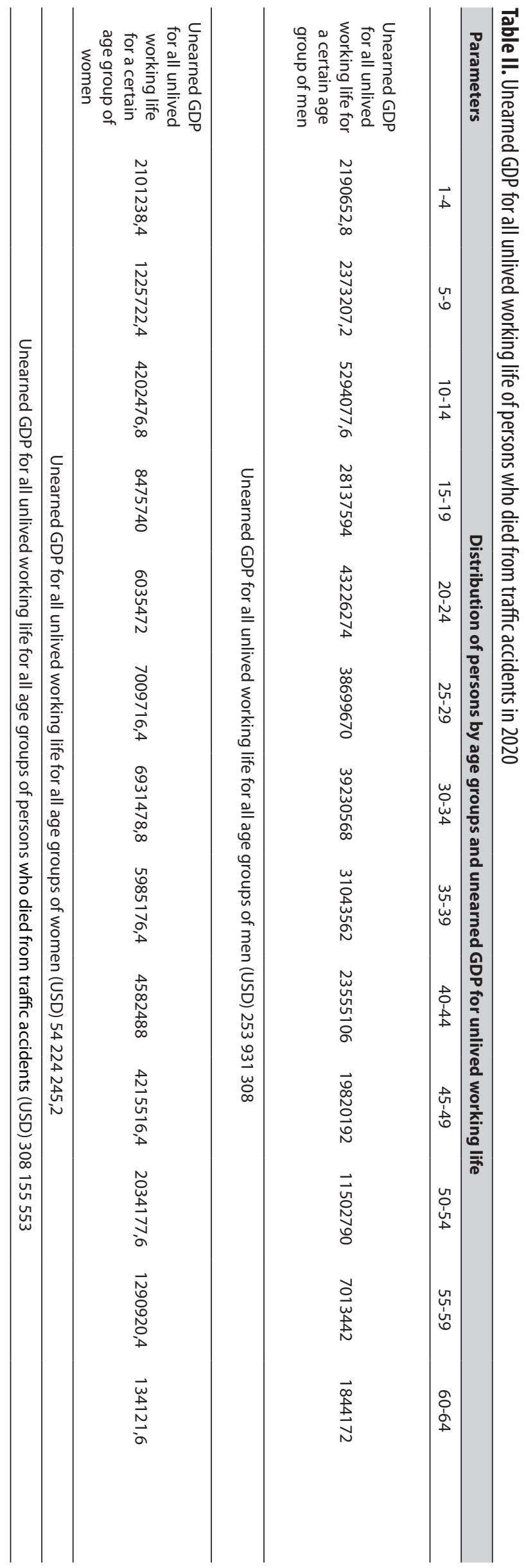


size once again that this also leads to an annual loss of GDP, as indicated by foreign scholars [18, pp. 25-34; 19]. By the way, when we applied to the Ministry of Health of Ukraine, we were unable to obtain information on the number of people who received a disability due to an accident.

\section{DISCUSSION}

The problem of differences in the statistical accounting of persons injured in road accidents, which exists both in Ukraine and in the world as a whole, needs further study. For example, in Ukraine, at least three government agencies maintain similar statistics, namely the State Statistics Service of Ukraine, the Office of the Prosecutor General, and the National Police of Ukraine. Due to the specifics of accounting for road accidents and victims, this information may differ too much, which was pointed out by Ukrainian scientists N. Gutorova and O. Rudneva. However, such differences exist in other countries. Therefore, we should agree with the conclusion of experts that the development of measures to combat mortality and injury resulting from traffic accidents should be based on statistical information provided by WHO experts [24, p. 2]. Therefore, one of the urgent tasks in solving the problem of reducing mortality and injuries on the roads of the European space should be the development of a unified methodology for calculating accidents.

To stop the negative dynamics of road accidents and improve the situation with road injuries in Ukraine can prevent action, the measures of which would have a positive impact on legal nihilism, morally impaired consciousness, will, and emotions of potential offenders, forcing them to strictly follow traffic rules. Thus, in the Ukrainian realities such should be the culturological precautionary direction, restraining potential of which consists of measures and means of normative-legal, modern technical, organizational-administrative, etc. character [25]. In addition, the hypothesis is that a significant restriction of personal benefits for the vast majority of drivers is the permanent or long-term deprivation of the right to drive a vehicle, which will force these road users to change radically their attitude to traffic rules. Therefore, there is an urgent need to develop as soon as possible both theoretical issues and applied aspects of culturological direction of road injury prevention with the accompanying solution of problems to make appropriate changes and additions to current legislation in the field of road safety, improvement of disaster medicine personnel, etc. It is these ideas that should underpin the national approach to improving the catastrophic situation on Ukraine's roads.

\section{CONCLUSIONS}

The goals declared in international and national documents, the statement of which follows from the analysis of the catastrophic situation in this area in some regions of the world and countries, put the use of decisive and radical action to prevent both the offense and the consequences of road accidents on the agenda. What has been said directly applies to Ukraine as well. After all, in Ukraine, road accidents, being a significant cause of death and disability, are a significant threat to public health, which forces us to define this situation as a serious socio-legal and criminological problem of Ukrainian society. This is because today the first and main threat to the human potential of Ukraine, represented at the age of 15-24, is death in an accident. In the age group of 25-29, death from such cases also occupies a leading position among the external causes of death, second only to intentional self-harm (suicide). Every third child among the victims of the accident dies in the status of passengers, which indicates the guilt of relatives and friends in their deaths. The statistics of criminally punishable offenses have not yet shown a tendency to a steady decline in the number of such offenses. In addition, there are often cases when persons injured in an accident from the driver are left without the necessary assistance.

The death of people as a result of road accidents causes huge material and human losses to Ukraine. Thus, the amount of YPLLs due to premature death in 2020 is $98,039.22$ years, and the number of working years - 82,677. In material terms, the loss of unlived life is almost 308,155,553 US dollars. This damage is caused primarily by the death of men of working age.

An unsatisfactory state of legal awareness of Ukrainian citizens is a direct threat to public health and a source of the perpetuation of the generally unfavorable trend with the level of criminally punished violations of traffic rules. In this regard, the national approach to improving road safety needs to be reconsidered.

One of the key directions of the national approach to the implementation of the tasks of the Second Decade of Action to ensure road safety (2021-2030), and therefore an important task of the Ukrainian state is to create a service of specialized emergency care according to world standards of so-called disaster medicine and ensure rehabilitation victims of road accidents from the stage of the accident to the restoration of health to the extent possible.

\section{REFERENCES}

1. Burzyńska M, Pikala M. Decreasing Trends in Road Traffic Mortality in Poland: A Twenty-Year Analysis. International Journal of Environmental Research and Public Health. 2021; 18(19):10411. https://doi. org/10.3390/ijerph181910411

2. Derzhavna prohrama pidvyshchennia rivnia bezpeky dorozhnoho rukhu v Ukraini na period do 2020 roku [State program to increase the level of road safety in Ukraine for the period up to 2020]: zatv. postanovoiu Kabinetu Ministriv Ukrainy vid 25 kvitnia 2018 r. № 435. Ofitsiinyi visnyk Ukrainy. 2019. № 100. St. 3348 (in Ukrainian).

3. Stratehiia pidvyshchennia rivnia bezpeky dorozhnoho rukhu v Ukraini na period do 2020 roku [Strategy to increase the level of road safety in Ukraine until 2020] : skhvalena rozporiadzhenniam Kabinetu Ministriv Ukrainy vid 14 chervnia 2017 r. № 481. Ofitsiinyi visnyk Ukrainy. 2017. № 59. St. 1808 (in Ukrainian).

4. Stratehiia pidvyshchennia rivnia bezpeky dorozhnoho rukhu v Ukraini na period do 2024 roku [Strategy to increase the level of road safety in Ukraine until 2024] : skhval. rozporiadzhenniam Kabinetu Ministriv Ukrainy vid 21 zhovtnia 2020 r. № 1360-r. Uriadovyi kurier. 2020. 4 lystop. № 214 (in Ukrainian).

5. Death on the roads. Available from: https://extranet.who.int/ roadsafety/death-on-the-roads [reviewed 2021.08.01]. 
6. Global status report on road safety 2018: summary. Geneva: World Health Organization, 2018. 20.

7. Pryrodnyi rukh naselennia za 2020 rik. Statystychnyi zbirnyk [Natural population movement in 2020. Statistical bulletin]. Kyiv: Derzhavna sluzhba statystyky Ukrainy, 2021. Tabl. 26 (in Ukrainian).

8. Evropeiskyi doklad o sostoianyy bezopasnosty dorozhnoho dvyzhenyia [European report on road safety]. Kopenhahen: Vsemyrnaia orhanyzatsyia zdravookhranenyia, Evropeiskoe rehyonalnoe biuro, 2009. 173. (in Russian).

9. 2018/2019 Road-traffic fatality data for WHO European Region. Available from: https://www.euro.who.int/__data/assets/pdf_ file/0006/440763/2018-2019-road-traffic-fatality-data.pdf

10. 2019Road Safety Statistics:What is Behind theFigures? European Commission: Brussels, Belgium, 2019. Available from: https://ec.europa.eu/commission/ presscorner/detail/en/qanda_20_1004 [reviewed 2021.08.01].

11. Poiasniuvalna zapyska do proiektu postanovy Kabinetu Ministriv Ukrainy «Pro zatverdzhennia Derzhavnoi prohramy pidvyshchennia rivnia bezpeky dorozhnoho rukhu v Ukraini na period do 2023 roku» [Explanatory note to the draft resolution of the Cabinet of Ministers of Ukraine «On approval of the State program to improve road safety in Ukraine until 2023»]. Available from: https://mtu.gov.ua/projects/317/ (in Ukrainian).

12. DTP v Ukrayne: skolko chelovek travmyruetsia y hybnet na dorohakh [Accidents in Ukraine: how many people are injured and die on the roads]. Available from: https://ru.slovoidilo.ua/2021/07/21/infografika/ obshhestvo/dtp-ukraine-skolko-chelovek-travmiruetsya-i-gibnetdorogax (in Ukrainian).

13. Blahodyr V. S., Blahodyr S. M. Pytannia vdoskonalennia diialnosti patrulnoi politsii shchodo zabezpechennia bezpeky dorozhnoho rukhu [The issue of improving the activities of the patrol police to ensure road safety]. Pravo i suspilstvo. 2021;1:132-138 (in Ukrainian).

14. Yedynyi zvit pro kryminalni pravoporushennia za 2014-2020 roky [The general report on criminal offenses for 2014-2020]/ Ofis Heneralnoho prokurora. Available from: https://www.gp.gov.ua/ua/1stat (in Ukrainian).

15. Road traffic injuries. Available from: https://www.who.int/news-room/ fact-sheets/detail/road-traffic-injuries

16. Schoeters, A., Wijnen, W., Carnis, L. et al. Costs related to serious road injuries: a European perspective. Eur. Transp. Res. Rev. 2020; 12: 58. doi:10.1186/s12544-020-00448-0

17. Valovyi vnutrishnii produkt [Gross Domestic Product]. Available from: https://index.minfin.com.ua/economy/gdp/2020/ (Ua).

18. The High Toll of Traffic Injuries: Unacceptable and Preventable. World Bank: Washington, DC, USA, 2017/ 103 p.

19. Wim Wijnen Socio-economic costs of road crashes in middle-income countries: Applying a hybrid approach to Kazakhstan. IATSS Research. 2021;3:293-302. doi: 10.1016/j.iatssr.2020.12.006.

20. Van der Vlegel M, Haagsma JA, de Munter L, de Jongh MAC, Polinder S. Health Care and Productivity Costs of Non-Fatal Traffic Injuries: A Comparison of Road User Types. Int J Environ Res Public Health. 2020;17(7):2217. doi: 10.3390/ijerph17072217.

21. Enoch F. Sam, David K. Blay, Samuel Antwi, Constance Anaafi and Juliet A. Adoma (July 19th 2019). Pre-Hospital and Trauma Care to Road Traffic Accident Victims: Experiences of Residents Living along Accident-Prone Highways in Ghana, Emergency Medicine and Trauma, Ozgur Karcioglu and Müge Günalp Eneyli, Intech0pen, DOI: 10.5772/intechopen.86118. Available from: https://www.intechopen.com/chapters/68200
22. YPLL calculated as the sum of the differences between a predetermined end point and the ages of death for those who died before that end point. Principles of Epidemiology in Public Health Practice: Self-study Course SS1978. Third Edition. Atlanta: U.S. Department of Health and Human Services, 2006 (Updated May 2012). 511.

23. Vtraty Ukrainy cherez DTP otsinyly v 2\% VVP [Ukraine's losses due to road accidents were estimated at $2 \%$ of GDP]. Available from: https:// ua.korrespondent.net/ukraine/4271930-vtraty-ukrainy-cherez-dtpotsinyly-v-2-vvp (in Ukrainian).

24. Gutorova N., Rudnyeva 0. Preventative role of criminal law for traffic safety. Society. Health. Welfare. SHS Web of Conferences 68, 01012 (2019). doi:10.1051/shsconf/20196801012.

25. Golina V.V. Kultorohichnyi napriam pidvyshchennia rivnia bezpeky dorozhnoho rukhu v Ukraini [Culturological direction of increasing the level of road safety in Ukraine]. Hromadianske suspilstvo yak chynnyk modernizatsii suchasnoi derzhavy: materialy Mizhnar.nauk.-prakt. konf. (m. Kyiv, 20 kvit. 2021 r.). Kyiv, 2021:217-220 (in Ukrainian).

The scientific article was prepared for the fundamental study Academician Stashis Scientific Research Institute for the Study of Crime Problems National Academy of Law Sciences of Ukraine "Crime prevention Strategy in the field of traffic and transport exploitation in Ukraine» (the registration number 0120U105615).

\section{ORCID and contributionship:}

Vladyslava S. Batyrgareieva: 0000-0003-3879-2237 ${ }^{A, B, D, E, F}$

Sabriie S. Shramko: 0000-0002-4453-9118 B,C

Olena M. Samoilova: 0000-0001-8209-3762

\section{Conflict of interest:}

The Authors declare no conflict of interest.

\section{CORRESPONDING AUTHOR Vladyslava S. Batyrgareieva}

Academician Stashis Scientific Research Institute

for the Study of Crime Problems of the

National Academy of Law Sciences of Ukraine,

Kharkiv, Ukraine

tel. +380505830788

e-mail: vladis2229@yandex.ru

Received: 10.06 .2021

Accepted: 15.10 .2021

A - Work concept and design, B - Data collection and analysis, C - Responsibility for statistical analysis, D - Writing the article, $\mathbf{E}$ - Critical review, $\mathbf{F}$ - Final approval of the article 


\title{
MEDICAL CONFIDENTIALITY DISCLOSURE IN CONDITIONS OF EPIDEMIC THREATS
}

DOI: 10.36740/WLek202111203

\author{
Tetiana 0. Mykhailichenko ${ }^{1}$, Oksana P. Horpyniuk², Victor Yu. Rak ${ }^{3}$ \\ 'POLTAVA LAW INSTITUTE OF YAROSLAV MUDRYI NATIONAL LAW UNIVERSITY, POLTAVA, UKRAINE \\ ¿LVIV STATE UNIVERSITY OF INTERNAL AFFAIRS, LVIV, UKRAINE \\ ${ }^{3}$ M.V. SKLIFOSOVSKY POLTAVA REGION CLINICAL HOSPITAL, POLTAVA, UKRAINE
}

\begin{abstract}
The aim: To establish public opinion on the limits of medical confidentiality in an epidemic and the widespread use of applications that contain personal data, including those regarding health, to understand the possibility of changing the paradigm of public policy to protect medical confidentiality in an exacerbation of the epidemic situation. Materials and methods: This research is based on regulatory acts, scientific articles, and opinions of both medical workers and ordinary citizens of Poland, Germany, and Ukraine, judicial practice, doctrinal ideas, and views on this issue. Such methods as dialectical, comparative, analytic, synthetic, comprehensive, statistical, and generalization. Results: the results of a survey of residents of Poland, Germany, and Ukraine showed that one of the pandemic consequences was that a significant number of respondents were willing to partially renounce the right to medical confidentiality in the face of exacerbating epidemic threats to reduce the number of infected.

Conclusions: In the face of the SARS-Cov-2 virus, nations worldwide have faced the challenge of respecting the right to privacy, particularly in terms of medical confidentiality. Virtual methods of patient communication with healthcare professionals use mobile electronic services (applications), and other new technologies in the context of the COVID-19 pandemic have exacerbated the issue of understanding the boundaries of medical confidentiality and personal data protection. In order to maintain an effective balance between human rights and public health, the mass collection and storage of sensitive personal data must take place following the Regulation of the European Parliament and of the Council on the protection of natural persons with regard to the processing of personal data and on the free movement of such data. At the same time, it is expedient to recommend states to specify specific provisions of this Regulation in order to avoid an expanded interpretation of certain of its provisions.
\end{abstract}

KEY WORDS: public health, epidemic safe, medical confidentiality, personal data

Wiad Lek. 2021;74(11 p.2):2877-2883

\section{INTRODUCTION}

The concept of medical confidentiality has long been known to society ${ }^{1}$. Today, the postulate of prohibiting the disclosure of medical confidentiality is enshrined by the vast majority of countries and is part of the legal guarantees for the protection of human rights and freedoms. At the same time, the COVID-19 pandemic has exacerbated the eternal conflict facing people: individual vs. public interests? Furthermore, the question was raised: what are the limits of protecting confidential information about a person's illness in an epidemic/pandemic and the retention period of such information? A separate challenge was the rapid spread and use of various applications that contain personal data. So, it seems that today society is probably at the next stage of rethinking the boundaries of medical confidentiality

\section{THE AIM}

The purpose of this article is to establish public opinion on the limits of medical confidentiality in the face of epidemic threats exacerbation ${ }^{2}$ and rapid spread of the use of various applications that contain personal data, including the state of individual's health. This may be the basis for the possibility of changing the paradigm of state policy on the protection of medical confidentiality in an exacerbation of the epidemic situation

\section{MATERIALS AND METHODS}

This research is based on regulatory acts, scientific articles, and opinions of both medical workers and ordinary citizens of the Republic of Poland (hereinafter, RP), the Federal Republic of Germany (hereinafter, FRG), and Ukraine. Additionally, judicial practice, doctrinal ideas, and views on this issue have been used. In order to achieve the goals were used a set of general and special scientific approaches as well as the series methods, namely: dialectical, comparative, analytic, synthetic, comprehensive, statistical, and generalization.

\section{RESULTS AND DISCUSSION}

The COVID-19 pandemic continues to actively change the face of the world, while more and more variants of this virus (SARS-CoV-2 Alpha, Beta, Gamma, Delta, Lambda) are 
constantly appearing [3]. In such a challenging environment, society faces a number of questions: 1 ) how to strike a balance between respecting the right to medical confidentiality in a pandemic and protecting public health, 2) what is prevalent in an epidemic/pandemic state: individual or public interests, 3 ) Is it appropriate in an epidemic/pandemic state not to disclose the fact of a particular person infection, 4) what are the limits of protection of medical information about a person's health, 5) what are the current threats of illegal use of personal data stored in various electronic databases? However, this list is not exhaustive, and addressing these issues requires lengthy discussions and in-depth research. Therefore, in our study, we limited the questions range to only three positions.

1. Medical confidentiality: the concept and liability for its disclosure. Medical confidentiality is a consequence of the development of civilization, and therefore its concepts and boundaries are closely linked to the level of development of society and its institutions. As it was successfully noted by Rieder Ph., Louis-Courvoisier M., Huber $\mathrm{Ph}$. "Medical confidentiality was and is today a medical and societal norm that is shaped collectively. Any change in its definition and enforcement was and should be the result of negotiations with all social actors concerned" [4]. On the one hand, medical confidentiality is a burden for medical personnel and, on the other hand, a guarantee of their work safety and the quality of its performance. Medical confidentiality is still and will be a matter of the health care system and an ethical dilemma. Its concepts, limits, and conditions of the disclosure are always in the focus of scientists [5-10].

At the international level, the doctor's duty to maintain confidentiality was enshrined by the World Medical Association in the Geneva Declaration (1948): "I will respect the secrets which are confided in me, even after the patient has died" [11]. But what is medical confidentiality? No international legal act contains a clear definition of this concept. At the same time, in each state, regulatory legislation contains provisions on medical confidentiality. In general, medical confidentiality meaning is "the principle of keeping secure and secret from others, the information given by or about an individual in the course of a professional relationship, and it is the right of every patient, even after death" [8]. Also, researchers and practitioners have now developed generally accepted recommendations on the limits of medical confidentiality and the rules of its disclosure [12].

However, health professionals and lawyers are constantly faced with dilemmas about the appropriateness of disclosing confidential health information and addressing the issue of liability for such disclosure. Each country has laws governing the collection, receipt, storage, use, dissemination, ensuring, and protection of confidential information, including the healthcare field. First of all, this right is protected by the Basic Laws of the states. For example, in Art. 51 of the RP's Constitution, Art. 32 of the Constitution of Ukraine, Art. 2 of the FRG Constitution. Also, this right is detailed and specified in other regulations. For example, in Ukraine, these are the Laws "On Information", "On Per- sonal Data Protection", the Fundamentals of Health Care Legislation, "On Psychiatric Care", the Civil Code, etc. In RP - The Patient Rights and Patients Ombudsman Act, The Medical Profession Act, The Civil Code Act, and Code of Medical Ethics which is not considered a legal act [9]. In FRG, the right of every individual to respect and respect for private and intimate spheres and to informational self-determination can be derived from the Basic Law in relation to the state vis-à-vis the citizen (Art. 1 I in conjunction with Art. 2 I GG), the (model) Professional Code of the German Medical Association (MBO), the German Civil Code, etc. [10, p. 290-291]. In addition, each of the states has criminal law provisions that prohibit the disclosure of medical confidentiality and determine the limits of punishment of a person who commits such an offense. In particular, in the Penal Code of RP, it is Art. 266, in the Criminal Code (hereinafter, CC) of Ukraine - Art. 132 and Art. 145, in the CC of FRG - Section 203. How often are convictions handed down for these offenses? Quite rarely. Thus, for example, according to the Unified State Register of Judgments of Ukraine, only one sentence was passed under Art. 132 of the Criminal Code of Ukraine (judgment of the Central District Court of Simferopol dated 22.01.2013, case № 122/9610/2012) on the disclosure of medical confidentiality [13].

Some cases have also been considered by the European Court of Human Rights (for example, "Panteleyenko v. Ukraine" (Application no. 11901/02) 29.06.2006, "L.L. v. France" (Application no. 7508/02) 10.10.2006, "Armonas v. Lithuania" (Application no. 36919/02) 25.11.2008, "Biriuk v. Lithuania" (Application no. 23373/03) 25.11.2008, "Avilkina and Others v. Russia" (Application no. 1585/09) 06.06.2013, "L.X. v. Latvia" (Application no. 52019/07) 29.04.2014, "Konovalova v. Russia" (Application no. 37873/04) 09.10.2014, "Sidorova v. Russia" (Application no. 35722/15) 28.05.2019 etc.

The question of the expediency of using the terms "doctors secret" and "medical confidentiality" is also debatable today. Researchers claim that doctors' secret is a more slang term, and the wording of medical confidentiality is more appropriate because not only doctors but also other healthcare professionals and staff are in contact with patients during treatment. Thus, the scope of people who are in touch with the information that they are obliged to keep as a secret of the patient is not limited to the doctor only [14, p. 206]. We could agree with this caveat because "doctors secret" is a subjectively narrower concept. Instead, "medical confidentiality" fully reflects the reality, encompassing not only doctors but also junior medical staff and persons who have become aware of confidential information in connection with the performance of professional or official duties.

In order to protect the rights of patients and medical professionals (also including from state's interference), the legislation prescribes cases when the disclosure of medical confidentiality is lawful. Usually, a person can disclose confidential information if 1) the individual has given consent, 2) the information is in the public interest (that is, the public is at risk of harm due to a patient's condition), 

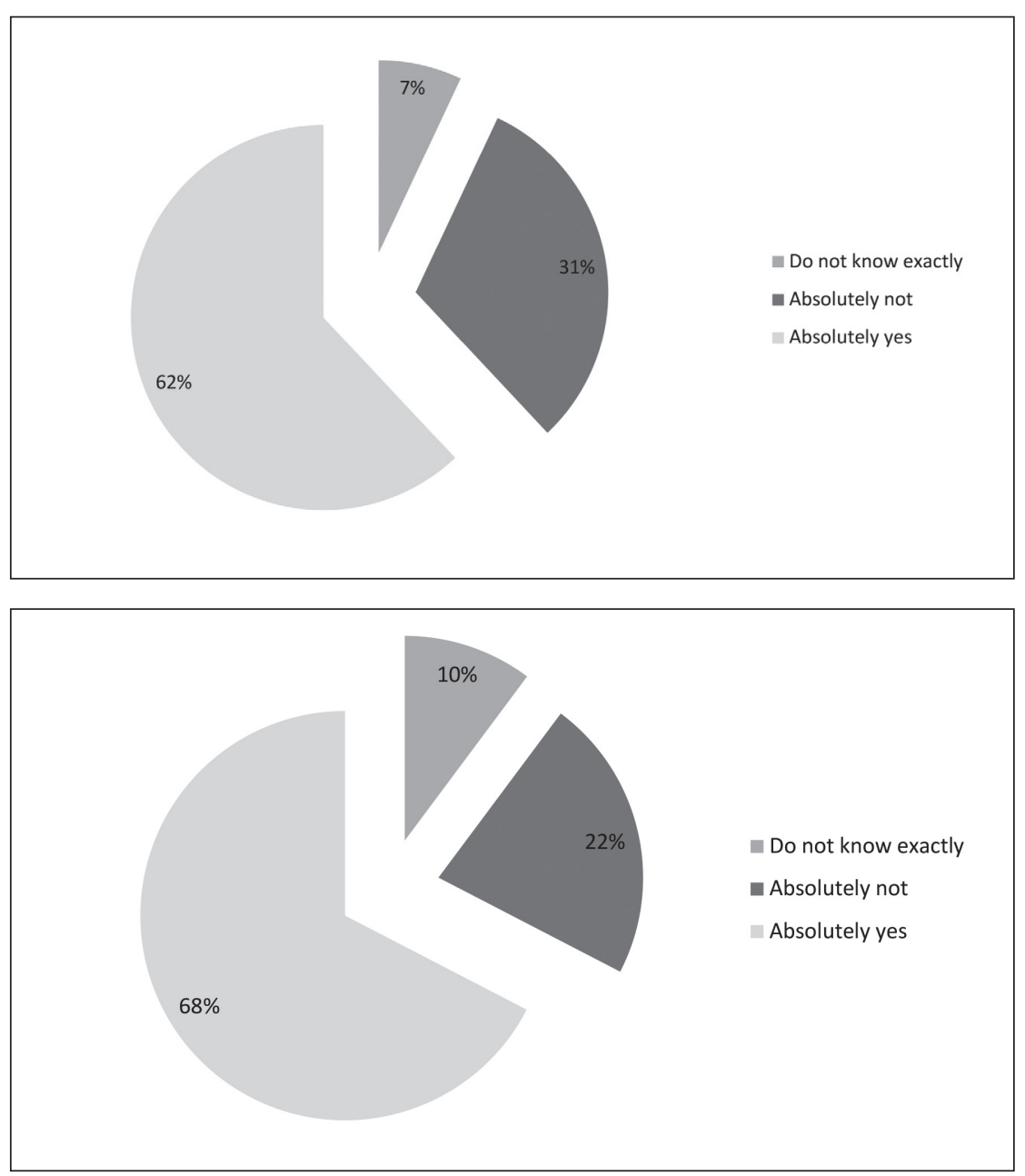

Fig. 1. The answer of the respondents of the second group regarding the disclosure that the person is ill, in the epidemic conditions

Fig. 2. The answer of the respondents of the first group regarding the disclosure that the person is ill, in the epidemic conditions
3) disclosure is compelled by law (often public risk issues are covered by laws that compel disclosure, such as for positive test results for HIV/AIDS) and 4) the information is in the public domain already [15]. Exactly the second exception is of interest in our study. As the authors of the publication emphasize, "You may disclose information to prevent 'serious or imminent threat to the life or health of the individual concerned, or another. An example is if you become aware of information that could result in a disease epidemic" [15]. So, the logical question arises: is it advisable for a healthcare professional to keep a secret of the fact of person's infection in an epidemic/pandemic?

2. The expediency of medical confidentiality in the face of epidemic threats. Today, there seems to be a need to review or confirm the current limits of medical confidentiality. We may not focus on the time of Hippocrates when only one doctor examined the patient. Today, in addition to health workers, access to medical information is available to a number of others through the introduction of health insurance, active digitalization of society (electronic data storage systems, mobile applications) [16], and most importantly - modern society is faced with the rapid and hard-to-control spread of coronavirus infection. SARS-CoV-2 and its strains.

As already noted, the concept of medical confidentiality and its boundaries are changing along with the development of our society [3]. In such circumstances, it seems appropriate to raise the question: will the COVID-19 pandemic become the driving force that will once again change the boundaries of medical confidentiality. We surveyed residents of Ukraine, Poland, and Germany: medical workers (Group I, 100 people) and ordinary citizens (Group II, 300 people) on a number of issues. And this poll seems to have shown that a pandemic could be another starting point for a new paradigm.

Thus, answering the question "Do you consider it permissible to disclose data that a person is sick in an epidemic" only $31 \%$ of respondents in group II replied, "categorically no". Another $7 \%$ did not have an exact answer to this question. Furthermore, as many as $62 \%$ agreed because it can help reduce the infection spread. It is noteworthy that from this group, $49.7 \%$ of people had coronavirus infection, $28.3 \%$ - not, $21.4 \%$ - do not know exactly, and $0.6 \%$ did not want to answer this question. At the same time, when surveying health professionals regarding the question "Do you consider it permissible to disclose data that a person is sick in an epidemic" $22.4 \%$ answered "absolutely not", $10.2 \%$ - do not know the answer to this question and 67, $4 \%$ of respondents consider it appropriate. That is, in general, $61.7 \%$ of respondents understand the need to change the view on the limits of strict protection of medical confidentiality in the face of epidemic threats, which is clearly seen in the diagrams below. (Fig. 1 and 2). 


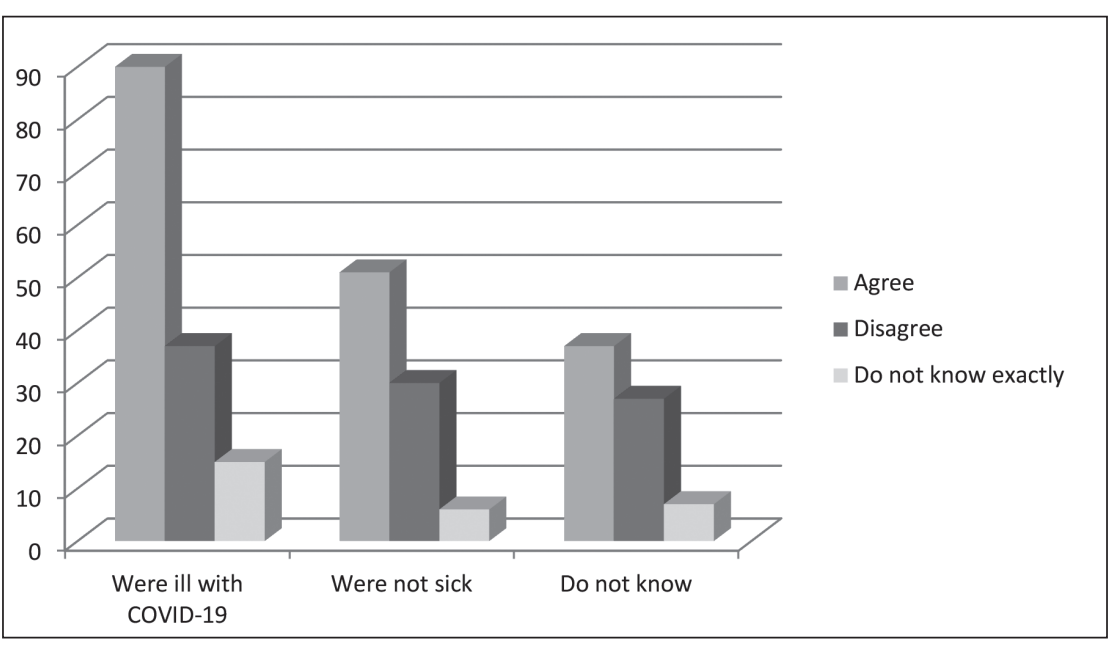

Fig. 3. Correlation between the presence of the disease and the attitude towards disclosure
Respondents from regional centers, district centers, and rural areas were involved in the survey of both medical professionals and ordinary citizens. And 66.7\% (64 people) of surveyed health professionals live in regional centers. From their total number answering the question: "Do you consider it permissible to disclose data that a person is ill in an epidemic?" $72 \%$ of respondents answered affirmative, $20 \%$ of respondents were categorically against the disclosure, and the rest chose "I do not know". Representatives of medical professionals from district centers and rural areas were $33.3 \%$ ( 36 people). Of these, $67 \%$ of respondents believe that information about sick people should be available in an epidemic, $5.5 \%$ voted against such an approach, and $27.5 \%$ had no answer.

$75.3 \%$ of Group II respondents (230 people) live in regional centers. Of their total number, $56.5 \%$ are convinced that disclosing medical secrets in the face of epidemic threats will help reduce the number of infected people, $33 \%$ believe that this is unacceptable, and $10.5 \%$ chose the option "I do not know". The number of respondents from district centers and rural areas is $24.7 \%$. At the same time, out of 70 people, $83 \%$ voted for the dissemination of information, $11 \%$ (8 people) - categorically against disclosure, and $6 \%$ did not decide on the answer.

In general, we see that the vast majority of respondents from rural areas, district centers, and regional centers believe that the disclosure of medical confidentiality in the face of epidemic threats is justified, while residents of rural areas and small towns are more inclined to the necessity of disclose.

In our opinion, such results can be explained by: 1) a smaller population in district centers and rural areas, which results in 2) closer ties between the inhabitants of these settlements and 3) faster dissemination of information.

In general, this thesis is confirmed by the following information: most often, the expediency of disclosure is emphasized by those respondents of group II who became ill with COVID-19 (63.38\%), while the lowest percentage of those who are committed to "concessions regarding the right to medical confidentiality" does not know whether they were sick (52.11\%). At the same time, regardless of the category of respondents, the majority still agree with the expediency of disclosure in order to reduce the infection spread rate. Correlation between the presence of the disease and the attitude towards disclosure is presented in Figure 3.

It is clear that in order to adjust the current regulative provisions, one should first conduct a large-scale opinion poll and evaluate all the pros and cons of such changes. However, on the other hand, the results of our survey seem indicative and may form the basis of further, more in-depth research.

3. Use of applications to control the epidemiological situation and the issue of relevant personal data storing. As a result of the coronavirus pandemic, states have begun using a variety of programs to communicate with medical staff and patients, monitor their health, and people's compliance with self-isolation through the use of mobile services and cell phone surveillance software. Appropriate software has been developed to monitor the symptoms of COVID-19, map the population movements, monitor contacts of infected persons, execute quarantine orders, etc. In turn, this has caused the need to ensure the confidentiality of medical data and proper cybersecurity of relevant software and mobile services (applications), which is now actively discussed in society [17-18; 19, pp. 27-31]. Australia, China, Israel, Norway, Singapore, and South Korea were among the first to introduce mobile-based contact tracking. In the United States, there is a need to remove restrictions on access to communication programs for specific categories of people, so it was allowed to use Apple FaceTime, Facebook Messenger, Google Hangouts, Zoom and Skype, etc., for communication. [17]. RP launched the Kwarantanna Domowa mobile service. In Ukraine, for citizens crossing the state border, a mobile application of the electronic service "Act at home" was also introduced [22].

At the same time, it should be noted that the degree of interference with a person's privacy or the level of tracking of persons in need of self-isolation through mobile services varies among the countries. Due to the general privacy policy in the countries of the Asian region, stricter 
control over the population has been established there. For example, in Singapore, the Trace Together application was created, which not only monitors a person's compliance with the self-isolation mode but also records the phones of people with whom the person who installed the application is in contact via Bluetooth. In China, the authorities did not develop any applications but instead tracked the movement of citizens via GPS coordinates or the use of bank accounts [23].

It should be emphasized that many human rights defenders, specialists in the field of law (N. Korshivsky [24], C. Veliz [18, p. 110], M. French, A. Guta, M. Gagnon, and others [25]) challenge the effectiveness of such applications to reduce the level of infection spread [18, p. 112]. Regarding the respondents of the first group, when asked about the effectiveness of using the mobile application of the electronic service to reduce the epidemic tension on a five-point scale, the majority (36\%) focused on mark three. At the same time, among the surveyed respondents of group II, the majority (46.5\%) indicated zero efficiencies of the mobile application. Such a response rather indicates a low awareness of the population about the primary purpose of implementation and the use of this electronic service or distrust of the government. In addition, this answer to the question about the effectiveness of the application is associated with a low percentage of use of this service because $76 \%$ of the respondents of group II indicated that they did not try the application.

Today, the threat to privacy from the uncontrolled use of personal data, including sensitive (vulnerable) personal data, should be noted through applications. It seems that they can be divided into three main types:

1. Threats of various kinds of abuse by the authorities and/or large private corporations. In the long run, the confidential data obtained during the pandemic period can be illegally used by both governmental and non-governmental organizations for marketing purposes to influence the behavior of active users of social networks, and so on $^{3}$. In addition, large technology companies now gain more power than government institutions.
2. Threats related to cybercrime: today, electronic systems of health care facilities that store personal medical information about patients and biometric data are under threat more than ever before. Although many people believe that biometric authentication systems cannot be hacked or tricked, biometrics is not as reliable as they think ${ }^{4}$.

3. Threats related to discrimination, undermining the reputation of certain ethnic groups or national minorities $^{5}$. After all, information about health and habits can be especially vulnerable in the case of employment and insurance [19, pp. 27-31]. Detection of disease through digital technology in certain religious or ethnic groups can also lead to various forms of harassment and violence. However, despite the existing threats to privacy, under certain conditions, namely the controlled use of mobile services, mobile phone tracking programs to identify risks of COVID-2019 infection and prevent this disease, the pandemic can be stopped, and they could be of help to physicians who fight the disease. After all, most of the respondents we interviewed, as noted, allow the disclosure of data on the disease of a person in an epidemic because it can help reduce the spread of infections. However, in order for users of mobile services to help stop the spread of diseases, states must ensure these programs to be user-friendly, the legality, clarity, and accessibility of the rules of processing and storage of personal data, their reliable protection.

The use of such mobile services must be strictly regulated. In particular, Regulation of the European Parliament and of the Council on the protection of natural persons with regard to the processing of personal data and on the free movement of such data, and repealing Directive 95/46/EC defines clear principles of personal data processing in automated systems, databases (Article 5): 'lawfulness, fairness and transparency', 'purpose limitation,' 'data minimisation', 'accuracy', 'storage limitation', 'integrity and confidentiality' and 'accountability' [27]. At that time, the poll showed that state officials often violate its requirements, which, in our opinion, may further exacerbate the conflict between individuals and government institutions.

\footnotetext{
${ }^{1}$ Traditionally, the cure for the medical secrecy concept development begins with the appearance of the Hippocratic oath. However, some researchers note that this concept earlier appeared in ancient India, where the rule was: "You can be afraid of a brother, mother, friend, but never - a doctor!” [1].

${ }^{2}$ Hereinafter we will talk about epidemic threats coming from viruses that are characterized by high virulence and contagiousness.

${ }^{3}$ For example, one of the most high-profile privacy scandals is related to Cambridge Analityca, when the company used the personal data of more than 87 million users to build psychological profiles of voters around the world to develop personalized political propaganda and election influence [18, pp. 108].

${ }^{4}$ For example, in 2011 Israeli authorities announced that the entire national biometric database they owned had been stolen, along with information on names, dates of birth, social security card numbers, family members, immigration dates, and medical records. of the Israelites. This information was stolen by a contractor and sold to a criminal corporation, which later made it fully available online in the digital underground. That provided additional opportunities for a wide range of crimes [26, p. 397].

${ }^{5}$ In South Korea, for example, cell phone tracking has been used to confirm the link between infections and a number of LGBT nightclubs, which has provoked a backlash against a marginalized group. And in Guangzhou, China, dozens of Africans have reported evictions and other discriminatory treatment due to misrepresentation of connection with COVID-19 [25]. ${ }^{6}$ The Norwegian National Data Protection Authority (Datatilsynet), which allowed data processing without depersonalization to track the smartphones of COVID-2019 contacts in case of impossibility to draw accurate conclusions, raised some reservations about maintaining a balance between privacy and protection of public health interests. [20]. It should be noted that among the respondents of the II group surveyed by us (ordinary citizens) $73.3 \%$ indicated that they were not informed about the purpose of collecting their personal data during COVID-19 and $66.7 \%$ did not consent to the processing of these data.

${ }^{7}$ The survey of respondents of group II showed that $89.2 \%$ did not aware of the subsequent use of personal information provided by persons during self-isolation through a mobile application. In addition, $81.1 \%$ of respondents indicated that they were not informed about the period of storage and deletion of the information provided. As for the retention period of the collected personal data, $39.8 \%$ believe that they should be deleted immediately after the end of self-isolation or recovery of the person; $22 \%-14$ days after the end of self-isolation or recovery; $19.5 \%$ - after the end of the active phase of the disease; another $18.7 \%$ - 30 days after the end of quarantine.
} 


\section{CONCLUSION}

Thus, it can be stated that virtual means of communication between patients and healthcare professionals, the use of mobile electronic services (applications), and other latest technologies in conditions of increased risk of infection have exacerbated the understanding of medical confidentiality and protection of personal data collected during the COVID-19 pandemic. The survey shows that a significant number of respondents recognize the expediency of disclosing the fact of infection of a person in the face of increased epidemic threats. However, mass collection of personal sensitive data and non-compliance with the Regulation of the European Parliament and of the Council on the protection of natural persons with regard to the processing of personal data and on the free movement of such data further may lead to exacerbation of social conflict. Therefore, we consider it appropriate to recommend that national governments to specify certain provisions of this Regulation (for example, on the amount of personal data collected, the retention period of such information, the procedure and timing of its destruction) in order to avoid broad interpretation of certain its provisions and to ensure a balance between private and public interests. Although previous polls show that society, in general, is ready to change the paradigm of public policy to protect medical confidentiality in the face of an epidemic situation escalation.

\section{REFERENCES}

1. Argunova YU. N. Prava grazhdan pri okazanii psikhiatricheskoj pomoshchi [The rights of citizens in the provision of psychiatric care]. Moskva: Grifon, 2014. 640 c. (Ru).

2. Tracking SARS-CoV-2 variants. WH0. Available from https://www.who. int/en/activities/tracking-SARS-CoV-2-variants/

3. Rieder Ph., Louis-Courvoisier M., Huber Ph. The end of medical confidentiality? Patients, physicians and the state in history. Med Humanit. 2016 Sep; 42(3): 149-154. doi: 10.1136/medhum-2015-010773

4. Ablamskyi S. Ye., Romaniuk V. V., Chycha R. P., Ablamska V. V. Temporary access to documents containing medical confidentiality (criminal procedural aspect). Wiad. Lek. 2020;73(5):1032-1036. doi: 10.36740/ WLek202005136.

5. Horodovenko V. V., Pashkov V. M., Udovyka1 L. G. International legal instruments in the field of bioethics and their impact on protection of human rights. Wiad. Lek. 2020;73(9 p. II):2056-2061. doi: 10.36740/ WLek202007144.

6. Klepka D. I., Krytska I. 0., Sydorenko A. S. Obligation of the disclosure of medical confidential information in criminal proceedings. Wiad. Lek. 2019;72(12 p. II):2602-2608. doi: 10.36740/WLek201912235

7. Plebanek E. Ujawnienie tajemnicy lekarskiej w procesie karnym a odpowiedzialność karna lekarza. Białostockie Studia Prawnicze. 2020;25(2):65-98. doi: 10.15290/bsp.2020.25.02.04

8. Bourke Ju., Wessely S. Confidentiality. BMJ. 2008;336(7649):888-891. doi: 10.1136/bmj.39521.357731.BE

9. Jaroszyński Ja., Husarz R., JurekA., Mela A. Doctor-patient confidentialityright and duty of a doctor in law regulations. Journal of Education, Health and Sport. 2018;8(3):444-452. doi: http://dx.doi.org/10.5281/ zenod0.1207230

10. ParzellerM.,WenkM., Rothschild M.Zertifizierte Medizinische Fortbildung: Die ärztliche Schweigepflicht. Dtsch Arztebl. 2005;102(5):A 289-296.
11. WMA Declaration of Geneva. Adopted by the 2nd General Assembly of the World Medical Association, Geneva, Switzerland. September 1948. Available from: https://www.wma.net/policies-post/wma-declaration-of-geneva/

12. Confidentiality: protecting and providing information. General Medical Council. April 2004. Available from: https://www.gmc-uk.org/-/media/ documents/confidentiality-2004---2009-55664503.pdf?la=en

13. Yedynyi derzhavnyi reiestr sudovykh rishen [Unified state register of court decisions] Available from: http://reyestr.court.gov.ua/

14. Dragana D. Medical Secret as a Basis of Medical Confidence in Relation Doctor-Patient - a View from Healthcare System of the Republic of Serbia Jahr : Europski časopis za bioetiku. 2018;9(2):205-222.

15. Understanding medical confidentiality and privacy laws for health professionals. https://www.slatergordon.com.au/blog/featured/ understanding-medical-confidentiality-and-privacy-laws-for-healthprofessional

16. Unachukwu A. Medical Confidentiality: What Does it Mean to the Vulnerable? https://www.academia.edu/29756371/Medical_ Confidentiality_What_Does_it_Mean_to_the_Vulnerable

17. Jalali M. S., Landman A., Gordon W. J. Telemedicine, privacy, and information security in the age of COVID-19. Journal of the American Medical Informatics Association. 2020;28(7):1-2. doi:10.1093/jamia/ ocaa310

18. Veliz C. Privacy During Pandemic and Beyond. The Philosophers Magazine. January 2020. p. 107-113. doi:10.5840/tpm20209075

19. Boudreaux B., Denardo M. A., Denton S. W. et al. Data Privacy During Pandemics: a Scorecard Approach for Evaluating the Privacy Implications of COVID-19 Mobile Phone Surveillance Programs. RAND Corporation, Santa Monica, Calif. January 2020. 143 p. doi:10.7249/RRA365-1

20. Magklaras G., Lo'pez-Bojo'rquez L. N. A review of information security aspects of the emerging COVID-19 contact tracing mobile phone applications. Norwegian Center for Molecular Medicine, University of Oslo, Norway and Steelcyber Scientific. May 2020. doi:10.13140/ RG.2.2.34790.65606

21. Aplikacja Kwarantanna domowa. Koronawirus:informacjeizalecenia.Available from: https://www.gov.pl/web/koronawirus/kwarantanna-domowa

22. Instruktsiia z vykorystannia elektronnoho servisu «Dii vdoma» Yedynoho derzhavnoho veb-portalu elektronnykh posluh dlia vyrishennia pytannia shchodo observatsii (izoliatsii) osib, yaki peretynaiut derzhavnyi kordon abo vizhdzhaiut z tymchasovo okupovanykh terytorii u Donetskii ta Luhanskii oblastiakh, Avtonomnoi Respubliky KRYM i Sevastopolia [Instructions for using the electronic service "Act at home" of the Unified state web portal of electronic services to address the issue of observation (isolation) of persons crossing the state border or entering from the temporarily occupied territories in Donetsk and Luhansk regions, the Autonomous Republic of Crimea and Sevastopol]. Available from: https:// www.kmu.gov.ua/storage/app/sites/1/18\%20-\%20Department/18\%20 -\%20PDF/04.2020/instrukciya-diy-vdoma.pdf (in Ukrainian).

23. Shcho ne tak $z$ dodatkom Dii «Vdoma»? [What's wrong with the app Action 'AtHome'?] LB.ua. Available from: https://lb.ua/ society/2021/04/26/483087_shcho_z_dodatkom_dii_vdoma.htm

24. Korshivskij N. Global'nyj vyzov vs privatnost': personal'nye dannye v usloviyakh pandemii [Global challenge vs privacy: personal data in a pandemic]. Liga.Tech. Available from: https://tech.liga.net/technology/ opinion/globalnyy-vyzov-vs-privatnost-personalnye-dannye-vusloviyah-pandemii (in Russian).

25. French M., Guta A., Gagnon M. et al. Corporate contact tracing as a pandemic response. Critical Public Health. Published: October, 2020. doi: 10.1080/09581596.2020.1829549 
26. Hudmen M. Zlochyny maibutnoho [Crimes of the Future] / Per. z anhl. I. Mazarchuk, Ya. Mashyko. Kharkiv: Vyd-vo «Ranok»: Fabula, 2019. 592 p. (in Ukrainian).

27. Regulation (EU) 2016/679 of the European Parliament and of the Council on the protection of natural persons with regard to the processing of personal data and on the free movement of such data, and repealing Directive 95/46/EU. 27 April 2016. Available from: https://eur-lex.europa. eu/legal-content/EN/TXT/PDF/?uri=CELEX:32016R0679

\section{ORCID and contributionship:}

Tetiana O. Mykhailichenko: 0000-0002-4668-3375 C,D,E,F

Oksana P. Horpyniuk: 0000-0003-3110-6564 ${ }^{\text {B,D,E,F}}$

V. Yu. Rak: 0000-0003-4427-9907 ${ }^{A, D, E, F}$

\section{Conflict of interest:}

The Authors declare no conflict of interest

\section{CORRESPONDING AUTHOR}

Tetiana 0. Mykhailichenko

Poltava Law Institute of Yaroslav Mudryi National Law University

Poltava, Ukraine

tel: +380976437653

e-mail: myhailichenko_t@yahoo.com

Received: 17.06 .2021

Accepted: 14.10 .2021

A - Work concept and design, B - Data collection and analysis, C - Responsibility for statistical analysis,

D - Writing the article, $\mathbf{E}$ - Critical review, $\mathbf{F}$ - Final approval of the article 


\title{
AUTOMATED DECISION-MAKING SUPPORT SYSTEM FOR QUALIFICATION OF CRIMINAL OFFENSES AS AN ELEMENT OF HUMAN RIGHTS HEALTH PROTECTION SYSTEMS
}

DOI: 10.36740/WLek202111204

\author{
Valery F. Obolentsev ${ }^{1}$, Oleh M. Hutsa ${ }^{2}$, Dmytro B. Yelchaninov ${ }^{3}$ \\ 'YAROSLAV MUDRYI NATIONAL LAW UNIVERSITY, KHARKIV, UKRAINE \\ 2V. N. KARAZIN KHARKIV NATIONAL UNIVERSITY, KHARKIV, UKRAINE \\ ${ }^{3}$ NATIONAL TECHNICAL UNIVERSITY «KHARKIV POLYTECHNIC INSTITUTE», KHARKIV, UKRAINE
}

\begin{abstract}
The aim: 1) To develop an informative model of the process of automated qualification of criminal offenses against human health for countries with a continental legal system; 2) on the basis of information model to create a decision support system in the form of a software product in terms of qualification of a criminal offense against human health. Materials and methods: The information model of the process of automated qualification of a criminal offense against human health was developed using the BPMN method on the basis of European countries' legislation with a continental legal system. According to the information model, a decision support system was developed in the form of a software product.

Results: 1 . An information model of the process of automated qualification of criminal offenses against human health for countries with a continental legal system has been developed. 2. A system of decision support in the form of a software product as an element of law enforcement in terms of qualification of a criminal offense against human health. Conclusions: The proposed decision support system for automated qualification is a means of preventing unreasonable qualification of committed offenses as it minimizes the errors of this process. As a result, it will increase the preventive effect and the quality of law enforcement work to prevent crimes against human health.
\end{abstract}

KEY WORDS: health; criminal offenses; qualification, decision support system

Wiad Lek. 2021;74(11 p.2):2884-2890

\section{INTRODUCTION}

The right to life is enshrined in Article 3 of the Universal Declaration of Human Rights [1]. Accordingly, health care as a basic component of life was and remains the primary task of law enforcement.

However, statistics show that crimes against health involving the use of computer technology are becoming more widespread. For example, in an analytical report Internet Crime Complaint Center Federal Bureau of Investigation Paul Abbate pointed out [2, p. 3]: "In 2020, when American society focused on protecting our families from the global pandemic and helping the needy, cybercriminals took the opportunity to profit from our dependence on technology and engage in cybercrime. These criminals have used phishing, spoofing, extortion, and various forms of Internet fraud against the most vulnerable members of our society - health workers seeking personal protective equipment, families checking billing information, and many others. "Given the globalization of cybercrime and the COVID-19 pandemic, we can say the globalization of this problem around the world.

In order to protect the health of the population in democratic countries, the systematic activities of law enforcement and the judiciary are implemented, where computer technol- ogy is used more and more every year. In fact, the so-called "Digital Forensics", which is based on the latest software, is already being claimed. Alisha Asquith and Graeme Horsman in the article "Let the robots do it! - Taking a look at Robotic Process Automation and its potential application in digital forensics "[3] investigated the state of digital forensics and outlined the prospects of robotic automatic technology (Robotic Process Automation, RPA) in forensic activities.

Graeme Horsman in his article "Raiders of the lost artifacts: Championing the need for digital forensics research" [4] asserts the concept of "digital artifacts" as an element of "digital forensics". The researcher points out that the use of the latest technologies allows to record and digitize traces of objects that are important in the investigation and forensic activities; to make a forecast of the possibility of finding out new data on crimes that can not be detected and recorded, so to speak, "classic" forensic means.

A new level of litigation is also being developed - litigation with the use of digital technologies [5]. In particular, in American legal practice, two electronic systems that provide electronic litigation there have existed for a long time. The first of these, Public Access to Court Electronic Records (PACER), has been operating since 1988 [6] and is a database of court documents with free access by users. 
The second system - CM / ESF is designed to submit documents to the court (in force since 2001) [7]. The system of electronic courts is increasingly established in various countries around the world [8].

Therefore, it is not surprising that the assertion of electronic litigation in the European Union is supported by significant regulatory support [5, p. 106]. In particular, the recommendations of the Committee of Ministers of the Council of Europe were adopted in this regard [9].

However, even in the conditions of the outlined digitalization of law enforcement and judicial activity, their obligatory component remains the qualification of the detected offenses in accordance with the norms of criminal law. Until recently, such work was based solely on the knowledge and experience of law enforcement, on a person's organizational and mental functionality. But with the development of scientific and technological progress in this area, new opportunities open up - computers with special software allow you to process large amounts of data and make informed decisions in a short time. Therefore, the creation of decision support systems (DSS) for the qualification of criminal offenses against human health in accordance with criminal law should be considered an urgent task for scientists.

DSS is an interactive automated system that helps the decision-maker to use data and models to solve unstructured or poorly structured problems [10]. Unstructured problems are characterized by the fact that their description is dominated by qualitative factors that are difficult to formalize, and quantitative relationships between these factors are usually not defined. Weakly structured problems combine quantitative and qualitative dependencies, and insufficiently certain aspects of the problem tend to dominate [11].

DSS has already found its application in various fields of jurisprudence.

1. DSS in rule-making. Thus, Mirna El Ghosh, Hala Naja, Habib Abdulrab, Mohamad Khalil in [12] "Towards a Legal Rule-Based System Grounded on the Integration of Criminal Domain Ontology and Rules" outlined DSS for the Lebanese criminal sphere based on ontology integration criminal area and a set of logical rules that are defined using the SWRL language.

Obolentsev V.F., Hutsa O.M., Demchenko O.B. in the study "Information technology of verification of algorithmic of medical regulations" [13] revealed the technology of using the method BPMN (Business Process Model and Notation) for logical and analytical verification of texts of regulations.

2. DSS in criminology. As an example, we can highlight the criminal analysis system RICAS (Real-time Intelligence Crime Analytics System) [14]. This system allows you to perform analysis of the criminal situation, analysis of the general profile, analysis of a specific investigation, comparative analysis, analysis of group crime, analysis of the profile, analysis of investigations [15]. There are other systems of criminal analysis with similar tasks and functionality [16].
3. DSS in the judicial sphere. An example of a court decision support system is the VERDICTUM court decision analysis system [17]. It allows you to work with a complete database of court decisions; quickly select similar decisions on one subject and circumstances of the case; analyze the practice of law enforcement with the help of the regulatory framework, etc. [18].

\section{THE AIM}

In order to ensure the proper qualification of offenses as part of the preventive activities of law enforcement in the prevention of criminal offenses against human health, there is obviously a need to create a system that would:

- reduced qualification errors, including due to corruption factors;

- accelerated the qualification process.

Research hypothesis: it is possible to create a DSS for the automated classification of criminal offenses against human health in accordance with the rules of criminal law that would be universal for countries with a continental legal system.

Tasks of work:

1) to develop an information model of the process of automated qualification of criminal offenses against human health for countries with a continental legal system;

2) on the basis of the information model to create DSS in the form of a software product as an element of law enforcement activities in terms of qualification of a criminal offense against human health;

3) to test DSS for qualification of criminal offenses against human health in a country with a continental legal system.

\section{MATERIALS AND METHODS}

Regarding the implementation of the first task.

The information model of the process of automated qualification of a criminal offense against human health was developed using the BPMN method and Microsoft Visio software (vector graphics editor with a library of graphic elements of BPMN notation version 2.0).

Regarding the implementation of the second task.

The software product is developed using software engineering technologies:

- HTML5;

- Bootstrap 4.6.0 (CSS) framework;

- JavaScript;

- JQuery 3.5.1;

- the jQuery plugin Bootstrap-select (The MIT License). Regarding the implementation of the third task.

The DSS check on the qualification of criminal offenses against human health was carried out based on the verdict of the court of Ukraine - a country with a continental legal system. Namely, the verdict of the Dzerzhinsky City Court of the Donetsk Region of October 21, 2013, in case № 225/3371/13-k. [19]. The perpetrator was then prosecuted for encroaching on human health under Part 2 of Article 134 of the current Criminal Code of Ukraine "Illegal abortion". 


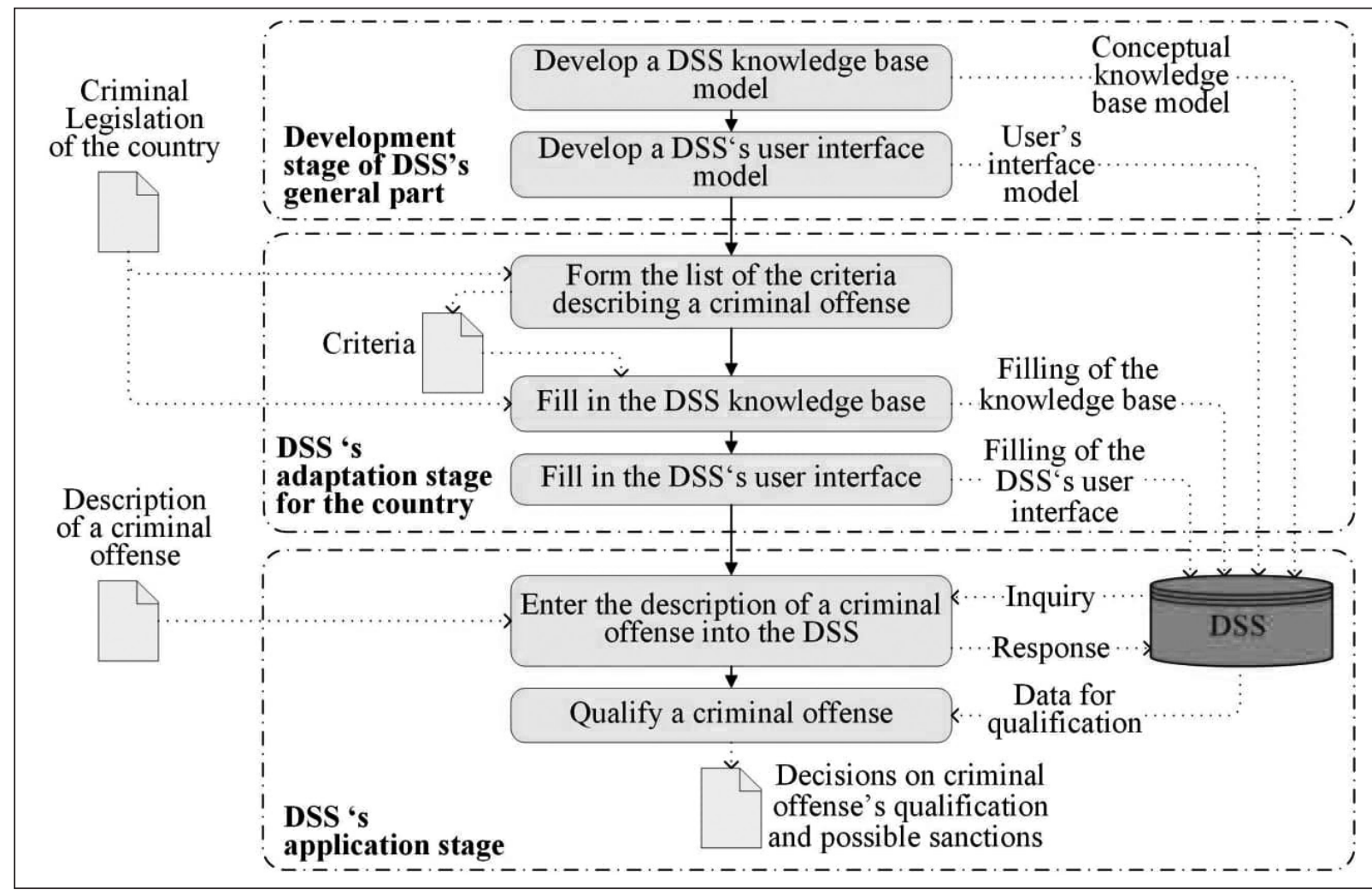

Fig. 1. The information model of the process of automated qualification of a criminal offense

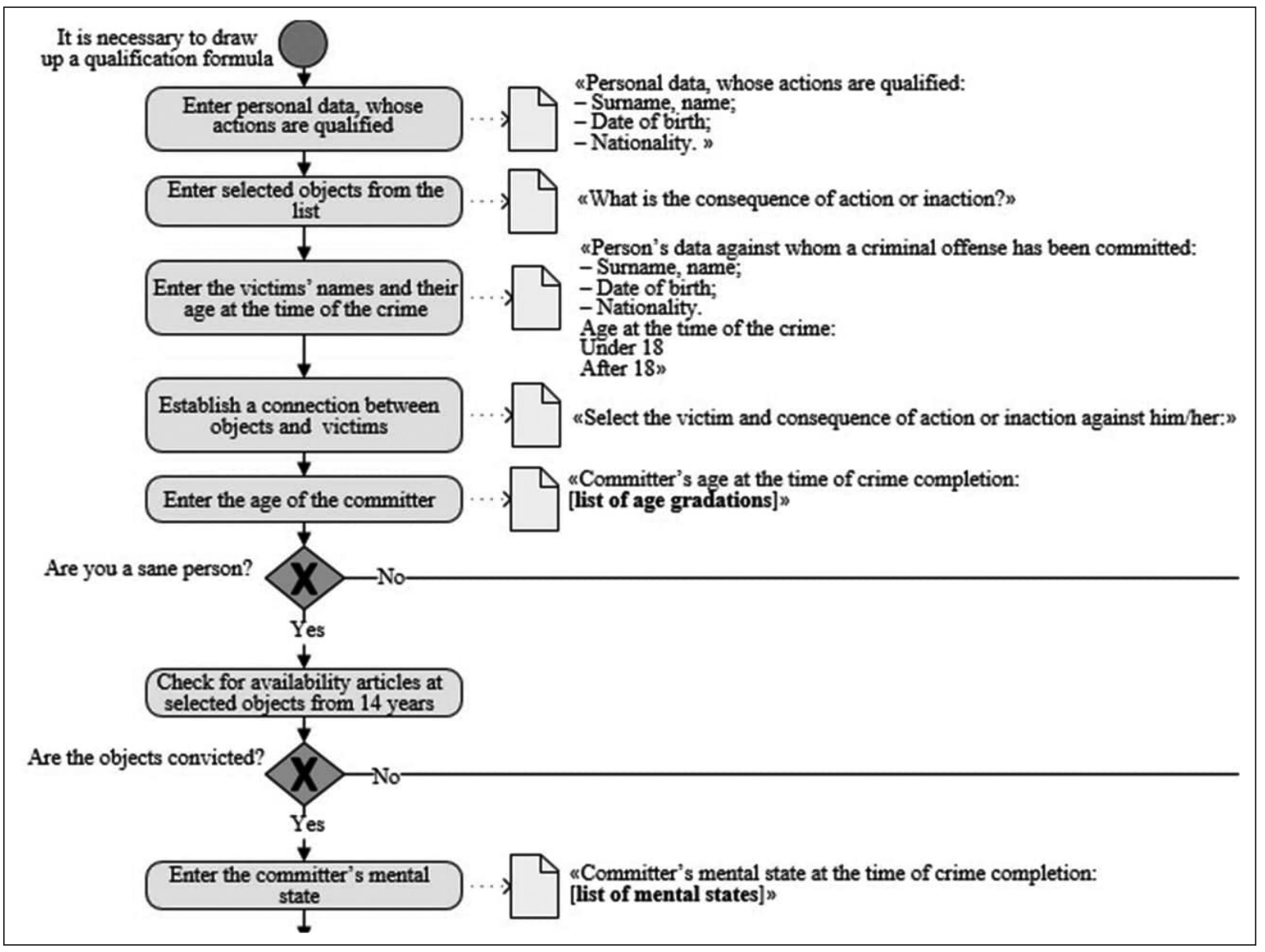

Fig. 2. Fragment of the DSS knowledge base 


\section{RESULTS}

Results for the first task.

Based on the analysis of the criminal legislation of European countries with a continental legal system, an information model of the process of automated qualification of a criminal offense was developed (see Fig. 1). The BPMN (Business Process Model and Notation) method and Microsoft Visio software were used.

The information model presented in fig. 1, determines the structure of the process of automated qualification of a criminal offense against human health. Its elements are:

1) the stage of development of the general part of DSS:

- development of a conceptual (substantive) model that determines the structure of the DSS knowledge base, the properties of its elements, and the causal links between them;

- development of a DSS user interface model that defines the appearance and functionality of visual elements (headers, menus, windows, system messages, etc.) through which DSS "communicates" with the user.

This stage is performed once at the beginning of DSS development;

2) the adaptation stage of DSS for the country:

- formation of a criteria list of describing the criminal offense based on the criminal law of the country selected to automate the process of automation of qualifications;

- filling the DSS knowledge base following the developed conceptual model of knowledge base and the formed criteria list (set and order of questions and answers);

- filling in the DSS user interface according to the interface model and a set of questions and answers in the country language chosen to automate the process of automation of qualification of criminal offenses.

This stage is performed for each of the countries that implement DSS or after a change in the criminal law of a country that already has DSS;

3) the stage of using DSS:

- introduction of a criminal offense's description in DSS according to the content of knowledge base (set and order of questions and answers) and through the user interface;

- qualification of a criminal offense against human health and determination of possible sanctions on the basis of its description, which is formed based on the analysis of user responses to DSS questions.

This stage is performed in case of need of qualification of a criminal offense.

An analysis of the criminal law of European countries with a continental legal system gives grounds to claim that they all contain articles providing for liability for criminal

Choose committer's age at the time of commission

Choose an age group

under 14

from 14 to 16

from 16 to 18

from 18 to 21

from 21

Please, make a choice

Fig. 3. Screenshot of the computer screen from the menu for choosing the age of the criminal offense's subject.

\begin{tabular}{|c|c|c|}
\hline \multicolumn{2}{|l|}{$\begin{array}{l}\text { PERSONAL DATA } \\
\text { SURNAME, NAME } \\
\end{array}$} & \multirow{5}{*}{$\begin{array}{l}\text { Algorithm for performing the qualification } \\
\text { formula is carried out relatively: } \\
\text { Committer's: Person_4 } \\
\text { Date of birth XX.XX.XX } \\
\text { Citizen of Ukraine }\end{array}$} \\
\hline Person_4 & $\checkmark$ & \\
\hline Date of birth & Nationality & \\
\hline Xx.xx.xx & Ukraine & \\
\hline \multicolumn{2}{|l|}{ ОВJECT } & \\
\hline \multicolumn{2}{|l|}{ Choose the object } & \multirow{6}{*}{$\begin{array}{l}\text { Object's: Personal's state of health } \\
\text { Victim's: Person_2 } \\
\text { Date of birth XXXXXXX } \\
\text { Citizen of Ukraine } \\
\text { Victim's age: After } 18\end{array}$} \\
\hline Personal's state of health & $\checkmark$ & \\
\hline $\begin{array}{l}\text { VICTIM'S DATA } \\
\text { SURNAME, NAME }\end{array}$ & & \\
\hline Person_2 & $\checkmark$ & \\
\hline Date of birth & Nationality & \\
\hline XX.XX.xx & Ukraine & \\
\hline \multicolumn{2}{|c|}{ Choose victim's age at the time of offence commission } & \\
\hline After 18 & $\checkmark$ & \\
\hline
\end{tabular}

Fig. 4. Screenshot of the computer screen with answers to DSS requests. 
regarding the committed act by: PERSON_4

date of birth XX.XX.XX

citizen of Ukraine

as concerns victim

PERSON 2

date of birth XX.XX.XX

citizen of Ukraine

Committed act against Human health is determined by a criminal violation provided for in

paragraphs (a) and (b) of Art. 4.2.10. Illegal abortion

Qualification Formula (Art.2.8.2):

\begin{tabular}{|c|c|c|c|c|c|c|c|c|}
\hline $\begin{array}{c}\text { Article of } \\
\text { the Special Part }\end{array}$ & $\begin{array}{l}\text { Property } \\
\text { damage }\end{array}$ & $\begin{array}{l}\text { Reducing signs } \\
\text { for } 3 \text { degrees }\end{array}$ & $\begin{array}{l}\text { Reducing signs } \\
\text { for } 2 \text { degrees }\end{array}$ & $\begin{array}{l}\text { Increasing signs } \\
\text { for } 2 \text { degrees }\end{array}$ & $\begin{array}{l}\text { Increasing signs } \\
\text { for } 1 \text { degree }\end{array}$ & $\begin{array}{c}\text { Preparation or } \\
\text { criminal attempt }\end{array}$ & $\begin{array}{l}\text { Criminal } \\
\text { complicity }\end{array}$ & $\begin{array}{l}\text { Renunciation } \\
\text { of crime }\end{array}$ \\
\hline paragraphs (a) and (b) of Art 42,10 . & - & - & - & - & - & - & - & - \\
\hline
\end{tabular}

Fig. 5. Screenshot of the computer screen with the qualification formula

\section{Data for qualification and Formula}

Basic degree of severity of the crime, committed by PERSON_4 - 3

-no established Reducing signs for 3 degrees

-no established Reducing signs for 2 degrees

-no established Increasing signs for 2 degrees

-no established Increasing signs for 1 degree

CONCLUSION:

Basic degree of severity of the crime, committed by PERSON_4 - 3

Possible sanction:

1) a fine of 1,000 to 2,000 units of account

2) imprisonment for a term of 3 to 4 years.

Fig. 6. Screenshot of the computer screen on the severity of the criminal offense and the possible sanction.

offenses against human health. Therefore, we can say that the developed information model is universal.

The result of the second task.

To compile a criteria list describing a criminal offense, the criminal legislation of Ukraine was chosen, namely the Draft of the Criminal Code of Ukraine (hereinafter-DCCU) estimate March 29, 2021 [20], which was established by the Working Group on Criminal Law Development by Presidential Decree № 584 / 2019 of August 7, 2019 "Issues of the Commission for Legal Reform" [21]. A total of twenty-five criteria (multiple choice questions) have been identified to qualify an act as a criminal offense or to establish that it is not. The order of questions, their content, and options for possible answers are determined by the relevant articles of the General Part, and the items and numbers of articles that are the result of qualification - the Special Part of the DCCU. The DSS knowledge base has the form of an algorithm developed using the BPMN method and Microsoft Visio software (see Figure 2).

In the created software product, the user interface has the form of windows with titles in the form of questions, answer options in which appear at the cursor. From them, the user chooses the necessary answer. An example is the choice of the age of the criminal offense's subject at the time of its commission (see Fig. 3).

The result of the third task.

The DSS created in the form of a software product was tested on the data from the actual court verdict in the case of the Court of Ukraine № 225/3371/13-k [19] on the committed offense of human health in the manner outlined above. In fig. 4 shows an image (screenshot) of the computer screen with the answers to the requests of the developed software product according to the circumstances of the criminal offense.

The result of the approbation is an automatically created qualification formula under the norms of the DCCU on criminal offenses against human health (see Fig. 5).

The next stage of DSS work is to determine the severity of the criminal offense and the conclusion on a possible sanction. The screenshot of the computer screen with its results is shown in Fig. 6.

\section{DISCUSSION}

This allows us to say that the results of the work are original, its scientific goals are implemented in due course. The 
effectiveness of the proposed DSS on the qualification of other offenses under the PKKU was confirmed at a webinar held on May 11, 2021, with the participation of the Working Group on the Development of Criminal Law of Ukraine [21] and other legal professionals.

The DSS developed together with other technologies of digitalization of legal activity should become a part of a new technological format of jurisprudence, which has already been largely formed - the so-called Legal tech. Legal tech is an industry that combines jurisprudence and high technology (chatbots, webbots, search engines, DSS, and other technologies) in order to speed up, increase convenience and economy, and thus increase efficiency in resolving legal issues.

We pay attention to this circumstance as well. More and more software is used in rule-making. This practice is based on the latest approach in processing texts and creating a format that is understandable to computers. I.A. Karpov, S.V. Antonenko in the article "Review of methods of intellectual analysis of the text" [22, pp. 44-45] argue that at this time a promising area for natural language processing is the use of technologies of "artificial intelligence" (Natural Language Processing, NLP) so that computers can understand it. Natural language processing is used in conjunction with Natural Language Generation (NLG) and Natural Language Understanding (NLU). At the same time, texts are created that have a very high degree of similarity to texts of so-called "natural" origin. It is significant that the capabilities of "artificial intelligence" (for example, GPT-2 and GPT-3 technologies) allow you to create even poems. Nils Köbis, Luca D.Mossink, based on the results of their research in the article "Artificial intelligence versus Maya Angelou: Experimental evidence that people cannot differentiate AI-generated from human-written poetry" found that even experts find it difficult to distinguish poetic text created by intelligence from human poetry [23, p.1].

So it is not surprising that digital technologies are also used for rule-making concerning criminal law. Thus, Mirna El Ghosh, Hala Naja, Habib Abdulrab, Mohamad Khalil in the work "Towards a Legal Rule-Based System Grounded on the Integration of Criminal Domain Ontology and Rules" [24] proposed a comprehensive methodology for modeling legal norms in the criminal sphere. According to it, the ontology of the criminal area is first obtained from legal texts using a special algorithm, and then on the basis of this ontology legal rules-norms are formalized.

Taking into account the above circumstances, we can say that the proposed DSS technology can be implemented in the process of criminal lawmaking to verify the algorithmicity of the texts of regulations. At the same time, we pay attention to the forecast of OE Radutny [25] - digitalization generally changes the value of legal regulation, which will lead to new forms of the socially dangerous behavior of "digital man" (Homo numerals, Homo digitalis, Homo Horologium) and the corresponding new criminal law.

\section{CONCLUSIONS}

The proposed DSS should increase the effectiveness of human rights activities, as it significantly speeds up the process of qualifying offenses and minimizes errors. Also, this technology can provide proper control of the results of such work. Therefore, the proposed DSS will promote the right to a fair trial, which is enshrined in Article 6 of the Convention for the Protection of Human Rights and Fundamental Freedoms [26].

\section{REFERENCES}

1. Zahal'na deklaratsiya prav lyudyny: Rezolyutsiya Heneral'noyi Asambleyi 00N 217 A (III) vid 10 hrudnya 1948 roku [Universal Declaration of Human Rights: Resolution 217 A (III) UN General Assembly of December 10, 1948] Available from: https://zakon.rada.gov.ua/laws/ show/995_015\#Text [Ru].

2. Abbate, P. Intpoduction. Internet Crime Report 2020. Federal Bureau of Investigation. Internet Crime Complaint Center. (on-line) Available from: https://www.ic3.gov/Media/PDF/AnnualReport/2020_IC3Report.pdf [reviewed 2021.07.15].

3. Asquith, A., Horsman, G. Let the robots do it! - Taking a look at Robotic Process Automation and its potential application in digital forensics. Forensic Science International: Reports. 2019; 1: 1-6. (on-line) Available from: https://www.sciencedirect.com/science/article/pii/ S2665910719300076 [reviewed 2021.07.15].

4. Horsman, G. Raiders of the lost artefacts: Championing the need for digital forensics research. Forensic Science International: Reports. 2019; 1: 1-5. (on-line) [download: 15.07.2021] doi: 10.1016/j. fsir.2019.100003

5. Kushakova-Kostyts'ka, N. V. Elektronne pravosuddya: ukrayins'ki realiyi ta zarubizhnyy dosvid. [Electronic justice: Ukrainian realities and foreign experience]. Legal Journal of the National Academy of Internal Affairs. 2013; 1: 103-109. Available from: http://nbuv.gov.ua/UJRN/ aymvs_2013_1_20 (Ua) [reviewed 2021.07.15].

6. PACER. Public Access to Court Electronic Records. Available from: https:// pacer.uscourts.gov/

7. Electronic Filing (CM/ECF). Available from: https://www.uscourts.gov/ court-records/electronic-filing-cmecf [reviewed 2021.07.15].

8. Kalancha, I.H. Mizhnarodnyy dosvid vykorystannya elektronnoho sehmentu v kryminal'niy protsesual'niy diyal'nosti sudu [International experience in the use of the electronic segment in criminal proceedings of the court]. National Legal Journal: theory and practice. 2015; 6(16): 224-228. Available from: http://www.jurnaluljuridic.in.ua/ archive/2015/6/50.pdf (in Ukrainian).

9. Recommendation $\operatorname{Rec}(2001) 3$ of the Committee of Ministers to member states on the delivery of court and other legal services to the citizen through the use of new technologies: adopted by the Committee of Ministers on 28 February 2001 at the 743rd meeting of the Ministers' Deputies. Available from: https://search.coe.int/cm/Pages/result_ details.aspx?0bject|D=09000016805e2aa7

10. Larichev, O.I., Petrovskiy, A.B. Sistemy podderzhki prinyatiya resheniy: sovremennoye sostoyaniye i perspektivy razvitiya. [Decision support systems: current state and development prospects] Results of Science and Technology. Moscow: VINITI; 1987 (21): 131-164. (in Russian).

11. Larichev, 0.I. Verbal'nyy analiz resheniy. [Verbal decision analysis]. Moscow: Nauka; 2006. (Ru).

12. Mirna El Ghosh, Hala Naja, Habib Abdulrab, Mohamad Khalil et al. Towards a Legal Rule-Based System Grounded on the Integration of Criminal Domain Ontology and Rules. Procedia Computer Science. 2017; 112:632-642. Available from: https://www.sciencedirect.com/science/ article/pii/S1877050917314643 
13. Obolentsev, V.F., Hutsa, O.M., Demchenko, O.B. Information technology of verification of algorithmic of medical regulations. Wiad Lek. 2019; 72 (12) cz. 2: 2427-2433. doi: 10.36740/WLek201912206.

14. Strukov V., Uzlov, D. Web-based Protected Geoinformation System of Criminal Analysis (RICAS) for Analytical Support for Crimes Investigation. 2017 4th International Scientific-Practical Conference Problems of Infocommunications. Science and Technology (PIC S\&T). doi: 10.1109/ INFOCOMMST.2017.8246450.

15. RICAS (REAL-TIME INTELLIGENCE CRIME ANALYTICS SYSTEM). Available from: https://ricas.org/uk/ [reviewed 2021.07.15].

16. Palantir Gotham. Available from: https://www.palantir.com/palantirgotham/ [reviewed 2021.07.15].

17. VERDICTUM. Available from: https://verdictum.ligazakon.net/analysis [reviewed 2021.07.15].

18. VERDICTUM. Available from: https://www.softcom.ua/ru/liga/system/ liga_verdictum.php?gclid=CjwKCAjw3MSHBhB3EiwAxcaEu7seN1Zg

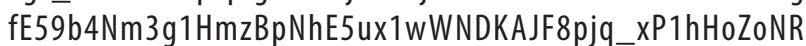
oCCAQQAvD_BwE [reviewed 2021.07.15].

19. Vyrok u spravi Dzerzhyns'koho mis'koho sudu Donets'koyi oblasti vid 21 zhovtnya 2013 roku № 225/3371/13-K. Available from: https://reyestr. court.gov.ua/Review/34537723 (in Ukrainian).

20. Archive of drafts of the new criminal code. Available from: https:// newcriminalcode.org.ua/criminal-code-arhiv [reviewed 2021.07.15].

21. Pytannya Komisiyiz pytan' pravovoyi reformy: Ukaz Prezydenta Ukrayiny vid 07.08.2021 p. №584/2019. Available at: https://zakon.rada.gov.ua/ laws/show/584/2019\#Text (in Ukrainian).

22. Karpov, I. A., Antonenko, S. V. Ohlyad metodiv intelektual'noho analizu tekstu. Aktual'ni problemy avtomatyzatsiyi ta informatsiynykh tekhnolohiy. 2020; 24: 40-46. (on-line) Available from: https:// actualproblems.dp.ua/index.php/APAlT/article/download/151/129 (in Ukrainian).

23. Nils Köbis, Luca D.Mossink. Artificial intelligence versus Maya Angelou: Experimental evidence that people cannot differentiate Al-generated from human-written poetry. Computers in Human Behavior. 2021; 114: 1-13. doi: 10.1016/j.chb.2020.106553
24. Mirna El Ghosh, Hala Naja, Habib Abdulrab, Mohamad Khalil et al. Towards a Legal Rule-Based System Grounded on the Integration of Criminal Domain Ontology and Rules. Procedia Computer Science. 2017; 112: 632-642. Available from: https://www.sciencedirect.com/science/ article/pii/S1877050917314643

25. Radutny, 0. E. Novel criminal delicts related to digital human being. Bulletin of the Association of Criminal Law of Ukraine. 2020; 1(13): 16-28. doi: 10.21564/2311-9640.2020.13.204761

26. Convention for the Protection of Human Rights and Fundamental Freedoms: Signed on 4 November 1950. Available from: https://zakon. rada.gov.ua/laws/show/995_004\#Text

\section{ORCID and contributionship:}

Valery F. Obolentsev: 0000-0003-2172-5441 D, E, F

Oleh M. Hutsa: 0000-0002-0194-0315 A, B, C, D

Dmytro B. Yelchaninov : 0000-0002-5163-9117 B,D

\section{Conflict of interest:}

The Authors declare no conflict of interest.

\author{
CORRESPONDING AUTHOR \\ Valery F. Obolentsev \\ Yaroslav Mudryi National Law University \\ Kharkiv, Ukraine \\ tel: +380503028924 \\ e-mail: hortisa71@gmail.com
}

Received: 16.06 .2021

Accepted: 15.10 .2021

A - Work concept and design, B - Data collection and analysis, C - Responsibility for statistical analysis,

D -Writing the article, E-Critical review, F- Final approval of the article 


\title{
FORMS OF CRIMINAL LIABILITY IN CASE OF DEATH OF THE PATIENT
}

DOI: 10.36740/WLek202111205

\author{
Natalia 0. Antoniuk \\ SUPREME COURT, KYIV, UKRAINE
}

\begin{abstract}
The aim: Establishing the forms of criminal liability in case of death of the patient and the presence of such a condition as the desire of the relatives of the deceased to reconcile with the subject of the criminal offense.

Materials and methods: In the course of the study, 62 court judgements were used. Comparative, systematic, analytic, and empiric research methods have been used in this research.

Results: The position of the victims - relatives of the deceased - has a direct influence on the choice of the form of criminal liability. A medical worker who is the subject of a criminal offense may reconcile with the relatives of the deceased patient and enter into a reconciliation agreement. It is the parties of the agreement who consent to the punishment and the possible exemption from it.

At the same time, the court cannot exempt a medical worker from criminal liability in case of a patient's death. This thesis is based on the fact that the possibility of such exemption is directly related to the reconciliation with the victims who are patients that were provided with medical service. Besides, death is a consequence that is irreversible. Conclusions: The exemption from criminal liability according to the reconciliation of the guilty person with the victim in case of death of a patient is stated to be impossible. At the same time, the possibility of concluding a reconciliation agreement in this case has been established.
\end{abstract}

KEY WORDS: a medical worker, death, criminal liability, reconciliation

Wiad Lek. 2021;74(11 p.2):2891-2895

\section{INTRODUCTION}

Criminal liability is the most severe type of legal liability. It involves the actual use of negative consequences because of the commission of a criminal offense or an obligation to endure them $[1,171]$. Criminal liability is considered to be a possible negative impact on a person who has committed a criminal act which reflects the reaction of the state to what has been committed by this person. Therefore, the balance between the radical restrictions which are the criminal measures to the person who committed a criminal offense must be imposed with such careful "dosing" as to be proportionate to the socially dangerous act committed by the person. The legislator must also take into account the characteristics of the person who committed the criminal act. Only the choice of different combinations of criminal law influence on a person that depends on the guilty person, the essence and typical degree of public danger of the committed offense will allow to establish justice in criminal law. These criteria differentiate criminal liability.

Foreseeing criminal liability for the consequence in the form of death, the legislator should distinguish between the cases of an intentional and negligent death, take into account the risk (potential possibility) of death, based on the initial state of the victim, etc. Thus, the medical professionals whose activities are directly related to providing medical service to patients are at high risk of such a possible consequence as the death of the patient. The conditions of the patient who requires urgent medical service are meant primarily.

Therefore, the peculiarities of the profession of medical workers, the constant impact of their activities on such values as human life and health are the basis for the conclusion that there are grounds for the differentiation of criminal liability of medical professionals for the damage caused by them while performing their professional duties [2, 2731].

The burden of ensuring a fair balance between the crime and the reaction of the state to criminal law measures is imposed not only on the court but also on the legislator. After all, the court individualizes the criminal liability already differentiated by the legislator. Initially, it is the legislator who lays the foundations for ensuring the principle of justice by establishing different responsibilities depending on the stage of the crime, the presence of qualifying or privileged features, complicity, etc.

The differentiation of criminal liability is necessary as it allows to fairly and proportionately distinguish the measures of criminal law that can be applied to the guilty person, including the medical professional in whose medical practice the death of the patient occurred. 


\section{THE AIM}

This research analyses the impact of reconciliation between the relatives of the deceased patient and the health worker on the choice of the form of criminal liability. The aim of the study also is to determine the forms of criminal liability in case of the patient's death and the presence of such a condition as the desire of the relatives of the deceased to reconcile with the subject of the criminal offense.

\section{MATERIALS AND METHODS}

The basis for this study consists of a number of philosophical, general, and specific scientific methods. The necessity to study the issues of substantive criminal law in inseparable connection with the criminal procedural aspects required the use of the system method, comparative, analytical, methods of formal logic and interpretation. The analysis of a large number of court judgements and court case files (62 judgements and 12 court case files) created a sufficient empiric basis for the further study of the issues declared in this paper. In the course of the study, a survey of judges, prosecutors, and lawyers was conducted on a number of issues related to the forms of criminal liability of medical professionals in case of a patient's death (156 respondents were interviewed, including 64 judges, 32 prosecutors, and 60 lawyers). The studies by the Ukrainian and foreign scientists related to the issues outlined in the article were also used. Personal experience of scientific work (18 years) and practical experience of working as a judge and an advocate (12 years in total) were used. In particular, personal experience of work as a judge (cases № 439/397/17, № 608/2388/20), materials of 12 criminal cases that became the subject of consideration by the Supreme Court, conclusions of members of the Supreme Court Scientific Advisory Council were applied.

\section{RESULTS}

The basic forms of criminal liability are conviction, punishment, and criminal record. Each of these forms can be combined with the other in a variety of ways. Their use is directly related to the committed socially dangerous act. In addition, in a number of cases, the legislator provides for the possibility of exemption from criminal liability as a separate institution of the General Part of the Criminal Code of Ukraine (hereinafter - the Criminal Code). According to the results of my survey, 94 percent of respondents consider the existence of the institution of exemption from criminal liability appropriate, as it helps to differentiate criminal liability.

Analysis of the works of a number of scientists proves that the researchers consider the criminal prosecution of doctors for their medical errors to be an excessive punishment [3; 4]. However, such statements should not be accepted. First of all, I would like to note that the Ukrainian legislator has provided for the criminal liability of medical professionals in such a way that it is less severe than the liability for similar actions of ordinary citizens. For example, the failure to provide medical care to a patient if it has resulted in death or other serious consequences may be punishable by a maximum term of imprisonment of up to three years.

Among the 12 cases that became the subject of cassation review during 2018-2021 (acts qualified as the improper performance of professional duties by a medical or pharmaceutical worker) acquittals were issued in half of them (6 cases), 3 were closed due to the expiration of terms statute of limitations and only in 3 cases convictions were issued with the imposition of real punishment (proceedings № 51-690km18, № 51-1299km20, № 51-1835km19, № 51-4837km19, № 51-4842km19, № 51-5171km19, № 51-5472km19, № 51-6099km20, № 51-6454km19, etc.).

It should also be noted that a conviction is possible only if other medical experts in criminal proceedings indicate that the offender has indeed committed a medical error or failure to perform his or her medical duty.

Scholars aptly state that in the field of errors of medical professionals the positions of other medical professionals and experts are decisive for the court or the prosecutor [5]. Thus, a lawyer is unaware whether a medical manipulation has been performed correctly or not. For example, in criminal proceedings № 749/400/17 as a result of several examinations, it was stated by the experts that the anaesthesiologist made three unsuccessful attempts to intubate the trachea of a woman in labour for artificial lung ventilation while using muscle relaxants [6]. Due to the untimely implementation of this medical procedure, the woman died during childbirth, and the new-born died soon after. The experts stated that the cause of death of the baby was oxygen starvation. Only the conclusions of the experts allowed the court to conclude that the actions of the anaesthesiologist who performed these medical manipulations were wrong.

I believe that the criminal liability of medical professionals is not excessive. It is important to note that 90 percent of respondents also came to the same conclusion. In addition, I completely agree with the researchers who state the high latency of medical crimes [7, 2550]. However, I believe that it is necessary to distinguish between the cases when a medical worker tried to provide medical care to a patient but still made a medical error, and the obvious gross violations by doctors, such as refusal to provide medical care, providing medical care in a state of alcohol intoxication, etc. The need for distinction in these cases was supported by all respondents.

The institute of exemption from criminal liability provides for the possibility of such exemption without punishment and criminal record. Exemption from criminal liability is possible only in the case of accusation or suspicion of committing criminally punishable acts of a certain severity, committed with a prescribed by law form of guilt. Thus, the legislator clearly defines which criminal offenses the exemption from criminal liability is generally applicable for and what are the conditions and grounds for this.

Therefore, the exemption from criminal liability is directly related to the differentiation of criminal liability. If to take into consideration the forms of criminal liability, 
the application of this institution affects each of them (conviction, punishment, criminal record).

However, in this study, I will focus only on one of the types of exemption from criminal liability. It is the exemption due to the reconciliation of the guilty person with the victim. Is such an exemption possible in case of medical crimes, does the consequence for the patient affect the resolution of the issue, is the position of the patient or his relatives decisive or even obligatory for the court?

Judicial practice shows that in many cases victims express a desire to reconcile with the medical professionals who are prosecuted for committing a medical crime $[8 ; 9]$. However, in this case, there are debatable issues, the most relevant of which are the possibility of such reconciliation, its dependence on the consequences (death or other health consequences), the form of criminal influence on the subject of the crime, and its legal content.

It is necessary to elaborate on the possibility of applying the institution of exemption from criminal liability to medical professionals as a result of the death of a patient under the condition of the reconciliation of the guilty person with the victim. In fact, this institution is a legally provided possibility for the state to refuse to apply criminal liability to a medical worker who is the subject of a crime. This in turn entails several important legal consequences: non-application of such a form of liability as punishment or criminal record.

\section{DISCUSSION}

Ukrainian criminal law provides for the possibility of exemption from criminal liability due to the reconciliation of the guilty person with the victim under the following conditions: the act was committed for the first time; the act belongs to criminal offenses or minor negligent crimes; there is reconciliation with the victim; the inflicted damage was compensated or eliminated. The scholars point out that a similar criminal law institution is provided only in the criminal codes of the CIS member states, Latvia, Lithuania, Mongolia, and Romania [10, 72].

In Ukraine, criminal offenses or negligent serious crimes, which are the most common medical criminal offenses, include illegal abortion or sterilization (Article 134 of the Criminal Code), failure to provide medical service to a sick person by the medical professional (Article 139 of the Criminal Code), improper performance of professional duties by the medical or pharmaceutical professional (Article 140 of the Criminal Code). In fact, all specially qualified components of these acts belong to minor crimes. Therefore, based on the form of guilt and belonging to this category of criminal offenses, it can be stated that the institution of exemption from criminal liability due to reconciliation is possible to apply in the case of these acts.

No problem arises when a patient who is a victim of a medical crime is alive. Obviously, this patient can reconcile with the medical worker who is the subject of the crime. However, the discussion arises if the patient dies. Relatives of the deceased may be recognized as victims in such a case according to the Ukrainian procedural legislation.
The notion of the concept of "victim" has been investigated in the scientific literature. In particular, the studies by Y.V. Baulin [11], O.O. Dudorov [10], V.V. Navrotska [12], O.V. Perepadia [13], K. Chumak [14], A. Yashchenko [15], and others. O.O. Dudorov emphasizes that the exemption from criminal liability can occur only in the case of reconciliation with the direct victim - the victim of the crime. At the same time, the scientist notes that he has changed his position on this problem, as he previously agreed with Y.V. Baulin, V.V. Navrotska, and A. Yashchenko, i.e., allowed the possibility of reconciliation not only with the victim of the crime but also with their relatives [11].

However, the answer to the question of the range of people with whom reconciliation is possible is based on the parallel analysis of substantive and procedural criminal law. After all, there are elements of reconciliation in criminal proceedings. Exemption from criminal liability due to the reconciliation of the guilty person with the victim is not tantamount to the conclusion of a reconciliation agreement. These are different legal institutions that have completely different criminal consequences and are manifestations of various forms of criminal liability. As a result of the exemption from criminal liability, the person who committed the crime is not sentenced and, as a consequence, is not recognized as convicted; in contrast, as a result of the court's approval of a reconciliation agreement, a person is formally convicted by the appointment of an agreed punishment or the exemption from it with probation [14, 137-138].

These are the most important differences between these institutions. Therefore, the question arises about the possibility of their application in case of death of the patient due to certain criminal acts of a medical worker.

I believe that the concepts of "victim" in criminal and criminal procedural law are different. According to criminal law, the victim who is entitled to express the will to reconcile is only the direct patient to whom the damage was inflicted as a result of a medical crime. The relatives do not have such authorities.

Also, the use of exemption of a medical worker from criminal liability due to the reconciliation with the victim in the case of the patient's death is excluded due to another factor. A condition for such exemption is compensation for the inflicted damage or its elimination.

The damage caused by a criminal offense must be subject to compensation (elimination). However, deprivation of human life is an irreversible consequence. In the case of committing a criminal offense with fatal consequences, according to the criminal law, the victim at the time of resolving the issue of damage no longer exists physically.

Thus, death as the termination of the existence of one of the competent subjects of criminal law relations for the reconciliation of the guilty person with the victim makes it impossible to enter such reconciliation.

The loss of a person's life is the highest social value and is a special object of criminal law protection. It is not a subject for compensation. Human life cannot be restored due to the irreversibility of death. 
If the victim (victim of a criminal offense) is not physically present, no one else can express their will when resolving issues related to the exemption from criminal liability.

According to the conclusions of the members of the Scientific Advisory Council at the Supreme Court in the case № 439/397/17 it follows that all Ukrainian scientists who provided their scientific conclusions on this issue stated the impossibility of acquitting a person whose actions resulted in the death of the victim [8]. Scientists noted such arguments in support of this approach as the understanding of the victim in criminal law, the ability of only the victim to express a desire to forgive the guilty person because it is the victim that was inflicted with damage.

As a result, it can be concluded that in the case of the patient's death, the use of such differentiation as an exemption from criminal liability due to reconciliation with the victim is excluded. If none of the other types of exemption from criminal liability is applicable, then the use of forms of criminal liability that are not related to punishment and criminal record is excluded.

At the same time, this conclusion does not lead to the impossibility of applying a number of other legal institutions, in which there is an element of reconciliation with the victim in the case of a criminal medical offense that resulted in death. Scientists state that the application of highly severe punishments to doctors (especially those associated with imprisonment) is not justified [16]. In particular, exemption from criminal liability due to the reconciliation should not be confused with the conclusion of a reconciliation agreement between the guilty person and the victim.

In judicial practice, there are cases when the prosecution a priori denies the possibility of concluding a reconciliation agreement in case of conviction for acts that resulted in the death of the victim. Sometimes this reason is the main basis for cassation appeal of court decisions [9, 17].

However, this approach is completely wrong. A distinction should be made between the exemption from criminal liability due to the reconciliation and the conclusion of a reconciliation agreement. 75 percent of respondents who took part in the survey claimed that in their practice they faced the problem of identifying the abovementioned legal phenomena. This significant figure indicates the existence of a problem in distinguishing both legal phenomena and the grounds for their application.

It should be emphasized that the possibility of concluding an agreement on reconciliation of the guilty person with the victim is provided by the criminal procedure legislation. And in the criminal process, the concept of the victim is broader than the corresponding substantive legal understanding.

In criminal law, a victim is a person who is directly inflicted with physical, moral, and/or material damage by a criminal offense (or there is a direct threat of its infliction). Instead, the criminal procedure law defines that a victim in criminal proceedings may be a natural person who has suffered moral, physical, or property damage as a result of a criminal offense, as well as a legal person who has suffered property damage as a result of a criminal offense. Thus, according to the criminal procedure law, the relatives of the victim who are entitled to enter into a reconciliation agreement (including relatives of the deceased patient) may also be recognized as victims.

In the process of exemption from criminal liability due to the reconciliation of the guilty person with the victim, the will of the relatives is irrelevant, as such reconciliation is possible only with the victim of the crime. Since the patient (victim) died, there is no one to reconcile with. The exemption from criminal liability under Article 46 of the Criminal Code of Ukraine is impossible.

However, these relatives may reconcile with the medical worker who is the subject of the crime, as a result of which the patient died according to the provisions of Part 3 of Article 469 of the Criminal Procedure Code of Ukraine.

A reconciliation agreement between a victim and a suspect or accused person may be concluded in case of minor crimes and in the form of private prosecution, including those resulting in the death of a person.

The Supreme Court has concluded that exemption from criminal liability is not identical to the conclusion of a reconciliation agreement and has completely different legal consequences [9]. As a result, it is quite possible to arrange a reconciliation agreement with the relatives of the injured patient who have the procedural status of victims.

According to the national procedural law, the parties of the reconciliation agreement shall state the suspicion or accusation and its legal qualification. They shall refer to the article (part of the article) of the Law of Ukraine on the criminal liability; the circumstances relevant to the criminal proceedings; the measure of damage; the time period of its compensation or the list of actions not related to compensation for the damage that the suspect or accused are obliged to commit in favour of the victim; the term of their commission; the agreed punishment and consent of the parties to its appointment or to the appointment of punishment and release from probation; the consequences of non-compliance.

Thus, as a result of concluding the agreement, the parties themselves, within the limits provided by the criminal law, choose an agreed punishment and may even decide on the exemption from serving it with probation. The task of the court, in this case, is to check whether an agreement can be concluded in the relevant proceedings.

\section{CONCLUSIONS}

The exemption of a medical professional from criminal liability due to the reconciliation of the guilty person with the victim is possible only when the patient survived. It is the patient with whom the medical professional who is the subject of the criminal offense can enter into the reconciliation agreement. In this case, such forms of criminal liability as punishment and criminal record are not applied. However, in the case of a consequence in the form of the death of the patient, the possibility of reconciliation between the guilty person and the victim is excluded. 
Therefore, the exemption from criminal liability on the analysed basis is impossible.

At the same time, this conclusion does not exclude the possibility of entering into a reconciliation agreement with the relatives of the deceased patient. In the case of concluding a reconciliation agreement, the parties agree on both the type and amount of punishment and the possibility of exemption from serving it. The form of criminal liability that will be applied to the guilty person depends on the agreement of the victim's relatives and the medical professional who is the subject of the criminal act. However, the individualization of liability still occurs within the provisions of the articles of the General and Special Parts of the Criminal Code, i.e., within the limits of criminal liability differentiated by the legislator.

\section{REFERENCES}

1. Antoniuk N.0. Kontseptsii rozuminnia kryminalnoi vidpovidalnosti [The concept of understanding criminal responsibility]. Chasopys Kyivskoho universytetu prava. 2019. №2. S.170-175 (in Ukrainian).

2. Antoniuk N. Differentiation of criminal liability of medical professionals. Wiad Lek. 2020;73(12 p. II):2728-2732.

3. Pizarro Carlos W. Perspectives in medical liability Rev Med Chil 2008 Apr;136(4):539-43. https://pubmed.ncbi.nlm.nih.gov/18769798/

4. Gornostay A, Ivantsova A, Mykhailichenko T. Medical error and liability for it in some post-soviet countries (Belarus, Kazakhstan, Moldova, Ukraine). Wiad Lek. 2019;72(5 cz 1):877-882. https://pubmed.ncbi. nlm.nih.gov/31175788/

5. Ulsenheimer K. Medical expert assessment in criminal processes from the legal viewpoint Z Arztl Fortbild (Jena) 1996 Nov;90(7):574-81. https://pubmed.ncbi.nlm.nih.gov/9064925/

6. Postanova Kasatsiinoho kryminalnoho sudu vid 04.02.2021. (sprava № 749/400/17) https://reyestr.court.gov.ua/Review/94873970 (in Ukrainian).

7. Bondarenko Olha S., Reznik Oleg M, Dumchikov Mykhailo 0., Horobets Nadiia $S$. Features of criminal liability of a medical professional for failure to perform or improper performance of their professional duties in Ukraine Wiadomości Lekarskie, VOLUME LXXIII, ISSUE 11, NOVEMBER 2020 P. 2549-2554.

8. Postanova Velykoi Palaty Verkhovnoho Sudu vid 16.01.2019 (sprava № 439/397/17, provadzhennia № 13-66ks18) https://reyestr.court.gov. ua/Review/79298600 (in Ukrainian).

9. Ukhvala Kasatsiinoho kryminalnoho sudu vid 27.05 .2021 (sprava № 608/2388/20, provadzhennia № 51-2634sk21) (in Ukrainian).

10. Dudorov 0.0. Pro problemy kryminalno-pravovoho prymyrennia [0n the problems of criminal law reconciliation]. Yurydychnyi naukovyi elektronnyi zhurnal. № 1 2013. S. 73-77. http://www.lsej.org. ua/1_2013/ukr/Dudorov.pdf (in Ukrainian).
11. Baulin Yu.V.Zvilnennia vid kryminalnoi vidpovidalnosti Visnyk Asotsiatsii kryminalnoho prava Ukrainy, 2013, № 1(1). S. 185-207 (in Ukrainian).

12. Navrotska V.V.Zasada dyspozytyvnosti ta yii realizatsiia v kryminalnomu protsesi Ukrainy: monohrafiia. Lviv. Lvivskyi derzhavnyi universytet vnutrishnikh sprav, 2010.440 s. (in Ukrainian).

13. Perepadia 0.V. Kryminalno-pravovi aspekty prymyrennia mizh osoboiu, yaka vchynyla zlochyn, ta poterpilym (porivnialnyi analizzakonodavstva Ukrainy ta FRN) [Criminal law aspects of reconciliation between the perpetrator and the victim (comparative analysis of the legislation of Ukraine and Germany)] [dissertation]; NAN Ukrainy. In-t derzhavy i prava im. V.M.Koretskoho. K., 2003. 18 s. (in Ukrainian).

14. Chumak K. Zvilnennia vid kryminalnoi vidpovidalnosti u zviazku iz prymyrenniam vynnoho z poterpilym vs. uhoda pro prymyrennia: problemy rozmezhuvannia. Naukovyi chasopys Natsionalnoi akademii prokuratury Ukrainy. 2016. № 2. Ch. 2. S. 135-141. (in Ukrainian).

15. lashchenko A. Problemni aspekty zvilnennia vid kryminalnoi vidpovidalnosti u zviazku iz prymyrenniam iz poterpilym . Visnyk natsionalnoi akademii prokuratury Ukrainy. - 2008.- № 1. - S. 64-70. (in Ukrainian).

16. Gutorova N, Zhytnyi 0 , Kahanovska T. Medical negligence subject to criminal law. Wiad Lek. 2019;72(11 cz 1):2161-2166. https://wiadlek. pl/wp-content/uploads/2020/02/WL-11-cz-I-2019.pdf

17. Postanova Pershoi sudovoi palaty Kasatsiinoho kryminalnoho sudu u skladiVerkhovnoho Sudu vid 15.02.2021 (sprava №395/773/18) https:// reyestr.court.gov.ua/Review/95139607 (in Ukrainian).

ORCID and contributionship:

Natalia O. Antoniuk: 0000-0002-7582-2071 A,B,D,E,F

\section{Conflict of interest:}

The Author declares no conflict of interest.

\section{CORRESPONDING AUTHOR Natalia 0. Antoniuk \\ Supreme Court, Kyiv, Ukraine \\ tel: +380679665233 \\ e-mail:antoniuk_natalia@ukr.net}

Received: 28.06.2021

Accepted: 19.10.2021

A - Work concept and design, B - Data collection and analysis, C - Responsibility for statistical analysis, D-Writing the article, $\mathbf{E}$-Critical review, $\mathbf{F}$ - Final approval of the article 


\title{
CORRUPTION OFFENCES IN MEDICATIONS CIRCULATION: INVESTIGATION PROBLEMS
}

D0I: 10.36740/WLek202111206

\author{
Kateryna V. Latysh, Yevhenia E. Demidova \\ YAROSLAV MUDRYI NATIONAL LAW UNIVERSITY, KHARKIV, UKRAINE
}

\begin{abstract}
The aim: The article aims to focus attention on the pressing problems of corruption in the field of pharmaceutical activities at the stage of medicines sale. Possible ways to solve the problems are elucidated.

Materials and methods: The research has been carried out using the results of analysis and generalization of different countries' regulation acts governing pharmaceutical activity implementation, also of legal practice, including author's private practice, interviewing investigators, interviews, and questionnaires of pharmaceutical companies and professionals. General scientific and special scientific methods (dialectical, logical-normative, system-structural, comparative-legal, etc.) were used.

Results: As a result of the study, the main problems of corruption that exist in the pharmaceutical activity sphere at the stage of medicines sale have been outlined. One of the most widespread corrupt manifestation are a relationships between a doctor and a pharmacist and sale medicine which contain drugs without doctors prescription. Proposals are formulated regarding possible ways to solve the problems, including other countries experience such as introduce digital control tools when concluding contracts.

Conclusions: Investigation problems of pharmaceutical corruption offences deals with the absence of forensic investigation methodic of such crimes. It is caused by high latency of this category of criminal offenses. Among the main problems of the existence of corruption in the field of pharmaceutical activities at the stage of medicines' sale can be those: insufficiency and imperfection of the legislative regulation of medicines circulation; lack of professional relations regulation between medical institutions, doctors, and pharmaceutical entities; lack of an electronic database of prescribed prescriptions, etc.
\end{abstract}

KEY WORDS: pharmaceutical activity, corruption offenses, corruption offenses investigation, circulation of medicines

Wiad Lek. 2021;74(11 p.2):2896-2900

\section{INTRODUCTION}

Corruption in the health care system is not only a major obstacle to the economic growth and development of any state but also such a negative social phenomenon that can endanger human health and life.

The misalignment of private profit-maximizing objectives with public health needs causes institutional corruption in the pharmaceutical sector and systematically leads firms to act contrary to public health [1].

The pharmaceutical industry, as a part of the health care system, is a separate transnational unit that can influence government policy not only at the micro and macro levels but also internationally. However, current trends show that such activities, in addition to the implementation of its main task, that is the production and provision of citizens with effective, high quality, safe and affordable medicines, are increasingly changing the perspective for enrichment through unfair activities, emphasizing the priority of commercial interests ensuring in the sale of medicines. This is practically confirmed. Today, there are a sufficient number of cases involving the corruption offenses commission in the field of pharmaceutical activities at various levels, including with wide publicity in the media. In addition, the possibility of a corrupt relationship between a medical worker (doctor) and pharmaceutical companies, unfortunately, is known to almost every ordinary citizen, which proves the existence of relevant problems in this area once again.

\section{THE AIM}

The purpose of the article is to attract attention to the corruption existence pressing problems in the field of pharmaceutical activities. Possible ways to solve the problems have been elucidated.

\section{MATERIALS AND METHODS}

The research has been carried out using the results of analysis and generalization of different countries' regulation acts governing pharmaceutical activity implementation, also of legal practice, including author's own practice, interviews, and questionnaires of investigators, pharmaceutical companies, and professionals. General scientific and special scientific methods were used (dialectical, logical-normative, system-structural, comparative-legal, etc.)

The empirical basis of the study is also the results of our interviews with 143 people, including 43 medical workers (doctors of various specialties), 35 pharmaceutical workers, and 65 researchers, in $2020-2021$. The author took part 
in the international medical project, its participants were interviewed, too. The purpose of the survey and questionnaire was to find out how the subjects of pharmaceutical activity influence both medical workers and their patients who show signs of corruption.

General scientific and special scientific methods (dialectical, logical-normative, system-structural, comparative-legal, etc.) were used at work.

\section{RESULTS}

According to the Code of Ethics of Pharmaceutical Workers of Ukraine, their main task is to preserve life and protect human health following the principle of bioethics "do no harm" not only to all living things but also to the ecosystem in general, which includes disease prevention, preservation, and promotion of health, etc. [2]. However, the commercial color, which is typical of pharmaceutical activities today, is gaining the global scale and carried out through corrupt methods for obtaining necessary results from medicines sales.

Corruption in the medical sphere can be subdivided into the following levels: from patient to doctor; inside the hospital - from a healthcare institution employee to the executive hospital staff; on state-level concerning state procurements of medications [3]. At the same time, corruption in the field of pharmaceutical activity can be manifested from the moment of certain drug development, ending with its distribution, finding its manifestation at all intermediate stages.

Investigating corruption offenses related to the sale of medicines is rather a difficult issue. Firstly, because the criminalization of corruption actions of such persons took place relatively recently, therefore, pre-trial investigation bodies have not yet established a well-established system of tactical and methodological actions that would facilitate this process [4]. And secondly, the situation is complicated with the fact that the corresponding actions are characterized by a high level of latency.

The sale of medicines can be carried out both in prescription and non-prescription forms. Prescriptions are necessary for: prescription drugs; over-the-counter medicines, medical devices in case of their release free of charge or on preferential terms; medicines that are manufactured in a pharmacy for a specific patient [5].

However, in contrast to many developed countries, the types of drugs that can be sold over-the-counter are extremely wide in Ukraine. For example, in Germany, most drugs, including antibacterial, immunomodulatory, etc., can be purchased only with a doctor's prescription, and without such a prescription you can buy certain vitamins, cosmetics, or some antihistamines at the pharmacy. A similar approach is followed in such countries as the United States, Japan, Israel, and others.

It should be mentioned that a significant number of drugs can be purchased without a prescription at pharmacies in Ukraine. This is one of the reasons why a large number of pharmacies have been opened in Ukraine "per square meter". It is because virtually anyone can buy almost any prescription drug (even such as "lyrics" with the active ingredient pregabalin, codeine-containing drugs, etc.). As a result, pharmacies are being opened offering only over-the-counter codeine drugs. Thus, it was ascertained in the criminal proceedings on the fact of illicit drug trafficking that codeine-containing drugs. "Kodterpin IS" and "Pyatirchatka IS", were sold at a pharmacy violating the rules of drugs storage, accounting, release. A total of 50 tablets of such drugs had been sold. In addition, it was found out that a whole network of private enterprise pharmacies had been engaged in illegal storage and uncontrolled sale of drugs [6]. In the course of such criminal offense investigations, it is important to record the traces of their commission, seize criminal encroachment objects, primary and other documents, including accounting logs, recipes, for further analysis and forensic examination. In these cases, it is not just about codeine-containing drugs for which subject-quantitative accounting has not been established [7]. As investigators' interviews have shown, unfilled prescriptions are often found in pharmacies in such cases, including those with a "red stripe", as well as other documents with available seals and stamps, which become document technical examination subjects later on. The purpose of this type of study is to get answers to questions about the time the document was made, whether changes were made to it, determining the relative prescription of the document (text), the time of making certain records [8].

One of the requirements for receiving free medicines within the framework of an international project having been implemented in the city of Kharkiv was providing a prescription in the prescribed form, having been prescribed by a relevant doctor, by a person who intended to receive free medicines. However, the citizens began to complain that doctors had refused to issue such prescriptions en masse, but such recipes were still prescribed for a small "thanks". The same thesis is confirmed by other researchers, who also point out that health care professionals were given bribes for writing out a "necessary" prescription [9]. During the communication on this issue with the local management at the region level, this problem was partially solved, however, a request had been done to buy medicines only at certain pharmacies. Purchasing drugs only at a particular pharmacy or from a specific supplier is a very common corruption manifestation.

For example, one of the health ministers used the state of emergency to buy more than half of essential medicines from a single supplier. In addition, the prices of these drugs were $41 \%$ higher than the international average [10].

A widespread problem is the mass sale of prescription medicines without a prescription at pharmacies. One way to solve this problem is to introduce a drug electronic prescription system. In the plans of work in this direction, drugs, insulins, immunosuppressive medicines - 2021, antibiotics - 2022, other groups of prescription drugs, defined by the Ministry of Health in 2023, are to be sold with an electronic prescription [11]. In Germany, the plan for the introduction of electronic prescriptions must have 
been implemented by 2022 in accordance with the law Das Gesetz für mehr Sicherheit in der Arzneimittelversorgung (GSAV) of July 16, 2019 [12].

However, there is no prescription electronic database in Ukraine today, which makes it impossible for prescription authenticity verifying. It is evidently due to pharmaceutical giants' direct impact on state policy at the macro level, which delays the introduction of mandatory prescription forms and electronic control systems for them.

Encouraging this is confirmed with the practice of doctors when they write down a diagnosis and prescribed medicines on a sheet of paper, which is purely designed for records on its one side but contains information about a particular drug indicating a particular pharmaceutical company on its other side. That may be essentially a manifestation of a corrupt connection between the doctor and a pharmacist. This practice has been known for a long time, but it has not lost its relevance nowadays. Such notebooks are distributed to doctors free of charge: they are for notes on one side and contain latent advertising on the other one. However, such corruption is found not only in notebooks or other paper media but also in pens, labeled gowns, other medical clothing, calendars, and other labeled objects that are put in a prominent place in a doctor's office. Due to the fact that this information medium comes from the subject of medical care, which has a high degree of public confidence in the quality assessment of truly effective drugs, it helps to increase sales of drugs from this manufacturer.

The thesis is confirmed by other researchers, who note the following. In the area of relations with HCP, pharmaceutical companies make extensive use of sponsorship of scientific events that advertise their products, pay for the lectures of doctors who share positive experiences with the use of such products, and pay for the travel of doctors to scientific events, including abroad. Medical representatives also provide doctors with free samples of medicines, as well as souvenirs and some other products with a company logo that they can use at the workplace [13].

A significant corrupt manifestation in the "doctor - pharmacist" relationship is getting a reward for drugs sale, both directly to the patient and indirectly. For example, in her own legal practice, the author encountered a situation in which a German doctor in the Federal Republic of Germany issued a certificate to a citizen of Ukraine confirming that his relative had been sold drugs worth 1245,90 euros. Such a certificate was made on the German hospital official form and contained all the necessary details together with the doctor's signature. The author's request to the chief physician of this hospital was answered that doctors were forbidden to sell drugs, this could be done by appropriate pharmacies only. Therefore, the chief physician of the hospital was also surprised by such a certificate.

One example more. In 2011, Johnson \& Johnson (J\&J) paid US $\$ 70$ million dollars to settle claims that it bribed doctors in Greece, Poland, and Romania to prescribe medicines made by it [14].

\section{DISCUSSION}

Some researchers are right to point out that the practice of locating pharmacies in hospitals and other medical institutions is widespread in Ukraine. Since patients buy more than $90 \%$ of medicines in our country, most of the medications prescribed for patients with inpatient treatment are purchased in such pharmacies. This situation makes it possible to quickly determine the number of particular medicine prescriptions written out by a doctor and, accordingly, provide material incentives for doctors [13]. On condition of anonymity, respondents reported cases when such drugs, after having been purchased in a hospital pharmacy, were returned to the hospital pharmacy by junior medical staff in exchange for money.

The investigation of relevant corruption offenses in the field of pharmaceutical activity is characterized by the presence of certain problems. Firstly, this concerns the lack of an appropriate developed forensic investigation methodology, which is due to the high latency of this category of criminal offenses. For example, it was in practice, when Pfizer paid 60 million US dollars in the case of bribing not only doctors and hospital administrators but also drug regulators in the countries of Europe and Asia. It is interesting, these payments were included in the accounting documents as legitimate costs,

along with tuition, cargo delivery, and entertainment. According to the court documents, the company had made monthly payments for what it called "consulting services" to a doctor in Croatia who helped to decide which drugs the government would register for sale and reimbursement. Pfizer has not acknowledged or denied these allegations, which is a routine practice as pharmaceutical companies often try to pay off the allegations of fraud [15].

It should be mentioned that this practice is less common in Ukraine due to the fact that the tax authorities are quite meticulous in analyzing the economic efficiency of the costs declared by the company delving into the content of such costs. Therefore, law enforcement agencies need to interact with the tax authorities, and it will be possible to establish a corruption offense existence by identifying possible tax evasion.

The scientific literature also confirms that pharmaceutical companies rely heavily on marketing strategies to gain the loyalty of doctors prescribing and patients. These aggressive marketing activities sometimes take an illegal twist by turning into corruption [16]. One way of such corruption risks prevention, which is proposed in this article, is to assess the corruption risks associated with doing business in the world's poorest countries. This proposal is seen to be justified and confirmed with the practice of realization both in Ukraine and in the world. For example, it is of great help when assessing corruption risks in the activities of the relevant Ministry of Health and other bodies, including the State Service of Ukraine for Medicines.

The identified corruption risks description is being done through the prism of highlighting the factors of such corruption risks and corrupt offenses possible consequences, as well as measures to eliminate corruption risk, its priority, 
the person responsible for eliminating measures, resources needed to implement measures, and the results expected.

Some researchers point out that one of the ways to solve the above problems should be the insurance medicine introduced in Ukraine [17]. However, this cannot be accepted and is confirmed with the practice of Croatia, when a pharmaceutical company paid doctors from 5 to 10 percent for each prescription, and doctors received gifts, coupons for shopping in megamarkets, traveled abroad at the expense of "Farmala" "[18]. The difference is that, in Ukraine, a drug is paid for directly by the citizen, but, in Croatia, by the relevant insurance funds, companies, etc., though the corrupt relationship "doctor - pharmacist" remains unchanged.

Due to the constant digitalization in all spheres of life, including medicine, it is necessary to introduce digital control tools when concluding contracts. In particular, the following is proposed. It is important in open contracting when red flags appear indicating a potential breach of standards, to ensure that the red flag is investigated to determine whether or not corruption is a factor. Red flags are triggered by using procurement data to detect corruption risk through the use of an algorithm. Further information on different digital technologies in different stages of development used to enhance transparency in medicines procurement (including additional discussion about e-procurement systems and open contracting), is accompanied by a discussion about technical challenges and opportunities faced by these digital tools [10].

The European Union countries' positive experience, when used in Ukraine, can also help to solve health care system corruption problems. In particular, it would be worth studying the reforms mechanism of the Minister of Health in Poland E. Kopacz (November 2007, to November 7, 2011), who was awarded the Excellence Award for achievements in the fight against corruption in the medical field, too [19]. The basis for reforming Poland's health care system was the compulsory health insurance introduction. The proposals made by other researchers [20] are noteworthy, too.

\section{CONCLUSIONS}

Corruption in the field of pharmaceutical activity is a rather specific international phenomenon as it can manifest itself from a drug development beginning to the end of its distribution, and finds its manifestation at all intermediate stages. Among the main problems of the existence of corruption in the field of pharmaceutical activities at the stage of medicines' sale can be those: insufficiency and imperfection of the legislative regulation of medicines circulation; lack of professional relations regulation between medical institutions, doctors, and pharmaceutical entities; lack of an electronic database of prescribed prescriptions, etc.

One of the ways to solve these problems is using the positive experience of Poland through compulsory health insurance installation, as well as a system of electronic prescriptions for medicines creating.

\section{REFERENCES}

1. Gagnon, M. Corruption of Pharmaceutical Markets: Addressing the Misalignment of Financial Incentives and Public Health. Journal of Law, Medicine \& Ethics, 41(3), 571-580

2. Etychnyi kodeks farmatsevtychnykh pratsivnykiv Ukrainy. Available from: https://nuph.edu.ua/wp-content/uploads/2015/04/etichnij_ kodeks_pharm_pratsiunik.pdf (in Ukrainian).

3. Batyrgareieva VS, Babenko AM, Kaija S. Corruption in medical sphere of Ukraine: current situation and ways of prevention. Wiad Lek. 2019;72 (9 cz 2):1814-1821.

4. Bondarenko OS, Pakhomov VV, Saulyak SV, Dumchikov MO. Relevant issues of the criminal liability of the private doctors for corruption crimes. Wiad Lek. 2019;72(7):1354-1358.

5. Pravyla vypysuvannia retseptiv na likarski zasoby i vyroby medychnoho pryznachennia [Rules for prescribing medicines and medical devices]: Nakaz MOZ Ukrainy vid 19.07.2005, № 360 (in Ukrainian).

6. Pravookhorontsi pid chas slidstva zafiksuvaly prodazh u merezhi aptek kodeinovykh preparativ bez retseptu [During the investigation, law enforcement officers recorded the sale of codeine drugs without a prescription in a network of pharmacies]. Available from: https://od.gp.gov.ua/ua/news.html?_m=publications\&_ $\mathrm{t}=\mathrm{rec} \& \mathrm{id}=252146 \& \mathrm{fbclid}=$ I $\mathrm{wAR} 11 \mathrm{~h} 3 \mathrm{JJ5}$ INQMyglg107 $\mathrm{rmIQPC2t}$ DSSNHtDrsgSviKE4bRaiuJokRp3TMHM (in Ukrainian).

7. Gutorova N.O., Yemelianenko V.V. Kryminalna vidpovidalnist za porushennia poriadku realizatsii preparativ, yaki mistiat malu kilkist narkotychnykh zasobiv ta (abo) psykhotropnykh rechovyn: borotba z narkozlochynnistiu abo yii imitatsiia [Criminal liability for violation of the order of sale of drugs that contain a small amount of narcotic drugs and (or) psychotropic substances: the fight against drug crime or its imitation]. Zakhyst prav i svobod liudyny u sferi okhorony zdorovia: vyklyky ta realii reform: zbirnyk materialiv medyko-pravovoho forumu (Poltava, 2-3 hrudnia 2016 r.). Kyiv, 2017. 93-127 (in Ukrainian).

8. Kuzmenko 0., Lazebnyi A., Komyshniuk Yu., Yusupov V., Herasymenko L. Features of the Investigation of Corruption Abuses in the Medical Industry Systematic Reviews in Pharmacy Vol 11, Issue 10, 0ct-Nov 2020.

9. Batyrgareieva V.S., Babenko A.M., Kaija S. Corruption in medical sphere of Ukraine: current situation and ways of prevention. Wiad Lek. 2019;72(9 cz 2):1814-1821.

10. Jillian Clare Kohler, Deirdre Dimancesco. The risk of corruption in public pharmaceutical procurement: how anti-corruption, transparency and accountability measures may reduce this risk. Global Health Action, 2020; 13.

11. MOZ rozrobylo plan perekhodu do elektronnykh retseptiv [The Ministry of Health has developed a plan for the transition to electronic prescriptions]. Available from: https://www.kmu.gov.ua/news/mozrozrobilo-plan-perehodu-do-elektronnih-receptiv (Ua).

12. Gesetzes für mehr Sicherheitin der Arzneimittelversorgung (GSAV). Available from: https://www.bundesgesundheitsministerium.de/gsav.html

13. N. Gutorova, O. Soloviov, D. Olejnik. Improper healthcare marketing: german and ukrainian experience in prevention. Wiad Lek. 2019; 72:2408

14. Securities and Exchange Commission, SEC charges Johnson \& Johnson with foreign bribery. Available from: https://www.sec.gov/news/ press/2011/2011-87.htm

15. Pyvovarov V.V. Kryminolohichna kharakterystyka suchasnoï transnatsionalnoï korporatyvnoï zlochynnosti u farmakolohichniy" haluzi [Criminological characteristics of modern transnational corporate crime in the pharmacological field]. Naukovyy" visnyk Uzhhorodskoho natsionalnoho universytetu. Seriia Pravo. 2016; 40:96. (in Ukrainian). 
16. Peltier-Rivest Dominic. The prevention and detection of corruption in pharmaceutical companies. Pharmaceuticals Policy and Law. 2017;12:17-31.

17. Busol 0. Yu. Protydiia koruptsiinii zlochynnosti v Ukraini u konteksti suchasnoi antykoruptsiinoi stratehii [Combating corruption crime in Ukraine in the context of modern anti-corruption strategy] [dissertation]. Kyiv : Instytut derzhavy i prava im. V.M. Koretskoho, NANU, 2015. 479. (in Ukrainian).

18. U Khorvatii zaareshtuvaly kerivnykiv farmatsevtychnoi kompanii ta 50 likariv [In Croatia, the heads of a pharmaceutical company and 50 doctors were arrested]. Available from: https://www.radiosvoboda. org/a/24770085.html

19. Jillian Clare Kohler \& Deirdre Dimancesco. The risk of corruption in public pharmaceutical procurement: how anti-corruption, transparency and accountability measures may reduce this risk. Global Health Action, 2020; 13:sup1, DOI: 10.1080/16549716.2019.1694745

20. Shevchuk, 0., Shevchuk, V., Zuy, V., Chub, 0., Rzhevska, 0.Georgian Legal regulation of procurement of narcotic drugs in Ukraine with involvement of international specialized organizations. Georgian Med News. 2018 Nov;(284):143-149.

\section{ORCID and contributionship:}

Kateryna V. Latysh: 0000-0002-9110-116X ${ }^{A, B, E}$

Yevhenia E. Demidova: 0000-0002-5049-7946 ${ }^{B, D, F}$

\section{Conflict of interest:}

The Authors declare no conflict of interests.

\section{CORRESPONDING AUTHOR}

\section{Kateryna V. Latysh}

Yaroslav Mudryi National law University

Kharkiv, Ukraine

tel: + 380989000531

e-mail: latysh78@gmail.com

Received: 20.06.2021

Accepted: 15.10 .2021

A - Work concept and design, B - Data collection and analysis, C - Responsibility for statistical analysis,

D-Writing the article, $\mathbf{E}$-Critical review, $\mathbf{F}$ - Final approval of the article 


\title{
CORRUPTION BETWEEN DOCTORS AND PHARMACISTS: CRIMINAL LAW PROBLEMS OF COUNTERACTION
}

DOI: 10.36740/WLek202111207

\author{
Oleksandr K. Marin, Iryna Z. Sen \\ IVAN FRANKO NATIONAL UNIVERSITY OF LVIV, LVIV, UKRAINE
}

\begin{abstract}
The aim: To draw the attention of the scientific community to the problem of corruption between doctors and pharmacists and to find out the available possibilities to counteract it via criminal law measures.

Materials and methods: The sources of this research include international legal acts and Ukrainian legislation; official reports of law enforcement agencies of Ukraine and other countries; NGO "Transparency International" studies; media materials; the results of a survey conducted using the Google Forms service; reports of the Accounting Chamber of Ukraine; judicial statistics data and materials of judicial practice in Ukraine, as well as special anti-corruption studies of Ukrainian and foreign scholars.

The main methods used in the study are the legal-dogmatic method, the method of extrapolation, some methods of formal logic and open-source analysis of law-enforcement practice, as well as the survey method.

Results: The problem of corrupt relationships between doctors and pharmacists is urgent both in Ukraine and abroad, and accordingly, requires an adequate legal assessment. Ukraine has the necessary criminal law tools to combat this negative phenomenon but uses them ineffectively.

Conclusions: A corrupt relationship between a doctor and a pharmacist may occur at three levels. Corrupt forms of unlawful interaction between medical and pharmaceutical workers at all these levels are covered by the existing norms of the Criminal Code of Ukraine; there is no need to single out a special norm that would reflect the corrupt relationship between a doctor and a pharmacist.
\end{abstract}

KEY WORDS: Corrupt relationship, healthcare sector, unlawful interaction between a doctor and a pharmacist, criminal law assessment

Wiad Lek. 2021;74(11 p.2):2901-2906

\section{INTRODUCTION}

The corruption in the healthcare sector in Ukraine is a matter of serious concern not only within our country but also abroad. The current situation in the world, mainly related to the spread of the Covid-19 pandemic, exposes the problem of misuse of their special status by public officials of the healthcare sector, private medical workers to gain personal benefits and advantages.

In general, corrupt forms of unlawful behavior in the field of health care are described in special anti-corruption studies. Thus, in the doctoral dissertation of Olena Busol "Counteraction to corruption crime in Ukraine in the context of modern anti-corruption strategy" (2015) a whole section is devoted to the characteristics of the current state of corruption in the field of health care in Ukraine [ 1 , pp. 258-273]. This author points out that similar corruption relationships are also typical for European countries. As an example, the researcher lists the most common corruption schemes in the healthcare sector in Poland [1, p. 272].

Among the "corruption schemes" in the healthcare sector, special attention should be paid to such forms of using the opportunities of special status by medical workers as "mutually beneficial cooperation" with pharmaceutical workers. The threat of corruption in the relationship be- tween healthcare professionals (HCPs) and the pharmaceutical industry was highlighted in Transparency International study "Corruption in the Pharmaceutical Sector. Diagnosing the Challenges" (2016): "Due to the industry's need to recoup R\&D (Research and Development) costs and maximise profits, without strong regulatory systems and oversight mechanisms unethical marketing practices can take place. The close relationship between the pharmaceutical industry and HCPs can make it hard to detect corrupt marketing practices, since the line between violations and normal collaboration is often blurred" [2, p. 17].

This area's particular vulnerability to corruption is also emphasized by foreign researchers. This is one more confirmation that the issues under investigation are relevant not only in Ukraine but also abroad. For instance, Assistant Professor at the University of Toronto Jillian Clare Cohen notes: "The interface between the pharmaceutical industry and physicians is an area that is particularly susceptible to corruption, as service delivery can be influenced by the marketing practices of the pharmaceutical industry" [3, p. 82].

The urgency of the problem is also confirmed by high-profile scandals in this area. According to the official website of the National Police of Ukraine, in 2019 the police exposed a group of pharmaceutical companies in bribing doctors 
for UAH 140 million: "For the received reward doctors of several medical institutions prescribed the medicines in the realization of which representatives of the pharmaceutical companies were interested" [4].

Similar news can be found in foreign sources. For example, the title of one of DownToEarth's publications (May 2019) reads: "There's an unhealthy alliance between doctors and pharma firms". The publication also indicates a lack of attention of the Indian government to this problem: "The government has shown little interest to penalise pharma companies that offer sops to doctors to push their drugs" [5]. The website of Special Investigation Service of the Republic of Lithuania notes that criminal case on large-scale corruption in the field of pharmacy has been referred to the court. In particular, it reads that " 12 employees of the pharmaceutical company were operating in an organised group. Some of the members of this group - the company's managers - have allegedly agreed with the doctors of the medical institutions of Lithuanian cities and districts they serve to recommend patients to purchase for an illegal fee, and later to inject the products distributed by their company" [6].

According to the report of the United States Department of Justice (September 2009), "American pharmaceutical giant Pfizer Inc. and its subsidiary Pharmacia \& Upjohn Company Inc. have agreed to pay $\$ 2.3$ billion, the largest health care fraud settlement in the history of the Department of Justice, to resolve criminal and civil liability arising from the illegal promotion of certain pharmaceutical products" [7]. One more report of the United States Department of Justice (July 2012) notes: "Global health care giant GlaxoSmithKline LLC (GSK) agreed to plead guilty and to pay $\$ 3$ billion to resolve its criminal and civil liability arising from the company's unlawful promotion of certain prescription drugs" [8].

The pharmaceutical company Johnson and Johnson (J\&J) was also charged with corruption (2011): U.S. Securities and Exchange Commission (SEC) charged J\&J with violating the Foreign Corrupt Practices Act by bribing public doctors in several European countries and paying kickbacks to Iraq to illegally obtain business. According to the SEC's complaint filed in federal court in the District of Columbia, public doctors and administrators in Greece, Poland, and Romania who ordered or prescribed J\&J products were rewarded in a variety of ways, including with cash and inappropriate travel [9].

Thus, the phenomenon of corrupt relationships between doctors and pharmacists takes place in reality, is quite common, and requires an adequate legal assessment.

\section{THE AIM}

The article aims to draw the attention of the scientific community to the problem of corruption between doctors and pharmacists and to find out the available possibilities to counteract it with the help of criminal law measures.

\section{MATERIALS AND METHODS}

The sources of this research include international legal acts and Ukrainian legislation; official reports of the National
Police of Ukraine, Special Investigation Service of the Republic of Lithuania, The United States Department of Justice, U.S. Securities and Exchange Commission; NGO "Transparency International" studies; media materials; the results of a survey of 249 respondents of different ages and from different parts of Ukraine conducted using the Google Forms service on 25-31 July 2021; reports of the Accounting Chamber of Ukraine; judicial statistics data and materials of judicial practice in Ukraine, as well as special anti-corruption studies of Ukrainian and foreign scholars.

The main methods used in the study are the legal-dogmatic method, the method of extrapolation, some methods of formal logic and open-source analysis of law-enforcement practice, as well as the survey method.

\section{RESULTS AND DISCUSSION}

Achieving the aim of this research involves answering several key questions.

What forms of interaction between a doctor and a pharmacist are illegal?

This question arises because, in principle, the interaction between a doctor and a pharmacist is quite natural and legitimate. In the most general form, a doctor and a pharmacist are called to perform a common task of ensuring the health of both the individual and the population in general. Therefore, communication, mutual consultations, etc. between the representatives of these professions are not illegal or dangerous.

In this regard, Jillian Clare Cohen notes: "Some physician-industry interaction is necessary to educate doctors about the therapeutic qualities of new drugs. However, there is compelling evidence that suggests that the motivation is often not health education, but profit maximisation" [3, p. 82].

This was also emphasized by Ukrainian researchers. Nataliya Gutorova, Oleksii Soloviov, Dimitri Olejnik in the article "Improper Healthcare Marketing: German And Ukrainian Experience In Prevention" (2019) underline: "Studies show that there are cases of pharmaceutical companies using improper drug marketing, putting their financial interests above the interests of patients. With such marketing, direct and indirect bribing of doctors is used to maximize the promotion of drugs on the market" [10, p. 2404].

Thus, the exception to the generally useful and necessary interaction of doctors and pharmacists is only those forms of relationships that are designed to achieve an illegal result contrary to the main vocation of these professions.

The legislation of Ukraine sets restrictions for medical, pharmaceutical workers, and rehabilitation specialists in the course of their professional activities, most of which relate to the field of interaction "doctor-pharmacist" [11]. It should be noted that any prohibition will be effective only if its observance is ensured by the establishment of legal responsibility, the most severe form of which is criminal liability. The analysis of the current Criminal Code of Ukraine makes it possible to single out the criminal law 
norms aimed at ensuring the observance of one of the established restrictions - the prohibition to receive illegal benefits from business entities or their representatives engaged in the production and/or sale of medicines, medical devices, technical and other means of rehabilitation.

Counteraction to non-compliance with other restrictions for medical and pharmaceutical workers is provided by the provisions of Article $44^{2}$ of the Code of Ukraine on Administrative Offenses "Violation of restrictions imposed on medical and pharmaceutical workers in the course of their professional activities". The low efficiency of this norm is evidenced by the data of official statistics of cases on this administrative offense: a total of 6 relevant cases were considered from 2013 to 2019 [12]. In 2020, 5 proceedings were initiated under Article $44^{2}$ of the Code of Ukraine on Administrative Offenses, 3 of which were returned by the courts as improperly filed [13].

However, such statistics show rather the latency of the relevant violations. As part of the research, we conducted a survey ${ }^{1}$ to determine whether health professionals adhere to certain restrictions, including the restriction on prescribing drugs on forms that contain advertising information. Respondents were asked the following question: "Has your doctor prescribed you any medicines on a form advertising a drug / pharmaceutical company?" 249 respondents took part in the survey. $80.3 \%$ of them, i.e. the absolute majority of respondents, answered "yes". Two more provided their answer version, which also indicates that the medical workers did not comply with the analyzed prohibition.

However, can such results give grounds for an unambiguous conclusion that there is a corruption component between the doctor and the pharmacist / pharmaceutical company in these cases? Obviously not. But such results undoubtedly indicate the insufficient effectiveness of the analyzed administrative-law prohibition.

As for the criminal-legal counteraction to illegal relationships between a doctor and a pharmacist, it should be noted that concerning doctors and pharmaceutical workers there is no separate criminal-legal prohibition (special norm) providing for the criminal liability of these categories of workers for corruption, however, all general prohibitions established in the current Criminal Code of Ukraine are applicable to them if their behavior contains corpus delicti of a criminal offense. There is the approach expressed in special literature about the need to eliminate the relevant gap. In this regard, the position of the working group on the draft Criminal Code of Ukraine is mentioned about the formulation of two new criminal offenses in the next Criminal Code of Ukraine: Article 4.3.8 "Illegal promotion of medical products" and Article 4.3.9 "Receiving illegal benefits for the promotion of medical products" [14]. It seems to us that the answer to the question on the need to criminalize illegal behavior, as done in Article 4.3.8 of the draft Criminal Code of Ukraine, or to differentiate criminal liability - Article 4.3.9 of the draft Criminal Code of
Ukraine - can be given only by answering the following question.

So the next question to be clarified is: do the analyzed forms of interaction belong to acts of corruption within the meaning of the Criminal Code of Ukraine and, accordingly, is it possible to apply criminal law tools of counteraction to persons committing such acts?

The analysis of international legal acts and Ukrainian legislation makes it possible to state that on formal grounds the illegal relationships of a doctor and a pharmacist (both in the case one of them is an official, and in the case none of them is an official) may belong to acts of corruption within the meaning of the Criminal Code of Ukraine if: 1) one of these two subjects (either a doctor or a pharmacist) misuses his/her special status and commits an illegal act prohibited by the Criminal Code of Ukraine; 2) offers, promises / accepts an offer, a promise or provides / receives in this regard an illegal benefit or intends to receive it in the future.

The analysis of media publications, available judicial practice, analytical reports of the regulatory authorities and the results of our survey makes it possible to identify the following forms of corruption between a doctor and a pharmacist, which can appear at different levels:

1) the level of government relations in terms of the use of budget funds (public authority - pharmaceutical corporations): for example, abuse of office by a public official in the procurement of medicines for the implementation of state targeted programs in the field of health care.

For instance, according to the calculations of the Accounting Chamber of Ukraine, the reference prices of full and partial reimbursement of 18 out of 30 items of insulin drugs released to patients with diabetes in the period from 17.03.2020 to 30.08 .2020 were overstated. This resulted in unnecessary reimbursement of the total amount of UAH 862.7 thousand from local budgets. According to the officials of the State Expert Center of the Ministry of Health of Ukraine, such an overstatement of wholesale prices for drugs occurred due to technical inaccuracies [15, p. 27].

It should be noted that the problem of corrupt relationships between a doctor and a pharmacist at the government level is typical not only for Ukraine. For example, there is a well-known case of the activities of Pfizer Company in 2012, which agreed to pay $\$ 60$ million to settle the US federal investigation into a case of bribery abroad. Pfizer had been accused of bribing not only doctors but also hospital administrators and drug regulators in European and Asian countries. According to court documents, the company had been making monthly payments for what it called "consulting services" to a doctor in Croatia who helped decide which medicines the government would register for sale and reimbursement [16, p. 96];

2) the level of economic relations between legal entities (hospital - pharmacy): for example, procurement of overpriced medicines to obtain illegal benefits through the so-called "rollback";

${ }^{1}$ Footnote. The survey was conducted using the Google Forms service. More details on its results can be found at the link: http://surl.li/ayxqz 
3) the level of direct provision of medical services (doctor - patient - pharmacist): for example, the direct sale by a doctor of medicines received from a pharmacist "for sale" (including the counterfeit ones); recommendation of a specific pharmacy to a patient for the corresponding reward so that the patient bought drugs right there; prescribing of drugs from specific manufacturers for a fee, etc.

In the framework of the above-mentioned survey, respondents were also asked the question: "Has it ever happened to you that a doctor, when prescribing medicines, referred you to a specific pharmacy to buy them there (recommended you to buy medicines in this very pharmacy)?" 171 out of 249 answers, i.e. $68.7 \%$, were affirmative. An interesting fact: a significant proportion of respondents (54.1\%) found out later that the price of these drugs in another pharmacy was lower. The difference in cost, according to the respondents, ranged from a few $\mathrm{UAH}$ to even $\$ 150$.

Less often, but situations of selling medicines directly by a doctor can also take place. 39 out of 249 respondents (15.7\%) answered "yes" to the question "Have you ever bought medicines directly from the doctor who prescribed them?" Two more gave answers "sometimes", "from the agent".

Of course, such survey results cannot unequivocally indicate the presence of a corruption component in each of these cases, but they undoubtedly indicate the particular corruption vulnerability of this sector.

An example of such a situation is the proceedings of the Main Investigation Department of the Security Service of Ukraine under Part 5 of Article 191 of the Criminal Code of Ukraine. During the pre-trial investigation, it was established that a person with the use of the controllable business entities, in agreement with officials of pharmaceutical companies, created an illegal mechanism for misappropriation of funds and providing illegal benefits to employees of healthcare institutions of Ukraine, in order to promote and sell their products among patients [17].

It should be emphasized once again that if corruption behavior at each of the above-described levels contains the necessary features of a criminal offense, the existing criminal remedies of counteraction to corruption are applied.

As a result of the reform of criminal legislation, which has taken place over the past ten years, Ukraine has created a specific criminal law regime to combat corruption, which includes not only the presence in the Criminal Code of Ukraine [18] of the relevant prohibitions but also:

1) the existence in the Criminal Code of Ukraine of the definitions of the notions "corruption criminal offense" and "criminal offense related to corruption", which are formulated by providing an exhaustive list of the relevant criminal law prohibitions;

2) restriction on the application to a person found guilty of committing the relevant criminal offense of incentive criminal law measures: discharge from criminal liability, from punishment and from serving it, imposition of a punishment milder than prescribed by the law, etc.

Analysis of the relevant provisions of the Criminal Code of Ukraine makes it possible to conclude that various forms of corrupt relationships between a doctor and a pharmacist at all the levels identified in this article can receive a criminal assessment under the following articles of the Criminal Code of Ukraine, which can be grouped into two relatively large groups:

1) Articles $191 ; 210 ; 364 ; 364^{1}$ - for example, in cases of medicines procurement (qualification under one or another article depends on the specific circumstances); 2) Articles $354 ; 368 ; 368^{3} ; 368^{4} ; 369 ; 369^{3}$ - in cases of bribery, depending on the characteristics of the special subject and the nature of the opportunities that "are being bought". As to the second group of criminal offenses that may be committed in tandem "doctor - pharmacist" - bribery - the following should be borne in mind. Indeed, the legislation of Ukraine prohibits medical workers to receive illegal benefits from business entities or their representatives engaged in the production and/or sale of medicines, medical devices, technical and other means of rehabilitation. This gives some authors grounds to claim that "...free business breakfasts, conferences, round tables, etc., organized by pharmacological companies, are illegal benefits" [1, p. 265]. They are indeed, but from the criminal law point of view, such benefits will be relevant as a feature of bribery only if they are offered, promised, or provided for the behavior of a special subject related to his/her status. In the absence of such relation, the fact of transferring illegal benefit, for example, by a pharmacist to a doctor can be assessed only as an administrative offense under Article $44^{2}$ of the Code of Ukraine on Administrative Offenses.

Therefore, if the corrupt relationship between a doctor and a pharmacist contains a corpus delicti of any criminal offense provided for in the above-mentioned lists of criminal law prohibitions, the persons found guilty of their commitment are subject to the restrictions inherent in any corruption criminal offense. The effectiveness of these tools will be commensurate with the effectiveness of the legal tools to combat any corruption offense.

So the next question in our research is: are the existing criminal law tools able to counteract corrupt forms of interaction between a doctor and a pharmacist effectively?

The answer to this question is essentially the answer to the question of whether it is necessary to single out a special norm in the Criminal Code of Ukraine, which would provide for corrupt forms of relationships between the analyzed subjects? Probably not.

Some reasons to justify such a point of view. Volodymyr Kudryavtsev quite rightly noted that the existence of a special norm is justified only if it solves the issue of criminal liability differently: establishes a higher or a lower sanction, narrower limits of the sanction, etc. [19, p. 250]. That is, for the separation of a certain special norm from the already existing general one to be expedient and necessary, it must reflect either a higher or a lower degree of social danger of the respective types of acts in comparison with the general norm. But is it possible to state unequivocally that the corrupt relationship between a doctor and a pharmacist is more socially dangerous than the corruption in other spheres of social life? Or less socially dangerous? In our 
opinion, it is impossible to give an unambiguous answer to this question.

Thus, we come to the conclusion that singling out a special norm, which would provide for the corrupt relationship between a doctor and a pharmacist, will indicate only an excessive differentiation of criminal liability and will not contribute to the effectiveness of the criminal law. The corresponding, most dangerous, forms of illegal interaction between medical and pharmaceutical workers are covered by the existing criminal law norms. This raises the long-standing problem of the dialectical relationship between an abstract and a specified legal prohibition: which one is more effective. The preventive effect of a special norm is questioned in the study of one of the authors of this article [20, pp. 122-151] and there are no other studies in this regard that would refute the obtained results. The reference to foreign experience [21] seems unconvincing since it does not take into account the current state of the Ukrainian legal system, which has the necessary legal tools but uses them inefficiently. Therefore, the appearance of a special (specified) prohibition in the Criminal Code of Ukraine, which would reflect the corrupt relationship between a doctor and a pharmacist, will create, in our opinion, an excess of legal regulation and complicate the already ineffective mechanism of legal regulation.

\section{CONCLUSIONS}

The study of the problems of criminal law counteraction to corrupt relationships between a doctor and a pharmacist gives us grounds for such conclusions:

- the problem of corrupt relationships between a doctor and a pharmacist is relevant both for Ukraine and for other countries, and accordingly, requires an adequate legal assessment;

- corrupt interaction between a doctor and a pharmacist may occur at these levels: 1) the level of government relations in terms of the use of budget funds (public authority - pharmaceutical corporations); 2) the level of economic relations between legal entities (hospital - pharmacy); 3) the level of direct provision of medical services (doctor - patient - pharmacist);

- corrupt forms of unlawful interaction between medical and pharmaceutical workers at all these levels are covered by the existing norms of the Criminal Code of Ukraine; there is no need to single out a special norm that would reflect the corrupt relationship between a doctor and a pharmacist.

\section{REFERENCES}

1. Busol 0.lu. Protydiia koruptsiinii zlochynnosti v Ukraini u konteksti suchasnoi antykoruptsiinoi stratehii: dysertatsiia ... dokt. yuryd. nauk [Counteraction to corruption crime in Ukraine in the context of modern anti-corruption strategy: Thesis for the degree of Doctor of Law]. Kyiv, 2015. 479. (in Ukrainian).

2. Corruption in the Pharmaceutical Sector. Diagnosing the Challenges. Transparency International; 2016. Available from: https://apps.who. int/medicinedocs/documents/s22500en/s22500en.pdf
3. Cohen JC. Pharmaceuticals and Corruption: A Risk Assessment In: Corruption in the Pharmaceutical Sector. Berlin: Transparency International; 2006; 77-85.

4. Politsiia vykryla hrupu farmatsevtychnykh kompanii u pidkupi likariv na 140 milioniv hryven [Police have exposed a group of pharmaceutical companies in bribing doctors for UAH 140 million] (06.12.2019) / Official site of the National Police of Ukraine. Available from: https://www.npu. gov.ua/news/korupcziya/policziya-vikrila-grupu-farmaczevtichnixkompanij-u-pidkupi-likariv-na-140-miljoniv-griven/ (in Ukrainian).

5. Kaur B. There's an unhealthy alliance between doctors and pharma firms (15.05.2019).Availablefrom:https://www.downtoearth.org.in/news/health/ there-s-an-unhealthy-alliance-between-doctors-and-pharma-firms-64230

6. Criminal case on large-scale corruption in the field of pharmacy have been referred to the court (22.03.2021) / Special Investigation Service of the Republic of Lithuania. Available from: https://www.stt.It/en/ news/7481/criminal-case-on-large-scale-corruption-in-the-field-ofpharmacy-have-been-referred-to-the-court:3095

7. Justice Department Announces Largest Health Care Fraud Settlement in Its History. Pfizer to Pay \$2.3 Billion for Fraudulent Marketing. Available from:https://www.justice.gov/opa/pr/justice-department-announceslargest-health-care-fraud-settlement-its-history

8. GlaxoSmithKline to Plead Guilty and Pay \$3 Billion to Resolve Fraud Allegations and Failure to Report Safety Data. Available at: https:// www.justice.gov/opa/pr/glaxosmithkline-plead-guilty-and-pay-3billion-resolve-fraud-allegations-and-failure-report

9. SEC Charges Johnson \& Johnson With Foreign Bribery. Available from: https://www.sec.gov/news/press/2011/2011-87.htm

10. Gutorova N, Soloviov 0 , Olejnik D. Improper healthcare marketing: German and Ukrainian experience in prevention. Wiad. Lek. 2019;72(12 (z. 2):2404-2409.

11. Fundamentals of the Legislation of Ukraine on Health Care: Law of Ukraine on November 19, 1992 № 2801-XII (revision on April 23, 2021). Available from: https://zakon.rada.gov.ua/laws/show/2801-12\#Text (in Ukrainian).

12. Statystychnyi biuleten «Administratyvni pravoporushennia v Ukraini» [Statistical Bulletin «Administrative Offenses in Ukraine»]. Available from: https://ukrstat.org/uk/druk/publicat/Arhiv_u/15/Arch_ap_ bl.htm (in Ukrainian).

13. Zvedenyi zvit sudiv pershoi instantsii shchodo rozghliadu sprav pro administratyvni pravoporushennia u 2020 rotsi [Consolidated report of the courts of the first instance on cases of administrative offenses in 2020] / Sudova vlada Ukrainy. Available from: https://court.gov.ua/ inshe/sudova_statystyka/rik_2020 (in Ukrainian).

14. Gutorova N. Nezakonna vynahoroda pid chas prosuvannia medychnoi produktsii yak proiav pryvatnoi koruptsii v farmatsii [lllegal remuneration in the promotion of medical products as a manifestation of private corruption in pharmacy]. Apteka.ua. 2021;25(1296). Available from: https://www.apteka.ua/article/599889 (in Ukrainian).

15. Zvit pro rezultaty audytu efektyvnosti vykorystannia koshtiv medychnoi subventsii z derzhavnoho biudzhetu mistsevym biudzhetam dlia likuvannia khvorykh na tsukrovyi ta netsukrovyi diabet: zatverdzheno rishenniam Rakhunkovoi palaty vid 26.01.2021 № 1-1 [Report on the results of the audit of the effectiveness of the use of medical subvention funds from the state budget to local budgets for the treatment of patients with diabetes and non-diabetes mellitus: approved by the decision of the Accounting Chamber from 26.01.2021 № 1-1]. Available from: https://rp.gov.ua/upload-files/Activity/Collegium/2021/1-1_2021/ Zvit_1-1_2021.pdf (in Ukrainian). 
16. Pyvovarov V.V., Hlushanovska S.V. Kryminolohichna kharakterystyka suchasnoi transnatsionalnoi korporatyvnoi zlochynnosti u farmakolohichnii haluzi [Criminological characteristics of modern transnational corporate crime in the pharmacological industry]. Naukovyi visnyk Uzhhorodskoho natsionalnoho universytetu. 2016; 40-2:94-97 (in Russian).

17. Ukhvala Dniprovskoho raionnoho sudu m. Kyieva [Ruling of the Dnipro District Court of Kyiv] vid 26.07.2019 (sprava № 755/3244/19). Available from: http://reyestr.court.gov.ua/Review/83365705 (in Ukrainian).

18. Criminal Code of Ukraine: Law of Ukraine on April 5, 2001 № 2341-III (revision on July 21, 2021). Available from: https://zakon.rada.gov.ua/ laws/show/2341-14\#Text (In Ukrainian).

19. Kudriavtsev V.N. Teoreticheskiye osnovy kvalifikatsii prestupleniy [Theoretical foundations of the qualification of crimes]. Moscow: State publishing house of legal literature, 1963. 323 p. (in Russian).

20. Sen I.Z. Spetsialni normy u kryminalnomu pravi Ukrainy: dysertatsiia ... kand. yuryd. nauk [Special norms in criminal law of Ukraine: Thesis for the Candidate Degree in Law]. Lviv, 2020. 268 p. (in Ukrainian).

21. Gutorova N. Kryminalna vidpovidalnist za pidkup medychnoho pratsivnyka predstavnykom farmatsevtychnoi kompanii [Criminal liability for bribery of a medical worker by a representative of a pharmaceutical company]. Apteka.ua. 2021;1(1272). Available from: https://www.apteka.ua/article/579162 (in Ukrainian).

\section{ORCID and contributionship:}

Oleksandr K. Marin: 0000-0003-3463-8523 $3^{A, B, C, D, F}$

Iryna Z. Sen: 0000-0003-0648-6948

\section{Conflict of interest:}

The Authors declare no conflict of interest.

\section{CORRESPONDING AUTHOR}

\section{Oleksandr K. Marin}

Department of Criminal Law and Criminology,

Ivan Franko National University of Lviv

Universytetska Str., 1, 79000, Lviv, Ukraine

tel: +380983474278

e-mail: oleksandr.marin@lnu.edu.ua

Received: 01.07.2021

Accepted: 20.10 .2021

A - Work concept and design, B - Data collection and analysis, C - Responsibility for statistical analysis, D-Writing the article, $\mathbf{E}$-Critical review, $\mathbf{F}$ - Final approval of the article 


\title{
PENALIZATION OF NON-COMPLIANCE WITH THE COVID-19 VACCINATION: TO BE OR NOT TO BE?
}

DOI: 10.36740/WLek202111208

\author{
Olha I. Denkovych, Viktor I. Markin, Snizhana V. Shevchenko \\ IVAN FRANKO NATIONAL UNIVERSITY OF LVIV, LVIV, UKRAINE
}

\begin{abstract}
The aim: This paper is aimed to identify criteria with regard to which government should evaluate whether criminal penalties for non-compliance with the Covid-19 vaccination can be envisaged and reveal the community's attitude to support such criminalization.

Materials and methods: This research is based on the analysis of the case-law of the European Court of Human Rights, Supreme Court of the US, and Supreme Court of Ukraine; statistical database, in particular of the World Health Organization and survey of 100 Ukrainian residents. During the research of the stated issue systematic method, formal-legal method, comparative method and case study method were used.

Results: In total 100 respondents participated in the survey, of which 27 (27\%) are health care workers (17 doctors, 9 nurses and 1 medical registrar). $39 \%$ of respondents supported the mandatory vaccination against Covid-19 for adults and $21 \%$ have not yet decided. Almost the same results pertain to the compulsory vaccination of doctors and representatives of other target groups (retired, teachers, etc.) (supported by $52 \%$ and $48 \%$ respectively). By contrast, the compulsory Covid- 19 vaccination of minors was supported only by $20 \%$ respondents.

Conclusions: The international human rights law provides grounds to impose mandatory vaccination to control the spreading of Covid-19. Such vaccination constitutes the intervention with the right to physical integrity and can be justified only when it is clearly provided by law, pursue the legitimate aim of the protection of public health, and is necessary for a democratic society. This survey highlights the need to critically evaluate the implementation of non-compliance penalties to determine their effectiveness. Despite the well-recognized efficiency of the vaccination against Covid-19, society is still hesitant whether a mandate for such vaccination should be delivered and more reluctantly accepts other containment measures. Criminal penalties for non-compliance with Covid-19 vaccination are consistently opposed by society that pertains to the historical background on vaccination policy in a certain country.
\end{abstract}

KEY WORDS: pandemic, criminalization, vaccination policy

Wiad Lek. 2021;74(11 p.2):2907-2911

\section{INTRODUCTION}

The most serious global public health concern is the Coronavirus (Covid-19) pandemic, which resulted in 4180161 deaths, reported to the World Health Organization [1]. Vaccination against Covid-19 initially was seen as the best solution to the disease which was killing millions worldwide. Nevertheless, it also gave grounds for objections from vaccine skeptics and opponents. Thus, the controversy over vaccines is not a new issue. Strong anti-vaccination sentiment accompanied vaccination against smallpox in the UK back in the 18th century [2]. In the mid-1970s, an international controversy over the safety of diphtheria, tetanus, and pertussis immunization erupted in Europe, Asia, Australia, and North America [3]. Despite controversy over vaccination, health and medical scholars estimated it as one of the top ten achievements of public health in the 20 th century [4]. Moreover, mandatory vaccination against some diseases has been introduced globally and as a result 'in the first decade of the 21st century, an estimated 2.5 million deaths were prevented each year among children aged $<5$ years using measles, polio, and diphtheria-tetanus-pertussis vaccines [5].
Currently, the same issue comes to a head again and pertains to the Covid-19 vaccination: should it be mandatory, and what legal consequences should follow from the violation of the mandatory vaccination. Therefore, within the challenges of the Covid-19 pandemic, legislators are confronted with the problem of how to set appropriate legal frameworks for the protection of public health from Covid-19 threats and not to limit individuals' autonomy excessively. The more intrusive instruments are used by a legislator - the more well-grounded reasoning should be provided. That is, if vaccination against Covid-19 is mandatory, the legislator must prepare clear reasoning why less intrusive means are not effective in the protection of public interest. Moreover, it should be decided whether to incorporate penalties for non-compliance with a Covid-19 vaccine mandate and what type of penalty should prevail.

Legal policy on mandatory vaccination varies widely among countries. A study published last year 'Global assessment of national mandatory vaccination policies and consequences of non-compliance, revealed that over 100 countries out of 193 under survey have nationwide mandatory vaccination policy requiring one or more vaccines, 
and of those, 62 countries (59\%) also impose one or more penalties against individuals who do not comply [6]. Most commonly vaccine refusal results in educational penalties (i.e., limiting a child's entry or ongoing access to school) or imposition of financial ones. Thus, some state authorities back mandatory vaccination with criminal sanctions. For example, under the French Criminal Code a child's health neglect, including a vaccine refusal, is amenable to a fine of up to EUR 30,000 or even punishable by deprivation of liberty for up to two years. In Belgium Article 5 of the Health Law of 1 September, 1945 provide for and penalizes non-compliance with the mandatory polio vaccine with a fine of between 26 and 100 francs and imprisonment for a period between eight days and one month or by one of these penalties only. Penalties that entail a loss of liberty for non-compliance with a vaccination mandate are provided for in 12 countries, and they are most common in Africa $[6,7868]$.

At the beginning of the Covid-19 pandemic, many countries has imposed sanctions on persons who fail to comply with containment measures. Nevertheless, national governments are still inconsistent on the question of whether Covid-19 vaccination should be mandatory and whether to impose penalties for non-compliance with this vaccination. Currently, 15 countries imposed compulsory Covid-19 vaccination. In particular, in Tajikistan, Turkmenistan and the Vatican City such vaccination is obligatory for all adults. By contrast in other countries (i.e., UK, France, Italy, Greece) its compulsory only for certain groups of adults - healthcare workers or other professions with a high level of human contact.

In any case imposition of any penalties and criminal ones in particular, for non-compliance with the mandatory vaccination against Covid-19 cannot be groundless and superficial. In the decision-making process states should assess different aspects and data and the severity of penalties should comply with the proportionality principle. In such a case it should be accurately defined: who is the subject to the prohibition, under what circumstances it is applicable, its scope. It is widely accepted by the legal doctrine that punishment of any act can be justified by appeal to some grounds, one of which is when people (normally a particular minority) want it $[7,512]$. Yet, no comprehensive review on people's attitude to the criminalization of non-compliance with vaccination against Covid-19 has been undertaken.

\section{THE AIM}

This paper is aimed to identify criteria with regard to which the criminal penalties for non-compliance with the Covid-19 vaccination can be provided for and whether society supports such criminalization.

\section{MATERIALS AND METHODS}

This research is based on the analysis of the case-law of the European Court of Human Rights (hereinafter - the
ECtHR), Supreme Court of the US and Supreme Court of Ukraine, statistical database, in particular of the World Health Organization. During the research of the stated issue several methods were used: systematic method, formal-legal method, comparative method, and case study method. Also, the survey of 100 Ukrainian residents was conducted. The collection of all responses was supported by Google form, which enables participation in various virtual groups. Participation in the survey was voluntary. The research tool was a questionnaire of 14 questions, prepared by the researchers.

\section{RESULTS}

The main rule under the international human rights law, which pertains to vaccination, is that it must be based on the recipient's free and informed consent. Like any other compulsory medical intervention, mandatory Covid-19 vaccination interferes with the person's right to physical integrity which is covered by the concept of 'private life'. The first pronouncement on the right to respect for privacy was set out in the Universal Declaration stipulating that 'no-one shall be subjected to arbitrary interference with his privacy, family, home or correspondence. Similar legal provisions currently are incorporated in several international instruments: the International Covenant on Civil and Political Rights (Article 17), European Convention on Human Rights (Article 8), American Convention on Human Rights (Article 11), etc.

The international human rights law recognizes that the person's right to private life is not absolute and can be interfered, in particular, to safeguard public health. Therefore, mandatory Covid-19 vaccination can be justified only on condition that it falls within the legally permissible margins for the limitation of the right to private life: clearly provided by law, pursue the legitimate aim of the protection of public health, and is necessary for a democratic society. While the first two criteria are rather precise, the latter one - a necessity in a democratic society - provides the state government with the opportunity to assess 'the ins and outs of an affair' and to provide the most adequate response to Covid-19 challenges. In the ECtHR case law, the 'necessity in democratic society' is defined as meeting 'a pressing social need' and 'relevant and sufficient' to a legitimate aim. In order to comply with this criterion in the mandatory Covid-19 vaccination issue, the government should assiduously assess different circumstances, in particular the attitude of the society towards such measure.

In total 100 respondents participated in the survey, of which $27 \%$ are health care workers (17 doctors, 9 nurses, and 1 medical registrar). $50 \%$ of respondents are already vaccinated against Covid-19. Among those who had not been vaccinated yet, 16 (32\%) consider vaccinating in the close future. $39 \%$ of respondents supported the mandatory vaccination against Covid- 19 for adults and $21 \%$ have not decided yet. Nevertheless, more respondents claim for the compulsory vaccination of doctors and representatives of other target groups (retired, teachers, etc.) (supported by 
$52 \%$ and $48 \%$ respectively). By contrast, the compulsory Covid-19 vaccination of minors was supported only by 20 $\%$ of respondents.

In the entire group surveyed, $87 \%$ of participants claimed that they do not support the criminalization of non-compliance with compulsory Covid-19 vaccination of adults. $78 \%$ are opponents to envisage criminal penalties on doctors and $91 \%$ voted against parents' criminal liability for non-compliance to vaccinate their child from Covid-19.71 $\%$ of respondents claim that they agree that non-compliance with other containment measures should be provided by penalties, in particular by financial ones $67 \%$.

\section{DISCUSSION}

It is proven that the efficiency of Covid-19 responses depends on multiple factors, in particular on governmental policy. As a result, the magnitude of Covid-19 impacts varied a lot among countries - some have been very successful in limiting the spread of the disease. It is undebatable that this is more than just a challenging task when it comes to ensuring public health safety in times of pandemics. Thus, in such cases, public health well-being endangers and limits such personal rights as right for private and family life, freedom of movement, freedom of thought, conscience and religion, freedom of assembly and association, right of children to free and compulsory education, etc. Nevertheless, even liberal governments choose to limit individuals' autonomy. The question is whether and when restrictions are justified.

Notwithstanding the government has 'margin of appreciation', no legislator obtains an unlimited discretion (socalled carte blanche) in imposing measures to respond to the Covid-19 pandemic. Legal doctrine and practice use the 'intervention ladder concept' $[8,60]$ to determine which measure is appropriate in certain cases. The latter entails the rule that if the least intrusive instrument is effective in risks mitigation, then it should be used, and the most intrusive one should be considered only after all the others failed to be effective. We do agree that 'determining which rung on the ladder is appropriate for a particular society at a specific moment ultimately depends on contextual factors $[9,210]$. For instance, each country determines which vaccines to use for COVID-19 vaccination, with regard, in particular, to the general well-being of the country.

The same rule applies when the government decides how to reach high immunization rates in the COVID-19 campaign. The COVID-19 vaccination policy can entail persuasion, nudging, financial incentives, disincentives, outright compulsion $[8,59]$; no-jab-no-pay policies [9, 211], and many others. In general vaccination policies can be voluntary and involuntary. The latter has two types: compulsory or mandatory, which should be distinguished. Both types of involuntary vaccination are more intrusive than e.g., persuasion or nudging, that relate to marketing and promo of benefits from voluntary vaccination or creating adherent conditions for vaccination. If persuasion or nudging result in high rates of participation in voluntary vaccination programs, then it seems no argument to justify the compulsory or even mandatory one. A compulsory vaccination unlike the mandatory one entails coercive and secured by criminal punishment for non-compliance policies. By contrast under mandatory vaccination policy, non-compliance with vaccination is backed by parental, educational, or financial penalties that provide little but still some space for decision-making. Thus, the difference between mandatory and compulsory vaccination pertains to the legal consequences that can be envisaged for non-compliance.

Co-dependencies and laddering of different vaccination policies may be illustrated by the vaccination of school-age children. If the vaccination is not mandatory, unenrolling in school or kindergarten of the unvaccinated child would be treated as discrimination and unlawful limitation of the child's right to educate. If vaccination is mandatory, the parents are still entitled not to vaccinate a child and proceed with home education or provide tutors engagement. Thus, these alternatives deem to be rather relative ones as parents with low-income seem to leave no choice (nudging). The main argument for such strict intrusion is the sake of the best child's interest - his or her physical health. The decision to non-vaccinate, which leads to homeschooling or private lessons of a child, benefits only the health interest of the child. Other interests of the child are limited or even neglected. Thus, the argument to protect health should be balanced with arguments of mental health protection and socialization.

Moreover, it is hard to overcome the arguments for the child's best interest once the parents' freedom of thought, conscience, and religious belief is at stake. For instance, if parents are vegetarians/vegans and vaccination of their child contradicts parents' freedom of thought, conscience, or religious beliefs. It should be noted that there is not universally acknowledged way of how to rise children and what good parenting must include. Thus, it is questionable whether parenting approach not to vaccinate a child should be punished. In the landmark case Vavrička and Others v. the Czech Republic, the ECtHR pointed out that 'objection to vaccination was primarily health-related; philosophical or religious aspects were secondary' [10]. ECtHR emphasized that if philosophical or religious arguments were primary, they might have influenced their decision on the case. Philosophical and religious believes are harder to overcome than the arguments on health policy mistrust from non-subject opinion matter. The same emphasis was mentioned in the ECtHR case Bayatyan v. Armenia: 'opposition to military service, where it is motivated by a serious and insurmountable conflict between the obligation to serve in the army and a person's conscience or his deeply and genuinely held religious or other beliefs, constitutes a conviction or belief of sufficient cogency, seriousness, cohesion, and importance to attract the guarantees of Article 9' [11]. Similar to Vavřička and Others v. the Czech Republic decision was holded by the Supreme Court in Ukraine [12]. The Supreme Court refused to take into consideration the applicant's arguments against refusing to vaccinate a child 
on the grounds of 'distrust to vaccines', mainly because of its quality. The latter argument was debunked by the argument that 'the State's task is to ensure an optimal balance between the child's right to pre-school education and the interests of other children' [12].

Moreover, it should be taken into account that coercive medical treatment is an exceptional highly-scrutiny instrument of acting in the best interest of the ill person and can be applied only under the limited circle of people and conditions [13]. The question of effectiveness and efficiency of mandatory/compulsory vaccination of all population or its certain groups (e.g., doctors (Bridges, et al v. Houston Methodist Hospital case [14]), teachers, state or city workers, children) should be weighted as well.

Compulsory vaccination should be regarded as the most severe form of the state's intrusion in fundamental rights and freedoms. Nevertheless, a survey of mothers from nine European countries revealed that in countries with mandatory vaccinations parents have their children vaccinated less willingly than in countries with voluntary vaccinations $[15,7868]$. The same consumption is promoted in WHO Policy Brief according to which mandatory Covid-19 vaccination 'would not be ethically justified, as achieving public health goals with less restriction of individual liberty and autonomy yields a more favorable risk-benefit ratio' [16]. Thus, the effectiveness of compulsory vaccination is double triggered, in particular from the end beneficiary side. This tendency is clearly demonstrated by the results of the survey. In the entire group, only $39 \%$ of respondents supported the mandatory vaccination against Covid-19 for adults and $21 \%$ have not decided yet, though most $77 \%$ considered the vaccination an effective measure to prevent the Covid-19 pandemic. Among those surveyed, who recovered from Covid-19, 14 (59 \%) claim compulsory vaccination. By contrast, more respondents (76\% against $39 \%$ who claimed for the compulsory vaccination) supported the mandatory mask regime in public places. Therefore, despite the well-recognized efficiency of the vaccination against Covid-19, society, in general, is still hesitant whether such vaccination should be involuntary and more reluctantly accepts other containment measures. By contrast, 18 (67\%) healthcare workers out of 27 surveyed claimed that a mandate for Covid-19 should be imposed. So, people, who directly witnessed the challenges of the Covid-19 pandemic and are more confident about its consequences and, therefore, are disposed to more intrusive measures for Covid-19 prevention.

The decision of the government on the type of vaccination policy correlates with legal consequences which can be imposed for non-compliance with such policy. Thus, only in the case of mandatory or compulsory vaccination policies for Covid-19, the country can include provisions for levying penalties against those who do not comply. Our survey provides grounds to assume that even though vaccination is considered an effective measure for Covid-19 prevention, society opposes compulsory vaccination policy. In the entire group surveyed, $87 \%$ of participants claimed that they do not support the criminalization of non-compliance with compulsory Covid-19 vaccination of adults. $78 \%$ are opponents to envisage criminal penalties on doctors and $91 \%$ voted against parents' criminal liability for non-compliance to vaccinate their child from Covid-19. Obviously government should take into consideration such consistency in opposition to compulsory vaccination against Covid-19 and opt for a mandatory one. Though $71 \%$ of respondents claim that they agree that non-compliance with other containment measures should be provided by penalties, in particular by financial ones $(67 \%)$. We can assume that such results pertain to the historical background to vaccination policy in Ukraine where compulsory vaccination was never envisaged.

The abovementioned results lead us to a classical Machiavelli type of dilemma: what aims can justify burdensome instruments of limiting human rights and freedoms. For this reason, we can assume that the utilitarian approach is a core in deciding which vaccination policy to choose: "legislator must equally consider effective ways of balancing of human rights protection, as well as public interests protection, at the same time fitting a demand of policy for criminal law being used as ultimum remedium" $[17,61]$. Only compelling public interests can provide grounds to envisage a compulsory or mandatory vaccination against Covid-19: if such policy is the last resort to ensure public health safety.

\section{CONCLUSIONS}

The international human rights law provides grounds to impose mandatory vaccination to control the spreading of Covid-19.

Such vaccination constitutes the intervention with the right to physical integrity and can be justified only when it is clearly provided by law, pursue the legitimate aim of the protection of public health, and is necessary for a democratic society. This survey highlights the need to critically evaluate the implementation of non-compliance penalties for mandatory Covid-19 vaccination to determine their effectiveness. Despite the well-recognized efficiency of the vaccination against Covid-19, society is still hesitant whether a mandate for such vaccination should be delivered and more reluctantly accepts other containment measures. Criminal penalties for non-compliance with Covid-19 vaccination are consistently opposed by society that pertains to the historical background on vaccination policy in a certain country.

\section{REFERENCES}

1. Dashboard: Coronavirus (Covid-19). World Health Organization. Available from: https://covid19.who.int/ (accessed 29 July 2021).

2. MacMillan A. Mandatory vaccination: legal, justified, effective? The IBA. 2021. Available from: https://www.ibanet.org/article/70E1F93E-A23B4F1A-A596-AEEF84750241

3. History of Anti-vaccination Movements. Educational resource. Colleague of physicians of Philadelphia. Available from: https:// www.historyofvaccines.org/index.php/content/articles/history-antivaccination-movements (accessed 29 July 2021). 
4. Ten great public health achievements - United States, 1900-1999. Centers for Disease Control and Prevention. Available from: https:// www.cdc.gov/mmwr/preview/mmwrhtml/00056796.htm (accessed 29 July 2021).

5. Ten Great Public Health Achievements. Worldwide, 2001-2010. Centers for Disease Control and Prevention. Available from: https:// www.cdc.gov/mmwr/preview/mmwrhtml/mm6024a4.htm?s cid=mm6024a4_w (accessed 29 July 2021).

6. Gravagna K, Becker A, Valeris-Chacin R. et al. Global assessment of national mandatory vaccination policies and consequences of non-compliance. Vaccine. 2020;38(49):7865-7873. doi: https://doi. org/10.1016/j.vaccine.2020.09.063

7. Jareborg N. Criminalisation as last resort (Ultima Ratio). Ohio State Journal of criminal law. 2005;V.2:521-534.

8. Giubilini A. The ethics of vaccination. Cham: Palgrave Pivot. 2019:126.

9. Pierik R. Vaccination Policies: Between Best and Basic Interests of the Child, between Precaution and Proportionality. Public health ethics. 2020;13(2):201-214.

10. Vavřicka and 0thers v. the Czech Republic: Judgment of 8 April 2021. Application no. 47621/13 and 5 others. European Court of Human Rights. Available from: https://hudoc.echr.coe.int/fre\#\{\%22item id\%22:[\%22001-209039\%22]\}

11. Bayatyan v. Armenia: Judgment of 7 July 2011. Application no. 23459/03. European Court of Human Rights. Available from: https://hudoc.echr. coe.int/tur\#\{\%22itemid\%22:[\%22001-105611\%22]\})

12. Case № 682/1692/17: Judgment of 17 April 2019. Verkhovnyi Sud. Available from: https://reyestr.court.gov.ua/Review/81652333

13. Immunization Laws and Regulations. Department of Health. Available at: https://www.health.ny.gov/prevention/immunization/laws_regs. htm (accessed 29 July 2021).

14. Bridges, et al v. Houston Methodist Hospital et. al. Order on dismissal of 12 June 2021. United States District Court. Southern District f Texas. Available from: https://docs.justia.com/cases/federal/district-courts/ texas/txsdce/4:2021cv01774/1830373/18

15. Pisaniak P, Konarska M, Tarczon A. et. al. Mothers' Opinions on Vaccinations and Penal Responsibility for Vaccination Avoidance in Nine Selected European Countries: Findings from a Cross-Sectional Survey. Risk Management and Health care Policy. 2021;14:1241-1254.

16. Policy Brief: COVID-19 and mandatory vaccination: Ethical considerations and caveats. Geneva: World Health Organization, 2021. Available from: https://www.who.int/publications/i/item/WH0-2019-nCoV-Policybrief-Mandatory-vaccination-2021.1).

17. Shevchenko SV. Analysis of utilitarian approach to criminalization justification. Kryminalna yustytsia pid chas pidhotovky maybutnikh suddiv, prokuroriv ta slidchukh v kontesti yevropeiskykh standartiv: zbirnyk statei za materialamy pershoii mizhnarodnoi konferentsii. 2020:61-66. (in Ukrainian).
18. Demidova L, Demidova E, Dudchenko A. Vaccination against infectious diseases: international standards of patient's rights. Wiadomości Lekarskie. 2019;72(12,2):2518-2524.

19. Holland M. Compulsory Vaccination, the Constitution, and the Hepatitis B Mandate for Infants and Young Children. Yale Journal of Health Policy, Law, and Ethics. 2021,12(1):39-86.

20. Krasser A. Compulsory Vaccination in a Fundamental Rights Perspective: Lessons from the ECtHR. ICL Journal. 2021,15(2):207-233.

21. Gravagna K, Becker A, Valeris-Chacin R. et. al. Global assessment of national mandatory vaccination policies and consequences of noncompliance. Vaccine. 2020;38:7865-7873.

The Article is written within the Scientific and Research Theme of the criminal law and criminology department of Ivan Franko National University of Lviv'Theoretic and practical problems of the efficiency of criminal legislation of Ukraine'.

\section{ORCID and contributionship:}

Olha I. Denkovych: 0000-0001-5581-7913 ${ }^{A, B, C, D, F}$

Viktor I. Markin: 0000-0002-2399-9342 ${ }^{A, B, D, E}$

Snizhana V. Shevchenko: 0000-0002-5570-4529A, B, E,D

\section{Conflict of interest}

The Authors declare no conflict of interest.

\section{CORRESPONDING AUTHOR}

\section{Olha I. Denkovych}

Lviv National University named after Ivan Franko

Ukraine, Lviv

tel: +380979601771

e-mail:0.denkovych@gmail.com

Received: 29.06.2021

Accepted: 11.10 .2021

\footnotetext{
A - Work concept and design, B - Data collection and analysis, C - Responsibility for statistical analysis, D-Writing the article, $\mathbf{E}$ - Critical review, $\mathbf{F}$ - Final approval of the article
} 


\title{
THE PROBLEMS OF DEFINITION OF THE ABETTING IN THE COMISSION OF THE OFFENCES INVOLVING THREATS TO PUBLIC HEALTH (PART 1 OF ARTICLE 9 OF THE COUNCIL OF EUROPE CONVENTION ON THE COUNTERFEITING OF MEDICAL PRODUCTS AND SIMILAR CRIMES INVOLVING THREATS TO PUBLIC HEALTH)
}

DOI: 10.36740/WLek202111209

\author{
Pavlo S. Berzin', Ivan S. Demchenko ${ }^{2}$, Anzhela B. Berzina² \\ 1 DEPARTMENT OF CRIMINAL LAW POLICY AND CRIMINAL LAW, TARAS SHEVCHENKO NATIONAL UNIVERSITY OF KYIV, UKRAINE \\ ${ }^{2}$ DEPARTMENT OF FORENSIC MEDICINE AND MEDICAL LAW, BOGOMOLETS NATIONAL MEDICAL UNIVERSITY, KYIV, UKRAINE
}

\begin{abstract}
The aim: based on the features of the notion of "abetting the commission of crimes established in accordance with the Convention" provided for in Part 1 of Art. 9 of the Medicrime Convention, it is necessary to offer an adequate understanding of the notion of "abetting" and define the types of criminal offenses (crimes) that are the "subject" of such abetting. Materials and methods: the research is based on an analysis of the provisions of the Medicrime Convention and the criminal law of Ukraine. The following methods were used: dialectical method; hermeneutic method; systemic-and-structural method; and comparative-legal method.

Results: at the legislative level, there is a problem of designating the relevant socio-legal phenomena with adequate concepts and interpretations of these concepts. In the current criminal legislation of Ukraine, there is no definition of the concept of "abetting", which is used in Part 1 of Art. 9 of the Medicrime Convention. Therefore, in the implementation of the requirements provided for in Part 1 of Art. 9 of the Medicrime Convention, each Party takes the necessary legislative and other measures to recognize abetting in committing any crimes, established under this Convention, as a crime, therefore we should take into account the existence of two alternative ways to explain the meaning of "abetting": 1) to recognize at the legislative level that "abetting" and "incitement" are synonyms, and therefore the meaning of the term "abetting" can be explained by using the term "inclination"; 2) to recognize at the legislative level that the concept of "abetting" has a meaning different from the concept of "incitement", and covers not only "inclination", but also "coercion", "motivation" and "encouragement".

Conclusions: the main disadvantage of using the concept of "abetting" in the text of the Ukrainian translation of the Medicrime Convention is that without an independent explanation of this concept at the legislative level, its content should be determined depending on the meaning of the term "inciter" under Part 4 of Art. 27 of the Criminal Code of Ukraine), and means inciting a person to commit any of the crimes specified in the Medicrime Convention.
\end{abstract}

KEY WORDS: criminal offense, crime, falsified medical products, abetting, Medicrime convention

Wiad Lek. 2021;74(11 p.2):2912-2915

\section{INTRODUCTION}

Part 1 of Art. 9 of the Council of Europe Convention on the Counterfeiting of Medical Products and Similar Crimes Involving Threats to Public Health (hereinafter referred to as the "Medicrime Convention"), signed on behalf of Ukraine on October 28, 2011 [1], stipulates that "each party shall take the necessary legislative and other measures in designating any intentionally committed abetting as a crime... to commit any of the crimes established in accordance with this Convention". However, the definition of "abetting" is not enshrined in the Medicrime Convention.

As the terms "abetting the commission of the crimes" and "abetting the commission of the criminal offenses" are actually absent in the current criminal legislation of Ukraine, there are problems in defining these terms, as well as those criminal offenses (crimes) that are provided for in the current Criminal Code of Ukraine (hereinafter referred to as CC) and may be the "subject matter" of the abetting provided for under Part 1 Art. 9 of the Medicrime Convention. The lack of solutions to these problems prevents the implementation of these conditions of the Medicrime Convention, as well as hinders the effectiveness of the implementation of the mechanisms provided by the Medicrime Convention to prevent crimes related to the counterfeiting of medical products and similar crimes involving threats to public health. Although some of these mechanisms were defined at the regulatory level (see, for example, the Concept of State Policy on Prevention of Counterfeiting of Medicines, approved by the Decree No.301-p of the Cabinet of Ministers of Ukraine as of April 3, 2019), but were not analyzed at the scientific level, which in the science of criminal law is considered 
primarily within the formulated scientific model of the criminal law mechanism for the prevention of criminal offenses (crimes), defined in the Medicrime Convention [2, pp. 856-861]. However, the problems of designation of the relevant socio-legal phenomena with adequate terms and interpretations, as well as a special legal level of solving the problem of using the term "abetting the commission of crimes" in legal acts still remain outside the scientific analysis. In this regard, there is still a serious problem of ensuring the general and special norms of criminal law to prevent the mentioned criminal offenses [3; 4].

\section{THE AIM}

Based on the peculiarities of concretization of actions in Part 1 of Art. 9 of the Medicrime Convention, which is included in the concept of "abetting the commission of the crimes established under the Convention", and taking into account the analysis of the relevant provisions of the CC of Ukraine, to offer an adequate understanding of the term of "abetting", to determine the types of criminal offenses (crimes) which are provided for in the CC of Ukraine and are "subject matter" of abetting provided for in Part 1 of Art. 9 of the Medicrime Convention, as well as to find out which of the criminal offenses (crimes) provided by the CC of Ukraine for specific types would "fall out" of the content of such a "subject" of abetting.

\section{MATERIALS AND METHODS}

The conducted research is based on the analysis of the provisions of the Medicrime Convention, as well as the relevant provisions of the criminal law of Ukraine. The following methods to achieve this aim were used: the dialectical method - in clarifying the nature of abetting the commission of the criminal offenses (crimes) that threaten public health, and in defining specific types of such criminal offenses (crimes) under the CC of Ukraine, as well as their compositions; the hermeneutic method - in the process of concretization of basic terms and conceptual phrases, as well as in the formulation of proposals to improve the provisions of the CC of Ukraine; the systemic-and-structural method - in substantiating the systemic nature of the interrelation between the norms of the Medicrime Convention and the norms of the criminal law of Ukraine, which ensure the protection of public health; the comparative-legal method - in defining common and different provisions in designating the term of abetting the commission of the criminal offenses (crimes) that threaten public health in the Medicrime Convention and the criminal law of Ukraine.

\section{RESULTS AND DISCUSSION}

1. Problems of designation of the relevant socio-legal phenomena with adequate terms and interpretations. The term "Abetting the commission of any of the offenses established in accordance with this Convention" [5] is used in the official text of the Medicrime Convention in English, which is stated as "спонукання в скоєнні будь-якого зі злочинів, установлених відповідно до цієї Конвенціï" in the official Ukrainian-language text of the Convention [6]. Thus, the English term "abetting" was translated as "спонукання" into Ukrainian and as “подстрекательство" into Russian [7] when translating the text of the Medicrime Convention, which cannot be considered an unambiguous and accurate method of legislative technique, especially given the different meanings of these terms. The English term "abetting" should be interpreted in terms of help or encouragement (the term "encourage" is used meaning "to make someone more likely to do something, or to make something more likely to happen" [8]) of someone to do something wrong or illegal ("to help or encourage someone to do something wrong or illegal") [9]. However, when interpreting the Ukrainian-language term "спонукання", such ambiguity in the interpretation is absent, as this term is used in the sense of "causing someone to want to do something; to force, incline, encourage to some action, to certain act" [10].

Thus, there is a problem of unambiguous interpretation in the Ukrainian text of the translation of the term “спонукання (abetting)" in the Medicrime Convention and its replacement by another term (in particular, "підбурювання" incitement), that reflects synonymity in the motivation for something which is inherent to the term "abetting". The solution to this problem and the use of the necessary terminology depends on the general and special legal level of use of the term "abetting", which is shown below.

2. The general legal level of solving the problem of using the term "спонукання/ abetting" depends on its adequate relation with the term "підбурювання (incitement)", which in the current CC is specified depending on how a person "persuaded another accomplice to commit a criminal offense" (Part 4 of Art. 27 of the CC). At the general criminal law level, the understanding of the term "спонукання (abetting)" taking into account the meaning of the term "схиляння (inclination)" (in particular, another person to something) is obvious and generally accepted, primarily taking into account the fact that in the draft of the new CC of Ukraine, substantiation of the term "підбурювання (incitement)" is also performed by indicating that the person persuaded another accomplice to commit a criminal offense (Part 4 of Art. 2.5.2 of the CC) [11]. Thus, at the general level, the terms "спонукання (abetting)" and "підбурювання (incitement)" are synonymous, and the substantiation of their content is specified by using the term "схиляння (inclination)" and a general reference to the commission of a criminal offense (crime) regardless of its type.

If at the general legal level the term "спонукання (abetting)" is understood only as "схиляння (inclination)", then outside of such motivation are the actions of a person related to forcing another person to commit a criminal offense, causing him/her to commit a criminal offense (crime), as well as actions associated with encouraging another person to certain behavior. Thus, at the general level, the understanding of the term of inclination can be only one of the possible forms of abetting but does not exhaust its possible meaning. Other possible forms of abetting, in this 
case, may be: forcing another person, causing him/her to desire, and encouraging a person to commit a criminal offense (crime).

\section{Special legal level of solving the problem of using} the term "abetting" in legal acts.

3.1. Art. 9 of the Medicrime Convention uses the term "abetting" to define intentional actions related to the following types of crimes specified in the Medicrime Convention: 1) intentional manufacturing of counterfeit medical products, active substances, excipients, parts, materials and accessories (Part 1 of Art. 5 of the Medicrime Convention); 2) intentional supplying or offering to supply, including brokering, trading, storing in a warehouse, importing and exporting of counterfeit medical products, active substances, excipients, parts, materials and accessories (Part 1 of Art. 6 of the Medicrime Convention);3) intentional making of false documents or forgery of documents (Part 1 of Art. 7 of the Medicrime Convention); 4) similar crimes involving threats to public health, namely: a) the manufacturing, warehousing, importing, exporting, supplying, offering to supply or placing on the market of: medical products without authorization where such authorization is required under the domesticlaw of the Party; or medical devices without being in compliance with the conformity requirements, where such conformity is required under the domestic law of the Party; b) the commercial use of original documents outside their intended use within the legal medical product supply chain, as specified by the domestic law of the Party.

3.2. A person may abet another person to commit any of the mentioned crimes under the Medicrime Convention, but the lack of a definition of "abetting" in the Medicrime Convention does not allow making an unambiguous conclusion as to the specific manner in which such abetting may be performed. If we take into account the understanding of the term "incitement" provided for in Part 4 of Art. 27 of the CC of Ukraine, then abetting is possible only as inclination, but such possible methods as forcing another person to commit a crime under the provisions of the Medicrime Convention, causing another person to desire to commit any of these crimes, and also encouraging another person to commit any of these crimes remain outside abetting. The meanings of all these forms are somehow related to abetting, which allows us to conclude that these forms can be divided into two groups:

a) "negative" forms of abetting in which a person's actions are connected with a negative impact on his/her will, are committed against the will of another person (a person as they say "overcomes the will" of another person, moves against it, receiving the result in the form of consent to commit a relevant crime under the Medicrime Convention). Such forms are forcing and inclination;

b) "positive" forms of abetting in which a person causes another person to want to commit a crime without adversely affecting the will of another person (such a person has a desire to commit a crime under the Medicrime Convention entirely voluntarily, without pressure from the other person on his/her will). In this sense, the forms of abetting are motivation and encouragement.

Conclusion: the term "abetting" in Part 1 of Art. 9 of the Medicrime Convention covers multi-order intentional ac- tions in various forms. Such actions affect differently the will of the person being abetted and are not the same (identical). From this point of view, the use of the Ukrainian-language term "спонукання (abetting)" in the translation of the official text of the Medicrime Convention is quite justified.

\section{CONCLUSIONS}

1. By interrelation of the specified actions which can form abetting provided for in Part 1 of Art. 9 of the Medicrime Convention, and its relevant forms and the relevant actions that form incitement in accordance with Part 4 of Art. 27 of the CC of Ukraine, the following should be taken into account.

1) In Part 4 of Art. 27 of the CC of Ukraine, the legislator provided the term "inciter" and reduced its meaning to only one form of incitement - inclination. In addition, Part 4 of Art. 27 of the CC of Ukraine specifies such methods of incitement as persuasion, bribery, threat, force, and inclination of another accomplice in another way;

2 ) in order for the committed actions to be recognized as the inclination of another accomplice and to form incitement under the provisions of p. 4 Art. 27 of the CC of Ukraine, the inciter's influence on the will of another person must lead to the actions that:

a) the person being incited is capable to perform;

b) the person being incited wishes to perform such actions;

c) the inciter himself/ herself wishes to perform such actions (such actions are desirable for the inciter [12, p. 50]);

d) form an independent type of criminal offense;

3) the person being incited must voluntarily perform the specified actions and, under the influence of the inciter, have an appropriate choice: to perform or not to perform actions to which the inciter is inclined;

4) there must be a causal link between the actions performed by the inciter and the actions of the person being incited;

5) the result is due to the fact that the inciter incites the person, i.e. the presence of a person who was inclined to commit a criminal offense is a determining factor in this case.

2. From a formal point of view, the drawback of using the term "abetting" in a legal act, which is the source of the criminal law of Ukraine, is the fact that without explaining the criminal law meaning of this term, the meaning of the term "abetting" should be determined depending on the meaning of the term "inciter" (Part 4 of Art. 27 of the CC of Ukraine), i.e. taking into account the term "inclination" provided for in Part 4 of Art. 27 of the CC, when some forms of abetting mentioned above remain outside its content.

Given this there is a problem of expediency of using the term "abetting" in the Ukrainian-language text of the translation of Part 1 of Art. 9 of the Medicrime Convention, which is different from the meaning of the term "incitement". This approach of the translators of the Medicrime Convention causes difficulties in understanding the term "abetting" depending on the content other than the content of the term "incitement". This, 
in turn, means that the use of the term "abetting" in the text of the Medicrime Convention translation, which is not explained in the criminal law of Ukraine, indicates the following:

1) violation of legal certainty as the main element of the principle of rule of law, covering "requirements of certainty, clarity, and unambiguity of the legal rule, as otherwise cannot ensure its uniform application, does not exclude" (par. 1 Part 3 of the motivating part of the decision of the Constitutional Court of Ukraine in the case on the constitutional petition of 59 people's councilors of Ukraine on the compliance of the Constitution of Ukraine (constitutionality) of Article 368-2 of the Criminal Code of Ukraine as of February 26, 2019, №1-p/2019);

2) violation of the principle of prohibition of the analogy of norms application of the CC of Ukraine (Part 4 of Art.3 of the CC of Ukraine), as the norms of the General and Special part of the CC defining a specific type of a criminal offense, its separate varieties, types and amounts of penalty, and other measures of criminal legal nature cannot be applied to similar situations not provided by these criminal legal norms [13, pp. 135-136];

3) the need to provide in the Law, which ratified the Medicrime Convention, a kind of precaution in the form of a legislative explanation of the content of terms that are not defined in the criminal law of Ukraine. The absence of such a precaution prevents the fulfillment of requirements provided for in Part 1 of Art. 9 of the Medicrime Convention, that each Party shall take the necessary legislative and other measures to designate abetting as an offense in the commission of any of the offences established in accordance with this Convention. Therefore, at the legislative level, there are two alternative ways to define such a precaution and to formulate a definition of the term "abetting", which is used in Part 1 of Art. 9 of the Medicrime Convention:

a) in the Law ratifying the Medicrime Convention, to recognize that "abetting" and "incitement" are synonymous, and therefore the explanation of the meaning of the term "abetting" can be done by using the term "inclination" used in Part 4 of Art. 27 of the CC of Ukraine;

b) to provide in the same Law that the term "abetting" has a meaning different from the term "incitement", and covers not only "inclination" provided for in Part 4 of Art. 27 of the CC of Ukraine, but also, in particular, forcing another person, causing the desire and encouraging a person to commit a criminal offense (crime).

\section{REFERENCES}

1. Pro ratifikaciyu Konvenciya Radi Evropipro pidroblennya medichnoi produkcii ta podibni zlochini, shcho zagrozhuyut' ohoroni zdorov'ya [Ratification of the Council of Europe Convention on Counterfeiting of Medical Devices and Similar Crimes Threatening Health] Law of Ukraine, dated 7.06.2012 No 4908-VI.VidomostiVerhovnoi Rady. 2013; 17: 160 (in Ukrainian).

2. Gutorova N., Zhytnyi 0., Soloviov 0. Falsification of medical Products: criminal law mechanism combating threats to public Health. Wiad Lek. 2019; 5:856-861.

3. Demchenko I.,Soloviov 0. Poperedzhennya poshyrennya fal'syfikovanykh likars'kykh zasobiv na mizhnarodnomu ta natsional'nomu rivni [Preventing the spread of counterfeit medicines at the international and national levels] Kyiv: Novyi Druk, 2014: 128 (in Ukrainian).
4. Kovalenko I.A. Kriminal'na vidpovidal'nist' za fal'sifikaciyu ta obig fal'sifikovanih likars'kih zasobiv[Criminal liability for falsification and trafficking counterfeit medicines]. Odesa: Nacional'nij universitet "Odes'ka yuridichnaa kademiya", MON Ukrainy, 2017:257 (in Ukrainian).

5. Council of Europe Convention on the counterfeiting of medical products and similar crimes involving threats to public health. Available from: https://rm.coe.int/CoERMPublicCommonSearchServices/ DisplayDCTMContent?documentld $=090000168008482 f$

6. Konvenciya Rady Evropy pro pidroblennyamedichnoiprodukcii ta podibnizlochini, shchozagrozhuyut' ohoronizdorov'ya. [Council of Europe Convention on Counterfeiting of Medical Devices and Similar Crimes Threatening Health] Oficijnij visnik Ukraiyni. 2012; № 50; № 96: 608; 49; 1954 (Ua).

7. Konventsija Soveta Evropy o borbe s falsifikatsiey meditsinkoy produktsii I skhodnumy prestupleniyamy, ugrozshayuschimy sdorovyu naseleniya (in Russian). Available from: https://docs.cntd.ru/document/560988161

8. Cambridge Dictionary. Available from: https://dictionary.cambridge. org/dictionary/english/encourage

9. Cambridge Dictionary. Available from: https://dictionary.cambridge. org/dictionary/english/abet?q=abetting

10. Slovnyk ukrainskoi movy. Akademichny tlumachny slovnyk. Available from: http://sum.in.ua/s/sponukaty (Ua).

11. Kriminal'ny kodeks Ukrainy (Proekt). Available from: https:// newcriminalcode.org.ua/upload/media/2021/07/06/tekst-proyektukk-ukrayiny-stanom-na-05-07-2021.pdf (in Ukrainian).

12. Naukovo-praktychny komentar do Kriminal'nogo kodeksu Ukrainy. [Scientific and practical commentary to the Criminal Code of Ukraine]. Ed. S.S. Yatsenko. K.: A.S.K, 2005: 848 (in Ukrainian).

13. Berzin P.S. Kriminal'ne pravo. Zagal'na chastina: pidruchnik u 3-h t. - T. I.Zagal'ni zasadi-2-ge vid., viprav. ta dop. [Criminal Law: General Part: textbook in 3 vol. Vol. 1 General Principles]. Kiyv:VD «Dakor», 2019:562 (in Ukrainian).

\section{ORCID and contributionship:}

Pavlo S. Berzin: 0000-0003-4146-7910 A, D, F

Ivan S. Demchenko: 0000-0001-8721-2775 ${ }^{B, D, E}$

Anzhela B. Berzina: 0000-0002-9885-309X ${ }^{B, D, E}$

\section{Conflict of interest:}

The Authors declare no conflict of interest.

\section{CORRESPONDING AUTHOR Ivan S. Demchenko \\ Forensic Medicine and Medical Law Department, Bogomolets National Medical University, Kyiv, Ukraine tel: +380503102281 \\ e-mail: demchenko.ivan@gmail.com}

Received: 17.06.2021

Accepted: 14.10 .2021

A - Work concept and design, B - Data collection and analysis, C - Responsibility for statistical analysis, D-Writing the article, $\mathbf{E}$-Critical review, $\mathbf{F}$ - Final approval of the article 


\title{
CARGOCULTISM OF PSYCHIATRIC CARE IN CUSTODY
}

D0I: 10.36740/WLek202111210

\author{
Oleksandra G. Yanovska' ${ }^{1}$ Alyona V. Chugaevska ${ }^{2}$, Mykhailo S. Ivanov ${ }^{3}$ \\ 'SUPREME COURT, KYIV, UKRAINE \\ 2INSTITUTE OF LAW OF VADYM HETMAN KYIV NATIONAL ECONOMIC UNIVERSITY, KYIV, UKRAINE \\ ${ }^{3}$ INSTITUTE OF LAW OF TARAS SHEVCHENKO NATIONAL UNIVERSITY OF KYIV, KYIV, UKRAINE
}

\begin{abstract}
The aim: To analyze the features of the realization mechanism of the persons' rights who have become ill with a mental illness and are in the detention of adequate (equivalent) medical care.

Materials and methods: A set of general and special methods of scientific knowledge were used. The study's empirical basis consists of international acts and standards in the field of health care, statistics of the United Kingdom, France, the United States, some countries in Eastern Europe and Central Asia, reports of international organizations, the case-law of the European Court of Human Rights. The study also used the personal experience of one of the co-authors as a lawyer for more than 20 years and 4 years as a judge of the Supreme Court.

Results: The conducted research gives grounds to state that for the last few decades the problem of receiving psychiatric care in conditions of imprisonment remains relevant. This situation is partly due to the fact that the certain standards' content is subject to clarification, as it is contained in optional international instruments or is given some understanding solely through the practice of the ECHR. Given the implementation of the prisoners' right of access to psychiatric care is entrusted primarily to penitentiary institution's administration, attention should be paid to methodological, material, and staffing of their work while introducing maximum openness of psychiatric care's algorithms to prisoners and facilitating access to legal aid for the mentally ill.

Conclusions: Creating external attributes of mechanisms to ensure the convicts' right to psychiatric care, the relevant national mechanisms do not take into account the specifics of the detained persons'legal status. Such a superficial imitation of the system of guarantees of the prisoners'rights to medical care is a kind of cargo cultism of public institutions, which is designed to provide non-discriminatory conditions for the realization of the right to health care for all categories of the population.
\end{abstract}

KEY WORDS: providing psychiatric care to persons in detention; protection of the rights of persons in custody; legal mechanisms for ensuring the right to health care

Wiad Lek. 2021;74(11 p.2):2916-2921

\section{INTRODUCTION}

The right to health is an integral part of fundamental human rights. The Constitution of Ukraine guarantees the right to health care to the citizens of Ukraine by creating conditions for effective and accessible medical care for all citizens [1]. According to Article 3 of the Law of Ukraine "On the Fundamental Principles of the Ukrainian Health Legislation", health is a state of complete physical, mental and social well-being and not merely the absence of disease or infirmity.

Ensuring the functioning of emergency medical care facilities or maintenance of public health care facilities is not the only function of the state to ensure the health of citizens. After all, the right to health care also applies to persons serving sentences in places of detention, along with this national legislation provides for the possibility of release of such persons from serving a sentence and, in the case of mental illness, application of coercive measures of medical nature.

\section{THE AIM}

To analyze the features of the realization mechanism of the persons' rights who have become ill with a mental illness and are in custody to adequate (equivalent) medical care.

\section{MATERIALS AND METHODS}

A set of general and special methods of scientific knowledge were used. The empirical basis of the study is such international acts and standards in the field of health care as The United Nations Standard Minimum Rules for the Treatment of Prisoners (the Nelson Mandela Rules), United Nations Rules for the Treatment of Women Prisoners, and Non-custodial Measures for Women Offenders (the Bangkok Rules), Convention against Torture and Other Cruel, Inhuman or Degrading Treatment or Punishment, Recommendation Rec (2006) 2 of the Committee of Ministers of the States Parties on "European penitentiary rules", Recommendation Rec (98) 71 of the Committee of Ministers to States Parties concerning the ethical 
and organizational aspects of health care in prison and others, statistics from the United Kingdom, France, the United States, some Eastern European and Central Asian countries, reports from international organizations, and ECtHR case law. The study also used the personal experience of one of the co-authors as a lawyer for more than 20 years and 4 years as a judge of the Supreme Court.

\section{RESULTS}

The research points out that in the last few decades the problem of receiving psychiatric care in custody remains relevant, despite the significant development of international standards, as evidenced by the studied materials, statistics, and case law. The development and implementation of high standards of psychiatric care in custody, even if enshrined in national law, does not fully achieve this aim, namely the right to health. This situation is partly due to the fact that the content of certain standards needs to be clarified, as it is contained in the provisions of the so-called "soft law", as follows in optional international instruments, or is given some understanding solely through the case-law of the ECHR.

Certain conceptual things, such as the "principle of equivalence" of medical care, in the face of the paradigm of the total institution, cannot be realized without consideration the restrictions' peculiarities on the rights and custody regime of convicts. Differences may be in the procedures for access to psychiatric care, but under any circumstances, they should ensure the implementation of a single protocol for the treatment of mentally ill persons, although access to psychiatric care in custody will always differ from the conditions of such access.

Seeing that the penitentiary system's administration is primarily responsible for ensuring the prisoners' right to access psychiatric care, attention should be paid to methodological, material, and staffing of their work while introducing maximum openness of algorithms for providing psychiatric care to prisoners and facilitating mental access of sick people to legal aid, increasing the effectiveness of mechanisms for reviewing complaints of convicts regarding the inadequate provision of the right to adequate psychiatric care. Taken together, these measures will encourage non-custodial institutions to provide real rather than formal psychiatric care to prisoners, and mentally ill convicts will be able to exercise their right to recover or stabilize their mental state.

The health care system in Ukraine, in particular, is based on such principles as the recognition of health care as a priority of society and the state; observance of human and civil rights and freedoms in the field of health care, and provision of related state guarantees; humanistic orientation; ensuring the priority of universal values over class, national, group or individual interests. This system is enshrined in the legislation of Ukraine as one that aims to preserve and restore physiological and psychological functions, optimal performance, and a person's social activity at the maximum biologically possible individual life expectancy.
An important component of the health care system, and not only in Ukraine, is the provision of mental health to the population and the provision of appropriate psychiatric care to its needy citizens. It should be noted that from $41 \%$ to $70 \%$ of prisoners suffer from mental disorders. In the United States, in particular, about one-third of prisoners have a mental illness, as opposed to the fact that only $18.3 \%$ of the population has such problems at large [4].

In addition, about a quarter of people in prison have bipolar disorder, depression, or personality disorder [5]. According to a study of the health of prisoners in 12 Western countries in the early $2000 \mathrm{~s}, 3.7 \%$ of men have psychotic illnesses, $10 \%$ have major depression and $65 \%$ personality disorders; $4 \%$ of women are serving sentences in imprisonment, suffering from psychosis, $12 \%$ suffer from severe depression and $42 \%$ have personality disorders. There is also a tendency to increase hospital accommodation in the penitentiary in 30 countries in the period from 1990 to 2019 by $24.7 \%$ [6].

Persons serving long sentences in prisons have the same level of mental health disorders as those with mental illness. That is, long period of custody contributes to the emergence of clinical symptoms of depression, paranoid disorders and psychosis [7].

\section{DISCUSSION}

Peculiarities of imprisonment are described by scholars as "total institution" which means a paradigm in which persons must obey a certain regulated regime, they are surrounded by the same as they are and are not able to leave this place [8]. And, in fact, the main factor influencing a prisoner with a mental illness is not the illness itself, but the institution in which he/she is, his/her reaction, adaptation to the relevant conditions.

Researches show that convicts with mental illness are more likely to violate the internal custody rules, are much more likely to be in solitary confinement and to be abused by other prisoners, and their mental health deteriorates when they do not receive adequate treatment [9]. Such convicts are more likely to commit suicide (according to the researches' data conducted in France, 7 times more often than outside custody) [10].

Therefore, maintaining health and preventing the violation of the rights of those suffering from mental illness, as a particularly vulnerable population group, requires additional measures and special attention.

To prevent the outlined negative phenomena, numerous standards and principles have been developed regarding the detention of mentally ill persons in custody and provision of the psychiatric care to them. The provisions of the International Covenant on Economic, Social and Cultural Rights (Article 12), according to which all prisoners have the right to the highest attainable standard of mental and physical health, are key [11].

According to the UN Minimum Standards for the Treatment of Prisoners (Mandela Rules), states should ensure the proper treatment and provision of psychiatric care to 
all convicts, as well as prevent the negative impact of detention on mental health (Mandela Rules 24, 25 and 33) [12]. Therefore, the standard of "equivalence of care" is set at the international level, which stipulates that psychiatric care and support should be provided at the same level as in the community (Mandela Rule 24). Convicted inmates should be treated on the basis of humanism and respect for their dignity (Mandela Rule 1), taking into account gender differences in the provision of psychiatric care (Bangkok Rule 10) [13]. Taking into account that prisoners are restricted in their rights in custody, the obligation to protect prisoners from abuse, torture and ill-treatment is established (Convention against Torture, Article 2) [14].

These standards are detailed in the recommendations of the Committee of Ministers of the Council of Europe of the Member States "European Penitentiary Rules" (Rec (2006) 2) [15] and recommendations on ethical and organizational aspects in prisons (Rec (98) 7) [16].

In the Council of Europe, national legislation on the protection of prisoners' rights to health is largely in line with international guidelines and standards. In particular, the equivalence of rights, free access to treatment and preventive care of appropriate quality, patient autonomy, confidentiality, medical professional independence and certification of competence are enshrined. In some countries, there are separate rules for the provision of medical care, including psychiatric care, to prisoners.

However, in practice the above-mentioned standards are not fully implemented, which is confirmed by the case law of the European Court of Human Rights. In particular, the ECHR, in its newsletter on psychiatric care for prisoners, provides information on numerous cases concerning violations of Article 3 of the Convention for the Protection of Human Rights and Fundamental Freedoms ("the Convention").

Summarizing the case law of the ECHR, there are three main elements considered by the Court regarding the violations' investigation in the provision of psychiatric care to prisoners: the prisoner's state of health, availability of medical care and treatment, as well as the expediency of leaving the person in custody in the aspect of prisoner's health. It should be noted that in some cases the Court finds a violation of Article $5 \$ 1$ of the Convention (right to liberty and security) when there is a delay in transferring to a specialized medical institution from the custody of persons with serious mental illness due to their state of health, which does not allow them to fully understand the essence of punishment, and therefore the purpose of punishment cannot be achieved. The detention of such a person in a prison instead of treatment is, in the Court's view, a violation of his/her right to liberty [18]. In cases where ill-treatment and failure to provide assistance lead to the suicide of a prisoner, the Court finds a violation of Article 2 of the Convention - the right to life $[19,20]$.

The reasons for the numerous violations of the above-mentioned standards of psychiatric care for prisoners in the Member States can be various: lack of adequate resources, insufficient motivation, insufficient level of training of penitentiary staff, absence of relevant authority, etc.

For example, in Wales, with the transfer of prison management to health services to improve the quality and accessibility of psychiatric care, initial improvements were offset by factors such as reduced funding, staff reductions, lack of access to care and certain services, as well as the untimely admission of sick people to hospitals [21].

There are hospitals in the Ukrainian penitentiary system, but they do not have psychiatric wards and involve a limited quantity of psychiatric specialists, and are therefore unable to provide psychiatric services to prisoners at the appropriate level. In particular, the convicted inmate is formally entitled to the free choice of both a doctor and a health care institution. To exercise this right, the convicted applies to the doctor of the health care institution of the State Criminal-Executive Service of Ukraine (hereinafter-SCES) with a request to admit to him/her the chosen psychiatrist. This institution must prepare a medical report within one day from the application date and set the deadline for the admission of the chosen doctor. The convict is treated by the doctor of his/her choice in the SCES's health care institution in the presence of medical workers. In case the convict needs treatment in a hospital, he also has the right to apply to the doctor of the SCES's health care institution with a request for his/her treatment (medical care) in the hospital of health care institution that provides paid medical services. The doctor of the SCES's health care institution must consider such an application and draw up an appropriate medical opinion no later than the next working day after the application. Despite the described procedures, obtaining psychiatric care in full is quite difficult, which leads to delays and untimely care, including due to lack of professional staff, proper mechanisms for timely diagnosis and limited rights of prisoners in custody [22].

In a situation where a mentally ill person serving a sentence in imprisonment refuses voluntary treatment and is not dangerous to himself/herself and / or others, the head of correctional colony must apply to the court under part 1 of Article 94 of the Criminal Code of Ukraine (hereinafter - the CC of Ukraine) on the application of compulsory medical measures in the form of coercive psychiatric care ${ }^{23}$. Such assistance, in this case, is provided by psychiatrists of medical units of prison. In this aspect, it should be noted that the number of persons whose court decisions came into force in 2020 in Ukraine - 90,509; 536 (0.6\%) from them were insane, to whom coercive measures of medical nature had been applied; 164 persons (31\%) committed minor crimes, 260 (49\%) - serious and especially serious crimes, 66 (12\%) crimes committed by women; 13 (2.4\%) crimes committed by minors; $4(0.7 \%)$ crimes related to domestic violence. At the same time, in 2020, 117 appeals were considered against decisions on application or refusal to apply coercive measures of medical nature, of which 52 were left unchanged (44\%), 65 (56\%) were changed and canceled. In 2020, at the stage of execution of court decision in Ukraine, it was considered 99760 petitions, from them there were $2421(2.5 \%)$ cases on abolition or change 
of coercive measures of a medical nature: $2273(94 \%)$ cases were satisfied, 60 cases were denied [24].

The problem of hospitalization of sick prisoners in conditions of "freedom of care" remains unresolved in most Council of Europe countries. At the same time, when introducing the principle of equivalence of psychiatric care to prisoners, it should consider that prison's medical part differs from a free medical institution. In particular, the prison has its own rules, and the incidence in prisons is high, care provision in the medical department of the same level, in particular under the laws on psychiatric care, is not possible [25].

The implementation of the principle of equivalence of psychiatric care to prisoners faces problems of insufficient staffing to provide psychiatric care [26], as well as inadequate levels of prison-hospital interaction, resulting in untimely diagnosis and limited provision of necessary medical care [27].

Isolation as a disciplinary measure (Rule 60.6 of the European Penitentiary Rules) is a separate issue of violation of prisoners' rights suffering from mental illness. National governments are required to set a maximum period of solitary confinement, monitoring requirements, but not all countries comply with these requirements. The European Committee for the Prevention of Torture and Inhuman or Degrading Treatment or Punishment (CPC) stipulates that the period of solitary confinement should not exceed 14 days, as even a shorter period has a significant impact on a person. Thus, in the case of "Renolde v. France "ECHR stated, inter alia, a violation of Art. 3 of the Convention, finding that the disciplinary commission had imposed on the applicant, who had psychiatric problems, a penalty of 45 days in a remand center, prohibiting him from visiting, communicating, etc [19].

In the decision in the case "Keenan v. the United Kingdom", as a result of proper treatment violation of a prisoner suffering from a mental illness, namely improper supervision and excessive measures of isolation, which led to the convict's suicide, the European Court found a violation of Articles 2 and 3 of the Convention [20].

At the same time, according to the CPC, suicide prevention should be provided not only by prison medical staff, but also by prison staff who should understand suicide risk indicators. In this regard, it is also important to ensure that all aspects of the prisoners' treatment are properly documented, which will further ensure effective investigation and identification of suicide causes.

Along with the problems associated with the isolation of mentally ill convicts, peculiarities of applying physical restraint to them in the provision of psychiatric care were also reflected in the CPC's recommendations [28]. In particular, the CPC emphasizes the need to address the following defaults: inadequate supervision of a person subject to physical restraint, absence of documentation in the application of such measures and reporting on the systematic monitoring of such persons.

In European countries, regardless of the regulation degree of these procedures in national law, there are cases of violation of the prisoners; rights in the application of physical restrictions on mentally ill convicts, as evidenced by the case law of the European Court of Human Rights.

For example, in Ukraine, use of physical restraint and (or) isolation in the provision of psychiatric care to convicts suffering from mental disorders is carried out in accordance with the Rules for the Application of Physical Restriction and (or) Isolation in the Provision of Psychiatric Care to Persons Suffering from Mental Disorders (hereinafter Rules) [30].

Thus, in accordance with the established Rules, the term of a single application of isolation may not exceed eight hours, extension is allowed only after examination of a convict by psychiatrists' commission consisting of at least two persons. Every two hours, a psychiatrist should assess changes in the patient's physical and mental condition. It is noted that insulation use is stopped after the person's condition improves to a level when it is no longer dangerous to themselves and the environment, and at night the insulation use is prohibited. In addition, the Rules provide for certain requirements for premises in which the convict is located: an area of at least 7 sq. m., with large windows, unimpeded access to sanitation, clean drinking water, food three times a day.

Regarding the application of physical restraint, the Rules clearly state that it may not exceed four hours, in extreme cases it may be extended to eight hours, but only by a new appointment of a commission of two psychiatrists. At the same time, every thirty minutes the psychiatrist must assess the changes in the patient's condition, and in case of negative changes in the person's physical condition to stop the physical restriction immediately.

However, in the case of Kucheruk v. Ukraine, the ECHR found a violation of Art. 3 of the Convention in connection with the application to the applicant of a physical restriction contrary to established rules and therapeutic necessity. In particular, handcuffs were used for physical restraint without taking into account the condition of the mentally ill convicted [31]. In addition, these Rules do not meet the approved standards of the CPC "Restraints means in psychiatric institutions for adults" [32], in particular, in terms of prohibiting the use of physical restraint in the presence of other patients; the use of exclusively certified fixation belts, a ban on the use of beds with armored nets, as well as the definition of chemical fixation procedures. At the same time, the ombudsman's reports in Ukraine repeatedly highlighted these negatives [33].

In general, in many European countries, it is noted that mentally ill convicts are not provided with full-fledged psychiatric care, and the only method commonly used in situations where mentally ill prisoner's behavior is aggressive is to be placed him/her in the prison hospital for a few days where prisoner is limited by medication. For example, in Italy, medicines are used to restrict such patients until a court decides on their safety for others, and in the United Kingdom, such people may not be released even after serving a sentence if they are considered mentally ill [34].

Ukraine faces the similar problems. Usually only pharmacotherapy is used for treatment, which consists of severe 
and outdated drugs (aminazine), there is no individual program and treatment strategy, there is no psychological therapy, which is necessary in treatment of mentally ill with involvement of a psychologist, social worker and other specialists, the purpose of which is rehabilitation and recovery [35].

Moreover, the standard of providing psychiatric care at the national level has not yet been approved in Ukraine, which also does not contribute to ensuring adequate protection of mentally ill persons' rights. After all, according to experts, the treatment duration and stay in places of involuntary treatment does not depend on the patients' state of health, disease dynamics and assessment of re-offending risks. Patients cannot influence the duration of involuntary treatment, most of them do not know their rights, do not have access to lawyers, and are not invited to their cases in court, even by videoconference. In addition, such convicts undergoing involuntary treatment, unlike convicts serving sentences, are not entitled to free legal aid under the free legal aid system. The attorney is provided to them only during the trial when deciding on release from serving a sentence under Part 1 of Article 84 of the Criminal Code of Ukraine or return to the penitentiary to continue serving the sentence after recovery and therefore the role of a lawyer in this situation is purely formal. The attorney is in not involved in any way in preparing the conclusion on the health state, the content of which is decisive for the court's decision to release a person from serving a sentence.

Conclusions: Ensuring the right of convicts to receive psychiatric care by the state, despite the numerous complaints to the ECHR and the CPT reports, is at a very low level not only in Ukraine but also in other countries. Creating external attributes of mechanisms for ensuring the right of convicts to medical care, including psychiatric care, the relevant national mechanisms do not take into account or deliberately ignore the peculiarities of persons' legal status in custody. Such a superficial imitation of the system of guarantees of prisoners' rights to medical care is to some extent a kind of cargo cultism of public institutions, which is designed to provide non-discriminatory conditions for the realization of the right to health care for all categories of the population. However, the negative result of the functioning simulation of the system of guarantees of prisoners' rights to medical care should not lead to the recognition of the ineffective equivalence of medical care principle, including psychiatric, for such a socially vulnerable category as convicted.

\section{REFERENCES}

1. Konstytutsiya Ukrayiny: Zakon. Verkhovna Rada Ukrayiny. 28.06.1996. № 254k/96-BP. [The Constitution of Ukraine: Law. Verkhovna Rada of Ukraine]. Available from: https://zakon.rada.gov.ua/laws/ show/254k/96-вp (in Ukrainian).

2. Osnovy zakonodavstva Ukrayiny pro okhoronu zdorov'ya: Zakon. Verkhovna Rada Ukrayiny. 19.11.1992. № 2801-XII. [Fundamentals of Ukrainian legislation on health care: Law. Verkhovna Rada of Ukraine]. Available from: https://zakon.rada.gov.ua/laws/show/2801-12 (in Ukrainian).
3. FazelS, Baillargeon J.The health of prisoners. Lancet. 2011;377:956-65.

4. Fazel S, Danesh J. Serious mental disorder in 23,000 prisoners: a systematic review of 62 surveys. Lancet. 2002; 359: 545-50.

5. Pont J, Harding W. T. Organisation and management of health care in prison: Guidelines. Strasbourg: Council of Europe. 2019; 73.

6. Mundt AP, Serri ER, Siebenförcher M et al. Changes in national rates of psychiatric beds and incarceration in Central Eastern Europe and Central Asia from 1990-2019: A retrospective database analysis. Lancet. 2021. doi:10.1016/j.lanepe.2021.100137.

7. Otte $S$, Vasic N, Nigel $S$ et al. Different yet similar? Prisoners versus psychiatric patients - A comparison of their mental health. European Psychiatry. 2017; 44:97-103. doi: 10.1016/j.eurpsy.2017.04.006.

8. Goffman E. Asylums: essays on the social situation of mental patients and other inmates. New York: Anchor Books. $1961.386 \mathrm{p}$.

9. McPherson W. Managing the mental health population at the Broward's Sheriff's office. Corrections Today. 2008; 70(3): 62-64,66,67.

10. France: Inadequate Mental Health Care in Prisons Detention Conditions, Lack of Treatment Increase Suffering. Human Rights Watch. April 5, 2016. Available from: https://www.hrw.org/news/2016/04/05/franceinadequate-mental-health-care-prisons.

11. International Covenant on Economic, Social and Cultural Rights. Adopted and opened for signature, ratification and accession by General Assembly resolution 2200A (XXI) of 16 December 1966. Available from: https://www.ohchr.org/en/professionalinterest/pages/cescr.aspx.

12. The United Nations Standard Minimum Rules for the Treatment of Prisoners (the Nelson Mandela Rules). Resolution adopted by the General Assembly on 17 December 2015. Available from: https://undocs. org/A/RES/70/175

13. United Nations Rules for the Treatment of Women Prisoners and Noncustodial Measures for Women Offenders (the Bangkok Rules). Adopted by the General Assembly on 21 December 2010 in A/RES/65/229. Available from:https://www.ohchr.org/EN/Professionallnterest/Pages/ BangkokRules.aspx.

14. Convention against Torture and Other Cruel, Inhuman or Degrading Treatment or Punishment. Adopted and opened for signature, ratification and accession by General Assembly resolution 39/46 of 10 December 1984. Available from: https://www.ohchr.org/en/ professionalinterest/pages/cat.aspx.

15. Recommendation Rec (2006) 2 of the Committee of Ministers of the States Parties on "European penitentiary rules". doi: MU06295.

16. Recommendation Rec (98) 71 of the Committee of Ministers to States Parties concerning the ethical and organisational aspects of health care in prison (Adopted by the Committee of Ministers on 8 April 1998 at the 627th meeting of the Ministers' Deputies). Available from: https:// rm.coe.int/09000016804fb13c.

17. The European Court of Human Rights. Factsheet - Detention and mental health. March 2020. 13 p. Available from: https://www.echr.coe.int/ Documents/FS_Detention_mental_health_ENG.pdf.

18. Case of L.B. v. Belgium (Application no. 22831/08): European Court of Human Rights, Judgment 02.10.2012. Available from: http://hudoc. echr.coe.int/eng-press?i=003-4102053-4819145.

19. Case of Renolde v. France (Application no. 5608/05): European Court of Human Rights, Judgment 16.10.2008. Available from: https:// policehumanrightsresources.org/renolde-v-france-applicationno-5608-05.

20. Case of Keenan v. the United Kingdom (Application no.27229/95): European Court of Human Rights, Judgment 03.04.2001. Available from: http://hudoc.echr.coe.int/fre?i=002-5699. 
21. Forrester A, Till A, Simpson A et al. Mental illness and the provision of mental health services in prisons. British Medical Bulletin. 2018. 127(1): 101-109. doi: 10.1093/bmb/ldy027.

22. Pro zatverdzhennya Poryadku orhanizatsiyi nadannya medychnoyi dopomohy zasudzhenym do pozbavlennya voli: nakaz Ministerstva yustytsiyi Ukrayiny ta Ministerstva okhorony zdorov"ya Ukrayiny, 15.08.2014, № 1348/5/572. [0n approval of the Procedure for organizing medical care for convicts: order of the Ministry of Justice of Ukraine and the Ministry of Health of Ukraine]. Available from: https://zakon.rada. gov.ua/laws/show/z0990-14 (in Ukrainian).

23. Kryminalniy kodeks Ukrayiny [Criminal Code of Ukraine]:Zakon Ukrayiny, 05.04.2001, № 2341-III. Available from: zakon.rada.gov.ua/laws/ show/2341-14 (in Ukrainian).

24. Statistichni danni Sudovoyi administraciyi Ukrainy [Court Administration of Ukraine Statistic Data]. Available from: https://court.gov.ua/inshe/ sudova_statystyka/rik_2020 (in Ukrainian).

25. Exworthy T, Wilson S, Forrester A. Beyond equivalence: Prisoners' right to health. Psychiatrist. 2011. 35(6): 201-202. doi: 10.1192/ pb.bp.110.033084.

26. MacDonald M. A Comparative Report of Health Care Provisions in Prisons in Poland, Hungary and the Czech Republic. Helsinki. 2003. 47 p. Available from: http://old.heuni.fi/material/attachments/heuni/ papers/6Ktkk96b1/HP19Painoon2.pdf.

27. Hadrys T, Kiejna A. Mental health care in Polish penitentiary system. BMC Psychiatry. 2007; 7(Suppl 1): 19. doi: 10.1186/1471-244X-7-S1-S19.

28. 29th General report of the European Committee for the Prevention of Torture and Inhuman or Degrading Treatment or Punishment (CPT). Strasbourg: Council of Europe. 2020; 101. doi:16809e80e1.

29. ECRI report on Serbia (fifth monitoring cycle). Strasbourg: Council of Europe. 2017. 49. Available from: https://rm.coe.int/third-report-onserbia/16808b5bf4.

30. Pro zatverdzhennya Pravyl zastosuvannya fizychnoho obmezhennya ta (abo) izolyatsiyi pry nadanni psykhiatrychnoyi dopomohy osobam, yaki strazhdayut' na psykhichni rozlady, ta form pervynnoyi oblikovoyi dokumentatsiyi: nakaz Ministerstva okhorony zdorov'ya Ukrayiny, 24.03.2016, № 240. [On approval of the Rules for the application of physical restraint and (or) isolation in the provision of psychiatric care to persons suffering from mental disorders, and forms of primary accounting documentation: order of the Ministry of Health of Ukraine]. Available from: https://zakon.rada.gov.ua/laws/show/z0570-16\#Text (in Ukrainian).

31. Case of Kucheruk v. Ukraine (Application no 2570/04): European Court of Human Rights, Judgment 06.09.2007. Available from: https://zakon. rada.gov.ua/laws/show/974_839\#Text.

32. Means of restraint in psychiatric establishments for adults (Revised CPT standards). Strasbourg: Council of Europe. 2017; 5. doi: 16807001c3.

33. Shchorichna dopovid' Upovnovazhenoho Verkhovnoyi Rady Ukrayiny z prav lyudyny za 2019 rik pro stan doderzhannya ta zakhystu prav i svobod lyudyny i hromadyanyna v Ukrayini. Kyiv. 2020.258 p. [Annual report of the Commissioner of the Verkhovna Rada of Ukraine for Human Rights for 2019 on the state of observance and protection of human and civil rights and freedoms in Ukraine. Kyiv]. Available from: https://dpsu. gov.ua/upload/zvit_za_2019.pdf (in Ukrainian).
34. Global Prison Trends 2021: Executive Summary. Available from: https:// www.penalreform.org/global-prison-trends-2021.

35. Reforming prison mental health services in Ukraine report on a monitoring and assessment visit \& recommendations to the Ukrainian penitentiary service. Strasbourg: Council of Europe. 2019;26p. Available from: https://ggzecademy.nl/web/uploads/2020/02/reforming-prisonmnh-ukraine-eng.pdf.

36. Report. Review of forensic psychiatric and prison mental health services in Ukraine. Kyiv. 2015. 28 p. Available from: https://www.gip-global. org/files/doc-3-final-report-undp-eng.pdf

The work is done at the Department of Criminal Procedure and Criminology of the Institute of Law of Taras Shevchenko National University within the plans of research work in the field of "Doctrine of Law in the Legal System: Theoretical and Practical Aspects".

\section{ORCID AND contributionship:}

Oleksandra G. Yanovska: 0000-0001-8451-3775 A, D, F

Alona V. Chuhaievska: 0000-0002-5522-2693 B, C, D

Mykhailo S. Ivanov: 0000-0002-7869-8176 C, D, E

\section{Conflict of interest:}

The Authors declare no conflict of interest.

\section{CORRESPONDING AUTHOR Oleksandra G. Yanovska}

Supreme Court

P. Orlyka st., 4-a, 01043 Kyiv, Ukraine

tel: +380674415434

e-mail:yanovskaya.a@ukr.net

Received: 25.06 .2021

Accepted: 19.10 .2021

A - Work concept and design, B - Data collection and analysis, C - Responsibility for statistical analysis,

D - Writing the article, $\mathbf{E}$ - Critical review, $\mathbf{F}$ - Final approval of the article 


\title{
VICTIMOLOGICAL RISKS FOR ROAD USERS AS AN ELEMENT OF PUBLIC HEALTH
}

DOI: 10.36740/WLek202111211

\author{
Vladyslava S. Batyrgareieva', Alina V. Kalinina', Kateryna 0. Poltava² \\ 'ACADEMICIAN STASHIS SCIENTIFIC RESEARCH INSTITUTE FOR THE STUDY OF CRIME PROBLEMS OF THE NATIONAL ACADEMY OF LAW SCIENCES OF \\ UKRAINE, KHARKIV, UKRAINE \\ 2POLTAVA LAW INSTITUTE OF YAROSLAV MUDRIY NATIONAL LAW UNIVERSITY, POLTAVA UKRAINE
}

\begin{abstract}
The aim: This article aims to analyze the statistics of road accidents victims in Ukraine in general and the level of criminal offenses' against traffic safety and transport operation victims, in particular, to consider the main victimological risks for road users and provide them with a public health approach.

Materials and methods: The theoretical basis of the article is specialized literature on law, economics, and sociology. The empirical basis of the research was the materials of generalization of more than 1,000 criminal proceedings under Art. 286 of the Criminal Code of Ukraine, the results of a survey of Ukrainian citizens on the state of road safety in Ukraine.

Results: According to the results of an empirical study, in terms of role, pedestrians clearly predominate among the victims (59.6\%), while every fourth victim is a passenger of a vehicle. Driver victims are only $14.6 \%$ of the total number.

Victimological risk on the roads is the probability of becoming a victim and suffering damage to one's life and health from criminal offenses against traffic safety and operation of transport. For each of the categories of victims there are both general and specific victimological risks. The causes of accidents can be grouped by the source of danger in the triangle "person - mechanism - road".

Conclusions: The most dangerous and widespread victimological risks for road users in Ukraine are speeding and maneuvering, drunk driving, parking violations, poor road infrastructure, physiological and psychological characteristics of road users, low professional skills of drivers, etc.
\end{abstract}

KEY WORDS: public health, road safety, victimological risks, road users

Wiad Lek. 2021;74(11 p.2):2922-2927

\section{INTRODUCTION}

Due to the development of the world's transport systems, the problem of road safety has become acute. Road transport from the middle of the 20th century became the leading among the types of land transport. The length of its network is growing and has reached 27.8 million $\mathrm{km}$, with about $1 / 2$ of that in the USA, India, Russia, Japan, and China. The level of motorization in the world is dominated by the US and Western European countries. Road transport also belongs to the priority in the volume of passenger transportation $-82 \%$ of the world volume [1]

Maintaining road safety is a challenging task, given the huge number of road accidents that occur every year worldwide, and the severity of the consequences of the latter for human life and health. In addition, its solution requires significant social resources. That indicates the urgency of the problem of ensuring traffic processes is only increasing. In particular, the United Nations General Assembly has set an ambitious target of halving the global number of deaths and injuries from road traffic crashes by 2030 (A / RES / 74/299) [2; 3]. Achieving this goal will contribute to the preservation of public health in all countries that implemented the model proposed by the World Health Organization Global Plan of Action for 2021-2030 within the framework of the II Decade of actions to ensure road safety [4].

Road safety (including the reduction of criminal offenses against traffic safety and transport operation) largely depends on the prevention of victimological risks, which is an essential element of the public health policy of a state. Effective and sustainable prevention of such risks is both national and global public health problem.

In the proposed study, the authors analyze the complexes of victimological risks that will arise for road users as a result of criminal violations of relevant rules on highways and can lead to serious consequences.

\section{THE AIM}

This article aims to analyze the statistics of road accidents' victims in Ukraine in general and the level of criminal offenses' victims against traffic safety and transport operation, in particular, to consider the main victimological risks for road users and provide them with a public health approach. 


\section{MATERIALS AND METHODS}

The study was conducted in 2020 and six months of 2021. The source base of this study is the information and analytical data of the World Health Organization, the State Statistics Service of Ukraine, the Patrol police, the General Prosecutor's Office of Ukraine. Collected and grouped materials were processed using the technology of descriptive statistics. The article is based on dialectical, analytical, synthetic, statistical, and sociological methods of research. The theoretical basis of the article is specialized literature on law, economics, and sociology.

The empirical basis of the research was the materials of generalization of more than 1,000 criminal proceedings under Art. 286 of the Criminal Code of Ukraine ( Violation of traffic safety rules or operation of transport by persons driving vehicles»), the results of a conducted online survey of Ukrainian citizens on the state of road safety in Ukraine, using the program «Google-forms» during six months of 2021.

\section{RESULTS}

According to the Law of Ukraine "On Road Traffic" (1993), road users in Ukraine are persons who use highways, streets, railway crossings, or other places intended for the movement of people and transportation of goods utilizing vehicles. Such participants include 1) drivers of vehicles, 2) passengers of vehicles, 3 ) pedestrians, 4) persons moving in the seats of wheeled vehicles, 5) cyclists, 6) drivers of animals [5]. Each of these groups of participants, influencing the general picture of the victimological situation on the roads of Ukraine, needs to identify and analyze victimological risks using a public health approach, as such an approach contributes to the identification of threats to public health.

According to the World Accident Mortality Rating compiled by the World Health Organization based on statistics from the World Health Organization, Ukraine is one of the countries with an average accident mortality rate and ranks 127th out of 183 countries [6]. Note that the last positions in the ranking are the countries with the lowest mortality rate. But such an "optimistic" position in the world ranking raises some doubts and does not give an idea of the real picture of road safety as an element of public health in Ukraine.

According to the accident statistics of the Patrol Police, the number of road accidents victims in Ukraine for 20172020 does not indicate a stable downward trend in this number, as as of 2020 there is, however, an increase in both the number of traffic accidents and the number of traffic accidents with victims (Table I).

Along with the above data of the Patrol Police, it is necessary to analyze the data of the Office of the Prosecutor General on the amount of recorded criminal offenses under Art. 286 of the Criminal code of Ukraine ("Violation of rules of safety of traffic or operation of transport by persons driving vehicles") and the number of victims of criminal offenses against the safety of movement and operation of transport (road accident) for the same period (Table II).

Therefore, in recent years in Ukraine almost 9,000 road accidents have criminal consequences, and more than 10,000 people annually fall victim to criminal offenses against traffic safety and transport operation.

In this regard, it is interesting to cite the point of view of the citizens of Ukraine, clarified during a survey conducted by the Research Institute. Thus, according to citizens, the state of road safety in Ukraine is unsatisfactory, as indicated by $58.2 \%$ of respondents. At the same time, $16.3 \%$ stressed that the state of such security is extremely unsatisfactory. In turn, every fifth respondent indicated that the state of road safety in Ukraine is satisfactory for all road users.

Assessment of the victim situation on the roads in Ukraine is impossible without an analysis of the categories of victims of road accidents. Thus, according to the results of an empirical study, the distribution of victims by gender is almost irrelevant (men accounted for $48.6 \%$ and women $51.4 \%)$. In terms of role, pedestrians clearly predominate among the victims (59.6\%), while every fourth victim is a passenger of a vehicle. Driver victims are only $14.6 \%$.

Here is distribution of deaths of road accident victims in Ukraine by road participant's role according to the State Statistics Service of Ukraine (Fig 1):

Also, according to the National Police, the main causes of road accidents, which result in injury and/or death (Fig. 2) $[7 ; 10]$.

Analysis of risk factors is one of the components of public health approach. The public health approach is a generic analytical framework that has made it possible for different fields of public health to respond to a wide range of health problems and diseases, including injuries and violence $[11$, p. $23 ; 12 ; 13]$. This approach is not only helpful in the analysis of risk factors but also provides a framework that guides decision-making throughout the entire process, from identifying a problem to implementing an intervention [11, p. 23]. Therefore, there is a large

Table I. The number of traffic accidents and the number of traffic accidents with victims in Ukraine in 2017-2020 [7]

\begin{tabular}{ccccc}
\hline Year & $\begin{array}{c}\text { Number } \\
\text { of traffic accidents }\end{array}$ & Dynamics & $\begin{array}{c}\text { Number } \\
\text { of traffic accidents with victims }\end{array}$ & Dynamics \\
\hline 2017 & 162526 & - & 27220 & - \\
\hline 2018 & 150120 & $-7,6 \%$ & 24294 & $-10,7 \%$ \\
\hline 2019 & 160675 & $7,0 \%$ & 26052 & $7,2 \%$ \\
\hline 2020 & 168107 & $4,6 \%$ & 26140 & $0,3 \%$ \\
\hline
\end{tabular}




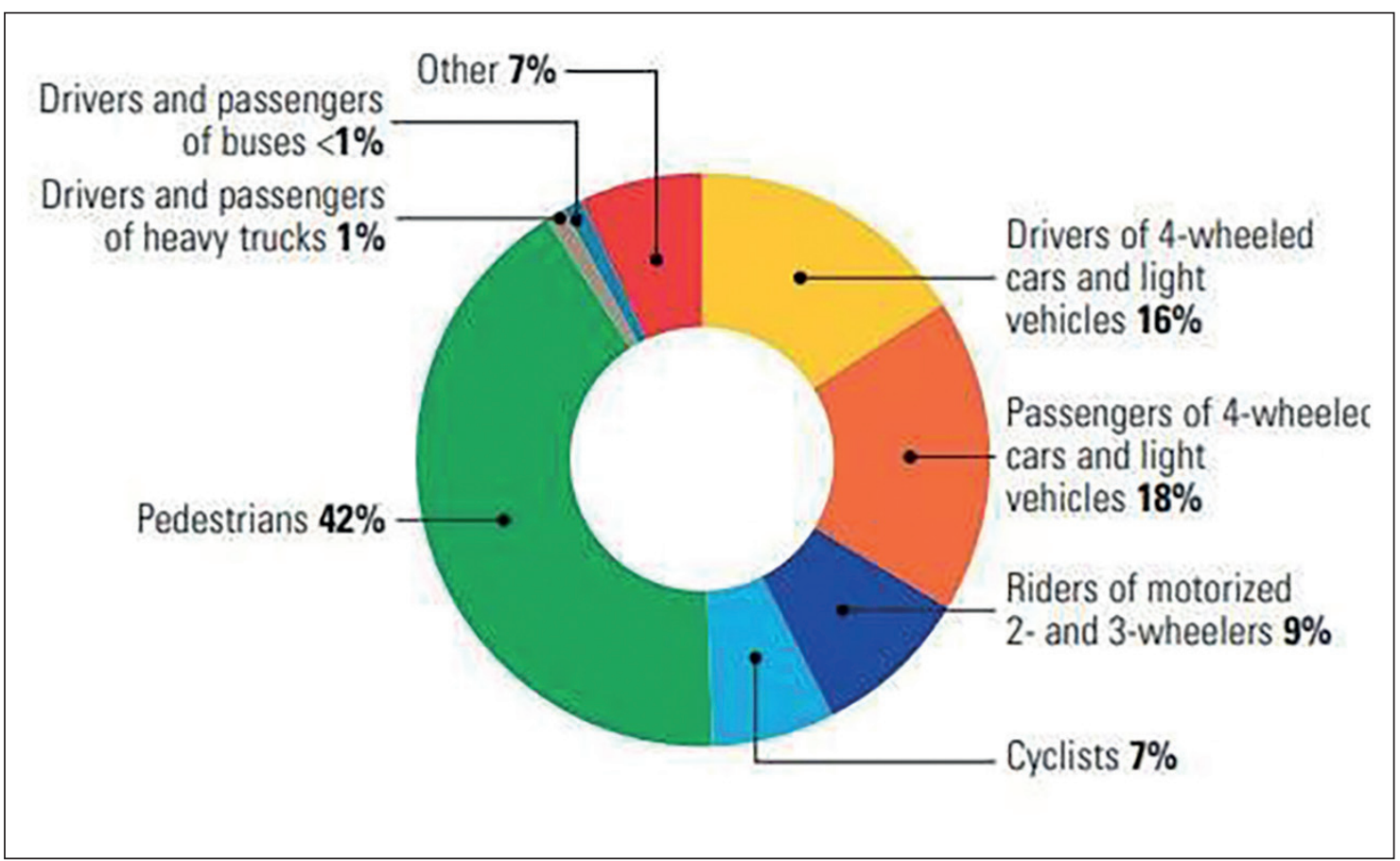

Fig. 1. Deaths by road user category $[9$, p. 255]

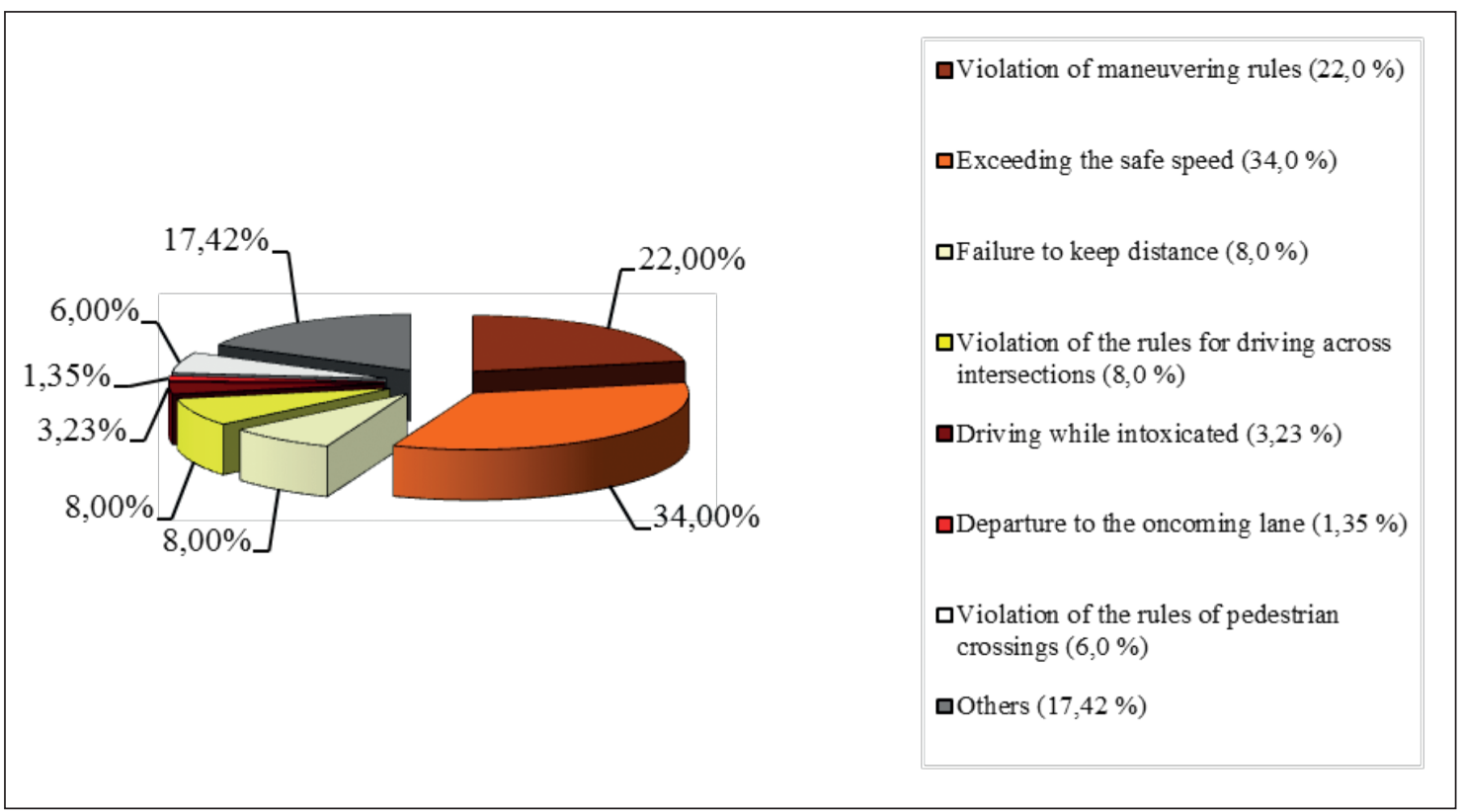

Fig. 2. The main causes of road accidents in Ukraine, which resulted in injuries and/or deaths

potential for road safety and public health practitioners to work closely [14, p. 4]. Road safety as an activity is inseparable from the aim of preventing injuries. This aim is an essential public health issue in itself $[14$, p. 5].

A universal category for reflecting potential danger is the concept of risk. This category makes it possible to adjust the initial goals and strategies for solving the problems of analysis of the latter, to compare hazards of different origins and mechanisms of action, to classify and rank potential sources of danger; to study the mech- anism and investigate the causal relationship between the occurrence and development of adverse events, as well as to identify the impact on the indicators of this risk of various factors of man-made, natural and social origin; to ensure the direction of risk reduction through optimal management of technical, organizational-methodological factors of influence (reduction of probability, reduction of damage) [15, p. 9].

There is no unified concept of risk in the literature. Moreover, this category is interdisciplinary: it is operated by 
Table II. The number of victims of criminal offenses against safety of movement and operation of transport in Ukraine in 2017-2020 [8]

\begin{tabular}{ccccc}
\hline Year & $\begin{array}{c}\text { Number of criminal offenses under the Aarticle } \mathbf{2 8 6} \\
\text { of the Criminal Code of Ukraine }\end{array}$ & Dynamics & Number of victims & Dynamics \\
\hline 2017 & 10148 & - & 12088 & - \\
\hline 2018 & 8257 & $-18,6 \%$ & 10260 & $-15,1 \%$ \\
\hline 2019 & 8739 & $5,8 \%$ & 10408 & $1,4 \%$ \\
\hline 2020 & 8864 & $1,4 \%$ & 10130 & $-2,7 \%$ \\
\hline
\end{tabular}

specialists in psychology, economics, security, medicine, transport, law, and others. It is common to understand risk as the probability of a negative consequence of a particular activity [16]. Risk is manifested in all spheres of human activity, at all stages of functioning and development of the object, its interaction with the environment and within itself $[15$, p. 7].

Victimological risk in the theory of criminological science is the risk of suffering losses from any criminally illegal manifestation. Victimological risk on the roads is the probability of becoming a victim and suffering damage to one's life and health from criminal offenses against traffic safety and operation of transport. For each of the above categories of victims, there are both general and specific victimological risks. Their characteristics are due to the causes of accidents, which result in injury and/or death of people, the main of which were listed above. The causes of accidents can be grouped by the source of danger in the triangle «person - mechanism - road»:

In this regard, the element "person» in this triangle should be described through the category that we have designated as «human influences». Thus, human influences are associated with such factors as a violation of traffic safety rules (speeding; violation of maneuvering rules; intoxicated driving; fatigue, sleep while driving; lack of sufficient driving experience, violation of the rules of self-driving) safety of passengers; crossing of the carriageway by pedestrians in an unspecified place or at a prohibited traffic light signal, etc.).

In turn, the element «mechanism» corresponds to the category of «vehicle influences»: the malfunction of the vehicle, its unsuitability for operation in specific traffic conditions, driving a faulty vehicle; non-compliance with the rules of operation of a vehicle, etc. However, it should be noted that the last two positions in this logical series are a clear combination of the elements «person» and «mechanism».

Finally, such an element of the triangle as «road» is revealed through the category of «road influences», which covers, in particular: violation of the rules of road maintenance; violation of road construction norms; insufficient engineering provision of road structures, shortcomings in road infrastructure planning, etc.

These accidents' causes are a basic set of victimological risks for road users. The main factor in saving human life and health in the accident is the degree of physical protection of the person. Thus, the WHO emphasizes that those road users who do not have a «protective shell» are particularly vulnerable: pedestrians, cyclists, and drivers of two-wheeled motorized vehicles [17, p. 13].

According to the authors' survey, the most dangerous and common victimological risks for road users are: violation of traffic rules by both drivers (especially speeding and driving while intoxicated) and pedestrians; parking of cars near pedestrian crossings, which reduces the visibility of the roadway in these areas; unsatisfactory condition of road infrastructure (insufficient provision of crossings with traffic lights and street lights, poor condition of the road surface); physiological and psychological characteristics of road users (health status, their inattention, calculation of hiring, risk behavior on the roads, self-confidence; the unsatisfactory reaction speed in dangerous situations, etc.), professional characteristics (insufficient driver competence, lack of driving experience), etc.

\section{DISCUSSIONS}

The problem of the victimological risks extends, of course, to non-fatal accidents, to the many major accidents, and the huge number of minor accidents [18, p. 140]. Therefore, emphasis should always be placed on a system for calculating these risks in order to at least understand the extent of the burden placed on emergency services. This is especially important given the fact that road traffic injury prevention has traditionally been considered to be outside the domain of the health sector with the result that the role and impact of the public health sector in prevention is rarely explored. A meaningful multisectoral response to prevention is encouraged in just a few countries. Emergency services consume a large portion of the total health sector expenditure, leaving limited resources and opportunities for prevention [2].

Road safety management should not be considered as a separate goal, but in the context of management methods through coordination, lawmaking, funding, resource allocation, promotion, monitoring, evaluation, research, development, and education [4]. Further, monitoring and evaluation, as well as conducting research, will mean nothing more than the introduction of a permanent practice of establishing the impact of victimological risks on the general state of road safety in the country as a whole or in a particular region.

Due to the analysis of the main reasons for the insufficient level of road safety in Ukraine, the above palette of victimological risks for road users is revealed and discussed. The current reasons are: 
1) low level of road discipline due to unsatisfactory state of legal awareness of road users, which leads to non-notification or insufficient awareness of the dangerous consequences of violating traffic rules;

2) inadequate level of practical provision of the inevitability of punishment for violation of traffic rules and awareness of this by road users;

3 ) insufficient level of coordination of central and local executive bodies activities in addressing road safety issues;

4) insufficient funding for measures aimed at reducing the level of accidents on the roads, lack of systematic approaches to the analysis of the effectiveness of financing such measures;

5) low level of use of modern training and advanced training methods for drivers, training of traffic rules of citizens;

6) insufficient efficiency of the system of organizational-planning and engineering measures aimed at improving the organization of traffic and pedestrians, creating safe traffic conditions;

7) insufficient level of automated means of traffic control and response use;

8) inefficiency of the vehicle safety control system during operation;

9) imperfection of the system of traffic accidents and assistance notification to victims, etc. [19, pp. 119].

Each of the listed victimological risks deserves to develop a separate program of its devictimization.

\section{CONCLUSIONS}

1. Road safety should be directly linked to the implementation of an important social task of today - the preservation of public health. Thus, improving road safety helps meet other needs, such as access to health, employment, and education, as highlighted in the Global Roadmap for 2021-2030, Decade of Action for Road Safety.

2. Victimological risk in the field of road traffic is the probability of any person becoming a victim of criminal offenses against traffic safety and transport operations. For different road users, a set of victimological risks can be identified, which are primarily related to the causes of accidents, the nature of which is due to the existence of the triangle " person mechanism - road" and which results in injury and/or death.

3. The study revealed the most dangerous and widespread victimological risks for road users in Ukraine. These include speeding and maneuvering, drunk driving, parking violations, poor road infrastructure, physiological and psychological characteristics of road users, low professional skills of drivers, etc.

\section{REFERENCES}

1. Prinston P. World Transport System and Logistics: the Main Directions of Development. Available from: https://www.searates.com/ru/blog/ post/world-transport-system-and-logistics-the-main-directions-ofdevelopment [reviewed 2021.07.05].

2. Technical discussion on Road traffic injuries: a growing public health concern. EM/RC56/Tech.Disc.1, 2009. Available from: https://
applications.emro.who.int/docs/EM_RC56_Tech_Disc_1_en.pdf [reviewed 2021.07.05].

3. Road traffic injuries, 2021. Available from: https://www.who.int/news$\mathrm{room} /$ fact-sheets/detail/road-traffic-injuries [reviewed 2021.07.09].

4. Global'nyj plan dejstvij na 2021-2030 gg. Desjatiletie dejstvij po obespecheniju bezopasnosti dorozhnogo dvizhenija [the Global Plan for the Decade of Action for Road Safety 2021-2030]. Available from: https:// cdn.who.int > global-plan-of-action_ru_web. [reviewed 2021.07.05] (Ru).

5. Pro dorozhnij rukh: Zakon Ukrainy vid 30.06.1993 № 3353-XII [On the Road Traffic : Law of Ukraine dated 30.06.1993 № 3353-XII]. Available from: https://zakon.rada.gov.ua/laws/show/3353-12\#Text [reviewed 2021.07.06] (Ua).

6. World Road Traffic Accident Report. Available from: https://www. worldlifeexpectancy.com/world-road-traffic-accidents-report [reviewed 2021.07.06].

7. Statystyka DTP v Ukraini za 2017, 2018, 2019, 2020 rr. [Statistics of the road traffic accidents in Ukraine of 2017, 2018, 2019, 2020]. Available from: http://patrol.police.gov.ua/statystyka/[reviewed 2021.07.10] (Ua).

8. Yedynyj zvit pro kryminal'ni pravoporushennia po derzhavi za sichen'hruden' 2017, 2018, 2019, 2020 rr. : stat. inform. Hen. prokuratury Ukrainy [Unified report on criminal offenses in the country of JanuaryDecember 2017, 2018, 2019 2020: statistical information of the Prosecutor General's Office of Ukraine]. Available from: https://www. gp.gov.ua/ua/1stat [reviewed 2021.07.10] (Ua).

9. Global status report on road safety 2018. Geneva: World Health Organization; 2018. Available from: https://www.who.int/ publications/i/item/9789241565684 [reviewed 2021.07.11].

10. Pro skhvalennia Stratehii pidvyschennia rivnia bezpeky dorozhn'oho rukhu v Ukraini na period do 2024 roku : rozporiadzhennia Kabinetu Ministriv Ukrainy vid 21.10.2020 № 1360-r [0n approval of the Strategy for improving the level of road safety in Ukraine until 2024: order of the Cabinet of Ministers of Ukraine dated 21.10.2020]. Available from: https://zakon.rada.gov.ua/laws/show/1360-2020-\%D1\%80\#Text [reviewed 2021.07.10] (Ua).

11. Mohan D, Tiwari G, Khayesi M, Nafukho FM. Road traffic injury prevention : training manual. Available from: https://apps.who. int/iris/bitstream/handle/10665/43271/9241546751_eng. pdf? sequence $=1$ \&isAllowed $=y$ [reviewed 2021.07.15].

12. Krug EG, Sharma GK, Lozano R. The global burden of injuries. American Journal of Public Health, 2000, 90:523-526.

13. Mercy JA et al. Public health policy for preventing violence. Health Affairs, 1993:7-29.

14. Duncan V, Road Safety and Public Health, 2014 Available from: https:// www.rospa.com/rospaweb/docs/advice-services/road-safety/practitioners/ rospa-road-safety-and-public-health.pdf [reviewed 2021.07.10].

15. Tkachenko I. 0. Ryzyky u transportnykh protsesakh: navch. posib. [Risks in transport processes: textbook]. Kharkiv: KhNUMH im. 0. M. Beketova, 2017. 114 s. (Ua).

16. Tsyba Ya. V. Pidkhody do rozuminnia poniattia «ryzyk» [Approaches to understanding the concept of «risk»]. Efektyvna ekonomika, 2014, 2. Available from: http://www.economy.nayka.com.ua/?op $=1 \& z=2761$ [reviewed 2021.07.10] (Ua).

17. Evropejskij doklad o sostojanii bezopasnosti dorozhnogo dvizhenija [European status report on road safety]. Kopengagen, Evropejskoe regional'noe bjuro V0Z, 2009 (Ru).

18. Christie N, Why we need to view road safety through a public health lens?, Transport Reviews, 201838:2, 139-141, D0I: 10.1080/01441647.2018.1411226. 
19. Stepanov 0. V. Suchasni prychyny vynyknennia problem bezpeky dorozhn'oho rukhu [Modern causes of road safety problems]. Vestnyk KhNADU, 2015, 68: 118-122 (Ua).

The scientific paper was prepared for the fundamental scientific research of Academician Stashis Scientific Research Institute for the Study of Crime Problems, National Academy of Law Sciences of Ukraine "Crime prevention strategy in the field of traffic and transport exploitation in Ukraine» (the registration number 0120U105615).

\section{ORCID and contributionship:}

Vladyslava S. Batyrgareieva: 0000-0003-3879-2237 A, B, C, D, E, F Alina V. Kalinina:0000-0001-8015-0807 A, B, C, D, E, F

Kateryna O. Poltava: 0000-0002-9927-1788 ${ }^{\text {B, C, D }}$

\section{Conflict of interest:}

The Authors declare no conflict of interest.

\section{CORRESPONDING AUTHOR}

\section{Alina V. Kalinina}

Academician Stashis Scientific Research Institute for the Study of Crime Problems of the National Academy of Law Sciences of Ukraine, Kharkiv, Ukraine tel: +380665192817

e-mail:alina.kalinina@ukr.net

Received: 18.06 .2021

Accepted: 15.10 .2021

A - Work concept and design, B - Data collection and analysis, C - Responsibility for statistical analysis, D - Writing the article, $\mathbf{E}$-Critical review, $\mathbf{F}$ - Final approval of the article 


\title{
DEPRIVATION OF REPRODUCTIVE RIGHT OF SEX OFFENDERS: SOCIAL OPINION AND LEGISLATIVE REGULATION
}

DOI: 10.36740/WLek202111212

\author{
Volodymyr V. lemelianenko, Alesia V. Gornostay, Olena V. Yevdokimova \\ YAROSLAV MUDRYI NATIONAL LAW UNIVERSITY, KHARKIV, UKRAINE
}

\begin{abstract}
The aim: The purpose of this article is to illustrate the social demand for the need to discriminate against perpetrators of sexual crimes by depriving them of reproductive rights. Materials and methods: The authors of the research used the legislation of various world countries, scientific papers, caselaw, the provisions of international legal acts, in particular, the Convention for the Protection of Human Rights and Fundamental Freedoms. The authors of the research used a complex set of general and special methods of cognition such as dialectical, comparative, analytical, generalization method, statistical and sociological method (questionnaire method).

Results: The survey conducted by the authors highlights the attitude of physicians and law enforcement officials (100 people) to the sterilization of criminals as a measure necessary to prevent the commission of sexual crimes both by such persons and by others who are prone to committing such crimes but will refrain from their commission due to the fear of sterilization. The questionnaire shows the gap between awareness and recognition of natural human rights such as the right to reproduce and the desire to deprive a certain deviant category of people of this right for their safety.

Conclusion: Based on the conducted analysis, the authors have formulated that there is currently a great social demand for radical measures to prevent the commission of sexual crimes by sterilizing those who committed such crimes. At the same time, the legislation of some countries also embodies such a desire of society in the relevant norms and provides the use of sterilization of criminals for special and general prevention of crimes against sexual freedom and inviolability. The research also demonstrates the erroneousness of this approach and proves the inadmissibility and medical inexpediency of depriving perpetrators of sexual crimes of their reproductive rights.
\end{abstract}

KEY WORDS: right to reproduction, non-consensual, forced and voluntary sterilization of criminals, general and special prevention of sexual crimes' commission, deprivation of reproductive right, sex offenders

Wiad Lek. 2021;74(11 p.2):2928-2933

\section{INTRODUCTION}

Crimes against sexual freedom and sexual integrity, especially those committed against minors and those in a helpless state, are always a big draw for society, and those who committed them are considered outcasts, even among criminals. Society demands the application of the most severe punishment for sex offenders. It Is the reason that the issue for the possibility to sterilize sex offenders, to deprive their reproductive rights is constantly discussed in society. Sterilization of criminals is provided by the legislation of the Czech Republic, Germany, the USA, etc. Although the world recognizes the inadmissibility of discrimination against persons on any ground, including through the commission of a sexual crime, society for its safety recognizes the possibility of deprivation of the right to reproduction to this category of criminals. Given the great public interest in the problem of sterilization of criminals, the authors have decided to choose a questionnaire method for three separate groups of respondents: employees of the health care sector, law enforcement officials, and ordinary people. They were offered to express their opinions on the possibility and necessity of sterilizing criminals and identifying sterilization as a violation of natural human rights.

\section{THE AIM}

The purpose is to analyze the opinions of employees of the health care sector, law enforcement officials, and ordinary people on the sterilization of criminals as a preventive measure that violates human reproductive rights; to analyze the situation of sterilization of criminals' regulation at the international level and in the laws of certain countries.

\section{MATERIALS AND METHODS}

This research is based on the legislation of certain countries (Poland, Germany, the Czech Republic, the USA), the provisions of international legal acts, in particular, the Convention for the Protection of Human Rights and Fundamental Freedoms, research and studies in this area, a survey of 46 health care employees and 52 representatives of law enforcement agencies. To achieve the set aim the authors have used a complex set of general and special methods of cognition, such as dialectical, comparative, analytical, generalization method, statistical and sociological methods (questionnaire method). 


\section{RESULTS}

Those who commit crimes against sexual freedom and sexual integrity are perceived by society as the most disgusting criminals within the system of criminal justice and cause an extremely negative emotional reaction in society. The public feels not only fear but also disgust and moral outrage against sex offenders. It is especially true for people who commit sexual crimes against children and people who are helpless due to mental or physical illness. Some studies show that people are more afraid to live in the same area with a known killer than with a sex offender, but they feel more anger and resentment towards a child rapist than towards a killer [1].

Those who have committed crimes against sexual freedom and sexual integrity are considered exiles and outcasts even in a criminal environment. Sex offenders are the lowest shameful caste out of all other castes of criminals.

A bright example of society's attitude to sex offenders is the story of Alan Turing, a genius who helped to break German ciphers during World War II and saved thousands of lives. In 1952 he was sentenced to chemical castration for homosexuality and later committed suicide. Only in 2013 Tuning posthumously received the official royal apology and a royal pardon, which cleared his name of "indecent behavior".

Such fear and disgust with sexual crimes and criminals provoke society to demand from the state the most radical and harsh measures to prevent the commission of sexual crimes. A large number of people consider the sterilization of criminals to be the most effective measure to prevent the commission of sexual crimes.

Sterilization is a medical manipulation aimed at losing fertility. Sterilization is achieved by: 1) surgical removal or deep suppression of the function by other methods (for example, irradiation or administration of special drugs) of the gonads (testicles) in men (castration) and ovaries in women (ovariectomy); 2) ligation or ablation of the canals, through which the sperm moves in men (vasectomy) and uterine tubes in women (salpingectomy) [2].

Sterilization of criminals can be divided by the method of conduction into:

Surgical sterilization - removal of the gonads, the canals, through which the sperm moves; ligation of uterine tubes or canals, through which the sperm moves.

Chemical sterilization - deep suppression of the functions of the gonads by the introduction of drugs.

Sterilization of criminals according to the consequences in the form of loss of reproductive function can be divided into:

Irreversible sterilization - a person is permanently deprived of reproductive function (removal of the gonads, canals, through which the sperm moves, ligation of uterine tubes).

Reversible sterilization - reproductive function can later be restored (suppression of gonadal functions by the introduction of drugs, ligation of the canals, through which the sperm moves).

With the consent of the offender to carry out such manipulation, sterilization can be divided into:
Forced sterilization - medical manipulation that is carried out against the will (ignoring the will) of a person.

Voluntary sterilization - medical manipulation that is carried out on the voluntary, conscious, and voluntary initiative or consent of a person [2].

Depending on the sex of the offender, sterilization can be divided into:

Sterilization of female criminals.

Sterilization of male criminals.

The practice of criminals' sterilization has a long history. Sterilization was used in the Middle Ages as a punishment for those who committed rape or were accused of adultery. In 1892, Switzerland became the first European country to castrate a criminal [3]. The widespread use of sterilization of sex offenders in Europe as a means of treatment and prevention began in the early XX century. Denmark was the first that pass law in 1929, legalizing this type of medical intervention for sex offenders. Most other European countries followed that example: Germany (1933), Norway (1934), Finland (1935), Estonia (1937), Iceland (1938), Latvia (1938), and Sweden (1944) and passed similar laws. The only exceptions were Catholic countries, such as Spain, Portugal, Belgium, and France, where castration was contrary to religious views.

The theoretical basis of European laws on sterilization of criminals was the theory of elimination of sexual motives, which were considered the dominant etiological factor in sexual criminal behavior.

The Voluntary Castration and Other Treatments Act (KastrG) of 1969 is currently in force in Germany [4]. The European Committee for the Prevention of Torture and Inhuman or Degrading Treatment or Punishment (CRT) has criticized Germany for this practice. Although the CRT noted that the procedure was voluntary and strictly controlled and that no surgical castration had been performed in recent years; the CRT called on Germany to change the laws and to stop the use of surgical castration in the treatment of perpetrators of sexual offenses in all Federal Lands. To date, the Federal Government has not implemented that recommendation. The German Government has stated that surgical castration is used to treat serious illnesses, mental disorders, or illnesses associated with abnormal sex drive and does not constitute coercion that degrades offenders.

Part III $\$ 17$ of the Czech Law "On Specific Medical Services" stipulates that testicular castration or pulpectomy may be applied to a 21-year-old patient who has been diagnosed with a specific sexual dysfunction manifested by a sexual offense (violent sexual offense and sexual violence), and whose professional medical examination demonstrated a high probability of committing a sexually motivated crime in the future; other treatments have failed or other treatments cannot be used for health reasons. Such castration is carried out based on a written request of the patient, a favorable opinion of the expert group, and the consent of the court. Castration is performed only to a patient who is in protective treatment or custody [5].

Nine US states have legislation on chemical castration. These are California, Florida, Iowa, Georgia, Louisiana, Montana, Oregon, Texas, Wisconsin, and Alabama. 
California was the first US state to offer the use of chemical castration for reconvicted child rapists as a condition of their parole. The California Chemical Castration Statute Stat 3339 provides that a person guilty of a particular sexual offense is punishable by chemical castration in addition to any other punishment. The person must be chemically castrated before releasing from prison [6]. California, Florida, and Iowa laws stipulate that offenders may be sentenced to chemical castration in all cases involving serious sexual offenses.

It was offered to castrate criminals in Poland (2009), Ukraine (2019), and France (2009). Relevant draft laws were submitted for consideration but did not finally become part of the legislation.

From time to time, there is a social demand in various countries around the world for the most radical measures to be taken for committing the most egregious sexual crimes. Society's attitude to sexual crime law has always been of scientific interest. Research has demonstrated that $73 \%$ of respondents are likely to support a policy to restrict or disqualify sex offenders, even without scientific evidence of its effectiveness [7].

Public opinion plays a significant role in the development of any laws, including laws relating to the criminal justice system. It influences politicians and through them the laws themselves. Politicians agree that public pressure is an influential force in drafting legislation, including laws on the liability of sex offenders [1]. It is obvious that most people do not have the necessary competence and knowledge of the specifics of committing and preventing sexual crimes, and require the introduction of the most radical measures, guided solely by emotions of anger, disgust to sex offenders. However, such public protest may be based on myths and misconceptions about sex offenders, such as the notion that sex offenders have very high recidivism and that they cannot be corrected, when, in fact, it is not true [1]. Thus, the opinion of society is formed by emotional reactions to disgusting crimes, which the community is trying to implement through the demand for the legislator to increase the repressive punishment for such acts.

In order to understand public opinion regarding the fair punishment for sexual crimes, an anonymous survey of physicians and law enforcement officials in Ukraine and Russia was carried out. The survey was conducted from August to October 2021. 46 physicians and 52 law enforcement officials took part in the survey. $57.7 \%$ of the surveyed physicians were men and $42.3 \%$ were women. There were $50 \%$ of men and $50 \%$ of women among law enforcement officials. The questions asked to the respondents were aimed at clarifying the level of understanding of the essence of sterilization as a serious violation of the natural human right to reproduction and the effectiveness of sterilization as a preventive measure. Respondents were offered several answers to each question.

The first question was aimed at assessing the understanding of the need to introduce such a radical measure of influence on criminals as sterilization, namely: "Does our system need irreversible sterilization of criminals?" Several options were suggested: 1) yes, it needs; 2) no, it does not need; 3 ) only male criminals; 4) only female criminals. Among the physicians 29 respondents (63\%) consider sterilization necessary, 16 people (34.78\%) believe that there is no need for such a radical measure and 1 person $(2.17 \%)$ believes that sterilization is necessary only for males. Among law enforcement officials, 26 respondents (50\%) consider sterilization necessary, 24 (46.15\%) believe that there is no need for such a radical measure and $2(3.85 \%)$ believe that sterilization is necessary only for males. Thus, the majority of respondents in both groups consider sterilization necessary for both male and female criminals.

To find out how the respondents imagine the methods of sterilization of criminals, the second question was formulated: "How should a criminal be sterilized?". The options of the answers to this question were the following: 1) surgical removal of the external genitalia; 2) surgical removal of the paired gonads (testicles/ovaries); 3) the function of the paired gonads is suppressed with drugs or by radiation; 4) vasectomy (ligation or removal of a fragment of the deferent canals in men) or ligation of the uterine tubes in women. Answering this question, 12 physicians (26.02\%) chose vasectomy, 7 (15.2\%) chose the most radical and cruel way - removal of the external genitalia, 13 (28.26\%) believe it appropriate to sterilize criminals by surgical removal of the paired gonads and 14 (30.43\%) tend to the sterilization exclusively with drugs. The majority of law enforcement respondents -28 people (53.85\%) chose vasectomy, 14 (26.92) preferred drug sterilization, 6 (11.54) tend to surgical removal of paired gonads, and only 4 people $(7.69 \%)$ chose radical surgical removal of the external genitalia. Physicians mostly chose drug sterilization, although the second place (1 vote less) was given to surgical removal of the paired gonads. But the vast majority of law enforcement officials chose sterilization by vasectomy (ligation or removal of a fragment of the deferent canals in men) or ligation of the uterine tubes in women.

The question on the purpose of sterilization of criminals was suggested separately in the questionnaire. It turned out that 22 physicians $(47,83 \%)$ consider punishment as a sterilization goal, just as many respondents among physicians determine the main purpose of sterilization to prevent such crimes in the future and 2 people $(4.35 \%)$ believe that sterilization of criminals should be used for treatment. Similar answers were chosen by law enforcement officials: 26 people (50\%) consider punishment to be a sterilization goal, 20 people (38.46\%) consider prevention to be a sterilization goal, and 6 people $(11.54 \%)$ prefer the medical purpose of sterilization.

Answering the question of whether sterilization of a criminal is a violation of the criminal's right to have children, 16 physicians (34.78\%) answered in the affirmative, 13 people $(28.26 \%)$ do not consider it a violation of the rights of the perpetrator, but the majority - 17 physicians $(36,96 \%)$ could not answer this question. Respondents among law enforcement officials also identified sterilization as a violation of the reproductive rights of perpetrators. The 
option with this answer was chosen by 24 people (46.15\%), 12 people $(23.08 \%)$ do not believe that sterilization violates the criminal's right to reproduction and 16 people $(30.77 \%)$ could not answer this question.

The question of whether criminals should be given the opportunity to surrender and preserve genetic material before the sterilization procedure was not easy to answer in the questionnaire. The following answers were offered: 1) no, these are unnecessary expenses for the state; 2) yes, it will ensure the right to reproduce; 3 ) yes but at the expense of the offender. The majority of physicians, 30 people (65.22\%) consider it costly and unnecessary, 12 people (26.09\%) do not mind that criminals have the opportunity to store their genetic material, but at their own expense, and only 4 people $(8,7 \%)$ have no doubt that this will provide an opportunity for the offender to realize inalienable natural rights. $22(42.31 \%)$ law enforcement officials identified such a procedure as unnecessary and costly for the state, as many considered it possible, but with full payment by the offender, and only 8 chose the option that recognizes the right of the offender to reproduce in case if such a radical measure as sterilization is applied.

The next question was aimed at analyzing the sterilization of criminals as a preventive measure and was formulated as follows: "Will the sterilization of criminals help to prevent crime in the future?" The majority of physicians - 28 $(60.87 \%)$ gave an affirmative answer and were convinced of the effectiveness of sterilization as a preventive measure, 10 physicians (21.74\%) did not believe in the effectiveness of prevention by the way of sterilization, another 8 people $(17.39 \%)$ could not answer this question. Most law enforcement officials - 24 people (46.15\%) also believed in sterilization as a measure that could help in preventing future crimes, 10 people (19.23\%) disagreed that sterilization could prevent new crimes, 18 people $34.62 \%$ ) could not answer this question.

It was important to get answers to the question of whether sterilization of criminals should be voluntary, whether there should be the consent of offenders in exchange for mitigation of liability. 23 physicians (50\%) believed that sterilization could only be voluntary, 13 people $(28.26 \%)$ answered that taking into account the consent of the offender or ignoring such consent depends on the nature of the committed crime, and 10 people (21.74\%) were sure that the consent of the offender was not required for sterilization. 22 respondents $(42.31 \%)$ representing law enforcement agencies determined that it would depend on the committed crime, 16 persons (30.77\%) admitted that such a decision could only be a manifestation of the will of the offender, and 14 persons $(26,92 \%)$ believed that we could ignore the opinion of the person to whom sterilization could be applied. The next question asked respondents to predict whether criminals would agree to be sterilized in exchange for mitigation of punishment. 17 physicians (36.96\%) are sure that criminals will not give such consent, 8 people (17.39\%) believe that such an offer will be interesting to criminals, but the majority - 21 people (45.65\%) admit that criminals will agree to sterilization, but such consent will be forced. Law enforcement officials mostly believe that such consent will be obtained under the pressure of circumstances, this option was chosen by 28 people (53.85\%), 12 people $(23.08 \%)$ are confident that criminals will not agree to sterilization in exchange for milder punishment than that provided in the sanction of the Article of the law on criminal liability, as many people, on the contrary, are convinced that criminals will agree to sterilization under such conditions.

Most of the physicians who took part in the survey acknowledged that sterilization was a more effective method of influencing the offender than any other. 29 people (63.04\%) are confident of this, while 17 (36.96\%) have doubts about it. On the contrary, the majority of law enforcement officials - 30 people (57.69\%) are pessimistic about the effectiveness of sterilization as a method of influence; 22 people (42.31\%) among respondents in this group still believe in the effectiveness of sterilization.

The opinion of physicians in regard to the question of who should make the final decision on the application of sterilization to a criminal - a physician or a judge - is almost unanimous. The vast majority of physicians - 38 people (82.61\%) chose the option that it should be an agreed joint decision of physicians and judges, 6 people (13.04\%) chose the option that only a judge should make such a decision and 2 people $(4,35 \%)$ believe that such a decision should be made exclusively by a physician. The answers of law enforcement officials are similar: the absolute majority of respondents 42 people $(80.77 \%)$ chose the option of a joint decision by a judge and a physician, 10 people (19.23\%) believe it possible to make such a decision only by a judge, no respondent in this group does not consider it possible for a physician to make such a decision on his own.

The conducted survey shows that despite the profession and professional knowledge in biology and law, physicians and law enforcement officers overwhelmingly approve of the use of sterilization for criminals. They believe that such a radical measure should be introduced precisely for the purpose of punishment for what was done. At the same time, the majority of respondents admit that sterilization violates a person's natural right to reproduction, but most of them believe that such a radical measure will prevent the commission of similar crimes in the future. Besides, if physicians are convinced that sterilization should be a voluntary procedure, law enforcement officials believe that voluntary sterilization should depend on the type of the committed crime, and for certain crimes it can be applied compulsorily. It is an interesting fact, physicians believe in the effectiveness of sterilization as a method of influencing the offender, but law enforcement officers do not consider such a measure of the influence the most effective. This research demonstrates that society, in a desire to protect itself or to take revenge for the harm caused by crime, agrees to intentionally and knowingly deprive the perpetrators of their natural rights. At the same time, people even are not sure that such discrimination is effective and beneficial.

This dissonance has existed since sterilization was suggested as a method of treating sex offenders. There has 
always been a question of its compatibility with the social notion of the individual's right to physical integrity. While one part of society wanted to introduce sterilization as a radical punishment for the most heinous crimes, another part considered such an intervention as a "barbaric punishment" that entailed humiliation and the inability to start a family [8]. It is especially true to irreversible sterilization, where a person forever loses reproductive function as a result of the sterilization.

Countries that allow surgical (irreversible) castration of criminals emphasize the high effectiveness of this method of treating criminals. Indeed, recidivism rates after castration are the lowest among all other forms of treatment. For example, the recidivism rate for castrated sex offenders in West Germany was $2.8 \%$, while for non-castrated people it was $39 \%$. Such countries as Denmark, Finland, the Netherlands, Norway, Sweden, and Switzerland, which have previously used surgical castration of criminals, provided data that confirmed the findings of German criminologists $[9,10]$. Czech supporters of castration, in particular Petr Weiss, state that none of the castrated convicts over the past 30 years (in the Czech Republic) have committed more violent crimes. However, criminal investigator Jiří Markovič referred to a case, where castrated criminal Antonín Vorel killed and raped a woman in the Kunratice-Michel forest $[11,12]$. The European Committee for the Prevention of Torture also reported three other cases of violent recidivism of castrated offenders after 1989 [11].

The World Federation of Societies of Biological Psychiatry (WFSBP) in its Guidelines for the biological treatment of paraphilias considers surgical castration as one of the methods that the offender can voluntarily choose for treatment [10]. Instead, the International Association for Suicide Prevention (IATSO), which is the undisputed international authority in the treatment of sex offenders, constantly publishing and regularly updating the principles of this therapy, does not provide surgical castration of offenders as a method of treatment [13].

It should be noted that surgical sterilization is currently very little used in practice. It was replaced by chemical (drug) sterilization as an alternative less invasive and more affordable chemical, hormonal treatment. The essence of chemical sterilization is that a person is prescribed a drug that blocks the production of testosterone. However, the effects of chemical sterilization can be prevented either by the use of drugs that contain testosterone or by the irregular use or refusal to take drugs intended for sterilization. Chemical sterilization can only be successful for criminals who agree to this measure. They should understand their sexual problems and be motivated to solve them. The drug for chemical castration does not work at all or works very poorly in about ten percent of cases. It is impossible to predict the cases when chemical sterilization is effective and when it is not effective. That is why the risk of recidivism can be reduced only for some sex offenders [14]. Besides, not all sex offenders are driven by "increased sex drive". In many cases, the trigger is that the desire for intimacy is combined with a lot of anger. Sex offenders are often afraid to look funny in their fantasies. On the other hand, chemical castration in such cases can add aggression and frustration, which will eventually lead to the commission of a new crime [14].

Thus, the opinion of society that sterilization is effective in preventing future crimes is a myth that is not confirmed by scientific research and practice. Sterilization may in some ways reduce the recurrence and recidivism of crimes, but the results of certain studies are too heterogeneous to conclude on the overall effectiveness of depriving sex offenders of fertility [15].

\section{DISCUSSION}

The next myth, which is believed by society, is the voluntary sterilization of criminals. In 2017, a judge from Tennessee issued a ruling offering prisoners a 30 -day reduction in their sentence, if they undergo a permanent birth control procedure - a vasectomy for men. Although that program was technically voluntary, the American Civil Liberties Union (ACLU) cited it as a form of coercion that forced prisoners to be sterilized, violating a fundamental constitutional right to reproductive autonomy [7]. According to statistical research conducted by the Czech Medical and Sexological Society, $12 \%$ of respondents said that they agreed to surgical sterilization only because it was the only way to get out of jail. The remaining $88 \%$ of respondents in an anonymous questionnaire said that the decision was voluntary [16].

It seems that an offer for a person regarding a sterilization surgery in exchange for release from punishment or mitigation of punishment should be considered as an influence on his will. The European Committee for the Prevention of Torture and Inhuman or Degrading Treatment or Punishment emphasizes that surgical castration cripples and degrades a person and does not meet international standards for the treatment of sex offenders. This procedure deprives a person of the ability to reproduce and causes serious physical and psychological disorders. It is the reason why surgical castration of criminals, despite its external voluntariness, must be recognized as forced and identified as a violation of human reproductive rights. According to the study conducted in the Czech Republic, people who underwent surgical sterilization suffer from obesity ( 36 percent), weight loss (20 percent), body hair loss (38 percent), fatigue (18 percent), or breast enlargement (so-called gynecomastia) (16 percent of respondents). They also have psychological problems: depression, feelings of inferiority, increased aggression (50 percent) [17]. Besides, the perpetrator is well aware that sterilization will be accompanied by the elimination of fertility, physical injury, as well as a possible change of personality. Thus, there is a question how the intervention, even if it was chosen voluntarily, is compatible with the state's obligation to respect human dignity [8].

\section{CONCLUSIONS}

The right to reproduction in modern democratic society, as an inalienable natural right of every human being, should not be subject to any restrictions. The decision on the refus- 
al to reproduce must be entirely voluntary, and the person making such a decision must not be bribed or pressured by either the state or others. In addition, the irreversibility of the surgical sterilization procedure imposes on the state the obligation to ensure that the person's consent to this procedure is complete, informed, and unforced.

The authors of this research analyze the differences between the actual facts about the recurrence (recidivism) of sexual crimes, the effectiveness, and purpose of their punishment, and how these facts are not taken into account due to the general biased negative attitude towards sex offenders and disgust with the crimes committed by them.

The conducted research allows us to conclude that public beliefs about sex offenders are based on myths and errors. Using a sample of 100 physicians and representatives among law enforcement officials, we found out that perceptions of the punishment of sexual offenders were largely due not the professional knowledge itself, but biased on a negative attitude towards such individuals and the crimes they committed. Besides, it has been established that the respondents are fully aware that the chosen in the questionnaire measures in the form of sterilization are violations of the natural human right to reproduction. Nevertheless, they consider it possible to discriminate against a certain group of people with deviant behavior and demonstrate a desire to enshrine the possibility to deprive the right to reproduction in law as the most radical measure of punishment.

\section{REFERENCES}

1. Rosselli MK, Jeglic EL. Factors Impacting upon Attitudes Toward Sex Offenders: The Role of Conservatism and Knowledge. Psychiatr Psychol Law. 2017;24(4):496-515. Published 2017 Jan 16. doi:10.1080/132187 19.2016.1254562

2. Alesia V. Gornostay, Volodymyr V. lemelianenko, Alona V. Ivantsova Reproductive rights violations: forced sterilization and restriction of voluntary sterilization)./ Wiad Lek 2019; 12: 2536-2540

3. Belgium, Germany, England, Denmark and the United States: The Implementation of Registration and Castration Laws as Protection Against Habitual Sex Offenders," Penn State International Law Review: Vol. 16: No. 2, Article 5. Available at: http://elibrary.law.psu.edu/psilr/ vol16/iss $2 / 5$

4. Gesetzüber die freiwillige Kastration und andere Behandlungsmethoden. Available at: https://www.gesetze-im-internet.de/kastrg/ BJNR011430969.html

5. Zákon o specifických zdravotních službách. Available at: https://www. zakonyprolidi.cz/cs/2011-373?text=kastrace

6. California Chemical Castration Statute Stat 3339. Available at: http:// leginfo.ca.gov/pub/95-96/bill/asm/ab_3301-3350/ab_3339_ cfa_960422_093708_asm_comm.htm

7. Voluntary sterilization of inmates for reduced prison sentences. Elise $B$. Adams/Duke Journal Of Gender Law \&amp; POLICY, 2018. 23-44

8. Annelie Ramsbrock, Das verlorene Geschlecht. Zur Kastration von Sexualstraftätern seit 1945, in: Themenportal Europäische Geschichte, 2016, <www.europa.clio-online.de/essay/id/fdae-1302>.

9. Annelie Ramsbrock. Die Würde des Mannes ist antastbar. 50 Jahre Kastrationsgesetz in Deutschland. Available at: https:// geschichtedergegenwart.ch/die-wuerde-des-mannes-ist-antastbar50-jahre-kastrationsgesetz-in-deutschland/
10. Florence Thibaut, Flora De La Barra, Harvey Gordon, Paul Cosyns, John M. W. Bradford \& the WFSBP. Task Force on Sexual Disorders. The World Journal of Biological Psychiatry, 2010; 11: 604-655. Available at: https://www.wfsbp.org/fileadmin/user_upload/Treatment_ Guidelines/Paraphilias_Guidelines.pdf

11. Vladimír Ševela: Zastavte kastrace! Nebo ne?, Týden, 20. 4. 2009 Available at: https://www.tribune.cz/clanek/5953

12. Fenomén masových vrahů Archivováno 5.7.2011 na Wayback Machine, kap. 6, část třetí: Dlouhá cesta, 20. 3. 2008, Tinek

13. Standards of Care for the Treatment of Adult Sex Offenders of the International Association for the Treatment of Sexual Offenders (IATSO). Available at: https://www.iatso.org

14. Chemische Kastration für rückfällig gewordene Pädophile und Vergewaltiger. Available at: https://www.parlament.ch/de/ratsbetrieb/ suche-curia-vista/geschaeft?Affairld $=20133870$

15. Schmucker, M. and Lösel, F. (2017), Sexual offender treatment for reducing recidivism among convicted sex offenders: a systematic review and meta-analysis. Campbell Systematic Reviews, 13: 1-75. https://doi. org/10.4073/csr.2017.8

16. Zvěřina, J.; Weiss, P., Hollý, M. Výsledky terapeutické kastrace u parafilních sexuálních delikventů. Ministerstvo zdravotnictví ČR [online]. Česká lékařská společnost J.E.P., Praha, sexuologická společnost, 2014.

17. Hana Válková. Vykastrovaní muži si pochvalujízvládáníagresivity i“klid od žen". Available at: Zdroj: https://www.idnes.cz/zpravy/domaci/ kastrace-novela-zakon-lekar-deviant-pedofil.A150117_091612_ domaci_hv.

This article is a part of the research program of the Department of Criminal Law of the Yaroslav Mudryi National Law University "Theoretical problems of efficiency of criminal legislation and practice of its application".

\section{ORCID and contributionship:}

Volodymyr V. Iemelianenko: 0000-0002-8999-3672 A, B, D, E, F Alesia V. Gornostay: 0000-0003-0101-6808 ${ }^{\text {A, B, C, D, E }}$ Olena V. Yevdokimova: 0000-0003-2211-4079 A, B, C, D

\section{Conflict of interest:}

Authors declare no conflict of interest.

\section{CORRESPONDING AUTHOR Volodymyr V. lemelianenko \\ Yaroslav Mudryi National Law University \\ Kharkiv, Ukraine \\ tel. +380501727091 \\ e-mail: don8@bigmir.net}

Received: 22.06 .2021

Accepted: 20.10 .2021

A - Work concept and design, B - Data collection and analysis, C - Responsibility for statistical analysis, D-Writing the article, $\mathbf{E}$-Critical review, $\mathbf{F}$ - Final approval of the article 


\title{
PRESUMPTION OF MENTAL HEALTH VS FORENSIC PSYCHIATRIC EXAMINATION REPORT: MEDICAL AND LEGAL ASPECT
}

DOI: 10.36740/WLek202111213

\author{
Olga I. Tyshchenko ${ }^{1}$, Ivan A. Titko ${ }^{2}$ \\ 'YAROSLAV MUDRYI NATIONAL LAW UNIVERSITY, KHARKIV, UKRAINE \\ 2POLTAVA LAW INSTITUTE OF YAROSLAV MUDRYI NATIONAL LAW UNIVERSITY, POLTAVA, UKRAINE
}

\begin{abstract}
The aim: The aim of this work is a legal analysis of the mental health presumption and its application by judges in assessing the report of the FPE; formulation of scientifically substantiated proposals for determining the criteria for the judge's assessment of the FPE report in refuting the presumption of mental health context.

Materials and methods: The basis for the article was the results of scientific research published by representatives of different states regarding the criteria for assessing the expert's opinion as a procedural source of evidence; legislation (in the field of psychiatric care and criminal justice) of a number of European and Asian states and its implementation experience; results of the survey of 88 judges conducted by the authors (judges of local courts of Ukraine, the survey was conducted in 2020) on key issues of ensuring the participation of a person suffering from a mental disorder in a court hearing.

In this research, a complex of general and special scientific methods of cognition was used (comparative legal method, systemic-structural method, generalization method, method of analysis and synthesis, method of sociological research, method of expert assessments, etc.)

Results: According to the results of the research: a) it is stated that the presumption of a person's mental health is a common European standard, regardless of the normative consolidation at the level of domestic legislation; b) it is proved that the effectiveness of the judge's use of the presumption of mental health in criminal proceedings directly correlates with his or her competent assessment of the FPE report and the providing appropriate argumentation in a court hearing; $c$ ) the factors that allow the judge to correctly assess the report of the FPE and put it in the basis of decision-making (that is, to refute the presumption of mental health of a person), or, on the contrary, to deny it (stating that the presumption of mental health has not been abolished).

Conclusions: As a principle of modern psychiatry, the presumption of mental health is directly correlated with the FPE report, based on which it can be refuted. This determines the special importance of a competent assessment of this procedural source of evidence, the need for the judge to take into account several factors and to provide appropriate argumentation in the court hearing.
\end{abstract}

KEY WORDS: presumption of mental health, forensic psychiatric examination, expert opinion, expert report, assessment of expert opinion / report, court

Wiad Lek. 2021;74(11 p.2):2934-2939

\section{INTRODUCTION}

In modern psychiatry, the problem of presumption of mental health is one of the most complex ones. Sharing the widely recognized importance of this principle for the protection of the rights and legitimate interests of persons falling into the field of view of a psychiatrist [1, p. 109], we should note its special significance in the field of criminal justice. Since the formula for the presumption of mental health is reduced to the key rule that a person is considered mentally healthy and capable of being aware of and controlling their actions until proven otherwise, in turn, only one piece of evidence can refute the presumption of mental health - the report of an expert psychiatrist.

Thus, the correlation between the presumption of mental health and the FPE report in criminal (as well as largely in civil, administrative) proceedings is obvious. At the same time, the issue of the criteria to be taken into account by the judge when assessing the FPE report in the context of the presumption of mental health remains quite controversial.

\section{THE AIM}

The aim of this work is a legal analysis of the presumption of mental health and its application by judges in assessing the FPE report; formulation of scientifically substantiated proposals for determining the criteria for the judge's assessment of the FPE report in the context of refuting the presumption of mental health.

\section{MATERIALS AND METHODS}

The basis for the preparation of the article was the published results of scientific research by representatives of different states regarding the criteria for assessing the expert's opinion as a procedural source of evidence; legislation (in the field of psychiatric care and the field of criminal justice) of a number of states in Europe and Asia (Belarus, Georgia, Kazakhstan, Lithuania, Moldova, Poland, Russia, Turkmenistan, Uzbekistan, Ukraine, Estonia) and the practice of its application; some results of the survey of 88 
judges conducted by the authors (judges of local courts of Ukraine, the survey was conducted in 2020) on key issues of ensuring the participation of a person suffering from a mental disorder in a court hearing.

In the process of research, a complex of general scientific and special methods of cognition was used (comparative legal method, systemic-structural method, generalization method, method of analysis and synthesis, method of sociological research, method of expert assessments, etc.)

\section{RESULTS}

The historical aspect of the presumption of mental health in forensic psychiatry has traditionally been associated with the 1843 M'Naghten trial in England. This case initiated the eponymous rule (M'Naghten's rule), in the formulation of which fourteen of the fifteen judges concluded that "everyone is considered mentally healthy and intelligent enough to be held accountable for their crime until proven otherwise" [see: 2]. The quoted rule has been the subject of lively discussions, as evidenced by some scientific papers [see: 3, pp. 93-109]. The concept of presumption was known to forensic psychiatry in pre-revolutionary Russia. Thus, the founder of Russian psychiatry V. H. Kandinskiy stated the following: I will not presume mental illness in a healthy person, because health is the rule, and illness is the exception $[4$, p. 30; 2]. In modern psychiatry, assessments of the importance of the presumption of mental health differ: some experts say that this presumption looks attractive, but this is not enough to put it on the role of one of the fundamental principles of modern psychiatry [1, p. 112], others insist on the need to spread the use of this principle [5, p. 5].

In modern legal regulation, the principle of the presumption of mental health follows the norms of international law. For example, Article 16 of the International Covenant on Civil and Political Rights of 16 December 1966 stipulates that everyone, wherever he or she may be, has the right to recognition as a person before the law [6]. According to the Principles for the Protection of Persons with Mental Illness and the Improvement of Psychiatric Care, adopted by UN General Assembly Resolution 46/119 of 17 December 1991, no person or authority may classify an individual as having a mental illness other than for a purpose that is directly related to a mental illness or as a result of a mental illness (paragraph 5 of principle 4 - Definition of mental illness).

It should be noted that the legislation of some states does not directly provide for the presumption of mental health (Law of the Russian Federation On Psychiatric Care and Guarantees of Citizens' Rights in its Provision of 2 July 1992; Law of the Republic of Uzbekistan On Psychiatric Care of 12 May 2021 [7]. In the Law of the Republic of Poland On Mental Health of 19 August 1994 [8], the key issue is the concept of mental health and its protection [9, p. 19]; however, the presumption of mental health is also not directly regulated.

- Instead, the presumption of the absence of a mental disorder (disease) is enshrined in Art. 6 of the Law of the Republic of Belarus On the Provision of Psychiatric Care of 7 January 2012 [10]; Art. 7 of the Law of Turkmenistan On the Provision of Psychiatric Care of 23 November 2016 [11]; Art. 3 of the Law of Ukraine On Psychiatric Care of 22 February 2000 [12]. There are two rules behind the presumption of mental health [13] The first is that a person is considered mentally healthy and capable of being aware of and controlling their actions until proven otherwise. That is, every person who has reached the legal age is a priori considered to be mentally healthy and capable of being aware of and controlling their actions. Second, doubts that cannot be eliminated are interpreted in favor of a condition that is more probable or possible. When conducting an examination in criminal cases, the doubts are interpreted in favor of the accused. In this context, the benefit is associated with the least restriction of the rights and freedoms of the subject related to punishment [13].

Being a legal presumption, in terms of content, it has a medical character. Establishing the presence or absence of a mental disorder occurs not through legal norms, but using clinical diagnostic methods and criteria [1, p. 110]. In turn, in criminal proceedings, the presence or absence of a person's mental disorder is formalized in the FPE report. At the same time, on the one hand, the act of forensic psychiatric examination is a medical document that should reflect the process of expert examination against the background of clinical, psychopathological and expert methods, and on the other hand, it is a source of evidence in court and subject to court assessment [13, p. 105]. Accordingly, the scientific interest of the authors of this article in the presumption of mental health is due to its correlation with the FPE report in criminal proceedings.

Survey results: Among the judges we interviewed, 98\% agreed that in proceedings on the application of compulsory medical measures, the FPE report is de facto the key evidence (we have also noted this in previous publications).

These statistical indicators relate to the final court decision in criminal proceedings on the application of compulsory medical measures (hereinafter referred to as CMM). However, it should be noted that on the basis of the report of the forensic psychiatric examination, the court also issues interim decisions that limit the convention rights of the person. Thus, the court's decision to conduct a stationary FPE limits the provisions of Art. 5 of the Convention the right of a person to liberty and security of person [for more details see: 14]; the court's decision on the possibility of participating in the trial of a person suffering from a mental disorder restricts the right to a fair trial, regulated by Art. 6 of the Convention [for more details see: 15; 16].

Given that the fundamental convention rights and freedoms of a person are subject to restrictions on the basis of a forensic psychiatric examination report, the question of the criteria for assessing such an expert opinion is of particular importance. It should be noted that the issue of the court's assessment of this procedural source of evidence has been known since ancient times, as the view of a forensic expert as a "scientific judge" was widely discussed by pro- 
ceduralists in the early twentieth century [see: 17, p. 3]. In the modern criminal process, this issue does not lose its relevance, as evidenced by numerous scientific studies [see, e.g.: $17 ; 18 ; 19 ; 20 ; 21 ; 22 ; 23$ ]. Analysis of these scientific papers suggests that modern science takes the position of the equality of all procedural sources of evidence. The same conclusion follows from the study of the criminal procedural law of some foreign countries. Thus, the rule of the absence of any evidence of pre-established force is provided in Part 2 of Art. 94 of the Criminal Procedure Code of Ukraine; Part 2 of Art. 17 of the CPC of the Russian Federation; Part 2 of Art. 82 of the CPC of Georgia; Part 3 of Art. 101 of the CPC of Moldova; Part 1 of Art. 61 of the CPC of Estonia and others. There is no doubt that the judges are familiar with this assessment of evidence rule. At the same time, a logical question arises as to why the absolute majority of the judges we interviewed $(98 \%$ of the respondents) agreed that the report of the forensic psychiatric examination is de facto the key evidence in this category of cases? The answer lies on the surface - the medical aspect is the decisive factor for the court to make both the final decision in the criminal proceedings on the CMM and interim decisions (on the possibility of participation in the trial of a person suffering from a mental disorder; on the inpatient FPE). Undoubtedly, the use by an expert of special knowledge in the field of psychiatry to a certain extent blocks a competent assessment by a judge of the research part of the expert's opinion. According to Polish scientists J. Dzierżanowska and J. Studzińska, the use of expert knowledge and research methods by experts creates real difficulties in assessing the evidence provided by experts. This is evidenced by a study in which the majority of judges who heard criminal cases (78 out of 148 respondents) acknowledged that they were insufficiently prepared to assess scientific evidence [21, p. 21]. In turn, 1. Markiewicz and $€$. Mazur emphasizes that if the court could assess the validity of the scientific views provided by experts, there would be no need to appoint an examination. Then the court itself, based on its own knowledge, could make a decision [24, p. 73].

Investigating the outlined problem, V. B. Pervomaiskyi puts forward the thesis that the court does not have a method of assessing the opinion of a psychiatrist expert, which is confirmed by empirical data $-73.2 \%$ of judges are convinced of this [2]. According to O. Dufeniuk, Polish lawyers have different views in the assessment of evidence, since there is no universal standard that could be used when assessing an expert's opinion [19, p. 52]. For example, R. Kaczor proposed a certain algorithm for the court to assess the expert's opinion, which consists of the following sequence of actions: first, it is necessary to determine whether the form of the expert's opinion meets the requirements of criminal procedure law. Secondly, the analysis of the report according to the criteria: incompleteness, the ambiguity of the expert's opinion, the presence of contradictions in the report itself, and with other reports of the expert. Only in the event of non-compliance with any of the criteria should an expert be questioned, an additional examination appointed, or an examination assigned to another expert [22, p. 53-54]. The approach of assessing the expert opinion proposed by M. Hrehorowicz and K. Bronowskiej undoubtedly deserves attention. It includes the following stages: 1) formal assessment - assessment of the opinion according to the form; 2) assessment in essence-assessment of the content of the report; 3) contextual assessment - assessment of the expert's opinion in conjunction with other evidence [op. cit.: 19, p. 52].

The algorithms proposed by the Polish authors for the judge's assessment of the expert's opinion are general, and therefore can be used, in particular, in the assessment of the FPE's opinion. At the same time, any examination with regard to the subject of research has its own features that somewhat transform the general algorithms, and therefore must be taken into account. The analysis of the legislation of individual states of Europe and Asia, as well as the practice of its application, obliges to pay attention to a number of factors that must be taken into account when assessing the FPE report in criminal proceedings. In this context, in particular, we are talking about:

- the ability of the court to directly perceive not only the expert's opinion, but also the "object" of the expert study. In one of the previous publications on this topic, we have already indicated that "a person suffering from a mental disorder has a dual role in court proceedings: he or she is an interested person and, at the same time, the main object of judicial investigation" (See at $\$ 72$ Case of Shtukaturov v. Russia; $\$ 62$ Case of Zagidulina v. Russia, etc.). Explaining the above position in the Case of Shtukaturov v. Russia, the ECHR stated that a person's participation is necessary not only to state their position on a case but also for a judge to have their idea of his or her mental state. In the present case, the Court agreed that "the applicant did indeed have psychiatric problems, but on the basis of the case file he was a relatively independent person. In such circumstances, the judge needed to have at least a brief visual contact with the applicant, and preferably his interrogation" $(\$ 72,73)$ [4]. Thus, the manual for prosecutors emphasized the thesis that "A judge must determine if the defendant is fit to plead and to stand trial. This is a determination on the balance of probabilities if the defendant raises the issue, or if he contests it then it is for the prosecution to satisfy the court beyond a reasonable doubt" [16, p. 2740]. At the same time, the above approach of the European Court is currently reflected in the legislation of not all countries. At the present stage, the criminal procedure legislation of many states provides for the possibility of restricting the right of a person suffering from a mental disorder to participate in the trial on the basis of the reports of forensic psychiatric examination on the nature and extent of their disease (CPC of the Russian Federation (Article 441); CPC of Belarus (Article 445); CPC of Kazakhstan (Article 511); CPC of Moldova (Article 496); CPC of Estonia (Article 400), CPC of Uzbekistan (Article 570), etc.). If, in general, the legislative approaches of these states link the possibility of personal participation in 
court proceedings with the determination of the nature and degree of mental disorder, the Ukrainian legislator spoke on this issue quite clearly in Art. 512 of the CPC: the trial is carried out with the obligatory participation of the person in respect of whom the issue of application of the CMM, their legal representative, and defense counsel is being resolved [for more details see: 15];

- equal value of all parts of the expert's opinion. The expert's opinion contains three parts, each of which must be analyzed by the court in terms of admissibility and reliability. At first glance, this rule is so clear that it does not require further comment. However, experts in the field of forensic psychiatry emphasize that sometimes they mistakenly believe that the main, most important part of the examination report is the conclusions (final part). They are the subject of court proceedings. But this is a misconception. The court must examine and evaluate the entire act of examination as a source of evidence. In this sense, conclusions as evidence are not self-sufficient. Without a motivational part, they are worthless, because it is unknown how and on what basis the expert concluded. Without a motivational part, the conclusion acquires a personalized character when the arguments are replaced by the authority of the expert, his academic title, degree, or position. This approach is unacceptable for examination, as it deprives the court of scientific guarantees of erroneous decisions [see: 13];

- features of appointment and carrying out of repeated examinations. Repeated FPE is an effective way for a judge to assess an expert's initial opinion. At the same time, failure to take into account the peculiarities of the appointment of re-examination (including re-FPE) quite often leads to the recognition of the results of such examination as inadmissible evidence. In this context, it is important to note that re-examination (as opposed to, for example, additional) is characterized by: a) the immutability of the object of study; b) the invariability of the scope and content of the issues raised by the expert; c) appointment of another expert as the executor of the examination. The immutability of the object of study in the context of the FPE means not only that the repeated FPE is carried out against the same person (which is obvious), but also that the expert must use the same related materials: documents containing information about the state of health of the person in respect of whom the FPE is prescribed, the facts of their application for medical care, their diagnosis, medical history, certificates of stay on treatment in institutions for the provision of psychiatric care, etc. The consistency of the scope and content of the questions posed to the expert is a formal but important criterion, non-compliance with which may lead to the expert's report as inadmissible evidence (court decision on the appointment of a second FPE can serve as an example of Ukrainian law enforcement practice that illustrates negative legal consequences of non-compliance with this rule). [see: 25]. At the same time, only a different expert can be the executor of the repeated FPE. Moreover, this rule may have its variations (for example, the same expert may not be a member of the commission if the examination is conducted by a commission; if the expert on the initial examination was the head of the expert institution, the re-examination can no longer be appointed employees of this institution, etc.);

- taking into account professional explanations of the expert's opinion. Given that, usually, neither the court nor the parties to criminal proceedings are specialists in psychiatry (or in other non-legal fields of knowledge), the legislation of many states provides for the possibility of obtaining professional explanations from an expert in court. For example, according to the Article 285 of the CPC of Lithuania, an expert is summoned to testify in court only when the court decides that his or her testimony regarding special conclusions needs clarification or addition. Following Part 1 of Art. 355 of the CPC of Kazakhstan, the examination of an expert may be conducted only after the announcement of the conclusion for clarification, clarification, or addition. Regulatory provisions of Art. 374 of the CPC of Moldova provides for the interrogation of an expert in court, which is under Part 2 of Art. 153 of the CPC of Moldova is carried out if the expert's opinion is not clear enough or has some shortcomings that do not require additional research, or there is a need to clarify the methods used by the expert or some concepts. Part 2 of Art. 292 of the Estonian CPC stipulates that at the request of a party to the proceedings, the court may order the questioning of an expert to clarify the content of the examination report or its supplement. The possibility of interrogation of the expert in court follows from the content of Part 2 of Art. 390 of the CPC of Poland. Article 282 of the CPC of the Russian Federation provides that an expert may be summoned by a court for questioning to clarify or supplement his opinion. A similar rule is contained in Art. 356 of the CPC of Ukraine. Moreover, the law of individual states allows the court to order the simultaneous questioning of two or more experts to determine the reasons for disagreement in their conclusions concerning the same subject or issue of research (see, for example, Part 4 of Article 356 of the CPC of Ukraine). The effectiveness of this method of assessing the expert's report is practically confirmed. For example, in one of the criminal proceedings, which was the subject of consideration by the Ukrainian court, it was the interrogation of the expert in the court session that made it possible to establish that the FPE report in its content contradicted the circumstances of the criminal proceedings, namely, the diagnosis of a person as a mental disorder was not differentiated (medical criterion of limited sanity under Art.20 of the Criminal Code of Ukraine) or as a mental illness (as a medical criterion for insanity under Art.19 of the Criminal Code of Ukraine) [26].

Taking into account the above factors allows the judge to correctly assess the FPE report and put it in the basis of decision-making (that is, to refute the presumption of mental health of a person), or, on the contrary, to deny it (stating that the presumption of mental health has not been abolished). 


\section{DISCUSSION}

The presumption of mental health can only be rebutted by the FPE's finding that a judge makes decisions restricting a person's Convention rights (right to liberty and security of person, Art. 5 of the Convention; right to a fair trial, Art. 6 of the Convention). Given the particular importance of the FPE report, the factors that the judge must take into account when assessing this procedural source of evidence become relevant. It should be noted that scientific research by both Ukrainian and foreign scholars is mainly devoted to the judge's assessment of the expert's opinion as a procedural source of evidence. Thus, R. Kaczor proposed an algorithm for assessing the expert's opinion [22, p. 41-55]. Investigating judicial practice, the criteria for assessing the expert's opinion were highlighted in the work of J. Dzierżanowska, J. Studzińska [21, p. 21-47]. Certain issues of this problematics under Polish law were studied by O. Dufeniuk [19, p. 51-56]; E. Orehova [20, p. 151-152]. Actual aspects of the assessment of the report of forensic psychological examination were set out in the work by 1 . Markiewicz, Ł. Mazur [24, p. 72-86]. At the same time, the review of the works allows us to state that today there are several debatable issues related to the definition of the importance of the presumption of mental health in making legally significant decisions in criminal proceedings; algorithmization of activities to assess the FPE reports; a list of factors that should be taken into account when assessing the results of FPE, etc.

\section{CONCLUSIONS}

1. The presumption of human mental health today is a common European standard, regardless of the normative consolidation at the level of domestic legislation. At the same time, the only legally significant way to refute this presumption is to submit a court to the FPE report. It is noteworthy that even in those states where the absence of priority of any evidence (including expert opinion) is directly established at the level of the law, the decision of rebuttal of the presumption of mental health is de facto recognized as key evidence in resolving the issue of rebutting the presumption of mental health.

2. Assessing the importance of the presumption of mental health as a principle aimed at protecting fundamental human freedoms, it is necessary to take into account the fact that its rebuttal not only leads to a final decision in criminal proceedings on the application of the CMM but also imposes significant time of the criminal proceedings: placement in a psychiatric institution for an inpatient examination; application of specific precautionary measures; restrictions on the right to appear in court (according to the legislation of individual countries, etc.). The effectiveness of a judge's use of the presumption of mental health in criminal proceedings is directly correlated with his or her competent assessment of the FPE report and the appropriate reasoning in the judgment. In turn, this fact increases the importance of the court's correct assessment of the FPE report.
3. Taking into account a number of factors allows the judge to correctly assess the FPE report and put it as the basis for making a decision (that is, to refute the presumption of mental health of a person), or, on the contrary, to refuse it (stating that the presumption of mental health has not been canceled). In particular, when assessing the FPE report, the court must keep in mind: the ability of the court to directly perceive not only the opinion of the expert but also the "object" of the expert study; an equal value of all parts of the expert's opinion; features of appointment and carrying out of repeated examinations; the possibility of obtaining professional explanations of the conclusion from the expert.

\section{REFERENCES}

1. Shishkov S. N., Skibina N. V. Prezumptsiya psihicheskogo zdorovya: mozhno li schitat ee obosnovannoy? [The mental health presumption: is it valid?] Journal of Neurology and Psychiatry. 2017; 5:109-113. (in Russian).

2. Pervomayskiy V. Prezumptsii v psihiatrii [Presumptions in psychiatry]. Available from: http://www.psychiatry.ua/books/forensic/paper12.htm (in Russian).

3. Simon E. Sobeloff. From McNaghten to Durham, and Beyond - a Discussion of Insanity and the Criminal Law. 1995;15(93). Available from: http://digitalcommons.law.umaryland.edu/mlr/vol15/iss2/2

4. Kandinskiy V. K voprosu o nevmenyaemosti [On the issue of insanity]. 1890:238. (in Russian).

5. Mendelevich V.D. "Prezumptsiya psihicheskogo zdorovya": ot unikalnogo sudebnogo pretsedenta $\mathrm{k}$ rutinnoy praktike [The presumption of mental health": from a unique judicial precedent to routine practice]. Neurological Bulletin. 2019;LI(1):5-9. (in Russian).

6. Mizhnarodnyi pakt pro hromadianski i politychni prava vid 16 hrudnia 1966 r. [International Covenant on Civil and Political Rights of 16 December 1966]. Available from: https://zakon.rada.gov.ua/laws/ show/995_043 (in Ukrainian).

7. 0 psihiatricheskoy pomoschi: Zakon Respubliki Uzbekistan ot 12 maya 2021 g. No. ZRU-690 [On psychiatric care: Law of the Republic of Uzbekistan of 12 May 2021 No. ZRU-690]. Available from: https://lex. uz/docs/5422217 (in Russian)

8. Ustawa z dnia 19 sierpnia 1994 r. o ochronie zdrowia psychicznego. (Dz. U. z dnia 20 października 1994 r.). Available from: http://opsinfo.pl/ pliki/prawo/ps/uo0zp_1994-535_zm-do_2011-19.pdf

9. Bobińska Kinga, Eichstaedt Krzysztof Zygmunt, Gałecki Piotr. Ustawa o ochronie zdrowia psychicznego. Komentarz. Warszawa. 2016. wyd. II. Available from: https://sip.lex.pl/komentarze-i-publikacje/ komentarze/ustawa-0-ochronie-zdrowia-psychicznego-komentarzwyd-ii-587512069? unitld=

10. Ob okazanii psihiatricheskoy pomoschi: Zakon Respubliki Belarus ot 7 yanvarya 2012 g. No. 349-3 [0n the provision of psychiatric care: Law of the Republic of Belarus of 7 January 2012 No. 349-3]. Available from: https://kodeksy-by.com/zakon_rb_ob_okazanii_psihiatricheskoj_ pomowi.htm (in Russian).

11. Ob okazanii psihiatricheskoy pomoschi: Zakon Turkmenistana ot 23 noyabrya 2016 g. No. 477-V [0n the provision of psychiatric care: Law of Turkmenistan of 23 November 2016 No. 477-V]. Available from: http://www.ilo.org/dyn/natlex/docs/ ELECTRONIC/105737/129369/F-785842145/477.pdf (in Russian). 
12. Pro psykhiatrychnu dopomohu: Zakon Ukrainy vid 22 liutoho 2000 r. No. 1489-III [0n psychiatric care: Law of Ukraine of February 22, 2000 № 1489-III]. Available from: https://zakon.rada.gov.ua/laws/show/148914 (in Ukrainian).

13. Ileiko V.R., Pervomaiskyi V.B. Obgruntuvannia ekspertnykh vysnovkiv $v$ akti sudovo-psykhiatrychnoi ekspertyzy [Substantiation of expert opinions in the act of forensic psychiatric examination]. Ukrainian Medical Journal. 2003;4:105-108. Available from: http://www. psychiatry.ua/articles/paper277.htm (in Ukrainian).

14. Tyshchenko 0.I., Titko I.A. Placement of a person in a medical institution in order to conduct a psychiatric examination: international standards and national realities. Wiad Lek. 2020;9:2020-2025.

15. Tyshchenko 0.I., Leiba 0.A., Titko I.A. European standards of respect for human rights in the application of compulsory medical measures in criminal proceedings. Wiad Lek. 2019;12:2448-2449.

16. Tatsiy V.Y., Tyshchenko 0.I., Titko I.A. Mental health of a person as a criterion of personal participation in the trial during criminal proceedings. Wiad Lek. 2020;12:2737-2742.

17. Ilina V.R. Problemy otsenki zaklyucheniya sudebno-meditsinskogo eksperta v sovremennom ugolovnom protsesse Rossii [Problems of assessing the conclusion of a forensic expert in the modern criminal process of Russia]. Thesis for Candidate of Legal Sciences. 2005:20. (in Russian).

18. VorobchakA.R. Vysnovok eksperta yak dzherelo dokaziv u kryminalnomu provadzhenni [Expert opinion as a source of evidence in criminal proceedings]. Thesis for Candidate of Legal Sciences. 2019:20. (in Russian).

19. Dufeniuk 0. Assessment of the evidences in opinions of forensic experts in Polish criminal proceeding from the point of Ukrainian scientist. Visegrad Journal on Human Rights. 2018;1(2):51-56.

20. Orehova E. P. Taktika otsenki zaklyucheniya eksperta. Ugolovnaya yustitsiya v svete integratsii pravovyih sistem i internatsionalizatsii kriminalnyih ugroz [Tactics of assessing the expert's conclusion. Criminal justice in the light of the integration of legal systems and the internationalization of criminal threats]. Collection of scientific papers dedicated to the 90th anniversary of Doctor of Law, Professor Martinovich I.I. 2017:51-152. (in Russian).

21. Joanna Dzierżanowska, Joanna Studzińska. Kryteria oceny dowodu z opinii biegłego w orzecznictwie sądów powszechnych i sądu najwyższego. Roczniki nauk prawnych. 2015;XXV(2):21-47.

22. Kaczor R. Etapy i kryteria oceny opinii biegłego w postępowaniu karnym. Prokurator. 2010;1-2(41-42):41-55.
23. Benini, A., Chataigner P., Noumri N., Parham N., Sweeney J. and Tax L. The Use of Expert Judgment in Humanitarian Analysis - Theory, Methods, Applications. 2017:200.

24. Inga Markiewicz, Łukasz Mazur. Opinia sądowo-psychologiczn a pod lupą krytyka - czyli o tym, co złe w opiniach biegłych. Pozycja i rola biegłego w polskim systemie prawnym. Warszawa 2016. 72-86.

25. Ukhvala Rivnenskoho apeliatsiinoho sudu vid 20 sichnia 2021 r. u spravi No. 569/16180/20 [Decision of Rivne Court of Appeal of 20 January 2021 in case No.569/16180/20]. Available from: https://reyestr.court.gov.ua/ Review/94379201

26. Ukhvala Zhmerynskoho miskraionnoho sudu Vinnytskoi oblasti vid 9 bereznia 2021 (sprava No. 131/380/20) [Decision of Zhmerynskyi City District Court of Vinnytsia Region of 9 March 2021 (case No. 131/380/20)]. Available from: https://reyestr.court.gov.ua/ Review/95417158 (in Ukrainian).

\section{ORCID AND contributionship:}

Olga I. Tyshchenko: 0000-0003-1551-1367 A, B,D

Ivan A. Titko: 0000-0003-4126-6967 C, E, F

\section{Conflict of interest:}

The Authors declare no conflict of interest.

\section{CORRESPONDING AUTHOR}

\section{Ivan A. Titko}

Poltava Law Institute of Yaroslav Mudryi

National Law University, Poltava, Ukraine

tel: +380975150748

e-mail: titko.iv@gmail.com

Received: 22.06 .2021

Accepted: 19.10 .2021

A - Work concept and design, B - Data collection and analysis, C - Responsibility for statistical analysis,

D -Writing the article, $\mathbf{E}$-Critical review, $\mathbf{F}$ - Final approval of the article 


\title{
EPIDEMIOLOGIC ACTIVITIES IN THE MODERN CRIMEA: HUMANITARIAN CHALLENGES AND POSSIBLE SOLUTIONS
}

DOI: 10.36740/WLek202111214

\author{
Borys V. Babin, Andrii M. Chvaliuk, Olexiy V. Plotnikov \\ ASSOCIATION OF REINTEGRATION OF CRIMEA, KYIV, UKRAINE AND PARIS, FRANCE
}

\begin{abstract}
The aim of this article is to determine the current organisational and normative policies in Crimea concerning epidemiology, in conditions of seven years of Russian effective control over the Peninsula and ongoing COVID-19 pandemic.

Materials and methods: The authors analysed the normative acts, budget and governing practice regarding to the current challenges for epidemiologic activities in Crimea, issued by international structures, by the Ukrainian bodies and Russian de-facto "authorities", comparing the ongoing situation to the international obligations of both conflicting states. Conclusions: The research proves that a systematic medical crisis, caused by Russia's efforts aimed at establishment of its own control over Crimea, resulted in new challenges in COVID-19 pandemic conditions. It is further argued that the activities of the Anti-Plague Station located in Simferopol require attention and relevant international action. States and international organisations with the relevant mandate must pay more attention to the epidemiologic issues in Crimean Peninsula, especially in the framework of the Convention on the Prohibition of the Development, Production and Stockpiling of Bacteriological (Biological) and Toxin Weapons and on their Destruction (1972) mechanisms. A new international treaty for pandemic preparedness and response must reflect specific features of interstate conflict situations and illegal occupation of a foreign territory with effective control over its population.
\end{abstract}

KEY WORDS: Crimea, COVID-19 pandemic, Epidemiology, Ukrainian Anti-Plague Station

Wiad Lek. 2021;74(11 p.2):2940-2945

\section{INTRODUCTION}

The attempted annexation of the Crimean peninsula by Russia in 2014 is well reflected in the international acts, such as UN General Assembly's resolutions 2014 68/262, 2016 71/205, 2017 72/190, 2018 73/263 2019 74/168, 2020 75/192, 2018 73/194, 2019 74/17, 2020 75/29, resolutions of the OSCE Parliamentary Assembly, of the Parliamentary Assembly of the Council of Europe 1988 (2014), 2028 (2015), 2067 (2015), 2112 (2016), 2132 (2016), 2145 (2017), 2198 (2018), 2231 (2018), etc., of the European Parliament's 2014/2841 (RSP), 2014/2965 (RSP), 2016/2556 (RSP), 2016/2692 (RSP), 2017/2596 (RSP), 2017/2869 (RSP), 2018/2754 (RSP), 2018/2870 (RSP), 2019/2734 (RSP), 2019/2202 (INI); those issues are subject to consideration in international courts, including the International Court of Justice (case 166) and the European Court of Human Rights (case 20958/14 and others) [1].

Those issues were reflected in scientific essays on international law and policy, human rights, and humanitarian aspects [2-4]. However, the points of the 'Crimean health care system' and of the enjoyment of the right to health by the residents of Crimea as well as the relevant social interest in public health were not well reflected in international acts and doctrinal research. One can outline certain analytics and plans, produced by the Ukrainian authorities in 2018 [5-6] and on certain articles on relevant issues. In 2019 it was pointed out that the present attempts of Ukraine to provide the special mechanisms of medical aid for the residents of Crimea did not lead to a positive result. The authors proposed relevant international organizations to pay more attention to health care issues for the inhabitants of the peninsula and stressed that such circumstances should be monitored of the UN and OSCE missions and be covered by the International Committee of the Red Cross' mission in Kyiv, that Ukrainian health care reform must take into account the needs of Crimean residents, temporarily leaving the peninsula for medical aid [7]. But later, in 2020, the COVID-19 pandemic created new systematic challenges for the 'Crimean health care system', with the main role of the epidemiologic institutions and mechanisms that were located in the peninsula before 2014 when Ukraine lost control over them.

\section{THE AIM}

The aim of our article is to analyze both the general situation with the COVID-19 pandemic in the peninsula and the functioning of the epidemiologic institutions and mechanisms, located in Crimea, with the key example of the Ukrainian Anti-Plague Station (UAPS), being under the full control of Russia in the COVID-19 pandemic conditions. 


\section{MATERIALS AND METHODS}

The authors researched the normative acts, reports, publications of the international structures, authorities of Ukraine and Russia, so-called Crimea's "administration". Special attention was paid to the published reports of the Russia-controlled epidemiologists, related to Crimea and to the data on the UAPS that is in the public access. Analysis of such data, relevant norms, and statistics was done by authors in full compliance with the ethic requirements of their current employment (Association of the Reintegration of Crimea). Furthermore, Dr. B. Babin used his own experience as the Permanent Representative of President of Ukraine in Crimea in 2017-2018, in full compliance with the requirements of Ukraine's public service ethic rules.

This article is based on the plans and reports, prepared by the Mission of the President of Ukraine in Crimea, and the analytics published by our Association in 2020-2021 and presented to the international bodies, including Association's submissions, available on the UN website [1, 5-6, 8-10]. As it was pointed out before, the scientific publications, devoted to the situation in Crimea, do not reflect the issues of epidemiology, medical law, relevant human right on health, and states' obligations, especially regarding the COVID-19 pandemic situation. Therefore, most attention will be paid to the current data, presented by the governing structures and Crimea's "authorities", and other relevant normative sources.

\section{REVIEW AND DISCUSSION}

According to the statistical data, distributed by Crimean "authorities" in August 2021, the COVID-19 mortality rate in Crimea remains high and the total death toll caused by COVID-19 in 2020-2021 exceeded 1000 in Sevastopol and 2000 in the rest of Crimea (that is $0,1 \%$ of all peninsula population). The reasons for this situation can be traced back to 2014 when Russia started a "medical reform" in Crimea and implemented its "own insurance medicine model". In 2020, this resulted in the absence of an adequate quantity of medical personnel in Crimean hospitals, that minimized the possibility of effective medical aid to the residents of Crimea, violated their right to health and right to life, guaranteed by the multilateral human rights treaties. At the same time, Russia as the occupying power has an obligation under Geneva Convention IV to ensure adequate medical aid to the population of Crimea, which is violated by its ineffective medical policies [8].

So, exactly the "medical reform" started in Crimea by the Russian "authorities", with forcibly implemented the insurance medicine since 2014, made a strong negative impact on the level of protection the rights to health in the region. Thousands of persons, who refused or could not get "Russia's citizenship" in Crimea after its attempted annexation has lost the possibility to get adequate aid even in vital issues, including pregnancy. Almost all the state hospitals in Crimea, occupied by Russian "authorities" in 2014, are now in unsatisfactory sanitary, technical, and organizational conditions [1].

As experts point, since 2014 Russia bans the usage of medical drugs certified by the Ukrainian authorities, including antibiotic and antivirus medicals produced in European countries, and allowed for usage in the mainland of Ukraine by its government. Instead, Russia provided Crimean medical institutions and pharmacies with own-produced drugs, often of extremely low quality. Furthermore, Russian "authorities" ban citizens from carrying high-quality medical drugs from Ukraine's mainland, which is punishable as "smuggling", including confiscation of drugs. Such actions violate the right to health and right to life guaranteed by multilateral human rights treaties, as well as the requirements of the Geneva Convention IV to preserve legislation and public order on the occupied territory, including medical and pharmacy certification procedures [8].

Public health in Crimea was compromised by the Russian military, economic and demographic policies resulting in a water crisis in the region. It was pointed out by some experts that the only way to prevent violations and restore the delivery of fresh water and sanitation is the pressure of the international organizations, including the UN organs, aimed at putting an end to the Russian policy of resettlement and militarization of Crime [9]. Furthermore, experts stated that the current situation in the peninsula makes impossible the effective realization of the right to health for Crimean residents, including the right to make free and responsible decisions and choices, free of violent coercion and discrimination. The minimum adequate volume of health facilities, goods, services, and information, which would ensure all people full enjoyment of the right to health, is absent in present-day Crimea, the territory of lawlessness and arbitrariness [1].

Recent publications stress that Russia’s "authorities" did not take steps to address vulnerabilities that the COVID-19 has created for the population and its groups in Crimea. They failed to develop effective social protection in Crimea, resilience to prevent future possible public health crises, and they did not take effective measures and steps to strengthen access to water, sanitation, and hygiene as part of strengthening the public health policy in Crimea [10]. Furthermore, in 2020, Russia banned all WHO-recognized anti-COVID vaccines in Crimea, except those "vaccines" which are produced in Russia without internationally recognized certification procedure (like the "Sputnik" "vaccine"). To make things worse, the vaccination of Crimeans by the Russian non-certified "vaccines" is de-facto obligatory for citizens and such policies bear features of a medical experiment over the population of the occupied territory (due to the fact of the non-certification of those "vaccines" by the WHO). That is another impermissible violation of the Geneva Convention IV. This also violates the rights of Crimeans to health, to life, and to privacy, as well as a prohibition of degrading treatment and forcible medical experiments, guaranteed by the multilateral human rights treaties [8].

The current research proves that Russia violated the right to freedom of movement by systematic blockade of all three administrative boarding line's (ABL) checkpoints used to enter and exit Ukraine's mainland due to "COVID-related quarantine measures". All Russian policies and measures 
"to minimize health risks associated with the COVID-19" by blocking the visits of Crimean residents to Ukraine's mainland and of internally displaced persons (IDPs) and other Ukrainians to Crimea are not effective even potentially since in 2020-2021 Russia's "authorities" organized mass visits of Russian tourists to Crimea (more than one million in summer-2020), the resettlement of own residents to Crimea (more than sixty thousands of Russians have been resettled to Sevastopol alone in 2020), and by massive military training (more than twenty thousand Russian soldiers were re-dislocated from Russia to Crimea only during 6 months of 2021) [8].

Experts believe that measures of Russia's "authorities" in Crimea aimed at the limitation of crossing the ABL, were disproportional and bluntly violated human rights and fundamental freedoms of the citizens of Ukraine [11]. They are not effective and may be qualified as part of Russia's social "iron curtain" and militarization policy in the peninsula. While limiting the crossing of the ABL, Russia's "authorities" in Crimea, closely related to criminal groups in the area of human trafficking, take part in or cover the transfer to Crimea of working migrants from Russia, first of all in area of the illegal housing construction [12]. These processes are lawless even under the Russian legislation illegally implemented in Crimea, so there are no "regularization programs" or "long-term solutions" in the peninsula for conditions of the COVID-19 pandemic [8].

The Russian "anti-COVID" policy in Crimea violates the right to sustainable development, guaranteed by the above-pointed multilateral treaties. Russia's "authorities" did not adopt the "COVID-19 socio-economic response and recovery plan" and do not use the human rights-based approach in pandemic-related issues, they do not use the human rights and gender-sensitive indicators in this area, ignore the relevant interests of the indigenous peoples [13]. The only way to effectively influence Russia in those issues is the UN and other international structures' decisions and judgments of the international courts. Russia's "authorities" do not protect the human rights of the population of Crimea, including IDPs, in the COVID-19 context. Such "powers" violate their right to health, housing, education, information, social protection, basic services, safe and dignified return, and sustainable reintegration [8].

On the other hand, Ukraine had strong epidemiologic potential in Crimea before 2014, including the major specialized national centre - Ukrainian Anti-Plague Station (UAPS). So, analysis of the current situation may help us to reflect the practical level of counteraction to the epidemics by the Russian "authorities" in Crimea. The Crimean Peninsula is the place of spread and even the origin of such commonly dangerous diseases as cholera, plague, and Crimean-Congo hemorrhagic fever, some rickettsioses, etc. [14].

Thus, it predetermined the location of the UAPS, as a specific state institution of the Ministry of Health of Ukraine, in Crimea, exactly at 42 Promyslova Street in Simferopol. It should be noted that this institution was established in Soviet times and that USSR ratified the Convention on the
Prohibition of the Development, Production and Stockpiling of Bacteriological (Biological) and Toxin Weapons and on Their Destruction in 1975. This universal legal act obligates all participating states not to develop, produce, stockpile, or otherwise acquire or obtain microbial or other biological agents or toxins of types and in quantities that have no justification for prophylactic, protective, or other peaceful purposes; not to develop, produce, stockpile, or otherwise acquire or obtain weapons, equipment, or means of delivery designed to use such agents or toxins for hostile purposes or in armed conflict; to destroy, or to divert to peaceful purposes all agents, toxins, weapons, equipment, and means of delivery; not to transfer to any recipient, and not in any way to assist, encourage, or induce to manufacture or otherwise acquire any of the agents, toxins, weapons, equipment, or means of delivery; to take necessary measures to prohibit the above within their own territories [15].

As ARC's experts determined, the level of execution of this act by the USSR before 1991, including the activities of the abovementioned station in Simferopol, is the subject of strong political and legal discussion [16]. However, in any event, independent Ukraine declared the usage of the anti-plague stations, including the UAPS, directly and exclusively for their intended purpose, to counter possible outbreaks of extremely dangerous natural not artificial infections. The transparency of such activities and their adequate funding was provided through the Science and Technology Center of Ukraine, (STCU) established under the Agreement between Ukraine, Canada, USA, and Sweden of October 25, 1993, and under its 1997 Protocol [17]. As part of the STCU's work in 2011, the European Union allocated four million euros to Ukraine under contracts $9800-9804$ "Biosafety and Biosecurity Improvement at the Ukrainian Anti-Plague Station (UAPS) in Simferopol” to improve biosafety, establish a new laboratory, and purchase equipment for the UAPS. The next STCU's audit of these funds was conducted by the Riga office of the international audit corporation KPMG just before the attempted annexation of Crimea, and it confirmed that the funds were spent on appropriate tasks [18]. At that time Ukraine's activities at the Simferopol-located UAPS was distorted by Russian propaganda before 2014, which began to spread fake information about the alleged "American biolaboratory in Simferopol" in the "once active anti-plague station" where "viruses from all over Europe are allegedly transported", and hat this dangerous object is allegedly located in the "center of the city" [16].

ARC's experts point that when Crimea was occupied by Russia, relevant propaganda on UAPS's allegedly "illegal activities" stopped. The official head of the UAPS, prof. Oleksander Khaitovich was suspended by the Russian invaders from his chair but he still resides in the peninsula and he was appointed as the head of the so-called "Crimean Regional Branch of the All-Russian Scientific and Practical Society of Microbiologists and Parasitologists". Russian "administration" not only tolerated his professorship in the Russian-controlled "Medical Academy named in honor S.I. 
Georgievsky" but also "awarded" prof. Oleksander Khaitovich in 2016 for "training of qualified medical personnel and specialists, many years of conscientious work" by the "medal of the Republic of Crimea" "For Valiant Works" [16].

And later, ARC's experts say, the UAPS itself was illegally "liquidated" by the Russian "administration" under the "Prescript of the Council of Ministers of September 29, 2014, № 998-p" [19] and the so-called "Federal State Unitary Health Institution" "Anti-Plague Station of the Republic of Crimea" was declared on its basis, and Dr. Sergei Tikhonov from Volgograd Anti-Plague Institute was appointed as the "director" of this "station" [20]. There are many scientific publications of Dr. Tikhonov available in the open sources, and it is worth adding that his father, prof. Nikolay Tikhonov headed researches in the Soviet times the Volgograd institute "Microb", involved in the USSR's military bacteriologic for a certain period [16]. After 2014 there are some publications of the new staff of the "Anti-Plague Station of the Republic of Crimea", including forks of Dr. Iryna Kovalenko, Dr. Nadiya Pidchenko, Dr. Oleksandra Sytnikova, Dr. Olga Poluektova, Dr. Lilia Zinich, and others, related to the issues of the epidemiological situation in natural focal infectious diseases in Crimea and in the South of Russia. The website of the "Anti-Plague Station of the Republic of Crimea", which operated till 2020, is currently "temporarily suspended" and previously it posted news about the involvement of "station's" specialists in the fight against COVID-19 [16].

Ukraine reacted to this situation in the framework of its obligations under the Convention on the Prohibition of the Development, Production and Stockpiling of Bacteriological (Biological) and Toxin Weapons and on Their Destruction, 1972. At the Eighth Review Conference on this Convention in November 2016 in Geneva, the Ministry of Foreign Affairs of Ukraine emphasized the significant deterioration of Ukraine's biosecurity and biosafety system due to the aggression of Russia and subversive activities of Russia-backed illegal armed groups, which, in particular, led to the loss of control over the UAPS, and Crimean Republican Diagnostic Laboratory also. In this connection, the Convention, 1972 member states were appealed by Ukrainian diplomats to elaborate a relevant mechanism of proper reaction to these challenges in the sphere of biosafety and biosecurity both in Ukraine and other regions in the world [21].

Recent research undertaken by our Association proved that Russia's "administration" in Crimea began to invest a powerful resource in the infrastructural development "Anti-Plague Station of the Republic of Crimea" from 2015, as it is evidenced by information about "public procurements" of this "anti-plague station", which we analyzed very carefully. First of all, we selected the costs that relate to the supply of special machinery, reagents, and equipment for this institution's work. In 2018, we calculated such direct costs for the "development" of the institution by a total of 9,258.2 thousand rubles, in 2019 - by 13,735 thousand rubles, in 2020 - by 36,139 thousand rubles, and for the first half of 2021, the "station" has already spent 19706.4 thousand rubles for these needs. It is hard to explain this increase in costs directly by the outbreak of COVID-19, as the major increase in purchases, done by the "station" is observed in 2019 before the incident in Wuhan, China. And even more, the special purchases of the "station", that are directly related exactly to the COVID-19 issues, contain the small part of all "station's" Russian federal funding, exactly the 120 thousand rubles allocated in December 2019 for reagents for polymerase chain reactions and 240 thousand rubles in 2020 for reagents for the detection of COVID-19 (in common $0.33 \%$ of the total annual special expenses). And more, as Association established, such purchases were supplied by specific Russia-controlled companies, including some without information about them in the Russian public registers [16].

At the same time the epidemic situation regarding other diseases, except COVID-19 and including the natural focal ones, is stable in Crimea in the last decade. We researched the Analytical Review published in 2019 by Russia's Stavropol Anti-Plague Institute that gives information on the current situation and risks in the peninsula, including Crimean-Congo fever, West Nile fever, infection encephalitis, Marseille fever, and borreliosis, etc. So there were no objective preconditions for increasing the potential and capacities of the "Anti-Plague Station of the Republic of Crimea" in 2019-2021 [14; 16]. So the above-pointed situation with UAPS needs to be in the focus of attention of scientists, Ukrainian and other governments, and of the relevant international institutions.

The Convention, 1972 gives the right to the member states to lodge a special complaint with the UN Security Council against Russia's actions and to demand the relevant investigation, organized by the UN bodies [22] ARC's experts pointed that Ukrainian and other European academicians, NGOs, research institutions, and competent authorities had to provide the current data on UAPS to the UN, Council of Europe's and OSCE monitoring missions in Ukraine. Also, they may propose to the International Committee of the Red Cross to provide their own servants to minimize the possibility for possible violations of international humanitarian law and Convention, 1972, in Crimea. Those issues might be discussed at the Ninth Review Conference on the Convention 1972, also as at the Meeting of States Parties of this Convention, and at the ongoing Experts' Consultations [16]. Ukraine may also discuss the UAPS problem with the STCU Agreement participants, including Canada, the United States, and the European Union, also as on the "Crimean Platform" summits. Some national investigations may be done also under Articles 321-2, 325, and 326 of the Criminal Code of Ukraine, that establish the responsibility for violating the procedure for pre-clinical studies, clinical trials, and state registration of medicines; for violation of sanitary rules and regulations and for violation of the rules of handling microbiological or other biological agents or toxins $[16 ; 23]$. 


\section{CONCLUSIONS}

International acts adopted since 2014 regarding Crimea, including sanction issues, contain some requirements for Russia but not on the issues of the inflectional diseases and epidemiology on the peninsula. Such problems may be discussed on the international multilateral level, including the "Crimean Platform" - a recent initiative proposed by some UN states, so in the current international conventional and administrative mechanisms. Modern challenges in Crimea prove that a potential new international treaty for pandemic preparedness and response must reflect specific features of interstate conflict situations. Academicians, research institutions, European states, and international organizations with the relevant mandate must pay more attention to the epidemiologic issues in the Crimean Peninsula, especially in the framework of the COVID-19 pandemic and the demands of the Convention, 1972. Special complex researched on such issues in situations of armed conflicts and related "grey zones" like the modern Crimean Peninsula may be a starting point for improvement of the situation.

\section{REFERENCES}

1. UN Special Rapporteur on the Right of Everyone to the Enjoyment of the Highest Attainable Standard of Physical and Mental Health. Challenges for the Reproductive Health in the Modern Crimea: Submissions to the UN SR. ARC [Internet]. 2021. Available from: https://www.ohchr.org/ Documents/lssues/Health/sexual-reproductive-health-covid/CSOs/ngo. association.of.reintegration.of.crimea.rtf

2. Czapliński W., Dębski S., Tarnogórski R., et al. The Case of Crimea's Annexation under International Law. Warsaw: Scholar Publishing House; 2017, 355.

3. Grant. T. D. Aggression Against Ukraine: Territory, Responsibility, and International Law. London: Palgrave Macmillan; 2015, 283.

4. Marxsen C. Crimea Crisis. An International Law Perspective. Kyiv-Mohyla Law and Politics Journal. 2016; 2: 13-36.

5. Analitychno-informatziyna dovidka shchodo stanu okhorony zdorovya na tymchasovo okupovaniy teritoriyi Ukrainy v Krymu [Analyticalinformational Review on Level of Health Care on the Ukrainian Temporarily 0ccupied Territory in Crimea] Mission of the President of Ukraine in ARC, 2018 [Internet]. 2019. Available from: http://www. ppu.gov.ua/13727-2/analitychno-informatsijna-dovidka-shhodostanu-ohorony-zdorovya-na-tymchasovo-okupovanij-terytoriyiukrayiny-v-krymu/

6. Pro zatverdzhennya planu nevidkladnykh zakhodiv z protydiyi rosiyskyi ahresiyi z tymchasovo okupovanoi teritoriyi Ukrainy v Krymu, zakhystu interesiv derzhavy, hromadyan Ukrainy ta ukrainskykh yurydychnykh osib v Krymu ta yoho spryamuvannya : rozporyadzhennya Postiynoho Predstavnyka Prezydenta Ukrainy v Avtonomniy Respublitzi Krym [On Adoption the Urgent Action Plan of Counteraction the Russian Aggression from the Temporarily 0ccupied Territory of Ukraine in Crimea, of Defence the State, Ukrainian Citizens' and Ukrainian Legal Entities' Interests in Crimea for 2018-2019 and Its Transfer] 20.06.2018 № 17 [Internet]. 2019. Available from: https://zakon.rada.gov.ua/rada/show/ v0017755-18

7. Babin B. Health Care for Crimean Residents: Interstate Conflict Challenges and Possible Legal and Organisational Solutions. Wiad Lek. 2019; 12: 2441-2444.
8. UN Independent Expert on the Promotion of Democratic and Equitable International Order. Modern Multilateralism and Covid Pandemia: Example of Crimea: Submissions to the UN IE. ARC. [Internet]. 2021. Available from: https://www.ohchr.org/Documents/Issues/IntOrder/ Multilateralism/AssociationReintegrationCrimea.pdf

9. UN Special Rapporteur on Human Rights and Environment. Too Dirty, Too Little, Too Much:The Global Water Crisis and Human Rights: Submissions to the UN SR. ARC. [Internet]. 2020. Available from: https://www.ohchr. org/Documents/Issues/Environment/EnvironmentWater/ Civil\%20 Society/ARC.doc

10. UN Special Rapporteur on the Human Rights to Safe Drinking Water and Sanitation. Water Crisis in Crimea: Submissions to the UN SR. ARC. [Internet]. 2020. Available from: https://www.ohchr.org/Documents/ Issues/Water/PlanningReportWater/input-nonstates/ Association-ofReintegration-of-Crimea.doc

11. UN Special Rapporteur on Contemporary Forms of Slavery, Including its Causes and Consequences. Role of Organised Criminal Groups with regard to Contemporary Forms of Slavery: Call for UN SR's Input. ARC. [Internet]. 2021. Available from: https://www.ohchr.org/Documents/ Issues/Slavery/SR/Submissions/CSOs/Association-of-reintegration-ofCrimea.docx

12. UN Special Rapporteur on the Sale and Sexual Exploitation of Children, including Child Prostitution, Child Pornography and other Child Sexual Abuse Material. Situation with Child Sexual Abuse in the Crimea: Submissions to the UN SR. ARC. [Internet]. 2021. Available from: https:// www.ohchr.org/Documents/lssues/Children/SR/GA76/Association-ofreintegration-of-crimer.pdf

13. UN Special Rapporteur on the Rights of Indigenous Peoples. Situation of Indigenous Peoples living in Urban Areas: Submissions to the UN SR. ARC. [Internet]. 2021. Available from: https://www.ohchr.org/ Documents/Issues/IPeoples/SR/Urban-areas_Submissions/Indigenous_ Organisations_Civil_Society/association-of-reintegration-of-crimea.pdf

14. Kulichenko A.N., Maletzka 0.V., Pryslegina D.A. et al. Epidemiologicheskaya obstanovka po pryrodno-ochagovym infektziynym boleznyam v Yuzhnom i Severo-Kavkazskom federalnykh okrugakh v 2019. Analitichesky obzor [Epidemiological Situation in Natural Focal Infectious Diseases in the Southern and North Caucasian Federal Districts in 2019. Analytical review] Stavropol: Litera, 2020.96 p.

15. Convention on the Prohibition of the Development, Production and Stockpiling of Bacteriological (Biological) and Toxin Weapons and on their Destruction, 1972. UN [Internet]. 2021. Available from: https:// treaties.un.org/doc/Publication/UNTS/Volume\%201015/volume-1015I-14860-English.pdf

16. Lords of the Plague: Russia's Illegal Bacteriological Studies in Crimea. 16.07.2021. ARC. [Internet]. 2021. Available from: https://arc. construction/17171

17. Science and Technology Center of Ukraine. History. STCU. [Internet]. 2021. Available from: http://www.stcu.int/weare/missionstatement/ history/

18. Science and Technology Center of Ukraine. Management letter for the year ended. 31.12.2013. STCU. [Internet]. 2021. Available from: http://www.stcu.int/documents/stcu_inf/reports/audit/2013/2013_ Management_Letter.pdf

19. 'Rasporyazheniye Soveta Ministrov Respubliki Krym ot 29.09.2014 № 998-p' ['Prescript of the Council of Ministers of September 29, 2014 № 998-p'] [Internet]. 2021. Available from: https://rk.gov.ru/file/pub/ pub_233924.pdf 
20. 0 naznachenii direktora FGKUZ «Protivochumnaya stantsiya Respubliki Krym» Rospotrebnadzora [0n the appointment of the Director of the FSUHI "Anti-Plague Station of the Republic of Crimea" of Rospotrebnadzor] [Internet]. 2015. Available from: https://www. rospotrebnadzor.ru/gosservice/naznashenie/details.php?ELEMENT_ ID $=3055$

21. Eighth BWC Review Conference takes place in Geneva. Ministry of Foreign Affairs of Ukraine. 8 November 2016 [Internet]. 2016. Available from: https://mfa.gov.ua/en/news/52248-eighth-bwc-reviewconference-takes-place-in-geneva

22. Tuzmukhamedov B. Introductory Note. Convention on the Prohibition of the Development, Production and Stockpiling of Bacteriological (Biological) and Toxin Weapons and on their Destruction. UN Office of Legal Affairs [Internet]. 2021. Available from: https://legal.un.org/avl/ ha/cpdpsbbtwd/cpdpsbbtwd.html

23. Criminal Code of Ukraine, 2001 № 2341-III [Internet]. 2021. Available from: https://www.legislationline.org/documents/action/popup/ id/16257/preview

This article was done in the framework of the Scientific Research Theme "Scientific Legal Providing the Legislative Activities" state number $0104 U 006963$ of the Legislation Institute of the Verkhovna Rada of Ukraine.

\section{ORCID and contributionship:}

Borys V. Babin: 0000-0002-9317-3845 A, B, D, F

Andrii M. Chvaliuk: 0000-0001-9795-2734 ${ }^{B, D, E}$

Olexiy V. Plotnikov: 0000-0001-9814-1108 ${ }^{B, D, F}$

\section{Conflict of interest:}

The Authors declare no conflict of interest.

\section{CORRESPONDING AUTHOR}

Borys V. Babin

Association of Reintegration of Crimea

Ukraine, Kyiv

tel: +380639495556

e-mail: arcconstructionofcrimea@gmail.com

Received: 18.08.2021

Accepted: 15.10 .2021

A - Work concept and design, B - Data collection and analysis, C - Responsibility for statistical analysis, D -Writing the article, $\mathbf{E}$-Critical review, $\mathbf{F}$ - Final approval of the article 


\title{
FALSIFICATION OF MEDICINES AND DISTRIBUTION OF FALSIFIED MEDICINES IN UKRAINE: CRIMINALISTIC MEANS OF DETECTION AND COUNTERACTION
}

DOI: 10.36740/WLek202111215

\author{
Viktor M. Shevchuk' ${ }^{1}$, Ihor V. Parfylo ${ }^{1}$, Mykyta 0. Sokolenko ${ }^{2}$ \\ 'YAROSLAV MUDRYI NATIONAL LAW UNIVERSITY, KHARKIV, UKRAINE \\ ${ }^{2}$ RESEARCH INSTITUTE FOR THE STUDY OF CRIME PROBLEMS OF NATIONAL ACADEMY LEGAL SCIENCES OF UKRAINE, KHARKIV, UKRAINE
}

\begin{abstract}
The aim: To formulate criminalistic recommendations to increase the effectiveness of combating falsification and contribution of falsified medicines. To accomplish analyze of the current state and trends in combating this criminal offense, to create the basis of criminalistic characteristics and methods of their investigation, taking into account the results of the generalization of judicial investigative practice and foreign experience.

Materials and methods: The examine and analysis of results and generalization of 128 criminal proceedings of such criminal offenses, court decisions for the period $2012-$ 2020; questionnaires of practical workers (205 people); results of generalization and analysis of published materials of investigative and judicial practice; foreign experience in combating falsification of medicines, etc. In the process of conducting this research, general scientific and special research methods were also used.

Results: Based on the results of the generalization of investigative and judicial practice, a criminalistic description of falsification and contribution of falsified medicines in the form of descriptive and statistical information model has been developed, its elemental composition was determined and analysed. Reasonable that in theoretical terms criminalistic characteristics are the basis for building appropriate criminalistic methods, and in practical terms is considered as a kind of guideline that can be successfully used by investigators in the conduct of specific criminal proceedings, which allows choosing the most effective directions and means of investigation.

Conclusions: One of the priority areas of research in criminalistics is the development of criminalistic characteristics and basics of investigation methods of falsification and contribution of falsified medicines, which must be carried out on the basis of the modern general theory of criminalistics, current legislation and practice, results of generalization and analysis of investigator of judicial practice and foreign experience.
\end{abstract}

KEY WORDS: falsification of medicines, methods of investigation, tactical operation, criminalistic characteristics, optimization of investigation

Wiad Lek. 2021;74(11 p.2):2946-2953

\section{INTRODUCTION}

Falsification and contribution of falsified medicines pose a large threat to the life and health of the population [1, p. 857], and the results of such criminal activities cause significant damage to the state budget and legal pharmaceutical manufacturers and in general threaten the internal security of the country [2, p. 5]. At the same time, according to the study of practice, the investigation of such criminal offenses causes some difficulties for practitioners and is largely associated with a complicated procedure of pre-trial investigation, evidence gathering, prosecution of perpetrators, as most subjects of these offenses are well informed and competent in health care, pharmacology, pharmacy, and often jurisprudence, have a wide range of business connections and actively oppose the investigation.

This category of criminal offenses is characterized by their significant prevalence and high level of latency. Thus, according to the statistics of the Office of the General Prosecutor in Ukraine in 2013-2020 was entered information on the commission of criminal offenses under Art. 321-1 of the Criminal Code of Ukraine and was registered 269 criminal proceedings. According to the results of the investigation, 85 such proceedings were closed, 1 - suspended under paragraph 2 of Art. 280 of the CPC of Ukraine (location of the suspect is unknown), in 154 - the decision is not made, and only in 32 proceedings the persons were served with a notice of suspicion, and 29 of them were sent to the court with an indictment [3].

A significant indicator of latency of falsification and contribution of falsified medicines is primarily explained by the fact that the above official statistics do not reflect the real scale of the spread of falsification and contribution of falsified medicines. There are only a few cases of falsification of medicines, although there are known criminal proceedings, during the investigation of which hundreds of episodes of such criminal activity were not detected. The latent criminal offenses in this category include such major scams as, the illegal supply of large consignments of counterfeit medicines from abroad, large-scale fraudulent operations to move vaccines across borders [4], stolen alcohol, as well as smuggling of falsified medicines [5] and committing other related offenses related to them $[6, p$. 
30-38]. In addition, such criminal manifestations, often veiled under the usual civil law relations (implementation of «drugs» by means of the Internet, the provision of medical services using «latest technologies» and «drugs», etc.), which creates difficulties in gathering evidence, distinguishing them from others related criminal offenses.

The falsification of medicines and their contribution has ancient historical roots [7], however, recently such criminal activity has become a separate branch of the shadow economy, which has acquired the characteristics of the most profitable areas of criminal business, carried out by criminal groups with appropriate "criminal specialization", and has a massive, deeply secretive and commercialized nature. In the international scope of the shadow economy, the pharmaceutical market ranks third (after the illicit trafficking of weapons and drugs). Moreover, as practice shows, such criminal acts acquire the character of transnational crime, often they are committed on the territory of several states [8], which necessitates close cooperation with law enforcement agencies of other countries in their detection and investigation [9].

According to WHO [10] in developed countries, falsification is about $10 \%$, and in third world countries - half of all medicines. In Ukraine, according to various experts, these figures range from 10 to $60 \%$ of sold falsified medicines [11], the scope of their spread poses a real threat to the economic and social security of the state, as they risk the health and lives of the population, legitimate pharmaceutical manufacturers suffer losses as a result of loss of profits, lose the trust of their consumers, increase costs for counterfeit products; state revenues in the form of non-receipt of taxes and fees are lost; society is losing the resource potential of the nation's health [12].

Falsification and contribution of falsified medicines, according to M. Kalinyak and O. Blavatska, is generally considered the fourth evil of health care - after malaria, AIDS and smoking. About 200,000 people die each year from counterfeit drugs, and counterfeiters make more than $\$ 50$ billion in these lives. The profitability of manufacturing and marketing of $1 \mathrm{~kg}$ of pharmaceutical counterfeits can reach almost 2000\% [13]. Death from counterfeit drugs is among the top ten causes of destruction [14, p. 22]. It's alleged that manufacturers of falsified medical products by their illegal activities killed three times more people than terrorists [15, p. 4].

Given the above, the proliferation of falsified medical products poses a global threat to public health, can lead to death or cause significant harm to human health. Given the extreme danger, high prevalence, latency, and complexity of the investigation of such criminal acts, there is a need to create and implement an effective mechanism to combat such acts, including criminalistic means.

\section{THE AIM}

To analyse the current state and trends in combating falsification and contribution of falsified medicines in Ukraine by using means of criminalistics, form the main provisions of criminalistic characteristics and methods of investigation of such criminal offenses in the form of the descriptive and statistical information model, determine its elemental composition and analysis, taking into account the results of investigative practice and foreign experience. To analyse the methods of falsification and contribution of falsified medicines as a central element of the researched criminalistic characteristics. To accomplish an analysis of the peculiarities of detecting signs of falsification and contribution of falsified medicines and the use of special knowledge during the detection and investigation of this category of criminal offenses. To formulate criminalistic recommendations to increase the effectiveness of combating falsification and contribution of falsified medicines.

\section{MATERIALS AND METHODS}

To achieve the objectives of the study, the results of generalization and analysis of 128 criminal proceedings on the facts of falsification and contribution of falsified medicines and court decisions on them entered in the Unified Register of Judgments of Ukraine considered by courts in Vinnytsia, Dnipropetrovsk, Zaporizhia, Ivano-Frankivsk, Kyiv, L'viv, Poltava, Sumy, Kharkiv, Kherson, Cherkasy, Chernihiv regions and the city of Kyiv for the period 2012-2020; survey data of employees of pre-trial investigation bodies and operational units (205 people); results of generalization and analysis of published materials of investigative and judicial practice; information from the statistical reports of the State Service for Medicines and Drug Control, the State Fiscal Service of Ukraine, the State Enterprise "State Expert Center of the Ministry of Health of Ukraine"; official statistics of the Ministry of Internal Affairs of Ukraine, the Ministry of Justice of Ukraine, the Office of the General Prosecutor of Ukraine; foreign experience in combating falsification of medicines, etc.

The methodological basis of the study is a dialectical method of scientific knowledge, which reflects the relationship between theory and practice, as well as the conceptual provisions of criminalistic science. In the process of this study used general and special research methods: system-structural - to build the content and structure of a separate criminalistic methodics of investigation and determine the system of elements of its criminalistic characteristics (their relationships and dependencies), developing a system of typical investigative situations, investigative versions, tactical operations; functional - to determine ways to optimize the investigation of falsification and contribution of falsified medicines and to research the mechanism of such criminal offenses, to determine the effectiveness of individual investigative (search) actions, and role and significance of certain elements of criminalistic characteristics; formal-logical - to formulate the concepts of criminalistic categories studied in the work, and to classify and typify methods of commission, traces, investigative situations and tactical operations; comparative law - for the analysis of the norms of criminal and criminal procedural legislation, other normative legal acts; 
statistical - for the generalization of criminal proceedings on the falsification and circulation of falsified medicines, as well as in the collection and processing of information obtained from statistical reporting; modeling - for the formation of typical investigative situations of the initial stage of the investigation of falsification and contribution of falsified medicines and action programs of the investigator to resolve them; sociological - to conduct a survey of practitioners regarding the organization of the investigation of this category of criminal offenses.

\section{RESULTS AND DISCUSSION}

Falsification of medicines and their illegal contribution is a multifaceted criminal phenomenon, for the successful detection and investigation of which it is important to clarify their specifics and identify criminalistic features, analysis of criminalistic nature, establishing the features of the mechanism [16, p. 142-154] such criminal manifestations and the development of criminalistic means of counteracting this category of criminal offenses. The remark of R.A. Nikolayenko is appropriate that in committing falsification and contribution of falsified medicines the implementation of the criminal plan involves misleading the end consumer by creating false information about such medicines to obtain funds for medicines that cost much less and are of poorer quality. That is, in practice, the falsification of medicines is one of the types of deception - it can be a deterioration in the quality while maintaining a certain product type, artificial improvement of the product appearance in order to give the appearance of valuable (branded) products, etc. Such deception is connected not only with the production of medicines but also with their sale [17, p. 280].

In the criminalistic meaning, the falsification and contribution of falsified medicines, in our opinion, should be understood as a system of interdependent actions that include preparation, commission, concealment and aimed at creating false information about the composition of medicines and their manufacturer, properties, and characteristics that determine their choice and use to achieve a criminal goal and provide for their illicit trafficking as a certain cycle of operations - from manufacture to sale to a particular consumer, and the results of such criminal activity are characterized by a causal link between such actions (inaction) and the onset of criminal consequences (death of a person, other serious consequences, prolonged health disorders, etc.).

At the same time, investigations into the falsification of medicinal products and the contribution of falsified medicinal products have their specifics, often cause certain difficulties, and rightly belong to the most complex types of criminal proceedings for practitioners. According to a survey of investigators and prosecutors, $93.2 \%$ of respondents indicated that the investigation of falsification and contribution of falsified medicines has its characteristics. Moreover, as noted by practitioners, during the investigation of such criminal offenses, they encountered difficulties related to the shortage of separate criminalistic methods - 71.2\%; shortage of information and reference data $-33,7 \%$; shortage of proper interaction between investigators and operatives - $41.5 \%$; insufficiency of literary sources $-28.1 \%$; difficulties in conducting expert research and application of special knowledge - 67.8\%; heavy load - 54.6\%; the presence of opposition from stakeholders - 21.0\%; low material and technical support $-45.4 \%$; the rest $-3.4 \%$. Obviously that these problems require some special research and development.

It should be noted that in the special literature some aspects of the investigation of falsification of medicines covered in their works L.A. Budantsev [18], G.A. Vardanyan [19], O. G. Huk [20], M. A. Hurkin [21], R. D. Daraha [22], A. A. Lytvyn [23], A. V. Pakhomov [24], A. H. Kholevchuk [25], B. V. Schur [26], N. V. Faizrakhmanova [27] etc. At the same time, comprehensive, systematic research of the methods for investigating the falsification and contribution of falsified medicines has not been conducted yet. Therefore, the improvement and optimization of the process of detection and investigation of falsification of medicines and their contribution necessitate the development and proposal of separate criminalistic methods (micromethodics of investigation) of this category of criminal offenses.

In the structure of separate methods of investigation of falsification and contribution of falsified medicines, the criminalistic characteristic of this type of criminal offense is primary. V.A. Zhuravel rightly notes that criminalistic characteristics as an important category in scientific, theoretical, and practical terms has an inexhaustible internal potential and therefore needs further development [28, p. 143]. The practical significance of using such a criminalistic characteristic as a descriptive-statistical information model is primarily due to the need to study the elements of this characteristic and establish the existence of correlations between them, due to which the presence of some elements allows to predict with sufficient confidence the existence of others moment of investigation, contributes to the nomination of investigative versions.

The analysis of criminalistic sources and the results of the survey of investigators of the National Police, the Security Service of Ukraine, and the prosecutor's office make it possible to include the following elements of the criminalistic characteristics of the considered type of criminal offenses: 1) the method of committing a criminal offense (out of 205 investigators we interviewed, $95.6 \%$ of respondents indicated this element);2) the identity of the offender $83.4 \%$; 3 ) the subject of criminal encroachment $-68.8 \%$; 4) typical traces $-51.7 \%$; 5) the situation (place, time and conditions) $-16.6 \%$; 6 ) the person of the victim $-13.7 \%$; 7) other $-2.4 \%$.

Thus, the criminalistic characteristics of falsification and contribution of falsified medicines should be considered as a descriptive and statistical information model that reflects criminalistic information about the methods of criminal offense and typical traces ("trace picture"), the subject of criminal encroachment, the identity of the offender, motives actions, situation (conditions, place, time), the identity of the victim, the analysis of which helps to 
establish correlations between them and serves as a basis for building and verifying investigative versions. The use of this information and links contributes to the establishment of the event of a criminal offense, the organization, and planning of the investigation, and form the information basis for the formation of separate criminalistic methods for the investigation of this category of criminal offenses.

According to the results of the analysis of the given data, not all of the selected structural elements of the criminalistic characteristics of the considered criminal offense «work» equally. It's seen that the key place among the proposed elements is the methods of committing this criminal offense (as shown by a survey of practitioners, of the 205 respondents we interviewed, $95.6 \%$ indicated this element). This is primarily due to the specifics of the criminal offense. Establishing signs of falsification of medicines and their contribution, proving the fact of commission and the presence in the actions of specific persons of the relevant criminal offense is the main task of the investigator in the investigation process. In turn, the identity of the victim $(13.7 \%)$ as an element of this characteristic is much less important, because the choice of the victim is usually situational.

The method of committing a criminal offense is one of the most important elements in the formation of criminalistic characteristics of falsification and contribution of classified medicines. In criminalistics, the study of the method of criminal offense contributes to the formation and use of criminalistic techniques, means, and methods of detection, fixation, and examination of evidence and serves as a basis for the development of methods of investigation $[29$, p. 18].

With regard to the falsification and contribution of falsified medicines, the method of committing a criminal offense is a system of criminal actions to prepare, directly commit and conceal the falsification and contribution of falsified medicines, which is determined by the subject of criminal encroachment, the identity of the offender and the circumstances a source of information for the detection and investigation of this type of criminal offense.

The study and analysis of the results of the generalization of the materials of criminal proceedings show that criminals often use the following preparatory actions: 1) choice of method of committing and concealing falsification of medicines $(40.6 \%)$; 2 ) study of demand for certain drugs (31.2\%); 3) search for accomplices (70.3\%); 4) search for means and tools of falsification of medicines $(89.8 \%)$; 5) finding a place for storage and manufacture of falsified medicines (purchase, lease of warehouses, shops, etc.) $(81.2 \%) ; 6)$ purchase, lease of necessary equipment (78.1\%); 7) finding a place to sell such medicines (individuals, pharmacies, Internet sites) $(67.2 \%) ; 8$ ) resolving the issue of the method of delivery of counterfeit to the consumer (transportation by transport, mailing or delivery by courier) $(4.7 \%)$; 9 ) research of the situation in which the offender was to act $(13.3 \%) ; 10)$ other $(2.3 \%)$.

In the criminalistic study of the methods of direct commission of this criminal offense, it is necessary to take into account the disposition of Art. 321-1 of the Criminal Code of Ukraine, which provides for several independent forms of the objective side of the criminal offense. According to the objective aspect, the composition of this criminal offense is formal and complete from the moment of endangering the life or health of a person or from the moment of committing the actions provided for in the disposition of the article, the subject of which was falsified medicines. The objective side can manifest itself in one of the following forms of action: production; output; acquisition; transportation; forwarding; storage; sale of knowingly counterfeit medicines [30]. Depending on the mechanism and degree of generalization, the methods of this criminal offense should be divided into two groups: a) methods of falsification of medicines; $b$ ) ways of circulation of counterfeit medicines.

The results of generalization of materials of 128 criminal proceedings on falsification and contribution of falsified medicines indicate that the most common forms (methods) of illegal trafficking in falsified medicines are as follows: 1) production (took place in $40.6 \%$ of criminal proceedings); 2) manufacturing (53.9\%); 3) acquisition (7.0\%); 4) transportation (13.3\%); 5) forwarding (34.3\%); 6) storage (74.2\%); 7) sale of knowingly falsified medicines (86.7\%). The most common in investigative and judicial practice is a combination of two or more specified in the norm forms of active criminal behaviour.

The significant variety of methods of committing falsified medicines necessitates their criminalistic classification to develop standard features that allow improving the methods and means of their detection, collection, and research. It's worth noting that scientists have tried to classify methods of falsification of drugs and organize them into separate types. In particular, a certain scientific interest is the classification of methods of falsification of medicines, proposed by O.I. Hryzodub, their division into «white» and «black» [31]. The first group of so-called «white counterfeits» are those in which: 1) the qualitative and quantitative composition of the active substance corresponds to the labeling, but the manufacturer's trademark is falsified; 2) the quantitative composition is not maintained (there may be other excipients); 3) the active and excipients do not meet the requirements of the Pharmacopoeia (lower level). The second group includes "black counterfeits", those in which the qualitative or quantitative composition of the medicines does not correspond to the labeling, namely: instead of the declared amount of active substance contains less or no other substance, cheaper substance or no active substance [32, p. 34].

In turn, O.G. Huk, based on the criterion of the presence of the active substance of the medicines, distinguishes the following types of falsifications: a medicines in which there is no active substance at all; a medicines in which all substances are present, but it is unknown under what conditions and technologies they were obtained; a medicines in which a more expensive substance is replaced by a similar but cheaper one [33, p. 9]. V. Pashkov, A. Solovyov, and A. Alefir point to the use of the following methods of falsification: excellent 
imitation (copy) of the active substance and packaging of a well-known brand; imitation of medicines that do not contain the active substance (insufficient amount or other substance that does not correspond to the information on the package); medical preparations containing contaminants or toxic substances; medicines with counterfeit packaging; falsification of medicines that contain false information about their composition or their real source; medical devices that may be ineffective [34, p. 847].

Given the above, in our opinion, the methods of falsification of medicines at the stages of their production and manufacture should be divided into three groups: a) falsifications associated with the change and forgery of the qualitative and quantitative composition of medicines; $b$ ) falsifications related to alteration, violation, and forgery of the external form of medicines; c) falsifications related to alteration and forgery of the source of origin of medicines and their improper registration. For example, according to the method of falsification of packaging, counterfeit medicines can be of the following types: a) forgery of both primary and secondary packaging; $b$ ) falsification of design (special form of packaging (labels), control strokes and labels, microtext, elements with a three-dimensional effect, special defects, hidden images; $c$ ) the use of special material for manufacturing (colours, watermarks, special inclusions, physical or chemical properties); d) forgery by applying paint (water-soluble, reactive to chemical reagents, invisible fluorescent, UV and IR paints, magnetic); e) falsification of special markings (barcoding, hologram, radio frequency identification) [35, p. 2-7].

The most common ways to conceal the falsification and contribution of falsified medicines are: to destroy traces of criminal activity related to the falsification of medicines; masking of criminal activity (periodic change of residence, precautions for wiretapping, creation of hiding places to store counterfeit products, etc.); falsification (forgery of customs and other documents, medical products, accompanying documentation, etc.); concealment of information and its carriers about the circumstances of falsification medicines; forgery of permits; destruction of documents proving the origin of falsification medicines or their accounting; destruction of the rests of raw materials, accessories or medicines; imitation of lawful economic activity (double-entry bookkeeping); sale, destruction of the equipment on which falsification medicines were made; use of intermediaries; etc.

Summarizing the research of the problem of classification and systematization of methods of falsification and circulation of falsified drugs, it should be noted that an exhaustive list of them is unattractive because they are under the influence of subjective and objective factors are constantly changing and supplemented by new, previously unknown in practice. It's expedient to create in Ukraine a system of accumulation of information on the most typical ways of this category of criminal offenses and to further improve the system of accumulation of information on the most typical ways of falsification and contribution of falsified medicines. [35, p. 106].
An important place in the system of criminalistic characterization of the considered type of criminal offense is occupied by counterfeit medicines as objects of encroachment, as their features allow to establish stable connections with the person of the offender, the way, the situation, typical traces, and the person of the victim. Knowledge of the criminalistic nature and signs of falsification medicines makes it possible to separate them from the mass of other objects of encroachment, helps to put forward investigative versions, and determine the direction of the investigation.

Among the criminalistically significant features of a falsified medicines as a subject of criminal encroachment, the following should be taken into account: 1) quantitative and qualitative compliance or non-compliance of the chemical formula (active components) of the original medicines, in the presence of the appropriate composition of the medicines; 2) violation and inconsistency of the external form of medicines, including their labelling, primary and secondary packaging, instructions, etc.; 3 ) establishing the conformity or inconsistency of the originality of the source of the medicinal product, its manufacturer, the license applicant, etc .; 4) physicochemical properties of medicines and their effect on the person who took such medicines; 5) consumer value or purpose of such medicines; 6 ) the price of medicines, their exchange value and taking into account the cost of selling a counterfeit medicine; 7) the impact of the legal regime of circulation of medicines on the methods of their falsification and access of a limited number of persons to certain of their species; 8 ) the ability of drugs to harm human life or health as a result of their use.

We conducted a study and generalization of the materials of criminal offenses under Art. 321-1 of the Criminal Code of Ukraine, allowed us to conclude that the most common falsified medicines, taking into account the pharmacotherapeutic group are: analgesics and antipyretics (citramon, analgin, aspirin, etc.) - 2.3\%; antiseptics and disinfectants (alcohol, AHD 2000, chlorhexidine, etc.) - 51.6\%; non-steroidal anti-inflammatory and anti-rheumatic means (fastum gel, nurofen, diclofenac, etc.) - 3.9\%; antispasmodics in combination with analgesics (spasmalgon, combispasm, baralgin, etc.) - 9.4\%; medicines used in cardiology (corvalment, validol, tricardin) 2.3\%; antimicrobials for systemic use (azithromycin, compendium, moximac, etc.) - 7.0\%; combined medicines for use in colds and coughs (fervex, vix active, teraflu, etc.) $-30.4 \%$; medicines that improve digestion, including enzymes (creon, mesylate, festal, etc.) $-6.2 \%$; others $-3.9 \%$.

Taking into account the data on typical traces of falsification and contribution of falsified medicines is essential for building a methodology for investigating criminal offenses [36, p. 115], in particular, they are in close correlation with other elements of the criminalistic characterization of the investigated criminal offenses and serve as a basis for proposing investigative versions. During the investigation of falsification of medicines and contribution of falsified medicines, the following traces are most often found: material traces - 43.0\%; ideal traces (memory traces) $-27.3 \%$; electronic traces $-23.4 \%$; microtrace and microobjects $-3.3 \%$, etc. 
Thus, the formation of separate criminalistic methods of falsification and the contribution of falsified medicines requires research and analysis of the criminalistic characteristics of this criminal offense. This conclusion is confirmed by the results of our survey of practitioners, in particular, $69.7 \%$ of surveyed investigators of the National Police of Ukraine, Security Service of Ukraine, and prosecutors indicated that there is a need to develop and use criminalistic characteristics of counterfeiting and trafficking in counterfeit drugs.

The effectiveness of the investigation of falsification of medicines and their contribution largely depends on the timely initiation of criminal proceedings, a complete and objective investigation of the source information about the event of a criminal offense. This is an essential prerequisite for the successful discovery of evidence and the establishment of all the circumstances of a criminal offense. Therefore, the stage of collecting and verifying primary information is mandatory for the correct qualification of a criminal offense, the choice of directions of investigation, depends on the quality, optimality, and efficiency of criminal proceedings [37, p. 207].

The results of our survey of practitioners indicate that it is the effectiveness of investigative (search) actions at the beginning of criminal proceedings that determine the success of the entire pre-trial investigation. According to the respondents (68.3\% of respondents), making mistakes by investigators (prosecutors) at the beginning of criminal proceedings can lead to the loss of important evidence, and in some cases necessitates re-investigation and conflict.

The most common reasons for entering information about the unified register of pre-trial investigations of such criminal offenses may be: 1) statements and notifications of victims $-9.3 \%$; 2 ) notification of officials and representatives of various organizations, institutions during inspections and controls - $10.9 \% ; 3$ ) detection of signs of such an offense as a result of operational and investigative measures preceding the beginning of criminal proceedings $-50.8 \%$; 4) statements and notifications of officials and individual employees of pharmaceutical enterprises, pharmacy establishments - subjects of incoming control of medicinal products $-13.3 \%$; 5 ) detection of signs of a criminal offense from information from the customs authorities of the SFS of Ukraine, the State Tax Service of Ukraine, SE «State Expert Center of the Ministry of Health of Ukraine» - $6.2 \%$; 6) detection of signs of a criminal offense from mass media, forums, Internet sites $-4.6 \% ; 7$ ) detection of signs of a criminal offense during the investigation of other criminal offenses $-3.9 \%$; 8) other $-1.6 \%$.

An important direction of activity and the structural stage of the beginning of criminal proceedings is the conduct of procedural and non-procedural actions (measures) for the initial collection of information about the event of a criminal offense. In this regard, three levels of intermediate (local) tactical tasks should be distinguished regarding the process of detection and initiation of investigation: 1) detection of signs of falsification or circulation of falsified medicines; 2) establishing the fact of falsification of med- icines; 3 ) establishing the fact of circulation of counterfeit medicines. To address them, it is advisable to conduct appropriate tactical operations.

The effectiveness and completeness of establishing all the circumstances of criminal offenses related to the falsification and circulation of falsified medicines largely depend on the active and correct application of special knowledge by the investigator (prosecutor) in the process of pre-trial investigation [38]. The main forms of using special knowledge in the investigation of such criminal offenses are forensic examination; involvement of specialists during individual investigative (search), court actions, or security measures; obtaining consultations and explanations from specialists [39, p. 12]. The following types of forensic examinations are most often appointed: forensic-pharmaceutical, forensic-pharmacological, forensic-medical, forensic-biological, forensic-technological, forensic-commodity, technical examination of documents, forensic handwriting, forensic-trasological, computer-technical, forensic -economic, forensic psychological, forensic psychiatric, etc.

\section{CONCLUSIONS}

Thus, the improvement and optimization of the process of detection and investigation of falsification and contribution of falsified medicines are one of the urgent tasks facing criminalistic scientists today. Solving this problem requires the separation and in-depth study of issues related to the development and implementation of pre-trial investigation bodies of relevant scientific and methodological recommendations, which would be based on the conceptual provisions of the theory of criminalistics and the results of generalization of practice. Moreover, $71.2 \%$ of the investigators surveyed indicated that they had difficulties in investigating such criminal offenses due to the lack of separate criminalistic methods. Therefore, one of the priority areas of research in criminalistics is the development of criminalistic characteristics and the basics of methods for investigating the falsification and contribution of falsified medicines.

The researched method of investigation of falsification and contribution of falsified medicines should be referred to the category of specific criminalistic methods, which is an information-cognitive model containing a system of methods, tools, techniques, recommendations, investigative technologies of standardized nature, set out in the descriptive or formalized form. and the optimal implementation of the process of collecting, evaluating, and using evidence regarding the specifics of committing criminal offenses under Art. 321-1 of the Criminal Code of Ukraine, in order to ensure their effective investigation and trial. The form and content of the criminalistic characteristics of falsification and contribution of falsified medicinal products should be determined by the classification level of the relevant separate criminalistic methods of investigation, the information base, and a component of which it acts.

In addition, the results of a survey of practitioners on the possibilities and ways to improve the effectiveness of the investigation of such criminal offenses, especially at the initial stage 
of criminal proceedings, are of scientific and practical interest. Among them, the most important are the following: the need to provide for the verification of applications and notifications of criminal offenses $-71.2 \%$; systematization of signs of this criminal offense $-62.4 \%$; development and application of the tactical operation «Detection of signs of falsification or contribution of falsified medicines»-51.2\%; prevention of mistakes at the beginning of criminal proceedings $-68.3 \%$; development and implementation of algorithms of actions at the stage of detection of signs and the beginning of criminal proceedings - 54.6\%; effective conduct of investigative and covert (investigative) actions - 40.5\%; application of tactical and criminalistic complexes (tactical combinations and operations) $-50.7 \%$ and other $-2.4 \%$. In our opinion, it is in these areas that it is necessary to conduct research aimed at improving the quality of the investigation and the effectiveness of the implementation of these criminalistic methods.

\section{REFERENCES}

1. Gutorova, N., Zhytnyi, 0., Soloviov, 0. Falsification of Medical Products: Criminal Law Mechanism Combating Threats to Public Health. Wiad Lek 2019; 5: 856-861.

2. Mytrofanov I.I., Prytula A.M., Streltsov Ye.L. Zlochyny proty zdorov'ia naselennia, shcho porushuiut pravo na yakisne zabezpechennia likarskymy zasobamy: monohrafiia [Crimes against health which violated the right in quality provisions of medicines: monograph]. In: Ye.L. Streltsova, ed. Odesa: Feniks; 2015, p. 5 (in Ukrainian).

3. Statystychna informatsiia Ofisu Heneralnoho prokurora [Statistical information of the Office of the Attorney General]. Available from: https://old.gp.gov. ua/ua/stst2011.html (in Ukrainian).

4. V Ukrainu kontrabandoiu zavezly pidrobku vaktsyny proty Covid-19. Fakty ICTV [A counterfeit vaccine against Covid-19 was smuggled into Ukraine. ICTV facts]. Available from: https: fakty.com.ua/ua/ proisshestvija/20210108-v-ukrayinu-kontrabandoyu-zavezly-pidrobkuvaktsyny-proty-covid-19-sbu (in Ukrainian).

5. Ofis Heneralnoho prokurora spilno z pravookhorontsiamy prypynyv kontrabandu v Ukrainu z Turechchyny falsyfikovanykh likiv dlia onkokhvorykh [The Office of the Prosecutor General together with law enforcement officers stopped the smuggling of counterfeit medicines for cancer patients to Ukraine from Turkey]. Available from: https:// www.gp.gov.ua/ua/news =view\& (in Ukrainian).

6. Lebed S. 0., Nemchenko A. S. Ekspertna otsinka efektyvnosti borotby z falsyfikatsiieiu likarskykh zasobiv v Ukraini [Expert assessment of the effectiveness of the fight against drug counterfeiting in Ukraine]. Farmatsevtychnyi zhurnal; 2020; 4: 30-38 (in Ukrainian.

7. Guidelinesforthe development ofmeasures to combat counterfeitdrugs (1999). Geneva,Switzerland:WorldHealth Organization:Department of essential drugs and other medicines, WHO/EDM/QSM/99.1. Available from: http://apps.who. int/iris/bitstream/10665/65892/1/WHO_EDM_QSM_99.1.pdf.

8. Soloviov 0. S. Mizhnarodnyi mekhanizm protydii falsyfikatsii medychnoi produktsii yak zasib pidvyshchennia yakosti u farmatsii Ukrainy. [International mechanism for combating falsification of medical products as a means of improving quality in pharmacy] Upravlinnia, ekonomika ta zabezpechennia yakosti u farmatsii; 2019; 3 (59): 28-34 (Ua).

9. Shepitko V. Y., Shepitko M. V. The role of forensic science and forensic examination in international cooperation in the investigation of crimes. Journal of the National Academy of Legal Sciences of Ukraine. 2021; 28 (1): 179-186.
10. Ofitsiinyi sait Vsesvitnoi orhanizatsii okhorony zdorov'ia [Official site of the World Health Organization]. Available from: http://www.who.int (in Ukrainian).

11. Sur S. Stvorennia, rozvytok i zanepad systemy borotby z falsyfikatsiieiu likarskykh zasobiv v Ukraini [Creation, development and decline of the anti-counterfeiting system in Ukraine]. Of 25 January 2021; Ezhenedelnyk APTEKA; 3. Available from: https://www.apteka.ua/ article/581247 (in Ukrainian).

12. Zozulia 0. Falsyfikatsiia likarskykh zasobiv: problemni aspekty y shliakhy yikh vyrishennia [Drug falsification: problematic aspects and ways to solve them]. Available from: https://yur-gazeta.com/publications/ practice/medichne-pravo-farmacevtika/falsifikaciya-likarskih-zasobi v.html (in Ukrainian).

13. Kalyniak M., Blavatska 0. Problema yakosti ta bezpeky likarskykh zasobiv. Falsyfikatsiia ta kontrol yakosti [The problem of quality and safety of medicines. Falsification and quality control]. Available from: http://www. aptekagal.com.ua (in Ukrainian).

14. Kovalenko I. A. Falsyfikatsiia ta obih falsyfikovanykh likarskykh zasobiv: kryminalno-pravove doslidzhennia: monohrafiia [The fabrication and accounting of medicines: the criminal research: monograph]; Ye. L. Streltsova ed. Odesa:Vyd. dim «Helvetyka», 2018, p. 22 (in Ukrainian).

15. Ilikbaeva E.S. Obrashhenie fal'sificirovannyh, nedobrokachestvennyh i nezaregistrirovannyh lekarstvennyh sredstv, medicinskih izdelij i oborot fal'sificirovannyh biologicheski aktivnyh dobavok: voprosy kriminalizacii, differenciacii otvetstvennosti i penalizacii: avtoref. dis. ... kand. jurid. nauk: 12.00 .08 . [The circulation of adulterated, unregistered biologically active additives: questions of the differentials of the responsibility: Ph. D. thesis abstract: 12.00.08.]; FGBOU V0 «Kubanskij gosudarstvennyj universitet»; Krasnodar; 2019, p. 4 (in Russian).

16. Zhuravel, V.A. Crime mechanism as a category of criminalistics. Journal of the National Academy of Legal Sciences of Ukraine, 2020, 27(3): 142-154.

17. Nikolaienko R. A. Oznaky zlochyniv, pov'iazanykh iz vyhotovlenniam ta poshyrenniam falsyfikovanykh likarskykh zasobiv za sposobamy operatyvno-znachymoi povedinky na stadii yikh vyrobnytstva. [Signs of crimes related to the manufacture and distribution of counterfeit drugs by methods of operationally significant behavior at the stage of their production]. Pravo i suspilstvo, 2018; 3 (2): 276-281. (in Ukrainian).

18. Budancev L. A. Razrabotka metodikanaliza dlja vyjavlenija fal'sificirovannyh lekarstvennyh sredstv: avtoref. dis. kand. jurid. nauk [The development of analytical techniques for the detection of adulteration medicines: Ph. D. thesis abstract]. Moskva, 2011, p. 27 (in Russian).

19. Vardanjan G.A. Metodika rassledovanija prestuplenij, svjazannyh s proizvodstvom i obrashheniem ne sootvetstvujushhih licenzionno-razreshitel'nym trebovanijam i (ili) fal'sificirovannyh, nedobrokachestvennyh, nezaregistrirovannyh lekarstvennyh sredstv, medicinskih izdelij ili biologicheski aktivnyh dobavok: avtoref. dis. k.ju.n. 12.00.12. [The methodologies of investigations of crimes, connected with production does not comply with license and permission requirements, adulteration of spoiled and unregistered medicines and biologically active additives: Ph. D. thesis abstract 12.00.12.]. Tul'skij gos. un-t. 2015, p. 29 (in Russian).

20. Huk 0.H. Rozsliduvannia falsyfikatsii likarskykh zasobiv ta obihu falsyfikovanykh likarskykh zasobiv: avtoref. dys. kand.. yuryd. nauk: 12.00.09. [Investigations of adulterations and processes of adulteration of the medicines: Ph. D. thesis abstract: 12.00.09.]. MVS, Nats. akad. vnutr. sprav Ukrainy. Kyiv, 2016, p. 20 (in Ukrainian). 
21. Gurkin M.A. Protivodejstvie organizovannoj prestupnoj dejatel'nosti v sfere obrashhenija fal'sificirovannyh, nedobrokachestvennyh i nezaregistrirovannyh lekarstvennyh sredstv: kriminalisticheskie aspekty: avtoref..... dis. kand. jurid. nauk [The counteraction of organized criminal activity at the field of adulteration non-registered medicines: the criminal aspects: Ph. D. thesis abstract]. Tula, 2017, p. 26.

22. Daraha R. D. Vyiavlennia ta fiksatsiia faktiv obihu falsyfikovanoi produktsii, shcho vyhotovliaiut na nelehalnykh vyrobnytstvakh [Detection and recording of facts of circulation of counterfeit products manufactured in illegal industries]. Naukovyi visnyk Natsionalnoi akademii vnutrishnikh sprav. 2013; 2: 222-231 (in Ukrainian).

23. Lytvyn A.A. Osoblyvosti taktyky ohliadu mistsia podii pid chas rozsliduvannia zlochyniv, uchyniuvanykh u sferi obihu likarskykh zasobiv. [Features of the tactics of inspection of the scene during the investigation of crimes committed in the field of circulation of medicines. Legal scientific electronic journal]. Yurydychnyi naukovyi elektronnyi zhurnal. 2018; 1:200-203 (in Ukrainian).

24. Pahomov A. V. Kriminalisticheskoe issledovanie poligraficheskih jelementov upakovki lekarstvennyh sredstv: metodicheskie rekomendacii MVD Rossii [The criminal research by polygraphic methods of the packaging of pharmaceutical products: methodological recommendation of the Ministry of Internal Affairs of Russia]. JeKC. Moskva, 2011, p. 20.

25. Holevchuk A. G. Fal'sifikacija kak ob"ekt kriminalisticheskogo issledovanija: avtoref. dis. kand. jurid. nauk [Adulteration is an objects of the criminalistics research: Ph. D. thesis abstract.] Moskva, 2010, p. 28 (in Ukrainian).

26. Shchur B. V., Kamenieva H. V. Problemy formuvannia metodyky rozsliduvannia obihu nezakonnykh likarskykh zasobiv. [Problems of formation of a technique of investigation of circulation of illegal medicines]. Visnyk Lvivskoho torhovelno-ekonomichnoho universytetu. Yurydychni nauky. 2018; 7:271-278 (in Ukrainian).

27. Fajzrahmanov N. F. Rassledovanie oborota fal'sificirovannyh i nedobrokachestvennyh lekarstvennyh sredstv, biologicheski aktivnyh dobavok: avtoref. dis... kand. jurid. nauk [ Investigations of the circulation of adulterate and spoiled medicines, biologically active additives: Ph. D. thesis abstract]. Moskva, 2013, p. 30 (in Russian).

28. ZhuravelV.A. Kryminalistychni metodyky: suchasni naukovi kontseptsii: monohrafiia [The criminal techniques: the modern scientific conceptions: monograph] . Kharkiv: Vyd. ahentsiia «Apostil», 2012. p. 143 (in Ukrainian).

29. Panov N.I., Shhur B.V. Ob izuchenii sposoba sovershenija prestuplenija v naukah kriminal'nogo cikla: mezhdisciplinarnyj pohod [On the study of the method of committing a crime in the sciences of the criminal cycle: an interdisciplinary approach]. Kryminalist pershodrukovanyi: mizhnar. nauk.-prakt. yuryd. zhurn. 2013; 6: 17-33 (in Russian).

30. Pro sudovu praktyku spravakh pro zlochyny u sferi obihu narkotychnykh zasobiv, psykhotropnykh rechovyn, yikh analohiv abo prekursoriv: Postanova Plenumu Verkhovnoho Sudu Ukrainy [On case law crimes at the field of drug trafficking, psychotropic substance, precursors and analogue : Resolution of the plenum of the supreme court of Ukraine] № 4 of 26 april 2002 (in Ukrainian).

31. Grizodub A.I. Problemy kachestva i fal'sifikacii lekarstvennyh sredstv. [Problems of quality and falsification of medicines]. Ezhenedel'nik APTEKA; 20 (591). Available from: https: www.apteka.ua/article/4880

32. Kovalenko I. A. Falsyfikatsiia ta obih falsyfikovanykh likarskykh zasobiv: kryminalno-pravove doslidzhennia: monohrafiia; Ye. L. Streltsova ed. Odesa : Vydavnychyi dim «Helvetyka», 2018. p. 34 (in Ukrainian).
33. PashkovV., Soloviov A., Olefir A. Legal Aspects of Counteracting the Trafficking of Falsified Medicines in the European Union. Wiad Lek 2017; 4: 843-849.

34. HromovykB.P.,Miroshnykova I.O., IvaskevychYu.V.Shtrykh-koduvanniayak zasib zakhystu likarskykh preparativ i vyrobiv medychnoho pryznachennia vid falsyfikatsii [Bar coding as a means of protecting drugs and medical devices from counterfeiting]. Provyzor. 2010; 10: 2-7 (in Ukrainian).

35. Parfylo I.V.Sposobyvchynenniafalsyfikatsiita obihufalsyfikovanykh likarskykh zasobiv yak obiekt kryminalistychnoho doslidzhennia [Ways of committing falsification and circulation of falsified medicines as an object of criminal investigation]. Aktualni pytannia sudovoi ekspertyzy i kryminalistyky: zbirnyk materialiv mizhnar.-prakt. konf., prysviach. 95-richchiu KhNDI sudovykh ekspertyz imeni Zasl. prof. M. S. Bokariusa (Kharkiv, of 10-11 october 2018 r.). Kharkiv: Pravo, 2018. 105- 107 (in Ukrainian).

36. Matusovskij G.A. Jekonomicheskie prestuplenija: kriminalisticheskij analiz. Har'kov: Konsum, 1999. P. 115 (in Ukrainian).

37. Vapniarchuk, V.V., Kaplina, O.V., Shumylo, M.Y., Tumanyanc, A.R. Proof in the Science of the Criminal Process in Ukraine: Conceptual Approaches to Understanding the Essence. International Journal of Offender Therapy and Comparative Criminology. 2021; 65(2-3): 205-220.

38. Shevchuk 0., ShevchukV., Matyukhina N., Zatenatskyi D. Testing of drugs in the implementation of customs control in Ukraine: legal aspects. Georgian Medical News. 2020; 1(298): 165-169.

39. Shepitko V. Iu. Problemy vykorystannia spetsialnykh znan kriz pryzmu suchasnoho kryminalnoho sudochynstva v Ukraini [Problems of using special knowledge through the prism of modern criminal justice in Ukraine]. Sudova ekspertyza. 2014; 1: 11-18 (in Ukrainian).

The scientific paper is prepared pursuant to the fundamental scientific researches of Academician Stashis Scientific Research Institute for the Study of Crime Problems, National Academy of Law Sciences of Ukraine «Scientific and technical support of investigative activity in the conditions of adversarial criminal process» (state registration №: 0117U000282).

\section{ORCID and contributionship:}

Viktor M. Shevchuk: 0000-0001-8058-3071 A, B, D, E, F

Ihor V. Parfylo: 0000-0000-0001-5788-2268 ${ }^{B, C, D, E}$

Mykyta O. Sokolenko: 0000-0002-0302-162X $X^{B, D}$

\section{Conflict of interest:}

The Authors declare no conflict of interest.

\section{CORRESPONDING AUTHOR Viktor M. Shevchuk \\ Yaroslav Mudryi National Law University \\ Kharkiv, Ukraine \\ tel. +380503641250 \\ e-mail:Shevchuk_viktor@ukr.net}

Received: 28.06.2021

Accepted: 07.10.2021

A - Work concept and design, B - Data collection and analysis, C - Responsibility for statistical analysis, D-Writing the article, E-Critical review, $\mathbf{F}$ - Final approval of the article 


\title{
THE EVOLVING IDEA OF “HEALTH" IN THE LEGAL LANDSCAPE: AN ATTEMPT TO IDENTIFY CRITICAL ASPECTS
}

DOI: $10.36740 /$ WLek202111216

\author{
Yevdokiia J. Streltsova' ${ }^{1}$, Yevgen L. Streltsov ${ }^{2}$, Eduard E. Kuzmin ${ }^{2}$ \\ 'ODESA I. I. MECHNIKOV NATIONAL UNIVERSITY, ODESA, UKRAINE \\ 2NATIONAL UNIVERSITY"ODESA LAW ACADEMY", ODESA, UKRAINE
}

\begin{abstract}
The aim: The overall purpose of the research is to shed light on the evolving understanding of the concept of "health" in the legal field, attempting to identify its critical aspects. Materials and methods: The study constitutes a comprehensive analysis of a large number of scholarly publications and international legal provisions through the prism of the principles of concreteness and objectivity, coupled with methodological pluralism, including both philosophical, general scientific, theoretical, general, and special legal research methods.

Conclusions: Considering the evolving idea of "health" in the legal landscape, it is noted that, in the current context, "health" should be perceived both as an individual and a collective feature, as well as the substance, legal right, and a state's obligation.
\end{abstract}

KEY WORDS: coronavirus, health, public health, World Health Organization, international cooperation

Wiad Lek. 2021;74(11 p.2):2954-2958

\section{INTRODUCTION}

Over the past decades, it has become abundantly clear that the events that had shattered the world and affected the lives of millions of people have profoundly changed the research agenda. Epidemic and pandemic illnesses have contributed immensely to the developments in perspective that go far beyond traditional approaches to widespread and entrenched problems, shifting the focus towards a formidable array of new challenges. The present-day realities of the massive and rapid spread of COVID-19 coronavirus infection [1] and devastating Ebola virus disease outbreaks [2] have certainly brought to the fore the tremendous number of various health-related extraordinarily complex issues, encompassing both purely medical aspects and the relevant area of public management and administration. Such an ambivalent mixture of all those matters is inextricably bound to the subtleties of moral and ethical considerations, along with the legal niceties of their normative regulation.

This kind of situation is compounded by the fact that all of them nowadays conditionally constitute relatively separate stand-alone frontiers of knowledge with rather autonomous directions of activities that may exist either simultaneously, parallel to each other, in different dimensional planes, - international, regional, national, and local levels or even interfere with one another, overlapping, intersecting and penetrating their domains both on a global scale and a specific case-by-case basis.

At the current point, the "health" itself might serve as a vivid example. Regarded as a systemically important central category of medicine, solely in biological form and perception, it fell within the purview of governmental bodies, and evokes a whole different meaning, while implementing the state health policy. A similar phenomenon occurs within the operation of the entire healthcare system and the functionality of a health service in general. The same trend is likewise valid for the health research ethics and the "health law" in a generic way, involving the "right to health", its promotion and protection not only domestically but also regionally and globally.

Under these circumstances, all the complexities presently seem to necessitate a critical conceptual redeeming of the concept of "health" in the legal sphere, clarifying the contours and normative content of the "right to health", reimagining and clearly outlining the extent and depth of the commitments undertaken by the states to that end.

\section{THE AIM}

The research objective is to contrast differences in the perception of the concept of "health" in the legal field and identify potential points of challenge and difficulty, as well as to seek to recognize and highlight the common pitfalls.

\section{MATERIALS AND METHODS}

The present study is based on the extensive review of the most pertinent scholarly writings, namely over 35 scientific articles, contained in the PubMed database, and a 
large variety of other publications, including monograph series, encyclopedias, and books, along with many international regulations, in particular, the major human rights conventions adopted under the auspices of the United Nations, and the basic official documents, fact sheets and summary reports of the World Health Organization, as well as the results of the activities of other organizations like the Committee on Economic, Social and Cultural Rights, Committee on Assuring the Health of the Public in the 21st Century and Committee for the Study of the Future of Public Health, and many more.

The foundation of the methodology of the research is represented by analytical, phenomenological, hermeneutic, and dialectical methods of cognition with the use of linguistic and systemic-functional methods, as well as the abstract logical thinking, comprehensive and critical analysis, synthesis, inductive and deductive reasoning, and several others.

\section{REVIEW AND DISCUSSION}

It is quite telling that "health" and "law" have a fairly long-standing history of their mutual relations. At an earlier stage of the development, legal norms and provisions that were designed to regulate the relationship between medical personnel and patients arising predominantly in connection with medical treatment and clinical practice were referred to as "medical law" [3, p. 241].

However, with the passage of time and increase in the number of health problems associated with "medical errors" [4, p. 1043], the scientific parlance has gradually been replenished with a couple of alternatives, among which the most commonly used were and still are "medical negligence law" [5, p. 37] or much less frequently "clinical negligence law" [6, p. 120-121], and "medical malpractice law" [7, p. 339].

The further rapid evolution of the situation that has taken place in the medical field since then has led to substantial expansion of the range of relations that extended beyond a mere doctor-patient relationship [8, p. 26]. Apart from it, growing attention was given to the issues of administration of health services and the role of law in maintaining public health care [9, p. 3-4], as well as ethical issues relating to the human body [10], as a result of which the new terms "health care law" [11] and/or "healthcare law" [12] were coined.

In that respect, it has been commonly argued that despite the difference in the spelling, these two categories are equivalent, whereas the contrary view is that they are identical neither in wording nor in their meaning. The possibility of such ambiguities in interpretation is of crucial importance, as it mainly leads to the unduly broadening or narrowing of the content and scope of the term. In turn, such a change in discourse largely affects the spectrum of public and social relations that are subject to legal regulation.

In the light of the foregoing observations, it was suggested considering the use of another different category, thereby the term "health law" [13] came into being in order to deal with old and new problems. As it became apparent that a narrow approach was no longer appropriate, such novelty marked a further conceptual shift in the process of expanding the extent of the substantive sphere of its application $[9$, p. 4$]$.

Despite the growing popularity and frequent resort to this term over others, issues regarding the peculiarities of their reciprocal relations remain highly relevant today [14]. Even more, the dilemma deepens, becomes more complex and sophisticated, which entails a number of additional problems.

Foremost among these are issues related to the definition of the term "health" [15, p. 735], concerned with the attempt to explain the meaning of the "right to health" [16], as well as to establish its place in the field of international law [17, p. 189], identify the bearers of this right, as well as to clarify the nature of the state's obligation [18, p. 371], and the limits of the competence of state bodies to protect it [19].

Concerning "health", in most cases, the starting point for determining its content remains the comprehensive analysis of the definition, outlined in the Constitution of the World Health Organization, signed at the International Health Conference [20], dated back to 1946, which stipulates that "... health is a state of complete physical, mental and social well-being and not merely the absence of disease or infirmity ..." [21]. In addition, it has also been traditionally associated with an attempt to further refine the legal understanding of the notion during the 1st International Conference on Health Promotion [22] in 1986, resulting in the adoption of the Ottawa Charter for Health Promotion [23], containing the provision that "... health is, therefore, seen as a resource for everyday life, not the objective of living. Health is a positive concept emphasizing social and personal resources, as well as physical capacities ..." [22].

Such significance usually stems from the fact that "health" was initially and up until that moment perceived, to a large extent, exclusively as the absence of any disease or impairment [24, p. 662]. However, since then it has no longer been defined simply in "physical terms", as the "absence of illness or disability", but also includes "mental and social dimensions" [25].

This idea, in turn, received a rather mixed reception. On the one hand, it contributed to a very useful broadening of the lens through which the health has to be considered [26, p. 127], whereas its attractiveness as an ideal was vitiated by the impossibility of its practical realization, on the other [27, p. 87], thus giving rise to a substantial amount of criticism.

In particular, it has been argued that health is not a "state of complete physical, mental, and social well-being", and nor is it "merely the absence of disease or infirmity" [28, p. 781]. And what is more, that state need not be "complete", but it must be at least adequate, i.e., without significant impairment of function. It also need not encompass "mental" well-being; one can be healthy yet anxious, well yet depressed. And it surely ought not to encompass "social well-being", except insofar as that well-being will be 
impaired by the presence of large-scale, serious physical infirmities [27, p. 87].

It is also alleged that the definition of "health", formulated and developed by the World Health Organization 75 years ago [26, p. 127], as a "complete wellbeing" [29, p. 1, 3] is no longer adequate for dealing with the new challenges in health care systems [15, p. 735], no longer fit for purpose given the rise of chronic disease $[29$, p. 1,3$]$ and the nuanced needs of an aging population, especially in the emerging era of value-based care, nor can it provide clear and useful goals for the value-based care movement [26, p. 127].

Accordingly, there had been calls for the amendment of the current definition [30] and over the years various proposals have been presented as an alternative. One of the views expressed was that the term "health" should be defined as a "state of physical well-being" [27, p. 87], that serves as a certain reference to its "classical sense". Other suggestions made were to include the idea that something more practical is required and a new improved definition of "health", as the "experience of physical and psychological well-being" [26, p. 127] was introduced. However, that definition likewise was not entirely flawless.

Also worthy of attention were several other more specific innovative approaches. Considering the fact that disease and disability can and often do co-exist with wellness, the new conception has been created based on the point that "health" should be transformed from a "state that requires the absence of disease" to a "state where the central theme is the fullness of life" so that it becomes not a "static state of being", but a "dynamic quality of living where body, mind, and spirit are fully employed to make the most of each day" [31, p. 204].

Almost the same thinking lies at the core of the pretty similar definition of "health", indicating that it is a "state of balance, an equilibrium that an individual has established within himself and between himself and his social and physical environment" [24, p. 662], together with the formulation of "health" as the "ability of an individual to adapt to the unique prevailing conditions" $[28$, p. 781$]$ and to "self manage" $[29$, p. 1, 3].

Notwithstanding the numerous appeals concerning the need to redefine the concept, all of these efforts have been made so far seem futile to date. Complicating the situation, however, is the fact that the definition of "health" is not just a theoretical issue, because it has many implications for practice, policy, health services [15, p. 735], and, arguably equally important, for the "right to health".

And remarkably, just as the "health" itself, the "right to health" has also trod a long and thorny path of its evolution. Originally, the concept of "the right to the enjoyment of the highest attainable standard of health" [21] was used with regard to "health" in the texts of the international instruments. Shortly after, "the right to the enjoyment of the highest attainable standard of physical and mental health" [32] was developed and applied as well. Side by side with that, therefore, "the right of access to health care services" [33], "the right to receive medical care" [34] and "the right to access to health service" [35] may well also be found in the international legal documents.

Though typically synonymous [36, p. 603], such diversity of terms, made the concept of the "right to health" to be the subject of much debate, whilst defining its content, - a formidable challenge [37, p. 1457]. Torn between being both "human" [17] and "international" [19] right, it is frequently associated with the "access to health care and the building of hospitals", but, in fact, the "right to health" extends much further, including a wide range of factors that can help to lead a healthy life [38, p. 3]. It is also commonly identified as an "inclusive right extending not only to timely and appropriate health care" but also to the "underlying determinants of health", such as access to safe and potable water and adequate sanitation, an adequate supply of safe food, nutrition, and housing, healthy occupational and environmental conditions, and access to health-related education and information, including on sexual and reproductive health [39, p. 3]. Apparently, these definitions can hardly ever be considered reasonably accurate, precise, conclusive, and exhaustive that, to some degree, opens up the whole idea of the need to develop a coherent universal one [40].

The problem becomes even more complex owing to the existing paradigm of the so-called "individual health", where the "right to health" is seen mostly as the "right to individual medical care", which is so far slowly coming to be treated as the collective right [41, p. 102]. Thus, the emphasis is gradually shifting from individual-private to public-global issues.

Apart from "individual health", "public health" [42] or yet occasionally the "health of the public" [43] is becoming both common and essential, facing almost similar difficulties in its definition, continuing uncertainty about what counts as "health", and introducing additional complexities concerning the meaning of "public" [44, p. 7] in "public health" [45, p. 13]. And indeed, it is still not sufficiently clear whether this is intended to refer to the "health of nations" [46], "health of a nation" [47], "population health" [48], "community health" [49] or all of it at once, especially considering that each of these concepts has at least its own formal definition, as well as a large number of own problems. Given that, "public health" is quite often understood as an "... organized community effort to address public concerns about health by applying scientific and technical knowledge ..." that is distinguished from health care by its focus on communitywide concerns - the public interest rather than the health interests of particular individuals or groups [50, p. 140], in its broadest sense.

The same pattern can also be observed in relation to the "right to public health" [51]. For example, there is a view that the "public health right" has to be distinct from the "right to health" because it does not aim to ensure an affirmative right to access health-care services, health protection, or aspirational standards of health for individuals and is grounded in the "old" public health, which aims at collective action problems, not the "new" public health, which aims broadly to ensure the "underlying determinants" for people to be healthy [52]. 
As a result of such a wide variety of controversial issues and events recently, there has emerged an increased interest in the need for the development of the relevant direction in the legal environment, which also was presented with a number of terms, including "public health law" [53], "global public health" [54], or even broader scaled "world health law" [55] and "global health law" [56], which, in turn, also address questions of policy and international relations.

It is in this sense that the "health" and "public health" are starting to be seen as a "governmental duty" and "an obligation of a state" [19], rather than a "right of individuals, nations, nation, population, and community" [57].

\section{CONCLUSIONS}

Contemporary highly complex emergencies that are indissolubly linked with the outbreaks of contagious diseases have mainstreamed a wide range of issues, relating to "health". Through all appropriate means to confront them nowadays, the pivotal role has been given to the law, establishing a framework to manage successfully threats, regulating the relations, ensuring and protecting the rights, freedoms, and legal interests. With the multidimensional nature of "health", it is crucial to create the definition that will not only possess the more realistic and practical interdisciplinary character, comprising medicine, policy, and law but also correspond to the needs of the demands of the times, treating it both from individual and collective perspectives. In contrast, further refinements of the legal understanding of the concept of "health" should be accompanied by the "three ones" model, including "health" - "right to health" - "obligation of a state".

\section{REFERENCES}

1. World Health Organization. Coronavirus Disease (COVID-19) Pandemic (2021). Available from: https://www.who.int/emergencies/diseases/ novel-coronavirus-2019 [reviewed 2021.07.24].

2. World Health Organization. Ebola Virus Disease (2021). Available from: https://www.who.int/health-topics/ebola\#tab=tab_1 [reviewed 2021.07.24].

3. Grubb A. The Emergence and Rise of Medical Law and Ethics. The Modern Law Review. 1987;50(2):241-267.

4. Kalra J. Medical Errors: An Introduction to Concepts. Clin Biochem. 2004;37(12):1043-1051. doi: 10.1016/j.clinbiochem.2004.08.007. PMID: 15589809.

5. Powers M., Barton A. Introduction to Medical Negligence Law. AVMA Medical \& Legal Journal. 1995;1(1):37-39. doi: 10.1177/135626229500100112.

6. Panting G. Clinical Negligence. East Afr Med J. 2005;82(7):120-121. PMID: 16167730.

7. Bal B. S. An Introduction to Medical Malpractice in the United States. Clin Orthop Relat Res. 2009;467(2):339-347. doi: 10.1007/s11999-0080636-2. Epub 2008 Nov 26. PMID: 19034593; PMCID: PMC2628513.

8. Dorr Goold S., Lipkin M. Jr. The Doctor-Patient Relationship: Challenges, Opportunities, and Strategies. J Gen Intern Med. 1999;14(1):26-33. doi: 10.1046/j.1525-1497.1999.00267.x. PMID: 9933492; PMCID: PMC1496871.
9. Farrell A.-M., Devereux J., Karpin I. et al. Health Law: Frameworks and Context. Cambridge: Cambridge University Press; 2017. doi: 10.1017/9781316092675.

10. Owusu-Dapaa E. The Historical Development of Health Care Law and Bioethics in England and Wales: A Symbiotic Relationship? Med Law. 2014;33(1):22-39. PMID: 24946511.

11. Montgomery J. Health Care Law. Oxford: Oxford University Press; 2002.

12. Stanton C., Devaney S., Farrell A.-M., Mullock A. eds. Pioneering Healthcare Law: Essays in Honour of Margaret Brazier. London: Routledge; 2015.

13. Beran R. Health Law in the 21st Century. Med Law. 2010;29(2):129-139. PMID: 22462278.

14. Todorovski N. Medical Law and Health Law - Is It the Same? Acta Medica Medianae. 2018;57(2):34-39. doi: 10.5633/amm.2018.0206.

15. Leonardi F. The Definition of Health: Towards New Perspectives. Int J Health Serv. 2018;48(4):735-748. doi: 10.1177/0020731418782653. Epub 2018 Jun 14. PMID: 29902944.

16. Hahn R. A., Muntaner C. Why a Right to Health Makes No Sense, and What Does. Health Equity. 2020;4(1):249-254. doi: 10.1089/ heq.2019.0116. PMID: 32587938; PMCID: PMC7310297.

17. Castleberry C. A Human Right to Health: Is There One And, If So, What Does It Mean? Intercultural Human Rights Law Review. 2015;10:189-232.

18. Donders Y. The Right to Enjoy the Benefits of Scientific Progress: In Search of State Obligations in Relation to Health. Med Health Care Philos. 2011;14(4):371-381. doi: 10.1007/s11019-011-9327-y. PMID: 21533845; PMCID: PMC3190088.

19. O'Brien P. The International Right to Health:State Obligations and Private Actors in the Health Care System. J Law Med. 2013;21(1):194-209. PMID: 24218792.

20. World Health Organization. Summary Report on Proceedings, Minutes and Final Acts of the International Health Conference Held in New York from 19 June to 22 July 1946 (1948). Available from: https://apps.who. int/iris/handle/10665/85573 [reviewed 2021.07.27].

21. World Health Organization. Constitution of the World Health Organization. Basic Documents, Forty-fifth edition, Supplement (2006) 2006-2021. Available from: https://www.who.int/governance/eb/ who_constitution_en.pdf [reviewed 2021.07.26].

22. World Health Organization. The 1st International Conference on Health Promotion, Ottawa (1986). Available from: https://www.who.int/ teams/health-promotion/enhanced-wellbeing/first-global-conference [reviewed 2021.07.26].

23. World Health Organization. Ottawa Charter for Health Promotion (1986). Available from: https://www.euro.who.int/_data/assets/ pdf_file/0004/129532/0ttawa_Charter.pdf [reviewed 2021.07.26].

24. Sartorius N. The Meanings of Health and Its Promotion. Croat Med J. 2006;47(4):662-664. PMID: 16909464; PMCID: PMC2080455.

25. Larson J. S. The World Health Organization's Definition of Health: Social versus Spiritual Health. Social Indicators Research. 1996;38(2):181-192. doi: 10.1007/BF00300458.

26. Card A. J. Moving Beyond the WHO Definition of Health: A New Perspective for an Aging World and the Emerging Era of Value-Based Care. World Medical \& Health Policy. 2017;9:127-137. doi: 10.1002/ wmh3.221.

27. Callahan D. The WHO Definition of "Health". Stud Hastings Cent. 1973;1(3):77-88. PMID: 4607284.

28. What is Health? The Ability to Adapt. Lancet. 2009;373(9666):781. doi: 10.1016/50140-6736(09)60456-6. PMID: 19269498. 
29. Huber M., Knottnerus J. A., Green L. et al. How Should We Define Health? BMJ. 2011;343:d4163. doi: 10.1136/bmj.d4163. PMID: 21791490.

30. Fallon C. K., Karlawish J. It's Time to Change the Definition of "Health" (2019). Available from: https://www.statnews.com/2019/07/17/ change-definition-health/ [reviewed 2021.07.27].

31. Bradley K. L., Goetz T., Viswanathan S. Toward a Contemporary Definition ofHealth.Mil Med.2018;183(suppl_3):204-207.doi:10.1093/milmed/ usy213. PMID: 30462340.

32. United Nations. The Office of the High Commissioner for Human Rights. International Covenant on Economic, Social and Cultural Rights (1966). Available from: https://www.ohchr.org/EN/Professionallnterest/Pages/ CESCR.aspx [reviewed 2021.07.29].

33. United Nations. The Office of the High Commissioner for Human Rights. Convention on the Rights of the Child (1989) 1996-2021. Available from: https://www.ohchr.org/EN/Professionallnterest/Pages/CRC.aspx [reviewed 2021.07.29].

34. United Nations. The Office of the High Commissioner for Human Rights. International Convention on the Protection of the Rights of All Migrant Workers and Members of Their Families (1990). 1996-2021. Available from:https://www.ohchr.org/EN/Professionallnterest/Pages/CMW.aspx [reviewed 2021.07.29].

35. United Nations. The Office of the High Commissioner for Human Rights. Convention on the Rights of Persons with Disabilities (2006). 1996-2021. Available from: https://www.ohchr.org/EN/HRBodies/CRPD/Pages/ ConventionRightsPersonsWithDisabilities.aspx [reviewed 2021.07.29].

36. Hunt P. The Human Right to the Highest Attainable Standard of Health: New Opportunities and Challenges. Trans R Soc Trop Med Hyg. 2006;100(7):603-607. doi: 10.1016/j.trstmh.2006.03.001. Epub 2006 May 2. PMID: 16650880.

37. Kinney E. D. The International Human Right to Health: What Does This Mean for Our Nation and World? Indiana Law Rev. 2001;34(4):14571475. PMID: 16211755.

38. Office of the United Nations High Commissioner for Human Rights. World Health Organization. The Right to Health. Fact Sheet No. 31. (2008) 1996-2021. Available from: https://www.ohchr.org/documents/ publications/factsheet31.pdf [reviewed 2021.07.18].

39. Committee on Economic, Social and Cultural Rights. General Comment No. 14:The Rightto the Highest AttainableStandard ofHealth (2000). Available from: https://tbinternet.ohchr.org/_layouts/15/treatybodyexternal/ Download.aspx?symbolno=E\%2fC.12\%2f2000\%2f4\&Lang=en [reviewed 2021.07.29].

40. Hendriks A., Toebes B. Towards a Universal Definition of the Right to Health? Med Law. 1998;17(3):319-332. PMID: 9922624.

41. Meier B. M., Mori L. M. The Highest Attainable Standard: Advancing a Collective Human Right to Public Health. Columbia Human Rights Law Review. 2005;37:101-147.

42. Novick L. F., Morrow C. B. Defining Public Health: Historical and Contemporary Developments. Chapter 1. Available from: https:// samples.jblearning.com/0763738425/38425_CH01_001_034.pdf.

43. Institute of Medicine (US) Committee on Assuring the Health of the Public in the 21st Century. The Future of the Public's Health in the 21st Century. Washington (DC): National Academies Press (US); 2002. PMID: 25057638.

44. Mold A., Clark P., Millward G. et al. The Public and Public Health. In: Placing the Public in Public Health in Post-War Britain, 1948-2012. Cham: Palgrave Macmillan; 2019, p. 7-32.

45. Verweij M., Dawson A. The Meaning of "Public" in "Public Health". In: Dawson A., Verweij M. eds. Ethics, Prevention, and Public Health. Oxford: Clarendon Press; 2007, p. 1330.
46. Allott P. The Health of Nations: Society and Law beyond the State. Cambridge: Cambridge University Press; 2002.

47. Jenkins R. The Health of the Nation: Recent Government Policy and Legislation. Psychiatric Bulletin. 1994;18(6):324-327. doi: 10.1192/ pb.18.6.324.

48. Silberberg M., Martinez-Bianchi V., Lyn M. J. What Is Population Health? Prim Care. 2019;46(4):475-484. doi: 10.1016/j.pop.2019.07.001. Epub 2019 Jul 31. PMID: 31655744.

49. McKenzie J. F., Pinger R. R., Kotecki J. E. An Introduction to Community Health. Sudbury, MA: Jones \& Bartlett Learning; 2012.

50. Committee for the Study of the Future of Public Health. The Future of Public Health. Washington, D.C.: National Academy Press; 1988.

51. Wilson J. The Right to Public Health. J Med Ethics. 2016;42(6):367-375. doi: 10.1136/medethics-2015-103263. PMID: 27030479.

52. Weeks E. L. The Public's Right to Health: When Patient Rights Threaten the Commons. Washington University Law Review. 2009;86(6):13351396.

53. Gostin L. 0. Public Health Law: A Renaissance. J Law Med Ethics. 2002;30(2):136-140. doi: 10.1111/j.1748-720x.2002.tb00379.x. PMID: 12066591.

54. Fidler D. P. International Law and Global Public Health. Spec Law Dig Health Care Law. 2001;261:9-66. PMID: 11211725.

55. Gostin L. 0. World Health Law: Toward a New Conception of Global Health Governance for the 21st Century. Yale J Health Policy Law Ethics. 2005;5(1):413-424. PMID: 15742585.

56. Taylor A. L. Global Health Law: International Law and Public Health Policy. International Encyclopedia of Public Health. 2017;268-281. doi: 10.1016/B978-0-12-803678-5.00238-1. Epub 20160ct 24. PMCID: PMC7150305.

57. Holtzman J. N., Schwartzstein R. M. Health Care in the United States: Individual Right or Government Duty? Acad Med. 2020;95(6):868-871. doi: 10.1097/ACM.0000000000002986. PMID: 31517686.

\section{ORCID and contributionship:}

Yevdokiia J. Streltsova: 0000-0002-7114-1105 C, D, E

Yevgen L. Streltsov: 0000-0002-4418-1275 A, D, E, F

Eduard E. Kuzmin: 0000-0002-9953-8008 A, B,D

\section{Conflict of interest:}

The Authors declare no conflict of interest.

\section{CORRESPONDING AUTHOR Yevdokiia J. Streltsova}

Odesa I. I. Mechnikov National University

Odesa, Ukraine

tel: +380675250652

e-mail:streltsova@onu.edu.ua

Received: 10.07.2021

Accepted: 11.10 .2021

A - Work concept and design, B - Data collection and analysis, C - Responsibility for statistical analysis,

D-Writing the article, $\mathbf{E}$-Critical review, $\mathbf{F}$ - Final approval of the article 


\title{
INTERNATIONAL LEGAL FRAMEWORK FOR PUBLIC HEALTH: FROM ITS ORIGINS TO THE PRESENT DAY
}

DOI: 10.36740/WLek202111217

\author{
Tetiana L. Syroid, Lina 0. Fomina \\ V.N. KARAZIN KHARKIV NATIONAL UNIVERSITY, KHARKIV, UKRAINE
}

\begin{abstract}
The aim: Is to examine the establishment and development of the international legal framework in the field of public health; to identify objects of public health regulation; to outline ways to improve and develop the existing public health standards, taking into account new challenges facing humanity.

Materials and methods: The research is based on the analysis of international agreements of universal and regional levels on public health, and scientific achievements in this field. The methodological basis comprises special and general methods, in particular, dialectical, axiological, formal, and other methods.

Conclusions: The international community makes significant efforts to develop regulations in the field of public health. The emergence of these acts is associated with the emergence of a problem that affects the health of many categories of people, tends to spread rapidly, and results in significant damage to public health. Unfortunately, the objects of regulation of such agreements tend to expand due to the emergence of new challenges to human health, the evolution of diseases, and the factors that determine their occurrence. It is considered necessary to unite the efforts of the world community in order to improve the situation in the field of public health. These efforts should include: greater accession to international agreements in the field of public health; organisation of international cooperation to assist in combating the spread of new diseases, including the development of medicines, vaccines, exchange of best practices in this field, etc.; carrying out preventive medical measures at the national level, educational work among the whole population on the observance of sanitary norms, norms of hygiene, consequences of use of harmful substances (narcotic and psychotropic substances, tobacco, etc.), and so on.
\end{abstract}

KEY WORDS: vulnerable categories of persons, health, medical care, pandemic, preventive measures

Wiad Lek. 2021;74(11 p.2):2959-2965

\section{INTRODUCTION}

The issue of public health, commonly seen as "the art and science of preventing disease, increase life expectancy and promoting health through the organised efforts of society", is constantly on the international agenda due to new challenges, such as the active cross-border spread of a new type of coronavirus infection (COVID-19) and updating of existing challenges and threats, including smoking, drug addiction, HIV, etc. Serious negative effects of climate change on public health are strongly felt around the world, including record-breaking heat waves, severe air, and water pollution, which has led to a resurgence of cholera and endangered clean drinking water and sanitation for more than a billion people worldwide, food shortages and malnutrition as a result of droughts and desertification, disease pandemics, and increasing natural hazards such as floods, hurricanes, and earthquakes [1]. This requires the international community to take certain steps to strengthen the capacity of public health to create conditions in which people can stay healthy, improve their health and well-being, or prevent their health from deteriorating. According to the WHO, public health focuses on the full spectrum of health and well-being, not only on overcoming individual diseases, and involves the provision of personal services to individuals, such as vaccinations, behavioural or medical counselling [2]. The global nature of public health has also been confirmed in separate papers on this issue. In particular, Colin Binns and Wah Yun Low pointed out that public health works to monitor disease outbreaks, both acute and chronic, to prevent injuries and to understand the distribution of risk factors, and that it is global in nature as epidemics, acute or chronic, have no boundaries [3]. Given the above, the international legal regulation of public health issues is urgent, taking into account the current challenges and the global nature of this area.

\section{THE AIM}

The article aim is to study the establishment and development of the international legal framework in the field of public health, its essence and significance, the grounds for preparation and adoption; to identify objects of public health regulation; to outline ways to improve and develop existing public health standards, taking into account new challenges facing humanity and avenues of cooperation in this area.

\section{MATERIALS AND METHODS}

The research are based on the analysis of international agreements of universal and regional levels on public 
health, and scientific achievements in this field. The methodological basis comprises special and general methods, in particular, the dialectical, axiological, and formal methods, etc. The use of the axiological method made it possible to understand the importance of the right to health in the face of modern challenges and threats. The formal legal method is used to analyse the provisions of international instruments on public health. The application of a set of scientific methods together with the principles, as well as modern scientific approaches made it possible to achieve the aim of the study.

\section{REVIEW AND DISCUSSION}

At the present stage of the society development there is no generally accepted and agreed definition of "public health". Existing definitions reflect a variety of contexts and activities in the field of public health. In particular, public health means: something we as a society do together to ensure the conditions in which people can be healthy (Institute of Medicine 1988); the science and art of disease prevention, life extension and health promotion through the organised efforts of society (Faculty of Public Health of the Royal Colleges of the United Kingdom, as cited in Nuffield Bioethics Council Report 2007, p. 6); the movement dedicated to the equitable improvement of the health and well-being of communities with their full participation (World Federation of Public Health Associations as cited in Nuffield Bioethics Council Report 2007, p. 6); the science of protecting and improving community health through education, the promotion of healthy lifestyles, and research on disease and injury prevention (Association of Schools of Public Health USA); assessing public health needs, developing health policies in response to specific community and country health needs and ensuring that conditions contribute to good health, including high-quality health services, water supplies, adequate nutrition, unpolluted atmosphere and environment (World Medical Association 1995); health promotion and prevention of diseases and disabilities; collection and use of epidemiological data, recognition of the multidimensional nature of health determinants with the focus on complex interaction of many factors - biological, behavioural, social and environmental - in the development of effective measures (Childress et al. 2002) [4].

Addressing public health issues, Edlyne Eze Anugwom notes that the empathise should be placed on the social and environmental context of diseases and health problems... improving health through large-scale public initiatives such as vaccination, fluoridation of drinking water, providing easy and available access to medical facilities, and actions such as smoking bans and demonisation of cigarettes. The author identifies main directions or issues of public health such as hygiene and sanitation; epidemiology; environmental factors; disease prevention; and policy/rules that address these issues, etc. [5].

Thus, the definition of public health is usually global in nature and includes various aspects aimed at maintaining and improving health and well-being. This thesis was confirmed in the research of Linda Fried, Margaret Bentley, Pierre Buekens, Donald Burke, Julio Frenk, Michael Klag, who note that global health and public health do not differ - both consider health in terms of physical, mental, and social well-being, rather than simply the absence of disease; they focus on population-based policy as well as individual approaches to health promotion and address the root causes of ill health through a wide range of scientific, social, cultural and economic strategies [6].

It is also worth noting that the issue of public health has received considerable attention in the activities of international organisations since their inception.

Thus, after the establishment of the United Nations and the adoption of the International Charter of Human Rights, the active development of agreements in the field of public health has begun under the auspices of the organisation. Among this category of acts, emphasis should be placed on agreements of a general nature, which determine the application of certain measures to ensure access to medical care, the procedure for providing care, contain targets in the field of medical care, and so on. In particular, the International Health Regulations (IHR), first approved by the fourth session of the World Health Assembly in 1951, IHR of 1969 [7] and had several editions (of 1973 [8] and of 1981 [9] These changes provided for a reduction in the number of diseases covered from six - cholera, plague, yellow fever, smallpox, typhus (spotted fever), relapsing fever to three - yellow fever, plague and cholera; and to reflect the global eradication of smallpox) contained measures to prevent "quarantine diseases" and to ensure measures to preserve public health. In 2005, WHO adopted new IHRs, the purpose, and scope of which are "to prevent and control the international spread of diseases and to take appropriate measures at the level of public health that are proportionate to the risks to public health and limited by them and that do not create additional obstacles for the population and are limited by them and that do not create additional obstacles for international transportation and trade". The application of IHR (2005) is not limited to specific diseases, moreover, the Rules are expected to remain relevant and applicable for many years, even in the context of the long-term evolution of diseases and the factors that determine their occurrence and transmission. The provisions of the IHR update and change many technical and other regulatory functions, including the certificates used in international travel and transport, as well as the requirements for international ports, airports, and land transport hubs [10].

The need for urgent and effective international and national action to develop and implement primary health care worldwide, especially in developing countries in a spirit of technical cooperation and in accordance with the New International Economic Order, was reaffirmed in the provisions of the Almaty Declaration (1978) [11].

The Health-2020 policy framework, adopted by the WHO Member States of the European region in 2012, identified among the main principles and policy priorities: the promotion of good health throughout life as a 
socio-economic imperative; ensuring social justice for health by influencing its social determinants and taking into account the important relationships between health and other social factors; the need to pay special attention to increasing the resilience of local communities to adverse external influences, strengthening their cohesion and creating a supportive social environment; gender mainstreaming in health care practice, etc. [12].

The Ashgabat Declaration on the Prevention and Control of Noncommunicable Diseases in the Context of Health 2020 (2013) emphasised that noncommunicable diseases (NCDs) cause suffering to people and hinder the social and economic development of countries. These diseases are largely preventative, involving four common risk factors (tobacco use, unhealthy alcohol consumption, unhealthy diet, and lack of physical activity) and can remain preventable until the later stages of human life. To this end, several measures set out in the document should be introduced, and the Declaration also sets new targets for reducing tobacco use in order to minimize the burden of NCDs in the European region [13].

Among the categories of specialised acts, there are acts in the field of the response to harm related to drug use and illicit drug trafficking. They pose one of the greatest tasks of social policy nowadays. All aspects of this problem have implications for human rights and date back to the League of Nations, which helped to get under control the trade in opium and other potent drugs that harm human health. Under the auspices of the organisation, many agreements were adopted in this area aimed to protect the health and well-being of people, which provides for full respect for human rights (p.14-15) [14].

Within the framework of the United Nations, the League of Nations line on the development of norms in this area has continued and a set of treaties were concluded, including the Single Convention on Narcotic Drugs (1961) [15], as amended by the 1972 Protocol containing obligations on the parties to take special measures to control drugs; prohibitions on the manufacture, production, export, and import of any such drug, its trade, and storage or use, other than those which may be necessary for medical and research work, including clinical trials conducted under direct supervision and control of a party or subject to such direct supervision and control, etc.; provides for the establishment of control bodies for compliance with the provisions of the agreement. The Convention on Psychotropic Substances (1971) provides for a procedure for coordinated and universal control measures for the use of psychotropic substances in order to combat the abuse of such substances and ensure safety for human health [16]. The United Nations Convention against Illicit Traffic in Narcotic Drugs and Psychotropic Substances (1988) was adopted to promote cooperation between the parties so that they could more effectively address the various issues of illicit trafficking in narcotic drugs and psychotropic substances of an international nature [17]. The Lucknow Accord on the Adoption of Uniform Measures to Control International Trade in Precursors and Other Chemicals
Used in the Illicit Manufacturing of Narcotic Drugs and Psychotropic Substances (1999) provides for measures to be taken by states to ensure uniformity of controls on international trade in all substances included in Table I of the 1988 UN Convention against Illicit Traffic in Narcotic Drugs and Psychotropic Substances, as well as the international trade in acetic anhydride and potassium permanganate listed in Table II; determines the procedure for exercising such control [18]. The International Convention against Doping in Sport (2005) provides for assistance in preventing and combating doping in sport in order to eradicate it. To achieve the objectives of the Convention, states parties undertake appropriate measures at the national and international levels in accordance with the principles of the World Anti-Doping Code (2003); encourage all forms of international cooperation aimed at ensuring the protection of athletes, adherence to ethical principles in sport and the sharing of research results; promote international cooperation between states parties and leading anti-doping organisations in sport, in particular cooperation with the World Anti-Doping Agency (Article 3) [19].

In 2012, the UN Office on Drugs and Psychotropic Substances together with the WHO developed International Standards for Drug Prevention, which summarise available scientific data describing interventions and policies that, according to research, provide positive prevention results. In addition, they identify the main components and characteristics of an effective national drug prevention system [20].

In 2016, the final document of the UN General Assembly Special Session on the World Drug Problem "Our Joint Commitment to Effectively Address and Combat the World Drug Problem" provided a number of operational recommendations for reducing demand and related measures, including prevention and medical treatment, as well as other health care issues [21].

The International Guidelines on Human Rights and Drug Policy, approved in 2019, contains comprehensive international legal standards to determine human condition, their dignity, and sustainable development, as well as the impact of drug trafficking on the economies of member states. The Guidelines covers a wide range of key issues, from development to criminal justice and public health [22].

The 2019 Ministerial Declaration "Intensify our activities at the national, regional and international levels in order to accelerate the implementation of our joint commitments to address and combat the global drug problem" contains a commitment to ensure future existence; to ensure that none of the people affected by the global drug problem is overlooked; intensify efforts to address gaps in response to existing and emerging trends and challenges by taking balanced, comprehensive and evidence-based measures to address the global drug problem with the focus on security, health and well-being of the society, especially young people and children, at the centre of these efforts [23].

Summarising the above, it should be noted that, despite the development of legal instruments and institutional mechanisms for drug control (Commission on Narcotic 
Drugs of the Economic and Social Council and the International Narcotics Control Board (INCB) established under the 1961 Single Convention on Narcotic Drugs), according to INCB statistics, as of 2018, problems exist in many regions of the world. Thus, Africa is a major transit region in the structure of drug trafficking, as well as a growing drug market. The most widespread is the illicit trafficking of cocaine, heroin, and cannabis, although the trafficking of each of them has its own characteristics.

HIV and AIDS are global public health problems. Gilbert L. notes that HIV/AIDS, especially in high-impact countries such as South Africa, challenges traditional perceptions of public health and the role of health workers. The HIV/AIDS crisis, in particular, the pressure it has put on the health care system and medical workers, requires new appropriate measures [24].

Thus, sexually transmitted infections (STIs) have a profound effect on sexual and reproductive health around the world. According to the WHO, there are more than 1 million cases of infection every day. In 2016, there were 376 million cases of infection with one of the four STIs: chlamydia (127 million), gonorrhoea (87 million), syphilis (6.3 million), and trichomoniasis (156 million). More than 500 million men live with genital HSV infection (genital herpes), and about 300 million women are infected with HPV, the leading cause of cervical cancer. It is estimated that about 240 million people worldwide live with chronic hepatitis B [25].

Among the acts approved in this area are the Political Declaration on HIV and AIDS: Intensifying Our Efforts to Eliminate HIV and AIDS (2011), which contains commitments to intensify comprehensive global action against HIV and AIDS; redoubled efforts to prevent HIV infection; intensifying efforts that will increase the life expectancy and quality of life of all people living with HIV; step up efforts to ensure access to antiretroviral (ARV) treatment for everyone in need; ensuring the protection of human rights in order to eliminate stigma, discrimination, and violence related to HIV; providing resources for measures to combat AIDS, etc. [26].

The Global Health Sector Strategy for Sexually Transmitted Infections 2016-2021: Towards the Elimination of STIs [27] sets out actions to be taken by states and WHO to accelerate and intensify efforts to combat STIs aimed at making progress towards the eradication of this epidemic. The draft strategy addresses the health sector's response to the STIs epidemic as an important condition for achieving universal health coverage - one of the key health-related goals of sustainable development, which are set out in the 2030 Agenda for Sustainable Development. Adoption of the strategy and its implementation will dramatically reduce the number of new STIs and mortality due to these infections (including stillbirth and cervical cancer) while improving the health of individuals, the sexual health of men and women, and the well-being of all people. The strategy serves as a guide for the accelerated use and targeted use of comprehensive prevention measures by expanding the application of various behavioural, biomedical, and structural approaches based on evidence; promote public access to information about their status regarding STIs; improve access to treatment and, if necessary, comprehensive long-term care; help to overcome the widespread practice of stigma and discrimination. The draft strategy promotes a needs-based and people-centred approach based on the principles of human rights, gender equality, and health equity.

The Global Health Sector Strategy on HIV 2016-2021 [28] builds on the impressive progress made by public health in the global fight against HIV since the WHO launched the Special Health Program in 1986, AIDS programs. It reinforces the impetus given by the Millennium Development Goals set out in the Millennium Declaration and the commitment to universal access. To end the AIDS epidemic, the rapid response needs to be accelerated rapidly over the next five years, and then action needs to be taken on an ongoing basis until 2030 and beyond. HIV interventions approved by the health sector have a key role to play in addressing one of the most important health goals of the Sustainable Development Goals - achieving universal health coverage. A needs-based and people-centred approach based on human rights and health equity is promoted. The strategy helps sharply reduce the number of new HIV infections and HIV-related deaths, as well as improve the health and well-being of all people living with HIV.

Tobacco consumption is a significant threat to public health. Thus, Gupta Prakash noted that the growing epidemic of tobacco mortality continues, despite a large amount of knowledge about it based on tens of thousands of original research and scientific articles. Discussing the effects of tobacco use on public health is topical and important... as tobacco products are carefully designed to undermine smoking cessation efforts, and smoking cessation is not just a matter of choice for most tobacco users, but also a fight against it. Tobacco use is usually part of daily life and can provide physiological, psychological, and social support... Danish Saleheen, Wei Zhao, Asif Rasheed also pointed out that cigarette smoking, the predominant form of tobacco consumption worldwide, is one of the strongest lifestyles associated with the risk of heart disease. With this in mind, there is a strong need for comprehensive and multi-level public health strategies, including laws banning smoking, tobacco taxation policies, limiting the impact of the tobacco industry on health policies, bans on direct and indirect methods of tobacco promotion, and the implementation of international treaties, such as WHO FCTC, the MPOWER [29].

To this end, several acts aimed at reducing tobacco use have been adopted within international organisations. In particular, the Framework Convention on Tobacco Control is the first WHO document in the field of public health (2003), which aims to protect current and future generations from the devastating effects on human health and the social, environmental, and economic consequences of tobacco consumption and exposure to tobacco smoke by providing appropriate criteria for tobacco control mea- 
sures to be implemented by the parties at the national, regional and international levels in order to continuously and significantly reduce the prevalence of tobacco use and exposure to tobacco smoke [30].

In September 2015, the Roadmap was adopted in pursuance of the provisions of the Framework Convention on Tobacco Control (2003) to strengthen measures to implement the WHO Framework Convention on Tobacco Control in the European region for 2015-2025, which allows future generations to leave tobacco in the past. It contains measures to achieve the greatest effect in certain areas of regulation in this field, including a ban on smoking in places that cater to children, a ban on tobacco advertising, awareness-raising on the dangers of smoking, etc. [31].

Since the advent of COVID-19, the United Nations has made significant efforts to combat the disease, which has claimed hundreds of thousands of lives, damaged the health of millions of people, accelerated the global economic downturn, and raised fears for the future. The COVID-19 pandemic is a crisis not only in the health sector but also in the economic, humanitarian, security, and human rights sectors. The crisis has marked shortcomings and inequalities within and around the world. The way out of the crisis is provided by the collective efforts of governments, communities, and the entire population of the world based on the principles of humanity and solidarity as evidenced by international acts of a universal nature.

From the very beginning of the pandemic, the UN has been implementing a three-component response strategy. The first provides for the implementation of large-scale, coordinated, and comprehensive health response measures taken under the auspices of the WHO and in accordance with the Strategic Preparedness and Response Plan [32]. As part of these activities, the United Nations has been supporting efforts to accelerate the development and production of accessible and universal vaccines against COVID-19 and its diagnostic and treatment tools.

The second component is a large-scale effort to address the devastating socio-economic and humanitarian consequences of the crisis and its impact on the human rights situation, aimed at rescuing people, providing access to livelihoods, maintaining households, maintaining business solvency and the functioning of production chains, strengthening institutions and providing public services with an emphasis on mandatory respect for human rights. As part of these efforts, operational humanitarian responses are being taken to support the most vulnerable groups in the most vulnerable countries by providing vital assistance under the Global Humanitarian Response Plan, which sets out priorities for responding to COVID-19 in vulnerable and poor countries [33].

The third component is the recovery procedure, which helps states emerge from the current crisis in a sustainable fashion. In the process of overcoming this crisis, states have the opportunity to address the problems associated with the climate crisis, inequality, social exclusion, shortcomings in social protection systems, and many other shortcomings and manifestations of injustice. Instead of returning to unsustainable systems and approaches, the focus is on the transition to renewable energy and sustainable food systems, achieving gender equality, strengthening the social protection network, and ensuring universal access to health care.

The issue of countering the pandemic is in the focus of the UN Secretary-General. Thus, in June 2020, in his report, the UN Secretary-General launched the UN Plan of Action "United Nations Comprehensive Response to COVID-19: Saving People, Protecting Society, Better Recovery", which focuses on three main areas: large-scale, coordinated, and comprehensive health activities; taking policy measures to address the socio-economic, humanitarian and human rights issues that have arisen as a result of the pandemic; the recovery process in order to make better than it has ever been [34]. The UN Secretary-General's updated report on the comprehensive UN response to COVID-19, the UN Plan to Save Lives, Protect Communities, and Recover Better (September 2020), contains data analysis, policy recommendations, and an overview of measures used by UN agencies in response to the impact of COVID-19 on the health sector, socio-economic life, humanitarian assistance, and human rights protection [35].

\section{CONCLUSIONS}

Given the above, it should be noted that the international community since the League of Nations has made significant efforts to develop regulations in the field of public health. The emergence of these acts is associated with the emergence of a particular issue that affects the health of many categories of persons, tends to spread rapidly, and results in significant damage to public health, including vulnerable categories such as women and children, who constitute the basis of the gene pool of any nation. It should be noted that, unfortunately, the objects of regulation of such agreements tend to expand due to the emergence of new challenges to human health, the evolution of diseases, and the factors that determine their occurrence. Thus, in the XIX-XX centuries, this was drug and tobacco addiction, HIV, while the XXI century is marked by the emergence of the COVID-19 pandemic. In order to improve the situation in the field of public health, it is necessary to unite the efforts of the world community as a whole and actively involve each state in this process without exception, as these issues that require joint decision-making are relevant and have negative consequences for all states. These efforts should include: greater accession to international agreements in the field of public health; organisation of international cooperation to assist in combating the spread of new diseases, including the development of medicines, vaccines, exchange of best practices in this field, etc.; carrying out preventive medical measures at the national level, educational work among the whole population, focusing on vulnerable groups of the population regarding compliance with sanitary norms, hygiene standards, consequences of the use of harmful substances (narcotic and psychotropic substances, tobacco), etc.; active use for the treatment and 
prevention of information and communication technologies with mandatory observance of the right to confidentiality; introduction of volunteer assistance to needy persons, persons left without care (e.g., migrants, older people, single people, the disabled, etc.), in the event of the spread of mass epidemics; training of qualified medical staff. The implementation of preventive, curative, quarantine, and other measures in the field of public health should be based on an approach focused on the principles of respect for human rights and justice in the field of health.

\section{REFERENCES}

1. Weiss-Randall Debra. Impacts on Public Health. In: Research Anthology on Public Health Services, Policies, and Education. 2021; 647-672. doi:10.4018/978-1-7998-8960-1.ch030.

2. WHO Public health services. URL: https://www.euro.who.int/en/healthtopics/Health-systems/public-health-services.

3. Binns Colin, Low Wah Yun. What Is Public Health? Asia-Pacific journal of public health. 2015;27:5-6. doi:10.1177/1010539514565740.

4. The UW Dept. of Bioethics \& Humanities Public Health Ethics. URL: https://depts.washington.edu/bhdept/ethics-medicine/bioethicstopics/detail/76.

5. Anugwom Edlyne. Public Health Afflictions and Challenges in the Developing World. In: Public Health in Developing Countries Challenges and Opportunities. 2020. doi:10.5772/intechopen.93145.

6. Fried LP, Bentley ME, Buekens P, Burke DS, Frenk JJ, Klag MJ, Spencer HC. Global health is public health. Lancet. 2010. 13;375(9714):535-7. doi: 10.1016/S0140-6736(10)60203-6. PMID: 20159277

7. Ofitsialnyie otchetyi VOZ [WHO Official Records], № 176, 1969, Rezolyutsiya [resolution] WHA22.46, Prilozhenie [Annex] I. (Ru).

8. Ofitsialnyie otchetyi VOZ [WHO Official Records], № 209, 1973, Rezolyutsiya [resolution] WHA26.55. (Ru).

9. Dokument [Document] WHA34/1981/REC/1, rezolyutsiya [resolution] WHA34.13; Ofitsialnyie otchetyi VOZ [WHO Official Records], № 217, 1974, rezolyutsiya [resolution] WHA27.45, rezolyutsiya [resolution] EB67.R13: Popravka k Mezhdunarodnyim mediko-sanitarnyim pravilam [Amendment to the International Health Regulations](1969) (Ru).

10. International health regulations (2005). Available from: https://www. who.int/publications/i/item/9789241580496.

11. Declaration of Alma-Ata.URL: https://cdn.who.int/media/docs/defaultsource/documents/almaata-declaration-en.pdf?sfvrsn=7b3c2167_2.

12. Health 2020 - A European policy framework and strategy for the 21st century. Copenhagen: WHO Regional Office for Europe, 2013. Available from: https://www.euro.who.int/__data/assets/pdf_ file/0011/199532/Health2020-Long.pdf.

13. AshgabatDeclaration on the Prevention and Control of Noncommunicable Diseases in the Context of Health 2020. Available from: https://www. euro.who.int/_data/assets/pdf_file/0003/253506/64wd11_ AshgabatDeclarati onCovered_140455.pdf.

14. Syroid T.L. Mizhnarodnyi zakhyst prav liudyny: navch. posib [International protection of human rights] / T.L. Syroid, L.O. Fomina. Kharkiv : Pravo, 2019. 310. (Ua).

15. Single Convention on Narcotic Drugs, 1961, as amended by the Protocol amending the Single Convention on Narcotic Drugs. Available from: https://treaties.un.org/doc/Treaties/1975/08/19750808\%2006-05\%20 PM/Ch_VI_18p.pdf.

16. Convention on psychotropic substances. Available from: https://www. unodc.org/pdf/convention_1971_en.pdf.
17. United Nations Convention against illicit traffic in narcotic drugs and psychotropic substances. URL: https://www.unodc.org/pdf/ convention_1988_en.pdf.

18. Lucknow accord on the adoption of uniform measures to control international trade in precursors and other chemicals used in the illicit manufacture of narcotic drugs and psychotropic substances. URL: https:// www.unodc.org/unodc/en/Resolutions/resolution_1999-07-28_2.html.

19. International convention against doping in sport. Available from: https://unesdoc.unesco.org/ark:/48223/pf0000142594.page $=2$.

20. International standards on drug use prevention. Available from: https://www.unodc.org/documents/prevention/UNODC_2013_2015_ international_standards_on_drug_use_prevention_E.pdf.

21. Our joint commitment to effectively addressing and countering the world drug problem. URL: https:// undocs.org/en/A/RES/S-30/1.

22. International guidelines on human rights and drug policy. Available from: https://www.unaids.org/ru/resources/presscentre/ pressreleaseandstatementarchive/2019/march/20190315_guidelineshuman-rights-drug-policy.

23. 2019 Ministerial declaration on strengthening our actions at the national, regional and international levels to accelerate the implementation of our joint commitments to address and counter the world drug problem. Available from: https://www.unodc.org/documents/commissions/ CND/2019/Ministerial_Declaration.pdf.

24. Gilbert L. Public health and health professionals in the times of HIV/ AIDS. South African Review of Sociology. 2008;39(2):301-316. doi:10 $.1080 / 21528586.2008 .10425093$.

25. Infektsii, peredavaemyie polovyim putem (IPPP) [Sexually Transmitted Infections]. Available from: https://www.who.int/ru/news-room/ factsheets/detail/sexually-transmitted-infections-(stis). (Ru).

26. Political Declaration on HIV/AIDS: intensifying our efforts to eliminate HIV/AIDS. Available from: https://www.unodc.org/documents/ southeastasiaandpacific/2012/02/hlm-hiv/20110610_UN_ARES-65-277_en.pdf.

27. Global health sector strategy on Sexually Transmitted Infections, 20162021: towards ending STls. URL: http://apps.who.int/iris/bitstream/ handle/10665/246296/WHO-RHR-16.09-eng.pd? sequence $=1$.

28. Global health sector strategy on HIV 2016-2021: towards ending AIDS. Available from: http://apps.who.int/iris/ bitstream/handle/10665/246178/WH0-HIV-2016.05-eng. pdf?sequence $=1$ \&isAllowed $=\mathrm{y}$.

29. Danish Saleheen, Wei Zhao, Asif Rasheed. Epidemiology and Public Health Policy of Tobacco Use and Cardiovascular Disorders in Low- and Middle-Income Countries. Arteriosclerosis, Thrombosis, and Vascular Biology. 2014;34:1811-1819. doi: 10.1161/ATVBAHA.114.303826.

30. WHO Framework Convention on Tobacco Control. Available from: http://apps.who.int/iris/bitstream/handle/10665/42811/9241591013. pdf? sequence $=1$.

31. Making tobacco a thing of the past: Roadmap of actions to strengthen implementation of the WHO Framework Convention on Tobacco Control in the European Region 2015 - 2025. Copenhagen: WHO Regional Office for Europe, 2015. Available from: https://www.euro.who.int/_data/assets/ pdf_file/0005/297563/WHO-Roadmap-report-tobacco-control-15-25-en.pdf.

32. 2019 Novel Coronavirus (2019nCoV): Strategic preparedness and response plan. Available from: https://www.who.int/docs/defaultsource/coronaviruse/srp-04022020.pdf.

33. Global humanitarian response plan COVID-19. Available from: https:// www.unocha.org/sites/unocha/files/GlobalHumanitarian-ResponsePlan-COVID-19.pdf. 
34. United Nations Comprehensive Response to COVID-19: Saving Lives, Protecting Societies, Recovering Better. Available from: https://www. un.org/sites/un2.un.org/files/un_comprehensive_response_to_ covid-19_june_2020.pdf.

35. United Nations Comprehensive Response to COVID-19 Saving Lives, Protecting Societies, Recovering Better September 2020. Available from: https://www.un.org/sites/un2.un.org/files/un-comprehensiveresponse-to-covid-19. pdf.

\section{ORCID and contributionship:}

Tetiana L. Syroid: 0000-0002-8165-4078 A, B, D, E, F

Lina O. Fomina: 0000-0002-8756-4006 ${ }^{\text {B, D, F }}$

\section{Conflict of interest:}

The Authors declare no conflict of interest.

\section{CORRESPONDING AUTHOR}

Tetiana L. Syroid

V. N. Karazin Kharkiv National University

Kharkiv, Ukraine

tel: +380677042283

e-mail:syroid02@gmail.com.

Received: 08.07.2021

Accepted: 15.10 .2021

A - Work concept and design, B - Data collection and analysis, C - Responsibility for statistical analysis, D-Writing the article, $\mathbf{E}$-Critical review, $\mathbf{F}$ - Final approval of the article 


\title{
COVID-19 PANDEMIC CONSEQUENCES: CLASSIFICATION ISSUES
}

D0l: $10.36740 /$ WLek202111218

\author{
Viacheslav I. Borysov, Maxim G. Kolodyazhny, Daryna P. Yevtieieva \\ ACADEMICIAN STASHIS SCIENTIFIC RESEARCH INSTITUTE FOR THE STUDY OF CRIME PROBLEMS OF THE NATIONAL ACADEMY OF LEGAL SCIENCES \\ OF UKRAINE, KHARKIV, UKRAINE
}

\begin{abstract}
The aim: The aim of the research is to group the consequences of the COVID-19 pandemic according to different criteria, which will clarify their scope, determine diversity, and, if necessary, take measures for further prevention.

Materials and methods: The empirical basis of the study is the official statistics of the survey of citizens (2,388 people) and specialists in the field of economics and finance (116 people). The research methods were classification, questionnaire, statistical, analysis, and content analysis.

Conclusions: The COVID-19 pandemic was classified according to a number of criteria; its significance for theory and practice in all its manifestations is outlined.
\end{abstract}

KEY WORDS: pandemic, COVID-19, consequences, classification

Wiad Lek. 2021;74(11 p.2):2966-2971

\section{INTRODUCTION}

Acute respiratory disease COVID-19, caused by the coronavirus SARS-CoV-2, in a short time became a pandemic and spread to all world regions. The pandemic consequences are different in nature and permeate all spheres of public life. Now there is an urgent need for a comprehensive study of such consequences, which is based on their classification. Although some pandemic effects and their groups have already been analyzed in science, not enough attention has been paid to their classification.

\section{THE AIM}

The research aims to group the consequences of the COVID-19 pandemic according to different criteria, which will clarify their scope, determine diversity, and, if necessary, take measures for further prevention.

\section{MATERIALS AND METHODS}

The empirical basis of the study is the official statistics of the survey of citizens (2,388 people) and specialists in the field of economics and finance (116 people). The research methods were classification, questionnaire, statistical, analysis, and content analysis. As for the classification as the main method of this research, it is worth noting that it is most often used as a scientific method by which the division of the whole (generic concept) depends on the chosen criterion into parts (species, classes, groups) [1]. Thus, under classification, it is understood both processes and results. As some researchers rightly point out, classification is a category that reflects the obvious and is understandable to everyone, and at the same time, it is extremely rich and ambiguous. For these reasons, theoretical and practical foundations of classification are still insufficiently studied [2]. This provision can be attributed to the classification of consequences of acute respiratory disease COVID-19 caused by the coronavirus SARS-CoV-2.

\section{REVIEW AND DISCUSSION}

First of all, it is necessary to define the concept of the pandemic consequences, for which a broad and narrow meaning should be distinguished. In the first interpretation, this concept can be understood as a result caused by the spread of epidemics (pandemics), and in the narrow sense, it is proposed to define as a set of phenomena (processes) caused by the spread of epidemics (pandemics) for some persons, legal entities, society and state (direct consequences), as well as activities on the part of the latter to prevent the spread of such diseases and their concomitant phenomena (indirect consequences).

In classifying these consequences, one should take into account the general philosophical position that cause and effect are related categories of dialectics, organically related to each other; the consequence is the result of cause action and always includes a new meaning that was not in the cause. The causal relationship that exists between these categories suggests that: cause in time precedes consequence; the cause under specific conditions necessarily gives rise to consequence or several consequences; cause and effect interact; interaction of cause and effect is influenced by appropriate conditions; the same phenomenon, on the one hand, acts as a cause, and on the other - as a consequence [3]. 
For classification of the consequences of acute respiratory coronavirus disease COVID-19, it is necessary to select the appropriate criteria that will form the basis of their division into species. Without claiming to be complete and definitive, the consequences of the COVID-19 pandemic are proposed to be classified according to several criteria, following the rules of division adopted in logic: the division must be proportionate, continuous, and exhaustive; carried out only on one basis; members of the division must be mutually exclusive [4]. We consider it possible to get the following criteria to get a more or less complete picture of the COVID-19 pandemic consequences: the scale of the disease spread; the amount of damage caused to humanity; nature of damage; the most vulnerable spheres of public life; the nature of the consequences impact on the spheres of public life; the degree of restriction of human rights and freedoms.

It is possible to choose other criteria for dividing the pandemic consequences into components, which will allow obtaining other differentiation of consequences depending on the task of research (for example, criteria that reflect the pandemic medical aspect). In our case, the selected criteria allow us to see the phenomenon both in socio-global dimension (scale, amount of damage, etc.) and subject-professional (allocation within the social life of Ukraine is the socio-legal and criminological consequences).

1. The disease scale. Typically, this criterion distinguishes the global, regional, national, and local levels. A feature of the current coronavirus disease is its global nature. It endows it the status of a pandemic, as it is widespread in many countries around the world, covering large areas. At the first stage of its official spread in November 2019 in Wuhan (People's Republic of China), the disease was local, then regional, and finally global. As of early October 2021, the coronavirus has spread to 221 countries. Only 13 countries or territories have not been diagnosed with the disease. These are mostly island nations located in the Pacific Ocean [5].

2. According to the damage amount caused to humanity, the COVID-19 pandemic consequences can be divided into global (basic, significant) and non-global (concomitant, insignificant). The global ones undoubtedly include the death of 4.8 million people (as of the beginning of October 2021) [5], the reduction of world GDP in 2020 by $3.5 \%$ [6], which led to the global world economic and financial crises due to the introduction of lockdowns and other quarantine measures. In a sense, the significant consequences are a change in the nature of human development and the pace of radical transformations of the social sphere (change of social practices, behavior, forms of work, leisure, social communication, habits, etc.).

Concomitant consequences include other, less significant changes in social reality: non-lethal morbidity; cash costs for treatment; losses due to restrictions on business activities, etc.

3. According to the damage nature, the consequences are divided into tangible and intangible ${ }^{1}$.

Among the material are physical and property. The physical consequences are the death of more than 4.8 million people worldwide in just one and a half years [5], various disease complications, which sometimes cause disability, limited physical activity due to self-isolation. The property consequences are government spending on a set of measures to combat COVID-19, citizens' expenses for treatment, recovery from illness, the burial of relatives who died of the disease. Such consequences, it seems, can also include not only direct losses but also the so-called lost profits. In particular, with the introduction of quarantine at enterprises, institutions, and organizations of the country there were mass layoffs, forced referral of citizens on leave without pay, which led to leaving citizens without proper earnings and an overall decline in the economic development of the enterprise (institution, organization) and the state as a whole.

Intangible consequences include stigmatization of citizens with COVID-19, their moral suffering, including loss of work or forced leave, frustration, family tensions (eg, increasing domestic violence), and others.

4. In the spheres of public life it is possible to distinguish: economic, political, spiritual and social consequences ${ }^{2}$.

The economic consequences are economic decline, reduction of expenditures on important areas of public policy, rising prices for specific groups of goods, accelerating inflation, return of millions of workers from abroad, temporary suspension of enterprises and industries, freezing the tourism business, limiting services, termination of flights; reduced investment, additional external credit borrowing, the crisis in the banking sector, the need to allocate a fund to combat the pandemic, the allocation of funds to support businesses and employees during the lockdown.

The political consequences include: aggravation of the political struggle within the state against the background of criticism of the shortcomings of the government or government officials in the organization of anti-epidemic measures and restrictions on certain human rights and freedoms, closing borders; tension in interstate relations between some countries, accusations of states in connection with the appearance in them and the spread outside them of coronavirus, its strains.

Manifestations of spiritual consequences are: infodemia ${ }^{3}$, other types of misinformation in connection with the causes and spread of coronavirus, methods of treatment, disease consequences; changes in the organization of education, the bias towards distance education - forced, but not entirely effective; restriction of cultural events and flow of cultural life to the Internet; curtailment of sports competitions or weakening of their preparation.

Examples of social consequences are: increased mortality, complications from the disease, poverty, alcoholism, drunkenness, crime, drug addiction, closure of institutions (industries, institutions, organizations), unemployment, mass self-isolation, fear of vaccination for various reasons, the emergence of various phobias, exacerbation of suicidal tendencies, aggression, psychological isolation, feelings of loneliness and the growth of general mental disorders [10], the formation of mass distrust of official information, exacerbation of stress, the accumulation of collective anxiety $[11 ; 12]$ and so on. 
Based on a broad interpretation of the social sphere, in characterizing the social consequences, we consider it necessary to pay special attention to the classification of its varieties, such as socio-legal and criminological consequences of the pandemic, in particular, in Ukraine.

Socio-legal consequences can be divided into areas of their manifestation, in particular, the consequences related to the medical and epidemiological sphere (for example, providing citizens with free vaccination), economic sphere (for example, providing borrowers who have experienced financial difficulties due to quarantine measures), credit vacations in banks, legal sphere (for example, changes in the legislation on the regulation of the behavior of citizens during quarantine, strengthening of legal responsibility for violation of quarantine rules), spiritual and cultural sphere (for example, the introduction of restrictions on attending cultural events, sports competitions, tourist travel), etc.

Criminological consequences of social significance can be divided into negative and positive. The negative ones include an increase in the level of some mercenary criminal offenses, domestic violence $(+207.3 \%)$, and computer crimes, usually directed against property, in Ukraine during the first 9 months of 2020 compared to the same period in 2019,4\%) [13], an increase in the number of cases of vandalism, looting, hooliganism, especially at night [14]. Among the positive ones is the (official) decrease in the general level of indicators of criminally illegal encroachments during quarantine [15], for example, the reported thefts' quantity in Ukraine in 2020 decreased by $46.2 \%$ compared to the number of such acts in 2019.

By their nature, criminological consequences can be divided into those related to the actual criminal conduct (see the previous paragraph, as well as, in particular, the increase in the number of criminal offenses committed in a state of intoxication), as well as those related to its background phenomena (increasing the degree of alcoholism of the population, manifestations of spontaneous aggression, exacerbation of suicidal tendencies [16], etc.).

The selected consequences are the most informative, as they provide an opportunity to see all the variety of transformations that occurred after the conditional moment of non-return in the form of the appearance of the so-called zero-patient with coronavirus. Since then, the world has virtually changed beyond recognition, many new social practices have emerged, the movement toward a digital society has intensified, and some forms of social behavior that have taken place have been forgotten (or frozen or substantially diminished).

6. According to the impact nature of consequences on the public life spheres (social and other spheres) they can be divided into negative, positive, mixed (positive-negative) and conditionally neutral.

Most of the pandemic consequences, as seen from the analysis of the above classification groups, are negative. It manifests itself in human deaths, deteriorating health (officially 235.8 million people worldwide have been diagnosed with coronavirus [5]), development of so-called post-covid syndromes in humans, and colossal economic and financial losses. The moral damage of the dead victims' and sick's relatives themselves cannot be translated into money at all. Particularly obvious negative consequences were manifested in the medical and epidemiological sphere, in particular, it is a crisis of medical care (overcrowding of hospitals, lack of medical staff (qualified physicians), lack of personal protective equipment and antiseptics, medical equipment for critically ill, crisis management system response to modern epidemic (pandemic) threats, disease mutation, which led to the emergence of several thousand strains [17].

At the same time, it should be acknowledged that, as paradoxical as it may sound, the pandemic also has specific positive aspects. Thus, in the above-mentioned medical and epidemiological sphere there was a development of the culture of citizens' daily hygiene; creation of vaccines against coronavirus; actualization of public health issues; changing the system of sanitary and epidemiological surveillance bodies in Ukraine and improving their activities. In addition, the disease has accelerated the development of information technology, intensified the process of digitalization, as evidenced by the transition of Ukraine from 24.08.2021 to a new mode of operation of public authorities and local government - paperless [18]. This can be called one of the elements of the innovative system E-government, which provides for the communication of government agencies using modern information technology and which is expected to save huge budget funds. However, the main advantage of this approach is to change the psychology of the modern official to increase the virtue of its activities, promptitude, and transparency of decision-making.

In other areas, there are also positive effects from the pandemic effects: in the economy (introduction of digital tools for shaping the digital economy of the future); in the financial sphere (increasing demand for non-cash financial services by the population); on transport (development of unmanned vehicles using artificial intelligence technologies); in education (introduction of sustainable distance learning systems), etc.

Mixed, i.e. those that provide both positive and negative aspects, include such a consequence as, in particular, the transition to distance learning, which, in turn, led to the development of distance learning services, saving time for participants in the educational process, significant cost savings educational institutions for utilities (positive) and at the same time deterioration of education quality, restriction of direct communication of applicants with teachers, lack of professional practices (for example, in the field of medical education) and communication skills (negative).

Conditionally neutral consequences can be considered the transformation of leisure of citizens in quarantine (reduction of visits to public entertainment venues, restaurants, increase the hours of rest at home, away, in nature).

The multiplicity of pandemic consequences according to the considered criterion is confirmed by the surveys' respondents of citizens and experts. Thus, citizens (a total of 2,388 people) when asked about the benefits of quarantine in Ukraine and the world due to the spread of the COVID-19 pandemic pointed to: 
- promoting the development of communication through digital technologies - 41.9\%;

- digitalization of macro- and microeconomics (development of IT sphere, an increase of online sales) - 35.9\%;

- benefits related to educational activities (opening of online access to library funds, open lectures of scientists in the online format, etc.) $-32.9 \%$;

- development of the cultural sphere (online museum expositions, access to broadcast performances of world theaters and concerts of world-famous groups, video format of communication with artists and cultural figures) $-13.8 \%$.

Also among such advantages the interviewed citizens singled out: improvement of the state of ecology; paying more attention to self-education and self-employment; reassessment of human values, etc. [19: 4-26].

Similar answers with the selection of certain positive or neutral trends of the pandemic period of social reality were provided by the surveyed experts in the field of economics and finance (a total of 116 people). In particular, when asked about the defining crisis features experienced by the world economy in connection with the pandemic of acute respiratory disease COVID-19, respondents pointed out, among other things, the following:

- change of values;

- change in consumer lifestyle;

- restructuring of the economy to new conditions;

- development of digital technologies;

- growth of revenues of the pharmaceutical industry;

- introduction of new remote forms of labor and educational activities, etc. [19: 60].

According to this group of respondents, there are specific sectors in the Ukrainian economy that even found themselves in a favorable situation during the COVID-19 pandemic: pharmaceuticals (32.8\%); IT sphere (21.6\%); services, including delivery (20.7\%); retail (17.2\%); medical industry (15.5\%); food industry (15.5\%) and others [19:65].

The selection of different nature of the consequences of this criterion is confirmed in studies conducted by foreign scientists [20].

7. According to the degree of restriction of human rights and freedoms, it is possible to distinguish the consequences of the high, medium, or low degree. The first group includes countries where a long lockdown was introduced, a curfew was imposed, a total ban on travel without emergency was provided, and fines for violating quarantine requirements were significantly increased (Italy, Spain, Turkey, Great Britain, France, Belgium, Greece, Hungary, etc.). The second group includes countries, including Ukraine, where there have been relatively non-strict quarantine restrictions: a partial or short-term ban on transportation, relatively little liability for violating quarantine requirements, especially for individuals. The third group of countries includes those where the fight against coronavirus occurs almost imperceptibly (usually in the early stages of the disease), due to the high level of self-awareness and responsibility of citizens and the timely adoption of other anti-epidemic measures (Sweden).
It should be emphasized that, despite the various degrees of restriction of human rights and freedoms, the procedure for applying such restrictions is (should be) carried out only within a clear legal form and meet the stated purpose of such a restriction. The use of any coercion necessary to combat the COVID-19 pandemic must strike a balance between human rights and freedoms, on the one hand, and the need to carry out, in the interests of society as a whole, the task of combating a dangerous disease, on the other. Such a requirement follows from both acts of international law and constitutional norms of national legislation.

The consequence of the COVID-19 pandemic, such as the mass morbidity of the population, needs a separate allocation. This consequence can be classified:

- by the disease nature (severe, moderate, mild);

- on the manifestation of symptoms (symptomatic, asymptomatic);

- by treatment method: official (protocol), informal (self-treatment).

These classifications, as well as each of them, are a cognitive basis for in-depth study of the COVID-19 pandemic effects and, in addition, are a sufficient basis for further bias of those that pose a danger not only to public health but also that It is important to emphasize for the national security of Ukraine as a whole.

\section{CONCLUSIONS}

Classification of the COVID-19 pandemic consequences is important for both theory and practice in all its manifestations, which is expressed in:

a) clarification in general terms of the essence of classification as a universal scientific method;

b) knowledge of a wide range of transformations of social and other phenomena and processes that have occurred as a result of COVID-19 disease spread;

c) a deeper study of the coronavirus disease essence itself, consequences of which are not limited to the epidemic and medical aspects of social reality;

d) recognition of the fact of the emergence at the global level of a new condition (pandemic), which has significantly accelerated the transition of humanity in general and Ukrainian society in particular to singularity ${ }^{4}$ state, due to which our world will no longer be as before;

e) updating the consideration of the multiplicity of post-pandemic social changes to develop an effective state policy aimed at reducing human losses, socio-economic losses, creating a favorable legal environment, and ensuring the epidemic well-being of the population of Ukraine.

\section{REFERENCES}

1. Panov M., Kharytonov S. Kryminalne pravoporushennia: poniattia ta yoho vydy [Criminal offense: the concept and its types]. Law of Ukraine. 2021; 3: 49 (in Ukrainian).

2. Adamova 0. S. Poniattia pravovoi klasyfikatsii [The concept of legal classification]. Journal of Civil law. 2015; 18: 19-24. Available from: http://nbuv.gov.ua/UJRN/Chac_2015_18_6 (in Ukrainian). 
3. Danylian 0. H., Taranenko V. M. Osnovy filosofii: elektronnyi posibnyk [Fundamentals of Philosophy: an electronic manual] Available from: http://library.nlu.edu.ua/POLN_TEXT/4\%20KURS/4/1/07H2R7_4.htm (in Ukrainian).

4. Tytov V. D., Tsalin S. D., Nevelska-Hordieieva O.P. et al. Lohika: pidruchnyk dlia studentiv vyshchykh navchalnykh zakladiv [Logic: textbook for students of higher educational institutions]. Kharkiv: Pravo; 2005, p. 79-80 (in Ukrainian).

5. Koronavirus: statystyka po krainakh [Coronavirus: statistics in countries]. Minfin. Available from: https://index.minfin.com.ua/ua/reference/ coronavirus/geography (in Ukrainian).

6. MVF: svitovyi VVP u 2020 rotsi vpav na 3,5\%, u 2021 rotsi zroste na $5,5 \%$. [IMF: world GDP in 2020 fell by $3.5 \%$, in 2021 will grow by $5.5 \%$ ]. Finbalance. Finance and economics. Available from: http://finbalance. com.ua/news/mvf-polipshiv-prohnoz-zrostannya-svitovo-ekonomikiv-2021-rotsi-do-55 (in Ukrainian).

7. Bazhanov M. I., Baulin Yu. V., Borysov V. I. et al. Kryminalne pravo Ukrainy: Zahalna chastyna: Pidruchnyk [Criminal law of Ukraine: General part: textbook]. 2d ed. Kyiv: Yurinkom Inter, 2005, p. 131 (in Ukrainian).

8. Volosheniuk 0., Dehtiarova H., Kaliberda M. et al. Osvitni praktyky iz zapobihannia infodemii, abo Yak ne izoliuvatysia vid pravdy: navch. posib. [Educational practices for the prevention of infodemia, or How not to isolate from the truth: a textbook]. Kyiv: AUP, Interniuz-Ukraina, TsVP, 2020, p. 19 (in Ukrainian).

9. Batyrhareieva V. S. Osnovni napriamy poshyrenniu dezinformatsii (na prykladi pandemii COVID-19) [The main directions of dissemination of misinformation (on the example of the pandemic COVID-19)]. Information and Law. 2020; 2: 121-131 (in Ukrainian).

10. Li L. Z., Wang S. Prevalence and predictors of general psychiatric disorders and loneliness during COVID-19 in the United Kingdom. Psych. Res. 2020; 291: 0165-1781. doi: 10.1016/j.psychres.2020.113267.

11. Wang C., Pan R., Wan X., et al. Immediate Psychological Responses and Associated Factors during the Initial Stage of the 2019 Coronavirus Disease (COVID-19) Epidemic among the General Population in China. International Journal of Environmental Research and Public Health. 2020; 17(5): 1729. doi:10.3390/ijerph17051729.

12. Cao W., Fang Z., Hou G., et al. The psychological impact of the COVID-19 epidemic on college students in China. Psych. Res. 2020; 287: 112934. doi: 10.1016/j.psychres.2020.112934.

13. ledynyi zvit pro kryminalni pravoporushennia za sichen-veresen 2019 r. i 2020 r. (Forma 1) [Unified Report on Criminal Offenses for JanuarySeptember 2019 and 2020 (Form 1)]. Prosecutor General's Office. Kyiv, 2021. Available from: https://www.gp.gov.ua/ua/1stat (in Ukrainian).

14. Batyrhareieva V. S., Borysov V. I., Yevtieieva D. P., Kalinina A. V., Kolodiazhnyi M. H., Shramko S. S. Poshyrennia pandemii COVID-19 v Ukraini: sotsialno-pravovi ta kryminolohichni problemy [The spread of the COVID-19 pandemic in Ukraine: socio-legal and criminological problems]. Issues of combating criminality. 2020; 40: 9-22 (in Ukrainian).
15. Riven zlochynnosti v Ukraini pid chas karantynu znyzyvsia na 30\% [The crime rate in Ukraine during quarantine decreased by 30\%]. Lviv portal. 2020, March 20. Available from: https://portal.Iviv.ua/ news/2020/03/29/riven-zlochynnosti-v-ukraini-pid-chaskarantynuznyzyvsia-na-30 (in Ukrainian).

16. Saladino V., Algeri D., Auriemma V. The Psychological and Social Impact of Covid-19: New Perspectives of Well-Being. Front. Psychol. 2020; 11: 577684. doi: $10.3389 /$ fpsyg.2020.577684.

17. Mironova N. Opasnye mutanty: chto izvestno o novyh shtammah koronavirusa [Dangerous mutants: what is known about new strains of coronavirus]. The page. Available from: https://thepage.ua/exclusive/ novye-shtammy-koronavirusa-britanskij-yuzhnoafrikanskij-brazilskiji-indijskij-covid-19 (in Russian).

18. Ukraina uviide u rezhym paperless z 24 serpnia - Zelenskyi [Ukraine will enter paperless mode on August 24 - Zelensky] Ukrinform Available from: https://www.ukrinform.ua/rubric-society/3246699ukraina-uvijde-u-rezim-paperless-z-24-serpna-zelenskij.html (in Ukrainian).

19. Zvit pro rezultaty anketuvannia shchodo naslidkiv pandemii COVID-19 ta shliakhiv yikh usunennia [Report on the results of the survey on the consequences of the COVID-19 pandemic and ways to eliminate them]. Kharkiv: Nauk.-dosl. in-t vyvch. probl. zloch. im. akad. V. V. Stashysa NAPrN Ukrainy, 2021, 93 p. Available from: http://surl.li/ainlb (in Ukrainian).

20. Alghamdi A. A. Impact of the COVID-19 pandemic on the social and educational aspects of Saudi university students'lives. PLOS ONE. 2021; 16(4): e0250026. doi: 10.1371/journal.pone.0250026

21. Varlamova D. Chto takoe singulyarnost', ili pochemu istoriya chelovechestva odnazhdy stanetnepredskazuemoj [What is a singularity, or why the history of mankind will one day become unpredictable] Available from: https://theoryandpractice.ru/posts/6981-chto-takoesingulyarnost-ili-pochemu-istoriya-chelovechestva-odnazhdy-stanetnepredskazuemoy (in Russian).

The paper was prepared for the project "Socio-legal and criminological consequences of pandemics and ways to eliminate them in Ukraine" (Registration № 2020.01 / 0155), submitted to the competition "Science for human security and society" of the National Research Foundation of Ukraine.

\section{ORCID and contributionship:}

Viacheslav I. Borysov: 0000-0001-5807-2849, D, F

Maxim G. Kolodyazhny: 0000-0003-2149-9165, B, C, D

Daryna P. Yevtieieva: 0000-0003-0593-1632 $2^{A, D}$

\section{Conflict of interest:}

The Authors declare no conflict of interest.

1 Note. This division was supported by M.I. Bazhanov in characterizing the crime consequences [7].

2 Note. This classification of spheres of public life is supported, in particular, by 0.G. Danilyan and V.M. Taranenko [3].

3 Note. Infodemia is the dissemination of an excessive amount of information about a certain problem, which makes its solution even more difficult. The term itself was born in early 2020, when the WHO began to talk about the influx of false news about the COVID-19 pandemic, which leaves behind the outbreak of coronavirus infection and exacerbates its consequences [8]. For example, V.S. Batyrgareeva understands infodemia as a mass psychosis in the context of globalization, when even a small information impulse (especially supported by a frankly false context) on a key issue at a given moment can in a short time destroy the entire world order, social organism [9].

4 In philosophy, the concept of «singularity» (from the Latin «singulus» - «single») refers to the singularity, uniqueness of something - beings, events, phenomena [21]. 


\section{CORRESPONDING AUTHOR}

Daryna P. Yevtieieva

AcademicianStashisScientific Research InstitutefortheStudy of CrimeProblems

of the National Academy of Legal Sciences of Ukraine

Kharkiv, Ukraine

tel.: +380577156208

e-mail: evteeva.dar@gmail.com.

Received: 21.05.2021

Accepted: 12.10 .2021

A - Work concept and design, B - Data collection and analysis, C - Responsibility for statistical analysis,

D-Writing the article, $\mathbf{E}$-Critical review, $\mathbf{F}$ - Final approval of the article 


\title{
COVID 19-RELATED STIGMATIZATION: A HUMAN RIGHTS-BASED APPROACH
}

DOI: 10.36740/WLek202111219

\author{
Serhiy S. Vitvitskyi ${ }^{1}$, Marianna I. Liubchenko ${ }^{2}$, Oleksii 0. Liubchenko \\ 'DONETSK STATE UNIVERSITY OF INTERNAL AFFAIRS, MARIUPOL, UKRAINE \\ 2POLTAVA LAW INSTITUTE OF YAROSLAV MUDRIY NATIONAL LAW UNIVERSITY, POLTAVA, UKRAINE
}

\begin{abstract}
The aim: The article attempts to analyze what are legal responses to such Covid-19 related challenge like stigmatization.

Materials and methods: Given the specifics of the topic and goals, during the writing of the article were used methods of terminological research of the phenomena "stigma", "stigmatization", comparative method, formal-legal method (in the study of international documents). The following materials were used to reveal the topic: scientific papers (articles, book chapters, analytical materials, reports, etc.), international legal acts, court decisions (decisions of the European Court of Human Rights, decisions of the US Supreme Court, decisions of national courts of different countries).

Conclusions: More than a year after the spread start of Covid-19, it has become clear that in addition to the extremely catastrophic impact on human health and life, the pandemic, as well as the resulting quarantine restrictions, have profound and sometimes radical social consequences. Stigmatization of based on their infection with Covid-19 (including possible) has become one of these. The current international human rights framework allows for the assessment of such processes according to its standards. Implications of dignity and privacy as the highest social values pave the way to finding legal mechanisms to protect people who are carriers of a disease from being stigmatized. This is demonstrated by the legal justifications developed by the courts - the ECtHR as supranational and national Supreme and federal courts, which have been the subject of analysis within this article.
\end{abstract}

KEY WORDS: stigmatization, Covid-19, human rights, dignity, right to private life, discrimination

Wiad Lek. 2021;74(11 p.2):2972-2977

\section{INTRODUCTION}

The spread of coronavirus infection around the world has manifested a number of different types of crises: in the system of public health management, in the provision of medical services and treatment of coronavirus infection, and others. Particular attention should be paid to the crisis of confidence in societies around the world, which manifested itself in the strengthening of existing stereotypes and stigmas, the emergence of new forms of stigmatization and discrimination in society, the destructive effects of which have been reported in various sociological and psychological studies [1].

The connection between infectious diseases and stigma in society is not new. As noted in the literature, the "biocultural dynamic" of coexistence of humans and infectious disease agents includes stigma, and "it is well established that infectious disease triggers stigma and stigma worsens the disease." [2]. The history of the HIV epidemic shows that stigma and discrimination negatively affected people's physical and mental health and social support and led to significant human rights breaches and abuses. Myths and misconceptions about the spread of HIV have led to the stigmatization of people living with HIV in the workplace, in health care, in relationships, and in many other areas of life.
Due to differences in risk appraisal, transmission ways, lethality, the population at risk, "novel epidemics and pandemics are inherently plagued by scientific uncertainties and a rapidly evolving nature" [3]. Respiratory viruses, namely Covid-19, are more infectious and their spreading is less controlled. This fact combined with the fear of a global pandemic, economic breakdowns, and shortages can cause fear-driven like stigmatization, stereotyping, discrimination.

\section{THE AIM}

The article attempts to analyze what responses jurisprudence provides to these challenges, and whether a human rights-based approach is applicable here. It should be noted that the topic of stigmatization in the context of coronavirus infection has received considerable attention among researchers in various fields. Most of these works are presented within interdisciplinary articles by lawyers, physicians, sociologists, psychologists, which conducted quantitative and qualitative studies of the impact of the disease on human relationships, as well as behaviour by government agencies, businesses and other authorized agents. However, the literature lacks an overview of the issue of stigmatization from a legal point of view, because 
stigmatization affects human dignity and human rights values that are now recognized in civilized legal discourse as the social value. Therefore, the purpose of this article is to analyze the legal solutions that can potentially be used to address the stigma associated with Covid-19.

\section{MATERIALS AND METHODS}

Given the specifics of the topic and goals, during the writing of the article were used methods of terminological research of the phenomena "stigma", "stigmatization", comparative method, formal-legal method (in the study of international documents). The following materials were used to reveal the topic: scientific papers (articles, book chapters, analytical materials, reports, etc.), international legal acts, court decisions (decisions of the European Court of Human Rights, decisions of the US Supreme Court, decisions of national courts of different countries).

\section{REVIEW AND DISCUSSION}

\section{What is stigma?}

The term "stigma" belongs to the dictionary of social psychology, and it means "phenomenon whereby an individual with an attribute which is deeply discredited by their society is rejected as a result of the attribute". This definition belongs to E. Goffman, an outstanding American sociologist, a social psychologist of the XX century, who was the first to define 'stigma', seeing it as a 'process by which the reaction of others spoils normal identity" [4]. After the WWII period, the term started to be used in connection with mental illness, later - associated with HIV-positive, Ebola, MERS, SARS, cancer, epilepsy, overweight ('fattism'), becoming 'health stigma'.

Stigma means a situation in which a person who has a certain trait that differs significantly from the majority is negatively evaluated, ignored by others, denied communication, services, goods, and even aggressive behaviour. Stigma - is the term that marks experiences and feelings of a person being stigmatized blame, shame, worthlessness, loneliness, isolation, social exclusion, and discrimination in accessing social services and goods. Thus, most often stigmatization occurs in relation to people with mental disorders, when they are perceived as incapable and incapable of normal routine, which significantly limits their capabilities, turning the stigma into a vicious circle. [5].

Stigma is operating at individual, interpersonal, and structural levels. Individual form, or intrapersonal stigma, means that people are hiding their aspects and features, because of which they are stigmatized to avoid rejection.

Interpersonal stigma - process between the stigmatized and the non-stigmatized and includes intentional actions (discrimination, hate crimes) and unintentional actions. Structural stigma operates not at the individual and interpersonal levels, but at the social level within cultural norms and laws and practices that create an enabling environment for stigmatization [6]. It should be noted that in terms of preventing and overcoming stigma, interpersonal stigma and structural stigma are often mentioned, although a human rights approach also requires careful analysis of intrapersonal stigma, as such stigma inevitably leads to negative consequences for stigmatized and wider in general. For example, in the case of Covid-19, some people, who do not want to be associated (stigmatized) as ill, having some symptoms, avoid getting tested, wear a face covering, keep distance, and even receive necessary treatments. Thus, stigma becomes a 'barrier to effective prevention and control mechanisms', affecting 'not only the stigmatized group, but also a wide range of people, including patients, families, friends, and the whole community'[7].

Stigmatization as a psychological phenomenon plays several roles within the inner human world those, who stigmatize:

- increase one's self-esteem by stigmatizing others;

- maintaining a positive social identity, which in turn turns into the justification of discrimination against a certain group of people with characteristics;

- legitimization of inequality of the status of this or that group;

4) fear management, performing a protective function in connection with the occurrence of severe anxiety [8]. This feature very clearly reflects the stigma in times of societal threats such as the spread of infections. Stigmatization can temporarily bring feelings of security, by distancing from infected people, and scapegoating can help to feel that 'unknown situation' becomes more 'recognized and controllable one. Obviously, one may say, that avoiding potentially infected people is not stigmatization, but it is fair to admit that it is 'a delicate line separating stigmatization from necessary infection prevention measures' stigmatization has a component of moral judgment about an individual, a group of people, or a place [9], that makes stigmatized people feel a wide range of emotions - shame, hopelessness, mental disorders, all of that is an obstacle to recovery in case of health-stigma.

Covid-19 related stigmatization

Stigmatization marked the pandemic from the very beginning. The spread of the disease around the world was the result of the latest manifestations of discrimination and stigmatization, and hate speech also exacerbated existing inequalities in society.

Thus, the very beginning of the pandemic was marked by the hostile, suspicious and outspoken racist attitude of almost the whole world towards people of Asian origin, which was connected with the place of origin of the virus, added new nuances to modern xenophobic and racist practices. The hashtag "iamnotvirus" has been used by thousands of users around the world to draw public attention to xenophobia, which was justified by fear of infection. With the spread of the virus, people who had signs of becoming infected with the virus or became ill began to be stigmatized.

Stigmatization did not escape even the dead from complications, which funeral services, as well as relatives (!), Refused to hide behind all the traditional (especially where there are traditions and customs, for example, in India, 
where NGOs have taken the initiative to hold the last rites for the deceased).

With the advent of the vaccine, a new wave of tension has emerged in society, between vaccinated people and those who refuse to be vaccinated [10].

Those who are at the forefront of the war against the pandemic, doctors, have been severely stigmatized, which has exacerbated their already difficult psychological condition. Doctors, due to the spread of stereotypes and stigma, have fallen victim to neighbours, landlords, taxi drivers, and even members of their own families [11].

The stigma caused by the virus has even taken on an unexpected political context in the world. Thus, in the United States, face masks have evolved from personal protective equipment into political symbols, marking the division between "complacent liberals" (who wear masks) and "carefree Republicans" (who do not wear masks) [12].

\section{Stigmatization issues from legal perspective}

Stigmatization, as can be seen from the examples above, always affects a person's dignity when it makes people feel ashamed, humiliated, isolated. Human dignity is the very heart of the idea of human rights and means that every human being has value, despite class, race, gender, religion, abilities, or any other factor, except being human.

All international human rights instruments recognize the human person and his dignity as the highest social value. Universal Declaration on Human Rights in its article 1 provides, that ' $[a] 11$ human beings are born free and equal in dignity and rights. They are endowed with reason and conscience and should act towards one another in a spirit of brotherhood.' In its Article 22, also provides the right of everyone to social security. The idea of respect for human dignity is enshrined in the 1966 International Covenant on Civil and Political Rights, which imposes a concrete obligation on states to respect human dignity (Article 7 and others), equality of all people (Articles 20, 24, 26), even in time of public emergency (Article 4). The further major UN conventions developed the idea of human dignity as a priority in human rights discourse: Convention of Rights of Children 1989, Convention of Rights of Migrant Workers (1990), Convention of Protection against Forced Disappearance, Convention of the Rights of Disabled Persons (2007), Convention against Torture and Other Cruel, Inhuman or Degrading Treatment or Punishment (1985) and many others.

Regional documents also contain several provisions relating to equality and human dignity - Title III of the EU Charter of Fundamental Rights. Human dignity is a crucial concept for the Council of Europe: though there is no such a word in the text of the European Convention of Human Rights, but the references to this idea are made by the European Court of Human Rights in numerous cases, concerning the right to life, freedom of tortures and inhumane treatment, right to freedom and integrity, right to private life and many others.

None of the above-mentioned documents contains references to the notion of 'stigma'. The very first time, when stigmatization has been given particular attention is the Universal Declaration on Bioethics and Human Rights of UNESCO. Its article 11 proclaims principles of "non-discrimination and non-stigmatization", saying that 'no individual or group should be discriminated against or stigmatized on any grounds, in violation of human dignity, human rights, and fundamental freedoms'.

The analysis of international documents carried out above raises a logical question: if stigmatization affects human dignity, leads to suffering, isolating from public life, creating barriers to the realization of rights, as well as directly violating certain rights, can consider the state responsible for protecting people from stigma? It is clear that the processes of stigmatization are always associated with inequality and the division of others into "their" and "others".

In answering these questions, it is appropriate to look at what attention has been paid to this issue in judicial practice. First of all, attention is drawn to the activities of the US Supreme Court, "stigma" and "stereotype" have long been part of the equal protection law. In one of the cases (Wisconsin v. Constantineau), Supreme Court expanded the notion of "liberty" to include the right to be free of official stigmatization and found that such stigmatization requires due process, i.e, all the fair trial procedures. In this case, the Supreme invalidated a statutory scheme in which persons could be labeled "excessive drinkers," without any opportunity for a hearing and rebuttal, and could then be barred from places where alcohol was served. The Court, without discussing the source of the entitlement, noted that the governmental action impugned the individual's reputation, honor, and integrity [13].

Later, the stigma-plus doctrine was elaborated by Supreme Court and district courts that means that a plaintiff, in limited circumstances, can seek relief for government defamation under federal constitutional law, only if he demonstrates suffering some loss of property interest like continued employment in a government job [14].

It is also remarkable that US courts have become one of the first to give any analysis to vaccination issues. Recently, federal courts and the United States Court of Appeals (Seventh Circuit) in case Klaassen v. Trustees of Indiana University, where students of the University of Indiana challenged rules, according to which Indiana University students must be vaccinated against COVID-19 unless they are exempt for medical or religious reasons, and exempted students must wear masks and be tested for the disease twice a week. The Court of Appeals stated that each university may decide what is necessary to keep other students safe in a congregate setting, and health exams and vaccinations against diseases are common requirements of higher education. More interestingly, that the Court compared requirements on vaccination of the University with University's instructions 'about what to read and write. The Court justified it by the following considerations:

'A university will have trouble operating when each student fears that everyone else may be spreading disease. Few people want to return to remote education-and we do not think that the Constitution forces the distance-learn- 
ing approach on a university that believes vaccination (or masks and frequent testing of the unvaccinated) will make in-person operations safe enough'.

However, the Court said that the University of Indiana created ample educational opportunities for those who for different reasons do not want to be vaccinated, but 'people who do not want to be vaccinated may go elsewhere' [15].

Within the case-law of the European court of human rights 'stigmatization' has found its place primarily in cases concerning stereotypes and discrimination on the ground of race and gender equality. In Kiyutin v. Russia, where was refused a Russian residence permit solely because he was HIV-positive. In this case, the Court considered that:

'HIV infection has been traced back to behaviours such as same-sex intercourse, drug injection, prostitution or promiscuity that were already stigmatized in many societies, creating a false nexus between the infection and personal irresponsibility and reinforcing other forms of stigma and discrimination, such as racism, homophobia or misogyny'.

Finally, the Court defined that:

'Excluding HIV-positive non-nationals from entry and/ or residence in order to prevent HIV transmission is based on the assumption that they will engage in specific unsafe behaviour and that the nation will also fail to protect himself or herself. This assumption amounts to a generalisation which is not founded in fact' [16].

By the way, the later case of I.B. v. Greece (2013) was the first HIV-based employment discrimination. This case concerned an HIV-positive man, who was fired from his job, because of calling for his dismissal by a group of I.B.'s co-workers, who had found out about his HIV diagnosis and were afraid of contagion. ECHR named I.B. 's dismissal as such that results in the stigmatisation and have 'serious repercussions for his personality rights, the respect owed to him and, ultimately, his private life'. Also, the Court added 'the uncertainty surrounding his search for a new job, since the prospect of finding one could reasonably have appeared remote having regard to his previous experience'. Moreover, the Court noticed that 'the fact that the applicant did find a new job after being dismissed does not suffice to erase the detrimental effect of his dismissal on his ability to lead a normal personal life' [17]. This case raises the issue of the obligation of private entities to respect human rights, in particular, to refrain from discriminatory and stigmatizing behaviour.

In Aksu v. Turkey (2012) the Grand Chamber said that 'any negative stereotyping of a group, when it reaches a certain level, is capable of impacting on the group's sense of identity and the feelings of self-worth and self-confidence of members of the group. It is in this sense that it can be seen as affecting the private life of members of the group. This case concerned the use of derogatory stereotypical images of Roma in government-sponsored publications [18]. It is noteworthy that in this case the ECtHR did not analyze the issue of discriminatory treatment on ethnic grounds, but noted that stereotypes can lead to a violation of the right to privacy.

The 'richest anti-stereotyping reasoning' [19] is presented in Konstantin Markin v. Russia (2012). The case concerned a military serviceman who complained that he was not able to take extended parental leave, while such leave is available to servicewomen. The Grand Chamber held that

"Gender stereotypes, such as the perception of women as primary child-carers and men as primary breadwinners, cannot, by themselves, be considered to amount to sufficient justification for a difference in treatment, any more than similar stereotypes based on race, origin, colour or sexual orientation." [20].

There are some other interesting judgments delivered by national Supreme and Federal Courts, in which the latter have demonstrated that laws and practices that make stigmatization legal can be repealed after a judicial review, and victims of such unfair practices are compensated. First, it is worthy to notice Namibia's Supreme Court ruling in Government of the Republic of Namibia v LM and Others, where the practice of forcibly sterilizing HIV-positive women without their informed consent was recognized as a violation of their rights, allowing women who had been subjected to the procedure to seek redress for physical and psychological damages [21]. Another judgment was delivered by Malawi High Court in case, concerning a woman with HIV convicted for breastfeed, despite evidence that women who are on antiretroviral treatment have a minimal chance of transmitting the disease to their child. The Court overturned the conviction, demonstrating the importance of grounding judicial decisions in scientific evidence and protecting vulnerable groups from "the unjust consequences of public panic" [22].

Worthy of special attention is the ruling of the Supreme Court of India, where the pasting of posters outside the houses of COVID-19 positive patients was under review. The Court did not analyze whether this all violated the right to privacy and the right to life with dignity, but the judges did remark that such a practice was unnecessary, counter-productive, and would lead to stigmatization of people and their treatment as 'untouchables' [23].

\section{CONCLUSIONS}

More than a year after the spread start of Covid-19, it has become clear that in addition to the extremely catastrophic impact on human health and life, the pandemic, as well as the resulting quarantine restrictions, have profound and sometimes radical social consequences. Stigmatization of people based on their infection with Covid-19 (including possible) has become one of these. The current international human rights framework allows for the assessment of such processes according to its standards. Implications of dignity and privacy as the highest social values pave the way to finding legal mechanisms to protect people who are carriers of disease from being stigmatized. This is demonstrated by the legal justifications developed by the courts - the ECtHR as supranational and national Supreme and federal courts, which have been the subject of analysis within this article. The analyzed decisions, in particular, show the tendency of courts 1) to consider the issue of stigma within the issues of discrimination, violation of the right to privacy (ECtHR, US Supreme Court); 
2) not to regard any stigmatization as one that violates human rights, but one that causes material consequences (the 'stigma-plus' doctrine in the US Supreme Court), or one that is obviously ill-founded and simultaneously harming (for example, as in the case of putting posters at the homes of Covid-19 patients within the Supreme Court of India); 3) recognize that private actors have an obligation not to stigmatize and that the state is responsible for this (ECtHR).

The research conducted in this article has raised many important questions about how to address the challenges facing the world today, the study of which is limited by the format and scope of the article. In particular, understanding the issues of prevention, counteraction to stigma and compensation requires systematic and careful consideration in terms of state obligations in this area and the responsibility of private actors, relations with other social practices (discrimination, harassment, bullying, hate speech), etc.

\section{REFERENCES}

1. UNICEF poll: only a quarter of young respondents know how to act when encountering the first symptoms of coronavirus. Available from: https://www.unicef.org/ukraine/en/press-releases/unicefpoll-only-quarter-young-respondents-know-how-act-whenencountering-first

2. Brewis A, Wutich A, Mahdavi P. Stigma, pandemics, and human biology: Looking back, looking forward. Am J Hum Biol. 2020;32(5):e23480. doi:10.1002/ajhb.23480

3. van Daalen KR, Cobain M, Franco OH, et al Stigma: the social virus spreading faster than COVID-19 J Epidemiol Community Health 2021;75:313-314.

4. Goffman, E. (1963). Stigma: Notes on the Management of Spoiled Identity. Englewood (liffs, NJ: Prentice- Hall.)

5. The Stigma of Mental Illness - End of the Story? Editors: Gaebel, Wolfgang, Roessler, Wulf, Sartorius, Norman (Eds.). Springer International Publishing, 2017.

6. BlakeVK, HatzenbuehlerML. Legal Remediesto Address Stigma-Based Health Inequalities in the United States: Challenges and Opportunities. Milbank Q. 2019;97(2):480-504. doi:10.1111/1468-0009.12391

7. Saeed F, Mihan R, Mousavi SZ, Reniers RL, Bateni FS, Alikhani R, Mousavi SB. A Narrative Review of Stigma Related to Infectious Disease Outbreaks: What Can Be Learned in the Face of the Covid-19 Pandemic? Front Psychiatry. 2020 Dec 2;11:565919. doi: 10.3389/ fpsyt.2020.565919. PMID: 33343414; PMCID: PMC7738431.

8. Crocker J., Major B., Steele C. Social stigma. Handbook of social psychology. Eds. by D. Gilbert, S. T. Fiske, G. Lindzey Boston: McGraw-Hill, 1998, p.504-553.

9. Saeed F, Mihan R, Mousavi SZ, Reniers RL, Bateni FS, Alikhani R, Mousavi SB. A Narrative Review of Stigma Related to Infectious Disease Outbreaks: What Can Be Learned in the Face of the Covid-19 Pandemic? Front Psychiatry. 2020 Dec 2;11:565919. doi: 10.3389/ fpsyt.2020.565919. PMID: 33343414; PMCID: PMC7738431.

10. Ahmed A. Kayum. The Human Right to Vaccines: Preventing Discrimination Against the Unvaccinated. Health and Human Rights Journal. 2021, 15 February. Available from: https://www.hhrjournal.org/2021/02/ the-human-right-to-vaccines-preventing-discrimination-against-theunvaccinated/
11. Paola Forgione. 'Please, don't tell anyone!': healthcare stigma in the COVID-19 era. Humanitarian Law and Policy, November 12, 2020. Available from: https://blogs.icrc.org/law-and-policy/2020/11/12/ healthcare-stigma-covid19/

12. How America became a breeding ground for anti-maskers, according to social psychologists.https://www.businessinsider.com/ why-mask-wearing-politically-divisive-america-psychologistsexplain-2020-8

13. Wisconsin v. Constantineau, 400 U.S. 433 (1971). Available from: https:// supreme.justia.com/cases/federal/us/400/433/

14. Spinale v. USDA, 621 F. Supp. $2 d 112$ (S.D.N.Y. 2009); Paul v. Davis, 424 U.S. 693 (1976)

15. Klaassen v. Trs. of Ind. Univ., United States Court of Appeals, Seventh Circuit, Aug 2, 2021. Available from: https://casetext.com/case/ klaassen-v-trustees-of-ind-univ

16. Case of Kiyutin v. Russia, App. no. 2700/10, final judgement 15 September 2011. Available from: https://hudoc.echr.coe.int/ eng\#\{\%22fulltext\%22:[\%22kiyutin\%22],\%22documentcollectio nid2\%22:[\%22GRANDCHAMBER\%22,\%22CHAMBER\%22],\%22i temid\%22:[\%22001-103904\%22]\}

17. Case of I.B. v. Greece, App. 552/10, Judgement 3 0ctober 2013, final 03/10/2014. Available from: https://hudoc.echr.coe.int /eng\#\{\%22appno\%22:[\%22552/10\%22],\%22itemid\%22: [\%22001-127055\%22]\}

18. Case of Aksu v. Turkey, Application nos. 4149/04 \& 41029/04, Judgemnet 15 March 2012. Available from: https://hudoc. echr.coe.int/eng\#\{\%22fulltext $\% 22:[\% 22 \backslash \% 22$ CASE $\% 200 F \% 20$ AKSU\%20v.\%20TURKEYY\%22\%22],\%22documentcollectionid2\%22: [\%22GRANDCHAMBER\%22,\%22CHAMBER\%22],\%22itemid\%22: [\%22001-109577\%22]\}

19. Alexandra Timmer, Judging Stereotypes: What the European Court of Human Rights Can Borrow from American and Canadian Equal Protection Law, The American Journal of Comparative Law. 2015;1:239-284.

20. Case of Konstantin Markin v. Russia, App. no. 30078/06, Judgement 22 March 2012. Available from: https://hudoc.echr.coe.int/ eng\#\{\%22fulltext\%22:[\%22markin\%22],\%22documentcollectionid2\% 22:[\%22GRANDCHAMBER\%22,\%22CHAMBER\%22],\%22itemid\%22:[\% 22001-109868\%22]\}

21. Government of the Republic of Namibia v LM and Others, 2014, NASC 19. Available from: https://namiblii.org/na/judgment/supremecourt/2014/19

22. E.L Female v The Republic (Criminal Case No. 36 of 2016), MWHC 656 (19 January 2016). Available from: https://www.hrlc.org.au/humanrights-case-summaries/2018/6/25/malawis-high-court-takes-humanrights-approach-to-hiv-transmission-cases

23. Kush Kalra v. Union of India, December 9, 2020. Available from: https:// globalfreedomofexpression.columbia.edu/cases/kush-kalra-v-unionof-india/

\section{ORCID and contributionship:}

Serhiy S. Vitvitskyi: 0000-0002-4884-1883 A,B,D,E,F

Marianna I. Liubchenko: 0000-0001-7090-2403 A,B,D,E,F

Oleksii O. Liubchenko: 0000-0002-8068-5665 A,B,D,E,F

\section{Conflict of interest:}

The Authors declare no conflict of interest. 


\section{CORRESPONDING AUTHOR}

Marianna I. Liubchenko

Poltava Law Institute of Yaroslav Mudriy National Law University

Poltava, Ukraine

e-mail: lyubchenko.marianna@gmail.com

Received: 10.06 .2021

Accepted: 15.10 .2021

A - Work concept and design, B - Data collection and analysis, C - Responsibility for statistical analysis,

$\mathbf{D}$-Writing the article, $\mathbf{E}$-Critical review, $\mathbf{F}$ - Final approval of the article 


\title{
REALIZATION OF HUMAN RIGHTS DURING THE PANDEMIC OF COVID-19
}

D0I: 10.36740/WLek202111220

\author{
Viktor M. Baliuk', Iuliia I. Ostapenko' ', Larysa P. Grynko² \\ 'YAROSLAV MUDRYI NATIONAL LAW UNIVERSITY, KHARKOV, UKRAINE \\ 2POLTAVA LAW INSTITUTE YAROSLAV MUDRYI NATIONAL LAW UNIVERSITY, POLTAVA, UKRAINE
}

\begin{abstract}
The aim: The purpose of the article is to analyse the state of compliance with human rights during the introduction measures by different countries to combat the rapid spread of the pandemic of Covid-19.

Materials and methods: This research based on Kazakh, Hungarian, Ukrainian, Georgian, UK, Azerbaijan, German, French, Indian, Chinese, South African, Brazilian scientific publications. Additionally, were used statistics, expert opinions, doctrinal ideas and reviews. Besides, in the research process to achieve the goal, a complex of general scientific and special methods of cognition was used, in particular, the comparative legal method, the system and structural method, the method of generalization, the method of analysis and synthesis.

Conclusions: Response measures taken by countries during the Covid-19 period, which cause changes in the legal regulation of public relations, their validity and focus on achieving the goal of protection, must be based on democratic principles, human rights restrictions must be appropriate to the threat and must be justified the limits of intervention.
\end{abstract}

KEY WORDS: Covid-19 pandemic, human rights, keeping the rights, protection of human rights

Wiad Lek. 2021;74(11 p.2):2978-2982

\section{INTRODUCTION}

Nowadays human and civil rights - are the most valuable good that a person has. It is the rights and freedoms, inviolability of human dignity, equality, free development of individuals, protection from discrimination and contempt form the social foundation, which is the basis for building the humanity.

With the proclamation of Coronavirus-19 (Covid-19) pandemic by the World Health Organization around the world, the issue of the compliance with international standards on human rights has become relevant.

As never before since the Second World War, the Covid-19 pandemic has revealed the need for strong protection of human rights, including economic and social rights. It is precisely the model of society based on human rights, democracy and the rule of law that is now under threat - it is the duty of all of us to remain vigilant in the face of adversity and this disease [1].

\section{THE AIM}

The aim of this work is to identify and analyze the state of compliance with human rights during the introduction measures by different countries to combat the rapid spread of the pandemic of Covid-19.

\section{MATERIALS AND METHODS}

This research based on Kazakh, Hungarian, Ukrainian, Georgian, UK, Azerbaijan, German, French, Indian, Chinese, South African, Brazilian scientific publications. Additionally, were used statistics, expert opinions, doctrinal ideas and reviews. Besides, in the research process to achieve the goal, a complex of general scientific and special methods of cognition was used, in particular, the comparative legal method, the system and structural method, the method of generalization, the method of analysis and synthesis.

\section{REVIEW AND DISCUSSION}

The Covid-19 pandemic has a serious impact on people around the world. Covid-19, which poses like other infectious diseases an increased risk to the elderly and people with other health disorders such as cardiovascular disease, diabetes, chronic respiratory syndrome, hypertension, as well as for people who are in constant close contact with each other. Since 31 December 2019 and as of week 2021-36, the disease claimed more than 4636120 lives [2]. Millions of employees lost their jobs. Many citizens fear for their lives, health and the health of their families. Therefore, the fight against the coronavirus pandemic must be conducted in the compliance with the guaranteed rights of citizens. States 
cannot neglect such rights as privacy, freedom of thought and speech, freedom of expression and respect for human dignity. The most vulnerable rights during the pandemic are the right to health care, social protection, education, employment and the right to freedom of movement.

In order to prevent the spread of coronavirus Covid-19, many states have established sequestration on their territory, prohibiting visits to educational institutions, all mass events involving a certain number of people, except for measures necessary to ensure the work of public authorities and local self-governments.

Citizens of quarantined countries have difficulties of obtaining medical care and other essential goods and services. Tragic news on deaths and exacerbations unrelated to the Covid-19 has been reported in those countries. In addition, the greatest interference during sequestration has the right to respect for private life; the right to liberty and personal integrity - forcible placement of citizens in observation; civil rights to freedom of movement, prohibition of religious events, etc.

The evidence for the devastating impact of the pandemic on mental health is now overwhelming. The reasons for this are clear: the pandemic caused fear and anxiety for everyone, and many of us had to face illness, grief over lost family members, insecurity and loss of income. In addition to this extraordinary burden placed on our mental health, we were cut off from our usual support networks, friends and families, while the pandemic was also disrupting the delivery of existing mental health services themselves [3].

Most countries around the world have taken a number of decisions to restrict the operation of checkpoints, cancelled transportation and introduced new approaches and sanctions to prosecute individuals for violating quarantine measures.

The constant response measures taken by the countries during the Covid-19 period affect the health care, the economy, rights and freedoms, and cause changes in the legal regulation of public relations. Obviously, ensuring special regimes in the state occurs primarily by restricting basic human rights. Thus, the principle of the rule of law enshrined in the Articles 8, 9, 10 and 11 of the Convention for the Protection of Human Rights and Fundamental Freedoms [4], allows, if necessary, the restriction of fundamental human rights in a democratic society to protect the health. Therefore, it is now important to clarify the grounds and procedure for establishing restrictions on the rights, their validity and focus on achieving the purpose of protection.

Restrictions on liberties during pandemics are only possible temporarily for good reasons. Preservation of fundamental rights, such as freedom of expression, equality and religious diversity, is essential, since they are the foundation, on which the Europe is based. A pandemic should never be a reason to abolish democratic principles [5]. Thus, the rights guaranteeing (for instance, the right not to be discriminated) and principles (for example, transparency and respect for human dignity) will contribute to an effective response to threats during pandemics.
The Guidance note of the UN Human Rights Monitoring Mission in Ukraine highlights key principles that need to be complied with in the design and implementation of measures to respond to the Covid-19 pandemic. Any emergency responses to the Covid-19 pandemic must be proportionate, necessary and non-discriminatory [6].

While typically restriction of movement of free people would fall under a human rights violation, there is an exception for threats to a nation that pandemics fall under. Nonetheless this exception does not cover the human rights violations in the enforcement of quarantine measures which have been brought to light around the globe [7].

It should be noted that under the conditions of declaring the pandemic of Covid-19 both on the territory of a separate state and in the world in the whole, there is a violation of the balance of interests of individuals, state and society. Moreover, there are contradictions between private interests (meeting the needs of individual subjects by taking action to protect their own health) and public interests (meeting the needs of society in health care through the formation of appropriate state policy). At the same time, the public interest becomes dominant, which is a set of individual (private) interests of persons. Thus, in the case of the Covid-19 pandemic, the public interest is fundamental to the choice of areas of regulation and management of public relations, since it is aimed at protecting public health in general, rather than the health of individuals. This ratio of public and private interests in the field of health care sector determines the peculiarity for constructing mutual rights and responsibilities of the subjects of these relations.

Most countries around the world are taking steps to protect and support their population during the Covid-19 pandemic. Some governments provide unemployment benefits to those who have lost their jobs and incomes through the Covid-19 [8]. However, there are states that are almost unresponsive to the current situation or use it to their benefit. By gaining unlimited power and authority because of the Covid-19, they negatively affect not only on the economy, but also on human rights. Thus, the EU criticized the bill passed in Hungary, which gives the government extraordinary powers to organize measures to combat the Covid-19. We talk about the Hungarian emergency law adopted by the Hungarian Parliament giving the Prime Minister Viktor Orbán new powers to fight the virus and rule by decree without a set time limit. The move drew strong criticism from civil rights groups and international institutions, which warned that it gave the Hungarian leader unprecedented scope to pursue a crackdown on critics and dismantle democratic checks and balances. Members of the European Parliament voiced fears that the bill spells the end of Hungarian democracy and called for a European response [9].

European Parliament President David Sassoli said: «All European Union member states have a duty to uphold and protect these founding values. For us, parliaments must remain open and the press must remain free. Nobody can be allowed to use this pandemic to undermine our freedoms» [10]. 
Covid-19 has been an added punishment for human rights defenders who are unjustly imprisoned, and is also used as a pretext for further harassment, prosecution and even killings [11]. Thus, the authorities in Azerbaijan have intensified the fight against nonconformity, using the Covid-19 pandemic as an excuse. Authorities began harassing activists who criticized the government's efforts on combating the pandemic. Human rights activists have faced threats and harassment since petitioning the government for financial assistance to the Covid-19 victims or criticizing the government's response to the pandemic, by including disobedience to police orders or violations of quarantine rules $[12,13]$.

We believe that the states should refrain from any means of intimidation, opposition or other measures against activists, journalists, NGOs, bloggers or any other human rights defenders seeking to disseminate information about the Covid-19.

Governments of the most Eastern European and Central Asian countries have enacted a number of laws to combat the Covid-19, and some have imposed a state of emergency. Although some measures are justified in the face of a global threat, but they must be temporary and aimed at ensuring public health. The response of the governments of Eastern Europe and Central Asia has ranged from austerity measures to stop the spread of the virus to a formal denial of the problem, which has endangered the health of the population. Strict measures to stop the Covid-19 pandemic have often resulted in human rights violations, indirect discrimination against certain groups or individuals who are unable to follow them. Authorities of Kazakhstan, for example, has applied sequestration to houses, the residents of which had the Covid-19, making the closed doors [7]. India has imposed a nationwide 21-day blockade for 1.3 billion citizens, endangering people's lives because it is not clear how people are allowed to buy food and other things [14]. A family in the Eastern province of Jiangsu that had recently returned from Wuhan was barricaded with metal beams in their own home, so neighbors had to lower the food from the balcony with a rope [15]. In Brazil, when Brazil's far-right president Jair Bolsonaro claiming that the Covid-19 is just a "little flu" and refusing to impose stronger measures to fight the pandemic, some criminal gangs have started imposing their own "coronavirus curfew" in Rio-de-Janeiro's favelas [16].

The introduction of such quarantine measures disrupts the usual social system and endangers not only the well-being, but also the lives and health of people. However, a number of states, despite the principles of international law, seek to compensate for the inability to provide resources for the quarantine regime with an atmosphere of fear and uncertainty under the threat of large fines and imprisonment. There are cases of physical violence by the police. For instance, baton-wielding police in India have beaten those who flout the curfew-like restrictions or fail to maintain physical distancing, while others have publicly shamed violators by forcing them do squats, push-ups, crawl or roll around on the streets. Police in South Africa also forced people to roll along the road, kicking others as they performed squats for extended periods of time.
After enforcing a 21-day nationwide lockdown on Friday, officers in Johannesburg were seen indiscriminately using water cannons on civilians and firing rubber bullets in the city's poorest neighborhoods [17].

The most vulnerable are people in poor countries who earn income through personal manual labor or in the shadow economy sector. Social backwardness in impoverished places deprives people of access to high-paying jobs, food and water, etc. Therefore, government policies to restrict movement and the right to work, introduced in rich countries to combat the Covid-19, may have adverse consequences for low-income countries, depriving the population of such countries of livelihoods [18].

Governments must take action as the Covid-19 pandemic develops. At the same time, we must ensure that all those measures are in line with their human rights obligations.

While emphasizing the importance of human rights in shaping the response to the pandemic, in its resolution 44/2, the Human Rights Council underscored the central role of the State in responding to pandemics and other health emergencies and reaffirmed that emergency measures taken by States in response to the COVID-19 pandemic must be in accordance with States' obligations under applicable international human rights law [19].

The Human Rights Committee of the United Kingdom, and the National Coalition Against Domestic Violence of the United States say that during the lockdown domestic violence significantly increased, because the home - the place that should be the safest place during the pandemic - is often a place where the threat of violence looms. Statistics from China demonstrate that the number of cases of domestic violence in February 2020 was three times more comparing to February 2019.According to various sources, the number of calls about domestic violence during the lockdown in countries such as Italy, France, Germany, and the UK spiked by as much as 30-40 percent. In Ukraine there has also been a significant increase in domestic violence - according to the La Strada civil society organization, in March their hotlines received about 1,600 call about domestic violence. In comparison, the last peak of calls before the quarantine was during the New Year festive season, at 1,100 calls. In Ukraine during the first three month of this year, the National Police recorded 55,325 reports of domestic violence [20].

The Covid-19 pandemic has led to an unprecedented level of interest in research [21]. The surge in research activity is due to several reasons. The main of them is the enormous disruptions of Covid-19 on daily life. Laws and restrictions have affected the lives of everyone in the world regardless of age, gender and socioeconomic status [10]. The main task of researchers - the legitimacy of measures of state influence on man in the period Covid-19 and the limits of restriction of their rights. The right of the state to derogate from human rights in a state of emergency and the conditions of legal deviation in the context of Covid-19 are debatable among scientists. At work A. Lebret it argues that States must ensure that the general measures they adopt to face the crisis do not disproportionally harm vulnerable 
people [22]. During the pandemic the issue of the state's withdrawal from its obligations, which does not replace the permissible restrictions of human rights, was considered by Emilie Hafner-Burton and Gerald L. Neuman [23, 24], who argued that contradict the notion human right but may on the contrary contribute to their effective protection. According to A. Greene work's, the logic of this approach is as soon as the emergency is over, the deviation will removed and the law will be return to normal [25]. Other authors consider's that such deviations are not necessary. According to K. Dzehtsiarou, the convention has a mechanism of natural accommodation of emergencies such as the Covid-19 crisis and states shall act within their margin of appreciation, which can be broader than usual due to the magnitude of the crisis. Moreover, when the crisis is over, the scope of the margin will go back to normal, providing a 'natural' quarantining effect [26].

\section{CONCLUSIONS}

The current situation in the world can be used as a pretext for various kinds of abuses, ranging from domestic violence to detention or other repressive measures against life, freedoms and other human rights, the states' introduction of rules that allow legitimate restrictions on freedom. At the same time, fears are growing that some governments may use the COVID-19 to undermine democratic principles, to eliminate the nonconformity and to violate the principles of necessity and proportionality. We believe that states must abide by their human rights obligations, respect democratic principles. Achieving a balance between health protection and restriction of the rights is not an easy task for politicians. States' response to the COVID-19 pandemic must be based on evidence, but should not be due to political pressure. Measures to restrict human rights must be adequate to the threat, and the limits of intervention should be justified.

\section{REFERENCES}

1. Parliamentary Assembly . Covid-19: We must face the pandemic while respecting economic and social rights, says committee Chair. Available from: http://assembly.coe.int/nw/xml/News/News-View-EN. asp?newsid $=7836 \&$ lang $=2 \&$ cat $=133$

2. ECDC. COVID-19 situation update worldwide, as of week 22021. Available from: https://www.ecdc.europa.eu/en/geographicaldistribution-2019-ncov-cases

3. Dunja Mijatović. Reform of mental health services: an urgent need and a human rights imperative. Commissioner for Human Rights. Available from: https://www.coe.int/en/web/commissioner/home

4. European Convention on Human Rights. Available from: https://www. echr.coe.int/Documents/Convention_ENG.pdf. PDF file

5. The Federal Government. Speech by Federal Chancellor Angela Merkel on the German Presidency of the Council of the EU 2020 to the European Parliament in Brussels on 08 July 2020. Available from: https://www.bundesregierung.de/breg-en/news/speech-by-federalchancellor-angela-merkel-on-the-german-presidency-of-thecouncil-of-the-eu-2020-to-the-european-parliament-in-brusselson-8-july-2020-1768008
6. OHCHR on COVID and human rights. Human rights at the time of COVID-19 - a Guidance Note. Available from: https://www. globalprotectioncluster.org/wp-content/uploads/OHCHR-on-COVIDand-human-rights-25-March-2020-EN.pdf . PDF file

7. Fatima Tlis. COVID-19 Positive in Kazakhstan? The City Will Seal Your Door from the Outside. POLIGRAPH. info. Available from: https://www. polygraph.info/a/fact-check-kazakhstan-Covid-19/30561798.html

8. Giorgi Gakharia. Will help more than $150 \mathrm{GEL}$ for people who have lost their jobs. Available from: https://1tv.ge/news/giorgi-gakhariasheudzlebelia-tveshi-saarsebo-minimumze-naklebi-iyos-imadamianebis-mimart-dakhmareba-romlebmac-shemosavali-dakarges

9. POLITICO. What should the EU do about Hungary? New bill gives Viktor Orbán sweeping new powers to fight coronavirus. Available from: https://www.politico.eu/article/what-should-the-eu-do-abouthungary-coronavirus-viktor-orban

10. The President European Parliament. Sassoli on Hungary: Parliaments must remain open and the press must remain free. Available from: https://europarl.europa.eu/the-president/en/newsroom/sassolion-hungary-parliaments-must-remain-open-and-the-press-mustremain-free-1

11. Amnesty International. Virus-hit prisons still full of human rights defenders, as attacks continue. Available from: https://www.amnesty. org/en/latest/news/2020/08/attacks-on-hrds-during-pandemic-report

12. OC Media. Azerbaijan arrests opposition activists during Covid-19 outbreak. Available from: https://oc-media.org/azerbaijan-arrestsopposition-activists-during-Covid-19-outbreak

13. Parliamentary Assembly. COVID-19: Rapporteurs outraged by the Azerbaijani government's reliance on the pandemic to justify political repression. Available from: https://pace.coe.int/en/news/7829/ rapporteurs-outraged-by-the-azerbaijani-government-s-reliance-onthe-coronavirus-pandemic-to-justify-political-repression

14. BBC News. Coronavirus: India enters 'total lockdown' after spike in cases. Available from: https://www.bbc.com/news/world-asiaindia-52024239

15. Paul Mozur.China, Desperate to Stop Coronavirus, Turns Neighbor Against Neighbor. Available from: https://www.nytimes.com/2020/02/03/ business/china-coronavirus-wuhan-surveillance.html

16. Sandrine Gagne-Acoulon. Organized Crime Enforcing Quarantine in Brazilian Favelas. OCCRP. Available from: https://www.occrp.org/en/ daily/11930-organized-crime-enforcing-quarantine-in-brazilian-favelas

17. Philip J. Heijmans, Bibhudatta Pradhan and Pauline Bax. Locked in Cages, Beaten and Shamed: Virus Laws Lead to Abuses. Bloomberg. See at: https://www.msn.com/en-us/news/world/locked-incages-beaten-and-shamed-virus-laws-lead-to-abuses/arBB122UaS?ocid=spartandhp

18. Foreign Policy. Poor Countries Need to Think Twice About Social Distancing. Available from: https://foreignpolicy.com/2020/04/10/ poor-countries-social-distancing-coronavirus

19. Human Rights Council. Forty-seventh session 21 June-9 July 2021 Agenda item 3. Promotion and protection of all human rights, civil, political, economic, social and cultural rights, including the right to development. Reliefweb. Available from: https://reliefweb.int/report/ world/international-solidarity-aid-realization-human-rights-duringand-after-coronavirus

20. Denysenko L. Keeping safe from domestic violence during quarantine: tips from Larysa Denysenko, human rights defender. UNDP in Ukraine. Available from: https://www.ua.undp.org/content/ukraine/en/home/blog/2020/ keeping-safe-from-domestic-violence-during-quarantine.html 
21. Laine C., Taichman DB., GuallarE., Mulrow CD. Keeping up with emerging evidence in (Almost) real time, Ann Intern Med, 2020, 173:153-4.

22. Audrey Lebret, COVID-19 pandemic and derogation to human rights, Journal of Law and the Biosciences. January-June 2020;1: Isaa015, doi.org/10.1093/jlb/lsaa015

23. Emilie M. Hafner-Burton et al. Emergency and Escape: Explaining Derogations from Human Rights Treaties, International Organization, October 2011;4:673-707. doi: 10.1017/S002081831100021X

24. Gerald L. Neuman, Constrained Derogation in Positive Human Rights Regime, in Evan J. Criddle, Human Rights in Emergencies, CUP, 2016; 15-31. doi: 10.1017/CB09781316336205.002

25. Greene A. Derogating from the European Convention on Human Rights in Response to the Coronavirus Pandemic: If not Now, When? European Human Rights Law Review, 2020;3:262-276.

26. Dzehtsiarou K. Article 15 Derogations: Are They Really Necessary during the covid-19 Pandemic? European Human Rights Law Review, 2020;4:359-371.

\section{ORCID and contributionship:}

Viktor M. Baliuk: 0000-0002-3925-4943 B, D, E, F

Iuliia I. Ostapenko: 0000-0002-4033-5927 D, E, F

Larysa P. Grynko: 0000-0003-1861-8354

\section{Conflict of interest:}

The Authors declare no conflict of interests.

\section{CORRESPONDING AUTHOR}

Larysa P. Grynko

Poltava Law Institute Yaroslav Mudryi

National Law University, Poltava, Ukraine

tel: +380997623622

e-mail:gull_ukr@ukr.net

Received: 02.07.2021

Accepted: 15.10 .2021

A - Work concept and design, B - Data collection and analysis, C - Responsibility for statistical analysis,

D-Writing the article, $\mathbf{E}$-Critical review, $\mathbf{F}$ - Final approval of the article 


\title{
VACCINATION IN THE SYSTEM OF HUMAN RIGHTS AND OBLIGATIONS: IMPACT OF THE COVID-19 PANDEMIC
}

DOI: 10.36740/WLek202111221

\author{
Viktor V. Horodovenko, Larysa G. Udovyka, Tatiana 0. Shekhovtsova \\ ZAPORIZHZHIA NATIONAL UNIVERSITY, ZAPORIZHZHIA, UKRAINE
}

\begin{abstract}
The aim: To identify the problems and prospects of introducing mandatory vaccination against COVID-19 in the context of respect for human and civil rights and freedoms based on generalization and systematization of foreign experience in implementing such measures.

Materials and methods: In the research, we applied a complex of philosophical and ideological approaches, general scientific and special methods of scientific cognition, in particular civilizational and axiological approaches as well as dialectical, dogmatic, comparative, and statistical methods.

The empirical basis of the study is represented by the statistical data of the healthcare sector of European countries, generalization of the practice of vaccination. In the study, we use international and European regulatory legal acts and documents in the field of human rights, national legislation of foreign countries.

Conclusions: Vaccination represents an important component of the fundamental right to health. International legal acts on the human rights regulation, in particular the right to health, do not provide an unambiguous answer to the question of whether vaccination is the right or responsibility of a person, which has resulted in the existence of a wide range of vaccination policies and models. The existence of a wide range of policies and practices in States Parties to the Convention makes permissible the application of more imperative approaches to immunization, in particular, in cases where voluntary vaccination is not sufficient to ensure the threshold of herd immunity. In most countries, vaccination against COVID-19 is carried out voluntarily, whereas the complication of the epidemiological situation has resulted in following the path of introducing mandatory vaccination in some countries, both with regard to certain population categories (France, Greece, Russia, Ukraine) and the entire population (Tajikistan, Turkmenistan).
\end{abstract}

KEYWORDS: vaccination, human rights, human obligations, duties of the state, international legal acts

Wiad Lek. 2021;74(11 p.2):2983-2991

\section{INTRODUCTION}

One of the greatest challenges of our time, which has reached a global scale, is the pandemic of the coronavirus infection COVID-19. Having originated in the Hubei Province of China in early January 2020, the epidemic very quickly spread outside China and penetrated into almost all countries of the world. On March 11,2020, taking into account the pace and scale of the virus spread, the World Health Organization declared COVID-19 a pandemic.

As of September 30, 2021, over 233 million cases of COVID-19 had been detected worldwide, with nearly 5 million of them being lethal. The largest number of cases of virus infection occurred in North and South America jointly (nearly 90 million cases). High morbidity rates are also observed on the European subcontinent (over 70 million cases). A more favorable epidemiological situation has developed in the countries of Southeast Asia (nearly 43 million in total), which can be characterized by a rapid response to the first outbreaks of infection and the introduction of strict anti-epidemic measures, including state coercion [1].

The sudden appearance of the Corona Virus can be considered by some to be a "black swan" event, because it makes a devastating appearance and influence on all aspects of globalization and international relations $[2, \mathrm{p}$.
21]. Today, it is obvious that the pandemic is a global challenge that almost in no time changed the socio-economic, political, geopolitical, and humanitarian situation in the world and caused a systemic crisis in most spheres of public life, the way out of which can be difficult and protracted.

The major geopolitical turn is being observed in the economy, which is experiencing the largest collapse since the Great Depression. The experts and analysts of the International Monetary Fund have repeatedly stressed that the economic crisis caused by the pandemic will result in a significant decline, greater than that experienced during the global economic crisis in 2008. Among the political consequences, we should highlight, in particular, the spread of authoritarianism, increased state supervision, control, repressive measures, ethnic nationalism under the slogans of fighting against the pandemic, curtailing public freedoms, which in turn have resulted in a drop in the level of trust in governments and state institutions [3].

The COVID-19 pandemic has also had a devastating impact on the healthcare system, which proved unable to withstand an epidemic crisis of such a scale. The rapid spread of the disease and limited actual data on the virus resulted in the situation when national health systems were on the verge of collapse. Moreover, this situation turned out to be typical not only for developing countries but 
also for the countries with a traditionally high standard of living, which are considered developed. For example, according to $\mathrm{M}$. Kendrick, a doctor of the National Health Service, the British healthcare system has contributed to deepening the crisis by giving chaotic, often directly opposite instructions. One of these guidelines was the decision to place elderly people, including those with COVID-19 symptoms, in nursing homes, which led to the surge in the disease incidence at these institutions.

In the United States, the treatment of complex diseases, in particular, COVID-19, is too expensive and is not covered by basic health insurance, which resulted in the fact that access to healthcare services is not actually guaranteed to everyone [4].

In the context of the pandemic, the governments were forced to make serious legislative and managerial decisions within the shortest time possible, taking into account the epidemiological situation, which was constantly changing. The main focus has been placed on ensuring the proper functioning of the healthcare systems under crisis conditions, with the core issues being the search for effective measures to prevent the virus spread, minimization of the increase in morbidity, fast identification, and isolation of the people infected and providing them with qualified medical care [5]. One of the major consequences of the current public health crisis has been the resumption of debate about the need to introduce mandatory vaccination, which, according to WHO experts, is currently the only effective means of countering and overcoming the pandemic.

"Despite the fact that vaccination is a widespread preventive medical intervention, there is a scientific consensus that a number of vaccines might produce serious injuries to some people, and that these two facts create evident competing interests for any Government between public health, individual rights, and even the economic interests of some actors" [6, p.22]. Given the fact that each state has been developing and implementing its own strategy for overcoming the crisis caused by the pandemic with consideration of the epidemiological situation, peculiarities of mentality, public and legal life, the issue of vaccination against COVID-19 is marked by the polarity of views from incorporating the mandatory nature of such medical intervention into the legislation to implementing it on a voluntary basis.

\section{THE AIM}

To identify the problems and prospects of introducing mandatory vaccination against COVID-19 in the context of respect for human and civil rights and freedoms based on generalization and systematization of foreign experience in implementing such measures.

\section{MATERIALS AND METHODS}

In the research, we applied a complex of philosophical and ideological approaches, general scientific and special methods and means of scientific cognition, in particular civilizational and axiological approaches as well as dialectical, dogmatic, comparative, and statistical methods. The determinants of the research process were civilizational and axiological approaches used to justify the importance of human rights, their universality, and particularity; a dialectical method applied to identify the relationship between international, European, and national legislation in the field of human rights; a comparative legal approach used to analyze foreign experience in implementing the vaccination measures in the context of ensuring respect for human rights and freedoms, as well as systematization, analysis, and synthesis.

The empirical basis of the study is represented by the statistical data of the WHO and healthcare sectors of European countries, generalization of the vaccination practice. In the study, we use international and European regulatory legal acts and documents in the field of human rights, national legislation of foreign countries, namely the Universal Declaration of Human Rights, the International Covenant on Economic, Social and Cultural Rights, the CESCR General Comment No. 14: the Right to the Highest Attainable Standard of Health, the 1947 Nuremberg Code, the Convention for the Protection of Human Rights and Dignity of the Human Being with regard to the Application of Biology and Medicine, the Convention on Human Rights and Biomedicine, the Universal Declaration on Bioethics and Human Rights.

\section{REVIEW AND DISCUSSION}

The fundamental international document, which was the first to proclaim and enshrine the right to health protection, is the Universal Declaration of Human Rights adopted in 1948. According to Article 25, "Everyone has the right to a standard of living adequate for the health and well-being of himself and of his family, including food, clothing, housing, and medical care and necessary social services..." [7]. Despite the fact that the given Act only provides a generalized definition of the relevant right, it was an important step for this right to be further constituted and recognized internationally.

As an independent fundamental right, health was first defined in the WHO Constitution of 1946, where the preamble says: "The enjoyment of the highest attainable standard of health is one of the fundamental rights of every human being without distinction of race, religion, political belief, economic or social condition" [8]. Moreover, the Constitution provides a broad interpretation of the concept of 'health', which is understood not only as merely the absence of disease or physical disabilities but as a state of complete physical, mental and social well-being.

The content of the right to health is described in more detail in the International Covenant on Economic, Social, and Cultural Rights of 1966, which is a generally recognized core mechanism for protecting this right. Article 12.1 of the Covenant says that the States Parties to the present Covenant recognize the right of everyone to the enjoyment of the highest attainable standard of physical and mental 
health. The measures necessary to ensure the realization of this right are provided for by Article 12.2 and include those necessary for 1 ) the provision for the reduction of the stillbirth rate and of infant mortality and for the healthy development of the child;2) the improvement of all aspects of environmental and industrial hygiene; 3 ) the prevention, treatment, and control of epidemic, endemic, occupational and other diseases; 4) the creation of conditions which would assure to all medical service and medical attention in the event of sickness [9]. In the context of studying the place of vaccination in the system of human rights and responsibilities, para 3 , which directly concerns ensuring the implementation and legal guarantees for the protection of human health in epidemiological emergency situations, is of particular importance.

In the General Comment No. 14: the Right to the Highest Attainable Standard of Health, adopted on 11 August 2000, the UN Committee on Economic, Social and Cultural Rights interprets the relevant provision, according to which, inter alia, the control of diseases refers to the implementation or enhancement of immunization programs and other strategies of infectious disease control [10]. The Commission also notes that such immunization programs are implemented in relation to major infectious diseases, and their development and implementation is a state responsibility of comparable priority.

This position is generally reproduced in the European acts meant to regulate human rights. Thus, in the Statement on the Right to Protection of Health in Times of Pandemic, the European Committee of Social Rights emphasizes that the operation of widely accessible immunization programs is provided for in para 3 of Article 11 of the 1961 European Charter of Social Rights, under which the states are obliged to maintain high coverage rates not only to reduce the incidence of relevant diseases but also to neutralize the reservoir of virus and thus achieve the goals set by the WHO to eradicate a range of infectious diseases [11].

Thus, the international legal acts that directly or indirectly concern the problem of vaccination do not provide an unambiguous answer to the question of whether such medical intervention is a human right or obligation. Furthermore, the uncertainty of legislative regulations results in the lack of a unified approach to the use of immunization in practice.

Moreover, the European regulatory framework does not regulate whether vaccines are mandatory or recommended, since the EU's role in health policy is limited, and the Member States remain free in their decision. Thus, the National Health Services of most European countries have different vaccination systems, different vaccine recommendations, and different schedules of vaccine administration. For instance, 15 of the 27 European countries, namely, Austria, Cyprus, Denmark, Estonia, Finland, Germany, Ireland, Lithuania, Luxembourg, the Netherlands, Norway, Portugal, Spain, Sweden, and the United Kingdom have no obligation to vaccinate. The other countries have an obligation to vaccinate with between 1 vaccine (Belgium) and 12 (Latvia) [12, p. 145]. Generally, it is characteristic of most European countries to use a combined approach: mostly, vaccination is recommended for the population, but for some of its categories belonging to risk groups, it is mandatory.

A similar variety of approaches to vaccination is typical of other regions of the world. Thus, this situation is particularly pronounced in the Middle East. For example, in Pakistan, the National Expanding Program on Immunization provides for immunization of all children between 0 and 23 months against 8 vaccine-preventable diseases. Despite this, routine immunization coverage in Pakistan is far from optimal. The country is one of 10 countries with at least $60 \%$ of children unvaccinated. Moreover, the country has about $33 \%$ of the children who must be immunized in accordance with WHO immunization targets for the Region [13]. It is significant that in this country there is a difference in vaccination coverage in terms of geography: residents of urban communities have a higher level of immunization than provincial and, especially, rural ones, where local customs and beliefs are critical in solving the issue of vaccination as well as other medical interventions.

"The roots of this local resistance toward vaccination must be understood within overall geopolitical context. From this perspective, we can understand how vaccination may be perceived at the local level not as a life-saving endeavor but as a "political project" [14, p. 6]. The COVID-19 pandemic has provided an unexpected incentive for further spread of this interpretation: the Pakistani population has long perceived the new infectious disease as a "western scenario" designed to ensure the political hegemony of the Western world and placement of other states in the dependent position. This negative assessment served as another proof for the population of the general senselessness and even harmfulness of the vaccination.

The insufficient level of the population's vaccination leads to the spread of epidemic diseases in the country, including those currently considered suppressed. "Pakistan is one of the two polio-endemic countries; the other is its neighboring Afghanistan. Both have collectively contributed $85 \%$ of recent polio cases globally" [14, p. 5]. Measles and other diseases also prevail in the country. Under such circumstances, the Government of Pakistan is forced to implement supplementary vaccination measures against the most threatening epidemic diseases, but in the context of the pandemic and extreme contagiousness of the new virus, these programs have been mostly curtailed.

The diametrically opposite approach is applied by Oman, which is currently one of the most developed countries in the Arab East. The Sultanate's immunization policy is based on the principle to immunize all children under one year old against the 12 vaccine-preventable childhood diseases (primary immunization and boosters). In Manual of Expanded Program on Immunization it is especially emphasized that given the success of reduction in the incidence of the vaccine-preventable diseases in the Sultanate of Oman, and the consequent decline in levels of avoidable sickness, disability, and death, it is important that every opportunity should be taken to immunize the target population in order 
to sustain the gains made so far [15]. To achieve this goal, every contact of a child, mother, and female with the health delivery system is used. The vaccination exemption is only permitted if there are medical contraindications, with mild diseases not being the reason for the exemption.

Oman's balanced public policy in the field of healthcare in general, and immunization in particular, has had positive consequences for ensuring public health and epidemiological safety of the population. Thus, the Sultanate has been constantly demonstrating a high vaccination coverage level, which increased from 10\% in 1985 to over 95\% in 1995. In 2019 , the population vaccination rate reached $100 \%$ for all types of vaccines. Several vaccine-preventable diseases have either been eliminated or their numbers have reduced substantially. For instance, the country has maintained the polio-free status since 1994 as well as the zero incidence status of diphtheria since 1992 [16]. In 2016, the vaccine management system of Oman received an overall rating of 99\% as part of the WHO Effective Vaccine Management Project, which was the best rate among the 90 countries that participated in the study.

The immunization system in China, which is one of the major countries in the Asia-Pacific region and one of the world's largest vaccine manufacturers, has some special features. Vaccines in China are divided into two classes: a) the first class - vaccines, provided for citizens by the government free of charge: citizens should get immunized according to the government's regulations. Currently, the National Immunization Plan provides for immunization against 12 vaccine-preventable diseases. Also, this category includes supplemental vaccines paid for by lower-level governments, and emergency-use vaccines paid for by the government; $b$ ) the second class - other vaccines, provided at people's own expense and on a voluntary basis. The division of vaccines into classes is important for determining the nature of immunization. Thus, timely immunization with the first category vaccines is considered a societal duty, although not a mandate as there is no punishment associated with the non-compliance [17]. As far as vaccines of the second category are concerned, they are not mandatory: people are vaccinated at their own request and expense.

The original Chinese vaccination system demonstrates high efficiency in practice. The WHO states that China's immunization program has dramatically reduced the number of vaccine-preventable diseases. For example, polio in this country had been eradicated by the year 2000; in 2021, China was also certified as a malaria-free country. China has reached over $95 \%$ coverage for immunization [18]. Undoubtedly, this is also facilitated by the Chinese mentality traditionally characterized by a high level of trust and respect for the authorities as well as responsibility and strict implementation of government instructions, which was clearly demonstrated during the COVID-19 pandemic in this country.

In the context of the pandemic, the problem of searching for the optimal vaccination model has become particularly acute for national governments. High contagiousness of the SARS-CoV-2 virus, its resistance to the traditional treat- ment methods, an increased risk of negative consequences after the recovery as well as the emergence of new virus strains being more drug-resistant and resulting in a more complex course of the disease, make immunization the only reliable way to overcome the pandemic. To achieve an optimal result, vaccination against COVID-19 should have a systematic and comprehensive character, which is not always achieved by means of "soft power". Therefore, the need to ensure the balance between private (human rights, in particular, to medical care and medical interventions as well as possible restrictions on them due to refusal of vaccination) and public interests (state security, epidemiological well-being, and public health) requires caution when using stricter measures to ensure an appropriate level of immunization.

This situation has resulted in the fact that the decision on the introduction of mandatory vaccination in most countries has not been made yet. National states generally consider vaccination as a type of medical intervention, with the main consequence being the obligation to guarantee the patient's autonomy, including the requirement of voluntary informed consent, which is now the international standard for conducting medical research.

The first act that made mandatory the patient's voluntary consent in medical practice was the Nuremberg Code of 1947, adopted after the completion of the Nuremberg trial of Nazi doctors, in which para 1 enunciates that when carrying out experiments on human subjects, the voluntary consent of the human subject is absolutely essential. This means that the person involved should have the legal capacity to give consent; should be so situated as to be able to exercise free power of choice, without the intervention of any element of force, fraud, deceit, duress, overreaching, or another ulterior form of constraint or coercion; and should have sufficient knowledge and comprehension of the elements of the subject matter involved as to enable him to make an understanding and enlightened decision [19]. Despite the fact that this document is mainly aimed at regulating the conduct of medical experiments and research on people, the principles set out in it were fundamental for building the post-war system of health regulation and laid the basis for the majority of international legal acts on the regulation of medical practices.

Within the European legal framework, the main document regulating the procedure for conducting medical research is the 1997 Convention for the Protection of Human Rights and Dignity of the Human Being with regard to the Application of Biology and Medicine (Oviedo Convention). Articles 5-6 of the given Act set out the requirements to be met when intervening in the field of human health, among them there are as follows: a) an intervention in the health field may only be carried out after the person concerned has given free and informed consent to it; b) this person shall beforehand be given appropriate information as to the purpose and nature of the intervention as well as on its consequences and risks; c) an intervention may only be carried out on a person who does not have the capacity to consent, for his or her direct 
benefit; d) where a minor does not have the capacity to consent to an intervention, or an adult, because of a mental disability, a disease or for similar reasons, the intervention may only be carried out with the authorization of his or her representative or an authority or a person or body provided for by law. Moreover, the individual concerned shall as far as possible take part in the authorization procedure, and the opinion of the minor shall be taken into consideration as an increasingly determining factor in proportion to his or her age and degree of maturity. In addition, Article 2 of the Convention emphasizes that the interests and welfare of the human being shall prevail over the sole interest of society or science [20].

These provisions were further developed in the Case-law of the European Court of Human Rights. In the judgment in the case of M.A.K. and R.K. v. the United Kingdom, the court, taking into account the existence of a legislative gap in the definition of "medical intervention", clarifies: "Domestic law and practice clearly require the consent of either the patient or, if they are incapable of giving consent, a person with appropriate authorization before any medical intervention can take place" [21]. Thus, the European practice proceeds from a broad understanding of medical intervention, which includes not only therapy and surgical treatment but also preventive measures aimed at ensuring a state of physical and mental well-being.

A similar position is set out in the Universal Declaration on Bioethics and Human Rights adopted by UNESCO in 2005, where Part 1 of Article 6 contains an important provision that any preventive, diagnostic, and therapeutic medical intervention is only to be carried out with the prior, free and informed consent of the person concerned [22].

This standpoint is generally shared by Western researchers, who point out that "vaccine trials fall within interventional research and they are not 'low interventional studies' with minimal risk". Special carefulness concerning benefit/ risks assessment is required as healthy volunteers are the target population for vaccine trials. This fact determines two consequences: "astringent stress on safety both in clinical trials and in clinical practice, and a more rigid regulation concerning informed consent [12, p. 144]. Such a policy should promote ensuring the quality, effectiveness, and safety of the vaccination procedure as well as the realization of fundamental human rights and freedoms, their priority over other considerations.

It is obvious that mandatory vaccination will inevitably lead to restrictions or direct violations of some human rights, including 1) the right to life - vaccinations can be potentially dangerous to health, for example, if there are allergies, other medical contraindications, poor quality or unsuitability of the vaccine. In addition, "the European Commission on Human Rights explicitly states that if a state maintains a control and monitoring system that aims to minimize vaccine-associated side effects, isolated fatalities do not constitute an interference with the right to life" [23, p. 212]. Moreover, in this context vaccination is often seen as a positive duty of the state aimed at ensuring this right, especially in the context of the epidemic threats spread;2) the right to the physical integrity of a person - since vaccination is an intrusive medical intervention, the absence of a person's consent to it is considered a violation of the relevant right. Moreover, even the presence of such a consent to obligatory vaccination could become only a formality or a legal fiction [12, p. 147]; 3) the right to respect for private life - possible negative consequences of mandatory vaccination are manifested according to several criteria: a) a failure to have been vaccinated is sanctioned by exclusion from a certain social group (e.g. kindergarten and schools) relevant for the shaping of one's personality; b) restrictions on the access to a profession [23, p. 217-218]; 4) the right to respect for family life, including parents' right to make decisions with regard to their children - in the event of mandatory vaccination, parents' objections to it in the absence of medical indications are not accepted as a strong argument for refusal; 5) freedom of conscience and religion - if one decides not to be vaccinated because of his/her conscience, then the compulsory order interferes with the right to act in accordance with one's conscience at first glance. However, the ECtHR rejects a right to oppose state orders by invoking incompatibility with one's conscience provided that a generally and neutrally phrased act exists as the basis of the order [23, p. 224].

As far as vaccination against COVID-19 is concerned, it is the model of voluntary vaccination that underlies it in most countries. In particular, Germany has expressed its commitment to such a policy, since the population of this country shows high readiness for vaccination. Thus, in Germany, the total number of people fully vaccinated against COVID-19 exceeds the number of unvaccinated people $(43.7 \%$ of the overall population, which is 36.4 million people, against $41.5 \%$ respectively). $58.9 \%$ (49.1 million people) have received at least one vaccination. The highest vaccination rates are observed in Bremen (68.1\%), Saarland (63.7\%), Schleswig-Holstein (62.3\%), North Rhine-Westphalia (62.1\%), and Lower Saxony (61.2\%); the lowest rates are reported in Brandenburg (54.2\%), Thuringia (53.7\%) and Saxony (50.1\%) [24]. The Federal Government emphasizes that through voluntary vaccination, the authorities expect to gain the people's trust.

Among the European countries, the highest vaccination rates are demonstrated by Austria, where a total of people fully vaccinated against COVID-19 was 49.09\% (3.9 million people); $64.3 \%$ (5.1 million people) received at least one vaccination as of July 15 . The fastest pace of vaccination is reported in the Lands of Burgenland $(51.42 \%$ of the population are fully immunized; $63.22 \%$ received the first vaccination dose), Vorarlberg (46.76\% of the population are fully immunized; $56.21 \%$ received the first vaccination dose), Lower Austria (45.82\% of the population are fully immunized; $60.10 \%$ received the first vaccination dose). Lower vaccination rates are reported in Vienna (40.65\% of the population are fully immunized; $54.46 \%$ received the first vaccination dose), the lands of Upper Austria (40.88\% are fully immunized; $52.84 \%$ received one COVID-19 vaccination), Styria (41.71\% are fully immunized; $57.13 \%$ received one COVID-19 vaccination) [25]. In Austria, vaccination against COVID-19 is also carried out on a voluntary basis. 
However, some researchers hold the opposite view, emphasizing that the presumption of a patient's personal autonomy is not immutable: "... it is most overridden, for example, in the provision of emergency medical care, where, in the absence of evidence to the contrary (and when faced with a patient unable to provide consent at the moment), it is presumed by healthcare providers - in accordance with their duties of beneficence and non-maleficence - that the patient before them would wish to receive all necessary and reasonable medical treatment. In the context of compulsory vaccination, a similar rationale could be applied in order to justify the curtailment of personal autonomy" [26, p. 3-4]. In this regard, it is appropriate to note that by its nature, vaccination is significantly different from other medical interventions, since the refusal of vaccination threatens not only and not so much the health of an individual, but the epidemiological safety of a particular state and herd immunity of the population, which is an important factor in the prevention and control of infectious diseases.

It is well known that if too many elect not to receive a vaccination, the requisite threshold herd immunity required in order to be effective may not be reached, and the 'herd' or group may be left collectively vulnerable: an insufficiently immune proportion of a population can allow a disease to continue to circulate. Rates of refusal for measles vaccination are an example of this danger: in 2019, some 1282 individual cases of measles were confirmed in 31 states of the USA; the majority had not been vaccinated against the disease [26]. This example clearly demonstrates that vaccination is an important preventive measure; authorizing the state to only act in cases of a person being already ill, or disease having reached an enormous scale, significantly reduces the effectiveness of protecting human health.

Similar considerations are set out in the Report of the International Bioethics Committee of UNESCO (IBC) "On Consent", where para 56 reads: "... the threat of an epidemic legitimates the public hand to order compulsory measures", namely quarantine and immunization. "....Furthermore, even without immediate epidemic danger, it might be justified to declare immunizations compulsory in order to ensure a sufficient coverage in the population" [27]. The Committee notes that the application of such measures is legitimate to protect public health against serious diseases transmitted in everyday life in an uncertain environment.

In recent years, there has been a trend towards strengthening the population's obligations to be vaccinated in some states. For example, in Italy, after the measles outbreak in 2017, the number of mandatory vaccinations under the national immunization plan increased from 4 to 10 , and access to early childhood educational services became possible only after minor children had received all ten vaccinations. The exemption from mandatory vaccination is permitted in two cases: a) cases of pre-existent immunity stemming from having naturally contracted a disease (proof must be provided), and b) cases in which they pose a danger to one's health due to specific, documented medical circumstances. In addition, the law significantly tightened the sanctions for evading or refusing vaccination - a fine of EUR 100-500 is imposed on the parents of unvaccinated children of the relevant age [28]. The original version of the law provided for the minimum fine of EUR 500 and the maximum fine of EUR 7,500.

Having examined the relevant law in terms of its compliance with the Constitution of the Republic, the Constitutional Court declared it constitutional, stating that in the face of vaccine coverage that is unsatisfactory in the present and trending toward critical levels in the future, it falls within the discretion (and the political responsibility) of government bodies to appreciate the overriding urgency to intervene, in light of the new data and new epidemiological phenomena that have emerged in the meantime, including in the name of the principle of precaution, which must preside in an area as crucial for the health of every citizen as that of prevention. Moreover, the Court stated that the law imposing a legal-related treatment is not incompatible with the Constitution if: the treatment is intended not only to improve or maintain the health of the individual in receipt of treatment, but also to preserve the health of others; it is provided that the treatment may not have a negative impact on the health of the recipient, with the exclusive exception of those consequences that normally result and, as such, are tolerable; in the case of further injury, the payment of equitable compensation to the injured party is provided for, separate and apart from any damages to which they may be entitled [28]. Given this, and taking into account the sanitary and epidemiological conditions, the existence of a mandatory vaccination system in itself is not a violation of human rights.

Among all the European countries, France has the strictest immunization policy. Currently, 11 positions of mandatory vaccination have been established in this country (compared to 3 vaccinations before the adoption of the relevant amendments in 2017). In addition, the failure by parents, without a legitimate reason (the only reason being medical contraindications), to comply with their legal obligations to provide healthcare to their underage child shall be punished by a term of imprisonment of two years and a fine of EUR 30,000 [29]. In the written comments of the French government in the case "Vavrička and Others v. the Czech Republic", it is emphasized that "the interference represented by such a compulsory vaccination scheme with the right to respect for private life was accordingly proportionate to the objective of promoting the degree of vaccination coverage needed to reach the herd immunity threshold for the benefit of the entire population" [30].

The issue of mandatory vaccination is also covered in the Case-law of the European Court of Human Rights. In this context, the judgment in the case "Vavřička and Others v. the Czech Republic" [30], adopted on April 8, 2021, was of ultimate importance and is expected to become a precedent for resolving the issue of universal mandatory vaccination against COVID-19. According to the researchers, the transfer of the case to the Grand Chamber of the ECHR indicates the complexity of the issue, in particular, due to a possibility of contradictions with the previous court decisions. It is no coincidence that the first hearing in the case took place after the end of the "special regime" for the court's 
functioning established in connection with the COVID-19 pandemic. The hearing was held with the participation of the parties, with their addresses and replies being heard as well as with the involvement as the third party interveners of four EU states (Germany, Poland, Slovakia, and France) and four non-profit organizations, which also submitted their comments on the merits of the issue.

In its judgment, the European Court declared that, without calling into question the right to respect for private life provided for in Article 8 of the Convention for the Protection of Human Rights and Fundamental Freedoms and the presumption of a person's physical integrity as its part, compulsory vaccination should be recognized as an admissible practice. Reasoning its position, the court made several conclusions, namely: 1) the objective of the legislation on compulsory vaccination is to protect against diseases that may pose a serious risk to health, which is fully consistent with the aims of the protection of health and the protection of the rights of others, recognized by Article 8 of the Convention; 2) matters of healthcare policy are in principle within the margin of appreciation of the domestic authorities, who are best placed to assess priorities, use of resources and social needs of the population; the margin of appreciation will usually be wide if it is required to strike a balance between competing private and public interests. On the existence of a consensus, the Court discerns two aspects: a) vaccination is one of the most successful and cost-effective health interventions and each State should aim to achieve the highest possible level of vaccination among its population. Accordingly, there is no doubt about the relative importance of the interest at stake [30]; b) among the Contracting Parties to the Convention, there exists a significant range of vaccination policies and models as well as changes in policies towards a more prescriptive approach; 3 ) when deciding on ensuring the interests of children, the court emphasizes that in the context of health care, the best interest of the child is served by enjoying the highest attainable standard of health. In terms of preventing and countering serious diseases this standard is achieved by immunization: "In the great majority of cases, this is achieved by children receiving the full schedule of vaccinations during their early years. Those to whom such treatment cannot be administered are indirectly protected against contagious diseases as long as the requisite level of vaccination coverage is maintained in their community, i.e. their protection comes from herd immunity" [30]. Based on the stated above, a compulsory vaccination policy may be introduced if voluntary vaccination is not sufficient to ensure the threshold of herd immunity; 5) commenting on the violation of the right to education (non-admission to an educational institution in the absence of necessary vaccinations), the court pointed out that it cannot be regarded as disproportionate for a State to require those for whom vaccination represents a remote risk to health to accept this universally practiced protective measure, as a matter of legal duty and in the name of social solidarity, for the sake of the small number of vulnerable children who are unable to benefit from vaccination [30]. From the judgment, it is obvious that this primarily concerns conventional preventive vaccinations against major diseases. However, despite its high relevance, the issue of immunization against COVID-19 was not considered by the European Court.

Meanwhile, taking into account the difficult epidemiological situation, some states introduced compulsory vaccination against COVID-19 for certain categories of citizens. Thus, in France, mandatory immunization has been introduced for those who come into contact with vulnerable categories of citizens, in particular, doctors, nursing staff in hospitals, clinics, nursing homes, institutions for disabled people as well as all specialists or volunteers who are in contact with vulnerable categories of citizens [31] The checks of doctors for compliance with vaccination regulation and imposing fines on those unvaccinated started on September 15.

Despite the fact that for the majority of the French population vaccination against COVID-19 remains voluntary, the scope of application of a sanitary pass with information about vaccinations and tests for infection is significantly expanded: starting from July 21 , one can participate in events involving over 50 people only if this document is available; starting from August, without this document, one is not allowed to enter bars, restaurants, shopping centers, trains, intercity buses, planes [31].

Greece is implementing similar measures. The Greek Prime Minister, K. Mitsotakis, said in a televised address to the nation: "Immediate vaccination of nursing home workers is becoming since they represent the most vulnerable category. Those who do not do so will be suspended from work from August 16. From September 1, compulsory vaccination will also apply to public and private sector medical workers" [31]. Till the end of the summer, all indoor and entertainment venues were only open for those who received vaccinations. In addition to these countries, the conditionally compulsory vaccination against COVID-19 was introduced in Latvia and Russia, whereas in Tajikistan and Turkmenistan, COVID-19 vaccination was included in the Immunization Plan in July 2021, which resulted in the extension of this duty to the entire population.

According to the researchers, the difficulties in implementing compulsory vaccination against COVID-19 are associated with some characteristic features of both the infection itself and the nature of vaccines. First of all, it is about vaccination effectiveness and safety, which, in the absence of sufficient reliable scientific data on the pathogen virus, cannot be properly guaranteed. In addition, most COVID-19 vaccines have been approved for production and mass use in an accelerated manner, without conducting the third stage of clinical trials, which naturally leaves many questions about them affecting both a person and the general public.

\section{CONCLUSIONS}

Summarizing the experience of different countries, namely Germany, Austria, France, Italy, Greece, and China in 
implementing vaccination allows us to draw the following conclusions: vaccination is an important component of the fundamental right to health. The aim of vaccination consists in preventing and counteracting the spread of infectious epidemic diseases that pose a serious threat to the health of an individual and society as a whole; international legal acts on the regulation of human rights, in particular, the right to health, do not give a clear answer to the question of whether vaccination is a human right or obligation. This uncertainty has resulted in the existence of multiple vaccination policies and models designed in each national state with consideration of the epidemiological state, economic opportunities, and political conditions, as well as the mentality of its citizens; currently, there are two main models of vaccination in the world, which differ depending on the degree of imperativeness - voluntary (vaccination as a person's right) and mandatory (vaccination as a person's duty); most states consider vaccination as a type of medical intervention, National states generally consider vaccination as a type of medical intervention, which results in the duty to guarantee the patient's autonomy, including the requirement of voluntary informed consent. This approach to immunization is based on the priority of human rights and freedoms, which, as most international regulations provide for, prevail over other considerations, including the interests of state and society; however, the COVID-19 pandemic has demonstrated the vulnerability of this approach: a rapid spread of the virus, the severity of the disease and its subsequent consequences have revealed that no human rights can be properly and effectively implemented in the face of a threat to the public health; the model of compulsory vaccination is based on an exception to the general rule, according to which medical intervention in the health of a patient without his/her consent is only allowed in urgent cases, for the sake of preserving his/her life and health. In this context, vaccination has significant differences from other types of medical interventions, since it jeopardizes herd immunity and health of other people; the issue of compulsory vaccination and its compliance with human rights has been the matter of consideration for the European Court of Human Rights, whose recent judgment holds that vaccination is an important preventive medical measure that provides protection against diseases carrying serious health risks, which is a positive duty of the state according to the Convention for the Protection of Human Rights and Fundamental Freedoms. Moreover, the existence of multiple policies and practices in the States Parties to the Convention permits application of more imperative approaches to immunization, in particular, in cases where voluntary vaccination is not sufficient to ensure the threshold of herd immunity; in most states, vaccination against COVID-19 is now carried out on a voluntary basis. However, the complication of the epidemiological situation has resulted in the introduction of compulsory vaccination in several countries, which can affect both certain population categories (France, Greece, Russia) and the country's entire population (Tajikistan, Turkmenistan).

\section{REFERENCES}

1. WHO Coronavirus Disease (COVID-19) Dashboard. Available from: https:// covid19.who.int [reviewed 2021.07.02].

2. Simons G. The Corona Virus Pandemic and Global Transformations: Making or Breaking International Orders? Outlines of Global Transformations: Politics, Economics, Law. 2020;13(5):20-37. doi: 10.23932/2542-0240-2020-13-5-2.

3. HorodovenkoV,Bondar 0,UdovykaL.Jasticein the Covid-19eraThroughthePrism of Judicial Power. Ius Humani. 2021;10(1):51-72. Available from: http://www. iushumani.org/index.php/iushumani/issue/view/11 [reviewed 2021.07.02].

4. Stiglitz J. Conquering the Great Divide. Finance\&Development. September 2020:17-19.

5. Horodovenko V, Udovyka L, Dichko H. Ensuring respect for human rights and freedoms in the context of states' measures introduction to combat the COVID-19 pandemic: European experience. Wiad Lek. 2020;73(12):2773-2779. doi: 10.36740/WLek202012212.

6. Acosta Jl. Vaccines, Informed Consent, Effective Remedy and Integral Reparations: an International Human Rights Perspective. Vniversitas. 2015;131:19-64. doi:10.11144/Javeriana.vj131.vier.

7. The Universal Declaration of Human Rights Available from: https://www.un.org/en/universal-declaration-humanrights/. [reviewed 2021.07.06].

8. Basic Documents - 48th ed. (Including amendments adopted up to 31 December 2014). Geneva: WHO Press; 2014. Available from: https:// apps.who.int/gb/bd/PDF/bd48/basic-documents-48th-edition-ru. pdf?ua $=1 \# p a g e=9$ [reviewed 2021.07.09].

9. International Covenant on Economic, Social and Cultural Rights Available from: https://www.ohchr.org/en/professionalinterest/pages/cescr. aspx. [reviewed 2020.07.06].

10. CESCR General Comment № 14: The Right to the Highest Attainable Standard of Health (Art. 12) Available from: https://www.refworld. org/pdfid/4538838d0.pdf [reviewed 2021.07.06].

11. European Committee of Social Rights. Statement of interpretation on the right to protection of health in times of pandemic Available from: https://rm.coe.int/statement-of-interpretation-on-the-right-toprotection-of-health-in-ti/16809e3640 [reviewed 2021.07.06].

12. Ferro V. Legal aspects of Informed Consent in Clinical Research: the Case of Vaccination in the International Legal Framework. BioLaw Journal. 2019;1:139-149.

13. Pakistan country health profile Available from: https://applications. emro.who.int/dsaf/EMROPUB_2016_EN_19266.pdf?ua=1 [reviewed 2021.07.10].

14. Ali I, Sadique S, Ali S. COVID-19 and Vaccination Campaigns as"Western Plots" in Pakistan: Government Policies, (Geo-)politics, Local Perceptions and Beliefs. Front. Sociol. 2021;6:1-10. doi:10.3389/fsoc.2021.608979.

15. Manual of Expanded Program on Immunization Available from: https://www.moh.gov.om/documents/272928/4017900/EPI_Manual. pdf/7cdf4393-3ff9-3575-f911-c460ada5831b\#: :text=EPI\%20 in $\% 200$ man\%20was\%20launched, increasing\%20rates\%20of\%20 vaccination\%20coverage [reviewed 2021.07.11].

16. Annual Health Report 2019 of Ministry of Health Sultanate of Oman Available from: : https://www.moh.gov.om/

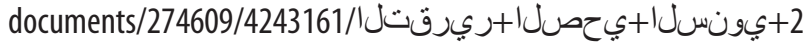
019/9afb3559-6f77-9e79-1251-e3d0a26b4861 [reviewed 2021.07.11]. [reviewed 2021.07.11].

17. Zheng Y, Rodewald $L$, Yang J et al. The landscape of vaccines in China: history, classification, supply, and price. BMC Infect Dis. 18, 502 (2018). doi: $10.1186 / s 12879-018-3422-0$ 
18. Protecting People through vaccination in China Available from: https:// www.who.int/china/activities/protecting-people-through-vaccination [reviewed 2021.07.12].

19. The Nuremberg Code (1947) Available from: https://media.tghn. org/medialibrary/2011/04/BMJ_No_7070_Volume_313_The_ Nuremberg_Code.pdf [reviewed 2021.07.12].

20. Convention for the Protection of Human Rights and Dignity of the Human Being with regard to the Application of Biology and Medicine: Convention on Human Rights and Biomedicine Available from: https:// rm.coe.int/168007cf98 [reviewed 2021.07.12].

21. Case of M.A.K. and R.K. v. the United Kingdom (Applications nos. 45901/05 and 40146/06): ECHR Judgment of 23 March 2010 Available from: https://hudoc.echr.coe.int/fre\#\{\%22item id\%22:[\%22001-97880\%22]\} [reviewed 2021.07.13].

22. Universal Declaration on Bioethics and Human Rights adopted on 19 October 2005 Available from: http://portal.unesco.org/en/ev.php-

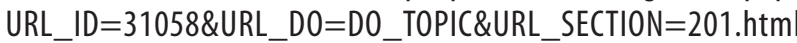
[reviewed 2021.07.13].

23. Krasser A. Compulsory Vaccination in a Fundamental Rights Perspective: Lessons from the ECtHR. ICL Journal 2021;15(2):207-233. doi: 10.1515/ icl-2021-0010.

24. COVID-19-Impfdashboard Available from: https://impfdashboard.de [reviewed 2021.07.15].

25. Corona-Schutzimpfung in Österreich Available from: https://info. gesundheitsministerium.gv.at [reviewed 2021.07.15].

26. Beazley A. Contagion, containment, consent: infectious disease pandemics and the ethics, rights and legality of state-enforced vaccination. J Law Biosci. 2020; 7(1):1-10. doi: 10.1093/jlb/lsaa021.

27. Report of the International Bioethics Committee of UNESCO (IBC) On Consent Available from: https://ethics.iarc.fr/Documents/IBC_consent. pdf [reviewed 2021.07.14].

28. Constitutional judgment № 5/2018 Available from: https:// www.cortecostituzionale.it/documenti/download/doc/recent_ judgments/S_5_2018_EN.pdf [reviewed 2021.07.15].

29. Decision № 2015-458 QPC of 20 March 2015 Available from: https:// www.conseil-constitutionnel.fr/en/decision/2015/2015458QPC.htm [reviewed 2021.07.15].
30. Case of Vavřička and Others v. the Czech Republic (applications № 47621/13 and 5 others) Available from: http://hudoc.echr.coe.int/ eng?i=001-209039 [reviewed 2021.07.17].

31. Sheludkova I. Vaktsinatsiia stanovitsia obiazatelnoi [Vaccination is becoming obligatory]. Euronews. 2021.07.12. Available from: https:// ru.euronews.com/2021/07/12/covid-measures-in-europe-includingobligatory-vaccination [reviewed 2021.07.16] (in Russian).

\section{ORCID and contributionship:}

Viktor V. Horodovenko: 0000-0001-6002-4192

Larysa G. Udovyka: 0000-0001-9260-4474 ${ }^{D, E}$

Tatiana O. Shekhovtsova: 0000-0002-5319-3323 ${ }^{\text {B, C }}$

\section{Conflict of interest:}

The Authors declare no conflict of interest.

\section{CORRESPONDING AUTHOR Larysa G. Udovyka \\ Zaporizhzhia National University \\ Zaporizhzhia, Ukraine \\ tel: +380500880309 \\ e-mail: lora.znu@gmail.com}

Received: 08.07.2021

Accepted: 11.10 .2021

A - Work concept and design, B - Data collection and analysis, C - Responsibility for statistical analysis, D-Writing the article, $\mathbf{E}$-Critical review, $\mathbf{F}$ - Final approval of the article 


\title{
IMPACT OF EPIDEMIOLOGICAL SITUATION ON RESPECT FOR HUMAN RIGHTS AND FREEDOMS: INFORMATIONAL ASPECT
}

DOI: 10.36740/WLek202111222

\author{
Mariya G. Shul'ha' ${ }^{1}$ Anatoliy V. Mazur' ${ }^{2}$, Iurii V. Georgiievskyi' ${ }^{1}$ \\ 'YAROSLAV MUDRY NATIONAL LAW UNIVERSITY, KHARKIV, UKRAINE \\ ¿UNIVERSITY OF CUSTOMS AND FINANCE, DNIPRO, UKRAINE
}

\begin{abstract}
The aim: To study an impact of the epidemiological situation on enforcement of the rights and freedoms in global informational space at international, regional, and national levels (by the example of the Republic of Poland and Ukraine).

Materials and methods: This research is based on empirical and analytical data of WHO, conventional norms on protection of rights and freedoms, anti-epidemic legislation of Ukraine and the Republic of Poland, reports of European and international institutions on human rights. Over 100 sources of information have been discovered, including regulatory legal acts, academic papers. Dialectical, comparative, analytical, synthesis, system analysis methods have been applied.

Conclusion: The priority of human rights and freedoms over the public interest in the fight against the previously unknown and rapidly spreading coronavirus while delivering medical care - is a paradigm that seems to be reconsidered under "syndemic" conditions in connection with "infodemic". Epidemiological situation and human rights are interdependent in a globalized world. Channels of formal and informal informing, as well as objective, current, full enough information content, make a "person-state" communication effective. During a pandemic, regional and international communication must be complete and regular.
\end{abstract}

KEY WORDS: rights and freedoms, pandemic, syndemic, information, infodemic

Wiad Lek. 2021;74(11 p.2):2992-2998

\section{INTRODUCTION}

From the moment of aggravation of an epidemic situation information as a phenomenon is investigated by representatives of various sciences: economy, finance, IT, medical, and many others. There are pointedly studied peculiarities of information dissemination on world markets during a pandemic, the influence of various sources of information on COVID-19, quality of online information about COVID-19 for the general public, decoding of information about coronavirus in view of the formation of approaches to the development of possible therapy, clinical information about the virus, etc.

In social sciences information is studied as a factor of impact in case of dissemination through social media [1], verity or inveracity of information [2], as a tool for effective communication during epidemics and as an important component of public health assessment [2], in terms of its dissemination through various channels and as a means of receiving feedback on health issues [4], and in other various projections.

In scientific publications on human rights and freedoms threatened by the pandemic, information appears through the prism of communication between an individual and a state, official and judicial interpretation of the right to health, the legality of handling information about the health of an individual, the legislative basis for the introduction of new information technology of personal observation, etc.
Among others, the right to health should be considered in the context of the Universal Declaration of Human Rights, Article 25 states: "Everyone has the right to a standard of living adequate for the health and well-being of himself and of his family, including food, clothing, housing, and medical care and necessary social services, and the right to security in the event of unemployment, sickness, disability, widowhood, old age or other lack of livelihood in circumstances beyond his control" [5]. Moreover, the Sustainable Development Goals (SDGs [6]) expand the scope of the above-mentioned [7]. One of 17 goals of SDGs also concerns the human right to health: goal 3 is formulated "Ensuring healthy lives and promoting well-being at all ages". Finally, it emphasizes the relationship between the goal and human rights (Hawkes and Buse, 2016 [8]). Despite the limited content, the declared right to health significantly contributes to the health of nations and peoples, as well as allows to implement fairer global health policies in the future (Forman ef al., 2015 [9]).

The paradigm is under threat: health and human rights [10]. A few months ago, a similar thesis on the risks of fundamental human values would have found its adherents in view of acute but well-known problems: poverty, poor environment, food insecurity, unequal living conditions, discrimination, imperfect health legislation, and many others. A coronavirus pandemic has now been added to the undisputed factors that could shake health and human 
rights systems in both wealthy and developing countries. The global coronavirus pandemic has radically changed the lives of many people and our information space.

\section{THE AIM}

The aim of the paper is to study the impact of the epidemiological situation on enforcement of the rights and freedoms in global informational space at international, regional, and national levels (by the example of the Republic of Poland and Ukraine), as well as the development of proposals, allowing to maintain a delicate balance between the interests of an individual and a state in connection with infodemic.

\section{MATERIALS AND METHODS}

The methodological thesis of this study is, firstly, the stated point of view of Scheinin M. (2021) on "The first defining characteristic of human-rights-based responses to COVID-19 is the recognition of the equal value and rights of every human being" [11, p.1]. Traditional approaches to overcoming epidemics are worth agreeing to have been usually based on the priorities of the community, its property, and security interests. Nowadays just a "technocratic reaction" to the pandemic should be avoided and the actions of public authorities should be verified for their strict adherence to human rights, including the right to equal access to information provided by many constitutions of different states. Thus, Article 61 of the Constitution of the Republic of Poland has the eloquent title of "Prawo dostępu do informacji publicznej" [12]. Part 2 of Article 34 of the Constitution of Ukraine declares: "Everyone shall have the right to freely collect, store, use, and disseminate information by oral, written, or other means at his discretion" [13]. Equal access to information is the fundamental basis of the so-called "information society". Therefore, the second initial thesis is that the response to a pandemic, if it is based on an established concept of human rights and freedoms, should be supported by reliable, evidence-based information. Due to the nature of this crisis, governments were unfortunately forced to make decisions based on incomplete medical and epidemiological information [11, p.2].

This study is grounded on empirical and analytical data of the WHO, conventional rules on the protection of rights and freedoms, anti-epidemic legislation and statistics of Ukraine and the Republic of Poland, reports of European and international human rights institutions. In total, more than a hundred sources of information have been analyzed, including regulations and academic papers. Dialectical, comparative, analytical, synthesis, system analysis methods have been applied.

\section{REVIEW AND DISCUSSION}

\section{EMERGENCY EPIDEMIOLOGICAL SITUATION AS A CHALLENGE TO HUMAN RIGHTS}

Epidemiological situation - is an indicator of the epidemiological well-being of the territory (object) at a certain time, characterized by the level and dynamics of human disease for infectious diseases, the presence or absence of relevant factors of infection, and other circumstances affecting the spread of infectious diseases [14]. On the website of the EU Agency - "European Centre for Disease Prevention and Control", changes in the epidemiological situation through the prism of the dynamics of diseases and other indicators of coronavirus infection can be observed in the mode of daily and weekly updated information [15]. One of the concomitant circumstances influencing the spread of COVID-19 is vaccination. For example, in terms of the level of vaccination of people over the age of 80 , the Republic of Poland ranks 21st out of 30 EU/EEA countries. At the same time, the country is currently in the top 5 of European countries in terms of the number of twice vaccinated population (17.4 million people), along with Germany (45.6 million people), France (33.9 million people), Italy 32.8 million people), Spain (27.3 million people) [16].

The epidemic in the Republic of Poland has been lasting since March 20, 2020. Prior to that, the "stan zagrożenia epidemicznego" was in force during the week. Currently, returning to such a less severe state, providing for the abolition of certain prohibitions and restrictions, is being discussed. In Ukraine quarantine and intensified anti-epidemic measures were introduced by a government decree on July 22, 2020 [17]. In any country, an epidemiological situation determines a set of measures, a combination of permits, restrictions, and prohibitions (legal regime), which directly affect an individual endowed with rights and freedoms. Their implementation in practice in such circumstances may occur with some precaution.

At the same time, the gradual approach of the next wave of the epidemic continues to keep society in tension, demanding decisive steps from public authorities, including health officials. As a preventive tool in political, economic, legislative, social, psychological, ethical manifestations, the issue of vaccination remains on the agenda and becomes actual. In this regard, the issue of political, legal, moral, and ethical responsibility becomes especially important. Through the prism of each of them, it is necessary to analyze the reasons and grounds for anti-vaccine protests, rolling in European cities. Their participants oppose mandatory vaccine certificates, declaring the threat of dictatorship and manipulation, in particular, against the background of the "my body, my choice, my rights, my freedom" slogan.

The WHO emphasizes the variability of the epidemiological situation around the world. The emergence of problematic variants of SARS-CoV-2 requires reviewing lessons learned about the virus and the response to the situation, identifying gaps in knowledge, anticipating potential challenges, responding to gender situations, and a fair response based on respect for human rights [18].

The United Nations has previously stated that "human rights are key in shaping the pandemic response, both for the public health emergency and the broader impact on people's lives and livelihoods" [19]. Human rights are in the spotlight. Thus, if the state's response is based on their 
respect, it really leads to better results in overcoming the pandemic, ensuring health for all, and preserving human dignity. And the concept of justice is here the key. If "Jus est ars boni et aequi", then international law is an instrument of justice in the global dimension. Thus, against the background of the refusal of individual countries to adhere to existing international treaties due to their own geopolitical interests imposed by political elites, a discourse on the systemic crisis of international law arose. However, a law in general and international law, in particular, are the best and potentially most powerful tools by which we can deal with common threats to the future international community [20]. It is no coincidence that Bodnar A. (2020) focuses on the reports of experts of The Lancet Commission, who insist on the rule of law in public health management [21].

\section{INFORMATION, MISINFORMATION, "INFODEMIC"}

Except for international law and the corresponding national law, information is another means of counteracting an unfavorable epidemiological situation while respecting human rights and freedoms. As Horodovenko V. et al. (2020) rightly remarked "for ensuring respect for human rights and freedoms it is essential to provide free dissemination of information ... A complex approach to the problem of ensuring human rights in the field of European and international activities to counter the spread of the COVID-19 pandemic is of extreme importance" [22, p.2778].

Free dissemination of information and access to it is critically needed in any emergency conditions, including epidemiological. For example, "the importance of ensuring an open flow of information in times of crisis" was recognized by the World Customs Organization in its Resolution on the role of customs in natural disaster relief (June 2011) [23]. One of the manifestations of such assistance is "to speed up the clearance and release of relief consignments at borders in order to ensure that aid reaches victims in need in a timely manner". The content of this Resolution is considered relevant against the background of a pandemic, when there is an urgent need to intensify the cross-border movement of humanitarian assistance, in particular medicines. Creating barriers at the customs border in such circumstances to move not only "relief goods" but also goods in general, will not minimize the negative impact of COVID-19 on economies and societies [24]. It is difficult to overestimate the role of customs regulation in the modern world, where people's lives and health may depend on the promptness of cross-border movements.

Health information can be directly related to the right to health. There is an overwhelming need for a state to value health data. Public administrations should protect and use such information to promote human rights. Otherwise, there is a risk of abuse by private companies (Google, Apple, Microsoft, Facebook and Amazon), which in turn threatens the social and economic rights of patients [25].

To ensure rights and freedoms in a pandemic, it is critical to create and maintain an up-to-date information space free of so-called infodemic, that is excessive amount of reliable and unreliable information, disseminated in physical and digital formats, causing behavioral responses that pose risks to public health [26]. A person is able to exercise his own right in case of maximum awareness of the grounds, algorithm, consequences, awaiting himself and surrounding persons. Therefore, health policy strategies to counter the effects of infodemic should be focused not only on the content of information but also on the clear articulation of its dissemination mechanisms, as there are communities that remain impenetrable to generated news [26].

"Infodemic", which is rapid, widespread dissemination of medical information and misinformation through a variety of media and information channels [27], significantly complicates the process of distinguishing between reliable and unreliable information and is particularly threatening during the continuing COVID-19 pandemic [3]. Misinformation is becoming increasingly complex, difficult to track, and emotional, threatening public confidence in health care authorities [28]. As a result, we have, for example, active opposition to the idea of vaccination, the spread of fakes about the simple negative impact of the vaccine on human health. On the other hand, overcoming the COVID-19 infodemic is a new and important challenge, an opportunity to find and adopt new preparedness and response tools to manage the information ecosystem, we live in [3]. Health care systems have developed gradually over the past decades. Strategies and means of spreading misinformation have also evolved. This must be obviously taken into account when formulating and operating algorithms to counter unreliable information. In particular, it goes about detecting fake accounts of vaccine manufacturers [29] and online sales channels of invalid COVID-certificates on social networks and stopping anti-vaccine fake campaigns by the administrators of these networks.

One of the means of counteracting infodemic during a pandemic is monitoring by international and regional non-governmental organizations of the state of observance of human rights in the context of a pandemic. It is important to carry out such an analysis by collecting and promptly summarizing the official information taken from the official web resources of public authorities of an individual country under study. The use of other methods significantly reduces the reliability of the obtained data and the following conclusions.

Without official documents, one of the non-governmental organizations offers a link to reports from the media and civil society organizations [30]. Is it always possible to achieve the set goals? Let us compare the Republic of Poland and Ukraine, which belong to the same model of public administration in the field of epidemiological well-being according to the classification of researchers of the institutional capacity of states to counteract infectious threats [31, p.345]. Thus, the above-mentioned non-governmental organization informs about the quarantine measures taken by the Republic of Poland, affecting civil freedoms and human rights: (1) the use of the military to 
assist the police [32], (2) the emergence of a mobile application to monitor compliance with quarantine restrictions [33]. Instead, it remains unclear why the Act of the Council of Ministers on the establishment of restrictions and prohibitions [34] on the outbreak of the coronavirus epidemic was overlooked. Among other things, the Act introduced the restriction of the right to liberty of movement established by Article 12 of the ICCPR [35].

Ukraine is mentioned three times. In one case, it is suggested to read the English version of the information from the governmental web portal. Stakeholders should be addressed to the current governmental act [36], posted on the web resource, which covers the vast majority of legal acts in force in Ukraine. The act is promptly amended in automatic. Such acts are now more than ten and they can be crucial for travelers. Another report of an emergency coronavirus announcement is just informative and has lost its relevance over time.

In a pandemic, where the rights and freedoms of an individual in different countries are limited in order to minimize risks to public health, in addition to public authorities of special competence, non-governmental human rights organizations also have a responsibility to provide impartial and prompt, reliable and complete information about quarantine restrictions and prohibitions, introduced in various states. True information ceases to be just an ideological canon of the world-famous media. At global confrontation between humanity and presently widespread viral infection with its new strains, the complete and objective information should become the same weapon as in the fight against hybrid aggression, which is currently taking place in the heart of the European continent.

\section{ROLE OF INFORMATION IN THE EXERCISE OF THE RIGHT TO HEALTHCARE AND PREVENTION OF THE PANDEMIC BY VACCINATION}

As a current pandemic crisis is not an exception, any crisis allows a more critical assessment of existing state and public institutions for compliance with their stated goals. Normative acts in the field of protection of human rights and freedoms are also subject to revision. In this aspect, the norm of Part 3 of Article 11 of the European Social Charter (ESC) seems to be prospective. Article 11 enshrines the right to protection of health. This right corresponds to the obligation of the state "either directly or in cooperation with public or private organizations, to take appropriate measures designed inter alia: 1 . to remove as far as possible the causes of ill-health; 2 . to provide advisory and educational facilities for the promotion of health and the encouragement of individual responsibility in matters of health; 3 . to prevent as far as possible epidemic, endemic and other diseases, as well as accidents". An updated version of Part 3 of Article 11 of the ESC, that is the exclusion from its text of "as far as possible" citation, is an urgent need. The expediency of such an innovation is important to be recognized both in the countries that have signed and ratified the ESC (such as Ukraine) and in the countries that have just signed but not ratified (such as the Republic of Poland). The prevention of epidemics, as evidenced by the events of the last year and a half, is not so much a matter of well-being and prosperity as survival. Lack of financial, organizational, or legal capabilities should be not an explanation of the absence or insufficiency of preventive measures, but an incentive to the search for interstate mechanisms for vaccine exchange (such as COVAX), cooperation in the organization of laboratory tests (the Wuhan Institute of Virology in China has yet to learn a lesson and draw the appropriate conclusions), etc.

The right to health care includes access to vaccines and drugs, other medicines. Ensuring access to the vaccine is not only the right decision, it is in the general interest. It is more appropriate than ever to say, "If anyone is in danger, no one can feel safe." A fair distribution of vaccines that respects human rights is also important for building trust between an individual and a state. Although recent advances in counteracting the pandemic inspire restrained optimism. An issue of adherence to human rights in the development and distribution of the COVID-19 vaccine remains relevant. Governments should be guided by the idea of general availability of the latest antiviral drugs, vaccines, medical technologies, etc. in the development and implementation of health care policy [37]. It must be unfortunately agreed that now "little attention has been given to human rights in discussions of access to COVID-19 vaccines. This must change. Unless we hold to the principle that everyone has equal rights to dignity, to health, and to benefit from scientific progress, our success against COVID-19 is at risk" [38, p.1525].

To cope with this threat, there is obviously working COVAX, a global initiative to immunize against COVID-19 and overcome the acute phase of the pandemic. In order to carry out emergency immunization as a fundamental human right, COVAX directs governments to give priority to immunization to persons belonging to high-risk groups formed by the WHO Strategic Advisory Group (SAGE). Regardless of the place of residence and legal status, such persons include internally displaced persons, refugees, migrants, and prisoners [39]. Prisoners, taken into custody, are close to each other, which leads to an increased risk of infection among prisoners and detainees [40]. According to a report by the European Court of Human Rights of July 2021 [41], most of the applicants are prisoners or persons subject to other restrictions on their liberty. Under these circumstances, the problem of ethics leads us to think about the existence of not one but several pandemics at the same time. COVID, racism, marginalization, economic inequality, unequal access to education, discrimination, migration crisis - these and other challenges together have been aptly named "Syndemic" [42, p.1]. "Syndemic" (abbreviated as "synergistic epidemic") - a term introduced by the American professor of anthropology M. Singer in the mid-1990s, later used in the educational literature to denote the concentration and harmful interaction of two or more diseases or other health conditions in the population, especially as a consequence of social inequality and unjust exercise of power. 
One of the means to prevent the further spread of coronavirus is the introduction of "vaccination passports". According to opinion polls, public views are divided on both governmental and private use of vaccination passports/ certificates. It is difficult to reach a public consensus on this issue [43], but it is extremely necessary. It is important to depoliticize it as much as possible, to carry out professional explanatory work. Its results can be evidenced by data from sociological surveys on a national scale on the introduction of "vaccination passports" [44], as well as the most key preventive measure. Thus, as of April 2021, $52.7 \%$ of Ukrainians were not ready for vaccination against COVID-19 [45]. Instead, in November 2020, according to the Centrum Badania Opinii Społecznej, 30\% of Poles did not plan to receive such vaccinations [46], and in June $2021-26 \%$ [47, p.1]. Most vaccine refusers are probably those who are trapped in misinformation about the vaccine and vaccination. On this ground, a wrong conclusion is made about the harmfulness of vaccination in comparison with the risk of severe coronavirus disease.

\section{CONCLUSIONS}

During a pandemic, regional and international communication must be complete and regular.

The current large-scale pandemic will test the ability of current standards and regulations of the international human rights system to withstand pressure in an extremely difficult epidemiological situation. The priority of human rights and freedoms over public interests in the fight against the previously unknown and rapidly spreading coronavirus is a paradigm that seems to be subject to revision in the context of "syndemic" in connection with "infodemic".

Epidemiological situation and human rights are interdependent in a globalized world. Channels of formal and informal informing, as well as objective, current, full enough information content, make a "person-state" communication effective. In this case, efficiency means, firstly, the ability of a person to make decisions on the exercise of his rights and freedoms without harming himself and others, and secondly, the ability of the state to take some unpopular anti-epidemic measures and find support from most of its citizens.

The desire to minimize an unpleasant prospect of becoming a defendant in human rights courts should not play a decisive role in the state's decision on the amount of information provided to officials responsible for monitoring an international or European treaty.

A balance between the interests of an individual and current challenges posed by the pandemic is possible in the case of the implementation of specific legal measures. Such a measure is the presentation of Part 3 of Article 11 of the ESC in an imperative form.

\section{REFERENCES}

1. Liu PL. COVID-19 information on social media and preventive behaviors: Managing the pandemic through personal responsibility. Social Science \& Medicine. 2021;277:113928. doi: 10.1016/j.socscimed.2021.113928.
2. Glasdam S, StjernswärdS. Information about the COVID-19 pandemic a thematic analysis of different ways of perceiving true and untrue information. Social Sciences \& Humanities Open. 2020;2(1):100090. doi: 10.1016/j.ssaho.2020.100090

3. Sell TK, Hosangadi D, Trotochaud M et al. Improving Understanding of and Response to Infodemics During Public Health Emergencies. Health Secur. 2021;19(1):1-2. doi: 10.1089/hs.2021.0044.

4. Zhang T, Robin C, Cai S et al. Public health information on COVID-19 for international travellers: Lessons learned from a mixed-method evaluation. Public Health. 2021;193: 116-123. doi: 10.1016/j. puhe.2021.01.028.

5. Universal Declaration of Human Rights. www.un.org/en/about-us/ universal-declaration-of-human-rights

6. The Sustainable Development Goals. www.un.org/ sustainabledevelopment/

7. Akgungor S, Alaei K, Chao W.-F et al. Correlation between human rights promotion and health protection: a cross country analysis. International Journal of Human Rights in Healthcare. 2020;13(1): 72-92. doi: 10.1108/ IJHRH-07-2018-0050.

8. Hawkes S, Buse K. Searching for the Right to Health in the Sustainable Development Agenda; Comment on'Rights Language in the Sustainable Development Agenda: Has Right to Health Discourse and Norms Shaped Health Goals?' Int J Health Policy Manag. 2016;5(5):337-339. doi:10.15171/ijhpm.2016.21

9. Forman $L$, Ooms $G$, Brolan CE. Rights language in the sustainable development agenda: Has right to health discourse and norms shaped health goals? International Journal of Health Policy and Management. 2015;4(12):799-804. doi:10.15171/ijhpm.2015.171.

10. Cohen J. Paradigm Under Threat: Health and Human Rights Today. Health and Human Rights Journal. 2020;22(2):309-312. PMID: 33390716; PMCID: PMC7762912.

11. Scheinin M, Molbæk-Steensig H. Pandemics and human rights: three perspectives on human rights assessment of strategies against COVID-19. EUI Working Paper LAW. Florence: European University Institute, 2021.

12. Konstytucja Rzeczypospolitej Polskiej. Tekst uchwalony w dniu 2 kwietnia 1997 r. przez Zgromadzenie Narodowe. https://www.sejm. gov.pl/prawo/konst/polski/kon1.htm

13. Konstytucija Ukrajiny [the Constitution of Ukraine] https://zakon.rada. gov.ua/laws/show/254\%D0\%BA/96-\%D0\%B2\%D1\%80\#Text (UA).

14. Pro zakhyst naselennia vid infektsiinykh khvorob: zakon Ukrainy vid 6 kvitnia 2000 roku № 1645 -III [On protection of the population from infectious diseases: the law of Ukraine of April 6, 2000 № 1645-III] https://zakon.rada.gov.ua/laws/show/1645-14\#Text (in Ukrainian).

15. European Centre for Disease Prevention and Control: COVID-19 situation updates. https://www.ecdc.europa.eu/en/covid-19/situation-updates

16. European Centre for Disease Prevention and Control: COVID-19 Vaccine Tracker. https://vaccinetracker.ecdc.europa.eu/public/extensions/ COVID-19/vaccine-tracker.html\#uptake-tab

17. Pro vstanovlennia karantynu ta zaprovadzhennia posylenykh protyepidemichnykh zakhodiv na terytorii iz znachnym poshyrenniam hostroi respiratornoi khvoroby COVID-19, sprychynenoi koronavirusom SARS-CoV-2: Postanova Kabinetu Ministriv Ukrainy vid 22 lypnia 2020 r. No 641 [On the establishment of quarantine and the introduction of enhanced anti-epidemic measures in the territory with a significant spread of acute respiratory disease of COVID-19 caused by SARS-CoV-2 coronavirus: Resolution of the Cabinet of Ministers of Ukraine of July 22, 2020 № 641] (in Ukrainian). 
18. COVID-19 Strategic preparedness and response planWHO/WHE/2021.02. p. VIII https://apps.who.int/iris/rest/bitstreams/1335425/retrieve

19. COVID-19and Human Rights:Weare all in this together (April 2020). https:// unsdg.un.org/sites/default/files/2020-04/COVID-19-and-Human-Rights.pdf

20. Bodnar A. A Journey Into the Unknown? Global and National Human Rights Implications of the Pandemic. European Journal of Transformation Studies. 2020;8(1):10-25. https://czasopisma.bg.ug.edu.pl/index.php/ journal-transformation/article/view/5540

21. Gostin L0, Monahan JT, Kaldor J et al. The legal determinants of health: harnessing the power of law for global health and sustainable development. The Lancet. 2019;393:1857-1910. doi:10.1016/S0140-6736(19)30233-8

22. Horodovenko VV, Udovyka LG, Dichko HO. Ensuring respect for human rights and freedoms in the context of states' measures introduction to combat the covid-19 pandemic: European experience. Wiadomości Lekarskie. 2020;12(2):2773-2779.

23. Resolution of the customs co-operation council on the role of customs in natural disaster relief (June 2011). http://www.wcoomd.org/-/media/wco/public/ global/pdf/about-us/legal-instruments/resolutions/resolution_e.pdf?la=en

24. COVID-19 - WCO updates. http://www.wcoomd.org/en/topics/ facilitation/activities-and-programmes/natural-disaster/coronavirus.aspx

25. Dickens A. From Information to Valuable Asset: The Commercialization of Health Data as a Human Rights Issue. Health and Human Rights. 2020;22(2):67-69. PMCID: PMC7762916, PMID: 33390695.

26. Sacco PL, Gallotti R, Pilati F et al. Emergence of knowledge communities and information centralization during the COVID-19 pandemic. Social Science \& Medicine. 2021;285: 114215. doi: 10.1016/j. socscimed.2021.114215

27. Tangcharoensathien V, Calleja N, Nguyen T et al. Framework for managing the COVID-19 infodemic: methods and results of an online, crowdsourced WHO technical consultation. J Med Internet Res. 2020;22(6):e19659. doi: 10.2196/19659.

28. Islam MS, Sarkar T, Khan SH et al. COVID-19-related infodemic and its impact on public health: a global social media analysis. Am J Trop Med Hyg. 2020;103(4):1621-1629. doi: 10.4269/ajtmh.20-0812

29. Facebook ostanovyl feik-kampanyiu o vaktsynakh, orhanyzovannuiu iz RF [Facebook has stopped a fake campaign about vaccines organized by the Russian Federation] www.dw.com/ru/facebookostanovil-antivakserskuju-kampaniju-organizovannuju-iz-rf-a58824296/a-58824296 (in Russian).

30. Methodology: COVID-19 Civic Freedom Tracker. Keep Civic Space Healthy. www.icnl.org/methodology-covid-19-civic-freedom-tracker

31. Zyma OT, Soloviova OM, Boiko IV et al. Search for the Optimal Model of Institutional Capacity to Counteract Infectious Threats in the Modern World. International Journal of Biology and Biomedical Engineering. 2021;15:342-349. doi: 10.46300/91011.2021.15.41.

32. Zarządzenie nr 180 Prezesa Rady Ministrów z dnia 23 października 2020 r. w sprawie użycia żołnierzy Żandarmerii Wojskowej do udzielenia pomocy Policji. Dziennik Urzędowy Rzeczypospolitej PolskiejWarszawa, dnia 26 października 2020 r. Poz. 1003. https://monitorpolski.gov.pl/ M2020000100301.pdf

33. Aplikacja "Kwarantanna domowa” - ruszył proces jej udostępniania (19.03.2020). https://www.gov.pl/web/cyfryzacja/aplikacjakwarantanna-domowa--ruszyl-proces-jej-udostepniania

34. Rozporządzenie Rady Ministrów z dnia 31 marca 2020 r. w sprawie ustanowienia określonych ograniczeń, nakazów i zakazów w związku z wystąpieniem stanu epidemii. Dziennik Ustaw Rzeczypospolitej Polskiej, Warszawa, dnia 31 marca 2020 r. Poz. 566. https://www.gov. pl/attachment/6bb2b889-1c29-4caa-93ba-e5b8c8134e12
35. International Covenant on Civil and Political Rights. Adopted by the General Assembly of the United Nations on 19 December 1966. https:// treaties.un.org/doc/publication/unts/volume\%20999/volume-999-i14668-english.pdf

36. Pro zapobighannja poshyrennju na terytoriji Ukrajiny ghostroji respiratornoji khvoroby COVID-19, sprychynenoji koronavirusom SARSCoV-2: postanova Kabinetu Ministriv Ukrajiny vid 11 bereznja 2020 r. No 211 [On prevention of the spread of acute respiratory disease of COVID-19 caused by SARS-CoV-2 coronavirus on the territory of Ukraine: Resolution of the Cabinet of Ministers of Ukraine of March 11, 2020 № 211] (in Ukrainian).

37. Human rights at the heart of response topics in focus access to COVID-19 vaccines (17 december 2020) https://www.ohchr.org/Documents/ Events/COVID-19_AccessVaccines_Guidance.pdf

38. Beyrer C, Pascale Allotey P, Amon JJ et al. Human rights and fair access to COVID-19 vaccines: the International AIDS Society-Lancet Commission on Health and Human Rights. The Lancet. 2021;397(10284):1524-1527. doi: 10.1016/S0140-6736(21)00708-X.

39. Protecting human rights in the COVAX roll-out. 8 April $2021 \mathrm{https}: / /$ www.gavi.org/covax-facility/protecting-human-rights

40. Kirby M. Incarceration, injustice and COVID-19. Alternative Law Journal. 2021;46(2):93. doi: 10.1177/1037969X211022096

41. COVID-19 health crisis. (July 2021). https://www.echr.coe.int/ Documents/FS_Covid_ENG.pdf

42. SIIAEC Conference 2021 „Ethical Action: COVID Affecting Human Rights and Democracy" Conclusions. https://www.icmica-miic.org/ wp-content/uploads/2021/05/SIIAEC-Conference-2021_Conclusions_ wk.pdf

43. Hall MA, Studdert DM. Public views about COVID-19 'Immunity Passports'. Journal of law and the biosciences. 2021;8(1):Isab016. doi:10.1093/jlb/lsab016.

44. Stavlennja ukrajinciv do «pasportiv vakcynaciji». Prezentacija rezuljtativ vseukrajinsjkogho doslidzhennja ghromadsjkoji dumky [Attitude of Ukrainians to "vaccination passports". Presentation of the results of the all-Ukrainian public opinion poll] (23.04-30.04.2021). Research \& Branding Group. http://rb.com.ua/wp-content/uploads/2021/05/ pasporti-vacinacii_ukr.pdf (in Ukrainian).

45. Dumky naselennja Ukrajiny shhodo problem pandemiji COVID-19: ocinka rivnja zakhvorjuvanosti, ryzykiv infikuvannja ta stavlennja do vakcynaciji: pres-reliz Kyjivsjkogho mizhnarodnogho instytutu sociologhiji za pidsumkamy vseukrajinsjkogho opytuvannja ghromadsjkoji dumky uprodovzh 13-15 kvitnja 2021 roku. [Opinions of the population of Ukraine on the problems of the COVID-19 pandemic: assessment of morbidity rate, risks of infection and attitude to vaccination: a press release of the Kyiv International Institute of Sociology on the results of the all-Ukrainian public opinion poll on April 13-15, 2021] https:// www.kiis.com.ua/?lang $=u k r \&$ cat $=$ reports $\& i d=1032 \&$ page $=4$ (in Ukrainian).

46. Stosunek do szczepień przeciw COVID-19. CBOS Newsletter. 2020;41. www.cbos.pl/PL/publikacje/news/2020/41/newsletter.php

47. Polacy o szczepieniach przeciw COVID-19. Komunikat z badań CBOS. 2021;75:1-10. www.cbos.pl/SPISKOM.POL/2021/K_075_21.PDF

\section{ORCID and contributionship:}

Mariya G. Shul'ha: 0000-0002-9725-3471 ${ }^{A, F}$

Anatoliy V. Mazur: 0000-0003-1073-4799 A, B,D

Iurii V. Georgiievskyi: 0000-0001-8014-7827 B, E,D 


\section{Conflict of interest:}

The Authors declare no conflict of interest.

\section{CORRESPONDING AUTHOR}

\section{Anatoliy Mazur}

University of Customs and Finance,

2/4V. Vernadskyi str., 49000, Dnipro, Ukraine

tel: +380501904064

e-mail:anvas.mazur@outlook.com

Received: 21.06 .2021

Accepted: 13.10 .2021

A - Work concept and design, B - Data collection and analysis, C - Responsibility for statistical analysis,

D-Writing the article, $\mathbf{E}-$ Critical review, $\mathbf{F}-$ Final approval of the article 


\title{
PROTECTION OF THE RIGHTS OF CHILDREN BORN BY SURROGATE MOTHERS DURING THE COVID-19 PANDEMIC
}

DOI: 10.36740/WLek202111223

\author{
Marija V. Mendzhul', Viktoriia V. Nadon' ${ }^{2}$, Zhanna 0. Rekova ${ }^{2}$ \\ 'UZHHOROD NATIONAL UNIVERSITY, UZHHOROD, UKRAINE \\ ${ }^{2} Y$ AROSLAV MUDRYI NATIONAL LAW UNIVERSITY, KHARKIV, UKRAINE
}

\begin{abstract}
The aim: Analyze the practice of resolving the problems of protecting the rights of children born to surrogate mothers in the context of the COVID-19 pandemic.

Materials and methods: In carrying out the study, an interdisciplinary approach was applied to the analysis of the problem of protecting the rights of children born to surrogate mothers in the context of the COVID-19 pandemic. This approach includes dialectical, comparative-legal, statistical, and systemic methods. The research used scientific developments in the field of problems of protecting the rights of children born to surrogate mothers, international acts, legislation, statistical data.

It has been established that although the understanding of surrogacy is the same for all states, there is a rather different approach to the possibility of its application. The issue of providing a child born to a surrogate mother with data on his genetic origin (in the absence of a genetic link with legal parents) should be resolved on the basis of this approach: maintaining a balance of interests between parents and the child, taking into account the principle of the best interests of the child.

Conclusions: It was concluded that the inadmissibility of closing borders and restricting the entry of foreigners to reunite with children born of surrogate mothers. It is proposed to create a register of persons those wishing to apply the surrogacy procedure, as well as the register of children born from surrogate mothers in Ukraine.
\end{abstract}

KEY WORDS: surrogacy, child, genetic parents, assisted reproductive technologies, COVID-19 pandemic

Wiad Lek. 2021;74(11 p.2):2999-3003

\section{INTRODUCTION}

The COVID-19 pandemic has changed the way of life that is customary for everyone and led to a number of restrictions on human rights and freedoms. Children born to surrogate mothers were especially vulnerable in the context of the COVID-19 pandemic. As of September 6, 2021, there have been more than 90.01 million cases and more than 1.7 million deaths since the start of the pandemic [4]. Governments of states are responding to the COVID-19 pandemic in different ways, with some resorting to harsh measures, including curfews and closing external borders, while others are introducing minimum sanitary and epidemiological restrictions.

The closure of borders, restrictions on freedom of movement led to a number of legal problems and collisions, did not allow genetic parents to register the fact of the birth of children by surrogate mothers and even to enter the territory of Ukraine. That is why it is relevant to study the problems of protecting the rights of children born to surrogate mothers in the context of the COVID-19 pandemic. This will contribute to the formation of an effective mechanism for protecting the rights of children born to surrogate mothers in emergencies, including pandemics.

\section{THE AIM}

Analyze the practice of resolving the problems of protecting the rights of children born to surrogate mothers in the context of the COVID-19 pandemic.

\section{MATERIALS AND METHODS}

In carrying out the study, an interdisciplinary approach was applied to the analysis of the problem of protecting the rights of children born to surrogate mothers in the context of the COVID-19 pandemic. This approach includes dialectical, comparative-legal, statistical, and systemic methods. The research used scientific developments in the field of problems of protecting the rights of children born to surrogate mothers, international acts, legislation, statistical data.

The attitude of some countries is analyzed, for example, Austria, Belgium, Pakistan, etc. to the issue of providing an opportunity for individuals to take part in the surrogacy procedure.

It has been established that although the understanding of surrogacy is the same for all states, there is a rather different approach to the possibility of its application. The issue of providing a child born by a surrogate mother with data on his genetic origin (if there is no genetic link with legal parents) should be resolved on the basis of this approach: maintaining a balance of interests between parents and the child, as well as taking into account the principle of the best interests of the child.

It is proposed at the legislative level to establish the right of a child upon reaching the age of majority (eighteen years of age) to receive information about his genetic origin, in the absence of a genetic link with both or one of the parents. 


\section{REVIEW AND DISCUSSION}

Various states have already formed a unified approach to understanding the concept of surrogate motherhood as an assisted reproductive technology used on a voluntary basis, in which a woman agrees to become pregnant, bear, give birth to a child, and, after giving birth, transfer to genetic parents for upbringing. At the same time, in world practice, there is a different approach to providing an opportunity for persons to take part in the procedure for applying for surrogacy. So, most states allow only free surrogacy with the payment of a surrogate mother exclusively compensation for the actual costs of bearing and giving birth to a child (Australia, Belgium, Brazil, Great Britain, Vietnam, Denmark, Canada, the Netherlands, New Zealand, Portugal, Hungary, most US states and other). Many states still prohibit surrogacy, including China, Pakistan, Saudi Arabia, etc.

The press quite often writes that Ukraine is one of the centers of world-class commercial surrogacy [3]. Unfortunately, there are no official statistics. Calculations of individual experts show that more than 50 medical institutions carry out surrogacy programs, more than $80 \%$ of clients of such institutions are foreigners, and the average compensation for surrogate mothers is from 12 to 18,000 US dollars [8], the cost of the entire service is estimated from 30,000 to 50,000 US dollars [9]. This is also facilitated by the insufficiently clear regulation of the surrogacy procedure by law.

At the moment, the Family Code of Ukraine in article 123 establishes that if a child is born as a result of transferring an embryo conceived by spouses into the body of another woman, then they are recognized by his parents. The draft law of Ukraine "On assisted reproductive technologies", submitted to the Verkhovna Rada of Ukraine in 2018, has not been adopted [13]. This act is planned to clearly limit the age of a surrogate mother, as well as to establish other restrictions on the use of surrogate motherhood, to regulate the rights and obligations of all parties involved in the use of this assisted reproductive technology, and to establish the essential terms of the contract. Until this law is adopted, the issue of the surrogacy procedure, the rights and obligations of genetic parents, a surrogate mother, and a medical institution are regulated by agreements.

Article 9 of the draft law of Ukraine "On Assisted Reproductive Technologies" establishes that only spouses (woman and man) who are in a registered marriage can use the surrogacy methodology [13]. Thus, same-sex partnerships and marriages concluded abroad will not be able to use surrogacy services in Ukraine.

A sociological study has shown that $34 \%$ of respondents support the granting of the same status by the state to secular and church marriages in Ukraine [1]. Today, a man and a woman who have entered into a church marriage are not spouses in Ukraine. Thus, if the citizens of Ukraine, through religious beliefs, conclude only a church marriage and do not register it with the government, they will not be able to use the services of surrogacy.

The issue of protecting human embryos and fetuses is urgent. Thus, scientists suggest that there is a "pre-subjec- tive" status, which provides for certain elements of legal protection [7]. In our opinion, from the standpoint of the principle of equality, regardless of whether a fetus is conceived naturally or with the help of assisted reproductive technologies, they have the same legal modus with individual elements of legal protection.

Scientists note that the very procedure of surrogate motherhood provides, first of all, the satisfaction of the interests of adults and does not fully take into account the interests of the child. A child born to a surrogate mother may have a relationship with six adults: genetic mother, genetic father (sperm donor), surrogate mother, her husband (presumption of paternity is possible), and a couple that intends to become the child's parents (may not be genetically related to the child ). In the case of using egg or sperm donors, who the genetic parents are is usually anonymous information. This leads to the fact that the child is deprived of most of the information about his origin [3].

These problems are really not resolved in the legislation of most states. Interestingly, the judgment of the Supreme Court of Israel in the case "Nachmani v. Nachman". Spouses without children decided to resort to surrogacy and signed an agreement with a surrogate mother. Eleven eggs were removed and fertilized with the husband's sperm, but by the time the surrogate mother's eggs were implanted, the couple divorced. The husband objected to the use of fertilized eggs by his sperm. The Supreme Court ruled in favor of the woman, since, in their opinion, the interests of the woman (in particular, the lack of another opportunity to become a genetic mother) prevailed the interests of the husband. Another position was expressed by the European Court of Human Rights in the case "Evans v. the United Kingdom" and, in particular, the Court noted that, given the lack of any consensus on this issue among European states, the right of one person cannot be genetically related to the child, to prevail over the right of another person not to have a genetic relationship with the child [2]. When considering such cases, the interests of children must also be taken into account.

The principle of the best interests of the child at the international level is enshrined in the UN Declaration of the Rights of the Child of November 20, 1959 (principle 2) [10] and Art. 3 of the Convention on the Rights of the Child of November 20, 1989. In particular, in Art. 3 of the Convention on the Rights of the Child of November 20, 1989, states that in all actions taken against children, regardless of who they are carried out by (public or private social welfare institutions, courts, administrative or legislative bodies), priority paid to the best interests of the child [12].

The principle of the best interests of the child has been established in the practice of the European Court of Human Rights. An analysis of the court decisions of the ECHR shows that the interests of the child may prevail over the interests of the parents [17]. For example, in the judgment in Haase v. Germany of April 8, 2004, the court stated: "if, after the children were separated from their parents, they have been under new care for a long time (live in a new family), the undesirability of new changes in their marital 
Table I. Dynamics of infection with the SARS-CoV-2 virus in selected countries

\begin{tabular}{|c|c|c|c|c|c|}
\hline $\begin{array}{c}\text { Country } \\
\text { (population) }\end{array}$ & $\begin{array}{l}\text { Total number } \\
\text { of infected / } \\
\text { percentage of } \\
\text { infected in the } \\
\text { total population } \\
(1.04 .2020)[5]\end{array}$ & $\begin{array}{l}\text { Total number } \\
\text { of infected / } \\
\text { percentage of } \\
\text { infected in the } \\
\text { total population } \\
(01.062020)[6]\end{array}$ & $\begin{array}{l}\text { Total died / } \\
\text { Percentage of } \\
\text { deaths from the } \\
\text { total number of } \\
\text { infected } \\
(01.062020)[6]\end{array}$ & $\begin{array}{l}\text { Total number } \\
\text { of infected / } \\
\text { percentage of } \\
\text { infected in the } \\
\text { total population } \\
\text { (17.09.2021) [15] }\end{array}$ & $\begin{array}{l}\text { Total died } \\
\text { / Percentage of } \\
\text { deaths from the } \\
\text { total number } \\
\text { of infected } \\
(17.09 .2021)[15]\end{array}$ \\
\hline $\begin{array}{c}\text { USA } \\
(330627484)\end{array}$ & $163199 / 0,05 \%$ & $1734040 / 0,52 \%$ & $102640 / 5,91 \%$ & $41395425 / 12,5 \%$ & $663141 / 1,6 \%$ \\
\hline $\begin{array}{c}\text { Spain } \\
(46754778)\end{array}$ & 94417 / 0,2\% & $239801 / 0,51 \%$ & $29045 / 12,11 \%$ & 4926324 / 10,5\% & $85739 / 1,7 \%$ \\
\hline $\begin{array}{c}\text { Italy } \\
(60461826)\end{array}$ & 105792 / 0,17\% & 233019 / 0,38\% & 33415 / 14,34\% & 4623155 / 7,6\% & $130167 / 2,82 \%$ \\
\hline $\begin{array}{c}\text { France } \\
(65273511)\end{array}$ & $51477 / 0,07 \%$ & 148524 / 0,22\% & $28746 / 19,35 \%$ & 6727094 / 10,3\% & $113813 / 1,69 \%$ \\
\hline $\begin{array}{c}\text { Germany } \\
(83783 \text { 942) }\end{array}$ & $67366 / 0,08 \%$ & 181815 / 0,21\% & $8511 / 4,68 \%$ & 4125878 / 4,9\% & 92857 / 2,25\% \\
\hline $\begin{array}{c}\text { United Kingdom } \\
\text { (67886 011) }\end{array}$ & 25154 / 0,03\% & 274766 / 0,4\% & 38489 / 14,0\% & $7339013 / 10,8 \%$ & $134805 / 1,8 \%$ \\
\hline $\begin{array}{c}\text { Sweden } \\
(10099265)\end{array}$ & 4435 / 0,04\% & 37542 / 0,37\% & 4395 / 11,7\% & $1143973 / 11,3 \%$ & $14753 / 1,28 \%$ \\
\hline $\begin{array}{c}\text { The Republic of } \\
\text { Korea } \\
(51260707)\end{array}$ & 9887 / 0,19\% & $11503 / 0,02 \%$ & $271 / 2,35 \%$ & $287938 / 0,56 \%$ & 2389 / 0,82\% \\
\hline $\begin{array}{c}\text { Poland } \\
(37846611)\end{array}$ & $2311 / 0,006 \%$ & 23786 / 0,06\% & 1064 / 4,47\% & 2896599 / 7,65\% & $75473 / 2,6 \%$ \\
\hline $\begin{array}{c}\text { Romania } \\
(19237691)\end{array}$ & $2245 / 0,012 \%$ & 19257 / 0,1\% & 1262 / 6,55\% & $1139505 / 5,9 \%$ & $35359 / 3,1 \%$ \\
\hline $\begin{array}{c}\text { Czech } \\
(10708981)\end{array}$ & 3308 / 0,03\% & $9273 / 0,08 \%$ & $320 / 3,45 \%$ & 1685435 / 15,7\% & $30427 / 1,8 \%$ \\
\hline $\begin{array}{c}\text { Ukraine } \\
\text { (43 } 733762 \text { ) }\end{array}$ & 669 / 0,001\% & 24012 / 0,05\% & 718 / 2,99\% & 2338164 / 5,34\% & $54750 / 2,34 \%$ \\
\hline $\begin{array}{c}\text { Belarus } \\
(9465300)\end{array}$ & $152 / 0,001 \%$ & $42556 / 0,44 \%$ & $235 / 0,55 \%$ & $510481 / 5,3 \%$ & $3966 / 0,77 \%$ \\
\hline $\begin{array}{l}\text { Hungary } \\
(9660351)\end{array}$ & 492 / 0,005\% & $3876 / 0,04 \%$ & $526 / 13,57 \%$ & $817159 / 8,45 \%$ & $30123 / 3,68 \%$ \\
\hline $\begin{array}{l}\text { Slovakia } \\
\text { (5 } 459642)\end{array}$ & $363 / 0,006 \%$ & 1522 / 0,027\% & $28 / 1,83 \%$ & 401250 / 7,3\% & $12569 / 3,1 \%$ \\
\hline
\end{tabular}

status for children may be more important factor than the interest of parents in the return of children" [14].

In our opinion, the issue of providing a child born by a surrogate mother with data on his genetic origin, if there is no genetic link with legal parents, should be resolved on the basis of this approach: maintaining a balance of interests between parents and a child, as well as taking into account the principle of the best interests of the child. Taking into account the practice of the European Court of Human Rights, the interests of the child may prevail over the interests of his legal parents, and if information about the genetic origin of the child does not harm him, then the child has the right to receive it. In our opinion, it is necessary at the legislative level to establish the right of a child upon reaching the age of majority (eighteen years of age) to receive information about his genetic origin, in the absence of a genetic link with both or one of the parents.
In the context of the COVID-19 pandemic, human rights have been restricted in many states, including as a result of quarantine measures and border closures. Undoubtedly, the threat of infection with the SARS-CoV-2 virus and the protection of public health is a legitimate aim of limiting human rights. [18]. At the same time, such restrictions must be proportionate and necessary.

In the table, we present data on Ukraine, neighboring states, and the UK, USA, Spain, Italy, Germany, France, where there is a fairly high level of medicine and standards in the field of human rights. In addition, Belarus, South Korea, and Sweden were highlighted in the table, since these states did not introduce strict quarantine measures, there was effective informing the population about ways to prevent infection with the SARSCoV-2 virus, the importance of social distance, and wearing masks. In Sweden and Belarus, educational institutions have not been closed since the beginning of the pandemic. 
An analysis of statistical data shows an increase in the rate of infection with the SARS-CoV-2 virus from April 2020 to September 2021 (up to the total population) in the United States from $0.05 \%$ to $12.5 \%$; Spain from $0.2 \%$ to $10.5 \%$; Italy from $0.17 \%$ to $7.6 \%$; Germany from $0.08 \%$ to $4.9 \%$; France from $0.07 \%$ to $10.3 \%$; Great Britain from $0.03 \%$ to 10.8\%; Czech Republic from $0.03 \%$ to $15.7 \%$; Poland from $0.006 \%$ to $7.65 \%$; Romania from $0.012 \%$ to $5.9 \%$; Ukraine from $0.001 \%$ to $5.34 \%$; Hungary from $0.005 \%$ to $8.45 \%$; Slovakia from $0.006 \%$ to $7.3 \%$ (more details in the table). At the same time, there are similar trends in the states that did not introduce severe restrictions, in particular in: South Korea from $0.019 \%$ to $0.56 \%$; Sweden from $0.04 \%$ to $11.3 \%$; Belarus from $0.001 \%$ to $5.3 \%$.

It is also necessary to analyze the mortality rate to the number of infected, and here there is a downward trend (as of September 17, 2021 in comparison with June 1, 2020) in: USA from $5.91 \%$ to $1.6 \%$; Spain from $12.11 \%$ to $1.7 \%$; Italy from $14.34 \%$ to $2.82 \%$; Germany from $4.68 \%$ to $2.25 \%$; France from 19.35\% to 1.69\%; Great Britain from 14\% to $1.8 \%$; Czech Republic from $3.45 \%$ to $1.8 \%$; Poland from $4.47 \%$ to $2.6 \%$; Romania from $6.55 \%$ to $3.1 \%$; Ukraine from $2.99 \%$ to $2.34 \%$; Hungary from $13.57 \%$ to $3.68 \%$; Slovakia from $1.83 \%$ to $3.1 \%$; South Korea from $2.35 \%$ to $0.82 \%$; Sweden from $11.7 \%$ to $1.28 \%$. Only in Belarus, there is an increase in the mortality rate from $0.55 \%$ to $0.77 \%$. At the same time, if the statistical data in Belarus may not reflect the real situation, then the same cannot be said about Sweden and South Korea. These statistics confirm that it is possible to achieve results in reducing mortality and curbing the spread of the SARS-CoV-2 virus not only by strict quarantine measures (border closures, curfews, etc.), but also by an effective information campaign and public health standards (on the example of South Korea and Sweden).

At the same time, the closure of borders in Ukraine in order to combat the spread of the SARS-CoV-2 virus has led to a violation of the rights and interests of newborn children from surrogate mothers. Genetic parents could not enter the territory of Ukraine to register the fact of birth, and those who entered the territory of Ukraine could not take their children out. In May 2020, it was reported in the press that 46 children born to surrogate mothers are in the Venice Hotel of the BioTexCom private clinic in Kyiv and cannot be reunited with genetic parents who are foreigners [16].

The Verkhovna Rada Human Rights Commissioner Lyudmila Denisova said that as of June 18, there were already 161 such children, whose parents come from 27 foreign countries. In total, 149 couples of foreign citizens applied for help in granting a permit to enter Ukraine [11]. Considering that the situation with the COVID-19 pandemic was for the first time and the legislation of Ukraine was not ready for the same as the legislation of other states, the issue was solved mainly by diplomatic means. At the same time, it became clear that it was necessary to develop an algorithm of actions and improve the legislation of Ukraine regulating the surrogacy procedure.

\section{CONCLUSIONS}

Thus, the COVID-19 pandemic has exacerbated the issue of the legal regulation of surrogacy and the protection of children's rights at the same time. Differences in the legislation of various states and the closure of borders have led to a violation of the rights and interests of both genetic parents and children. At the same time, the analyzed statistics show that the introduced anti-epidemic measures, the development of protocols for the treatment of the SARS-CoV-2 virus have reduced mortality rates in those countries that did not resort to strict restrictions. Based on this, we can conclude that the closure of borders and restrictions on the freedom of movement of all persons without exception is not a proportional restriction of human rights, and if there is a certificate of absence of disease at the time of crossing the border, such movement should be allowed. Moreover, there can be no restrictions on crossing the border in order to reunite the family of genetic parents and a child born to a surrogate mother.

In addition, Ukraine needs to adopt a special law that would regulate the procedure for surrogacy and other assisted reproductive technologies. In this law, the rights and obligations of genetic parents, a surrogate mother, her husband should be clearly regulated, and the principle of the best interests of the child should also be ensured. It is necessary to provide a register of persons wishing to apply for the surrogacy procedure, as well as a register of children born by surrogate mothers in Ukraine. At the same time, the protection of personal data must be guaranteed. Also, compulsory licensing of surrogacy intermediary activities in Ukraine should be introduced.

\section{REFERENCES}

1. Berveno S. M., Lazur Y. V., Mendzhul M. V. Marriage: religious and legal aspects. Cogito. Multidisciplinary Research Journal. 2020; 2: 77-85.

2. Case of Evans v. the United Kingdom, 10 April 2007, application n. 6339/05. Available from: https://hudoc.echr.coe.int/ eng\#\{\%22itemid\%22:[\%22001-80046\%22]\} [reviewed 2021.08.15].

3. Hougue C., Roux C. Surrogate Motherhoodand Human Rights. Analysis of Human, Legaland Ethicallssues. Available from: https:// www.nomaternitytraffic.eu/wp-content/uploads/2015/09/2015Contribution-HCCH-No-Maternity-Traffic-EN.pdf [reviewed 2021.08.15].

4. Weekly epidemiological update on COVID-19 - 14 September 2021. Available from: https://www.who.int/publications/m/item/weeklyepidemiological-update-on-covid-19---14-september-20211 [reviewed 2021.09.15].

5. Coronavirus disease 2019 (COVID-19). Situation Report - 72. Available from: https://cutt.ly/NuPbZo6 [reviewed 2021.08.15].

6. Coronavirus disease 2019 (COVID-19). Situation Report-133. Available from: https://cutt.ly/iuPb73D [reviewed 2021.08.15]

7. Dorofeieva L., Karabin T., Mendzhul M., Khokhlova I. Embryo and human fetus: legal protection issues. Georgian Medical News. 2020;9 (306): 162-166.

8. Pautov V. Tregubov Y. Dity «na prodazh» - skandal dovkola kliniky. I shcho treba znaty pro surohatne materynstvo v Ukrayini [Children "for sale" - a scandal around the clinic. And what you need to know about surrogacy in Ukraine]. Available from: https://www.radiosvoboda. org/a/29372579.html [reviewed 2021.08.15] (in Ukrainian). 
9. Perasso V. Surohatnykh nemovlyat ne mozhut' zabraty z Ukrayiny cherez karantyn. 16 travnya 2020 [Surrogate babies cannot be taken from Ukraine due to quarantine. May 16, 2020]. Available from: https:// www.bbc.com/ukrainian/features-52688929 [reviewed 2021.08.15] (in Ukrainian).

10. Deklaratsiya prav dytyny vid 20.11.1959 [Declaration of the Rights of the Child dated November 20, 1959]. Available from: https://zakon. rada.gov.ua/laws/show/995_384 [reviewed 2021.08.15].

11. Skachko I. Ukrayina potrebuye novykh zakoniv shchodo surohatnoho materynstva - Lyudmyla Denisova [Ukraine needs new laws on surrogacy - Lyudmila Denisova]. Available from: http://khpg.org/index. php?id=1593175046 [reviewed 2021.08.15] (in Ukrainian).

12. Konventsiya pro prava dytyny vid 20.11.1989 [Convention on the Rights of the Child of November 20,1989]. Available from: https://zakon.rada. gov.ua/laws/show/995_021 [reviewed 2021.08.15].

13. Proekt Zakonu pro dopomizhni reproduktyvni tekhnolohiyi [Draft Law on Assisted Reproductive Technologies] № 8629 dated July 19, 2018. Available from: http://w1.c1.rada.gov.ua/pls/zweb2/ webproc4_1?pf3511=64477 [reviewed 2021.08.15].

14. Sprava Khaas proty Nimechchyny [Haas v. Germany], 8 April 2004. Available from: https://zakon.rada.gov.ua/laws/show/980_225/print [reviewed 2021.08.20].

15. WHO Coronavirus (COVID-19) Dashboard. Available from: https:// covid19.who.int/ [reviewed 2021.09.17].

16. U stolychnomu hoteli utrymuyut' 46 nemovlyat vid surohatnykh materiv, yakykh ne mozhut' viddaty inozemtsyam cherez karantyn [In the capital's hotel, 46 babies are being held by surrogate mothers, who cannot be given to foreigners due to quarantine]. 13.05.2020. Available from: https://www.unian.ua/society/surogatne-materinstvo-ytorgivlya-ditmi-u-stolichnomu-goteli-utrimuyut-46-nemovlyat-dlyainozemciv-vid-surogatnih-materiv-novini-ukrajini-10994960.html [reviewed 2021.08.15].
17. Karnaukh B., Shymko A. Side effects of diethylstilbestrol (des) from the perspective of tort law. Wiad Lek. 2020; 12.

18. Zabuha Y. Yu., Mykhailichenko T. 0. Morochkovska 0. V. Overview and analysis of occupational risks in healthcare of eastern europe countries. Wiad Lek. 2019; 12: 2510-2517.

ORCID and contributionship:

Mendzhul V. Marija: 0000-0002-3893-4402 $2^{A, B, E}$

Viktoriia V. Nadon: 0000-0001-8240-7717 B,D,F

Zhanna O. Rekova: 0000-0001-5382-1175

\section{Conflict of interest:}

The Authors declare no conflict of interest.

\section{CORRESPONDING AUTHOR Viktoriia V. Nadon \\ Yaroslav Mudryi National Law University \\ Kharkiv, Ukraine \\ tel: +380504015121 \\ e-mail:nadonviktoria@gmail.com}

Received: 20.07.2021

Accepted: 20.10.2021

A - Work concept and design, B - Data collection and analysis, C - Responsibility for statistical analysis,

D-Writing the article, $\mathbf{E}$ - Critical review, $\mathbf{F}$ - Final approval of the article 


\title{
THE INVALIDITY OF CONTRACTS IN THE FIELD OF MEDICAL SERVICES AS A WAY TO PROTECT THE RIGHTS OF THE PATIENT
}

DOI: $10.36740 /$ WLek202111224

\author{
Roman I. Tashian \\ YAROSLAV MUDRYI NATIONAL LAW UNIVERSITY, KHARKIV, UKRAINE
}

\begin{abstract}
The aim of this article is to reveal the essential features of contracts providing medical services. The author also focused on the grounds for the invalidity of such contracts entering into medical services contract without license or permission, prohibition of some medical services or methods of treatment, the imposing of unnecessary medical services, a contradiction to corporate regulations, fraud. A significant part of the work is devoted to the consequences of the invalidity of the contract - the restitution of the money received under the contract and compensation of harm.

Materials and methods: The study is based on the statutory acts of European Union countries, the USA, and others. The author also uses acts of international law in the field of medical services and cases of court practice.

Conclusions: Although the invalidity of contracts in the field of medical services is not one of the most common ways to protect a patient's rights, it is in many cases essential to the reliable delivery of medical services. The patient has the right to initiate a legal dispute regarding the invalidity of the contract. The restitution of the money paid by the patient, as well as compensation for the harm caused, can be applied not only within the framework of tort law but also under the responsibility for the breach of the contract.
\end{abstract}

KEY WORDS: contracts in the field of medical services, the invalidity of the contract, restitution

Wiad Lek. 2021;74(11 p.2):3004-3008

\section{INTRODUCTION}

In the field of providing medical services, there are cases when a party entering into a contract can violate some requirements of the law. As a result, there is a risk of violation of the patient's rights.

It is essential in any democratic and legal state to timely provide qualified medical care. This process is regulated by medical services contract, which can be defined as a contract whereby the medical institution is authorized or duty-bound to perform medical treatment, epidemic prevention, health care, or medical inspection for patients [1].

Most of the reformers agree that the current law and practice relating to medical malpractice are unsatisfactory for many reasons. In particular, standards of health care are set too high, and with too little regard to cost; damages, especially for pain and suffering are too high and are socially wasteful; the collateral benefits rule duplicates compensation for a lucky handful and adds to costs; too few people are compensated in any case, given the need to prove fault; and the legal and administrative costs of the whole system are excessive. Therefore, they conclude, the contract would be a better instrument for regulating the physician/patient relationship [2; p. 2].

\section{THE AIM}

The paper is aimed at identifying types of invalidity of contracts in the field of medical services, grounds of their invalidity, and consequences of invalidity. The author also plans to study the legislation of this sphere as well as judicial practice in this issue and proposes ways to solve the identified problems.

\section{MATERIALS AND METHODS}

The paper is based on the statutory acts of countries of the European Union, the USA, and some others. In scientific researching the author uses:

1) the acts of legislation ("The Rules Governing Medicinal Products within the European Union' and the 'Eudralex Collection', 'High-Level Group on Innovation and Provision of Medicines in the EU' ('G10' Medicines Group), New York Limited Liability Company Law (LLCL), California Compassionate Use Act of 1996;

2) typical or standard forms of medical contracts (Standard Personal Medical Services Agreement 2018/19 (developed by National Health Service), Standard General Medical Services Contract;

3) case law (England v. La. State Bd. of Med. Exam'rs, 259 F.2d 626, 627 (5th Cir. 1958) in Derry v Peek (1889) 14 App. Cas 337, 374 (HL).

The author also uses acts of international law in the field of medical services and cases of court practice. Moreover, judicial practice, doctrinal ideas, and views on this issue have been used. In addition, the paper is based on complex of methods. Dialectical method bases on two principles: 
the principle of universal connection and the principle of development medical law. The author makes extensive use of the comparative method - comparing the law of Ukraine to the law of other European and some other foreign countries, which makes the basis for comparison to ensure the integration process of Ukraine. Functionalism typically applies at the level of micro-comparison. From a broader perspective, a more structural analysis of (parts of) legal systems may be used. The analytical method is a process that goes beyond the merely mechanical. The analytical method abstracts the essence of knowledge in an organized and premeditated form in the legal sphere.

\section{REVIEW AND DISCUSSION}

There are several different contracts in the sphere of medical services: agreement for provision of clinical and medical services, medical services contract, contract for the provision of medical services, etc.

Such contract covers the provision of medical and health services: preventative, promotive, curative, supportive, and rehabilitative services and shall, in conjunction with and as provided by the wider range of available health care services and providers, serve to enhance people's physical, emotional, and spiritual well-being. Such services also include medical services, surgical services, maternity services, new-born care, specialist services, anesthesia, X-ray, laboratory, and other diagnostic procedures, including interpretations, preventive medical services [3].

Medical services contract usually contains such terms and conditions: professional component and medical administrative services, management services and duties, compensation, the relationship of the parties, no connection to referrals, term and termination, proprietary confidential information and trade secrets, assignment, survival, and remedies, access to records, severability, costs of enforcement, headings, counterparts, notice [4].

The harmonization of the legislation of the EU member states requires further improvement of the standards for the provision of medical care.

Tamara Hervey, Bart Vanhercke notes that European integration creates a problem-solving gap where 'member governments have lost more control over national welfare policies, in the face of the pressures of integrated markets, than the EU has gained de facto in transferred authority'. A provision of goods or services that forms a part of a national health care system is not sufficient in itself to remove it from the application of EU law [6; p. 111].

The basic principle is the free movement of services, goods, and persons - patients and health care professionals.

In the legal regulation of medical services "The Rules Governing Medicinal Products within the European Union' and the 'Eudralex Collection', which have been adopted since the 1960s, play a great role.

According to Tamara Hervey and Bart Vanhercke, the 'High-Level Group on Innovation and Provision of Medicines in the EU' ('G10' Medicines Group), which was set up by Enterprise Commissioner ErkkiLiikanen and Health
Commissioner David Byrne to explore ways of improving competitiveness in Europe while encouraging high levels of health protection, are also of great importance. The Group consisted of health and industry ministers from five Member States, representatives from different sectors of industry, mutual health funds, and a specialist in patient issues, and reported to Commission President Romano Prodi after one year. It divided its work into three agenda areas: provision of medicines to patients; single market, competition, and regulation; and innovation. The rationale and remit of the Group came in part from DG SANCO's role as co-initiator of the European Medicines Agency, whose members are not permitted to have any direct financial or other interests in the pharmaceutical industry [6; p. 111].

Despite the importance of the above-mentioned institutions, the main document between a medical institution and a patient is a medical services contract.

The public authority cannot leave such an important area uncontrolled, and therefore the state legislation establishes requirements for the content of a medical services contract, the violation of which may be grounds for their invalidity.

For instance, Standard Personal Medical Services Agreement 2018/19 (developed by National Health Service) provides such terms and conditions: if any provision of this Agreement is held to be invalid, illegal, or unenforceable by any court, tribunal, or other competent authority, such provision shall, to the extent required, be deemed to be deleted from this Agreement and shall not affect the validity, lawfulness or enforceability of any other provisions of this Agreement [7].

In conclusion, in the scientific literature, it is quite rightly noted that the formation of a state policy on ensuring the rights of citizens to health and life, taking into account the various consequences of such a policy, cannot be narrowed down only to the proclamation of such rights, but also requires planning and development of relevant state programs [5; p. 1108].

The grounds for the invalidity of a contract may be very different, but among the most common are the following:

Entering into medical services contract without license or permission.

The provision of medical services requires a license or permission. The aim of this restriction is to protect public health from unqualified medical activities of physicians who are not qualified as doctors.

Normally, legislation requires a license directly from the person who will carry out the medical practice.

For example, New York Limited Liability Company Law (LLCL) Section 1207(b) requires that each member of a professional limited liability company (PLLC) formed to provide medical services must be licensed pursuant to New York Education Law (Ed. Law) Article 131 to practice medicine in New York. Article 131 permits only individuals to be licensed to practice medicine; it does not permit entities to be licensed to practice medicine [8].

WouterGekiere, Rita Baeten, and Willy Palm deal with the well-known case 294/00, Deutsche Paracelsus Schulen v. Gräbner, in which it goes about such prohibition. 
The Court concluded that this did 'not go beyond what is necessary to achieve the aim of safeguarding public health despite the fact that it could be argued that a less restrictive measure existed to safeguard public health. Deutsche Paracelsus Schulen submitted that the Austrian authorities could have made the exercise of the profession of 'Heilpraktiker' subject to a certain period of practice or to an examination (of the knowledge and aptitude of the applicant) similar to that provided for by the German legislation. The Court particularly referred to the fact that there was no definition at the EU level of activities that are restricted to persons with a doctor's qualification. Even though it respected the host Member State's assessment of the public health risk linked to the performance of medical acts by people without a doctor's qualification, it stressed nonetheless that this assessment was liable to change over time due to progress made on knowledge of methods and their effects on health [9; p. 479].

The agreement contains prohibited medical services or methods of medicine.

As B. Jessie Hill points out, this does not mean that individuals will have an unqualified right to obtain any medical treatment they and their physicians deem appropriate, but only that a constitutional right to protect one's health should be consistently recognized; that the recognition of this right should not be artificially limited by deference to legislative findings of medical fact; and that this right will have to be balanced against the state's real and legitimate interest in regulating the practice of medicine to protect the public. For instance, in the case England v. La. State Bd. of Med. Exam'rs, 259 F.2d 626, 627 (5th Cir. 1958) (emphasis omitted) the practice of chiropractic medicine was attributed to such activity, which was prohibited by the legislation of state Louisiana [10; p. 281-282].

The other occurrence is taking marijuana or other drugs as a treatment. So, the OCBC litigation arose out of the federal government's attempts to enforce the Controlled Substances Act's prohibition on distributing or manufacturing marijuana against the Oakland Cannabis Buyers' Club, a not-for-profit organization in California that provided cannabis to patients whose doctors recommended it in compliance with the California Compassionate Use Act of 1996 [11].

Law prohibition can be applied to such hazardous medical activity as abortion. Such treatment must contain an exception allowing the procedure to be performed when it is, in the opinion of the woman's physician, the safest method of abortion for a particular woman. In OCBC, the issue was whether a federal law prohibiting the manufacture, distribution, or possession of marijuana had to be understood to contain an exception allowing an individual to access the drug when it is, in the opinion of the patient's physician, the only effective or most tolerable method of treating the patient's illness or its symptoms [10; p. 281-282].

Likewise, the Supreme Court decided two cases during Prohibition that rejected challenges to the Volstead Act's limited exemptions for medicinal use of alcohol: James Everard's Breweries v. Day, a challenge to the exclusion of malt liquors from the Act's allowance of alcohol for medicinal purposes, and Lambert v. Yellowley, a challenge to the Act's limitation on the amount of alcohol that could be prescribed [10; p. 281-282].

The imposing of unnecessary medical services

The medical services contract may contain conditions regarding treatment that are not necessary for a particular situation. Such conditions may be of interest to a doctor or medical institution, for example, due to their high cost.

In this case, it goes about Medicare Fraud and Abuse.

Although no precise measure of health care fraud exists, those who exploit Federal health care programs can cost taxpayers billions of dollars while putting beneficiaries' health and welfare at risk. The impact of these losses and risks magnifies as Medicare continues to serve a growing number of beneficiaries [12].

In such cases, a court may apply the rules for invalidating part of the contract. The grounds for such invalidity are the imposition of unnecessary services and misleading the patient about the need for a certain course of treatment or drugs.

The content of the contract is contrary to corporate regulations. Recently, an Illinois court invalidated an employment contract containing a noncompete clause between a surgeon and a hospital on the grounds that the corporate bar should be strictly enforced. Under Illinois law, only contracts permitted by law may be enforced; accordingly, since by law the hospital could not employ the physician, the contract was unenforceable. The judge, however, explicitly noted that the case did not involve the employment of a physician who practiced a hospital-based specialty, such as anesthesiology, pathology, radiology, or emergency medicine, leaving the door open for exceptions to the bar [13; p. 48].

A plaintiff should prove that the other party made a false representation that was material to the transaction and that would prevent a reasonable person from reading the contract [14].

The most general fraud can be defined as any of the following acts committed by a party to a contract, or with his connivance, or by his agents, with intent to deceive another party thereto or his agent, or to induce him to enter into the contract: the suggestion as a fact, of that which is not true, by one who does not believe it to be true; the active concealment of a fact by one having knowledge or belief of the fact; a promise made without any intention of performing it; any other act fitted to deceive; any such act or omission as the law specially declares to be fraudulent.

The legal system of the majority of countries provides different offenses which involve components of fraud, for example, misappropriation; unlawful use of financial assets; maliciously causing financial loss to another; criminal mismanagement; exploitation of knowledge of confidential information; bankruptcy.

The classic definition of fraud is found in the judgment of Lord Herschell in Derry v Peek (1889) 14 App. Cas 337, 374 (HL) "...First, in order to sustain an action of deceit, there must be proof of fraud, and nothing short of that will 
suffice. Secondly, fraud is proved when it is shown that a false representation has been made (1) knowingly, or (2) without belief in its truth, or (3) recklessly, careless whether it be true or false....Third, if fraud be proved, the motive of the person guilty of it is immaterial. It matters not that there was no intention to cheat or injure the person to whom the statement was made"[15].

For example, a medical institution provides a patient with a large contract and asks to sign it as soon as possible. In this case, the patient simply does not have time to read it.

It should be noted that the consequences of the invalidity of medical contracts may differ from the general consequences of the invalidity of contracts.

The general resulting consequences of invalidity of the contract are the obligation of restitution and payment of damages. So, if the performance of a contract has nevertheless been carried out: each party may require any other party to return as far as possible their mutual relations to the position that would have existed if the acts had not been performed. The acts performed in good faith before the invalidity was invoked are not rendered unlawful by reason only of the invalidity of the contract.

This is primarily due to the fact that the return by each of the parties all received under the contract cannot be considered an effective method of legal protection. First of all, every patient needs effective treatment. Therefore, the legislation provides for the possibility of maintaining the legal force of the contract as a whole, if it is possible to invalidate only its separate condition.

For instance, Clause 27.6.1 of Standard general medical services contract determines if any term of this Contract, other than a mandatory term, is held to be invalid, illegal, or unenforceable by any court, tribunal, or other competent authority, such term shall, to the extent required, be deemed to be deleted from this Contract and shall not affect the validity, lawfulness or enforceability of any other terms of the Contract [16].

The compensation of damages caused in the process of providing medical services usually claims under the tort of negligence. Such claims focus on the existence of a duty of care including in the process of entering into a contract as well as the obligation to comprehensively inform the patient about the upcoming treatment. Compensation cannot be obtained simply because there has been an adverse outcome, but rather requires evidence that the doctor or other health professional has not exercised 'reasonable care'. Claims are sometimes made for breach of contract but even then the focus is on whether reasonable care has been exercised.

The law orders the medical institution to pay money to compensate the plaintiff for harm caused or loss suffered. Point of view should be noted that the principle of restoration in original condition (restitutio in integrum) can provide effective redress where the plaintiff has suffered an only pecuniary loss. The underlying function of damages in tortious and contractual claims differs, so it is important to identify the precise cause of action relied upon. A contractual claim based on breach of a contractual term is aimed at putting the plaintiff in the position he would have occupied if the term was properly adhered to (i.e. where the (fraudulent) representation became a term of the contract) [17; p. 100].

\section{CONCLUSIONS}

Thus, it should be noted that the problem of contracts invalidity in the field of medical services is one of the most controversial topics. It should be pointed out that the definition of invalidity, grounds of invalidity, and consequences of invalidity are parts of effective ways of protecting patient rights. The harmonization of the legislation of the EU member states requires further improvement of the standards for the provision of medical care. The public authority cannot leave such an important area uncontrolled, and therefore the state legislation establishes requirements for the content of a medical services contract, the violation of which may be grounds for their invalidity. The general resulting consequences of invalidity of the contract are the obligation of restitution and payment of damages. The compensation of damages caused in the process of providing medical services usually claims under the tort of negligence. The law orders the medical institution to pay money to compensate the plaintiff for harm caused or loss suffered.

\section{REFERENCES}

1. The Draft Civil Code of the People's Republic of China. Chapter 54.Medical Service Contracts. Available at: https://brill.com/previewpdf/book/ edcoll/9789004216631/Bej.9789004190429.i-550_055.xml

2. Atiyah. P.S. Medical Malpractice And The Contract/Tort Boundary // Professor of English Law, St. John's College, Oxford University; Visiting Professor, Duke Law School, spring term, 1985. p. 2.

3. The Saskatchewan Medical Care Insurance Act. Available at: https:// publications.saskatchewan.ca/api/v1/products/64152/formats/71428/ download

4. Medical Services Agreement. Available at: https://www.sec. gov/Archives/edgar/data/1077183/000119312512009414/ d281487dex101.htm

5. Tatsiy V., Gutorova N., Pashkov V. Legal aspects of cancer deseases prophylactics of cancer: patients'right context. Wiad Lek, 2017; 6:11081111.

6. Tamara Hervey, Bart Vanhercke. Health care and the EU: the law and policy patchwork. London School of Economics and Political Science, GovinPermanand, World Health Organization, Cambridge University Press. p. 84-133 p. 94-95., p. 111

7. Standard Personal Medical Services Agreement 2018/19 (developed by National Health Service). Available at: https://www.england. nhs.uk/wp-content/uploads/2019/04/personal-medical-servicescontract-19-20.pdf

8. Francis J. Serbaroli. Ownership of Medical Practices in New York and the Role of Private Investors. Health Care \& FDA PracticeOffices.New York. August 01, 2018 GT ADVISORY. Available at: https://www.gtlaw.com/ en/insights/2018/8/ownership-of-medical-practices-in-new-york-andthe-role-of-private-investors

9. Wouter Gekiere, Rita Baeten and Willy Palm. Free movement of services in the EU and health care. Health Systems Governance in Europe The Role of European Union Law and Policy. Edited by Elias Mossialos, GovinPermanand, Rita Baeten and Tamara K. Hervey.Cambridge University Press, 2010. p. 461-509. p. 479 
10. B. Jessie Hill. The Constitutional Right to Make Medical Treatment Decisions: A Tale of Two Doctrines CaseWestern University School of Law, 2006. p.279-345. p.281-282. Available at: https://scholarlycommons. law.case.edu/cgi/viewcontent.cgi?article $=1142 \&$ context=faculty_ publications

11. 23. United States v. Oakland Cannabis Buyers' Coop. (OCBC), On writ of certiorari to the United States court of appeals for the ninth circuit. 2001; 532: 483, 486-87. Available at: https://www.law.cornell.edu/ supct/html/00-151.Z0.html

12. Available at:https://www.cms.gov/Outreach-and-Education/MedicareLearning-Network-MLN/MLNProducts/Downloads/Fraud-AbuseMLN4649244.pdf

13. Edward B. Hirshfeld. Medical Necessity Determinations: The Need for a Legal Structure.1996. Health Matrix: The Journal of LawMedicine 1996;6:3-52. Available at: https://core.ac.uk/download/ pdf/214101584.pdf

14. Jason Scott, Aaron Kirkland and Kenneth Cochran. Best Practices For Defeating Attempts To Void Contracts. Available at: https://www. shb.com/-/media/files/professionals/s/scottjason/best-practices-fordefeating-attempts-to-void-contracts.pdf?la=en

15. Prof. Dr. Grothe. Recent Developments in European Contract Law. Winter term 2007/08.Fraud, Mistake and Misrepresentation. Available from: https://www.jura.fu-berlin.de/fachbereich/ einrichtungen/zivilrecht/lehrende/grotheh/_Archiv/veranstaltungen/ Wintersemester_2007_2008/European_Contract_Law/08_01_21_ fraud_mistake_misrepresentation.pdf

16. Standard General Medical Services Contract. Available from: https:// assets.publishing.service.gov.uk/government/uploads/system/ uploads/attachment_data/file/184931/Standard_General_Medical_ Services_Model_Contract.pdf
17. Mason Hayes \& Curran Louis. Mooney and Declan Black. Civil Fraud in Ireland. International Civil Fraud Edition: 13 Dec 2013; 99-115.

\section{ORCID and contributionship:}

Roman I. Tashian: 0000-0002-6876-5857 A,B,D,E,F

\section{Conflict of interest:}

The Author declares no conflict of interest.

\author{
CORRESPONDING AUTHOR \\ Roman I. Tashian \\ Yaroslav Mudryi National Law University \\ Kharkiv, Ukraine \\ tel: +380677799222 \\ e-mail: tashian.roman@gmail.com
}

Received: 18.06 .2021

Accepted: 15.10 .2021

A - Work concept and design, B - Data collection and analysis, C - Responsibility for statistical analysis, D-Writing the article, $\mathbf{E}$-Critical review, $\mathbf{F}$ - Final approval of the article 


\title{
LEGAL REGULATION OF THE "BIOLOGICAL" PROTECTION OF MARRIAGE AND FAMILY: ISSUES OF BALANCING BETWEEN THE RIGHT TO MEDICAL SECRET AND THE RIGHT TO CONSCIOUS MARRIAGE
}

D0I: 10.36740/WLek202111225

\author{
Oksana M. Ponomarenko ${ }^{1}$, Yuriy A. Ponomarenko ${ }^{2}$, Kateryna Yu. Ponomarenko ${ }^{3}$ \\ ${ }^{1}$ H. S. SKOVORODA KHARKIV NATIONAL PEDAGOGICAL UNIVERSITY, KHARKIV, UKRAINE \\ ${ }^{2}$ YAROSLAV MUDRYI NATIONAL LAW UNIVERSITY, KHARKIV, UKRAINE \\ ${ }^{3}$ NATIONAL AEROSPACE UNIVERSITY - KHARKIV AVIATION INSTITUTE, KHARKIV, UKRAINE
}

\begin{abstract}
The aim: The purpose of this article is to analyze the state policy of several states in creating an effective mechanism in which persons entering into marriage will be able to obtain the necessary information about the state of each other's health and thereby make an informed decision about registering a marriage, protecting the health of each other and future offspring.

Materials and methods: In the course of the study, a comparative analysis of the legal means used by some states in the field of biological protection of marriage was carried out. First of all, a study was carried out of the family legislation of states with different approaches to the system of premarital medical examination of persons entering into marriage. In addition, the scientific works of scientists from different countries were used, the object of study of which was the problems associated with the biological protection of marriage. The work also used the results of surveys that were conducted in some countries and highlighted in published scientific works.

Conclusions: Health information is essential when deciding whether to marry. Hiding such information can seriously harm the partner's health and children born in such a union. The task of the state is to find a middle ground, in which the balance of interests of the person, whose medical examination revealed health problems (the right to medical secrecy), on the one hand, and the person with whom it is planned to register a marriage (the right to health protection; the right on the voluntariness of marriage). At the same time, the emphasis in state policy on the biological protection of the family should be placed on preventive measures, including non-legal means of information.
\end{abstract}

KEY WORDS: premarital medical examination, information about the health, contract, criminal liability

Wiad Lek. 2021;74(11 p.2):3009-3015

\section{INTRODUCTION}

Getting married is an important decision for every person. Marriage is often characterized as a lifelong union to create a family and have children. The well-known marriage vow, which is used in marriage in many countries of the world: "I swear to love you in sorrow and joy, in wealth and poverty, in illness and health, until death do us part", characterizes the essence of marriage in the best way possible as a lifelong union. Of course, during their life, couples are faced with different circumstances that complicate family life. One of these circumstances, undoubtedly, is the state of health of the spouses and their children.

Health problems of a family member can be a serious challenge for family life. In addition to psychological problems, they also affect the material well-being of all family members. Indeed, against the background of significant financial costs that are required to receive medical care and treatment, as a rule, the size of the total family income also decreases due to the loss or decrease in the ability to work of that family member who is experiencing health problems. It has rightly been noted that the presence of hereditary or chronic communicable diseases can disrupt a marriage whether it affects the partners or their offspring [1].

For example, couples who, for health reasons, are not capable of having a child, face serious problems. Childlessness is one of the most common causes of divorce. The birth of a child with disabilities is also a big challenge for the family. It is especially difficult for parents who realize that the child's disease is of genetic origin and with the necessary information, such problems could be avoided. The presence of an infectious disease (sexually transmitted disease, tuberculosis, AIDS, etc.), in addition to psychological problems, jeopardize the health of other family members (first of all, the health of the other spouse).

That is why information about the health status of partners is essential for assessing the voluntariness of marriage since the content of this information can significantly affect the decision to marry. Concealment of such information may indicate the dishonesty of the person who hid it from another partner. The behaviour of a man and a woman during the marriage, their will, and expression of will are determined by the purely private interests of each of them, 
the need to receive certain benefits, etc. [2]. However, the rights and interests of the other spouse and future offspring should also not be left unprotected.

\section{THE AIM}

The purpose of this article is to analyze the state policy of several states in creating an effective mechanism in which persons entering into marriage will be able to obtain the necessary information about the state of each other's health and thereby make an informed decision about registering a marriage, protecting the health of each other and future offspring.

\section{MATERIALS AND METHODS}

In the course of the study, a comparative analysis of the legal means used by some states in the field of biological protection of marriage was carried out. First of all, a study was carried out of the family legislation of states with different approaches to the system of premarital medical examination of persons entering into marriage. In addition, the scientific works of scientists from different countries were used, the object of study of which was the problems associated with the biological protection of marriage. The work also used the results of surveys that were conducted in some countries and highlighted in published scientific works.

\section{REVIEW AND DISCUSSION}

The role of the state in creating conditions for awareness of each other's health status. Protection of marriage and family is one of the important areas of social policy of any state. And the issue of biological protection of the family should be one of the priority directions of state policy in this area since it affects not only the private interests of individual family members but also public interests. The family is the first cell that makes up the body of society, therefore it is useful for this body, and its decay is influenced by stagnation and decay. The family is the first cell to make up the body of the society so that it is good for this body and its corruption is affected by stasis and disintegration [3]. However, the legal regulation of this area should be delicate, since it affects the fundamental rights and freedoms of every person (the right to maintain medical secrecy, the right to marriage, the right to health care, and others). That is why the process of searching for the "golden mean" is of particular relevance for the state when such conditions will be created under which the interests of each person entering into marriage will be maximally observed.

It seems that the policy of the state in the matter of creating conditions under which persons entering into marriage will be informed about the state of health of each other should include two directions: firstly, the creation of conditions necessary for obtaining information about their health by each person entering into marriage; secondly, in guaranteeing to persons entering into marriage the right to receive information about the state of health of each other.
When it comes to creating the conditions necessary for a person entering into a marriage to obtain information about their health, states choose either a policy of mandatory medical examination (premarital genetic screening) or a policy of voluntary medical examination.

Mandatory medical examination of persons who are getting married. The first laws on compulsory medical examination of persons entering into marriage were passed in some states of the United States as early as 1913. The purpose of introducing compulsory medical examination before marriage registration was to prevent the transmission of venereal and some infectious diseases (in particular, syphilis, tuberculosis), which were widespread at that time [4]. It should be noted that the requirement for a mandatory medical examination before registering a marriage is still maintained in some states of the United States [5]. Compulsory medical examination before marriage registration is currently required also in such states as Azerbaijan, Bulgaria, Latvia, Turkey and others.

An analysis of the legislation of these countries allows us to conclude that they have developed a common approach to registering a marriage, namely, a certificate from a medical institution about a completed medical examination is mandatory when entering into a marriage. So, for example, by Art. 7 of the Family Code of Bulgaria, everyone who marries must provide the civil status official with a medical certificate that he does not suffer from such a disease and a statement that he has been informed about the diseases of the other (Article 9 of the IC of Bulgaria).

Mandatory premarital genetic screening. Some states in the Middle East (UAE, Saudi Arabia, Bahrain, Jordan) and North Africa require persons wishing to register a marriage to undergo compulsory genetic screening. The purpose of screening is to identify individuals with a higher risk of a disease or pathological condition in a healthy population to offer earlier treatment or intervention, which, in turn, will improve the health of some people who have undergone the examination [6].

At the same time, the number of countries that establish such an obligation at the legislative level has significantly increased in recent years. As a rule, these are countries in which incestuous marriages (between close relatives) are allowed and have a sufficient distribution, as a result of which the risk of genetic anomalies is significantly increased. Consanguineous marriages (usually between cousins and second cousins) are widespread in the countries of the southern Mediterranean coast, in the Middle East and Southeast Asia. This spread, as sociological studies show, is due to the fact that they increase the stability of the couple through compatibility between husband, wife and spouses' relatives, strengthen family ties and solidarity, support the transfer of shared values and facilitate premarital negotiations, in particular, by allowing wealth and property to remain within limits. families (Sociological studies indicate that they increase the couple's stability due to compatibility between the husband, the wife and the in-laws, strengthen family ties and solidarity, support the transmission of shared values and ease premarital nego- 
tiations, particularly by allowing wealth and property to remain within the family) [7].

According to the available data, pairs of second cousins or close relatives and their offspring now account for $10.4 \%$ of the world's population, leading to an increase in the incidence of autosomal recessive disorders. couples of second cousins or closer and their offspring currently represent $10.4 \%$ of the world's population, thus resulting in increased frequencies of autosomal recessive disorders [8].

Governments of countries in which marriages between blood relatives are common are forced to take measures to prevent the birth of children with genetic abnormalities, providing for mandatory premarital genetic screening in legislation. The effectiveness of such a measure can be assessed on the examples of such countries as Cyprus, Italy and Greece, in which it was possible to significantly reduce, and in some to practically exclude the cases of the birth of children with genetic abnormalities.

The population of countries whose legislation provides for mandatory premarital genetic screening, as a rule, understands the importance of such a screening and treat it positively. For example, in Jordan, a group of scientists surveyed the attitude of Jordanians to the compulsory premarital genetic screening. 432 participants took part in this poll. Based on the results of this survey, the following conclusions were made: the majority $(87.8 \%)$ reacted positively to the PGS program, while $49.8 \%$ of the participants were ready to change their decision about marriage if they received incompatible results. Moreover, the majority of participants $(75.1 \%)$ demanded the enactment of a law prohibiting incompatible marriages. The research team also found that positive attitudes toward PGS are most often associated with a university degree in women [9].

It should be noted, however, that although premarital screening is mandatory in some countries, couples with thalassemia can still marry if they so choose. For example, in Saudi Arabia, premarital genetic screening is compulsory for all couples who apply for marriage registration. These couples are given a referral for genetic screening. If both members of the prospective couple were found to be positive for sickle cell disease and/or thalassemia symptom/ disease, they were declared at high risk. These couples were not issued a marriage certificate and were referred to a regional genetic counselling centre. Both prospective partners (or the male partner together with the female partner's guardian) attended these centres together by appointment. During the meeting, the consultant explained the situation to both partners and issued them "certificates of incompatibility" after receiving their signatures and providing them with health education brochures. Couples had the right to marry regardless of the test results (All the couples found to have low risk were issued compatibility certificates. they were declared high risk. These couples were not issued a marriage certificate and were referred to a regional genetic counselling clinic. Both prospective partners (or male partners along with the guardian of the female partner) visited these centres together by appointment. During the meeting, the counsellor explained the situation to both the partners and issued them "certificates of incompatibility" after obtaining their signatures and providing them with health education brochures. Couples had the right to marry regardless of the screening test results [10]. However, research results showed that $64 \%$ of at-risk couples continued to marry despite receiving counselling. This, according to the researchers, indicates a serious public health problem [11] and gives grounds to assert that such a state program is ineffective.

The reasons for the ineffectiveness of premarital screening and genetic research programs were the lateness of its implementation (when it was not possible to cancel the wedding), the lack of knowledge of the spouses about hereditary diseases, as well as socio-cultural and religious problems [12].

However, unlike the population, which, as noted, is mostly positive about this kind of medical examination, the opinions of scientists in these countries are not so unambiguous. In addition to supporters of mandatory premarital genetic screening, there are also opponents of such state policy. Sceptics, besides the fact that this is contrary to the Quran, give the following arguments. First, compulsory premarital medical examination violates a person's autonomy. In their opinion, married couples should be encouraged to undergo premarital genetic testing and be informed of its benefits, but at the same time, they should be allowed to exercise their autonomy - whether to take the test or not. (Thus in the context of mandatory premarital genetic testing, they contend that an individual's autonomy should not be compromised and hence prospective marriage couples should be encouraged to undergo premarital genetic testing and to be educated about its benefits, but at the same time they should be allowed to exercise their autonomy either to undergo the test or not) Second, although one of the goals of marriage is procreation, women who have reached childbearing age may also want to marry for companionship rather than procreation. Therefore, it would be pointless to impose premarital genetic testing on such potential elderly couples. (while one of the primary objectives of marriage is procreation, women who have passed the age of childbearing may also wish to marry for the sake of companionship and not for procreation. It would therefore be meaningless to impose premarital genetic testing on such prospective elderly couples [13]. As you can see, the arguments of the opponents of mandatory premarital genetic research are quite convincing. However, the arguments of the supporters of such a state policy are no less weighty. They refer to the lesser of two evils rule. In the context of the problem under study, two disasters are 1) mandatory premarital genetic testing and 2) the prevalence of children born with genetic disorders. Therefore, in their opinion, it would be less evil to compromise autonomy for the sake of an urgent social need, that is, to prevent the birth of children susceptible to the inheritance of genetic disorders [13].

Voluntary medical examination of persons who are getting married. Governments of countries that do not provide for mandatory medical examination often create conditions 
under which persons wishing to register a marriage can properly fulfil their obligation to inform their partner of their health. In countries belonging to this group, the state provides the opportunity for such persons to undergo a medical examination, while in some countries, such examination (partially or completely) is free.

So, for example, in accordance with Art. 30 Investigative Committee of Ukraine, the betrothed are obliged to inform each other about their state of health. The state ensures the creation of conditions for a medical examination of the betrothed. In accordance with clause 2 of the Procedure for the implementation of voluntary medical examination of the betrothed, a medical examination is carried out only at their request. The body of state registration of acts of civil status during the filing of an application for registration of marriage informs the persons who submit such an application about the possibility of carrying out a medical examination and, if they wish, issues a referral. Such mechanisms are provided for in the family laws of Armenia, Belarus, Moldova, and the Russian Federation.

However, it should be noted that in the scientific literature of countries that have a system of voluntary medical examination of persons entering into marriage, one can often find criticism of this approach. For example, in the Russian scientific literature, a number of scientists insist on the introduction of compulsory premarital medical examination $[14 ; 15 ; 16]$. I.V. Trofimets, in particular, notes that in the current legislation, only concealment of a venereal disease or HIV infection is named as a basis for challenging the validity of a marriage, although concealing other diseases may have more negative consequences for the health of another spouse and offspring than concealing sexually transmitted diseases, which in most cases are curable. It seems that the problem can be solved in principle by establishing a mandatory premarital medical examination and informing the spouses about each other's health [17].

A scientific discussion has resumed on the need to introduce compulsory medical examination of persons entering into a marriage in Poland. The analysis of this discussion was carried out by M. Rzewuska, as a result of which she came to the conclusion that premarital medical examination has an important function of an informative and preventive nature. All this, in her opinion, confirms the relevance of revising the idea of their legal regulation in the Polish legal system. In this connection, it should be considered highly desirable to require the introduction of compulsory premarital medical examination [18]. The examinations in question would have the important function of informational and prophylactic nature. All this, argues in favour of the relevance of re-considering the idea of regulating them within the Polish legal system. It should be considered highly desirable to demand the introduction of mandatory prenuptial examinations, the results of which should be communicated to both nutrients, for only then the examinations would reach the set objectives.

The opposite trend is also worth noting. In a number of countries, whose legislation traditionally provided for mandatory medical examination of persons entering into marriage, governments began to abandon such public policies. For example, couples wishing to get married in Luxembourg from 1 January 2015 no longer have to undergo a mandatory medical examination. The Luxembourg authorities argued for such changes by the simplification of administrative procedures and the lack of need. They felt that health insurance has improved since there was a mandatory medical examination for marriages for the first time in 1970, and people tend to see a doctor more often, making additional examination unnecessary [19]. In France, the pre-marriage medical examination, which had been mandatory since 1942, was also abolished in 2008 .

The mandatory medical examination was also abandoned in China, making such examination voluntary. Indicative are the results of studies that were carried out after the abolition of mandatory premarital medical examination in China, according to which the number of couples undergoing medical examination before marriage dropped sharply: from $94.3 \%$ in 2003 to $1.6 \%$ in 2004 [20]. This clearly illustrates that only a small percentage of couples who get married are ready to make their own decisions about undergoing a medical examination before registering a marriage. Therefore, an important direction in the state policy of those countries that have settled on the system of voluntary medical examination of persons entering into marriage is to inform the population about the importance and effectiveness of such examinations. For the sake of fairness, it should be noted that a developed health care system and the availability of medical services, in which medical examination is carried out systematically throughout a person's life with the entry of health information into electronic medical databases, will make the requirement for a premarital medical examination irrelevant.

Mechanisms for guaranteeing the right of persons entering into marriage to receive information about each other's health status. There is no doubt that the state of health in no way can be the basis for limiting the human right to marriage, family, and childbirth. The only exception to this rule is the presence of mental illness, which makes it impossible for a person to form the will to marry. Disability is recognized as an obstacle to marriage registration in almost all legal systems. All other diseases, no matter how serious they are, should not interfere with marriage and the birth of children.

So, in accordance with Art. 23 of the Convention on the Rights of Persons with Disabilities of 13 December 2006, States Parties shall take effective and appropriate measures to eliminate discrimination against persons with disabilities in all matters relating to marriage, family, fatherhood, maternity and personal relationships, on an equal basis with others, while striving to ensure that :

(a) The right of all persons with disabilities who have reached the age of marriage is recognized to marry and found a family with the free and full consent of the spouses;

(b) The rights of persons with disabilities to freely and responsibly decide on the number and spacing of children and to have access to age-appropriate information and education on reproductive behaviour and family planning 
are recognized, and the means are provided to enable them to exercise these rights;

(c) Persons with disabilities, including children, maintain their fertility on an equal basis with others.

However, health information can be a decisive factor in shaping the will to marry. As Yu. F. Bespalov rightly writes a person entering into marriage must fully realize the consequences that follow from his conclusion. For example, for a person entering into marriage, the opportunity to give birth to a child in marriage may be a significant basis for marriage, which in case of infertility of the other spouse cannot initially be ensured [21]. That is why the state should consider such a mechanism under which the right of persons entering into marriage to receive information about each other's health status would be guaranteed.

For a long time, there has been a discussion in science about whether the state can oblige persons who have undergone a premarital medical examination to provide the results of such an examination to each other. As a result, the view was expressed that, in any event, the right to medical secrecy should be respected. That is why, even the legislation of those countries where the premarital medical examination is mandatory, the results of the medical examination are communicated only to the person who has passed this examination. It is worth noting, however, that in countries in which a certificate of the absence of a certain disease (HIV, sexually transmitted disease, etc.) is required to register a marriage, it is almost impossible to hide a positive result from a partner.

The guarantees of the right to receive information about each other's health should provide for other mechanisms, and they exist in the legal systems of some states. Thus, the family legislation of a number of countries specifies the concealment of information about certain diseases as a basis for invalidating a marriage. At the same time, as a rule, the law directly provides for the type of disease, the concealment of information about which entails unfavourable consequences. So, for example, in accordance with Art. 13 SK of Azerbaijan, if one of the persons wishing to get married, hides from another person the presence of skin disease and disease caused by the human immunodeficiency virus, then the other party may apply to the court with a demand to declare the marriage invalid.

At the same time, attention is drawn to the problem of vague and unclear formulations in the legislation of some countries. So, for example, in accordance with Art. 41 of the IC of Ukraine, a marriage can be declared invalid by a court decision if it was registered with a person who concealed his serious illness or illness that is dangerous for the other of the spouses and (or) their future offspring. At the same time, the legislation does not provide for a list of such diseases. This problem exists in the family codes of Belarus, the Russian Federation and other states.

It is not surprising that this approach of the legislator evokes constructive criticism from scientists. As Ye. L. Nevzgodina rightly writes: "As a result, a paradoxical situation arises: any deal, not even close to a marriage in terms of its significance, concluded under the influence of deception, can be invalidated with the onset of liability of an unscrupulous counterparty. The spouse, who concealed the presence of tuberculosis, alcoholism, inability to bear children, is not responsible, the marriage with him can only be dissolved in a general manner - with all the legal consequences of divorce, including preserving his right to the living space of the deceived spouse, to receiving alimony from him for his maintenance, for his surname, etc. [22].

In this regard, the approach of the Italian legislator is indicative. In accordance with Art. 122 of the Civil Code of Italy, a marriage can be challenged by the spouse whose consent was given as a result of a significant error in the personal qualities of the other spouse. An error with regard to personal qualities is significant if, taking into account the conditions of the other spouse, it is established that he would not have given his consent if he knew them exactly and provided that the error relates to the presence of a physical or mental illness, sexual abnormality or deviation, for example, hindering the development of married life. In this case, the disease or anomaly that persists at the time of the appeal must nevertheless exist during the marriage and not be known to the other spouse. The judge will have to determine its effect on consent. Anomaly archetype - sexual infertility [23]. This approach is in line with the concept of the contractual nature of marriage, which is dominant in the Italian legal system. It seems that the experience of the Italian legislator can also be useful for the legal systems of other states since it provides an effective mechanism for protecting the rights of a person entering into marriage from unfair actions of a partner in providing reliable information about the state of health, which may affect the decision to join marriage. In addition to declaring a marriage invalid, the right of a bona fide spouse to compensation for damages and moral damage must also be included in the remedies.

However, the disadvantage of all the listed methods of protection is that they can be applied only after the violation of the law. Violation of the law in this area can be very painful and lead to irreparable consequences, for example, to the birth of a child with a genetic disease. It should be recognized that neither invalidation of marriage, nor damages, nor compensation for non-pecuniary damage can be recognized as effective enough to prevent unfair behaviour in this area. Therefore, in addition to legal means, the state should actively engage in propaganda (in the media, in education, etc.) informing the population about the importance of medical examinations in family planning and childbirth.

Problem of the possibility of using the means of public legal liability as one of the mechanisms for guaranteeing the right of persons entering into marriage to receive information about the state of health of each other. In the legislation of a number of states, one can find norms of criminal or administrative law establishing liability for related acts. So, part 1 of Art. 212-1 of the Code of Administrative Offenses of Ukraine provides for liability for concealing circumstances that prevent the registration of marriage, or for communicating deliberately false information to state 
civil registration authorities. However, under this article, liability arises only for failure to report or distortion of information that prevents marriage (information about the state of health in accordance with Art. 26 of the Family Code does not apply to such), and only in cases where the addressee of hidden or distorted information becomes the state registration authority civil status. Failure to provide the future spouse with information about their health status is not covered by this article. Articles 130 and 133 of the Criminal Code of Ukraine provide for criminal liability for, respectively, infection with HIV or other incurable infectious diseases and infection with a venereal disease. In these cases, responsibility is imposed on the person who has already infected the victim with one of these diseases (moreover, regardless of the marriage relationship between them), and not only who concealed the fact that he had such a disease.

Such acts entail administrative or criminal liability under the laws of Belarus, Bulgaria, Moldova, Poland, Latvia, Lithuania, Russia and a number of other European countries. In none of the states, whose legislation is available for study, we have not established norms on criminal or administrative liability precisely for concealing information about the state of his health from the future spouse. It seems that the refusal of the legislators of these countries to establish public-law types of legal responsibility for the commission of such actions is fully justified, based on the following arguments. First, such acts are committed in an exclusively private sphere of human life, interference into which using public law means should be minimized. Secondly, the use of public legal remedies for persons who, upon marriage, concealed or distorted information about their state of health, is not proportional to the severity of the said acts and violates the ultima ratio principle. Finally, thirdly, for the effective protection of the right to a conscious marriage, the above means of private law are quite sufficient.

\section{CONCLUSION}

The conducted research allows us to conclude that information about the health status of a partner is an essential condition when making a decision to marry. The concealment of this information by an unscrupulous partner can cause significant (sometimes irreparable) harm to the rights and interests of not only the other spouse but also the children who will be born in this marriage. Therefore, the state policy on the biological protection of the family should be aimed both at creating conditions under which the person entering into marriage can receive appropriate information about his health, and at providing guarantees to the person entering into marriage to receive reliable information about the health status of the partner. ... At the same time, the task of the authorities is to find a middle ground in which the balance of interests of the person, whose medical examination revealed health problems (the right to medical secrecy), on the one hand, and the person with whom the registration of marriage is planned (the right to health protection; the right to the voluntariness of marriage). As a result of the analysis, it was concluded that the system of legal means that are used by states for the biological protection of marriage cannot be considered as effective preventive measures, since they are designed exclusively for application after a violation of the law. Therefore, in public policy, it is also necessary to use other, non-legal means of informational character.

\section{REFERENCES}

1. Melaibari M, Shilbayeh S, Kabli A. University Students' knowledge, attitudes, and practices towards the National Premarital Screening Program of Saudi Arabia. J Egypt Public Health Assoc. 2017 Mar 1;92(1):36-43. doi: 10.21608/epx.2017.7008. PMID: 29924926. [reviewed 2021.27.09]

2. Zamrii 0.N. Dobrosovestnost' i zloupotreblenie interesom pri nedeistvitel'nosti braka. Yuridicheskii vestnik Samarskogo universiteta. 2019.5 (1): 90-95. Dol: https://doi.org/10.18287/2542047X-2019-5-1-90-95 (in Russian).

3. Khazaleh, A., Hwaidi, TAH, Alnasraween, MES, \& Al-Taj, H. (2019). Students' Attitudes at Amman Arab University towards the Pre-Marital Medical Examination and Its Role in Reducing Disability from Their Point of View. International Education Studies. 12 (1): 80-89. Available from: https://files.eric.ed.gov/fulltext/EJ1201524.pdf [reviewed 2021.27.09]

4. Shafer JK. Premarital Health Examination Legislation: History and Analysis. Public Health Reports (1896-1970). 1954. 69 (5): 487-493.// www.jstor.org/stable/4588806. [reviewed Sept. 2021.13.09].

5. Marriage Laws of the Fifty States, District of Columbia and Puerto Rico. https://www.law.cornell.edu/wex/table_marriage

6. Screening programs: a quick guide. Improving efficiency, maximizing benefits and minimizing harm https://apps.who.int/iris/bitstream/ha ndle/10665/330828/9789289054812-rus.pdf

7. Hamamy H. Consanguineous marriages: Preconception consultation in primary health care settings. J Community Genet. $2012 \mathrm{Jul} ; 3$ (3): 185-92. doi: 10.1007 / s12687-011-0072-y. Epub 2011 Nov 22. PMID: 22109912; PMCID: PMC3419292.

8. Dahdouh A, Taleb M, Blecha L, Benyamina A. Genetics and psychotic disorders: A fresh look at consanguinity. Eur J Med Genet. 2016 Feb; 59 (2): 104-10. doi: 10.1016 / j.ejmg.2015.12.010. Epub 2015 Dec 22. PMID: 26721321.

9. Altaany Z, Khabour O, F, Alzoubi K, H, Alkaraki A, K, Al-Taani G: The Perception of Premarital Genetic Screening within Young Jordanian Individuals. Public Health Genomics 2021; 24: 182-188. doi: 10.1159/ 000517162

10. AlHamdan, N., AlMazrou, Y., AlSwaidi, F. et al. Premarital screening for thalassemia and sickle cell disease in Saudi Arabia. Genet Med 9, 372-377 (2007). Available from: https://www.nature.com/articles/ gim200760 https://doi.org/10.1097/GIM.0b013e318065a9e8

11. ROSHAN, BIBIASMA SYED. Prevalence of At-Risk Marriages among Couples Attending Premarital Screening (PMS) Programs: A Systematic Review and Meta-Analysis. MS thesis. 2020. Available from: http:// qspace.qu.edu.qa/bitstream/handle/10576/12628/BibiAsma\%20 Syed_0GS\%20Approved\%20Thesis.pdf?sequence $=1$

12. Saffi M, Howard N: Exploring the Effectiveness of Mandatory Premarital Screening and Genetic Counseling Programs for Ol-Thalassaemia in the Middle East: A Scoping Review. Public Health Genomics 2015; 18: 193203. doi: 10.1159 / 000430837 . Available from: https://www.karger. com/Article/Fulltext/430837 
13. Ebrahim, Abul Fadl. "Mandatory Premarital Genetic Screening For Hereditary Disease In Light Of The Five Objectives Of Islamic Law." The Egyptian Journal of Fertility of Sterility 22.1 (2018): 23-27. Available from: https://journals.ekb.eg/article_19211.html [reviewed 2021.27.09]

14. King IG Medical examination of persons entering into marriage: to be or not to be ?. Actual problems of the humanities and natural sciences, 2016, 2-3. Available from: https://publikacia.net/archive/2016/2/3/53;

15. Matveeva N. A. Pravovye aspekty meditsinskogo obsledovaniya lits, vstupayushchikh v brak, v Rossiiskoi Federatsii, Ukraine i Belarusi. Meditsinskoe pravo. 2007: 19-23 (in Russian).

16. Starodubtseva Yu. V. Pravovye problemy meditsinskogo obsledovaniya lits, vstupayushchikh v brak. Vestnik Vyatskogo gosudarstvennogo gumanitarnogo universiteta. 2014: 130-133 Available from: https://cyberleninka.ru/article/n/pravovye-aspekty-meditsinskogoobsledovaniya-lits-vstupayuschih-v-brak (in Russian).

17. Trofimets I.A. Nekotorye problemy nedeistvitel'nosti braka po rossiiskomu zakonodatel'stvu i zakonodatel'stvu gosudarstvuchastnikov Sodruzhestva Nezavisimykh Gosudarstv i Baltii. Yuridicheskie issledovaniya. 2013(5): 378 - 454. D0l: 10.7256 / 2305-9699.2013.5.810 Available from: https://nbpublish.com/ library_read_article.php?id=810 (Ru) [reviewed 2021.01.10].

18. Rzewuska M. Mandatory Prenuptial Medical Examinations - a Starting Point for the Discussion. Law and Forensic Science. 2019(1). Available from: http://lawforensics.org/mandatory-prenuptial-medicalexaminations-a-starting-point-for-the-discussion/

19. No more medical exams before marriage. Available from: https://www. luxtimes.lu/en/luxembourg/luxembourg-no-more-medical-exambefore-marriage-602d3633de135b9236283e6b

20. Gu, Y., Li, L., Zhou, C. et al. Factors influencing voluntary premarital medical examination in Zhejiang province, China: a culturally-tailored health behavioural model analysis. BMC Public Health 14. 659 (2014). Available from: https://doi.org/10.1186/1471-2458-14-659
21. Chastnoe pravo: problemy teorii i praktiki. Pod red. Bespalova Yu.F. 2015. (in Russian).

22. Nevzgodina E. L. Pravovaya zashchita braka po semeinomu kodeksu RF. Vestnik Omskogo universiteta.1998(4):103-106. (in Russian).

23. Codice Civile Available from: https://www.brocardi.it/codice-civile/ libro-primo/

\section{ORCID and contributionship:}

Oksana M. Ponomarenko: 0000-0001-6394-1834 ${ }^{D}$

Yuriy A. Ponomarenko: 0000-0002-1030-1072 A, E

Kateryna Yu. Ponomarenko: 0000-0001-5133-5036 ${ }^{B, F}$

\section{Conflict of interest:}

The Authors declare no conflict of interest.

\section{CORRESPONDING AUTHOR}

Oksana M. Ponomarenko

HS Skovoroda Kharkiv National Pedagogical University,

Kharkiv, Ukraine

tel: +380973325570

email: ponomarenkooksana1976@gmail.com

Received: 08.06.2021

Accepted: 12.10 .2021

A - Work concept and design, B - Data collection and analysis, C - Responsibility for statistical analysis,

D-Writing the article, $\mathbf{E}$-Critical review, $\mathbf{F}$ - Final approval of the article 


\title{
CERTAIN LIMITATIONS IN REPRODUCTIVE RIGHTS`S EXERCISING (CASES OF CHINA AND AUSTRIA)
}

D0I: 10.36740/WLek202111226

\author{
Roman A. Maydanyk, Kateryna V. Moskalenko \\ EDUCATIONAL AND SCIENTIFIC LAW SCHOOL OF TARAS SHEVCHENKO NATIONAL UNIVERSITY OF KYIV, UKRAINE
}

\begin{abstract}
The aim: To analyze the existing international legal framework, regulating limitations of exercising reproductive rights, and determine whether the limitations provided by Chinese and Austrian national legislators meet the international and regional standards.

Materials and methods: The article is based on international universal and regional European legal instruments, the jurisprudence of the European Court of Human Rights, national legislation of China and Austria, and scientific articles. The research is grounded on formal logical and dialectical methods, methods of synthesis and analysis, historical method, comparative legal method, and the method of modelling.

Conclusions: The authors concluded that despite the standards on reproductive autonomy, being set by the number of international conferences and international and regional acts, the governments may impose limitations on exercising the said autonomy. Such limitations can be either radical ones (taking into account Chinese example of birth control) or liberal ones (taking into account the Austrian case on the prohibition of heterologous gametes donation).
\end{abstract}

KEY WORDS: reproductive rights, limitations on exercising of rights, European Court of Human Rights

Wiad Lek. 2021;74(11 p.2):3016-3020

\section{INTRODUCTION}

Reproductive rights belong to personal inalienable rights, that are protected both by the international legal acts and, in some countries, are protected by the special legal framework. Reproductive rights were first mentioned in the middle of the XXth century at the international conferences of human rights. As L.B. Pizzarossa shows, the development of reproductive rights has passed three main stages:

- the population control phase (starting from the World Population Conference in 1954 in Rome and completed by the World Conference on Human Rights in Vienna in 1993), as many governments supported the idea of limitation of population growth. It was believed by the time an increase in population would lead to poverty and starvation. The World Population Plan of Action [1], adopted at the Bucharest World Conference on Population in 1974, slightly changed the population control approach, prescribing that any birth control policies should be compatible with human rights. This phase ended by underlining the importance of women 's rights at the World Conference on Human Rights in Vienna in 1993;

- the human rights phase (including the International Conference on Population and Development in Cairo (1994) and the Beijing Declaration and Platform for Action (1995), as the Programme of Action [2], established at the International Conference on Population and Development held in Cairo, clearly stated that any national policy on population control should be consistent with the principles of human rights. As L.B. Pizzarossa covers, the Programme of Action stated that "reproductive rights embrace certain human rights that are "already recognized" in national laws, international laws, and international human rights documents and other consensus documents";

- the fragmentation phase, starting after 1994, where fragmentation achievements have been made, such as e.g., emphasizing the crucial role of the reproductive rights in gender equality issues, or elaboration of recommendations on the right to sexual and reproductive health [3].

The reproductive rights, as stated in the Programme of Action, established at the International Conference on Population and Development held in Cairo, include the basic right of all couples and individuals to decide freely and responsibly the number, spacing, and timing of their children; have the information and means to do so; attain the highest standard of sexual and reproductive health; decide reproduction free of discrimination, coercion, and violence, as expressed in human rights documents [2]. As was stated above, reproductive rights embrace some separate human rights. Following the General comment No. 22 (2016) on the right to sexual and reproductive health (article 12 of the International Covenant on Economic, Social and Cultural Rights) (hereinafter - GC No. 22) [4], the right to sexual and reproductive health (not reproductive right) is indivisible from and interdependent with other human rights. It is linked to such rights as the rights to life; liberty and security of person; freedom from torture and 
other cruel, inhuman, or degrading treatment; privacy and respect for family life; and non-discrimination and equality.

The main legal instruments, that regulate reproductive rights, thus, are mostly the same ones that regulate the right to life and health rights. These legal instruments are adopted at different levels, such as:

1. international level, including universal international agreements and covenants, such as e.g., Universal Declaration of Human Rights [5], International Covenant on Civil and Political Rights [6], International Covenant on Economic, Social and Cultural Rights [7] etc.;

2. regional level, including acts, adopted and applied in some regions. In Europe, these are the Convention for the Protection of Human Rights and Fundamental Freedoms [8], and the Convention for the Protection of Human Rights and Dignity of the Human Being with regard to the Application of Biology and Medicine: Convention on Human Rights and Biomedicine [9] etc.;

3. national level, including the national legislation of the countries. While some countries opt not to regulate reproductive rights at all, the scientists distinguish several models of regulation of reproductive rights in those states that have special legal norms dedicated to reproductive rights. K. Nykolyna defines between the liberal model, where the reproductive choice is not limited and the wide scope of reproductive rights is listed (the author illustrates the legislation of the USA and Belgium as examples), and the paternalistic model, where the reproductive rights are limited due to some traditions or religious beliefs (Islamic countries, Ireland and Croatia are mentioned by the author as the example) [10].

Of course, exercising reproductive rights can be subject to certain limitations. General rules on such limitations can be found in the international legal acts. For example, Art. 4 of the International Covenant on Economic, Social and Cultural Rights [7] lays down that the rights, foreseen by this Covenant, shall be subject only to such limitations as are determined by law only in so far as this may be compatible with the nature of this rights and solely for the purpose of promoting the general welfare in a democratic society. As laid down by the Convention for the Protection of Human Rights and Fundamental Freedoms [8], the exercising of the right to respect for private and family life, foreseen by Article 8 of the mentioned Convention, can be interfered with by the public authority following the law in cases when it is necessary for a democratic society in the interests of national security, public safety or the economic well-being of the country, for the prevention of disorder or crime, for the protection of health or morals, or the protection of the rights and freedoms of others. When the state fails to make the interference in accordance with the mentioned standards, it is considered to be a violation. GC No. 22 provides some examples of such violations, namely violation of the obligation to respect occurs when the State through laws, policies, or actions, undermines the right to sexual and reproductive health. Such violations include State interference with an individual's freedom to control his or her own body and ability to make free, informed, and responsible decisions in this regard [4]. Following these rules, it is interesting to research the national legislation of China and Austria to analyze whether such limitations are established following the international standards.

\section{THE AIM}

This paper aims to analyze the existing international legal framework, regulating limitation of exercising of reproductive rights, and determine whether the limitations provided by the Chinese and Austrian national legislators meet the international and regional standards.

\section{MATERIALS AND METHODS}

The article is based on international universal and regional European legal instruments, the jurisprudence of the European Court of Human Rights, pieces of national legislation of China and Austria, and scientific articles. The research is grounded on formal logical and dialectical methods, methods of synthesis and analysis, historical method, comparative legal method, and the method of modeling.

\section{REVIEW AND DISCUSSION}

As it was stated above, the limitations in exercising reproductive rights are provided by national legislators and it is interesting to analyze whether such limitations are done in accordance with the international standards and bioethical principles. The choice of the countries was inspired by the necessity to investigate the limitations of exercising reproductive rights in different legal systems.

The Chinese birth control experience is well known in the world, as since the middle of the XXth century Chinese government was promoting decreasing the birth rate. In 1982 the Constitution of the People's Republic of China was adopted and the family planning provision was included in Art. 25, prescribing that the state promotes family planning so that population growth may fit the plans for economic and social development. Moreover, as follows from the Art. 49 of the Constitution, both husband, and wife have the duty to practice family planning [11]. As L.B. Pizzarossa notes, the adoption of birth control policies in China was discussed at the International Conference on Population in Mexico City (1984). The coercive methods that were introduced by the Chinese government were not publicly rejected during the conference, and that meant "the "basic human right of couples and individuals to decide freely and responsibly the number and spacing of their children" accepted in Bucharest were, therefore, circumscribed in its exercise following governmental demographic goals and in a manner that a given government considered "responsible" [3].

The Constitutional regulation in China was not followed by the adoption of the special legislation [12] until the adoption of the Law of the People's Republic of China on the Protection of Rights and Interests of Women [13] on 
April 3, 1992. Pursuant to Art. 51 of the mentioned law, women have the right to child-bearing in accordance with the relevant regulations of the State as well as the freedom not to bear aby child. In 2001 the Population and Family Planning Law [14] was adopted, containing Chapter III with the special norms on the regulation of fertility. Due to Art. 17 of the mentioned law, the citizens had both the right to reproduction and the duty to practice family planning according to the law. According to Art. 18 of the mentioned Law, the State encouraged late marriage and childbearing and advocated one child per couple. Arrangements for a second child should be subject to law and regulation and specific measures should be enacted in each province, autonomous region, and municipality. As Du Yifang notes, 28 provinces in China adopted the one-child policy; two provinces decided to maintain a two-children policy and 3 provinces did not provide for any special regulation [12]. The factors when a couple could opt for a second child depended upon the couple's situation, family's situation, and child's situation and varied in different provinces [12]. Different models were used to administer the birth control: postpartum certification system, registration system, and a licensing system [12]. The sanctions for violation were also provided at the provincial level and included: termination of pregnancy, remedial measures, collection of social maintenance fees [12].

In 2015 the Population and Family Planning Law of the People's Republic of China as amended shifted to a two-children policy. Under Art. 18 of the newly adopted amendments, the State recommended that couples had 2 children. Couples who met the requirements stipulated in the laws and regulations could have requested to arrange for the birth of an additional child and the specific procedures of such a request should have been decided on provincial level [15]. Most of the provinces have implemented a two-child policy in their regional norms and enacted respective regulations [16]. As open sources note, the most widespread punishment for having a third child was a social fee, which was usually much higher than the average income. Also, cases of forced abortion and sterilization are known [15].

In June 2021 the Politburo of the Chinese Communist Party has announced the three-child policy and the amendments to the Population and Family Planning Law of the People's Republic of China were entered on August 20,2021 , effective immediately. Due to the newly adopted ruling, every married couple in China is now allowed to have up to three children and the sanctions for violating the policy were deleted from the law (social fee, termination of employment for state officials, and other restrictive measures). Moreover, measures to promote childbirth were introduced, such as extended maternity leave and social benefits [17].

Multiple reports note that the Chinese birth control regulations contradict the standards set by the international conferences on population and the international conventions. For example, due to the report "Country Information and Guidance. China: Contravention of National
Population and Family-Planning Laws" official violence acts committed while executing the family planning policy contradict Article 1 of the Convention against Torture and Other Cruel, Inhuman or Degrading Treatment or Punishment, while refusal to register a child born in violation of the birth control policy, shall be a violation of the Convention of the Rights of the Child and the International Covenant on Economic, Social and Cultural Rights [18].

In our opinion, the mere establishment of birth control in China shall not be recognized as a violation of the international laws, as, following the ideology of the family planning policy it is instituted to fight the possible famine and lack of sources in case of overpopulation. Such aim falls in line with the promotion of the general welfare in a democratic society, which is a ground for limitation of rights in accordance with Art. 4 of the International Covenant on Economic, Social, and Cultural Rights [7]. However, such practices as forced abortions or sterilizations are violations of human rights. Such actions are recognized as a violation of the obligation of the State to protect pursuant to Pont 59 of the GC. No. 22 [4].

It is interesting to compare the experience of China, influenced by the communist ideology and traditional religious beliefs, with the experience of the European country. While a lot of European countries limit exercising of the reproduction rights to some extent, Austria was chosen as the illustrative example due to the prohibition of gametes ' donation, which was analyzed in detail by the European Court of Human Rights in the case S.H. and others v. Austria [19]. In this case, the applicants, two married couples, argued that the prohibition to use donated ovas and sperm for in vitro fertilization by the Austrian Artificial Procreation Act excluded them from having a child. The European Court of Human Rights has observed that the prohibition, provided by the Austrian Artificial Procreation Act, was made under the law and legitimate aim. The necessity of such a limitation in a democratic society was analyzed by the court separately in connection with the third and fourth applicants (who needed ovum donations) and the first and second applicants (who needed sperm donation). The court has decided that due to the fact that there is no consensus in the European states towards ova donation and no imperative requirements, establishing the imperative permission for such donation in any cases - the margins of appreciation, provided to the states are wide and the Austrian legislator has not overstepped respective margins. The Austrian legal rules did not prohibit sperm donation for in vivo fertilization, proving the careful approach of the law-maker in balancing the rights of all stakeholders, moreover, the couples could opt for medical reproductive tourism, which was not prohibited. Taking these considerations into account, the European Court of Human Rights has not found the breach of Article 8 of the Convention as regards all the applicants [19].

Despite the principle of primacy of human being, claimed by Art. 2 of the Convention on Human Rights and Biomedicine [9], pursuing that the interests and 
welfare of the human being shall prevail over the sole interest of society or science, the limitations on exercising on reproductive rights can be introduced by the lawmakers in Europe and the limitations provided by the Austrian legislator, although Austria has not ratified the Convention on Human Rights and Biomedicine, are an example. Such limitations in Europe shall fall within the international and regional standards, in particular, following the Art. 8 of the Convention for the Protection of Human Rights and Fundamental Freedoms [8], shall be strictly made in accordance with the law and necessary in a democratic society in the interests of national security, public safety, or the economic well-being of the country, for the prevention of disorder or crime, for the protection of health or morals, or the protection of the rights and freedoms of others.

\section{CONCLUSIONS}

Despite the standards on reproductive autonomy, being set by the number of international conferences and international and regional acts, the national lawmakers may impose limitations on exercising the said autonomy. Such limitations can be either radical ones (taking into account the Chinese example of birth control) or liberal ones (taking into account the Austrian case on the prohibition of heterologous gametes donation). In any case, the limitations should not impose sanctions that violate the integrity of the human body (e.g. forced sterilization and forced abortion), be adopted by the law, and be justified by the needs of the good of the whole society.

The Chinese government has overstepped the international standards of limitation of reproductive rights by introducing such practices as forced sterilizations or abortions.

It is interesting that the bioethical principle, provided by the Convention on Human Rights and Biomedicine, pursuing that the interests and welfare of the human being shall prevail over the sole interest of society or science, does not preclude European legislators on imposing the limitations on exercising the reproductive rights. The prohibition to use donated ovas and sperm for in vitro fertilization by the Austrian Artificial Procreation Act does not violate international or regional legal standards of limitation of exercising the reproductive rights.

\section{REFERENCES}

1. World Conference on Population (19 August, 1974). Available from: https://www.unfpa.org/events/world-conference-population

2. Programme of Action, adopted at the International Conference on Population and Development, Cairo, 5-13 September, 1994. Available from: https://www.unfpa.org/sites/default/files/event-pdf/PoA en.pdf

3. Lucia Berro Pizzarossa. Here to Stay: the Evolution of Sexual and Reproductive Health and Rights in International Human Rights Law. Laws. 2018. 7.29: 1 - 17. doi:10.3390/laws7030029
4. General comment No. 22 (2016) on the right to sexual and reproductive health (article 12 of the International Covenant on Economic, Social and Cultural Rights). Available from: http://docstore.ohchr.org/SelfServices/ FilesHandler.ashx?enc $=4$ sIQ60SmIBEDzFEovLCuW1a0Szab0oXTdlmn sJZZVQfQejF41Tob4CvljeTiAP6sGFQktiae1vlbb0Aekma0wD OWsUe7N8TLm\%2BP3HJPzxjHySkUoHMavD\%2Fpyfcp3Ylzg

5. Universal Declaration of Human Rights dated December 10, 1948. Available from: https://www.ohchr.org/EN/UDHR/Documents/ UDHR_Translations/eng.pdf.

6. International Covenant on Civil and Political Rights dated December 16, 1966. Available from: http://www.un.org.ua/images/International_ Covenant_on_Civil_and_Political_Rights_CCPR_eng1.pdf.

7. International Covenant on Economic, Social and Cultural Rights dated December 16, 1966. Available from: https://www.ohchr.org/en/ professionalinterest/pages/cescr.aspx

8. Convention for the Protection of Human Rights and Fundamental Freedoms dated November 4, 1950. Available from: https://www.echr. coe.int/documents/convention_eng.pdf

9. The Convention for the Protection of Human Rights and Dignity of the Human Being with regard to the Application of Biology and Medicine: Convention on Human Rights and Biomedicine (ETS No 164) (1997). Available from: https://rm.coe.int/168007cf98.

10. Kateryna V. Nykolyna. Reproductive Choice: International Ethical Standards and Prospects for Legal Regulation in Certain European Countries. Wiad Lek. 2020;73(9 p. II):2056-2061. doi: 10.36740/ WLek202009230

11. China (Peoples Republic of)'s Constitution of 1982. Available from: https://www.constituteproject.org/constitution/China_2018. pdf?lang=en

12. Du Yifang, The Evolution of China's Legislation on Reproduction, 18 San Diego Int'I L.J. 1 (2016). Available at: https://digital.sandiego.edu/ilj/ vol18/iss $1 / 2$

13. The People 's Republic of China on the Protection of Rights and Interests of Women on April 3, 1992. Availale from: http://www.china.org.cn/ english/government/207405.htm

14. China Population and Family Planning Law on December 29, 2001. Availble from: https://www.refworld.org/docid/42417cb54.html

15. Responses to Information Request - Immigration and Refugee Board of Canada. Available from: https://www.justice.gov/eoir/page/ file/1328956/download

16. China: 2016 Revised Provincial Family Planning Regulations (February 6, 2017). Available from: https://www.loc.gov/item/global-legalmonitor/2017-02-06/china-2016-revised-provincial-family-planningregulations/

17. China: Three-Child Police Becomes Law, Social Maintenance Fee Abolished. Available from: https://www.loc.gov/item/global-legalmonitor/2021-09-23/china-three-child-policy-becomes-law-socialmaintenance-fee-abolished/

18. Country Information and Guidance. China: Contravention of national population and family-planning laws (July, 2015). Available from: https://www.refworld.org/pdfid/55a395a14.pdf

19. Case of S.H. and others v. Austria (Application No. 57813/00) dated April 1, 2010. Available from: https://hudoc.echr.coe.int/ eng\#\%7B\%22itemid\%22:\%5B\%22001-98048\%22\%5D\%7D.

ORCID and contributionship:

Roman A. Maydanyk: 0000-0003-1661-0535 A, B, C, D, E.

Kateryna V. Moskalenko: 0000-0003-0152-9603 A, B, C, D, E, F 


\section{Conflict of interest:}

The Authors declare no conflict of interests.

\section{CORRESPONDING AUTHOR}

\section{Kateryna V. Moskalenko}

Educational and Scientific Law School

of Taras Schevchenko National University of Kyiv

Kyiv, Ukraine

tel: +380977175968

e-mail: kamoskalenko@gmail.com

Received: 11.06 .2021

Accepted: 15.10 .2021

A - Work concept and design, B - Data collection and analysis, C - Responsibility for statistical analysis,

D-Writing the article, $\mathbf{E}$-Critical review, $\mathbf{F}$ - Final approval of the article 


\title{
LEGAL BASIS FOR THE USE OF ASSISTED REPRODUCTIVE TECHNOLOGIES: A COMPARATIVE ANALYSIS OF THE LEGISLATION OF UKRAINE AND EUROPEAN STATES
}

DOI: 10.36740/WLek202111227

\author{
Viktoriia V. Nadon' ${ }^{1}$, Marija V. Mendzhul' ${ }^{2}$, Ilga I. Kotlyar $^{2}$ \\ 'YAROSLAV MUDRYI NATIONAL LAW UNIVERSITY, KHARKIV, UKRAINE \\ ¿UZHHOROD NATIONAL UNIVERSITY, UZHHOROD, UKRAINE
}

\begin{abstract}
The aim: Conduct a comparative legal analysis of the legislation of Ukraine and other countries on the use of assisted reproductive technologies (hereinafter - ART).

Materials and methods: The study used an interdisciplinary approach to the analysis of the problem of assisted reproductive technologies. This approach includes dialectical, comparative law, statistical and systemic methods. The study used scientific developments in the field of ART, international acts, legislation, statistics. Ukrainian legislation on surrogacy and other ARTs has been studied. The expediency of adopting a special law to regulate the use of ART in Ukraine is substantiated. According to the monitoring data, Denmark, Belgium, Iceland, Sweden, Slovenia, the Czech Republic, Estonia, and Serbia are the leaders in the use of ART among European countries.

Conclusions: The study allows us to conclude that the legislation of the studied European countries and Ukraine on the use of assisted reproductive technologies are quite different. European countries, except the United Kingdom, are very limited in allowing embryo research. It is noted that, first, not all countries allow surrogacy; second, a different maximum age is set for women to use ART; thirdly, the different shelf life of cryopreserved embryos has been established.

The issue of the possible maximum number of implanted embryos into the uterine cavity using ART requires clear legal regulation both in Ukraine and in the EU.
\end{abstract}

KEY WORDS: assisted reproductive technologies, surrogacy, legislation, Ukraine, EU countries

Wiad Lek. 2021;74(11 p.2):3021-3024

\section{INTRODUCTION}

Until now the use of reproductive technologies caused bewilderment among residents of both Ukraine and European countries. Now, various assisted reproductive technologies (hereinafter referred to as ART) are being used more and more often, and they have become available to ordinary citizens. According to WHO statistics, in each country, about $10 \%$ of couples suffer from infertility [1]. According to experts, over the past four decades, five million children were born using ART [2].

It is a well-established approach that assisted reproductive technologies involve medical procedures that are used to treat infertility. The most common ART is in vitro fertilization (also called "in vitro"), intrauterine insemination, surrogacy, and others. The possibility of using ART directly depends on the legislative regulation of both the right to use them and the procedure for performing them. That is why the issue of the quality of legislative regulation of ART use is extremely important.

\section{THE AIM}

Conduct a comparative legal analysis of the legislation of Ukraine and other states on the use of assisted reproductive technologies.

\section{MATERIALS AND METHODS}

The study used an interdisciplinary approach to the analysis of the problem of assisted reproductive technologies. This approach includes dialectical, comparative law, statistical and systemic methods. The study used scientific developments in the field of ART, international acts, legislation, statistics.

Approaches to the classification of surrogacy according to medical and legal criteria have been established. Countries have been identified that allow and restrict the use of surrogacy.

Ukrainian legislation on surrogacy and other ARTs has been studied. The expediency of adopting a special law to regulate the use of ART in Ukraine is substantiated.

It was noted that ART is often used in the European context (56\%). At the same time, there are significant differences in the legal regulation of ART between

EU countries, which has led to the spread of so-called "reproductive tourism" or

"cross-border reproductive care", when citizens of one EU country travel to another can use reproductive health services in different countries principles (better quality of services, low price, simplified procedures, etc.).

According to the monitoring data, Denmark, Belgium, Iceland, Sweden, Slovenia, the Czech Republic, Estonia, and Serbia are the leaders in the use of ART among European countries. 


\section{REVIEW AND DISCUSSION}

In Ukraine and European countries, there is a unified approach to ensuring the right to use ART, the only difference is which technologies the infertile couple has the right to use. If there are no restrictions on the use of intrauterine insemination, intracytoplasmic sperm injection, and in vitro fertilization, then there are different approaches to the use of surrogacy and its individual types in legal regulation. The issue of cryopreservation of gametes, zygotes, and embryos also raises discussions.

From the point of view of medicine, surrogacy is divided into full (or gestational), in which a human embryo conceived by spouses (or wife and donor, or donors) is transferred into the body of a surrogate mother, and "partial" (or gender), in which the surrogate mother's egg is used, and accordingly she has a genetic link with the child. From the standpoint of retribution in world practice, there are two models of surrogacy - free and commercial. In the legislation of most states, only free surrogacy is allowed (Australia, Belgium, Brazil, Great Britain, Vietnam, Denmark, Canada, the Netherlands, New Zealand, Portugal, Hungary, most of the US states, and others), which prohibits monetary reward and allows compensation of actual costs ... In addition, there are cases of recognition of commercial surrogacy as a crime (in Australia, Belgium, Hong Kong, etc.). In some states, there are no restrictions on the use of surrogacy on a commercial basis, in particular in Ukraine.

In the world, Ukraine, like India and Thailand, is recognized as a state where surrogacy is a business [3]. Ukrainian legislation does not regulate in detail the surrogacy procedure. The order of the Ministry of Health of Ukraine dated September 9, 2013 No. 787 "On approval of the Procedure for the use of assisted reproductive technologies in Ukraine" regulates the use of some ART. In the Family Code of Ukraine, only Article 123 establishes the rules for determining the origin of a child born as a result of the use of assisted reproductive technologies. And in particular, if an embryo conceived by spouses is transferred into the body of another woman, it is they who are recognized as the parents of the child. The relationship between the parents and the surrogate mother is regulated by a contract.

In 2018, a draft Law on Assisted Reproductive Technologies No. 8629 was submitted to the Verkhovna Rada of Ukraine. This draft proposed to clearly define the conditions for the use of all ART, including surrogacy. Unfortunately, this bill has not yet been adopted. In our opinion, it is advisable to adopt a special law in Ukraine to regulate the use of ART.

In the EU, despite the integration policy for more than a decade, there are significant differences between states in the legal regulation of ART. This has become the reason for the spread of the so-called "reproductive tourism" or "cross-border reproductive care", when citizens of one EU member state travel to another country to use reproductive health services for various reasons (better quality of services, low prices, simplified procedures, etc.). A significant part of European states establish the requirement of a stable marriage for the use of ART, and only about half allow single persons to use reproductive services.

When analyzing world practice, it was found that Europeans are quite active in using ART (56\%), while in Asia $-23 \%$ and in North America - 15\%. Within the EU, the legal regulation of ART was sufficiently influenced by the activities of the European Consortium for Monitoring IVF, the European Society for Human Reproduction, and Embryology. According to the monitoring data of these organizations, Denmark, Belgium, Iceland, Sweden, Slovenia, Czech Republic, Estonia, and Serbia are leading in the use of ART among European countries. Among the reasons is also the state financial support for the treatment of infertility [2].

Analysis of the legal regulation of ART in the EU revealed the features in such states:

- Austria (The law on reproductive medicine of June 4, 1992, allowed the use of ART only by spouses, over time the restriction was lifted. The law as amended in 2004 categorically prohibits the use of human embryos for any purposes other than assisted reproduction, that is, therapeutic and reproductive cloning prohibited) [4].

- Belgium (two special laws were adopted in 2003 and 2007, which regulate drug reproduction and research of embryos. In general, Belgian legislation is quite tolerant of the use of ART. Cryopreservation of unused embryos for 5 years is allowed, as well as their donation, destruction, and use for scientific purposes. Posthumous implantation of cryopreserved embryos is allowed, but no later than two years after the death of the father. Embryo implantation is allowed for women under the age of 47. Research on embryos is possible only for the purpose of treatment or prevention of diseases and during the first 14 days of development) [5].

- Bulgaria (the use of ART is regulated by the Law on Health Protection (2004) and the order of the Ministry of Health on activities to promote reproduction (2007) [6]. The use of ART is possible if a man or woman cannot perform a reproductive function for health reasons various ART related to fertilization.

- Great Britain (infertility treatment is regulated by special laws on the agreement on surrogacy (1985) [7], on fertilization and human embryology (1990) [8], and on human embryology (2008) [9]. The use of ART is impossible without a license issued by the Office of Human Fertilization and Embryology For research purposes, you can use: unborn embryos; embryos created explicitly for research; embryos created by nuclear transfer of somatic cells; "mixed embryos", including hybrids (created from human and animal gametes), "Cytoplasmic hybrids" (created by transferring nuclear somatic cells using human nuclei and animal oocytes), transgenic human embryos (created by introducing animal DNA into a human cell), or any other embryos containing both human and animal DNA, but in which DNA of pets does not prevail Commercial surrogacy is prohibited Since 2010 ART can be used enjoy single persons and same-sex couples) [10].

- Hungary (in Hungary, the procedures for the use of ART are regulated by the Law on Health [11]. Access to the use of 
ART is available to married couples, single women only in case of proven infertility. The maximum age of women for use of ART is 45 years. An anonymous donation of sperm, eggs, and embryos is allowed. Embryos can be stored in cryopreservation for up to 10 years, additional storage is allowed after confirmation of their state of preservation and a written statement. Hungarian legislation does not allow the use of sperm after the death of the donor).

- Greece (the first law to regulate ART was adopted in 2002. Women under 50 have the right to use ART after giving written consent. Surrogacy is allowed, provided that the place of residence of both women is in Greece. Fertilized eggs can be used for research transferred to another couple or destroyed. Research on embryos that are more than fourteen days old is prohibited) [12].

- Germany (in Germany, ART issues are regulated by the Embryo Protection Act (1990) [13], as well as the act that protects embryos in connection with the use of human embryonic stem cells (2008) [14]. More than 3 embryos are prohibited from women. embryos and their cloning is prohibited).

- Denmark (in 1997, the Law "On artificial insemination in connection with drug treatment, diagnostics and research" was adopted, significant changes to which were made in 2006, including access to ART for single persons and LGBT, extended shelf life cryopreserved embryos from 2 to 5 years) [10].

- Estonia (a special law on the regulation of ART was adopted back in 1997. Donation of sperm, eggs, and embryos is allowed and is anonymous. You cannot have more than 6 children from one sperm donor. It is prohibited to transfer more than 3 embryos. Cryopreservation of embryos is allowed up to 7 years) [15].

- Croatia (the law adopted in 2012 established a fairly liberal approach to the use of ART, in particular, single persons are allowed to use ART, as well as the donation of gametes and embryos, their cryopreservation for up to five years, but surrogacy and cloning are prohibited) [16].

- France (the use of ART is regulated by the Law on Bioethics (2011) and the Law on Donation and the Use of Elements and Products of the Human Body, Auxiliary Medical Care and Perinatal Diagnostics (1994). Scientific research of embryos is allowed up to 8 days of their development and only from written parental consent, which does not require further fertilization Research is allowed if it is: scientifically important; likely to achieve significant medical development, research cannot be carried out unless cells derived from embryos are used; the research project adheres to the ethical principles of embryonic and embryonic research stem cells. Married couples can use ART if their stable relationship lasts at least two years) [17].

- Czech Republic (in 2006, the Law on the Research of Human Embryonic Stem Cells and Related Activities and on Amendments to Certain Related Acts was adopted. This law prohibits interference that leads to the creation of a human embryo for purposes other than implantation into a woman's body there can be women between the ages of 18 and 35 and men between 18 and 40) [18]. Differences in the legal regulation of ART use are also observed in other European states.

\section{CONCLUSIONS}

Thus, the legislation of the studied European countries and Ukraine on the use of assisted reproductive technologies is quite different. European states, except the UK, are very limited in allowing research on embryos. Also, not all countries allow surrogacy, different maximum age limits for women for the use of ART is established, as well as the different shelf life of cryopreserved embryos.

The study also showed that among the unsolved problems in the use of ART is the placement of more than one zygote in a woman's uterus in order to increase the effectiveness of reproductive technology, which can lead to multiple pregnancies and be a threat to both the woman's health and fetuses. Not all states have limited the maximum number of embryos implanted in a woman's uterus. That is why, a clear legal regulation requires the issue of the maximum possible number of implanted embryos in the uterine cavity when using ART, both in Ukraine and in the EU countries.

\section{REFERENCES}

1. 5 causes of psychogenic infertility: the doctor's answer. 2018;July 3. Available from: https://24tv.ua/health/5_prichini_psihogennogo bezpliddya_vidpovid_likarya_n993103[reviewed 2021.08.20] (in Ukrainian).

2. Präg P., Mills M. Assisted Reproductive Technology in Europe: Usage and Regulation in the Context of Cross-Border Reproductive Care. Childlessness in Europe: Contexts, Causes, and Consequences. 2017: 289-309. Available from: https://link.springer.com/ chapter/10.1007/978-3-319-44667-7_14 [reviewed 2021.08.20].

3. Hougue C., Roux C. Surrogate Motherhoodand Human Rights. Analysis of Human, Legaland Ethical Issues. Available from: https:// www.nomaternitytraffic.eu/wp-content/uploads/2015/09/2015Contribution-HCCH-No-Maternity-Traffic-EN.pdf [reviewed 2021.08.20].

4. Fortpflanzungsmedizingesetz am 4 juni 1992. Available from: http:// www.ris.bka.gv.at/Dokumente/BgblPdf/19922750/19922750.pdf [reviewed 2021.08.20].

5. Loi relative alaprocr 'eation $m$ 'edicalement assist 'ee et ala destination des embryons surnum 'eraires et des gam 'etes. Available from: http:// www.ieb-eib.org/nl/pdf/l-20070706-pma.pdf [reviewed 2021.08.20].

6. The law for health. Available from: https://www.mh.government.bg/ media/filer_public/2020/10/05/zakon_za_zdraveto.pdf [reviewed 2021.08.18].

7. Surrogacy Arrangements Act, 1985. Available from: http://www. legislation.gov.uk/ukpga/1985/49 [reviewed 2021.08.17].

8. Human Fertilization and Embryology Act, 1990. Available from: http://www.legislation.gov.uk/ukpga/1990/37/contents[reviewed 2021.08.19].

9. Human Fertilization and Embryology Act, 2008. Available from: http://www.legislation.gov.uk/ukpga/2008/22/contents[reviewed 2021.08.18].

10. Busardò F., Gulino M., Napoletano S., Zaami S., Frati P. The Evolution of Legislation in the Field of Medically Assisted Reproduction and Embryo Stem Cell Research in European Union. Members BioMed Research International. 2014. Available from: http://downloads.hindawi.com/ journals/bmri/2014/307160.pdf [reviewed 2021.08.20]. 
11. 1997. évi CLIV. Törvény az egészségügyről. Available from: https://net. jogtar.hu/jogszabaly?docid=99700154.tv [reviewed 2021.08.20].

12. Law on Medically assisted reproduction techniques, 2005. Available from: http://www.nurs.uoa.gr/fileadmin/nurs.uoa.gr/uploads/ NomothesiaNosilefton/Nomoi/Nomos3305FEKA172005.pdf [reviewed 2021.08.20].

13. Gesetz zum Schutz von Embryonen, 1990. Available from: http:// www.gesetze-im-internet.de/eschg/BJNR027460990.html [reviewed 2021.08.20].

14. Gesetz zur Sicherstellung des Embryonenschutzes im Zusammenhang mit Einfuhr und Verwendung menschlicher embryonaler Stammzellen, 2008. Available from: http://bundesrecht.juris.de/stzg/index.html. [reviewed 2021.08.20].

15. Artificial Insemination and Embryo Protection Act, 1997. Available from: https://www.riigiteataja.ee/en/eli/530102013057/consolide20 [reviewed 2021.08.20].

16. Act on Medical Fertilization: http://hrcak.srce.hr/file/31910 [reviewed 2021.08.20].

17. LOI no. 2011-814 du 7 juillet 2011 relative alabio 'ethique. Available from: http://www.legifrance.gouv.fr/affichTexte. do? cidTexte $=$ JORFTE000024323102\&fastPos $=2 \&$ fastReqld $=$ $823265692 \&$ categorieLien $=$ cid\&oldAction=rechTexte [reviewed 2021.08.20].

18. Zákon o výzkumu na lidských embryonálních kmenových buňkách a souvisejících činnostech a 0 změně některých souvisejících zákonů, 75/2006, od 29.05.2006. Available from: https://www.zakonyprolidi. cz/cs/2006-227 [reviewed 2021.08.20].
ORCID and contributorship:

Viktoriia V. Nadon: 0000-0001-8240-7717 $7^{A, D, F}$

Marija V. Mendzhul: 0000-0002-3893-4402 $2^{B, D, E}$

Olga I. Kotlyar: 0000-0002-3485-4157

\section{Conflict of interest:}

The Authors declare no conflict of interest.

\section{CORRESPONDING AUTHOR \\ Viktoriia V. Nadon}

Yaroslav Mudryi National Law University

Kharkiv, Ukraine

Tel.: +380504015121

e-mail:nadonviktoria@gmail.com

Received: 31.06 .2021

Accepted: 15.10 .2021

A - Work concept and design, B - Data collection and analysis, C - Responsibility for statistical analysis,

D-Writing the article, $\mathbf{E}$ - Critical review, $\mathbf{F}$ - Final approval of the article 


\title{
ENSURING PHYSICAL AND MENTAL HEALTH OF ATHLETES BY THE LABOR LAW
}

DOI: 10.36740/WLek202111228

\author{
Olena V. Moskalenko ${ }^{1}$, Nataliia 0. Melnychuk' ${ }^{2}$, Denys 0. Novikov ${ }^{3}$ \\ 'FACULTY OF MANAGEMENT, ADMINISTRATION AND LAW, STATE BIOTECHNOLOGICAL UNIVERSITY, KHARKIV, UKRAINE \\ 2DEPARTMENT OF LABOR LAW AND SOCIAL SECURITY LAW, INSTITUTE OF LAW, TARAS SHEVCHENKO NATIONAL UNIVERSITY OF KYIV, UKRAINE \\ ${ }^{3}$ FACULTY OF LAW, DEPARTMENT OF CIVIL LAW DISCIPLINES AND LABOR LAW NAMED AFTER PROF. 0.I. PROTSEVSKIY, H.S. SKOVORODA KHARKIV \\ NATIONAL PEDAGOGICAL UNIVERSITY, KHARKIV, UKRAINE
}

\begin{abstract}
The aim: To identify the problems of exclusion of athletes from the sphere of labor law; characterize the main precarious practices in sports that are contrary to labor law, that lead to injury of athletes.

Materials and methods: The research materials cover the analysis of scientific literature, legal acts and jurisprudence; comparison; synthesis; generalization. Empirical methods related to the statistics processing of reports of international and regional organizations (ILO, EU Athletes, European Commission, FICA, FIFPro, United Nations) serve to combine and graphically display information in the field of sports.

Conclusions: Precarious practices in sports are widespread; cover all athletes (from elite to non-professional); constitute a threat to the health and working capacity of athletes. A direct relationship has been revealed between the regulation of the labor of athletes and their physical and mental health. Failure to protect labor rights increases the risks of disability for athletes. The international community and national states should reduce the inclusion of the so-called "sports exemption" and create legal mechanisms for transferring the labor of athletes to the scope of labor law.
\end{abstract}

KEY WORDS: athletes, health, precarious, labor law, medical law

Wiad Lek. 2021;74(11 p.2):3025-3030

\section{INTRODUCTION}

Since the mid-twentieth century, professional sports have become an area of employment for millions of people. In one recent market study, the value of the global sports market is estimated at 614 billion dollars [1]. In 2016, only 70 different international competitions were attended by 386,000 professional athletes and the dynamics of the number of competitions is increasing from year to year [2]. The load on athletes is increasing; the consequences of these loads are intensified and aggravated. On average, athletes receive 8.6 million injuries annually; about half of these injuries involve a doctor's intervention [3]. Most of all injuries occur in football, including injuries associated with physical and mental stress. In 2020, Manchester United player Marcus Rashford suffered a double stress fracture of his back due to excessive exertion. On June 12, 2021, during the Euro 2020 match against Finland, Denmark's player Christian Eriksen suffered a cardiac arrest. Scientists have repeatedly observed in recent years an increase in sudden deaths in athletes [4]. Besides, psychosocial factors and issues are present in athletic injuries and illnesses and their recovery. The load or stress that athletes experience during training can have psychosocial and physical components. In both cases, a load can result in positive adaptations and/or maladaptations [5]. These tendencies indicate unfavorable phenomena in the professional activity of athletes and require study from the point of view of improving their health by regulatory legal methods. To do this study, we have to research the problematic practices of legal regulation of the labor of athletes, which form risks for the violation of their physical and mental health.

\section{THE AIM}

We assume that the negative trends in the health status of athletes are a consequence of the excessive flexibility of the regulation of the labor of athletes, the weakness of the coverage of the professional activity of athletes by labor law. In this study, we will try to establish the relationship between the impact on the physical and mental health of athletes and their coverage of the protective instruments of labor law. So the article aims to identify the problems of exclusion of athletes from the sphere of labor law; characterize the main precarious practices in sports that are contrary to labor law, that lead to injury of athletes. 


\section{MATERIALS AND METHODS}

The research materials cover the reports of the main international and regional organizations (ILO, EU Athletes, European Commission, FICA, FIFPro, United Nations) on the health status of athletes and their working conditions. The study includes theoretical and empirical methods. Theoretical methods cover the analysis of scientific literature, legal acts, and jurisprudence; comparison; synthesis; generalization; legal forecasting. The comparative method was used to highlight the general and different characteristics of the working conditions of athletes in different countries. The method of synthesis and generalization was used to depict the fact that excessive loads and difficult working conditions negatively affect the health of athletes, regardless of the type of sport. The method of legal forecasting is used to identify possible legal ways to solve the problem of increasing injuries and diseases among athletes. Empirical methods related to the statistics processing of reports of international and regional organizations serve to combine and graphically display information in the field of sports.

\section{REVIEW AND DISCUSSION}

Such a developed industry as a sport should be subject to legal regulation, especially concerning the employment of persons engaged in professional sports.

The International Labor Organization defines a professional athlete as an athlete who receives income from competitive sports and whose activities are controlled by a sports organization, such as a club or federation. This definition includes a) athletes whose only professional activity is sports; and b) athletes who may have other jobs but spend considerable time in training and competitions from which they earn income (athletes in some Olympic disciplines) [6]. Many issues related to athletes, starting from contracts and ending with the rules of sports competitions, are governed by the rules of sports federations, which are often seen as organizations operating separately from labor law and other national laws under the concept of the so-called "sports exemption".

However, more and more often athletes challenge this exception and strive to resolve sports issues according to labor laws, whereas courts have to differentiate the question of purely sporting in nature and those that apply this branch of law. In the practice of the European Court of human rights (such cases as Walgrave, Dona, Bosman, Meca-Medina) existing cases of application of the European labor legislation in respect of sporting rules, in accordance with the principle that sport is also a labor activity in which the athletes are complete subjects. However, the practice of the European Court of human rights has been undergoing a systematic circumvention, which puts athletes in a vulnerable, dependent, unstable, and precarious position [7]. The danger of precarious employment began to spread to other sectors of society, namely sport. Short-term and informal contracts, relationships of loan labor, the risks of retirement with significantly reduced working capacity and no social security prospects, flexible working conditions without any guarantees, were first appeared in this area. Discrimination, violence, and limited protection are the constant companions of athletes. In this sense, the most important thing is that, due to the abuse of sports clubs and associations, athletes remain outside the scope of labor law - the branch of law, directed to the embodiment of the rights and interests of employees and e guaranteeing their implementation through the international norms and national labor law.

Among precarious practices which are most involved in sports, the most defining are informal and unstable contracts, violations of the right to work and restrictions on labor mobility, unfavorable working conditions, discrimination and violence, restrictions on the right to protection.

1. Informal and unstable contracts

Precarity in the field of sports is manifested in instability and sometimes informality, of employment. Sports have term or unstable contracts that are a source of risk for athletes [8]. In professional football, the average duration of an employment contract is 23 months, with a contractual age decreasing to a maximum of 1 year [9]. According to FIFPro, football players in Eastern Europe, Africa, and Latin America often faced problems because of their contract term, and 8 percent of players did not have a written contract with their club. In Ukraine, 22 percent of football players do not have a written employment contract, and 35 percent have a civil contract [9]. About 25 percent of professional football players at the age of 18 do not have formal written contracts [10]. In cricket, according to the Federation of International Associations, most male players feel uncertain about their contract term [11], while a quarter of female players do not even have contracts [12].

Unstable contracts provoke athletes' dual employment [13]. Especially in seasonal sports, many athletes work full-time or part-time along with their sports careers. In women's rugby, 60 percent of surveyed women who earn their wages for competing still feel the need to balance sports with other work to earn extra income [14]. The importance of stable contracts is also because the professional career of an athlete is mostly 12-15 years, without considering the risk of injury. According to the International Labor Organization, more than 50 percent of surveyed athletes by experts have experienced financial difficulties within five years of completing their careers, leading to some mental health problems [6]. Reducing this risk without improving the situation with a stable labor relationship with athletes can be pursued through higher education.

2. Violation of the right to work and labor mobility restrictions

One of the most common precarious practices in the field of professional sports is the so-called "transfer" of the athlete. For a club, the athlete in relation to other clubs is not an employee, but a certain asset that can sometimes be disposed of without the athlete's consent. In South 


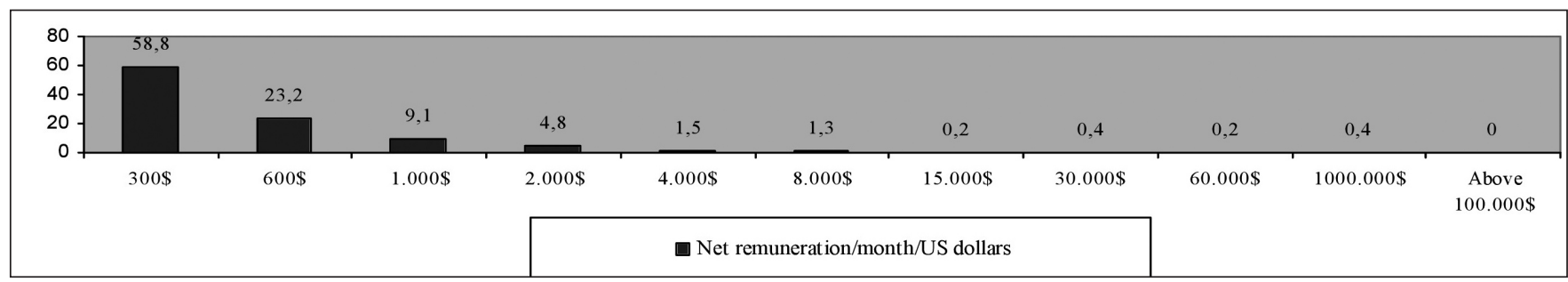

Fig. 1. Payment data for Ukrainian players (Data collection from FIFPro global employment report in collaboration with Working Conditions in Professional Football)

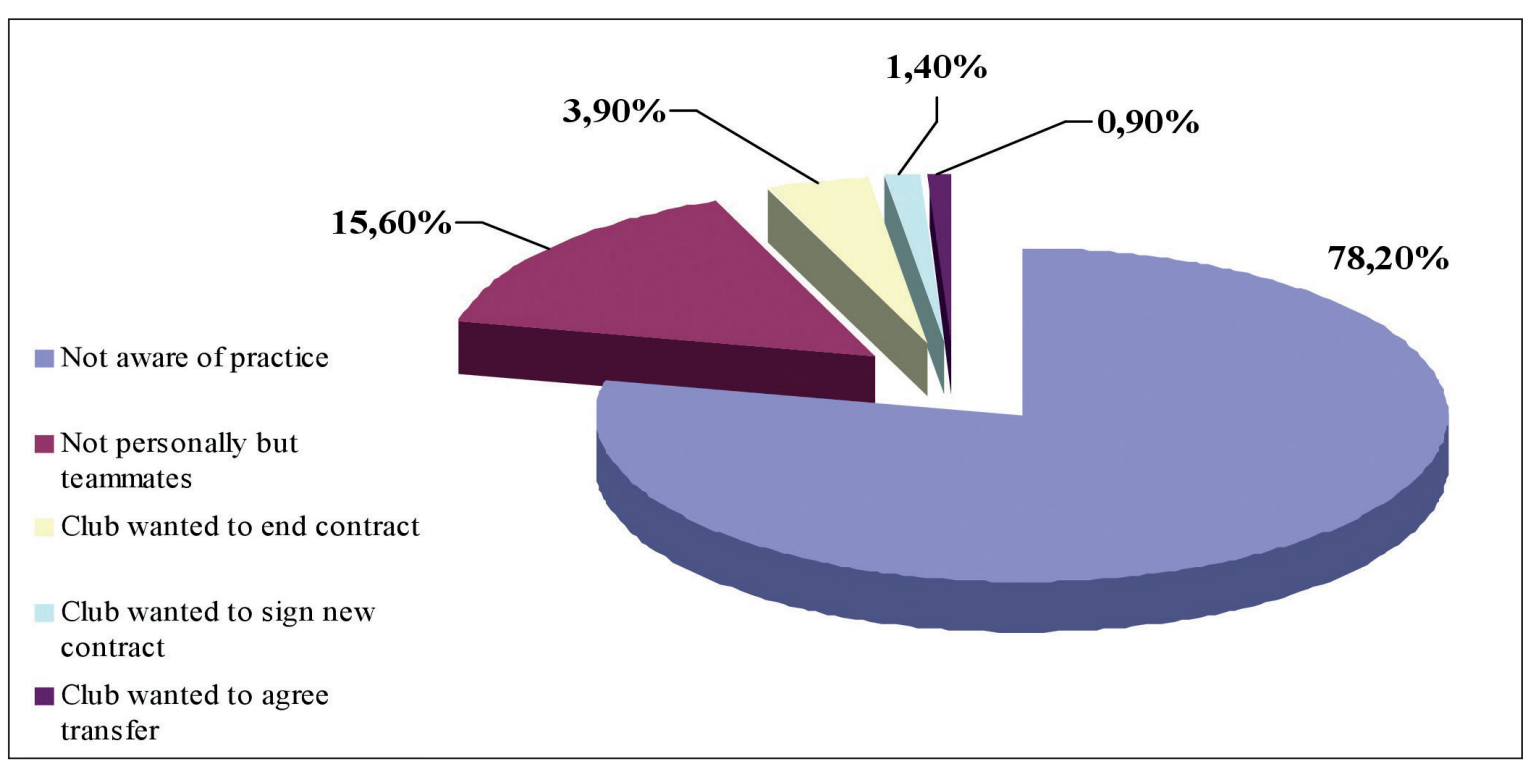

Fig. 2. Football players practices of isolated training (Data collection from FIFPro global employment report in collaboration with Working Conditions in Professional Football)

America, football players' contracts are bought and sold between clubs without the player's will [15]. A similar practice in the exchange of player contracts is available in the American Professional Basketball League (NBA). In Europe the situation of transfers is different. Legally, a player whose contract has expired with his current club may have contracts with other football clubs [16]. However, the transfer of contracted players must be agreed upon by the respective clubs and a transfer fee is set to compensate for the termination of the valid contract [17]. The transfer takes place by transferring the sports registration of a player from a holding club to a debtor club [18]. In European professional football, the player transferring system usually takes place during a "transfer window" or registration periods during which player registration can take place. Moreover, the arrangement of the place of new employment is primarily between the clubs, and the football player and his agent can influence the salary amount and various bonus payments. It is worth noting that, for transfers, football clubs spend around 3 billion dollars a year on player transfers [19].

Limited athletes have the right to terminate an employment contract on their own initiative. In most contracts, athletes who wish to terminate the contract early should, as a rule, find a breach of their contract [20]. Otherwise, for anticipatory termination of the contract, they have to pay the employer the amount marked in the contract.
After the termination of the contract, restrictions in certain sports continue to apply. In Europe, especially in football, transfer systems determine whether to pay a transfer fee between clubs to allow a player to contract with a new club. In the early 2000s, FIFA developed additional transfer rules to increase the labor mobility of football players. However, specific rules, such as the mid-season ban to terminate the contract, continue to restrict the right to work [20]. This is because the rules governing the employment of athletes (in particular, football players) are formulated by international sports governing bodies that do not respect the labor laws of national states or European Union regulations on the free movement of employees.

\section{Unfavorable working conditions}

The precarious state is caused by unfavorable working conditions, which include wages, working hours, and rest periods, which, due to their limitations or instability, do not allow them to maintain a decent standard of living.

Salary is a reward for the athletes' work, which should facilitate the reproduction of their strength and guarantee a fair distribution of profits from their performances in competitions. Instead, sports practice demonstrates the efforts of clubs and associations to manipulate athletes' earnings. In the United States, collective agreements can guarantee players a minimum wage or allow players to enter into contracts that mix a fixed amount of guaranteed 
pay with performance-related bonuses, such as in the $\mathrm{Na}$ tional Football League [20]. The FIFPro report indicates that 21 percent of interviewed football players by experts earn less than 300 dollars a month [9]. It should be noted that, first of all, in professional football, there is a violation of the principle of equal pay for equal labor. In Ukraine, 58 percent of football players receive 300 dollars a month, while 1.3 percent claims to earn between 4,000 dollars and 8,000 dollars a month [9] as described in Figure 1.

90 percent of African football players face a delay in wages. In cricket, 35 percent of male players are underpaid [8].

The working hours of athletes are mostly irregular. After all, in addition to the time spent on the competition, athletes must consider training time, travel time, and other obligations, such as promotional tours. Because of this, the working hours of athletes often exceed 40 hours per week, and, for example, 12 percent of football players do not receive even one day off [9]. Similarly, the minimum international standards for the duration of paid annual vacation have not been adhered to in the sports field. In women's rugby, many athletes devote their annual vacation to training [14]. In some sports, such as football, long seasons of competition reduce the annual vacation of players and jeopardize the required periods of training and health [21]. On average, only 30 percent of football players in America and 27.5 percent in Africa receive at least the minimum labor law vacation. In Ukraine, 14 percent of football players have an annual paid vacation of fewer than 24 days [9]. The increasing popularity of European football around the world has led to an increase in international tours of teams in Asia and the US, which are often used as a way to increase club profits. These tours tend to take place between game seasons, at a time previously set aside for annual player vacation [22].

4. Discrimination and violence

Sport has a precarious shade and because of the significant presence of discrimination and violence in it. First of all, women are discriminated against. In some countries, women may be prohibited from playing sports, while the overall lack of safe sports facilities around the world significantly impedes women's ability to play sports [23]. It should be noted that women achieved almost parity with male Olympians in representation at the Olympic Games: they accounted for 45 percent at the 2016 Summer Olympics and 41 percent at the 2018 Winter Olympics [24]. At the same time, many positions in the sports industry, such as coaches, assistant coaches, and heads of sports information services, are still under-represented [25]. When looking at all teams, both male and female, women have only 23 percent in coaching positions [26].

There is a significant gender pay gap in gender. This aspect is especially illustrative of the example when the US Women's Football Team, which won the World Cup in 2015, was paid a quarter of what was earned by men who had failed in a similar competition and the coach of the women's winning team was paid less than men's U-20 team [27]. In addition to the pay gap, female athletes have less access to quality treatment and injury recovery [6]. Discrimination in sport can also have a racial shade. There have been several high-profile racist incidents against African or Afro-Caribbean football players in recent years in European football [10]. In England and Wales, the Professional Footballers' Association has organized a 24/7 social media boycott through the \#Enough campaign to protest against racist abuse by social media fans. In football, it is common practice to discriminate against players who refuse to continue their contract with the club. For such players the so-called "isolation from the team" is used - exclusively one-off training and exclusion from participation in the matches of the team as shown in Figure 2. 22 percent of football players are under pressure to sign a new contract [9].

Women report a high level of sexual abuse in sport [13], but it is known that men report cases of such violence. A European Commission's report indicates that 2 to 8 percent of young athletes have been sexually abused [28]. There is a known case of a US Gymnastics team physician who has faced hundreds of allegations of sexual abuse by current or former gymnasts [10].

\section{Restrictions on the right to protection}

The application of law in sport is carried out through independent sports institutions. Most national sports governing bodies have their own rules-making and dispute settlement structures for internal regulation and enforcement. Some countries, such as Germany and New Zealand, have a specialized national sports tribunal that independently identifies specific sports disputes. There are international sports tribunals, such as the Football International Federation Association (FIFA) Dispute Resolution Chamber, the Court of Arbitration for Basketball, and the Court of Arbitration for Sport (CAS) based in Lausanne. Such a lack of access to a settlement of disputes on a general basis is an obstacle to protecting the athletes' rights. Many sports contracts contain "compulsory arbitration" clauses, which provide for the submission of complaints only to specific arbitration bodies [29].

The precarious practices in sports discussed in this article break international and national labor law and disregard European Court of Human Rights regulations. Transfer rules restrict the right to work; break the principle of "labor is not goods" as established in the Statute of the International Labor Organization; do not correspond to the conclusions of the European Court of Human Rights in Bosman, Meca-Medina cases. The practice of conclusion and termination contracts, working conditions, and the existence of discrimination and violence in sport are contrary to International Labor Organization's Convention № 29, 47, 87, 98, 100, 105, 111, 132, 182, as well as national labor law.

The use of sports arbitration bodies to resolve disputes deprives athletes guaranteed by the Universal Declaration of Human Rights and the Convention on the Protection of Human Rights and Fundamental Freedoms, the right to judicial protection, and nullifies the autonomy of the judiciary in the administration of justice. 


\section{CONCLUSIONS}

1. Precarious practices in sports are widespread; cover all athletes (from elite to non-professional); constitute a threat to the health and working capacity of athletes.

2. Precarious practices in sports contradict international and national labor laws nullify the activities of the judiciary, whose decisions are not accepted by sports clubs and associations. A direct relationship has been revealed between the regulation of the labor of athletes and their physical and mental health. Failure to protect labor rights increases the risks of disability for athletes.

3. Taking into account the complexity and intensity of training, the risk of injury, the need for a high level of physical and mental attention, the short term of a professional career, the labor of athletes to maintain their health and working capacity should be governed by labor law. The international community and national states should reduce the inclusion of the so-called "sports exemption" and createlegal mechanisms for transferring the labor of athletes to the scope of labor law.

\section{REFERENCES}

1. Business Wire. Sports: $\$ 614$ billion global market opportunities \& strategies to 2022. 2019. Available from: https://www.businesswire. com/news/home/20190514005472/en/Sports---614-Billion-GlobalMarket-Opportunities [reviewed 2021.06.23].

2. The Global Sports Impact Report. 2017. Available from: https://www. sportcal.com/PDF/GSI/Report/GSI_Report_2017_Sample_Pack_ v1.pdf [reviewed 2021.06.23].

3. Sheu Y, Chen L, Hedegaard H. Sports and Recreation-related Injury Episodes in the United States, 2011-2014. National Health Statistics Reports. 2016; 99. Available from: https://www.cdc.gov/nchs/data/ nhsr/nhsr099.pdf [reviewed 2021.06.23].

4. Wasfy M, Hutter A, Weiner R. Sudden Cardiac Death in Athletes. Methodist Debakey Cardiovasc Journal. 2016; 12 (2): 76-80.

5. Load, Overload, and Recovery in the Athlete: Select Issues for the Team Physician - A Consensus Statement, Current. Sports Medicine Reports. 2019; 18 (4): 141-148.

6. Decent work in the world of sport. Issues paper for discussion at the Global Dialogue Forum on Decent Work in the World of Sport (Geneva, 20-22 January 2020). IL0. 2020. 32.

7. Standing G. The Precariat: The New Dangerous Class. Bloomsbury Academic. 2011. 209.

8. An analysis of the working conditions of professional sports players. 2017. Available from: ttps://www.euathletes.org/wp-content/ uploads/2017/06/2013-UNI-An-Analysis-of-Working-Conditions-ofProfessional-Sports-Plyers-ilovepdf-compressed-1.pdf[reviewed 2021.06.23].

9. FIFPro global employment report: Working conditions in professional football. 2016. 268.

10. Report of the Special Rapporteur on the sale and sexual exploitation of children, including child prostitution, child pornography and other child sexual abuse material. United Nation. 2019.

11. FICA men's professional cricket global employment report. 2017. Available from: http://www.thefica.com/wp-content/uploads/2018/04/FICAMens-Employment-Report-2017-dp.pdf [reviewed 2021.06.23].

12. FICA women's global employment market report and survey. 2018. Available from: http://www.thefica.com/wp-content/ uploads/2018/10/FICA-Womens-Global-Employment-Report-Survey2018-final.pdf [reviewed 2021.06.23].
13. EU Guidelines on Dual Careers of Athletes: Recommended policy actions in support of dual careers in high-performance sport. European Commission. 2012. 40.

14. International Rugby Players: Women's survey:Who's playing the game? Available from: https://www.rugbyplayers.org/womens-survey-whosplaying-the-game/ [reviewed 2021.06.23].

15. Lawrence I. The Legal Context of a Player Transfer in Professional Football: A Case Study of David Beckham. 2013. Available from: https:// www.entsportslawjournal.com/articles/10.16997/eslj.16/ [reviewed 2021.06.23].

16. Binder J, Findlay M. The Effects of the Bosman Ruling on National and Club Teams in Europe. Journal of Sports Economics. 2011; 13 (2): 17-29.

17. Chetwynd J. Labor and Employment Law Issues in Sports: Play Ball? An Analysis of Final-Offer Arbitration, its Use in Major League Baseball and its Potential Applicability to European Soccer Wage and Transfer Disputes. Marquette Sports Law Review. 2009; 20: 109.

18. Feess $E$, Muehlheusser $G$. The Impact of Transfer Fees on Professional Sports: An Analysis of the New Transfer System for European Soccer. Scandinavian Journal Of Economics. 2003; 105 (1): 139-154.

19. Odogwu I. Player Contracts: Football transfers v European Union law: analysis. World Sports Law Report. 2014; 12 (2). Available from: https://gclaw.wordpress.com/2014/05/13/player-contractsfootball-transfers-v-european-union-law-analysis/ [reviewed 2021.06.23].

20. Barry M. Research Handbook of Employment Relations in Sport. Edward Elgar Publishing. 2016. 424.

21. FIFPro: At the limit: Player workload in elite professional men's football. Available from: ttps://synafoc.divisionafrica.org/en/health/limitplayer-workload-elite-mens-football-470 [reviewed 2021.06.23].

22. Revealed: The heavy price Premier League clubs pay for lucrative pre-season globetrotting. The Telegraph, 1 Aug. 2016. Available from: https://www.telegraph.co.uk/football/2016/08/01/premierleague-clubs-pay-heavy-price-for-lucrative-pre-season-gl/ [reviewed 2021.06.23].

23. European Institute for Gender Equality. Gender in sport. 2017. 28.

24. Nunes R.A. Women athletes in the Olympic Games. Journal of Human Sport and Exercise. 2019; 14 (3): 674-683.

25. Lapchick, R. The 2017 Racial and Gender Report Card: College Sport. University of Central Florida. 2018. 89.

26. Acosta V, Carpenter L. Women in Intercollegiate Sport. 2014. Available from: http://www.acostacarpenter.org/2014\%20Status $\% 20$ of $\% 20$ Women $\% 20$ in $\% 20$ Intercollegiate $\% 20$ Sport $\% 20-37 \% 20$ Year $\% 20$ Update\%20-\%201977-2014\%20.pdf [reviewed 2021.06.23].

27. Alvarez A. I thought the main issue in women's sports was equal pay. I was wrong. 2019. Available from: https://www.theguardian.com/ sport/2019/may/09/i-thought-the-main-issue-in-womens-sportswas-equal-pay-i-was-wrong [reviewed 2021.06.23].

28. Expert Group on Good Governance: Recommendations on the protection of young athletes and safeguarding children's rights in sport: Final document. European Commission. 2016. 25.

29. Geisinger E. Trabaldo-de Mestral E. Sports Arbitration: A Coach for Other Players? Huntington. 2015. 372.

ORCID and contributionship:

Olena V. Moskalenko: 0000-0002-0807-0519 ${ }^{\text {B }}$,

Nataliia O. Melnychuk: 0000-0003-3692-7601 E,F

Denys O. Novikov: 0000-0003-2727-5357 A,D 


\section{Conflict of interest}

The Authors declare no conflict of interest.

\section{CORRESPONDING AUTHOR}

\section{Denys 0 . Novikov}

Faculty of Law, Department of civil law disciplines

and labor law named after prof. 0.I. Protsevskiy,

H.S. Skovoroda Kharkiv national pedagogical university

Kharkiv, Ukraine

tel: +380978200517

e-mail:d.novikov@hnpu.edu.ua

Received: 07.06 .2021

Accepted: 14.10 .2021

A - Work concept and design, B - Data collection and analysis, C - Responsibility for statistical analysis,

D-Writing the article, $\mathbf{E}$ - Critical review, F- Final approval of the article 


\title{
CONSIDERATION OF STATE OF HUMAN HEALTH DURING APPLYING RESTRICTIVE MEASURES
}

DOI: 10.36740/WLek202111229

\author{
Oksana P. Kuchynska', Yulia V. Tsyganyuk², Serhiy 0. Shulgin ${ }^{3}$ \\ 'TARAS SHEVCHENKO NATIONAL UNIVERSITY OF KYIV, KYIV, UKRAINE \\ ¿LEONID YUZKOV KHMELNYTSKYI UNIVERSITY OF MANAGEMENT AND LAW, KHMELNYTSKY, UKRAINE \\ 3PROSECUTOR GENERAL'S OFFICE, KYIV, UKRAINE
}

\begin{abstract}
The aim: To establish optimal ways of solving a scientific problem of how a human health may affect his / her election, change or revocation of a restraint measure, and establish the state of affairs and scientific approaches of considering human health during applying precautionary measures.

Materials and methods: This study was conducted in 2021. It was used 2 judgments of the European Court of Human Rights (ECHR), 5 materials of analytical studies conducted by international organizations, as well as 2 normative legal documents as an empirical basis.

General methods (induction, synthesis, system method), as well as special scientific methods (special -legal method, comparative- legal) are used.

Conclusions: Health should be taken into account during choosing a restraint measure in at least one of the following cases: the state of human health provides for application of a precautionary measure of this kind, at the election of which he/she will be able to exercise the constitutionally guaranteed right to health care; the state of human health at the chosen precautionary measure has worsened and the person needs mitigation of conditions of precautionary measure for the purpose of effective treatment; the person fell ill during detention, and the conditions of medical care in places of detention cannot promptly ensure his/her proper treatment; it is necessary to prevent the infection of other persons, usually those who are in custody.
\end{abstract}

KEY WORDS: health, right to health care, precautionary measures, detention

\section{INTRODUCTION}

The absolute right of a person to life and health provided by international norms and constitutions of the countries finds its realization in various legal relations. One of such legal relations is criminal-procedural relations concerning election, change or cancellation of a precautionary measure. It is in this relationship that the absolute right of a person to life and health is combined with the positive obligations of the state to create a safe environment free from crime. This combination raises many problematic issues in the implementation of such legal relations, where on the one hand there is the human health, and on the other - the safety of citizens and the need to isolate the suspect / accused during the pre-trial investigation and criminal proceedings.

\section{THE AIM}

To establish optimal ways of solving a scientific problem of how a human health may affect his / her election, change or revocation of a restraint measure, and establish the state of affairs and scientific approaches of considering human health during applying precautionary measures.

\section{MATERIALS AND METHODS}

This research was conducted in 2021. It was used 2 judgments of the European Court of Human Rights (ECHR), in particular Case Salman v. Turkey. Application \# 21986/93 and Case of Kudła v. Poland. Application no. 30210/96, 5 materials of analytical research conducted by international organizations such as Open Society Foundations and WHO, as well as 2 legal documents (Constitution of the World Health Organization, The Constitution of Ukraine) and 13 publications of scientific and practical nature, which were used in study regarding state of human health during applying precautionary measures against him/her. In particular, there were the works of Nazarko Y.V., Spycher J., Dusheiko M., Beaupère P., Tomasini-Joshi D., Jürgens R., Csete J. and other scientists.

General methods (induction, synthesis, system method), as well as special scientific methods (special-legal method, comparative- legal) are used.

The method of induction was used to form logical general conclusions based on the analysis of all research materials, and using of synthesis method and system allowed to draw conclusions about medical and legal criteria for choosing to change and cancel precautionary measures and cases 
where health can be taken into account. The special-legal method was used in the research of both ECHR decisions and analytical research materials, normative documents and publications of scientific and applied nature in order to state the obviousness of the researched problem of taking into account a human health and its presentation in law. And the comparative legal method of studying the case law of the European Court of Human Rights allowed to single out the criteria on the basis of which the Court considers it correct to take into account the state of human health during applying precautionary measures.

\section{REVIEW}

The preamble to the Statute (Constitution) of the World Health Organization states that health is a state of complete physical, mental and social well-being and not merely the absence of disease or infirmity [1].

Nazarko Yu.V. has determined that the right to health is a natural inalienable and inviolable human right, enshrined in national and international levels, which includes all possible means for development, preservation, provision and, in case of violation, the restoration of a harmonious level of physical, mental and emotional state of her body [2, p. 199]. Having studied the constitutions of the EU, the author emphasized the main important elements of the right to health care. The Constitution of Hungary includes physical and mental health, access to healthy food and drinking water, environmental protection, regular physical education, and health education; in the Constitution of Portugal, it is the financial provision of health care, provision of quality medical services and the production of medicines and medical devices; in the Spanish Constitution, it is public health; in the Constitution of France - is protection of environment [2, p. 201].

It is stipulates in part 3 of Art. 27 of the Constitution of Ukraine that everyone has the right to protect their lives and health, life and health of others from unlawful encroachments [3]. Parts 1-3 of Art. 49 of the Constitution of Ukraine stipulate that everyone has the right to health care, medical assistance and medical insurance. Health care is provided by the state financing of the corresponding social and economic, medical and sanitary and improving and preventive programs. The state creates conditions for effective and accessible medical care for all citizens. In state and municipal health care facilities, medical care is provided free of charge; the existing network of such establishments cannot be reduced. The state promotes the development of medical institutions of all forms of ownership [3]. And according to international human rights treaties, medical services and benefits must be accessible, available, acceptable and of appropriate quality to all without discrimination [4]

At the same time, the right to health care and access to medical services guaranteed by states and international treaties often cannot be exercised when precautionary measures are applied to a suspect / accused. The system of precautionary measures in different countries of the world differs, but common to all countries is that the strictest precautionary measure is detention. When choosing one of the types of precautionary measures, the court must consider the various circumstances of criminal proceedings, while the state of human health of the in respect of whom the precautionary measure is chosen must also be taken into account. It should be noted that the chosen precautionary measure may also affect the health of a suspect / accused. It is these 2 aspects that provide an understanding of the concept of "considering the state of human health during choosing a preventive measure".

Regarding the aspect of how the precautionary measure chosen can affect a human health, it is clear that this relationship can be most clearly identified by examining the restraint measure. Studies of international organizations have shown that pretrial detention is one of the worst things that can happen to a person: the detainee immediately loses his freedom, and can also lose his family, health, home, job, and community ties $[5, \mathrm{c} .11]$. The excessive use of pretrial detention leads to overcrowded, unhygienic, chaotic, and violent environments where pretrial detainees - who have not been convicted - are at risk of contracting disease. Pretrial holding facilities, which include police lock-ups not designed for large numbers or extended stays, often force detainees to live in filthy, teeming conditions without access to fresh air, minimal sanitation facilities, health services, or adequate food. In the worst cases, detainees die from these conditions and associated disease, and surviving detainees sleep with the corpses. Some pretrial detention centers are so bad that innocent people plead guilty just to be transferred to prisons where the conditions might be better. For many pretrial detainees, being locked away in detention centers where tuberculosis, hepatitis $\mathrm{C}$, and HIV are easily contracted can be a death sentence $[6, c .11]$.

Even in highly developed democracies, the state of health of a person in custody, given the conditions of such detention and the impact on human state of health, is a matter of concern. For example, in the United States jails are not healthy environments People who are incarcerated pretrial are often exposed to poorly maintained and constructed jails, which are toxic to people's health. Overcrowding results in more rampant and more rapid spread of infectious diseases due to concentrated exposure. Harmful conditions include extreme temperatures, toxic water, and food prepared without regard for safety and hygiene standards. The experience of confinement can also impact mental health. The particular instability of pretrial incarceration, with high turnover of both the staff and incarcerated population, limited access to health care, and the shock of transition from freedom to incarceration could result in a heightened level of stress and trauma [7, c. iii].

Access to healthcare is another important element of detention conditions [8, c. 33], but new prisoners, pretrial detainees or repeat offenders utilize more all types of care $[9$, c. 1].

Tomasini-Joshi Denise, Jürgens Ralf, Csete Joanne determined that pre-trial detainees are a particularly vulnerable group when it comes to health conditions and the provision of health services. The authors conclude that: 
- Places of pre-trial detention are often ill-equipped to provide health services.

- People in pre-trial detention often spend time in worse conditions than people who have already been convicted.

- According to international legal standards, health interventions should be available at the earliest possible stage in the criminal justice system.

- Particular attention should be devoted to ensuring continuity of treatment at all stages of the criminal justice process.

- Under international legalstandards, pre-trial detention is to be used as an exceptional cautionary measure and wide use is to be made of alternatives to detention.

- Pre-trial release (release pending completion of the criminal justice process) can be an effective health intervention by allowing people to be supervised in the community where health services are more readily available. It is also an effective way to reduce prison overcrowding [10, c 36].

It is surprising how little information exists on the consequences and impact of pretrial detention. The available literature tends to focus on how pretrial detention affects the detainees themselves. This is understandable, as detainees are most directly affected by unfair and irrational pretrial detention regimes, especially if - as is all too often the case - the conditions under which they are detained are deplorable and inhumane.

Largely ignored in policy debates about the use and application of pretrial detention is its deleterious effect on detainees' families, wider society, state governance, and the effective administration of justice - all of which are explored more fully below. The consequence of pretrial detention on individual detainees can often have a domino effect on their families and communities. For example, a detainee who is infected with a communicable disease while in pretrial detention may, upon his release, pose a health risk not only to his immediate family but also to the broader community with which he interacts. To illustrate this link we first look at the consequence of pretrial detention on individual detainees and thereafter explore its impact on detainees' families, society, and the state [11, c. 17].

Prisoners typically come from the poorest sectors of society and consequently already suffer from health inequalities. Incarceration commonly aggravates existing health problems. Overcrowding, poor nutrition, lack of exercise, limited access to health care, violence, risky sexual practices, high rates of intravenous drug use, sharing razor blades, and tattooing make prisons a perfect habitat for the spread of infectious diseases [12, c. 3].

That is why researches, scientists'papers and some normative documents also point out that, given the state of detention system and the health of a suspect / accused, it is necessary to choose alternative precautionary measures that do not involve restriction of liberty. Greater effort must be placed on ensuring that pretrial detention is used as an exceptional measure, in accordance with International law. Reducing the number of people and the time spent in pretrial detention has the potential to significantly reduce the risk of torture and other ill-treatment and help ease the global problem of overcrowding in facilities where pretrial detainees are held [13, p. 12]. The choice of alternative precautionary measures became especially relevant with the COVID-19 epidemic [14, p. 1, 18; 15, c. 1-2; 16, c. 1]

The United Nations Office on Drugs and Crime \& Partners Comprehensive Package lists a series of specific interventions that are critical to tackling HIV (human immunodeficiency virus), TB (tuberculosis), and HCV (hepatitis $\mathrm{C}$ virus) in prisons. Among such measures is the reduction of use of pre-trial detention [17, p. 14].

The case law of the European Court of Human Rights contains examples where the Court has considered the question of considering the state of human health during choosing a restraint measure in criminal proceedings. At the same time, as noted by Massias Florence, the European Convention does not contain any specific guarantees regarding the situation of persons deprived of their liberty, sick a fortiori $[18$, p. 23]. The author notes that the European authorities must adapt these guarantees to the specific situation of detainees. For example, detainees can use Articles 6, 8, 10 and 1 [18, p. 23].

In one case (Gengoux contre Belgique), according to Blondel Marion, on May 9, 2011, a doctor noted the deterioration of the detainee's "catastrophic" condition and considered it "medically unacceptable for this patient to remain a prisoner". The patient is then immediately transferred to the hospital, where he died a week later. However, judging by the fact that it is impossible to establish a causal link between imprisonment and death, the Court considers that there is no violation of Article 2 (right to life) or Article 3 (prohibition of inhuman treatment) of the Convention [19, p. 1]. Analyzing the decision of the Court in this case, the author correctly notes that in this case, this limited interpretation deprives a prisoner with advanced cancer of increased protection, which would allow him not to avoid death, but to end his days in a special medical institution $[19$, p. 6].

Salman v. Turkey (application no. 21986/93) found that detainees were in a vulnerable situation and that the authorities had a duty to protect them (\$99).

But Massias Florence notes that the court has changed its practice and according to it the Court recognizes the right of detainees under Article 3 to health and welfare, while these rights remain only derived from the right to dignity, they do not borrow its absolute nature [18, p. 28]. So in the case of Kudła v. Poland court noted that nevertheless, under this provision the State must ensure that a person is detained in conditions which are compatible with respect for his/her human dignity, that the manner and method of execution of the measure do not subject him to distress or hardship of an intensity exceeding the unavoidable level of suffering inherent in detention and that, given the practical demands of imprisonment, his health and well-being are adequately secured by, among other things, providing him with the requisite medical assistance (see, mutatis mutandis, the Aerts v. Belgium judgment of 30 July 1998, Reports 1998-V, p. 1966, $\$ \$ 64$ et seq.) [21]. 
Analyzing these decisions, it can be concluded that the Court takes into account 2 criteria: both the state of human health and conditions that precautionary measure can provide in terms of respect for the rights of a person to health. However, adverse effects resulting from the conditions of precautionary measures and caused to a human health will be a violation of the rights provided for in the Convention only if they are causally related to the human illness or deterioration.

In the context of the research, the conclusion of Oleksandra H. Yanovska, Oksana P. Kuchynska, Alona V. Chuhaievska is correct, that in order to protect the interests of persons serving sentences and suffering from serious illness, and therefore requiring release from serving a sentence, state mechanisms should provide flexibility in the approach to assessing the state of health of each person; authorities assessing the convict's state of health must be independent, and the prisoner must be able to choose doctors not only for treatment but also for the assessment of his / her state of health [22, p. 2782-2783]. Although the authors have conducted research on convicts, their provisions also deserve attention with regard to detainees.

\section{DISCUSSION}

Taking into account the state of human health during applying precautionary measures against him/her is a complex theoretical and practical problem that requires research, as well as regulatory regulation at the national legislation level. Theoretical and practical problems of taking into account the state of health of a person applying precautionary measures against him/her are not often studied in the works of legal scholars. In the vast majority, including the works the authors analyzed $[9,10,11,14,18$, 19], the focus is on providing health care when applying preventive in the system of specialized institutions.

At the same time, the number of precautionary measures chosen in criminal proceedings and the case law of the ECHR indicate that the issue considering the state of human health during applying precautionary measures (election, change and cancellation) has its own significance and concerns a combination of human health categories and procedural aspects of the pointed measures application.

\section{CONCLUSIONS}

The state of human health during applying precautionary measures should be taken into account when choosing, changing or revoking a precautionary measure. It is necessary to pay attention to the medical and legal criteria for its election. The medical criterion of taking into account the state of health when applying a precautionary measure should be understood as the state of human health (illness, its course, its severity, etc.), which can be affected by the choice of precautionary measure and the conditions of this precautionary measure (its type, additional responsibilities, etc.). The legal criterion for taking into account the state of human health during applying precautionary measures is the provisions of the European
Court of Human Rights on the need to consider the state of health and the possibility of differentiation of precautionary measures depending on medical criteria.

Health should be taken into account when choosing a restraint measure in at least one of the following cases:

- the state of human health provides for application of a precautionary measure of this kind, at the election of which he / she will be able to exercise the constitutionally guaranteed right to health care;

- the state of human health at the chosen precautionary measure has worsened and the person needs mitigation of conditions of a precautionary measure for the purpose of effective treatment;

- the person fell ill during detention, and conditions of medical care in places of detention cannot promptly ensure his proper treatment;

- it is necessary to prevent the infection of other persons, usually those who are in custody.

These cases must be medically confirmed by a conclusion on the state of health of the person that makes it impossible to apply the precautionary measure, or there is a need to change or cancel it.

\section{REFERENCES}

1. Statut (Konstytutsiia) Vsesvitnoi orhanizatsii okhorony zdorovia [Constitution of the World Health Organization] vid 22.07.1946 roku. Available from: https://zakon.rada.gov.ua/laws/show/995_599\#Text [reviewed 2021.06.25] (in Ukrainian).

2. Nazarko YV. Konstytutsiine pravo na okhoronu zdorov'ia v Ukraini ta derzhavakh Yevropeiskoho Soiuzu: porivnialno-pravove doslidzhennia [The constitutional right to health care in Ukraine and the countries of the European Union: a comparative legal research]. Dysertatsiia na zdobuttia naukovoho stupenia doktora filosofii za napriamom 081-Pravo. Natsionalna akademiia vnutrishnikh sprav. 2019. 249 s. (in Ukrainian).

3. Konstytutsiia Ukrainy [The Constitution of Ukraine] vid 28.06.1996 № 254k/96-VR Available from: https://zakon.rada.gov.ua/laws/ show/254\%D0\%BA/96-\%D0\%B2\%D1\%80\#text [reviewed 2021.06.25] (in Ukrainian).

4. Health Available from: https://www.coe.int/uk/web/compass/health [reviewed 2021.06.25].

5. The Socioeconomic Impact of Pretrial Detention. Open Society Foundations; 2011,70 p.

6. Pretrial Detention and Health: Unintended Consequences, Deadly Results. Literature Review and Recommendations for Health Professionals. Open Society Foundations; 2011, 88 p. Available from: https://www.justiceinitiative.org/uploads/5e9f14f1-249f-4427-84d8ac6b30228a45/ptd-health-20111103.pdf [reviewed 2021.06.26].

7. Liberating Our Health: Ending the Harms of Pretrial Incarceration and Money Bail. Humanlmpact.org/HealthNotBail. February 2020, 44 p. Available from:https://humanimpact.org/wp-content/ uploads/2020/02/HIP_HealthNotBailNationalReport_2020.02_ reduced.pdf [reviewed 2021.06.26].

8. Criminal detention conditions in the European Union: rules and reality. Luxembourg: Publications Office of the European Union; 2019, $64 \mathrm{p}$.

9. Spycher J, Dusheiko $M$, Beaupère $P$ et al. Healthcare in a pure gatekeeping system: utilization of primary, mental and emergency care in the prison population over time. Health and Justice. 2021; 9(11):1-16 doi:10.1186/s40352-021-00136-8 
10. Tomasini-Joshi $D$, Jürgens $R$, Csete J. Health in pre-trial detention. In Enggist S, Møller L, Galea G et al. Prisons and Health. Edited by: World Health Organization; 2014. p. 36-41. Available from: https://www.euro. who.int/_data/assets/pdf_file/0003/249195/Prisons-and-Health,-6Health-in-pre-trial-detention.pdf [reviewed 2021.06.26].

11. Schönteich M. The Scale and Consequences of Pretrial Detention around the World p. 11-43 (Schönteich M. The scale and consequences of pretrial detention around the world. Justice Initiatives, 2008, spring:11 (https://www.justiceinitiative.org/uploads/2f65cc09-c4da-4a48-9929c8bff4110f53/Justice_Initiati.pdf).

12. Status Paper on Prisons, Drugs and Harm Reduction (WHO: Europe, EUR/05/5049062, May 2005), 3.

13. Pretrial Detention and Torture: Why Pretrial Detainees Face the Greatest Risk. Open Society Foundations; 2011, 60 p.

14. Carroll JE., Pretrial Detention in the Time of COVID-19, (2020). P. 1-18 Available at: https://scholarship.law.ua.edu/fac_working_papers/396 [reviewed 2021.06.27].

15. Memorandum for all heads of department components and all United States attorneys. April 6, 2020. Available at: https://www.justice.gov/ file/1266901/download [reviewed 2021.06.27]

16. Directive \# 05 -21 «Motions to Reopen Pretrial Detention Hearings - In the Matter of the Request to Release Certain Pretrial Detainees (_ N.J. (2021))» To: Assignment Judges Criminal Presiding Judges. February 12, 2021 Available at: https://www.njcourts.gov/notices/2021/ n210212a.pdf [reviewed 2021.06.27].

17. Technical Brief: Addressing HIV and TB in Prisons, Pre-Trial Detention and Other Closed Settings. Geneva, Switzerland; June 2020: 1-25. Available at: https://www.theglobalfund.org/media/9829/ core_prisonspretrialdetentionotherclosedsettings_technicalbrief_ en.pdf?u=637319005292270000 https://www.njcourts.gov/ notices/2021/n210212a.pdf [reviewed 2021.06.27].

18. Florence M. La protection de la santé et de la dignité du détenu par la jurisprudence de la Cour européenne des droits de I'homme. Cahiers de la recherche sur les droits fondamentaux [En ligne], 3/2004, mis en ligne le 18 décembre 2020, consulté le 16 février 2021:23-28 Available at: http://journals.openedition.org/crdf/7456 D0I : 10.4000/crdf.7456 [reviewed 2021.06.27] (in France).

19. Blondel M. La personne atteinte d'un cancer et qui décède en détention n'est pas vulnérable: 1-6. Available at: https://revue-jade.eu/article/ view/1859/pdf [reviewed 2021.06.27] (in France).
20. Delo Salman (Salman) protiv Turcii [Case Salman v. Turkey]. Zhaloba \# 21986/93, Reshenie ot 27 ijunja $2000 \mathrm{~g}$. Available at: https://hand-help. ru/documents/echr_Salman_vs_Turkey.doc [reviewed 2021.06.28] (in Russian).

21. Case of Kudła v. Poland. Application no. 30210/96, judgment 260ctober 2000 Available at: https:/www.globalhealthrights.org/wp-content/ uploads/2013/10/Kudla-Poland-2000.pdf [reviewed 2021.06.28].

22. Oleksandra H. Yanovska, Oksana P. Kuchynska, Alona V. Chuhaievska. Realization of the right to healthcare of convicted with serious illness. Wiad. Lek, 2020;12:2780-2784. doi: 10.36740/WLek202012213

\section{ORCID and contributionship:}

Oksana P. Kuchynska: 0000-0003-3464-4798 A, B,D

Yuliya V. Tsyganyuk: 0000-0002-8495-3583 A, B

Serhiy O. Shulgin: 0000-0001-6379-7393 ${ }^{A, B}$

\section{Conflic of interest.}

The Authors declare no conflict of interest.

\section{CORRESPONDING AUTHOR Oksana P. Kuchynska}

Taras Shevchenko National University of Kyiv

Kyiv, Ukraine

tel.: +380442393245

e-mail:2000_oksana@ukr.net

Received: 02.07.2021

Accepted: 11.10 .2021

A - Work concept and design, B - Data collection and analysis, C - Responsibility for statistical analysis, D-Writing the article, $\mathbf{E}$-Critical review, $\mathbf{F}$ - Final approval of the article 


\title{
INTERNATIONAL- LEGAL REGULATION OF TRANSPLANTATION IN THE SYSTEM OF PREVENTION OF ILLEGAL TRADE IN ORGANS, TISSUES AND CELLS
}

DOI: $10.36740 /$ WLek202111230

\author{
Andriy M. Orlean', Inna V. Berdnik', Mykhailo S. Puzyrov \\ 'PROSECUTOR'S TRAINING CENTER OF UKRAINE, KIEV, UKRAINE \\ ${ }^{2}$ CHERNIHIV POLYTECHNIC NATIONAL UNIVERSITY, CHERNIHIV, UKRAINE \\ ${ }^{3}$ ACADEMY OF THE STATE PENITENTIARY SERVICE, CHERNIHIV, UKRAINE
}

\begin{abstract}
The aim: To investigate the features of international - legal regulation of organ, tissue, and cell transplantation in the system of prevention of illegal trade and on the basis of analysis of international acts to formulate proposals for implementation of its norms to the modern national legislation of European countries.

Materials and methods: The study used international instruments in the field of human rights protection in organ, tissue, and cell transplantation using a set of philosophical approaches, general scientific and special legal research methods.

Conclusions: Based on the analysis of international acts in the field of organ, tissue, and cell transplantation, we can conclude that it is necessary to adopt an international legal act on transplantation and incorporate its provisions into national legislation. It will provide a legal basis for domestic policy, implementation of administrative measures in order to create an effective system for combating illicit trafficking in organs, tissues, and cells, and ensuring human rights and freedoms in the field of transplantation.
\end{abstract}

KEY WORDS: organ and tissue transplantation, human biological exploitation, human trafficking, implementation, biotechnology

Wiad Lek. 2021;74(11 p.2):3036-3041

\section{INTRODUCTION}

The rapid development of scientific-technological progress in the field of biology and medicine contributes to the emergence of new areas of life where people can be exploited. The emergence of opportunities for artificial insemination, surrogacy, transplantation of organs and (or) tissues, conducting experiments on humans, and acquisition of value expression of such opportunities contributes primarily to the commission of mercenary offenses related to human biological exploitation. Modern society must purposefully and effectively respond to threats to the use of biotechnological advances for illegal purposes by imposing regulatory restrictions and taking preventive measures. A special role in this area is devoted to criminal law, the basic function of which is, in particular, general prevention - the formation of criminal law-restrictions of the law on criminal liability. In addition, since December 2019 , the rapid spread of the new acute respiratory syndrome CoronaVirus-2 (SARS-CoV-2), which causes severe acute respiratory disease (COVID-19), has defined health crisis in many countries. In 2020, the United States, Spain, and Italy reported the most cases of infected patients, and COVID-19 was classified as a global pandemic [1]. Current EU criminal law contains rules on criminal liability for illegal transplantation of organs, tissues, and cells, as well as trafficking in human beings for the purpose of biological exploitation. At the same time, deep and diverse research of these issues in order to unify and implement them in modern European legislation has not been conducted.

\section{THE AIM}

To investigate the features of international - legal regulation of organ, tissue, and cell transplantation in the system of prevention of illegal trade and on the basis of analysis of international acts to formulate proposals for implementation of its norms to the modern national legislation of European countries.

\section{MATERIALS AND METHODS}

The research used international human rights instruments in the field of organ, tissue, and cell transplantation, including documents of the United Nations (UN), the World Health Organization (WHO), the World Medical Association (WMA), the decision of the Court of Justice of the European Union (EU), national legislation of foreign countries, scientific publications of leading experts in the field of medical law, Ukrainian legislation in the field of organ, tissue and cell transplantation. Judgments and legislation were accessed on the official websites of the EU Court, the Verkhovna Rada of Ukraine, the Supreme 
Court, and the Ministry of Health of Ukraine. In the research course, the analysis and comparison of Ukraine's and EU's medical legislation provisions were carried out. In addition, scientific publications of leading experts in medical law, current international and national legislation were used in the research.

The research methodology is based on an organic combination of philosophical approaches, general scientific and special legal research methods. In particular, the systematic method was used to analyze WHO documents on the basic principles of human rights in the field of organ and (or) tissue transplantation. The structural-functional method allowed studying the structure of modern international legislation on transplantation. The comparative-legal method was used to compare the legislation of the EU countries on the access of patients to transplantation medical programs with domestic medical legislation. The method of legal modeling allowed studying the legal phenomena in the field of transplantation to formulate proposals for improving existing legislation.

The research also used the practical experience of investigative bodies of the National Police of Ukraine (which conduct a pre-trial investigation of criminal offenses under Art. 143 "Violation of the statutory procedure for transplantation of human anatomical materials", Art. 149 "Trafficking in human beings" of the Criminal Code of Ukraine) prosecutors who perform the functions of procedural managers in criminal proceedings were initiated under these articles of the Criminal Code of Ukraine. This made it possible to confirm the hypotheses and formulate author's proposals.

\section{REVIEW AND DISCUSSION}

Recently, international agencies, including the United Nations, the Council of Europe, the WHO, and the EU, have announced measures on curbing the fight against organ trafficking, stressing the lack of official statistics on organ trafficking. The international community's meeting ended with the adoption of the Istanbul Declaration on Organ Trafficking and Transplant Tourism, which established the principles governing the government's professional conduct and policies. A joint study with the Council of Europe identified one of the signs of human exploitation (the purpose of human trafficking) - the removal of organs, tissues, and cells.

The main factors that contribute to the spread of illegal transplantation worldwide and hinder the global actions of mankind against these criminal offenses can be divided into two aspects.

The first includes complex global problems - rapid population growth in the poorest countries, which entails primarily the problem of food security; deterioration of human living conditions due to uncontrolled destruction of the environment; military conflicts caused by geopolitical disputes ("suppliers" of anatomical materials are looking for donors in areas of armed conflict, because in such "hot spots" human lives are not recorded); global and regional tensions due to the uneven development of different nations, countries, and regions. These processes result in the impoverishment of the population, inability to solve social problems through the legal labor market. According to the UN, up to $20 \%$ of the treasury of the Islamic State of Iraq and the Levant are replenished at the expense of human trafficking. It is estimated that only in 2014, terrorists earned between $\$ 35$ million and \$ 45 million in the kidnapping - and these are just a few people who were ransomed from a criminal organization. As for other hostages, they are sent to hard work, women are used as a currency, which the militants pay each other, and also given as donors to "black transplantologists" [2].

The second aspect concerns the normative component and is related, in particular, to the absence of universally accepted legal regulation on the delimitation of legal and illegal human organ transplantation, internationally agreed definition of "trafficking in organs, tissues and cells" and the lack of reliable official data on illicit organ trafficking; differences in the regulation of transplantation in the world and in countries where human rights are hardly respected (according to the international human rights organizations, most crimes related to the oppression of people are committed in India, China, Pakistan, Bangladesh, and Uzbekistan). These factors assist members of organized transnational criminal groups in committing crimes related in particular to trafficking in human beings, biological exploitation of human beings, and illegal transplantation of organs, tissues, and cells.

Successful organ trafficking requires the involvement of health professionals and sophisticated cooperation between licensed professionals and licensed institutions. Achieving the final result also requires coordination and technical support, involving heads of transplant departments, hospitals and medical staff, technicians of blood and tissue laboratories, dual surgical teams, nephrologists, and postoperative nurses. Surgeons are key figures, but most national legislation (except for Switzerland) imposes severe penalties on healthcare professionals without distinguishing between medical staff and other actors. Only in the Czech Republic, Iceland, Ireland, Panama, and China is a medical practice prohibited for health professionals involved in trafficking in human beings and their organs.

Crimes committed by medical personnel are rarely publicized as investigation results. In particular, the impunity of surgeons who have illegally removed and transplanted organs is determined by the importance of their status in many countries, and the detection of these crimes depends on the notification of physicians about the commission of relevant criminally illegal actions by their colleagues.

Some countries reimburse the cost of organ transplants for human trafficking to patients with health insurance. Public and private insurance companies facilitate transplantation abroad and ensure that it is performed regardless of the organ's source. The case of Israeli insurance companies reimbursing transplants received abroad, regardless of their origin, was well described, and the prohibition on the practice came into force in 2008 . This prohibition 
and other measures introduced at the same time reduced transplantation abroad of Israelis. In the United States, some health insurance programs encourage policyholders to travel to foreign countries for organ transplantation. It should be noted that the majority of medical and law enforcement officers involved in our research were positive about this practice.

Issues of ensuring respect for human rights in the field of organ and (or) tissue transplantation remain the subject of meticulous attention of international institutions. Thus, the WHO adopted resolutions on organ and tissue transplantation, in particular Resolutions WHA40.13, WHA42.5, WHA44.25, WHA57.18, WHA63.22. The most important of these is Resolution WHA63.22, which established the "Guidelines for Human Cells, Tissue and Organ Transplantation" (approved in May 2010) [3]. These principles govern the removal of organs for transplantation from both deceased and living donors, ensuring compliance with key international standards, such as:

- the need for consent or absence of objections from the donor, avoidance of conflict of interest of persons; availability of developed donation program in case of donation of deceased donor' organs;

- genetic, legal, or emotional connection of donors with organ recipients; their awareness of probable risks, donation's benefits and consequences in a complete and clear form; voluntary consent; absence of any excessive influence or coercion;

- providing professional care for donors;

- strict control over donor selection and organ allocation criteria based on clinical performance and ethics rather than financial considerations;

- prohibition on purchase or offer to purchase organs for transplantation or to sell them to living persons;

- prohibition on advertising of organs' availability for sale purpose;

- establishment of prohibitions for health care facilities and professionals involved in procurement and transplantation of cells, tissues, or organs to receive any payments in excess of a reasonable fee for services rendered;

- transparency and openness of donor and transplantation activities, its openness for verification; personal anonymity, and confidentiality of donors and recipients in case of donation of living donors.

According to medical staff, investigators of the National Police of Ukraine, and prosecutors who participated in the research, the widespread introduction of these international standards in Ukraine will help protect human rights in both health care and criminal proceedings.

The procedure for organ and tissue transplantation is regulated by official WMA documents, namely: WMA Statement on Trade in Living Organs (1985) [4], which condemned the purchase and sale of human organs for transplantation, and governments of all countries are obliged to take measures to prevent this phenomenon; WMA Declaration on Organ Transplantation (1987) [5], which states that no physician can assume responsibility for organ transplantation until all the rights of donors and recipients have been respected; The Edinburgh Statement on Human Organ Donation and Transplantation (2000) [6], which defines the ethical and legal responsibilities of transplant physicians, as well as certain aspects of organ procurement from a donor.

Transplantation issues are also regulated by separate statements by political leaders in the international arena, in particular, the Prague Declaration of Health Ministers of 11 European countries of April 2, 2004, provided for the introduction of the European Transplant Network.

Important in political terms is the Istanbul Declaration on Organ Trade and Transplant Tourism, adopted by the participants of the International Summit on Transplant Tourism and Organ Trade on May 2, 2008 [7]. This document defines the concepts of "organ trafficking", "transplant tourism", as well as sets out the basic principles and proposals for preventing the commercialization of organ and tissue donation. Similar statements by the Amsterdam (2004) [8] and Vancouver (2006) [9] transplant forums have also received considerable attention in the professional community.

The above documents are of a recommendatory nature, i.e. they are not sources of law. However, this does not preclude their use in the establishment of international human rights standards in the field of transplantation, as well as in decision-making by the courts. For example, in deciding the case of Nevmerzhitsky v. Ukraine (2005) The European Court of Human Rights based its findings on WMA documents.

Regional conventions governing relations in the field of organ and tissue transplantation include, first of all, the Convention for the Protection of Human Rights and Human Dignity in Respect of the Application of Biological and Medical Advances, concluded in the Spanish city of Oviedo on 4 April 1997. (the so-called Oviedo Convention) [10], which is considered the first mandatory normative document on bio-law. It sets out the rules for: removal of organs and tissues from a living donor for transplantation solely for the treating purpose of a recipient and in the absence of suitable cadaveric organs or tissues; the impossibility of conducting alternative treatment with comparable effectiveness, with the specific and expressed in writing or the relevant official instance of donor consent.

The Oviedo Convention also reveals the conditions for the removal of regenerative tissues from persons who are unable to consent to their removal and prohibits commercial activities related to transplantation. The Convention has been signed by 35 countries and 29 Oviedo Conventions have been ratified.

In addition to this Convention, an Additional Protocol to the Convention on Human Rights and Biomedicine on Transplantation of Human Organs and Tissues of January 24, 2002 (signed by Ukraine on June 26, 2006) [11] was developed, which defines the basic transplantation principles. At the same time, the disadvantage of this Protocol is the absence of rules on reproductive and embryonic organs and tissues, as well as blood and its components, which limits its provisions' scope. 
Several points of the Protocol should be highlighted, which, in our opinion, are of primary importance both for the provision of human rights and for the development of transplantation. The protocol stipulates that the removal of organs and tissues from a living person can be done only for medical purposes if it is impossible to obtain the relevant organ or tissues of a deceased person and there are no alternative treatments of similar effectiveness if available free, informed and certain understanding in writing. However, such removal cannot be performed on the donor if there is a serious risk to his/her life or health. For family donors, the condition for withdrawal of the Protocol is the compliance of the procedure for removal of the body with the domestic legislation of the states-parties of the Protocol; for unrelated transplants, in addition to the compliance of the procedure with the legislation requirements, an additional permit from the relevant independent body is required.

Under EU law, there is currently no directive on organ and tissue transplantation, although the European Parliament and the Council have the possibility of adopting such an act based on Article 152 of the Treaty establishing the European Community. Tissue transplantation from one person to another is regulated only in the framework of blood donation and its components (Directives 2002/98 / EC, 2004/33 / EC, 2005/61 / EC, 2005/62 / EC), as well as donation of individual tissues and cells (Directives 2004/23 / EC, 2006/17 / EC and 2006/86 / EC) [12].

In 2007, the European Commission, in its Communication to the European Parliament on Organ Donation and Transplantation: Policy Actions at EU Level, noted the high importance of transplantation as a treatment and outlined the main issues in this area, including transplant risks, organ failure and illegal trade in them.

According to the Commission, transplant risks are due not only to the spread of infectious diseases but also to the lack of uniform quality standards in the field of organ donation in the EU member states.

At the same time, citizens receiving medical care by transplantation outside the country of their permanent residence is becoming increasingly common in the EU. The reason for the organs' shortage is difficult to explain, given the complexity of this phenomenon, cultural, historical, social differences of EU member states, as well as different approaches to organizing their health care systems (for example, the level of cadaver donation in different EU member states varies from 0.8 to 35.1 per 1 million inhabitants) [13].

Illegal organ trafficking is caused by a lack of organs and tissues. According to the Commission, the main areas of Community action should be to improve the quality and safety, increase the number of available organs, improve the efficiency and accessibility of the transplant system as a whole, strengthen cooperation between the EU Member States, develop a legal instrument on EU quality and safety; organ transplantation.

The opt-out system for organ removal after death is a situation when at the time of a person's death there is no information about his/her disagreement with the removal of organs expressed in any possible way during his/her life. For example, according to Art. L1232 of the Health Code of the French Republic, organ removal may be carried out if the deceased has not in any way expressed his/her refusal to do so during their lifetime and is included in the relevant national register. In that case, if the physician is not directly aware of the deceased's will, he/she should try to figure out from the deceased's relatives, whether the latter expressed the above disagreement. Similar rules apply, in particular, in Austria, Belgium, Israel, Spain, Cyprus, and Costa Rica, Norway, Slovakia, Croatia, Sweden, and a number of other countries. Norms that provide for the coordination of medical manipulation with the family or other community are adopted by states within the so-called "principle of family autonomy" [14].

In Ukraine, according to the Law of Ukraine "On the use of transplantation of anatomical materials to humans" (17.05.2018), there is an opt-in system with the removal of organs and (or) tissues of a person after his/her death, which treats the unexpressed by the person or the absence of relevant documents that record a will, as the presence of a positive will to carry out such a seizure - although no one after death can not be subjected to this procedure if it is known about the negative attitude towards the recipient, his close relatives, legal representatives. Along with Ukraine, the opt-in system applies in a number of other countries (Great Britain, Romania, Korea, New Zealand, Japan, Australia, Canada, etc.).

In some states, there is a mixed system. Thus, in Singapore, with the current general opt-out system, a system of mandatory informed consent (opt-in system) is established for persons who profess Islam [15].

There are many ways to express informed consent (or disagreement), but the most common of them is the appropriate mark on the driver's license, registration certificate, and other documents. Registers of non-donors are maintained in Poland, Portugal, and France. Speaking of consent regulation to the organ or tissue's removal, it should be noted that virtually all national legal systems require the voluntary informed consent of a living donor to the procedure. However, there are exceptions: in the United States, the Kentucky Court of Appeal in Strunk v. Strunk [16] (1969) allowed the forced transplantation of a kidney from a mentally ill sibling at the request of the mother of both, arguing that the loss of a brother would do much more harm to the mentally ill than the loss of a kidney.

International tendencies in post-mortem donation development put the national legislator in front of the need to address another extremely important issue - establishment of objective criteria for human death, i.e., in fact, legislative consolidation through legal instruments a clear boundary between life and death.

A comparative analysis of regulations, as well as special medical and legal literature relating to the actual criteria of death, showed that there are currently two main approaches to determining human death: cardiopulmonary and neurological.

The cardiopulmonary (cardiopulmonary) criterion of death assumes that a person whose activity of cardiovas- 
cular and respiratory systems has irreversibly stopped is considered dead. This is the criterion of Christian Barnard, who performed the world's first heart transplant on December 3, 1967.

Somewhat later, in 1968, Harvard Medical School proposed a neurological criterion that defined human death as the complete and irreversible death of the brain, including its subcortical structures. Due to a number of objective reasons, the neurological criterion is currently the most widespread in the legislation of about $80 \%$ of EU member states, which have enshrined this criterion in national law. For example, the order of the Ministry of Health and Prevention of Denmark of December 6, 2006, №149 defines the procedure for the application of diagnostic procedures to determine the death of a person on the basis of brain death. It is also interesting to note that in Denmark, an order of the Ministry of Health and Prevention of March 27, 2007, № 320 prohibits doctors from stating brain death (as well as performing autopsies and issuing death certificates) from their relatives.

The criterion of brain death is implemented not only by European countries. The assessment of human death on the basis of brain death was established by the decision of the Federal Medical Council of Brazil of August 8, 1997, № 1,480/97 in pursuance of the Federal Law of May 2, 1997, № 9,434. In all states of the United States except New Jersey and New York (USA), human death is considered to be irreversible brain death. In Ukraine, the above criterion is also applied (Procedure for ascertainment and diagnostic criteria for human brain death, approved by the order of the Ministry of Health of Ukraine dated 09.11.2020 № 2559). The identification of human death with the irreversible death of the brain has opened up new benefits for transplantation, associated with the ability to remove organs and tissues undamaged by ischemia, as opposed to those removed from the human body after the diagnosis of cardiopulmonary death.

It should be noted that there are also cases when both criteria are used simultaneously to determine death. Following Art. 2 and 15 of the Law of the Bolivarian Republic of Venezuela "On transplantation of organs and anatomical materials in humans" obtaining donor organs is possible from a person whose death is established on the basis of traditional criteria of clinical death (cardiac and respiratory arrest, lack of response to external stimuli) or complete cessation of electrical brain activity for 30 minutes (in people whose vital functions are maintained artificially) [17]. It should be noted that the Law also specifically stipulates conditions that should not be equated with death: it is reversible toxic, metabolic changes and caused hypothermia.

In the states of New Jersey and New York (USA), human death is considered to be irreversible brain death and lack of activity of the respiratory and cardiovascular systems at the same time. A separate problem for the legal regulation of transplantation, as well as for biomedical ethics is the use of so-called anencephalic donors, i.e. newborns with completely or partially absent brains. On the one hand, these newborns are almost $100 \%$ doomed to imminent death; however, on the other hand, they can actively show signs of life. It is noted, however, that the problem of anenceph- alic donors occurs only in countries where post-mortem donation is legally permitted (eg. Italy).

\section{CONCLUSIONS}

Thus, the analysis of the regulation of certain issues of organ and tissue transplantation at the international level, as well as in the comparative legal aspect, allows the authors to come to the following conclusions:

- the general principles of international legal regulation of relations in the field of transplantation are far from systematic and ignore the issue of preventing illegal trade in organs, tissues, and cells;

- the formation of the legal landscape in the above area is associated with the need to address several issues related to the subject of both legal and biomedical sciences. Differences in ethical and philosophical approaches to certain aspects of transplantation, such as, for example, determining the death time, complicate the development of systematic international act to regulate the issue of transplantation;

- the need to develop such a legal act and its adoption at the level of state leaders is due to the growing trends of illegal trade in organs, as a semi-legalized transnational criminal business;

- adoption of the international legal act on transplantation and incorporation of its provisions into national legislation will provide a legal basis for the formation of domestic public policy, implementation of administrative-legal measures to create an effective system to combat trafficking in organs, tissues, and cells, and human rights and ensuring human rights and freedoms in the field of transplantation.

\section{REFERENCES}

1. Spoletini $G$, Bianco $G$, Graceffa $D$ et al. Transplantation during the COVID-19 pandemic: nothing noble is accomplished without danger. Spoletini et al. BMC Gastroenterology. 2020; 259:1-6. doi: 10.1186/ s12876-020-01401-0.

2. Petrov Y. Lezt ne v svoe telo: kak ustroen myrovoi trafyk «chernoi» transplantolohyy [Climbing into the wrong body: how the global traffic of "black" transplantation works]. Yzvestyia. 2019. 11 marta. doi: iz.ru/854493 (in Russian).

3. WHO guding principles on human cell, tissue and organ transplantation. Adopted by the sixty-third World Health Assembly, May 2010, Resolution WHA63.22. Available from: https://www.who.int/transplantation/ Guiding_PrinciplesTransplantation_WHA63.22en.pdf.

4. World Medical Association, Statement on Live Organ Trade. Adopted by the 37th World Medical Assembly Brussels, Belgium, October 1985. http://hrlibrary.umn.edu/instree/organtrade.html.

5. World Medical Association. Declaration on Human Organ Transplantation. WMA, Madrid, Spain, October 1987. Available from: https://www1. umn.edu/humanrts/instree/ organtransplantation.htm.

6. World Medical Association Statement on Human Organ Donation and Transplantation / Adopted by the 52nd WMA General Assembly in Edinburgh, Scotland during 0ctober 2000 and Revised by the WMA General Assembly, Pilanesberg, South Africa, October 2006. Available from: https://www.wma.net/policies-post/wma-statement-onhuman-organ-donation-and-transplantation/. 
7. The Declaration of Istanbul on Organ Trafficking and Transplant Tourism. Participants in the International Summit on Transplant Tourism and Organ Trafficking convened by The Transplantation Society and International Society of Nephrology in Istanbul, Turkey, 30 April to 2 May 2008. Nephrol Dial Transplant. 2008;23: 3375-3380. doi: 10.1093/ ndt/gfn553.

8. The Ethics Committee of the Transplantation Society: The Consensus Statement of the Amsterdam Forum on the Care of the Live Kidney Donor. Transplantation. 2004;78: 491-492. doi: 10.1097/01. tp.0000136654.85459.1e.

9. The Ethics Committee of the Transplantation Society: Pruett TL et al. The Ethics Statement of the Vancouver Forum on the Live Lung, Liver, Pancreas, and Intestine Donor. Transplantation. 2006;81:1386-1387. doi: 10.1097/01.tp.0000214976.36526.e3.

10. Convention on Human Rights and Biomedicine (Oviedo Convention). Oviedo, Spain, April 1997. Available from: https://www.coe.int/ru/ web/bioethics/oviedo-convention.

11. Additional Protocol to the Convention on Human Rights and Biomedicine concerning Transplantation of Organs and Tissues of Human Origin, Strasbourg, 24.01.2002. https://rm.coe.int/168008156212. Consolidated version of the Treaty establishing the European Community. Official Journal of the European Communities. 24.12.2002, p. 33-184.

12. Communication from the Commission to the European Parliament and the Counci I- Organ donation and transplantation: Policy actions at EU level, Brussels/COM(2007) 275, May 2007. https://ec.europa.eu/health/ ph_threats/human_substance/documents/organs_com_en.pdf.

13. Salagai 0. Some socio-cultural aspects of health law [Some sociocultural aspects of health law]. State and law. 2009. 8:54 - 61 (in Russian).

14. Pashkov V, Golovanova I, Noha P. Principle of serviceability and gratuitousness in transplantation? Wiadomości Lekarskie. 2016, 3 (cz. II):565-568.

15. Manzano A., Monaghan M., Potrata B et al. The Invisible Issue of Organ Laundering. Transplantation. 2014;98(6):600-603. doi: 10.1097/ TP.0000000000000333.
16. Yousaf F, Purkayastha B. Social world of organ transplantation, trafficking, and policies. Public Health Policy. 2016;37(2):190-199. doi: 10.1057/jphp.2016.2.

17. YousafF.Forced migration, human trafficking, and human security. Current Sociology/ 2018, 66(2):209-225. doi: 10.1177/0011392117736309.

The theme of the scientific research, within which the work was performed, is "Problems of state formation in Ukraine and the world, formation of the national legal system" (state registration № 0116U00364).

\section{ORCID and contributionship:}

Andriy M. Orlean: 0000-0002-7439-5311 $1^{A, D, E, F}$

Inna V. Berdnik: 0000-0003-2672-2864 ${ }^{A, B, C, D, E, F}$

Mykhailo S. Puzyrov: 0000-0002-7814-9476

\section{Conflict of interest:}

The Authors declare no conflict of interest.

\section{CORRESPONDING AUTHOR}

\section{Inna V. Berdnik}

Chernihiv Polytechnic National University, Chernihiv, Ukraine

Chernihiv, Ukraine

tel: +380932912211

e-mail: inna_berdnik1983@ukr.net

Received: 18.06 .2021

Accepted: 15.10 .2021

A - Work concept and design, B - Data collection and analysis, C - Responsibility for statistical analysis, D - Writing the article, $\mathbf{E}$ - Critical review, $\mathbf{F}$ - Final approval of the article 


\title{
LEGAL AND PRACTICAL PROBLEMS OF USE OF ARTIFICIAL INTELLIGENCE-BASED ROBOTS IN FORENSIC PSYCHIATRY
}

DOI: 10.36740/WLek202111231

\author{
Inga Kudeikina' ${ }^{1}$, Marina Loseviča' ${ }^{\text {, Nataliya 0. Gutorova }}{ }^{2}$ \\ 'RIGA STRADINŠ́' UNIVERSITY, RIGA, LATVIA \\ ${ }^{2}$ ACADEMICIAN STASHIS SCIENTIFIC RESEARCH INSTITUTE FOR THE STUDY OF CRIME PROBLEMS NATIONAL ACADEMY OF LAW SCIENCES OF UKRAINE, \\ KHARKIV, UKRAINE
}

\begin{abstract}
The aim: This research aims to analyze the possibilities of using artificial intelligence-based robotics in forensic psychiatry to assess the public hazard of a mentally disabled or suffering from a mental illness to improve the legal framework governing the use of compulsory medical measures.

Materials and methods: This study is based on the Republic of Latvia and Ukraine's regulatory acts and the juridical practice of the Republic of Latvia. Dialectical, comparative, analytic, synthetic, system analyses, and sociological research methods were used.

Conclusions: Different automated systems, including artificial intelligence-based robotics, can and should be used in forensic psychiatry. The last one would effectively improve the process of achieving goals in forensic psychiatry and help prevent subjective errors. At the same time, the application of artificial intelligence-based robotics in forensic psychiatry requires uniform medical and legal criteria to prevent violation of human rights.
\end{abstract}

KEY WORDS: artificial intelligence, compulsory medical measures, danger to the public, assessment of danger to the public, psychiatry, robotics

Wiad Lek. 2021;74(11 p.2):3042-3047

\section{INTRODUCTION}

One of the cutting-edge innovations of the modern world is robotic technologies based on artificial intelligence. Technological progress makes it possible to create fundamentally new medical equipment. Importantly, artificial intelligence technologies are mainly used in technological solutions for medical equipment, such as laboratory and radiological examination equipment. It should be noted that Latvian and Ukrainian national regulations confirm specific medical technologies in medical treatment. However, particular regulations have several legal challenges regarding patient safety. The terminology of robotics in healthcare is a challenge from the legal perspective as well [1]. Although clinical evaluation plays a significant role in psychiatry, particularly in forensic psychiatry, the use of artificial intelligence technologies is possible when assessing the mental state of a mentally disabled person or a person who has a mental illness in the context of danger to the public.

In forensic psychiatry, a psychiatrist is an expert whose task is to assess the public danger of a mentally disabled person or a person who has mental illness who has committed a criminal offense, in cases where such person is not punishable but subject to compulsory medical measures. Article 68 of the Criminal Law of the Republic of Latvia provides that compulsory measures of medical nature may be applied to persons who have committed a criminal offense in a state of mental incapacity or are recognized to have limited mental capacity, provided that by nature of the offense committed and their mental condition such persons are dangerous to society [2]. Article 92 of the Criminal Code of Ukraine consists of rules, which are similar [3]. The legal framework associates the application of compulsory measures of a medical nature with the public danger caused by the person. It is understood that a person with mental incapacity or limited mental capacity cannot be held criminally liable, provided that the person has not been aware of the harmful consequences of their act or omission and has been unable to manage their will. However, such a person may be dangerous to the public. Latvian Criminal Law and the Ukrainian Criminal Code do not contain a legal definition of danger to the public. The concept of danger to the public can be synthesized from the understanding of public safety. Publicly dangerous persons pose a threat to public safety. The Constitutional Court of the Republic of Latvia has indicated that the concept of "public safety" in democratic countries is oriented to protecting public interests [4]. The context of sustainable development of the public interest includes the protection of personal and material interests against various types of threats, including from mentally disabled persons or persons who have a mental illness. The application of measures of a medical nature is a way to protect the public from the dangers caused by such persons. However, it should be 
borne in mind that the application of compulsory measures of a medical nature constitutes a restriction on the rights of the persons to whom they are applied. Although the legal framework provides for exceptions when treatment is possible without a person's consent, the restriction of rights must be proportionate to the public interest.

Forensic experts - psychiatrists - play an essential role in ensuring proportionality. For the evaluation of the mental state of a person, a forensic-psychiatric examination is prescribed. According to Section 69 Paragraph Two of the Criminal Law of Latvia [2] and Article 93 of the Criminal Code of Ukraine [3], compulsory treatment and the type of treatment institution is determined by the court, and, understandably, the court is guided by the findings of the psychiatric expertise. This conclusion follows from Section 194 Paragraph One of the Criminal Procedure Law of Latvia [5] and Article 368 Part 4 of the Criminal Procedure Code of Ukraine [6], which stipulates that an expert examination shall be determined in cases where the conducting of a study is necessary wherein special knowledge is required. At this stage of criminal proceedings, criminal and criminal procedural relations form a conflict with the legal relationship of treatment. It is vital to prevent any subjectivity of the doctor-psychiatrist, as it affects the interests of both the examined person and the public. The application of measures restricting this person's freedom and the level of public safety will both depend on the quality of the assessment of the public hazard caused by the examined person.

Artificial intelligence plays an essential role in providing medical services. Standardizing and anonymizing the assessment procedure (the forensic - psychiatric expertise), making it independent of subjective perception of the doctor-psychiatrist, is one of the applications of robotic based on artificial intelligence. The scientific literature indicates that artificial intelligence allows specific criteria to be combined, creating new solutions [7]. In determining the level of public hazard caused by a person, this characteristic of artificial intelligence is especially relevant since it allows the modeling of a person's future behavior. The use of Artificial Intelligence in various areas has encouraged an extensive global discourse on the underlying ethical principles and values. It shall be noted that the future development of artificial intelligence in healthcare and a challenging and significant challenge, especially if the question about the patient's safety and society's well-being comes into the discussion [8].

We must agree with the opinion expressed in the scientific literature that 'when making the proper forensic qualification of the case and making a lawful and just decision in the case, the forensic psychiatric examination plays an important and sometimes decisive role" [9], therefore it is crucial to close the gaps regarding the application of robotics in forensic psychiatric expertise.

This research aims to analyze the possibilities of using artificial intelligence-based robotics in forensic psychiatry to assess the public hazard of a mentally disabled or suffering from a mental illness to improve the legal framework governing the use of compulsory medical measures.

\section{MATERIALS AND METHODS}

This study is based on the Republic of Latvia and Ukraine's regulatory acts and the juridical practice of the Republic of Latvia. It was analysed Criminal Law of the Republic of Latvia, Criminal Procedure Law of the Republic of Latvia, Law on Medical Treatment of the Republic of Latvia, Law on Forensic Experts of the Republic of Latvia, Criminal Code of Ukraine, Criminal Procedure Code of Ukraine, Judgment of Dec 6, 2004, of the Constitutional Court of the Republic of Latvia in the Case No. 2004-14-01, Decision of May 13, 2016, of the Department of Administrative Cases of the Supreme Court of the Republic of Latvia in the Case No. 6-80004416/37. Dialectical, comparative, analytic, synthetic, system analyses and sociological research methods were used.

\section{REVIEW AND DISCUSSION}

Forensic psychiatry is characterized by assessing the public hazard caused by mentally disabled persons and persons suffering from mental disorders and further treatment of such persons within the application of compulsory measures of a medical nature. The complexity of the activities of a forensic psychiatrist should be emphasized, combining both legal and medical measures. The task of a forensic psychiatrist is not only to assess the mental state of a person but also to choose the appropriate type of compulsory measure of a medical nature and the algorithm of treatment. These actions, of course, do not take place in a single process but successively follow each other. Thus, the quality of the decisions taken at the previous stage undeniably affects the progress of the following stages. In addition, one more peculiarity should be emphasized; namely, the achievement of the treatment results in the case of application of compulsory measures of a medical nature is not the only goal of the treatment. It is necessary to achieve the legal purpose of the compulsory measure of medical nature, characterized by Prof.U.K. Krastinš as - the compulsory measures aim to prevent or compensate for harmful consequences caused by criminal acts or omissions, which have arisen from the actions of a mentally incapable person. Also, these measures are used to deter from committing new offenses in cases where no criminal penalty is imposed or the person is exempted from serving it. Besides, the goal of compulsory measures is to warn other persons about the legal consequences of the law violations [10]. Given the above, it can be concluded that the application of robotics in forensic psychiatry as a complex multi-stage system has prospects for development at each stage of the system. However, at the same time, when developing legal solutions, these peculiarities must be taken into account.

As mentioned above, the court determines the type of compulsory measures of a medical nature applicable to the person who has committed the offense in a state of mental incapacity or while having limited mental capacity. Before making a decision, the guilty person undergoes an outpatient or inpatient forensic psychiatric examination. The procedure for designing and conducting forensic psy- 
chiatric expertise is determined by the Criminal Procedure Law of Latvia [5], while the law regulates the activity of forensic experts on Forensic Experts [11]. According to Section 200 of the Criminal Procedure Law, the person directing the proceedings shall decide to determine an expert examination and indicate the task set to the expert and the issues to be addressed. Thus, it can be concluded that the content of the forensic examination depends on the person directing the proceedings, on what questions the expert will be asked. The legal framework does not determine the range of issues to be addressed in expertise.

It should be emphasized that the activities of a psychiatrist are not limited to conducting a forensic psychiatric examination. Psychiatrists execute a court decision on compulsory measures of medical nature, i.e., the application of the compulsory measures of medical nature takes place under their guidance and supervision, which is defined as treatment in that particular aspect. When the treatment of a person is started, the criminal procedural legal relationship ceases, and legal relationships based on medical treatment begin.

Modern technologies can be used both in the former and in the latter case. It should be noted that in the conduct and treatment of forensic psychiatric expertise in the case of application of compulsory measures of a medical nature, two interrelated aspects can be distinguished:

1) the formal aspect of the legal framework in question;

2) the content aspect, which consists of the methods and technologies of treatment used.

Of course, the content aspect should not be included in the legal framework, as it is the area of responsibility of the medical psychiatrist as a specialist in each case to choose the appropriate treatment method and medication concerning each patient, determining the dosage and frequency of administration. Such assertion is also confirmed by the conclusion established in the case law that the therapeutic activity takes place in the field of private law, and the medical process cannot be assessed in the manner of the administrative procedure [12].

However, it is possible to establish criteria for the use of medical technologies in the legal framework.

The added value of robotics is their ability to process and analyze many factors in interconnection, which is impossible for humans, or even if possible, would nevertheless take much more time. For example, the patient's heart rate, speech rate, expressions, voice volume, gestures, and other information about the genetic markers, medications used, and previously committed socially hazardous offenses can be analyzed. In the future, it can be possibly also the neuroradiological examination results, so-called brainreading, which will allow recognizing lies and simulation [13]. These can be analyzed in conjunction with national guidelines and up-to-date information from the State Medicines Agency, taking into account that if the patient's medical history is recorded electronically, the appropriate recommendations appear in the course of its filling, thus increasing the accuracy of the decision to be taken in the treatment.
A deficiency of the modern legal framework is that artificial intelligence and robotics in psychiatry are not fully regulated. In practice, technological solutions have overtaken legal solutions.

There is a growing number of guidelines and other regulatory documents throughout medicine that medical practitioners should follow and comply with (guidelines, descriptions of medicines). Clinicians quickly learned to circumvent the clinical trail-based recommendations as they do not meet the needs of patients in real-world settings [14].

On the other hand, a departure from standards of care raises suspicions of neglect, and the investigation of negligence claims - proving that there has been a breach of the duty of care - is complex, the assessment of the results of expert examinations is problematic for the court, since the expert conclusions may not coincide with the public opinion of professionals [15].

Suppose the court applies the Bolam principle or legal test for adequacy of treatment, which saw the judgment of medical experts [16] (what a responsible body of doctors would do) as the primary criterion for assessing reasonable care in negligence cases. In that case, it may prove biased because many experts are not in identical conditions as clinicians - the conditions of limited time and information (or, on the contrary, they experience informative overload) and psycho-emotional stress. In addition, it should be noted that experts may also be aware of the situation's outcome (for example, in a small country such as Latvia), which may also affect their conclusions. Another feature is that it is difficult to prove or rule out the relationship between treatment received and harm in psychiatry since there may always be many psychosocial factors that significantly influence the outcome. It can be, e.g., the relationship between antidepressant replacement and subsequent depression exacerbations with suicide is not so apparent if at some point the patient has experienced additional psychotrauma, stressful conditions, which significantly affected both their well-being and the effects of antidepressants).

The main features of psychiatry, which set it apart from other medical specialties, are the absence of biological diagnostic tests or markers (biological diagnostic tests for psychiatric disorders are still not available). Therefore diagnosis and choice of treatment are based on a clinical assessment that is decidedly subjective [17], expert-centric, and associated with high rates of misdiagnosis and mistreatment [18], but the actual global burden of mental disorders appears to remain underreported, underestimated [19].

Artificial intelligence (AI)-based applications are being quickly developed for psychiatric research and diagnosis (Guang-DiLiu, Yu-ChenLi, Wei Zhang, Le Zhang, 2020). The utility of AI-based interventions in diagnosing, predicting, and treating psychiatric disorders is established [17].

In psychiatry, the doctor is obliged not only to take care of the patient (duty to care) but also to protect third par- 
ties (duty to protect), which is expressed as the obligation to take care of the public safety, assess the potential of a patient is all aggression.

In general, the development and implementation of AI assistance into clinical decision-making is an inevitability. However, the implementation of modern technologies (AI-assistance into decision-making) is expected in areas where there are more significant risks of legal liability, the necessity to protect the interests of third parties (duty to protect), or where the doctor's conclusions have far-reaching legal consequences.

1) decision making in capacity assessment - hospitalization of a person in a psychiatric hospital, selecting treatment option or participation in a clinical trial; following the wishes expressed by the patient and determining the moment when the future authorization comes into effect, as well as assessing the criteria for establishing a trustee in urgent cases;

2) in a case of impaired decision-making ability or capacity (in case of geriatric or psychiatric patients, as well as patients with severe motor disabilities - e.g., quadriplegic) - to predict a person's preferences regarding health care decisions [20];

3) with the informed consent of the patient - technologies will provide custom treatment outcomes and risks;

4) in diagnostics - for example, differentiating unipolar depression from bipolar, acute schizophrenic psychosis from limbic encephalitis, early detection of signs of dementia [21];

5) planning and implementing an individualized rehabilitation plan under the principles of personalized medicine, e.g., by deciding on the off-label and high-than-recommended doses (demonstrating that the expected benefit outweighs risk), choice of therapy in resistant cases and in patients with serious concomitant diseases and conditions where extensive interactions (drug-drug, drug-disease) are possible;

6) in assessing the risk of violence and aggression, both in assessing immediate violence/aggression or self-harm risk and anticipating future community violence/sexual offense risk. Today, different scales are used to assess the risk of aggression. It is accepted that aggression takes place in many forms and is not limited to physical attacks (e.g., stalking, intimidation), risk assessment schemes (e.g., unstructured clinical judgment, actuarial risk prediction tools, structured professional judgment) tend to focus on the prediction of serious assaults [22]. If a direct, immediate threat can be predicted reasonably well by a clinician, conducting risk evaluation for future violence in the community remains a challenging task, where AI could lend a helping hand [23];

7) in monitoring the behavior and mental state of persons who have been subject to a compulsory measure of medical nature (or specific behavioral monitoring or appropriate similar measures have been applied - community treatment order) by measuring the concentration of medication in the blood, determining the presence of alcohol or drugs, following sleep patterns or, for example, the activities of a pedophile on the Internet.
Perhaps in the future, technologies will be available that will affect the mental state in the long term and influence the behavior and beliefs of individuals by preventing criminal behavior $[24,13]$.

In forensic psychiatry, the adoption of AI-supported decisions promises to guarantee objective expertise, reasoned assessment of the risk of repeated aggressive actions, recommending optimal compulsory measures of medical nature, and, at the stage of its implementation impassioned selection of treatment methods. It should be by analogy with a legal system where the introduction of technology promises to improve the quality of judgments by eliminating judicial biases (neuroenhancements could be used to improve the abilities of criminal justice authorities - judges could be made more able to make adequately informed and unbiased decisions).[25]

Although, in general, in medicine, and, among others, in psychiatry, the number of guidelines and other regulatory documents that medical practitioners must comply with is increasing. In this way, the freedom of professional activity and creativity of medical practitioners is somewhat limited, but, through a legal framework, it is possible to clearly define the competence of the medical practitioners, the patients, and the court in the use of robotics, which would provide more excellent protection from mistakes for everybody.

Although the legal framework currently in force in Latvia, expresis verbis, does not regulate the use of robotics in medicine, including psychiatry, generally the application of the legal framework can be derived from Section 3 Paragraph One of the Medical Treatment Law, namely - medical equipment is used in healthcare [26]. The interpretation of the legal norm makes it possible to conclude that medical equipment can also be based on artificial technology and robotics. In addition to this general framework, there is a need for a specific legal framework since forensic psychiatry goes outside the medical legislation, considering that forensic psychiatry is related to treatment and forensic examination, regulated by the particular legal framework.

As for the legal responsibility of AI, in our opinion, because artificial intelligence does not yet possess men's rea, regardless of the scope of decisions taken and interventions carried out, it cannot perform actus reus. It cannot be obliged to take care of or protect (duty of care, duty to watch). That is why making an accusation, similarly as against a doctor or medical institution (regular neglect claim), against an $\mathrm{AI}$ is not possible - only product liability applies [27].

The authors agree that the future of technology implementation depends on how strict the liability of the developers and implementers of technology will be. It should be noted that issues of machine learning software manufacturers' and sellers' of software liability under product liability law will affect the cost and spread of the technology in the health sector, ultimately shaping the practice of medicine [28]. We believe that it is necessary to develop a comprehensive legal framework for technological solutions. 


\section{CONCLUSIONS}

As a result of this research, the authors have made the following conclusions:

1) there is a lack of uniform medical and legal criteria for the application of artificial intelligence-based robotics in forensic psychiatry;

2) in forensic psychiatry, it is possible to use different types of automated systems (e.g., testing, control of the use of medicines, behavioral control, etc.), whose legitimacy requires creating a new legal framework;

3) the use of artificial intelligence-based robotics in forensic psychiatry would reduce discretion in the treatment process, but in general, would effectively improve the process of goals to be achieved in forensic psychiatry and help prevent subjective errors.

Forensic psychiatry includes a set of two independent procedural actions - forensic psychiatric expertise and treatment within the framework of the application of compulsory measures of medical nature. Each of these processes has an independent legal framework, where the first process is mainly related to criminal procedural law and the second - to the legal regulation of medical treatment. The challenge of developing a potential legal framework for using robotic technologies based on artificial intelligence is not disrupting the logical unity of both processes. The forensic psychiatric examination determines the treatment strategy in the future application of compulsory measures of medical nature), ensuring the adoption of high-quality, effective legislation compliant with human rights.

The question of synchronization of legal norms and legislation is open for further discussion. As mentioned above, the integration of legislation governing artificial intelligence into the legal framework of medical treatment is more straightforward since it is subject to the general legal framework governing medical treatment. The issue of integrating this regulation into the forensic psychiatric examination phase is complicated. The current legal framework provides for the expert's obligation to specify the method to be used in the expertise. Conversely, the use of artificial intelligence-based robotics in forensic psychiatric expertise is not regulated. If the Medical Treatment Law provides that medical equipment is used in healthcare and, interpreting the concept of "medical equipment," it can be concluded that it includes robotics based on artificial intelligence. The Law on Forensic Experts, which is the specialized law governing the activity of forensic experts, there are no such norms. The modern technologies would analyze the data obtained in forensic psychiatric expertise and give an opinion, for example, on the potential violence of a person and assess the risk of aggression. For using it, it is necessary to provide a procedure in which these technological solutions are accepted for use, i.e., their legal status from the point of view of admissibility of evidence. A similar situation exists regarding using a lie detector or polygraph, which exists as a technological solution and in some cases is used, but whose regulatory status is not actually established in the legal system. Legal uncertainty hinders both the development of modern technologies and creates misunderstandings in their application, which can lead to infringement of the rights of individuals.

Successful technological solutions based on modern technologies in psychiatry must be based on precisely defined rights and obligations of the parties involved - forensic psychiatry experts, examined persons, persons directing the criminal proceedings (police, prosecutor's office, and court).

\section{REFERENCES}

1. Palkova. K.,Žukovs A., Description of the Concept of Medical Technologies and Devices in Latvia in the Context of Robotics. Socrates: Rigga Stradinš University Faculty of Law Electronic Scientific Journal of Law. Rīga: RSU, 2020, Nr. 2 (17):31.-39. doi: 10.25143/socr.17.2020.2.031-039.

2. Criminal Law. Law of the Republic of Latvia. Entered into force on 01.04.1999. Published in: Latvijas Vēstnesis, 199/200, 08.07.1998.

3. Criminal Code of Ukraine. Entered into force on 01.09.2001. Available from: https://zakon.rada.gov.ua/laws/show/2341-14\#Text.

4. Judgment of Dec 62004 of the Constitutional Court of the Republic of Latvia in the case No. 2004-14-01 (2004). Available from: https://www.satv.tiesa.gov.lv/web/viewer.html?file=/wp-content/ uploads/2016/02/2004-14-01_Spriedums.pdf\#search=

5. Criminal Procedure Law. Law of the Republic of Latvia. Entered into force on 01.10.2005. Published in: Latvijas Vēstnesis, 74, 11.05.2005.

6. Criminal Procedure Code of Ukraine. Entered into force on 15.08.2021. Available from: https://zakon.rada.gov.ua/laws/show/4651-17\#Text.

7. Clowes, R. W., Seth A.K. Axioms, properties and criteria: Roles for synthesis in the science of consciousness. Artificial Intelligence in Medicine, October 2008;2:91-104.

8. Leimanis, A. and Palkova, K. 2021. Ethical Guidelines for Artificial Intelligence in Healthcare from the Sustainable Development Perspective. European Journal of Sustainable Development. 10, 1 (Feb. 2021), 90. doi: 10.14207/ejsd.2021.v10n1p90.

9. Kaija S, Kudeikina I, Gutorova N. Medical and procedural-legal aspects of inpatient and outpatient forensic psychiatric examination. Wiad Lek. 2020;73(7):1533-1538.

10. Krastinš, U. Kriminālsods un citi kriminālie piespiedu ietekmēšanas lídzekli. Jurista Vārds 13.03.2007;11:464.

11. Law on Forensic Experts. Law of the Republic of Latvia. Entered into force on 15.03.2016. Published in: Latvijas Vēstnesis, 42, 01.03.2016.

12. Decision of May 132016 of the Department of Administrative Cases of the Supreme Court of the Republic of Latvia in the case No. 6-80004416/37; SKA-889/2016. Available from: http://at.gov.lv/ downloadlawfile/4281.

13. Ligthart, S., Douglas, T., Bublitz, C. et al. Forensic Brain-Reading and Mental Privacy in European Human Rights Law: Foundations and Challenges. Neuroethics, 2021; 14: 191-203. doi: 10.1007/s12152020-09438-4.

14. David D. Luxton. Artificial Intelligence in Behavioral and Mental Health Care. Elsevier Science \& Technology, PRINT PUB DATE, 2015:30.

15. Martyinihin, I. Prigovor psihiatru po state 0 halatnosti iz-za prekrascheniya prinuditelnogo lecheniya [Psychiatrist sentenced under article of negligence due to termination of compulsory treatment]. Rossiyskoe obschestvo psihiatrov, 17.06 2019. Available from: https:// psychiatr.ru/news/992 (in Russian).

16. Brahams, D. Superspecialists and the bolam test. 1995, The Lancet, 345(8949), 575. Available from: https://www-proquest-com.db.rsu.lv/ scholarly-journals/superspecialists-bolam-test/docview/198983121/ se-2? accountid $=32994$ 
17. Fackoury, M. Advances in Experimental Medicine and Biology. Frontiers in Psihyatry. 2019:119-125. Available from: https://www.researchgate. net/publication/337138251_Artificial_Intelligence_in_Psychiatry

18. Plantera, F. Dr Eduard Maron: how DocuMental fills the gap in mental healthcare with innovation. 2019. Available from: https://e-estonia. com/documental-healtcare-innovation/, November, 2019.

19. Vigo, Daniel et al. Estimating the true global burden of mental illness. The Lancet Psychiatry, 2016;3(2):171-8.

20. Lamanna C, Byrne L. Should Artificial Intelligence Augment Medical Decision Making? The Case for an Autonomy Algorithm. AMA J Ethics. 2018;20(9):E902-E910. doi:10.1001/amajethics.2018.902

21. Ding, Yiming et al. A Deep Learning Model to Predict a Diagnosis of Alzheimer Disease by Using 18F-FDG PET of the Brain. Radiology. 2019;2:456-464. doi:10.1148/radiol.2018180958

22. Makushkina, 0.A. Berezkin, A.S., Durneva, M.Yu., Avdonina, S.M. Aprobatsiya i vnedrenie metodiki strukturirovannoy otsenki riska povedeniya lits s psihicheskimi rasstroystvami [Approbation and implementation of the methodology for structured risk assessment of the behavior of persons with mental disorders]. Sotsialnaya $i$ klinicheskaya psihiatriya. 2017;27(4). Available from: https://psychiatr. ru/files/magazines/2017_12_scp_1209.pdf(Ru).

23. Cockerill, R. Ethics Implications of the Use of Artificial Intelligence in Violence Risk Assessment. Journal of the American Academy of Psychiatry and the Law. Online May 2020;003940-20. doi: 10.29158/ JAAPL.003940-20

24. Shaw E. The Use of Brain Interventions in Offender Rehabilitation Programs: Should It Be Mandatory, Voluntary, or Prohibited? In: Clausen J., Levy N. (eds) Handbook of Neuroethics. Springer, Dordrecht. 2015. doi: 10.1007/978-94-007-4707-4_169

25. Varelius J. Neuroenhancement, the Criminal Justice System, and the Problem of Alienation. Neuroethics. 2020;13:325-335. Available from: doi: 10.1007/s12152-019-09427-2
26. Law on Medical Treatment. Law of the Republic of Latvia. Entered into force on 01.10.1997. Published in: Latvijas Vēstnesis, 167/168, 01.07.1997.

27. Kingston J.K.C. Artificial Intelligence and Legal Liability. In: Bramer M., Petridis M. (eds) Research and Development in Intelligent Systems XXXIII.SGAI 2016.Springer, Cham. doi: 10.1007/978-3-319-47175-4_20

28. Ordish, J. Legal liability for machine learning in healthcare, August 2018, Policy briefing. Available from: https://www.phgfoundation. org/briefing/legal-liability-machine-learning-in-healthcare.

\section{ORCID and contributionship:}

Inga Kudeikina: 0000-0002-7895-4264 ${ }^{A, B, D, E, F}$

Marina Loseviča: 0000-0001-9371-5061 B,D, F

Nataliya Gutorova: 0000-0003-2485-0651 $1^{D, E, F}$

\section{Conflict of interest:}

The Authors declare no conflict of interest.

\section{CORRESPONDING AUTHOR Inga Kudeikina \\ Riga Stradiņš University, Riga, Latvia \\ e-mail:inga.kudeikina@rsu.Iv}

Received: 09.06.2021

Accepted: 11.10 .2021

A - Work concept and design, B - Data collection and analysis, C - Responsibility for statistical analysis, D-Writing the article, $\mathbf{E}$-Critical review, $\mathbf{F}$ - Final approval of the article 


\title{
SEARCH AND REMOVAL OF PROHIBITED ITEMS FROM THE HUMAN BODY: MEDICAL- PROCEDURAL ASPECT
}

DOI: 10.36740/WLek202111232

\author{
Oleksandr M. Drozdov', Oksana V. Lazukova', Serhiy 0. Shulgin ${ }^{2}$ \\ 'YAROSLAV MUDRYI NATIONAL LAW UNIVERSITY, KHARKIV, UKRAINE \\ 2PROSECUTOR GENERAL'S OFFICE OF UKRAINE, KYIV, UKRAINE
}

\begin{abstract}
The aim: Based on the research, to develop a scientific concept of medical and procedural aspects of restricting a person's right to physiological integrity related to the removal of prohibited items from his/her body and formulate recommendations for their implementation in law enforcement practice.

Materials and methods: The empirical basis of the study were five decisions of the European Court of Human Rights, the results of a survey of prosecutors, investigators, and lawyers, processing of materials of criminal proceedings. The practical evidence of the authors, their advocacy, and service in the prosecutor's office was also taken into account. To demonstrate the method of prohibited substances' concealment in a human body, a photographic image was used based on the results of the examination of a person using a scanner conducted by customs officials.

The methodological basis of the research is a complex combination of general-scientific and special methods, in particular, system-structural, comparative-legal; sociological; statistical; as well as the method of generalization.

Conclusions: The removal of evidence from a person's body is a strip search. The basis for this investigative action should be a court decision, and in urgent cases, the prosecutor. This investigative action must be carried out with the obligatory participation of a physician. To this end, it is necessary to develop an appropriate medical protocol.
\end{abstract}

KEY WORDS: human rights; prohibition of torture; personal integrity; admissibility of evidence; strip search

Wiad Lek. 2021;74(11 p.2):3048-3052

\section{INTRODUCTION}

The last few years in Europe have seen a rise in drug-related crime. However, in addition to the global fight against drug crime, no less important is the fight against its small manifestations, which ensure their receipt by the "end consumer".

An analysis of criminal proceedings in the field of combating drug crime, which is being investigated by the investigative units of the National Police, showed that the most common ways of drugs' undercover distribution are through so-called "stash". The scheme is that a "seller" hides the drug in hiding (make a stash) and after receiving payment informs the "buyer" of its coordinates. At the same time, in practice, there are cases of concealment of narcotic (and other illegal) substances directly in a human body.

It is possible to detect such a concealment method only after conducting an appropriate examination with the help of scanners, medical diagnostic equipment, or obtaining intelligence information. However, even after being certain that a person is hiding prohibited substances in his/her body, law enforcement agencies are faced with the imperfection of legislative regulation of their removal.

For example, on July 19,2021, with the help of a scanner, Kyiv customs officers at the Boryspil International Airport found bags of cocaine in a Brazilian citizen, which he hid in his stomach [4] (see Fig. 1).
It should be noted that the removal of prohibited items from the human body has been studied in forensic and procedural aspects, but there is no comprehensive medical-procedural study of this problem.

\section{THE AIM}

In order to ensure the scientific novelty of this work through scientific-practical analysis, we will analyze the current state of legal regulation and scientific development of removal of prohibited substances from the human body, clarify key issues and formulate the authors' own conclusions.

\section{MATERIALS AND METHODS}

The empirical basis of the research was 5 decisions of the ECHR: JALLOH V. GERMANY (№ 54810/00) on 11.07.2006; O'HALLORAN AND FRANCIS v. THE UNITED KINGDOM (№o 15809/02; 25624/02) 29.06.2007; BOKHONKO V. GEORGIA (№ 6739/11) on 22.10.2020; Case of FREROT V. FRANCE (№70204/01) on 12.06.2007; VAN DER VEN - NETHERLANDS (№ 50901/99) on 04.02.2002. It was processed materials of 10 criminal proceedings in the field of drug trafficking, pre-trial investigation of which was carried out by investigators of 


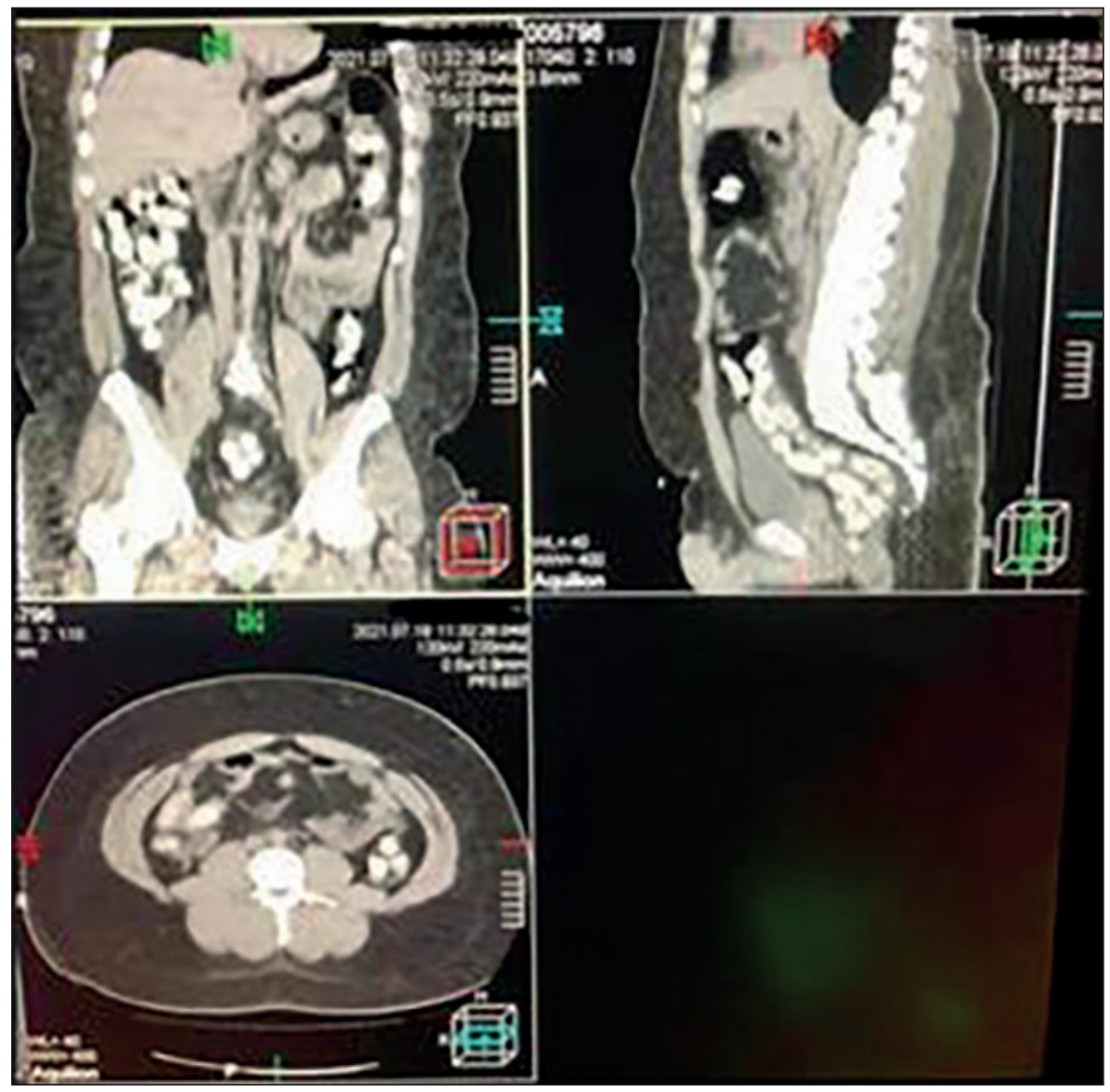

Fig. 1. Bags of cocaine in stomach

Desniansky, Pechersky, and Sviatoshynsky police departments of the Main Departments of the National Police in Kyiv. The personal evidence of the authors of more than 15 years of advocacy (Oleksandr M. Drozdov) and more than 10 years of service in prosecutorial and investigative positions of prosecutors of all levels (Serhiy O. Shulgin) was also taken into account.

For a visual demonstration of the concealment method and detection of prohibited substances hidden in a human body, a photographic image was used based on the results of a person's examination using a scanner conducted by customs officials published on the Internet.

In addition, the research used the survey results of 14 investigators of the Main Investigation Department of the State Bureau of Investigation, 19 prosecutors of the Prosecutor General's Office, and 17 lawyers, which was conducted in the period from 10.06.20201 to 25.06.2021.

The application of research methods is determined by a systematic approach, which makes it possible to study the chosen object in the unity of its legal and medical forms. To achieve this aim, scientific objectivity of the research, the system-structural method was chosen, which was used in determining the legal basis and procedural order of interference with the physiological integrity of a person, the combination of medical and legal criteria during this procedural action, their relationship with admissibility. evidence; the comparative-legal method was used during comparing the mechanisms of legal regulation of interfer- ence in person's physiological integrity under domestic and foreign criminal procedure legislation and provisions in the decisions of the ECHR; sociological and statistical methods were used during the study of the practice of application and questionnaires of lawyers, investigators, and prosecutors in the context of research subject and generalization of the results; the method of generalization allowed to consistently combine individual facts, the obtained research's results into a single whole and to formulate substantiated conclusions.

\section{REVIEW AND DISCUSSION}

As mentioned above, in practice there are cases of movement of prohibited substances in the human body. At the same time, our analysis of the Criminal Procedure Codes of Ukraine [1], Austria [2], and Poland [3] showed the lack of proper legal regulation of such seizures.

At the same time, such cases were the investigation subject by the ECHR, in particular in the judgment of JALLOH V. GERMANY (№ 54810/00) on 11.07.2006.

The ECHR concluded that the use of evidence obtained through the coercive use of a medicinal product against the applicant was a violation of his/her right not to testify against himself/herself, as in this case the emetics' use had not been inevitably needed to obtain proof. It was possible to wait for the package to be excreted naturally. The Convention does not prohibit the possibility of involuntary medical intervention 
that could assist in crime investigation. However, any interference with the physiological integrity of a person in order to obtain evidence must be subject to exceptional scrutiny [5].

In the context of the question of violation of the freedom from self-disclosure during the implementation of coercive means of obtaining information from S. Lisachenko, it draws attention to the peculiarities of implementation of the volitional element of actions. The coercion used in the examination and sampling is legitimate, provided that it results in the person's inaction in self-disclosure or testimony against close relatives and family members. If the compulsory examination and sampling motivate a person to take active actions against his/her will to expose himself/herself, relatives, and friends, it is a violation of the freedom from self-disclosure [6, p. 321].

A similar legal situation was the subject of a study by the ECHR in O'HALLORAN AND FRANCIS v. THE UNITED KINGDOM $(15809 / 02 ; 25624 / 02)$ on 29.06 .2007 where it is stated that the Court considered that the drugs concealed in the applicant's body, which had been obtained by involuntary vomiting, could be regarded as belonging to the category of materials that exist independently of the suspect's will, the use of which is generally allowed in criminal proceedings [7]. The situation mentioned in the decision of the European Court of Human Rights BOKHONKO V. GEORGIA (№ 6739/11) on 22.10.2020, which established a violation of Art. 3 of the Convention in the procedural aspect and the absence of violation of this article in substantive aspect, as the national courts failed to consider the applicant's main arguments concerning the illegality of the evidence thus obtained [8].

Also, it is still an unresolved question of what legal procedure will be appropriate during the seizure to be carried out during a search or examination.

The author's analysis leads to conclude that the removal of evidence from a person's body is a strip search. This approach agrees with the ECHR's position expressed in FREROT V. FRANCE (№70204 / 01) on 12.06.2007, which states that arbitrariness feelings, inferiority, and anxiety are often associated with this, as well as serious violations of dignity, Undoubtedly, the concomitant obligation to strip a person and inspect an anus, combined with excessive intimate activities that accompany searches with stripping, caused an excess of humiliation [9]. A similar legal position is set out in the decision VAN DER VEN - NETHERLANDS (№ 50901/99) on 04.02.2002 [10].

Y. Kurochka and V. Yu. Gladkikh proposes to enshrine at the legislative level a list of general conditions for the admissibility of coercive medical measures against a person by interfering with his/her physical integrity, as follows: the use of coercive medical procedure against the suspect's will, in order to obtain evidence, must degrade his/her honor and dignity or be dangerous to health, have the character of torture and inhuman treatment; interventions in the human body should be performed by a physician in a medical institution. This procedure must be preceded by a person's examination for his/her physical ability to endure such a procedure and establishment of restrictions on medical intervention means; the court obligation to take into ac- count the possibility of applying without coercive medical action (provided by law), obtaining evidence that can be used during the trial [11, p. 160-161]. The authors consider such positions to be appropriate and worthy of support.

As mentioned above in JALLOH V. GERMANY (№ 54810/00) on 11.07.2006, the Convention does not in principle prohibit the possibility of involuntary medical intervention that could assist in the crime investigation [5]. Since any interference with a person's physical integrity for the purpose of obtaining evidence must be subject to exceptional scrutiny, we consider it necessary to agree that evidence-based medicine is aimed at reducing the influence of subjective factors on a choice of criteria for diagnosis and treatment of a particular patient in accordance with the recommended algorithms [12, p. 2797].

In such circumstances, we propose to develop an appropriate medical protocol, which must be approved by the Ministry of Health. This medical protocol should regulate the procedure for medical manipulations, including the use of drugs. However, given the various possible options for concealment (use of containers to preserve their contents), the medical report should give the physician the right to deviate slightly from its contents, but only with medical contraindications that should not harm the life and health of the person. This view is shared by scientists, who believe that evidence-based medicine also provides a greater opportunity for the physician to choose the optimal method of treatment at his / her discretion. Thus, if at the same time there is a unified clinical protocol and a new clinical protocol, then according to the decision by the physician a new clinical protocol could be applied. In this case, the physician should explain the differences in treatment protocols and obligatory to obtain the patient's informed consent (in certain situations the decision is made by a legal representative). When a new protocol is used, the physician is relieved of the obligation to use a unified protocol [12, p. 2798]. From the results of our survey given in Table I, it is seen that $90 \%$ of respondents consider it necessary to develop a medical protocol.

At the same time, the answers result to question № 7 turned out to be quite unexpected for authors. $97 \%$ of lawyers, $22 \%$ of investigators, and $54 \%$ of prosecutors answered in the affirmative (see Table I).

The authors believe that the violation of the medical protocol cannot be considered an unconditional basis for recognizing the seized items as inadmissible evidence.

At the same time, we believe that such a procedural action has medical and legal aspects. Of course, a normative act cannot regulate all relations in a specific area, including the restriction of the physiological integrity of a person in the framework of procedural actions. Moreover, it is impossible to take into account such features of a person as age, sex, state of health, level of biological (physical) development of a person, and possible negative consequences of his/her life and health as a result of interference with his/her body. Therefore, deviating from the prescription of the medical protocol, the physician must take into account the individual characteristics of the person, in order to prevent deterioration of his/ 
Table I. The survey results

\begin{tabular}{|c|c|c|c|c|c|c|c|}
\hline \multirow{2}{*}{ № } & \multirow{2}{*}{ Questions } & \multicolumn{2}{|c|}{ Attorneys } & \multicolumn{2}{|c|}{ Investigators } & \multicolumn{2}{|c|}{ Prosecutors } \\
\hline & & Yes & No & Yes & No & Yes & No \\
\hline 1. & $\begin{array}{l}\text { Is it possible, in your opinion, to forcibly remove prohibited } \\
\text { substances hidden in the human body by limiting its } \\
\text { physiological integrity? }\end{array}$ & 24 & 76 & 87 & 12 & 78 & 22 \\
\hline 2. & $\begin{array}{l}\text { In your opinion, is it necessary for a physician to participate } \\
\text { in the forced removal of prohibited substances hidden in the } \\
\text { human body by restricting its physiological integrity? }\end{array}$ & 100 & & 100 & & 100 & \\
\hline 3. & $\begin{array}{l}\text { Is it necessary, in your opinion, to develop a medical protocol } \\
\text { during the forced removal of prohibited substances hidden in } \\
\text { the human body by limiting its physiological integrity? }\end{array}$ & 95 & 5 & 91 & 9 & 95 & 5 \\
\hline 4. & $\begin{array}{l}\text { In your opinion, the Prosecutor should make the decision on } \\
\text { carrying out compulsory revomal of the forbidden substances } \\
\text { hidden in a human body by restriction of its physiological } \\
\text { integrity? }\end{array}$ & 10 & 90 & 73 & 27 & 90 & 10 \\
\hline 5. & $\begin{array}{l}\text { In your opinion, the decision to carry out the forced seizure of } \\
\text { prohibited substances hidden in the human body by limiting } \\
\text { its physiological integrity should be made by the court? }\end{array}$ & 98 & 2 & 59 & 41 & 78 & 22 \\
\hline 6. & $\begin{array}{l}\text { In your opinion, are the seized items obtained as a result of } \\
\text { forced removal from a person by limiting his physiological } \\
\text { integrity admissible evidence? }\end{array}$ & 91 & 9 & 100 & & 88 & 12 \\
\hline 7. & $\begin{array}{l}\text { Is there, iln your opinion, deviation of the physician from the } \\
\text { content of the medical protocol during the forced removal of } \\
\text { prohibited substances hidden in the human body by limiting } \\
\text { its physiological integrity as a basis for recognizing these } \\
\text { things as inadmissible evidence. }\end{array}$ & 97 & 3 & 22 & 78 & 54 & 46 \\
\hline
\end{tabular}

her health and conduct appropriate medical manipulations, determining which drugs and medical equipment is most appropriate and necessary in such a situation. Thus all medical manipulations are carried out taking into account the general rules of medical practice. We believe that if these recommendations are followed, the medical aspect will not be violated.

Regarding the legal criterion, it will be observed under the following conditions: the decision to conduct a procedural action related to the restriction of a person's physiological integrity was made by the authorized entity; procedural action is carried out by an authorized person; a physician is involved in the procedure; the course of procedural action is recorded in a significant way, including the packaging of the seized items.

No less important is the subject of procedural decision, which is the basis for temporary restriction of physiological integrity. In our opinion, this should be a court decision. This opinion was supported by $98 \%$ of respondents, $78 \%$ of prosecutors, and $59 \%$ of investigators. However, in urgent cases that may lead to the loss of evidence, this decision may be made by the prosecutor.

\section{CONCLUSIONS}

Removal of evidence from a person's body by a search of a person related to strip search. The basis for this investigative action should be a court decision, and in urgent cases, the prosecutor's one. This investigative action must be carried out with the obligatory participation of a physician. To this end, it is necessary to develop an appropriate medical protocol, which must be approved by the Ministry of Health. A search related to strip search has medical and legal aspects. Medical one consists in carrying out medical manipulations by the physician within the limits of carrying out procedural action, and legal criterion consists in decision-making on carrying out procedural action and it's carrying out by the authorized subject; involvement of a physician in carrying out procedural action; fixation of the course and results of procedural action in the manner prescribed by law.

Violation (slight deviation from) of the medical report cannot be considered an unconditional ground for declaring the seized items inadmissible evidence, provided that there are no indications of a violation of Article 3 of the Convention.

\section{REFERENCES}

1. Kryminal'nyy protsesual'nyy kodeks Ukrayiny vid 13.04.2021 № 4651-VI [The Criminal Procedure Code of Ukraine] Available from: https://zakon. rada.gov.ua/laws/show/4651-17\#Text

2. Strafprozeßordnung 1975. (StPO)StF: BGBI. Nr. 631/1975 (WV) [Criminal Procedure Code 1975. (StPO) StF: Federal Law Gazette No. 631/1975 (WV)] Available from: https://www.jusline.at/gesetz/stpo

3. USTAWA z dnia 6 czerwca 1997r. Kodeks postępowania karnego Dz. U. $1997 \mathrm{Nr} 89$ poz. 555. [ACT of June 6, 1997. Code of Criminal Procedure Journal Of Laws 1997 No. 89 item 555] Available from: http://isap.sejm. gov.pl/isap.nsf/download.xsp/WDU19970890555/U/D19970555Lj.pdf 
4. V aerodromi "Boryspil'" zatrymaly inozemtsiv iz kokayinom: odyn skhovav "tovar" u shlunku. Foto [Foreigners with cocaine were detained at Boryspil airport: one hid "goods» in his stomach. Photo] Available from: https://incident.obozrevatel.com/ukr/kiyany/crime/vaeroportu-borispil-zatrimali-inozemtsiv-z-kokainom-odin-shovavtovar-v-shlunku-foto.htm?fbclid=IwAROe44nH7l5CqIZVKSKnUKbQpZ Kd5-J8jKw5Uc4eru9WrlQXf9l mqkW0uo;

5. Case of JALLOH V. GERMANNY (№ 54810/00) on 11.07.2006 Available from: https://hudoc.echr.coe.int/eng\#\{\%22appno $\% 22$ :[\%2254810/00\%22],\%22itemid\%22:[\%22001$76307 \% 22]\}$

6. Lysachenko S. Okremi prymusovizasoby otrymuyut' vidomosti pro osoby v kryminal'nomu dosudovomu provadzhenni v konteksti svobody vid samovykryttya ta prav ne svidchat' proty blyz'kykh bat'kiv ta chleniv sim'yi // Pidpryyemnytstvo, hospodarstvo ta pravo. 2018; 6: 316-321 (Ua).

7. Case of O'HALLORAN AND FRANCIS v. THE UNITED KINGDOM (№№ 15809/02; 25624/02) on 29.06.2007 Available from: https://hudoc. echr.coe.int/rus\#\{\%22itemid\%22:[\%22001-117697\%22]\}

8. Case of BOKHONKO V. GEORGIA (№ 6739/11) on 22.10.2020 Available from: https://hudoc.echr.coe.int/rus\#\{\%22tabview \%22:[\%22document $\% 22], \% 22$ itemid\%22:[\%22001-205226\%22]\}

9. Case of FREROT V. FRANCE (№70204/01) on 12.06.2007 Available from: https://hudoc.echr.coe.int/rus\#\{\%22tabview \%22:[\%22document\%22],\%22itemid\%22:[\%22001-119752\%22]\}

10. Case of VAN DER VEN - NETHERLANDS (№ 50901/99) on 04.02.2002 Available from: https://hudoc.echr.coe.int/rus\#\{\%22tabview \%22:[\%22document\%22],\%22itemid\%22:[\%22001-60915\%22]\}

11. Kurochka M. Y., Hladnykh V. Yu. Umovy zastosuvannya premusovykh medychnykh zakhodiv, shchodo pidozryuvanoho, za dopomohoyu navchannya u fizychniy nedotorkannosti osobystostey u kryminal'nomu protsesi [Conditions for the application of coercive medical measures against the suspect by interventionin the physical inviolability of the person in criminal proceedings]. Visnyk Luhans'koho derzhavnoho universytetu vnutrishnikh sprav imeni E. 0. Didorenka. 2013; 1: 155-161 (Ua).
12. Volodymyr A. Zhuravel, Galina K. Avdeeva, Mykyta 0. Sokolenko. Wiad Lek. 2020; 12: 2795-2803.

\section{ORCID and contributionship:}

Oleksandr M. Drozdov: 0000-0003-1364-1272 A, B, D, E, F

Serhiy O. Shulgin: 0000-0001-6379-7393 ${ }^{A, B, D, E}$

Oksana V. Lazukova: 0000-0001-8756-6944 ${ }^{A, B, D}$

\section{Conflict of interest:}

The Authors declare no conflict of interest.

\author{
CORRESPONDING AUTHOR \\ Oleksandr M. Drozdov \\ Yaroslav Mudryi National Law University, \\ Kharkiv, Ukraine \\ tel.: + 380509270177 \\ e-mail:Drozdov.am1978@gmail.com
}

Received: 30.06 .2021

Accepted: 15.10 .2021
A - Work concept and design, B - Data collection and analysis, C - Responsibility for statistical analysis,

$\mathbf{D}$-Writing the article, $\mathbf{E}$-Critical review, $\mathbf{F}$ - Final approval of the article 


\title{
UKRAINE'S DRUG POLICY ON PSYCHOLOGICAL DISORDERS AND BEHAVIOR DUE TO THE USE OF PSYCHOACTIVE SUBSTANCES: PROSPECTS FOR DEVELOPMENT
}

DOI: 10.36740/WLek202111233

\author{
Tetiana A. Pavlenko ${ }^{1}$, Viktoriia A. Mozghova² \\ ${ }^{1} \mathrm{H}$. S. SCOVORODA KHARKIV NATIONAL PEDAGOGICAL UNIVERSITY, KHARKIV, UKRAINE \\ ${ }^{2}$ CIVIL ORGANIZATION «UKRAINIAN INSTITUTE FOR THE FUTURE», KYIV, UKRAINE
}

\begin{abstract}
The aim: Is to review the current state of Ukraine's drug policy development, primarily on criminal justice response to crimes committed by a person under the influence of drug addiction, to evaluate its compliance with international standards and best foreign practices.

Materials and methods: The study is based on the analysis of international documents, drug control strategies, sociological research in this area. The article is grounded on dialectical, systemic, and structural, comparative legal methods, methods of analysis, and synthesis.

Conclusions: The search for effective measures to tackle drug-related crimes remains an integral part of drug policy both in Ukraine and abroad. Programs for the prevention, medical and psychological rehabilitation of addicts need a scientific basis. The current situation, in which criminal justice does not consider the specifics of persons who have committed criminal offenses due to mental disorders connected with the use of psychoactive substances, is not effective in terms of recidivism prevention and ensuring public safety.
\end{abstract}

KEY WORDS: drug addiction, psychoactive substances, drug policy, medical and psychological rehabilitation

Wiad Lek. 2021;74(11 p.2):3053-3059

\section{INTRODUCTION}

According to International Statistical Classification of Diseases, Injuries, and Causes of Death implemented in Ukraine, the use of psychoactive substances can lead to a number of severe mental and behavioral disorders (F10-F19), which negatively affect everyday life of a person with such disorders and his entourage. At the same time, such psychoactive substances include not only well-known illicit substances, so-called "heavy" drugs (such as heroin (opioids), cocaine, etc.), but also those that are to some extent permitted for civil circulation, including alcohol, sleeping pills, and tobacco. A person can also become addicted to several prescription drugs, mainly sedatives or painkillers, including by gaining illegal access to them. Of particular concern now are the so-called new psychoactive substances which are becoming more widespread among minors.

Substance use disorder (SUD) is a complex process in the human psyche under which it is unable to fully control the use of such substances, even if the person understand their harmful effects on the body or the prospects of such influence in the future. The use of such substances can become almost the only goal of human existence, and thus daily life becomes disrupted. In such circumstances it is already a syndrome of addiction and other comorbidities. Unfortunately, the problem of addiction to psychoactive substances is relevant in Ukraine. As a result of a loud exposure by National Police on April 12, 2021, it became known that three hundred kilograms of amphetamine was produced in one of the farms in Dnipro city per month. Three hundred kilograms is 1 million 200 thousand doses, and their monthly illicit turnover reached 120 million hryvnias. And it is only one plant and only one type of drug $^{1}[1]$. More developed countries also did not avoid this "epidemic", in the United States, in 2018 in particular, opioids accounted for two-thirds of all deaths due to drug overdoses [2].

\section{THE AIM}

The purpose of this article is to review the current state of drug policy in Ukraine, primarily on the criminal justice response to crimes committed by a person under the influence of drug addiction, and to make proposals for its further development considering international standards and best foreign practices.

${ }^{1}$ Law enforcement officers confiscated the largest batch of amphetamine in Ukraine's history - Ihor Klymenko Available at: https://mvs.gov.ua/uk/press-center/news/pravooxoronci-vilucili-naibilsu-partiyu-amfetaminu-v-istoriyi-ukrayini-igor-klimenko 


\section{MATERIALS AND METHODS}

The research is based on Single Conventions on Narcotic Drugs 1961 p; UN Convention against Illicit Traffic in Narcotic Drugs and Psychotropic Substances 1988 p.; EU Drugs Strategy 2013-20; EU Drugs Strategy 2021 - 2025. In addition, in the study, we used data from Ukrainian and international institutions: United Nations Office on Drugs and Crime (UNODC), results of a national sociological survey conducted by "New Image Marketing Group" commissioned by the "Ukrainian Institute of the Future" NGO within the framework of Anna Mishchenko and Victoria Mozgova's project "Drug and Alcohol Addiction: Public Safety, Protection of Minors, Mental Health".

The research methodology and results are based on a set of general and special methods of cognition. The dialectical method was used to analyze the essence of the drug addiction phenomenon and its consequences for society. The comparative method allowed to establish the experience of drug policy implementation in several countries. General methods (analysis, synthesis, induction, deduction, abstraction, generalization) were helpful in processing sources. The statistical method allowed to analyze information on drug addiction and crime.

\section{REVIEW AND DISCUSSION}

People who suffer from mental and behavioral disorders due to the use of psychoactive substances may be aware of their problem, but for the most part, they cannot stop on their own, even if they want to and try to do so. Addictive physical and mental problems often cause complexities in interpersonal communication, for example, with family members and friends, leading to job loss. Alcohol and drug use is one of the leading causes of preventable diseases and premature deaths nationwide [3]. Due to the fact that the relevant disorders destroy both physical and mental health very quickly, the connection between drug spreading and crime is obvious. Thus, first, under the direct influence of drugs and number of other psychoactive substances on the human body, the deterrent and control mechanisms in the personality structure weakens, which causes an increased risk of crime, in particular, violent and violent-mercenary ones; secondly, meeting the need for systematic use of psychoactive substances involves high costs for their acquisition, which is also a factor in the commission of mercenary crimes; thirdly, the need to meet addictive requests for the use of such substances implies the presence of demand for the latter, which generates a corresponding supply. That is, drug spreading causes an increase in the level of production (manufacture) and sale of drugs, their smuggling. In turn, the drug market is associated with other types of crime - organized, transnational [4, p. 90]. There is also a clear link between alcohol, drug addiction, and domestic violence. Thus, according to a sociological survey conducted by the Ukrainian Institute of the Future together with "New Image Group" on the scale of domestic violence in Ukraine from June 18, 2021, to June 28, 2021, in which the sample size was 2400 respondents, it was found that the vast majority of citizens consider the leading causes of domestic violence to be two - alcohol use (79\%) and drug use (68\%). According to respondents, such answers are the most common and certainly occupy the first and second positions in the list of domestic violence causes [5].

Unfortunately, today, the prevalence of drug use by adolescents has become acute, including new synthetic drugs that cause irreversible negative processes in the psyche of children, suicidal behavior. In general, the most vulnerable are young people aged 14 to 25 . This trend is common to all countries, to all regions. Long-term research has been conducted in countries where the problem of drug addiction has long been recognized and where the rate of drug addicts is highest according to the UN (for example, the country where the most significant number of officially recognized drug addicts is the United States - 28.6 million people, including minors), indicate the relationship between crime and drug (especially heroin) addiction [6, p. 134]. For example, studies of juvenile drug use in juvenile delinquency courts have shown an increase in abuse. More juveniles have positive results of drug testing as part of nationwide monitoring programs. Some jurisdictions have shown positive drug test scores of up to 58 percent. In 2017, the prevalence of cannabis use among 15-64-yearolds was estimated at $3.8 \%(2.7 \%-4.9 \%)$, or about 200 million people who use cannabis worldwide (regional use is highest in North America, Oceania, and West Africa, with a prevalence of 10-25\% in 2017, followed by Europe and other regions).

Moreover, cannabis use is most common among adolescents and young adults (e.g., 15-25 years). In this group, the prevalence in 2017 was $25 \%$ or higher in regions with high use, often higher than tobacco use [8, p. 2]. UNODC estimates that in 2019 almost 4 percent (range: $2.8-5.1 \%$ ) of the world's population aged 15-64 tasted cannabis at least once, equivalent to about 200 million people (range: 141- 256 million) [9, p. 19]. In Ukraine, this problem is no less acute. According to the results of the mentioned national survey conducted by "New Image Marketing Group" within the project "Drug and Alcohol Addiction: Public Safety, Protection of Minors, Mental Health" and presented on April 28, 2021 (2400 respondents were interviewed), it was found that every tenth Ukrainian has encountered drug addiction among his close circle - family, relatives, friends, neighbors or colleagues; the vast majority (65\%) of young people aged 18-24 have relatives, friends or acquaintances addicted to cannabis, which is twice the national rate; young people aged 18-24 were twice as likely as the national average to experience drug addiction - $10 \%$; in $53 \%$ of cases, people with drug and alcohol addiction were dangerous to themselves or others; most often those who encountered drug addiction in their immediate environment mentioned such substances as cannabis (31\%) and amphetamines (18\%); $13 \%$ of respondents stated that they knew about one or even several points of illegal drug trafficking, not far from their home [5].

Addiction due to the use of psychoactive substances is a socially dangerous phenomenon, a serious disease that 
negatively affects a person's relationship with the outside world. Most addicts belong to so-called "vulnerable groups" in terms of their health and lifestyle. Vulnerable groups are those who have limited opportunities to exercise their rights and freedoms and therefore need assistance. As for those who have committed criminal offenses due to their addiction, it is evident that punishment alone is not enough to counteract the risk of criminal recidivism. Such offenders, in the first place, need treatment and psychological rehabilitation in the interests of public safety, which is a positive international practice in the field of preventing a person from committing new crimes due to his addiction.

If we talk about recent Ukraine's drug policy in the field of drug addicts' treatment and rehabilitation, it is still moving towards positive change, albeit very slowly. In 2017, the mass practice of illegal detention of drug addicts in private rehabilitation centers became public, and the facts of their torture and exploitation became known. On the one hand, the real scale of the state's inability to meet the needs of drug addicts and their families in affordable, high-quality, individual-oriented psychiatric and rehabilitation care was exposed. On the other hand, there was despair, hopelessness, exhaustion of drug addicts' family members, their physical, psychological, and material suffering from socially harmful or dangerous behavior of their relatives; the problem of illegal profit of some dishonest rehabilitation centers built on people's distress and helplessness [10].

According to Single Conventions on Narcotic Drugs, 1961 [11] and the UN Convention against Illicit Traffic in Narcotic Drugs and Psychotropic Substances 1988 [12], other regulations in this area, the main task of drug control is to ensure the health and well-being of humankind. Human rights and freedoms derive from the recognition of the dignity and value of the individual. They are universal and holistic, and a person cannot be deprived of them on the grounds that he or she is using drugs or is HIV-positive. As the UN High Commissioner for Human Rights Navanethem Pillay aptly noted, "drug users should not be deprived of any rights" [13, p. 2928].

The European Union has applied a single approach to the fight against drug addiction, which is reflected in the EU Drugs Strategy 2013-20 [14], the main emphasis was on measures of medical and social response to this problem. Such measures were intended, first and foremost, to ensure the human right to the highest level of physical and mental health, appropriate treatment, and equal access to such treatment. Based on the Strategy for 2013-2020, a new Strategy (EU Drugs Strategy 2021 - 2025 [15]) was approved, which aims to ensure a high level of health promotion, social stability and security, and to promote awareness. Due to this EU strategy, its Member States have reaffirmed their commitment to an evidence-based approach grounded on factual data, comprehensive and balanced between the demand and the reduction in the supply of medicines with respect for human rights at the core. At the same time, the Strategy is built on the lessons learned from the COVID-19 drug crisis and uses a forward-looking approach, promoting research, innovation, and foresight, to respond more effectively to growing challenges and anticipate them. The scope of drug demand reduction policy consists of several mutually reinforcing measures, including prevention, early detection and intervention, counseling, treatment, rehabilitation, social reintegration, and recovery. Such actions must respond to the target population's local social context and needs, be informed by scientific evidence, and be safe and effective. The Strategy emphasizes the need for close cooperation between a number of health care and social support services.

Moreover, the COVID-19 crisis has further revealed the need to ensure the continuity of these actions. In addition, a new, particular chapter on the fight against drugs has been added. This section includes measures and policies to prevent or reduce potential health and social risks and harm to users, society, and prisons. It covers aspects such as reducing the prevalence and incidence of drug-related infectious diseases, preventing drug overdoses and deaths, and providing alternatives to coercive sanctions.

That, as well as the direct practical experience of countries whose drug policy today has reached a high and innovative level, is considered interesting and vital for Ukraine.

In particular, based on foreign experience, the impetus for developing effective state and local treatment, and psychological rehabilitation programs in Ukraine may become relevant legislative changes that will oblige the state to introduce them for drug-addicted offenders. It should be noted that it is not a question of spreading the use of substitution maintenance therapy drugs (which is already available in Ukraine and stimulated by the state), but of developing new and improving existing programs of psychiatric and psychological care for addicts, using best foreign practices in this industry.

The special legislation of some European countries and the United States is of interest. In particular, the special laws of Poland ("Ustawa o przeciwdziałaniu narkomanii" [16], Articles 70a-74), Portugal ("Legislação de combate à droga" [17], Articles 44-47, 52, 55, 56), Italy ("Testo unico sulla droga "([18], Articles 72-103), Germany (" Gesetz über den Verkehr mit Betäubungsmitteln ”[19], Chapter 7), Slovakia (“Trestný zákon ”[20], Articles 35, 51, 73, 74), Latvia (Krimināllikums [21], Articles 59, 61), Switzerland (Schweizerisches Strafgesetzbuch [22], Articles 60, 63a).

In general, the legislation of these EU countries has common features. First, the level of legislation identifies such a category of persons as "persons who have committed crimes related to drug addiction." In contrast to Ukraine, the emphasis is not primarily on the fact that the guilty person is addicted but on the fact that this addiction caused his criminal activity.

In Portugal, for example, if at any stage of the criminal proceedings it becomes known that a person may have committed a crime related to drug addiction, a medical diagnosis is made to confirm or deny the fact of such addiction. Under Polish law, in addition to such a diagnosis, an opinion may be provided on the possibility (expediency) of applying to a person such treatment or rehabilitation measures as alternatives to criminal prosecution, which are discussed below. 
Second, criminal proceedings against drug-addicted offenders are aimed at motivating a person to voluntarily undergo appropriate treatment. Usually, depending on the severity of the crime and the type of punishment, the course of treatment may be:

- a precondition for exemption from criminal liability,

- an alternative to serving a short-term (up to 2-3 years) imprisonment,

- a condition for early release from the institution of imprisonment.

Third, strict state supervision over the treatment process. When choosing any of the above three mechanisms or their analogs, the person is supervised during the treatment and in case of evasion of treatment, a gross violation of the medical institution regime, committing a new crime during treatment (or period of supervision), etc. - the person is sent to serve a sentence or the unserved part of it.

The court systematically receives information from the supervisory authority or medical institution about the treatment progress. For example, in Slovakia, Switzerland, if the treatment does not objectively yield the expected result, the court may terminate it.

Fourth, the duration of treatment is not determined by a court in advance, but it usually cannot last more than 2-3 years, i.e., the period during which the term of imprisonment would last. At the same time, if a person has successfully undergone a course of such treatment, for example, in one year, the state supervision of his behavior will be prolonged for another 1-2 years, respectively.

Fifth, drug treatment is provided by the state (in whole or in part) and is individually targeted, depending on the type of substance use disorder (SUD), and can be both outpatient and inpatient combined with psychological rehabilitation. Treatment and rehabilitation programs are clearly regulated, which prevents the risks of abuse and corruption.

Interesting, from the practice of motivation for treatment or rehabilitation point of view, as well as the procedures for their passage, is the experience of the United States, where there are specialized courts for drug addicts, whose judges are actively involved in providing treatment (rehabilitation) at all stages. One of the most successful (in terms of reducing crime recidivism) in the United States is the programs of the relevant courts in Utah (Utah's Drug Courts), which are mostly an alternative to imprisonment. The duration of the program is at least 52 weeks, and its successful completion requires that the person have "clean drugs tests" for at least six consecutive months. During treatment, individuals systematically visit a judge (almost weekly so that he can personally review progress), undergo regular drug testing, and are under police surveillance. Penalties for non-compliance with the program may include imprisonment. At the same time, treatment progress is encouraged by various certificates, gifts, and more. The program encourages and helps participants to study and get a job to change the circle of friends qualitatively. Treatment is, in fact, free of charge, but a person may pay a fee that partially covers the cost of drug testing [23].
As for adults in Salt Lake County who are charged for criminal offenses and have no violence records, they can be screened by the Drug Court program. Persons who can be convicted have the right to be referred to the Drug Court instead of a conviction as an alternative to sentencing by the traditional justice system. In this case, for at least a year, participants: are provided with intensive care and other services necessary to maintain cleanliness and sobriety; they are brought to justice before the court, society, themselves, and their families by a drug judge for the performance of their duties; regular and random drug testing is conducted; it is necessary to visit a court often so that the judge can check the progress; remuneration is provided for fulfilling the conditions of the program, or vice versa, sanctions are applied for non-fulfillment [23].

In general, it can be said that by stimulating the person's desire to receive treatment in the EU and the USA, the risks of committing new crimes based on drug addiction are minimized, and the preconditions for resocialization are created. At the same time, the sphere of providing relevant services also to persons who do not have problems with the law is actively developing.

In Ukraine, formally, there are separate mechanisms in criminal law that encourage the treatment of drug-addicted offenders, including those who have committed crimes related to drug trafficking. Practically, however, these mechanisms are "dead" and lead to avoiding liability rather than ensuring proper treatment and preventing recidivism. In general, the analysis of the problem of ensuring access to appropriate quality treatment and rehabilitation services in Ukraine is opposed by familiar factors, such as staff shortages, material and technical base, funding, and legislative shortcomings.

Today, in order to solve this problem, the Verkhovna Rada of Ukraine has registered a draft Law of Ukraine № 5715 of 29.06.2021 “On Amendments to Certain Legislative Acts of Ukraine Concerning the Peculiarities of Criminal Liability of Persons Who Commit Offenses in Connection with Drug and other psychoactive substances addiction, as well as the organization of rehabilitation of such persons", which is the result of fruitful cooperation of specialists - legal, medical, psychological and human rights' specialists [24]. This draft law is based on advanced foreign experience and pursues the interests of Ukraine. On the one hand, it introduces the peculiarities of the criminal liability application to convicted persons who have committed criminal offenses in connection with their mental and behavioral disorders due to SUD. And on the other hand, it is an impetus for the development in Ukraine of effective state and local programs of medical and psychological rehabilitation of persons with these types of disorders and prevention of such disorders among children. This draft law is consistent with the Declaration of the UN General Assembly on guidelines for reducing drug demand [25], as well as Article 21 of the Association Agreement between Ukraine and the European Union, the European Atomic Energy Community, and their Member States [26], which noted the importance of targeted action 
to reduce the demand for drugs, combating the health and social consequences of drug addiction.

This draft law introduces changes to several laws, which propose establishing effective criminal and criminal-procedure law mechanisms that will reduce crime caused by mental and behavioral disorders due to the use of psychoactive substances; reduce a level of new criminal activity offenses by the relevant category of persons. In addition, the draft law creates the grounds for the development of high-quality medical and psychological rehabilitation of persons with mental and behavioral disorders due to the use of psychoactive substances, which will be carried out on a competitive basis by entities of various forms of ownership, that in turn will eliminate the harmful practice of human rights violations for people with addiction. Also, the draft law improves specific provisions on the procedure of hospitalization of persons with mental disorders and the application of precautionary measures to them during criminal proceedings [27]. In particular, we are talking about the separation of the category of convicted persons - "persons who have committed a criminal offense in connection with the mental and behavioral disorders due to the use of psychoactive substances." The draft law provides for the possibility of releasing such persons from criminal liability, punishment, or serving it only if there are two conditions: the general conditions for all categories of offenders and the grounds for applying the appropriate type of release (i.e., acquired the right to release on general grounds); they have agreed to undergo rehabilitation in a specialized institution that has the right to carry out rehabilitation in the field of health care. That is, under the threat of actual punishment, such persons are motivated to undergo rehabilitation for persons with mental and behavioral disorders due to the use of psychoactive substances, which, in turn, creates conditions to reduce the risk of committing new criminal offenses in connection with the existing disorder.

In particular, it is proposed to ensure strict state supervision over the rehabilitation process, the implementation of which is entrusted to the probation body. And in case of non-compliance by the guilty person with the undertaken obligation, the court prosecutes such a person and sends him to serve a sentence.

As for the term of rehabilitation, it must be determined by a doctor, but for the needs of criminal justice it cannot be less than 3 or 6 months and longer than the probationary period set by the court of 1-3 years (if the latter was established). We emphasize that such rehabilitation, according to the draft law, should be carried out free of charge (i.e., at the expense of the state) and following the individual rehabilitation plan.

It is proposed to provide for the possibility of applying rehabilitation measures to minors (with their consent) who have committed a criminal offense in connection with mental and behavioral disorders due to the use of psychoactive substances.

It should be noted that work is underway to finalize specific provisions of the draft law, in particular, on a more comprehensive regulation of rehabilitation in the field of mental health and the exclusion of "dead" norms of current legislation which since the 1990s provide for such procedures for applying coercive measures to a dependent person, which is a gross violation human rights and in the long run could not lead to positive changes for either public safety, nor for the effective restoration of drug addicts mental health and their social reintegration. In addition to the draft law activities in the field of drug policy, the work carried out under the organizational guidance of Ukraine's Ministry of Health to develop and approve the government's State Drug Policy Strategy until 2030 [28] is should also be noted. An analysis of the current provisions of this Strategy draft shows its approximation to international standards in this area and strict observance of human rights.

The implementation of best foreign practices in Ukraine to combat drug trafficking, treatment, and rehabilitation of drug addicts, including those who have committed crimes due to such addiction, will also be influenced by the long-awaited accession to the Group for Cooperation in Combating Drug Abuse and Illicit Trafficking (Group Pompidou). According to the recently adopted Law of Ukraine 1647-IX of 14.07.2021, joining the Pompidou Group may take place as early as 2022, in connection with the entry into force of this Law on January 1, 2022 [29]

\section{CONCLUSIONS}

Based on the above, we can conclude that the guarantee and protection of human rights and freedoms should be a priority in the policy of modern states without any discrimination. And the basis for that should be the state drug policy for the prevention of mental and behavioral disorders due to the use of psychoactive substances, the search for and implementation of effective measures to address the problem of such disorders and minimize their negative consequences. First of all, offenders who have committed a crime related to drug addiction need treatment (rehabilitation) and social assistance to prevent them from committing new crimes. Such rehabilitation should be accessible, compelling, and differentiated, depending on the psychoactive substances used by the person. By providing such treatment, the state thus builds a system of assistance to other persons (relatives of the drug addict).

\section{REFERENCES}

1. Klymenko I. Pravookhorontsi vyluchyly naibilshu partiiu amfetaminu $v$ istorii Ukrainy [Law enforcement officers seized the largest batch of amphetamine in the history of Ukraine] Available from: https://mvs. gov.ua/uk/press-center/news/pravooxoronci-vilucili-naibilsu-partiyuamfetaminu-v-istoriyi-ukrayini-igor-klimenko (in Ukrainian).

2. Fritz L. Hershey, What Is Drug Addiction? PsyD, MFT on January 20, 2021 Available from: https://www.webmd.com/mental-health/addiction/ drug-abuse-addiction\#1

3. Hector Colon-Rivera, M.D., CMRO Alëna Balasanova, M.D. American Psychiatric Association December 2020 Available from: https://www. psychiatry.org/patients-families/addiction/what-is-addiction 
4. Iosypiv A.0. Vplyv zlovzhyvannia alkoholem ta narkotychnymy rechovynamy na zlochynnist osib z marhinalnoiu povedinkoiu. Naukovyi visnyk Mizhnarodnoho humanitarnoho universytetu. Ser.: Yurysprudentsiia. 2013;6-2: 89-91 (in Ukrainian).

5. Narkotychna ta alkoholna zalezhnist: bezpeka suspilstva, zakhyst nepovnolitnikh, psykhichne zdorovia. Sotsialnyi dialoh doslidzhennia [Drug and alcohol dependence: public safety, protection of minors, mental health. Research, surveys, reviews and reports on drug and alcohol dependence] Available from: https://socialdialogue.com.ua/ page19689112.html (in Ukrainian).

6. Kalimbet I.L. Zlochyny nepovnolitnikh, skoieni pid vplyvom narkotychnykhzasobiv. Naukovyi visnyk Mizhnarodnoho humanitarnoho universytetu. Ser.: Yurysprudentsiia. 2019;38:131-135 (in Ukrainian).

7. Juvenile Delinquency Court and Health Issues. Available from: https:// childsafety.losangelescriminallawyer.pro/health.html

8. B. Fischer, T. Robinson, C. Bullen et al. Lower-Risk Cannabis Use Guidelines (LRCUG) for reducing health harms from non-medical cannabis use: A comprehensive evidence and recommendations update. International Journal of Drug Policy. m5GeSdc;August 28, 2021;10:52, 1-21.

9. World Drug Report 2021 (United Nations publication, Sales No. E.21. XI.8). $125 \mathrm{p}$.

10. Viktoriia Mozghova Narkozalezhnist: likuvaty ne mozhna bez diiaty [Drug addiction: you can not treat inaction]. Available from: https://m. censor.net/ru/blogs/3260434/narkozalejnst_lkuvati_ne_mojna_ bezdyat (Ua).

11. Single Conventions on Narcotic Drugs 1961 (As amended by the 1972 Protocol amending the Single Convention on Narcotic Drugs, 1961). Available from: https://www.unodc.org/pdf/convention_1961_ en.pdf

12. UN Convention against Illicit Traffic in Narcotic Drugs and Psychotropic Substances 1988. Available from: https://www.unodc.org/pdf/ convention_1988_en.pdf

13. Inna K. Polkhovska, Anna S. Sydorenko, Olena D. Melnyk The right to medical assistance for drug addicts: examination of the problem Wiad Lek, 2020; LXXIII: 2927-2933.

14. EU Drugs Strategy (2013-20). Official Journal of the European Union 29.12.2012. ( 402/2

15. Council of the European Union. EU Drugs Strategy 2021 - 2025. Brussels, 18 December 2020 (OR. en) 14178/20

16. Ustawa o przeciwdziałaniu narkomanii. Dz. U. 2005 Nr 179 poz. 1485. Opracowano na podstawie: t.j. Dz. U. z 2020 r. poz. 2050.

17. Legislação de combate à droga (versão atualizada, com índice) - DecretoLei n. ${ }^{0}$ 15/93, de 22 de janeiro, atualizada até à Lei n. ${ }^{0} 8 / 2019$, de 1 de fevereiro. https://data.dre.pt/eli/dec-lei/15/1993/1/22/p/dre/pt/html

18. Testo unico sulla droga. Decreto del Presidente della Repubblica 9 ottobre 1990, n. 309. Gazzetta Ufficiale 31 ottobre 1990;255: 67

19. Gesetz über den Verkehr mit Betäubungsmitteln. In der Fassung der Bekanntmachung vom 1. März 1994 (BGBI. I S. 358).

20. Trestný zákon.z20. mája 2005 Available at: https://www.zakonypreludi. sk/zz/2005-300

21. Krimināllikums. Likums Saeimā pien̦emts 1998.gada 17.jūnijā. Available from: https://likumi.lv/ta/id/88966-kriminallikums

22. Schweizerisches Strafgesetzbuch vom 21. Dezember 1937 (Stand am 1. Juli 2021) Available at: https://www.fedlex.admin.ch/eli/ cc/54/757_781_799/de

23. Drug Court Program. Available from: https://slco.org/criminal-justice/ treatment-services/drug-court-program/
24. Avtorskyi kolektyv Proiektu Zakonu Ukrainy «Pro vnesennia zmin do deiakykh zakonodavchykh aktiv Ukrainy shchodo osoblyvostei kryminalnoi vidpovidalnosti osib, yaki vchyniaiut pravoporushennia u zviazku iz naiavnistiu zalezhnosti vid narkotychnykh ta inshykh psykhoaktyvnykh rechovyn, a takozh orhanizatsii reabilitatsii takykh osib» Available from: https://w1.c1.rada.gov.ua/pls/ zweb2/webproc34?id=\&pf3511 =72374\&pf35401=550375 (in Ukrainian).

25. Deklaraciya o rukovodyashchih principah sokrashcheniya sprosa na narkotiki. Prinyata rezolyuciej S-20/3 General'noj Assamblei ot 10 iyunya 1998 goda [Declaration on guidelines for reducing drug demand. Adopted by General Assembly resolution S-20/3 of 10 June 1998] Available from: https://zakon.rada.gov.ua/laws/show/995_347\#Text (in Russian).

26. Uhoda pro asotsiatsiiu mizh Ukrainoiu, z odniiei storony, ta Yevropeiskym Soiuzom, Yevropeiskym spivtovarystvom z atomnoi enerhii i yikhnimy derzhavamy-chlenamy, z inshoi storony. Uhodu ratyfikovano iz zaiavoiu Zakonom № 1678-VII vid 16.09.2014 [Association agreement between Ukraine, of the one part, and the European Union, the European Atomic Energy Community and their Member States, of the other part] Available from: https://zakon.rada.gov.ua/laws/show/984_011\#Text (in Ukrainian).

27. Poiasniuvalna zapyska do proiektu Zakonu Ukrainy «Pro vnesennia zmin do deiakykh zakonodavchykh aktiv Ukrainy shchodo kryminalnoi vidpovidalnosti osib, yaki vchyniaiut pravoporushennia u zviazku iz naiavnistiu zalezhnosti vid narkotychnykh ta inshykh psykhoaktyvnykh rechovyn, a takozh orhanizatsii reabilitatsii takykh osib» [Explanatory note to the Draft Law on Amendments to Certain Legislative Acts of Ukraine Concerning the Peculiarities of Criminal Liability of Persons Committing Offenses in Connection with the Presence of Addiction to Narcotic and Other Psychoactive Substances, as well as the Organization of Rehabilitation of Such Persons] Available from: http://w1.c1.rada.gov.ua/pls/zweb2/webproc4_1?pf3511=72374 (in Ukrainian).

28. MOZ proponuie zatverdyty Stratehiiu derzhavnoi polityky shchodo narkotykiv na period do $2030 \mathrm{r}$. [The Ministry of Health proposes to approve the Strategy of State Drug Policy for the period up to 2030.]. Available from: https://www.dls.gov.ua/ for_subject/\%D0\%BC\%D0\%BE\%D0\%B7-\%D0\%BF\%D1\%80\%D 0\%BE\%D0\%BF\%D0\%BE\%D0\%BD\%D1\%83\%D1\%94-\%D0\%B7 \%D0\%B0\%D1\%82\%D0\%B2\%D0\%B5\%D1\%80\%D0\%B4\%D0\% B8\%D1\%82\%D0\%B8-\%D1\%81\%D1\%82\%D1\%80\%D0\%B0\%D 1\%82\%D0\%B5\%D0\%B3\%D1\%96\%D1\%8E-\%D0\%B4\%D0\%B5/ (in Ukrainian).

29. Pro pryiednannia Ukrainy do Chastkovoi uhody pro stvorennia Hrupy zi spivrobitnytstva u borotbi proty zlovzhyvannia narkotykamy ta yikh nezakonnoho obihu (Hrupa Pompidu): Zakon Ukrainy, 14 lypnia 2021 roku № 1647-IX [On Ukraine's Accession to the Partial Agreement Establishing a Group on Cooperation in Combating Drug Abuse and Illicit Trafficking (Pompidou Group)] Available from: https://zakon.rada.gov. ua/laws/show/1647-IX\#Text (in Ukrainian).

\section{ORCID and contributionship:}

Tetiana A. Pavlenko: 0000-0002-6019-1086 A,B,D,F

Viktoriia A. Mozghova: 0000-0002-3225-7631 A,B,D

\section{Conflict of interest:}

The Authors declare no conflict of interest 


\section{CORRESPONDING AUTHOR}

\section{Tetiana A. Pavlenko}

H. S. Scovoroda Kharkiv National Pedagogical University

Kharkiv, Ukraine

e-mail: pavlenkotatyana7@gmail.com

Received: 30.07 .2021

Accepted: 14.10 .2021

A - Work concept and design, B - Data collection and analysis, C - Responsibility for statistical analysis,

D-Writing the article, $\mathbf{E}$-Critical review, $\mathbf{F}$ - Final approval of the article 


\title{
RESEARCH USE OF HUMAN IN VITRO EMBRYOS: LEGAL BOUNDARIES
}

D0I: 10.36740/WLek202111234

\author{
Natalia M. Kvit ${ }^{1}$, Sibilla B. Buletsa ${ }^{2}$, Vasyl V. Kopcha ${ }^{2}$ \\ ${ }^{1}$ IWAN FRANKO LVIV NATIONAL UNIVERSITY, LVIV, UKRAINE \\ 2 UZHHOROD NATIONAL UNIVERSITY, UZHHOROD, UKRAINE
}

\begin{abstract}
The aim: The purpose of this research is to study foreign experience in the field of legal regulation of the use of embryos in vitro to suggest ways to fill the gaps in current Ukrainian legislation and bring it into line with international law.

Materials and methods: The subject of the research was the legal regulation of the in vitro embryo research use, which is completely outside of the current Ukrainian legislation. That is why the European models of its regulation were analyzed. The experience of Germany and Hungary in the field of in vitro embryo research use regulation was considered as an example and was compared with the current Ukrainian regulation.

Conclusion: As the use of non-implanted embryos is outside the legal field, the anatomical materials of a dead embryo, whether implanted or not, can be removed both for scientific research within the statutory framework (subject to approval by the ethics committee) and with the therapeutic purpose (for cell transplantation), subject to the relevant proposed amendments to the legislation to comply with the requirements of the Convention on Human Rights and Biomedicine (Art. 18). Instead, the creation and further use of embryos for any purpose other than reproductive is illegal and should be prohibited by law with the imposition of appropriate criminal penalties. The right to dispose of embryos for research purposes may be granted by the woman and the man for whom the embryo was created, subject to informed consent and personal data processing consent.
\end{abstract}

KEY WORDS: human embryo, scientific research, embryonic stem cells, legislation

Wiad Lek. 2021;74(11 p.2):3060-3066

\section{INTRODUCTION}

In each country of the world, laws regulating human embryo research are rooted in national politics, native, religion, and history. Countries around the world have responded to the ethical problems raised by embryonic stem cell (hereinafter - ES cell) research in a number of ways. Some governments have passed laws prohibiting all research on human embryos, while others have explicitly endorsed and funded ES cell research.

The literature emphasizes that $95 \%$ of in vitro fertilized embryos die and some of them are deliberately destroyed: some due to unsuitability for implantation; others are initially stored as "spare" for further attempts to fertilize the same patient; they are discarded after their expiration date in the frozen state, or used in experimental studies of drugs, abortions, vaccines, oncogenic substances, etc. [1]. Ukrainian scientists, focusing on the ethical issues of in vitro fertilization (IVF), include the following: biological rights of the embryo and social problems, as well as the problem of ownership of "extra" embryos [2].

The above studies would be impossible without the existence of in vitro fertilization technology, the so-called In Vitro Fertilization (hereinafter-IVF) or IVF as it is called in domestic law. However, none of these types of research is part of the immediate goal of IVF. Moreover, IVF activities create favorable conditions for these studies and at the same time provide them with "material" that is no longer needed for the initial purpose, the so-called "Surplus (unused) embryos". We believe that, given that these embryos were not used for any reason and were not implanted in a woman's body, it is more correct, including from an ethical point of view, to apply the term "implanted embryos" instead of "unused" or "redundant".

The question is whether these live in vitro embryos, which have no prospects for further development due to the impossibility for some objective reasons to be implanted, and therefore, sooner or later, will inevitably die, can be used for research to expand knowledge about development embryos in the interests of reproductive medicine "and/or" the development of new treatments for the most severe and incurable diseases, mainly by obtaining embryonic stem cells from them.

When it comes to an embryo and embryonic stem cell research, it is important to first distinguish between "embryo research" and "embryo research". These are two different areas, which, both legally and ethically, have their own characteristics. If we are talking about "embryo research", then we are talking about research that is conducted in the interests of its healthy and full development, therefore, from an ethical point of view, there are no problems, because these studies are positive for the embryo. Instead, the second type of research raises much more questions in both the legal and ethical spheres. 


\section{THE AIM}

The purpose of this research is to study foreign experience in the field of legal regulation of the use of embryos in vitro to suggest ways to fill the gaps in current Ukrainian legislation and bring it into line with international law.

\section{MATERIALS AND METHODS}

The issue of in vitro embryo legal protection hasn't been the subject for scientific research in Ukraine, as Ukrainian legislation regulates only general questions of embryos usage in reproductive medicine. The research use of the in vitro embryo is unfortunately completely outside of the current legal regulation in Ukraine. The legislation, which is supposed to regulate the research involving human embryos, must undergo systematic analyzes and consider the experience of the other legislations for improvement suggestions to be made. Therefore, structural, functional, and legal comparative methods, as well as systematization, analysis, and synthesis were used during the research process.

\section{REVIEW AND DISCUSSION}

The problem of research on embryos has long been intensively discussed at the international level and the conclusions from this discussion are very different. And today the hottest discussions revolve around the so-called "14-day rule", which provides for the possibility of embryo examination only within the first two weeks after fertilization. Many other countries worldwide permit human embryo research, e.g., on the surplus in vitro fertilization embryos, until day 14 post fertilization. Countries around the world take a variety of approaches to human embryo research. Some - like Italy and Germany - don't allow it at all. Others, like the $\mathrm{UK}$, allow research to continue until the embryo is 14 days old, after which it must be destroyed. There are also some which permit embryo research without identifying a limit. Some, like the US, do not have any law regulating it (but there are guidelines that contain a reference to the 14-day rule). In South Africa, reference to the rule is found in the National Health Act (2003), which states that human embryo research may only be done with the permission of the minister and that the embryos must not be older than 14 days [3]. Four countries did not have a date limit: Brazil, France, Israel, and the USA. Brazil's laws on human embryonic stem cells (hereinafter - HESC) research prohibit "genetic engineering on human germ cells, human zygotes or human embryos" but do not address a development limit or other restrictions on human embryo research. Israel has a 1999 law banning reproductive cloning and a set of guidelines for HESC research, but it does not address nor limit in vitro human embryo research. French law permits the use of leftover IVF embryos for scientific research if scientifically justified and with prior authorization by the Agency of Biomedicine. This bioethics law is under review in 2020, and the new version could include more permissive language related to human embryo research, including potentially adding a 21-day limit [4]. In at least
12 countries (Canada, Iceland, Spain, Slovenia, the United Kingdom, Denmark, the Netherlands, Sweden, Australia, New Zealand, South Korea, and Switzerland, it has set a legal limit of 7 days), this limit is implemented in national legislation that regulates assisted reproductive technologies and embryo research [5]. This rule was introduced in 2016 in the Guidelines for conducting such research by the International Stem Cell Research Association for the global scientific community. But on May 26, 2021, new guidelines came into force, which allowed each country to decide or limit such research and how. Therefore, since this document is not a normative act, but is recommendatory, such changes do not mean that researchers around the world will now be able to conduct in vitro embryo research without restrictions and grow embryos in the laboratory as much as they want. After all, as mentioned above, many countries have adopted this rule by implementing it in national legislation, and until they amend their legislation, such research will continue to be prohibited. However, for countries that did not have the appropriate legal regulation, which includes Ukraine, this will create the preconditions for the formation of legislation loyal to such ethically controversial research and the use of such countries as "raw material bases". It has been noticed that there is no specific legislation regarding human embryo research or human ES cell research: Belgium, Italy, Luxembourg, and Portugal. Allowing by law for the creation of human embryos for research purposes: UK is for the moment the only Member State, which allows by law for the creation of human embryos either by fertilization of an egg by sperm or by somatic cell nuclear transfer (hereinafter - SCNT, also called therapeutic cloning) for stem cell procurement. The bill under discussion in the Belgian Parliament would allow for the creation of human embryos for research purposes including by SCNT. The Dutch Embryo Act of 2002 includes a five-year moratorium for the creation of embryos for research purposes including by SCNT.

Prohibiting the creation of human embryos for research purposes and the procurement of stem cells by law or by ratification of the Convention of the Council of Europe on Human rights and Biomedicine (далі - Конвенція про права людини та біомедицину) signed in Oviedo on 4 April 1997: Austria, Denmark, Finland, France, Germany, Greece, Ireland, Netherlands, Portugal and Spain [6].

The basic norms in this issue at the level of international law are the norms of Part 1 and 2 of Article 18 (In vitro Embryo Research) of the Convention on Human Rights and Biomedicine, which was signed by Ukraine on March 22, 2002. Article 18.1 states that "where the law allows research on embryos in vitro, it shall ensure adequate protection of the embryo." However, the term "adequate protection" is not defined in detail. Hence, Member States are at liberty to undertake the conditional authorization of research with "surplus" embryos. Thus, the admissibility at the national level of research on live embryos requires the unequivocal creation of legislative guarantees for their protection, although the wording "appropriate protection" does not contribute to a clear understanding of what is- 
sues need to be addressed to achieve the required level of protection. Although these provisions do not provide the human embryo with absolute protection from research, they create a certain framework and conditions for its protection during such research.

In the field of so-called foreign studies of human embryos (studies on embryos, but not in its interests) the most problems are caused by research and experiments conducted using embryonic stem cells, which are obtained from embryos at an early stage of their development, reproduce in the so-called. cell cultures and form the basis for the creation of whole-cell lines, which are then used to test and develop new drugs or even patented. The issue of embryo protection in the context of this issue is important because the production of embryonic stem cells from human embryos results in their destruction, and therefore the legality and ethics of such actions are debatable.

In this context, the decision of the ECHR from 18.10.2011 on the revocation of a patent for human ESCs, as a result of which the court generally prohibited such patenting (decision C-34/10) [7], the European Court of Justice ruled that German stem cell scientist Oliver Brüstle's patent on neural precursor cells derived from human ES cells violated Article 6 of the European Biopatent Directive, which specifies that "uses of human embryos for industrial or commercial purposes" cannot be patented. The judges argued that human embryonic stem cells could not be the subject of intellectual property rights because human embryos were destroyed to obtain them, in violation of the principle of protection of human dignity. However, there is no denying the possibility that the use of embryonic stem cells with therapeutic or diagnostic goals in the interests of the embryo (for example, in certain disorders of its development) - may be the subject of patents.

The ECHR judges reached another important conclusion in the analyzed decision, noting that since the use of a human embryo for research purposes cannot be imagined without future commercial use, medicines based on embryonic stem cells cannot be the exclusive right to sell them. This conclusion provoked a wave of outrage in Europe, emphasizing that now pharmaceutical companies and investors will lose interest in such research, which will negatively affect the development of the medical and pharmaceutical industries. However, we share the position of European bio-patent expert Ingrid Schneider from the University of Hamburg, who noted that today such projects and research are still mostly funded by public funds, and the lack of patents that could limit the space for research will expand for researchers. opportunities for the development of science [8]. In addition, this solution will provide an impetus for the intensification and development of research into the potential of adult human stem cells.

The issue of legal protection of intellectual property rights, the object of which is the human genome, tissues, or cells, is currently being hotly debated in the world. However, legal approaches to the possibility of patenting such objects can be divided into those that completely deny the patenting of the human genome, as well as other human tissues and cells, and those that cause such a process of certain restrictions of moral, ethical, and legal nature, such as, for example, the issue of ensuring the confidentiality of information about the person whose materials are being investigated. It seems that given the above practice of the ECHR, it would be appropriate to establish the possibility of free use of the results of such research, which would be in the interests of society and science. Six EU Member States (Cyprus, Ireland, Poland, Luxembourg, Malta, Romania) do not have clear written legislation on embryo and embryonic stem cell research or cloning, one in five Member States (Cyprus) refers to the biomedical convention. a means of filling the lack of national legislation.

In German law, the issue of embryonic stem cell research is based on $\$ 1$ Paragraph 1, Clause 2 and $\$ 2$ Paragraphs 1 and 2 of the German Embryo Protection Act, which stipulates that anyone who "uses" or creates an extracorporeally created embryo is subject to punishment. for other non-reproductive purposes [9].

Obtaining embryonic stem cells is possible in two ways. They can be obtained from non-implanted live embryos (from the 5th day of their development) or embryo-fetal (abortive) materials (dead embryo materials). Concerning the first option, German law completely prohibits such a procedure, as it leads to the destruction of a viable embryo, which is treated as misuse and is punishable by up to three years in prison or a fine, following $\$ 2$ Clause 1 . Embryo Protection Act [10]. The only exception to this protective rule is the use in the form of destruction of embryos in respect of which it was decided not to implant due to genetic abnormalities or disorders (preimplantation diagnostics) the reason for this exception was the interpretation of this rule in the German Federal Court. (Bundesgerichtshof) 06.07.2010 [11].

In Hungary, stem cell researchers are in an intermediate situation: the study of stem cells on embryos created within the country is prohibited, so embryonic stem cell researchers purchase embryonic cell lines from abroad (USA), not from abroad. Therefore, the type of laboratory communication between the IVF clinic and stem cells that exists in some countries does not work in Hungary. [12]. Thus, in Hungary there is no law on stem cell research, the relevant rules can be found in the Law on Health Care for special procedures for human reproduction, research of embryos and gametes, artificial infertility. It stipulates that embryos and gametes may be examined only with the permission of the Human Reproduction Committee in accordance with the documentation procedure specified in the permit and at the same time the approved research plan, in a medical institution, or another research facility. Circumstances under which the embryo or gametes may be used for research purposes are specified in Section 159 Part 1 of the Health Care Act [13]. Accordingly, it can only be used to improve diagnostic, therapeutic, prophylactic and rehabilitation procedures, to develop new procedures and to better understand the pathology and pathogenesis of diseases, and to collect clinical data on the efficacy and effectiveness of medical devices. [14]. 
In Ukraine, on the other hand, the legislator practically ignores the issue of creating guarantees for the protection of a live embryo in vitro, not to mention the existence of criminal liability for its illegal use, as is the case in Germany. There is only an indirect ban on the use of live non-implanted embryos for non-reproductive purposes, which follows from a systematic analysis of the Procedure for the use of assisted reproductive technologies. The conclusion that can be drawn, in particular from the analysis of this act, is that the purpose of the creation and use of embryos in vitro is exclusively reproductive.

Among the possible forms of its use are:

- embryo transfer and storage for implantation in the future (in case of unsuccessful attempts or if you want to use reproductive services again);

- storage for the purpose of embryo transfer to recipients by donation;

- application of pre-implantation medical-genetic diagnostics to embryos for the prevention of genetic abnormalities and diseases, but the legislator did not regulate the possible consequences of such research (the need to destroy embryos containing genetic abnormalities, as neither implantation nor donation is possible);

- reduction (removal) of excess already implanted embryos, which can be carried out based on a conclusion of the council (at least 3 ) doctors about its need, the number of embryos to be reduced is determined on the basis of a written application of the patient on the doctor's recommendation. The purpose of such destruction of already implanted viable embryos that develop in the mother's body is to prevent obstetric and prenatal complications associated with multiple births. This is the most problematic issue from both an ethical and a legal point of view. Therefore, we believe that it is necessary to amend Part 2 of paragraph 3.8. (Embryotransfer (hereinafter - ET)) The order of application of assisted reproductive technologies and state it in the following wording: "It is recommended to transfer no more than 2 embryos to the uterine cavity (if medically indicated and with the patient's consent) in order to avoid obstetric and prenatal complications associated with multiple births. ET of one selective embryo (with the patient's consent) and cryopreservation of the remaining embryos for use in subsequent cycles are recommended" and also to exclude from the Order Section 8 "Reduction of embryos" [15].

Studies that can be performed with embryonic stem cells, which in these studies are called cell transplants, are governed by Section 3 of the Procedure for Clinical Trials of Tissue and Cell Transplants and Examination of Clinical Trial Materials (Features of Studies Using Human Stem Cells). Item 1 of Section 3 states that "the general principle of the use of human stem cells is the importance of research in terms of obtaining benefits for human health. The implementation of this principle must be based on respect for human dignity, rights, and freedoms; individual approach to signing informed consent, confidentiality combined with respect for personal cultural and social aspects of human life; correctness in assessing the sever- ity of possible complications and benefits of treatment; charity in favor of improving the health of individuals and society as a whole; safety through the minimization of risks and maximization of benefits in strict compliance with the above regulatory requirements. Item 2 of Section 3 sets out the requirements that are required for the lawful use of such cells, namely: cell/tissue grafts subject to the following requirements: a) abortion and donation of anatomical material of embryo-fetal origin and extra-fetal material in exchange for monetary compensation is not allowed; b) consent to the donation of anatomical material of embryo-fetal origin and extra-fetal material for clinical use was obtained after the woman made the final decision to terminate the pregnancy; (c) the doctor responsible for terminating the pregnancy and observing the woman who plans to terminate it and the researcher/doctor who will continue to use anatomical material of embryo-fetal origin or non-fetal material may not be the same person; d) women who have given informed consent for the use of anatomical material of embryo-fetal origin and extra-fetal material may not choose the method of use of anatomical material of embryo-fetal origin and extra-fetal material or a specific person to be transplanted; (e) information concerning the identity of the woman authorizing the use of anatomical material of embryo-fetal origin and non-fetal material and the identity of the recipient is confidential and not disclosed. "

So, as we see, in the framework of this act we are talking only about the use of stem cells of embryo-fetal origin, i.e. obtained from cells and tissues of a dead, not a living embryo. Therefore, it can be presumed that the legislator did not establish a separate prohibitory norm, as the principles listed in paragraph 1 , section 3 of this act must serve as an indisputable basis for the conclusion that such use is impossible. However, it seems appropriate to supplement Article 1, Section 3 of the Procedure for Clinical Trials of Tissue and Cell Transplants and Examination of Clinical Trial Materials with the following provision: "Obtaining embryonic stem cells from live cryopreserved non-implanted embryos in vitro, resulting in their death and the creation of embryos in vitro for research purposes is prohibited." The introduction of such changes will allow the proper protection of live embryos, both from a legal and ethical point of view, and will allow the implementation in the national legislation of Article 18 of the Convention on Human Rights and Biomedicine, which has not yet been ratified by Ukraine. in the presence of a conflict of norms of national legislation and this international agreement, it will not take precedence [16].

As for the possibility of postmortem embryo creation or the use of reproductive biological material after the death of a person, to date, Ukrainian legislation does not regulate this issue. Such a significant gap can have a significant impact both in the area of personal non-property rights and inheritance rights and in the area of family law. Instead, an analysis of Hungarian legislation in this area suggests that there is a clear ban on the use of gametes after death, without exception. If the gamete collection 
was performed during the life of the partner, with his or her valid, informed consent, specifically for reproductive purposes, this is unreasonable for the deceased donor, because the embryos can only be fertilized later. In such cases, it may be appropriate to establish measures to allow in vitro fertilization, even if the partner has died in the meantime [17].

It should be noted that in Hungary, the right to dispose of in vitro embryos that have not yet been implanted is jointly exercised by the spouses or life partners who created it, until the death of one of the partners, regardless of whether there has been a change in their marriage or cohabitation. Each party may waive the right to dispose of it in an authentic document or a private document with a complete evidence base. However, this rule gives the partner a broader right of disposal, whereas after the embryos have been removed, he can continue the ART procedure even if his relationship with his partner has been severed (for example, divorced) or if the partner has died. Continuation of the procedure can be excluded only by participants in the event of death, so in the case of embryos, the human right to dispose of is limited to his death. It is unclear the man's right to dispose of the embryo after the death of his partner. The right of disposal includes the deposit of the embryo (storage of the embryo is technically carried out by freezing and cryopreservation of the embryo) for further use, as well as donating the embryo to other persons involved in the reproduction process and offering the embryo for research purposes [18]. For example, Zoltán Gyöngyösi states: "It is necessary to exclude that the in vitro embryo is a human being", and since gametes are the property of donors, "fertilization of things" occurs in fertilization, resulting in "joint ownership", which is the "result of labor", so there are no obstacles to the free disposal of it [19]. However, Article $180 \$ 3$ of the Law of the Republic of Hungary states that an embryo may not be created for research purposes, only embryos created during reproductive procedures may be used for research purposes at the request of those who have the right to do so (right holders), or in case of damage to the embryo [13]. However, under paragraph 5 of the Decree of the Ministry of Social Security 30/1998 (VI.24.), Applicants together after informing may accordingly exercise the right to dispose of embryos in a form called "Declaration on the placement of frozen embryos" and may facilitate embryo donation; or consent to the use of embryos for medical experiments, or may require the destruction of embryos [20]. The case-law of the Hungarian Constitutional Court - which includes a very small number of judgments - has hardly dealt with ART proceedings, if so, it has mainly discussed restrictions on the right to reproduction. On the other hand, the Ombudsman's practice provides greater support for legal protection both in the use of the gametes of the deceased and in the donation of eggs. [21].

In Ukraine, despite the lack of legal regulation of embryo disposal in vitro, an analysis of contractual and judicial practice in the field of assisted reproductive technologies allows us to conclude that managers of cryopreserved em- bryos are men and women together, so the death or death of one of the, if there is no joint written, will in the event of the death of one of them to transfer their embryos to others by donation or written order from the husband to transfer after his death the right to dispose of the embryos to his wife for reproductive purposes, such embryos must be disposed of.

Thus, in practice, a large number of "embryos" can be created, which are not affected by potential mothers or donors, in part because they do not even know how many fertilizations have taken place.

It should also be borne in mind that in the field of assisted reproductive technologies there is also the possibility or likelihood of abuse in order to create human embryos, obviously not for the purpose of their further implantation into a woman's body, but research purposes. The proposed changes to the legislation above will help prevent such abuses. In Germany, the legislator went ahead of this problem by setting a limit in the legislation governing the use of assisted reproductive technologies, which provides for the creation of only the required number of embryos for IVF. Other fertilized eggs are cryopreserved until the fusion of the female and male gametes, so they are not yet considered embryos. This method of embryo protection and creation of legal preconditions for their use exclusively for IVF, in our opinion, is quite an effective tool, although it is not generally accepted. To solve this problem, Part 2 of Article 18 of the Convention on Human Rights and Biomedicine was formulated, which enshrined the need to establish a legislative ban on the creation of human embryos for the purpose of their study.

The most rational and balanced from both legal and moral-ethical points of view is the establishment of the possibility of using unimplanted embryos in vitro but within a very strict and clearly defined framework, which must be established by law and subject to constant state control and only if enshrining a complete ban on the creation of embryos solely for research purposes (including therapeutic cloning). Therefore, in the context of creating legal guarantees for the protection of living unimplanted embryos, we support the position that they should be given the right to "species" rather than "individual" human dignity, which should be manifested in the possibility of their use only after their legal viability ceases, in particular, due to the impossibility of their use for reproductive purposes for various (established in the legislation) reasons, only for the social needs defined in the legislation (development of new methods of treatment and diagnosis of serious diseases, etc.) [22].

Another possible way out of this ethically and legally difficult situation may be the use of artificially created embryonic cells instead of human embryos for research purposes. In particular, importance to Australian science is the International Society of Stem Cell Research (hereinafter - ISSCR's) recommendation to address the creation of embryo-like or model structures from human stem cells, like the iBlastoids generated by Professor Jose Polo and his team at Monash University. The model embryos, created in a laboratory by researchers at Melbourne's Monash University, do not use egg or sperm, but ordinary cells that are reprogrammed to replicate the first few days of human 
life [23]. The new guidelines state that - given that these embryo models are not considered equivalent to human embryos under most legislation globally - they are not subject to the restrictions of the 14-day rule [24].

\section{CONCLUSIONS}

Today in Ukraine the issues of using unimplanted embryos are outside the legal field. Thus, we can conclude that the anatomical materials of the dead (dead) embryo, whether implanted or not, can be removed both for scientific research within the statutory (subject to the approval of the study by the ethics committee) and for therapeutic purposes (for cell transplantation), subject to the relevant proposed amendments to the legislation to comply with the requirements of Article 18 of the Convention on Human Rights and Biomedicine. Instead, the creation and further use of embryos for any purpose other than reproduction is illegal and should be prohibited by law with the imposition of appropriate criminal penalties.

Non-implanted embryos and embryo-fetal materials, as well as cells derived from them, are biological material of individuals, a carrier of genetic information of the patient/ patients to whom assisted reproductive technologies were applied, and in the case of embryos or fetuses removed from a woman's body - it is a woman's biological material. Assignment of embryos and embryo-fetal materials to the category of biological material does not mean that they are subject to the rules of property law, but they should be considered as special objects that are under state protection and are in a close legal personal relationship with the above entities, who are given the right to determine their future fate within the limits established by law.

The right to dispose of embryos for research purposes may be granted by the woman and the man for whom the embryo was created, subject to informed consent and consent to the processing of personal data. The healthcare facility/medical research center as the owner determines the level of access of health workers to the information of personal data of embryo managers by restricting a certain range of subjects (researcher, doctor, junior specialists with medical education, members of consultations, consultants, etc.). embryo). Each of these workers has access only to the embryo examination data that he needs in connection with the performance of his professional/official/work duties. The healthcare professional, as the person who has access to the embryo examination, must sign a written commitment to medical confidentiality and give a written commitment not to disclose personal data and information about the embryo examination entrusted to them or which became known to them in connection with the implementation. professional/official/labor duties. All requests for access to the results of the embryo examination must be in writing.

\section{REFERENCES}

1. Bachynska Llu Bioetychni problemy shtuchnoho zaplidnennia [Bioethical problems of artificial insemination]. Porivnialno-analitychne pravo [Comparative-analytical law]. 2016; 6: 296-299 (in Ukrainian).
2. Kovalova 0 Deontolohiia v medytsyni: pidruchnyk. [Deontology in medicine: a textbook.] Kyiv: VSV «Medytsyna»; 2015. p. 111 (in Ukrainian).

3. Soni S Limits for human embryo research have been changed: this calls for public debate. The Conversation. 2021; June 30. Available from: https://theconversation.com/limits-for-human-embryo-researchhave-been-changed-this-calls-for-public-debate-162305 (accessed 16 September 2021).

4. Matthews K RW, Moralí D National human embryo and embryoid research policies: a survey of 22 top research-intensive countries. RegenerativeMedicine. 2020; 15:7:905-1917. Availablefrom:https://www. futuremedicine.com/doi/10.2217/rme-2019-0138 [reviewed 2021.08.13].

5. Hyun I, Wilkerson A, Johnston J Embryology policy: revisit the 14-days rule. Nature. 2016;533:169-171. Available from: https://www.nature. com/polopoly_fs/1.19838!/menu/main/topColumns/topLeftColu-mn/ pdf/533169a.pdf [reviewed 2021.08.13].

6. Report on Human Embryonic Stem Cell Research. Available from: https:// ec.europa.eu/commission/presscorner/detail/en/MEM0_03_81 [reviewed 2021.08.13].

7. The decision of the European Court of Human Rights of 18.10.2011 № (-34/10. Available from: https://dejure.org/dienste/ver-netzung/ rechtsprechung? Text $=\mathrm{C}-34 / 10$ [reviewed 2021.08.13].

8. Ehrenstein C Kein Patent auf Embryo-Stammzellen. Die Welt. 2011. Available from: https://www.welt.de/print/die_welt/politik/ article13668377/Kein-Patent-auf-Embryo-Stammzellen.html (accessed 16 September 2021). (in German).

9. Neidert R Forschungsverbote im Embryonenschutzgesetz und ihre Grenzen. Diedrich et al. (ed.). 2007: 207-226. (in German).

10. Günther H-L, Taupitz J, Kaiser P Embryonenschutzgesetz: Juristischer Kommentar mit medizinisch-naturwissenschaftlichen Grundlagen. 2nd ed. Kohlhammer; 2014. (in German).

11. BGH Urteil vom 06.07.2010. 5StR 386/09. Available from: https://dejure.org/dienste/vernetzung/rechtsprechung? Gericht $=$ BGH\&Datum $=06.07 .2010 \&$ Aktenzeichen $=5 \% 20$ StR\%20386/ 09 [reviewed 2021.08.13] (in German).

12. Vicsek L, Szolnoki N Az embrió mint társadalmi-kulturális entitás. Az embriók konstruálása a lombikbébieljárásban részt vevő magyar páciensek körében. [The embryo as a socio-cultural entity. Construction of embryos among Hungarian patients participating in the flask procedure]. Available from:http://real.mtak.hu/29263/3/embrio_mint_tarsadalmi_ kulturalis_entitas.pdf [reviewed 2021.08.13]. (in Hungarian).

13. 1997. évi CLIV. Törvény az egészségügyről [Health Act] Available from: https://net.jogtar.hu/jogszabaly?docid=99700154.TV [reviewed 2021.08.15]. (Hungarian).

14. Varga RI Az embrionális őssejtkutatás hazai szabályozás. [Embryonic stem cell research in a domestic regulation.]. 2016. Available from: https://arsboni.hu/az-embrionalis-ossejtkutatas-hazai-szabalyozas/ [reviewed 2021.08.15]. (In Hungarian).

15. Kvit NM. Biobanky v Ukraini: tsyvilno-pravovyi aspekt: monohrafiia. [Biobanks in Ukraine: civil law aspect: monograph.] Lviv: Kvart; 2020. (in Ukrainian).

16. Kvit NM Pravovi mezhi stvorennia ta vykorystannia liudskykh embrioniv: porivniannia nimetskoho ta ukrainskoho zakonodavstva [Legal limits of creation and use of human embryos: comparison of German and Ukrainian legislation] Porivnialno-analitychne pravo [Comparativeanalytical law]. 2019; 3: 87-92. Available from: http://pap-journal. in.ua/wp-content/uploads/2020/08/Porivnyalno-analitichnepravo-3-2019-1.pdf [reviewed 2021.08.13] (in Ukrainian). 
17. Sándor JA humán reprodukciós orvosi eljárások jogi szabályozásáról. [0n the legal regulation of medical procedures for human reproduction.] Acta Humana. 1996; 25:36. (in Hungarian).

18. Jobbágyi G A magzat jogi helyzete múvi megtermékenyítés esetén. [Legal status of the fetus in the case of artificial insemination]. Miskolci Jogi. 2017;12(2):227-238. Available from: https://www.mjsz. uni-miskolc.hu/files/egyeb/mjsz/2017kulon2/23_jobbagyigabor.pdf [reviewed 2021.08.15] (in Hungarian).

19. Gyöngyösi $Z$ Az élet és a test feletti rendelkezések joga, [The right to life and disposition over the body]. HVG ORAC; 2002:286-375 (in Hungarian).

20. 30/1998. (VI. 24.) NM rendelet az emberi reprodukcióra irányuló különleges eljárások végzésére vonatkozó, valamint az ivarsejtekkel és embriókkal való rendelkezésre és azok fagyasztva tárolására vonatkozó részletes szabályokról [laying down detailed rules for the performance of special procedures for human reproduction and for the availability and frozen storage of gametes and embryos] Available from: https:// net.jogtar.hu/jogszabaly?docid=99800030.nm [reviewed 2021.08.13] (in Hungarian).

21. Zeller J A testen kívül létrejött embriók morális és jogi státusa a reprodukcióhoz való jog és a tudományos kutatás tükrében. [The moral and legal status of out-of-body embryos in the light of the right to reproduction and scientific research]. PHD értekezés tézisei. Pécs; 2009. (in Hungarian).

22. Kvit NM Problema vyznachennia pochatku liudskoho zhyttia y rehuliuvannia mezh vykorystannia embriona yak obiekta zberihannia $v$ biobanku [The problem of determining the beginning of human life and regulating the boundaries of the use of the embryo as an object of storage in a biobank]. Scientific Bulletin of the International Humanities University. Ser: Jurisprudence. 2019; 40:83-91 (in Ukrainian).

23. Mannix L Scientists create model embryos in lab, raising major ethical questions. The Age. 2021; March 18. Available at: https://www. theage.com.au/national/scientists-create-model-embryos-in-labraising-major-ethical-questions-20210317-p57bkc.html [reviewed 2021.08.13].

24. Carrol J Embryo research law needs tweaking to catch up with science. The Age. 2021; June 7. Available at: https://www.monash.edu/ discovery-institute/news-and-events/news/2021-articles/embryoresearch-law-needs-tweaking-to-catch-up-with-science (accessed 16 September 2021).
25. Buletsa SB Pravo na zhyttya zarodku: tsyvil'no-pravove rehulyuvannya shtuchnoho pereryvannya vahitnosti (abortu). [The right to life of the embryo: civil law regulation of abortion]. Current issues of state and law: Coll. Science. Odessa National Avenue jurid. acad. A .: Jurid. I-ra. 2004; 22:584-590 (in Ukrainian).

The work was performed within the research works "Ensuring the implementation of human rights of the 4th generation in the health care system"; registration number: 019H10000270b; deadline 2019-2023 and "Novelization of civil and civil procedure rights in the conditions of judicial reform"; registration number 0119U002358; deadline 2019-2021.

\section{ORCID and contributionship:}

Natalia M. Kvit: 0000-0002-4823-5541 ${ }^{A, D, F}$

Sibilla B. Buletsa: 0000-0001-9216-0033 ${ }^{A, D, E}$

Vasyl V. Kopcha: orcid.org 0000-0001-9888-1464 ${ }^{B, C, D}$

\section{Conflict of interest:}

The Authors declare no conflict of interest.

\section{CORRESPONDING AUTHOR}

Sibilla B. Buletsa

Uzhhorod National University

Uzhhorod, Ukraine

e-mail: sbuleca@gmail.com

Received: 27.06.2021

Accepted: 11.10 .2021

A - Work concept and design, B - Data collection and analysis, C - Responsibility for statistical analysis, $\mathbf{D}$-Writing the article, $\mathbf{E}$-Critical review, $\mathbf{F}$ - Final approval of the article 


\title{
ENVIRONMENTAL HEALTH LEGAL REGULATION AS A PREREQUISITE FOR PREVENTIVE MEDICINE
}

DOI: 10.36740/WLek202111235

\author{
Natalia D. Kogut \\ NATIONAL TECHNICAL UNIVERSITY OF UKRAINE "IGOR SIKORSKY KYIV POLYTECHNIC INSTITUTE", KYIV, UKRAINE
}

\begin{abstract}
The aim: To research scientific undeniable results in the sphere of health environment which are not taken into account in EU legal regulations and to find out ways of possible regulation of such issues.

Materials and methods: The research is conducted with help of both general and special juridical methods of investigation. The empirical basis: an international legal acts; domestic laws of EU countries; courts' decisions; statistics; juridical, ecological and medical articles.

Conclusions: Legal regulation of ecological standards in all kinds of pollution is much cost-effective and safe for ecology and human rights way in comparison with case law. Results of scientific researches in the sphere of medicine and ecology should be implemented in current legislation.
\end{abstract}

KEY WORDS: environmental health; food safety; right to health

Wiad Lek. 2021;74(11 p.2):3067-3071

\section{INTRODUCTION}

It is widely known that human life expectancy depends only $10 \%$ on the quality of health care, $20 \%$ - on genetics, and 30 $\%$ each on the favorable environment (ecology and safety of human living conditions) and person's lifestyle. The formation of a healthy lifestyle, to a large extent, depends on public policy and proper infrastructure of settlements, the same applies to the environment and safety of human life activities. The human right to a healthy environment was first mentioned in Stockholm Declaration on the Human Environment 1972 [1]. Global environmental issues regardless of human's subjective rights were enshrined in Rio Declaration on Environment and Development 1992 [2] and Johannesburg Declaration of World Summit on Sustainable Development 2002 [3].

\section{THE AIM}

The main goal of the sheet is to research ecological risks, which are not properly regulated or forbidden by law, and to find out possible ways of proper regulation for minimizing such risks taking into consideration the principle of proportionality between one's human's health, sustainable development and scientifically proved pieces of knowledge about dangerous of some materials, food additives, agrochemicals, radiofrequency radiation, and other contaminants.

\section{MATERIALS AND METHODS}

The legal basis of the study: The International Covenants and Declarations in the sphere of human rights and healthy environment, some domestic laws of European Union (EU) countries, courts' decisions; statistics; juridical, ecological, and medical articles.

The following methods of scientific research are used: comparative legal method; formal-logical (dogmatic) method; statistical method; methods of analysis and synthesis.

\section{REVIEW AND DISCUSSION}

Although there is no explicit right to a healthy environment in the European Convention for the Protection of Human Right and Fundamental Freedoms [4]; the International Convention on Civil and Political Rights [5]; the International Convention on Economic, Social and Cultural Rights [6], the European Court of Human Rights has developed a case law interpreting civil and political rights through environmental issues. International treaties provide only the right to health, still, a connection between a healthy environment and human's right to health is obvious. Nevertheless, one may apply for compensation only in case when his/her right to health is already violated. To prove the link between any kind of disease and some kind of environmental pollution is too difficult and often impossible due to multifactoriality. The other problem is that law doesn't give an answer to which extent the right to health afflicted by an anthropogenic factor may be protected taking into account constant environmental pollution due to technical development. In case law court considers proportionality between one's human right and social interest.

Still, it is a one-time case of defending human rights in court when they are already violated, court's decision 
is applicable only to co-plaintiffs, the rest of the victims should start the process and prove again their damages, causal link with pollution, etc. Thus, in our opinion, every state and international body should strictly regulate ecological standards, to ban the most toxic food additives, toxic construction materials, polyethylene packaging, etc. It will protect the population against adverse health consequences and even possible risks of such adverse effects.

Considering the impact of the environmental situation in some territories on the environmental situation in remote areas the issue of legal regulation of the environmental situation in the world should become a priority area of all intergovernmental organizations. Today, plastic and polyethylene residues are found at the North and South Poles, their toxic effects on fauna and excessive decomposition time indicate the need to completely abandon these types of materials, at least as packaging. In our opinion, the issue of waste sorting and recycling should become a prerequisite for countries' membership in the EU, other international organizations, as well as a prerequisite for providing them with loans and financial assistance. In Ukraine, more than 7 $\%$ of the country's territory is occupied by landfills, which is a critical situation for the environment of the largest country in Europe, which affects soil pollution and waterways.

The practice shows that each state will save huge amount of cost of the public health sector if it implements food safety standards only. Currently, more than 2 million deaths occur every year in developing countries due to foodborne diseases [7]. In addition, it has been scientifically proven that 95 percent of toxic substances enter the human body with food. There are two areas of regulation: 1) sanitary-epidemiological; 2) anthropogenic. The first is aimed at monitoring food safety in the context of the absence of pathogenic bacteria, viruses, prions, parasites, and fungi. The second regulation is aimed at the absence or not exceeding the maximum allowable content (concentration) of heavy metals in food; residues of pesticides, insecticides, fungicides, mineral fertilizers; antibiotics; hormones, etc. The control of the content of animal drugs and hormones in meat and fish products is entrusted to the veterinary service. Following the deregulatory trends in Ukraine, the sanitary-epidemiological service was liquidated, which led to a serious increase in the number of food poisonings, in particular, due to non-compliance with the technology of production, transportation, and storage of food products. Also, the obligation to certify food products was abolished, except for the certification of baby food, alcoholic beverages, and tobacco products.

An important shortcoming of food safety regulation in most countries of the world is the lack of legal obligation for food producers to indicate on the packaging not only the components of the product but also antibiotics, hormones, or agrochemicals used in animal feed or plant production. Also, the number of such contaminants should not exceed state standards for each chemical compound. In this context, it is important to separately regulate the maximum allowable concentration of certain agrochemicals that can be used in a given area when growing a particular crop in one harvest and the number of their traces in the final product. When calculating the maximum permissible content of a certain compound in food, the number of products that can be consumed by one person per day and the ability to accumulate these compounds in the human body are not considered.

It should also be noted that the impact on the human body of many new and relatively new agrochemicals, food additives (stabilizers, thickeners, dyes, preservatives, flavor enhancers) is unknown, as the study and collection of relevant data take decades. In addition, not all compounds are tested, testing may be indirect in the study of individual diseases or diagnoses, but their effects should be investigated to confirm or refute their relative safety. When denying the safety of a substance approved on the basis of preliminary testing, a ban on its further production must be ensured. However, there is a need to fund research by independent entities and to minimize losses to producers of agrochemicals, etc., when there is clear harm of such chemicals to human health. In addition, there are many additive supplements that have been the subject of numerous studies proving their serious harm to human health (monosodium glutamate, aspartame, etc.), but their usage continues to be legal almost worldwide.

Some countries, in particular the United States, believe that citizens can choose whether to consume harmful but cheaper products or more expensive but better ones. At the same time, it is necessary to ensure proper labeling of these products so that consumers have comprehensive information for such a free choice. Besides, the rights of children who are unable to make this choice on their own should be kept in mind, so their rights to a healthy and safe diet may be violated.

A serious challenge in the field of food safety is the violation of producers regarding the correct indication of the product components (even those used in the manufacture of products and not in the cultivation of raw materials). This issue is particularly relevant in the dairy sector, as the number of cattle in the world is declining rapidly, and the consumption and range of dairy products are increasing. There is a lot of evidence, including laboratory studies, covered in the media on the absence of labeled components of natural milk and the presence of palm oil, thickeners, and even wallpaper glue in the products.

Taking into account the advances in science related to the intensity of agricultural production, pest, disease control, and increased productivity of agricultural production, new challenges arise for the safety of the food industry. Genetically modified plants, due to disease resistance, drought, and high yields, can help with food security on the one hand, and on the other hand, genetically modified organisms (GMO) can be extremely harmful to health [8]. Recent scientific studies have unequivocally proven that GMO are harmful to human health, including infertility. For example, in experiments on laboratory animals (mice, rats, hamsters) when feeding them with various feeds of genetically modified crops it is evidently lead to pathological changes in the liver, pancreas and thyroid 
gland, spleen, and testes [9]. In addition, GMO contain plasmids that cause tumors because cytokines controlled by them induce uncontrolled cell division. They withstand prolonged boiling and go into an aqueous solution, so they can be absorbed in the gastrointestinal tract of animals and humans and stimulate certain cells in the body by the type of uncontrolled reproduction [10].

EU Council Regulation 834/2007 [11] banning the use of genetically modified organisms states that GMOs, GMO derivatives, and products produced from GMOs should not be used as food, feed, technological additives, plant protection products, fertilizers, soil improvers, seeds, vegetative planting material, microorganisms and animals in organic production. But organic production does not exceed $20 \%$ of the whole agricultural production. Still, the EU doesn't have a solid position about the prohibition of all GMO production. For example, an insect-resistant corn variety (MON810) is already approved for cultivation in the EU and is growing in Spain and Portugal.

Unfortunately, laboratory tests to confirm the presence of GMOs in a product are very expensive and in general there are few laboratories that can conduct such studies, which is why in most countries where there is a requirement to indicate the presence or absence of GMOs, manufacturers label them "GMO-free" despite the fact that everyone knows that almost all soybeans and corn grown on an industrial scale are genetically modified. Therefore, in countries where the use of GMOs (transgenic and gene editing) is completely prohibited, proper control over the spread of GMOs and imports of GMO products is not implemented. In countries such as the United States, Canada, India, and other countries, there is special legislation on the use of GMO products.

Under EU Council Regulation No 834/2007 on organic production, labeling of organic products production can't be notified as organic unless it is certified by the International Federation of Organic Agricultural Movements (IFOAM). Humanity has two ways: to choose organic agriculture or to use agricultural achievements which ruin human health. The law should predict all risks, even potential ones, that may threaten human life and health, environment, biodiversity, and more [12].

Of course, the protection of food from the effects of agro-industrial and man-made factors is of paramount importance for the preservation of the nation's ecosystem and gene pool. However, one should also keep in mind the natural factors that can be dangerous to human health bacteria, viruses, prions, etc. At the very least, controlling their absence in food and drinking water is an important task for the state to ensure a healthy environment. In particular, the lack of quality control of food, especially meat and fish, leads to a significant number of diseases caused by botulinum toxin and salmonella. EU countries use hazard analysis critical control point measures (HACCPM) during food production. The analysis of the control system in the EU gives an understanding that it covers both food products and health of animals, plants, environment state, feed and drugs for growing animals, plant protection products to the degree what their separate or complex effect can negatively affect the state of human health [13]. Although even this system does not solve those problems, the solution of which is not laid down in legal regulations. For example, there are many helminth eggs in raw smoked and cured meat or fish products, as the standards of technology for the production of such food do not require producers to a pre-deep freeze of such raw materials. There are even cases when this control system is not even aimed at protecting against toxic products that look like normal food, for example, cassia is widely used worldwide instead of cinnamon in products either for children, disregarding that it is poisonous.

The safety of water arteries and drinking water is another important human problem that needs to be solved immediately. This problem is closely related to the agricultural sector, as phosphates and other compounds enter all water arteries, leading to the so-called "water bloom" effect. Oxygen in water is spent on the oxidation of organic matter in decomposing cyanobacterial clusters that making it impossible for fish and other fauna living in such waters. It also emits toxins, which poison drinking water [14]. Therefore, strict control over the use of phosphate fertilizers is a crucial task of national and global importance.

The degree of danger of air pollution to humans remains a leading risk factor even in comparison with water or soil pollution [15]. The safety and quality of building materials are of great importance for the safety of air in megacities. For example, when polyurethane foam, which is widely used in constructions, is burning it emits hydrogen cyanide, one breath of which is deadly to humans. It is also known that asphalt, which contains bitumen, emits a lot of toxic substances, especially when heated, concrete for countries with high temperatures is a better alternative, moreover, much more durable. In some countries, in particular, in Ukraine, it is allowed to use asphalt as a residual material after uranium ore mining, which worsens the existing radiation background of the country.

One of the levers to minimize the toxicity of car exhaust is the presence of a sufficient number of park areas, trees in cities and suburban areas. Unfortunately, given the cost of land in megacities, the construction is such a density that does not meet the norms of normal human life, not all countries have a clear regulation of population density and the area of recreational zones per capita. Even if such norms exist, they are grossly violated in almost all megacities. There are quite simple things that can at least partially neutralize the air toxicity of megacities: planting poplars, which emit seven times more oxygen than trees of other varieties; control over the quality of fuel and technical condition of cars, etc.

Additional Protocol 1 to the Convention on human rights states 'Every natural or legal person is entitled to the peaceful enjoyment of his possessions. Doragu L. (2014) says that many cases have been solved referring to this article when the court established that damages caused by different forms of pollution have as a result a depreciation in the value of property objects [16]. In many countries, 
there is no adequate mechanism of compensation of such depreciation in value of property objects without the court's decisions (concerning the construction of factories, farms, highroads, landfills, mobile stations, transformers near one's real estate).

Toxic contamination of soils and waters from the decomposition of various debris, especially batteries, mercury bulbs, polyethylene, and plastic, necessitates the complete recycling of such facilities and in many cases the complete banning of some toxic materials. In particular, mercury bulbs, polyethylene, and plastic containers should be completely banned worldwide. There are standards for some kinds of production drafted by companies who are leading in providing a definite kind of production [17], such standards may be approved by state ministers and become compulsory for all producers of similar products.

Sometimes, excessive health care has negative consequences for the environment and overall health. For example, the forced mass use of medical masks to combat the spread of the epidemic has led to the spread of used masks made of polymeric materials on the earth's surface and in the waters of the world. This is despite the fact that a slight positive effect of their use occurs only if already sick people will wear them, and they should be in self-isolation. It's preferable to establish using of reusable masks of natural materials.

Legal regulation of the maximum permissible content or concentration of certain contaminants in food, waterways, air, etc. is quite common, but protection against radiofrequency radiation, in contrast to protection against ionizing radiation, is still at the concept stage.

According to current research, all radiofrequency radiation from wireless devices, has a negative effect on human health, in particular, on the cardiovascular system, and provokes cancer [18]. Even according to studies conducted in 2008-2009, the risk of developing brain cancer with prolonged use of a mobile phone increases by $90 \%$ [19], and parotid cancer - by 50-60\% [20]. It happens when a hand-held mobile device is used on the contralateral side, but consumers can't be aware of the vector of signals, so these statistics may be contingent twain. Thus, the International Agency for Research of Cancer (IARC) has classified radiofrequency radiation as 'possibly carcinogenic to humans in 2011 [21]. Nevertheless, these impressive results of scientific researches have not led to any legislative changes in terms of protection against the harmful effects of radiofrequency radiation. At least, the maximum duration of children's use of mobile phones, scientifically substantiated distance of radiofrequency towers from residential buildings and educational institutions should be regulated by law.

Given the irreversibility of scientific and technological progress and the importance of the use of mobile communications, a serious information policy should be implemented at the national and international level on the correct use of mobile phones and Wi-Fi routers. In particular, the following measures must be recommended: - the duration of telephone conversations should be recommended to reduce to few minutes; - the mobile phone should be no closer than 1.5 meters from the bed; - encourage the use of wired headphones when talking on the phone to reduce the oncogenic load on the human brain; - provide lockers for mobile phones in educational institutions, where they should be during classes; - turn off Wi-Fi routers at night and more. A double increase in brain cancer in children over the past decade [22] is a clear indication of the urgent need to respond to this problem, despite the lobbying interests of mobile network owners. $5 \mathrm{G}$ will bring new issues for scientific research and necessity to find new ways to resist harmful effects. Not only radiofrequency radiation but either torsion radiation is emitted by mobile phones and any kind of electronic equipment which also afflicts human's health [23].

In general, any electrical appliance has electromagnetic radiation that is harmful to human health, the most harmful device is a microwave oven. However, such devices have a certain range within a radius of $25 \mathrm{~cm}$ to 1.5 meters (for TVs). Therefore, to regulate the rules of use of such devices at home is impractical, it is important to draw public attention to the rules of safe use of these appliances. Another thing is the use of such electrical equipment in offices and children's institutions. However, the most dangerous is electromagnetic radiation from high-voltage cable lines, electrical switchboards, and transformators. Unfortunately, the legislation of most countries does not clearly regulate the issue of underground placement of such installations in megacities with clear scientifically sound distances from residential buildings. This leads to an increase in the incidence of various diseases, primarily cardiovascular disease, and cancer.

\section{CONCLUSIONS}

Proper and, preferably, unified legal regulation of environmental safety should become the prerogative of the international community over economic benefits and geopolitical interests. A safe environment is a basis for the prevention of various diseases, which ultimately saves a few times the cost of medicine, saves a human life, and a healthy human gene pool. Negative legal regulation, which is the responsibility of the "violator pays" approach essentially does not restore the violated rights and requires complicated litigation on a case-by-case basis, so detailed legal regulating of pollution minimization, standardization of environmental norms is a much better way to improve the environmental situation in the world and necessary condition for preventive medicine.

\section{REFERENCES}

1. Declaration of the United Nations Conference on the Human Environment, Stockholm, 5-16 June, 1972. Available from: https:// undocs.org/en/A/CONF.48/14/Rev.1 [reviewed 2021.07.18].

2. Rio Declaration of United Nations Conference on Environment and Development, 12 August 1992. Available from: https://www.un.org/ en/development/desa/population/migration/generalassembly/docs/ globalcompact/A_CONF.151_26_Vol.I_Declaration.pdf [reviewed 2021.07.18]. 
3. Johannesburg Declaration of World Summit on Sustainable Development, 2-4 September, 2002. URL: https://undocs.org/ pdf?symbol=en/A/Conf.199/20 [reviewed: 2021.07.20].

4. European Convention for the Protection of Human Rights and Fundamental Freedoms № 005 dated 04.11.1950. Available from: https://www.echr.coe.int/Documents/Convention_ENG.pdf[reviewed 2021.07.18].

5. International Convention on Civil and Political Rights, adopted by General Assembly of UN, 1966. Available from: https://www.ohchr. org/EN/Professionallnterest/Pages/CCPR.aspx [reviewed:2021.07.19].

6. Convention on Economic, Social and Cultural Rights, adopted by General Assembly of UN, 16 December 1966. Available from: https://www.ohchr. org/en/professionalinterest/pages/cescr.aspx [reviewed: 2021.07.19].

7. Olumide A. Odeyemi Public Health Implications of Microbial Food Safety and Foodborne Diseases in Developing Countries. Food Nutr. Res. 2016; 60 (1). Doi:10.3402/fnr.v60.29819

8. Aristidis M. Tsatsakis, Muhammad Amjad Nawaz, Victor A. Tutelyan et al. Impact on Environment, Ecosystem, Diversity and Health from Culturing and Using GMOs as Feed and Food. Food and Chemical Toxicology. 2017; 107:108-121.

9. Vecchio L. Ultrastructural analysis of testes from mice fed on genetically modified soybean. Eur. J. Histochem. 2003, 48:449-453.

10. Kulyk Ya. M, Obertiukh Yu. V, Khimich 0 . V et al. Nebezpeka vykorystannia transhennoi raundapostiikoi soi v produktakh kharchuvannia ditei cherez naiavnist u nii neidentyfikovanykh faktoriv [The danger of using transgenic round-resistant soy in children's food due to the presence of unidentified factors]. Visnyk problem biolohii i medytsyny. 2017, 1(137):88-94. [In Ukrainian].

11. Council Regulation (EC) No 834/2007 of 28 June 2007 on Organic Production and Labelling of Organic Products and Repealing Regulation (EEC) \# 2092/91 Available from: https://eur-lex.europa.eu/LexUriServ/ LexUriServ.do?uri=CONSLEG:2007R0834:20081010:EN:PDF [reviewed: 2021.07.20].

12. Kurman V. T, Kurman V. 0, Tuieva M. 0. The Legal Foundations as a Means of Providing Public Health Globalization. Wiad Lek. 2019; 12:2626-2630.

13. Bobkova G. A, Pavliuchenko M. Yu, Zakharchenko M. A. Legal Security of Agricultural Products as a Condition Public Health System's Development. Wiad Lek. 2019; 12: 2484-2488.

14. Sachidananda Mishra, Richard P. Stumpf, Blake A. Achaeffer et al. Evaluation of a Satellite-Based Cynobacteria Bloom Detection Algoritm using Field-Measured Microcystin Data. Scientific Reports. 2019; 9. Doi. org/10.1038/541598-019-54-453-y

15. Sokolova K. A, Vilchuk B. T, Cherkashyna K. M. Ensuring the Environmental Rights as a Prerequisite for the rights to Health in Ukraine and the European Union. Wiad Lek. 2019; 12:2489-2495.

16. Doragu Lucretia Preserving the Right to a Healthy Environment: European Jurisprudence. Procedia-Social and Behavioral Sciences. 2014, 141:1346-1352.

17. The NEFAB Group's List of Banned \& Restricted Substances, valid as of 2020-06-15. Available from: nefab.com/globalassets/nefab.com-group-site/documents/nefab_restricted_material_list.pdf [reviewed: 2021.07.25].
18. Uloma Igara Uche \& Olga V. Naidenko Development of Health-Based Exposure Limits for Radiofrequency Radiation from Wireless Devices Using a Benchmark Dose Approach. Environmental Health. 2021; 20 (84). Available from: https://ehjournal.biomedcentral.com/ articles/10/1186/s12940-021-00768-1 [reviewed: 2021.07.02].

19. Hardell L, Carlberg M, Mild K. Epidemiological evidence for an association between use of wireless phone and tumor diseases. Pathophysiology. 2009; 16(2-3):113-22.

20. Sadetzki S, Chetrit A, Jarus-Hakak A et al. Cellular phone use and risk of benign and malignant parotid gland tumors - a nationwide case-control study. Am J Epidemiol. 2008; 167 (4):457-67.

21. American Cancer Society. Known and Probable Human Carcinogens. 2011. Available from: cancer.org/cancer/cancer-causes/generalinfo/known-and-probable-human-carcinogens.html [reviewed: 2021.07.25].

22. Julius Graakjaer Grantzau A Report on Non-lonizing Radiation. June 11, 2019. Available from: microwavenews.com/news-tags/Juliusgraakjaer-grantzau [reviewed: 2021.07.25].

23. Pavlenko A. Methods and Protection Devices against Torsion Radiation. Invisible Hazards in the Wireless Age. Theory, technology and experiments. Kyiv, Open International University of Human Development 'Ukraine', 2018, $127 \mathrm{p}$.

\section{ORCID and contributionship:}

Natalia D. Kogut: 0000-0001-6990-8752

\section{Conflict of interest:}

The Author declare no conflict of interest

\section{CORRESPONDING AUTHOR Natalia D. Kogut \\ National Technical University of Ukraine \\ "Igor Sikorsky Kyiv Polytechnic Institute", \\ Kyiv, Ukraine \\ tel: +380977517403 \\ e-mail: kogut.nataly@gmail.com}

Received: 01.07 .2021

Accepted: 15.10 .2021

A - Work concept and design, B - Data collection and analysis, C - Responsibility for statistical analysis,

D-Writing the article, $\mathbf{E}$ - Critical review, $\mathbf{F}$ - Final approval of the article 


\title{
FOOD SECURITY AS A GUARANTEE OF THE REALIZATION OF THE RIGHT TO HUMAN HEALTH
}

DOI: 10.36740/WLek202111236

\author{
Olena M. Batyhina', Bogdan V. Derevyanko², Tetiana V. Khailova \\ 'POLTAVA LAW INSTITUTE OF YAROSLAV MUDRYI NATIONAL LAW UNIVERSITY, POLTAVA, UKRAINE \\ 22ACADEMICIAN F.H. BURCHAK SCIENTIFIC RESEARCH INSTITUTE OF PRIVATE LAW AND ENTREPRENEURSHIP OF THE NATIONAL ACADEMY OF LEGAL \\ SCIENCES OF UKRAINE, KYIV, UKRAINE \\ ${ }^{3}$ DONETSK STATE UNIVERSITY OF INTERNAL AFFAIRS OF UKRAINE, MARIUPOL, UKRAINE
}

\begin{abstract}
The aim: To investigate the theoretical and legal framework governing the relevant areas of food security, ensuring healthy, adequate and safe nutrition. To consider human rights to food security as a basis for health care, a basis for the realization of the right to health and life.

Materials and methods: The study analyzes and uses the normative legal acts of national legislation, international acts, data from international organizations and the results of scientific work of scientists. With the help of scientific methods, medical and legal point of view, the problems of ensuring food security are identified as a guarantee of the realization of the right to human health.

Conclusions: Food security and nutrition are central to the individual and fundamental factor to the whole of society in respect of human right to health. An adequate level of food security must be ensured by individual governments and the international community through the development, approval or implementation of an appropriate regulatory framework, as well as through the establishment of a political and institutional framework.
\end{abstract}

KEY WORDS: Food security, right to health, right to food

Wiad Lek. 2021;74(11 p.2):3072-3076

\section{INTRODUCTION}

The problem of ensuring food security has acquired a global scale, indicating the existing shortcomings of governments in fulfilling their international obligations to ensure affordable, adequate, and quality food and to ensure the highest possible standards of health for their citizens [1, p. 22]. This issue is globalized, and it is needed to find answers for health care ensurance, that require a global approach, specifically, cooperation with the international community and the development of an effective international legal framework for food safety [2, p. 1]. In addition, national human rights guarantees need to be continuously improved.

The human right to adequate food is not respected for more than a billion people in the world today [3].

According to forecasts, the world's population will continue to grow and it will be 9.1 billion by $2050[4$, p. 2]. Increasing the population means increasing food production, as well as improving their quality and safety, in order to provide people with access to high-quality and healthy food to maintain good health. Nutrition ensures normal development, contributes to the prevention of diseases, prolongation of life, and creates conditions for adequate adaptation of a person to the natural environment.
In his scientific work Damtew Bekele defines the role of human nutrition. It is the provision of essential nutrients that are necessary for the maintenance of human life and health. Proper nutrition is substantial for health and disease prevention [5].

It is human rights that create the universal framework for the realization of global justice in the availability, sufficiency, and safety of food. The realization of the right to health directly depends on the provision of quality, healthy, sufficient, safe food, within the appropriate level of food security. An appropriate level of food security must be ensured by individual governments and the international community. However, not everyone receives adequate and quality food every day, which necessitates additional attention to the problems of ensuring food security in countries within the framework of ensuring the right to health.

\section{THE AIM}

To investigate the theoretical and legal framework governing the relevant areas of food security, ensuring healthy, adequate, and safe nutrition. To consider human rights to food security as a basis for health care, a basis for the realization of the right to health and life. 


\section{MATERIALS AND METHODS}

The study analyzes and uses the normative legal acts of national legislation, international acts, data from international organizations, and the results of the scientific work. With the help of scientific methods, considering medical and legal points of view, the problems of ensuring food security are identified as a guarantee of the realization of the right to human health.

\section{REVIEW AND DISCUSSION}

The Constitution of the World Health Organization states that the enjoyment of the highest possible level of health is one of the fundamental rights of every human being and states are responsible for their peoples' health [6].

Taking into account global trends, in order to cover human rights to food security, the content of human rights to health and food security has changed significantly over the last 70 years. The right to health began to be based on the possibility of guaranteed and safe nutrition [7].

Article 11 of the ICESCR defines the right of everyone to an adequate standard of living for themselves, including adequate food. Against this background, states recognize the fundamental right of all people to be free from hunger and include specific commitments to guarantee that the world's food is distributed in a way that meets demand [8].

Article 12 of the ICESCR, in turn, defines the specific obligations of countries to take all necessary measures to ensure the right of all to enjoy the highest possible level of mental and physical health [8]. Thus, at the level of international law, it is determined that nutrition and food are connected to health.

Scholars agree with the above provisions of international documents. Thus, as the scientist Maria Anna Coniglio rightly points out, nutrition determines the relationship between food and health [9]. People who get enough food are more productive. After all, malnutrition (in any form) is a substantial threat to human health [10]. Food scarcity is a situation where people do not have reliable access to sufficient amounts of safe and nutritious food to grow and develop normally and also for healthy and active lifestyles [11]. Malnutrition reduces resistance to infections, including parasites. Malnourished children grow up slowly. It means that poor nutrition can cause poor health, and cause poor school performance; also poor schools can cause unemployment [5]. This situation arises at the intersection of food and health rights, creating cross-sectoral opportunities for the implementation of human rights provisions, food security policies, and programs.

Thus, food security directly affects general security and human rights, which inevitably affects economic and financial security. Unemployment will further reduce the income of the population, which, in turn, due to lower purchasing power, will further reduce the level of food security. At the same time, the threat may start from the regional and single-industry level and gradually globalize. For example, threats to economic security in one or more industries in a region are rapidly reflected in declining overall performance across the country [12].
The World Health Organization has emphasized that micronutrient deficiencies are a significant contributor to the global burden of disease and represent a wide range of non-specific physiological disorders that lead to decreased resistance to metabolic disorders, infections, as well as delay or impairment of psychomotor functions [13]. For example, a 2012 Public Health Nutrition study found that those who eat unhealthy foods are 51 percent more likely to show signs of depression. And the more unhealthy and low-quality food you eat, the more likely it is that your brain will malfunction [14].

Human health is influenced by many reasons of a different nature. Various authors $[1 ; 2 ; 5 ; 9 ; 14 ; 15 ; 16 ; 17 ; 18]$ conducted research on the impact of certain factors on human health. These studies reflect relevant analyzes of the effects of various factors on human health.

Among other factors, we recognize and support the opinion of Damtew Bekele, expressed in the scientific work, that if there is no food security and people are prone to disease, people's health deteriorates [5].

The right to food as a human right is formally acknowledged in the 1948 UDHR 9 (Article 25) [19]. Since then, the right to food or some aspects of this right has been included in a number of international human rights treaties. For example, Article 2 of the ICESCR obliges States parties to take the necessary measures to gradually achieve the full realization of the rights recognized in the Covenant [20].

Thus, Article 12 of the CEDAW determines the right of mothers and infants to food [21]. As malnutrition is the leading cause of child mortality in the world, the Convention on the Rights of the Child pays considerable attention to the protection of the right to food [22].

An important aspect in ensuring food security was the creation of the Committee on World Food Security in 1974. It was established as the most open international and intergovernmental platform for the collaboration of all stakeholders in order to ensure food security and nutrition for all [23]. Also, it was from 1974 that various criteria and definitions of the concept of food security began to form, which, given its multidimensionality and multifaceted nature, underwent significant changes over the following years. In 1974, the original definition appeared at the World Food Conference. Attention was focused on the availability of sufficient global stocks of basic foodstuffs to support sustainable growth in food consumption and compensate for fluctuations in production and prices at all times [24].

The right to adequate food as a fundamental right to protection against hunger was also reaffirmed at the 1996 World Food Summit, which promoted better ways to exercise food rights and asked states to ratify the ICESCR. On this occasion, the heads of state adopted a declaration confirming the right of everyone to have access to nutritious and healthy food [25].

In 1996, at the World Food Summit, the main concept was to highlight the need for nutrition as the basis of health. Food security was related to the situation, when all people have economic and physical access to sufficient, safe, and nutritious food in order to meet their nutritional needs 
and dietary preferences for an active and healthy life [26]. According to this definition, four main aspects of food security can be distinguished: physical availability, food utilization, physical and economic access to food, stability of the other three dimensions over time. In order to achieve food security goals, all four aspects must be carried out simultaneously [27].

The 2009 Rome Declaration on World Food Security also identified the components of food security: physical and economic affordability, food independence, seasonal and weather resilience, and sustainability of production growth [28], which differs from those defined in 1996. According to the Rome Declaration on World Food Security, each country has a responsibility to ensure the human right to adequate nutrition and to take urgent action to eradicate hunger, malnutrition, and food shortages. In the 2009 Rome Declaration on World Food Security supports the general concept of food security [28].

Based on the above provisions, most national laws enshrine four pillars of food security. They are availability, access, utilization, and stability. For example, in Ukraine, the constitutional level enshrines the right to an adequate standard of living for oneself and one's family, which includes adequate food, clothing, and housing (Article 48 of the Constitution of Ukraine), but internationally defined food security criteria are unfortunately not enshrined in the national legislation of Ukraine.

The content of the concept of food security should be disclosed in the system of criteria and indicators that give a comprehensive description of its current state, dynamics, and trends of change. At the same time, the availability of formalized indicators and criteria is especially important, with the help of which it is possible to assess the level of food security of the state both qualitatively and quantitatively.

Similar processes to guarantee the right to health through the prism of food security are taking place at the international and regional levels. For instance, the general principles of current food law came into force in 2002 by Regulation (EC) No 178/2002 [29]. The regulation also established the EFSA, which was responsible for assessing and reporting all risks associated with the food chain [30]. For the purposes of this Regulation, the concept of "food law" is introduced (Article 5) [29], which reaffirms the focus of European countries on consolidating and ensuring a level of food security that can guarantee everyone's right to health.

Another example of regionally related development of human rights to health and food security is the issuance of the Latin American Declaration of Human Rights, stating that "the Latin American's people have a right to food" (Article 7, 11) [25].

Since the RtFG was adopted, countries around the world have seen significant changes in legislation and case law. The RtFG has been developed as a practical tool for states seeking to realize the right to food [31].

Scholars determine three main ways of defining the right to food at the national level: first, by creating a constitutional right to food; second, by adopting a framework law on the right to food or food safety; and third, by ensuring that sectoral legislation promotes the right to adequate food [31].

It is important to focus on the provisions of the Constitutions of those countries that recognize and explicitly enshrine the right to food and food security. There are 23 national constitutions around the world, in which the right to food is recognized [32, p. 1]. For example, in accordance with Article 15 of the Constitution of the Republic of Bangladesh, food and health care are recognized as basic necessities [33]. The Republic of Niger's Constitution provides for the right to health, healthy and adequate food (Article 12) [34]. The Constitution of the Republic of Maldives includes the right to food (Article 23) [35]. Bolivias Constitution of states that the State must guarantee food security (Article 16) [36]. The Ecuadorian State shall promote food sovereignty (Article 13 of the Constitution of Ecuador) [37]. Such constitutional provisions provide the necessary basis for the development or reform of national legislation for the promotion of food security.

The constitutions of some countries do not explicitly guarantee the right to adequate food and food security and the recognition of international law is sufficient for them. Thus, Article 25 of the Basic Law for the Federal Republic of Germany establishes the primacy of international law - general provisions of international law shall be an integral part of federal law. They shall take precedence over the laws and directly create rights and duties for the inhabitants of the federal territory [38]. In 1973, the Federal Republic of Germany became a State party to the ICESCR through ratification. And this is precisely what is sufficient for the recognition, consolidation, and ensuring the right to food, food security, and, consequently, the right to health in the country.

Some countries took a different path and did not enshrine the right to food security at the constitutional level. Several countries adopted framework laws on food security that establish an institutional framework. They are the Republic of Guatemala, the Republic of Indonesia, the United Mexican States, the Republic of Nicaragua, etc. [31]. At the regional level, the Latin American Parliament adopted a Regional Framework Law on the Right to Food, Food Security, and Food Sovereignty (November 2012) [25, 40].

Among the above three ways of enshrining the right to food security at the national level, it is important to ensure the existence of sectoral legislation that can either hinder or promote the realization of the right to food security and nutrition. Sectoral legislation is of great importance because it regulates the economic environment in which people are or are not able to adequately feed themselves [3, p. 24]. An example of sectoral food legislation is the Global Food Security Act of the United States of 2016. The Act defines the concept of the term "food and nutrition security", which means access to, and availability, utilization, and stability of, sufficient food to meet caloric and nutritional needs for an active and healthy life [39].

A fourth way of enshrining and enforcing human rights to food security, food, and health is a state-guaranteed possibility to file a complaint before a court or other independent body for violations of their right and to obtain appropriate means of recourse and remedy [3]. Virtually 
all legal systems for judicial protection of human rights have only indirect access to justice to protect the right to food security and nutrition based on the protection of the right to life, health, or property. However, this has not prevented the development of significant jurisprudence in the African and American continents, which shows that access to justice for thousands of victims of violations of the right to food is ensured [40, p. 37].

The most famous cases are the Khosa \& Ors vs Minister of Social Development [41]; the Ogoni case [42]; the Kenneth George vs Minister of Environmental Affairs and tourism [43]; the Sawhoyamaxa vs. Paraguay [44]; various cases decided by the Swiss Federal Supreme Court [40, p. 21]. In all the above cases, it is necessary to ensure respect and guarantee states the right to food.

At the national level, there is much more potential to protect the right to food security, as in most countries this right is enshrined in domestic law. However, in most cases, national courts do not recognize the possibility of judicial protection of food rights. But it is the real and guaranteed access to justice that makes the rights to food security and health more effective and tangible.

In conclusion, it should be emphasized that the right to food security and food to some extent, in various ways described above, is enshrined in the national legislation of most countries. But there is a significant difference between the state's official recognition of food security as a human right and its full implementation in practice.

States are obliged to respect, protect and fulfill the human right. The state itself should not deprive anyone of access to adequate food. Also, it must protect everyone from being deprived of such access in any other way. And when anyone is in fact without adequate food the state must proactively create an enabling environment where people become self-reliant for food or, where people are unable to do so, must ensure that it is provided. Everyone has the right to demand that the state fulfill these obligations.

The state's approaches to food security, as well as approaches to development in general, can be called "human rights-based" only if they consider these points as fundamental. The rights-based approach sees governments guaranteeing food security as a duty, not a form of benevolence. It insists that the holders are accountable to the rights holders. The human rights concept places particular emphasis on the active participation of all stakeholders in policy-making, on government transparency, and on ensuring that people have access to effective remedies through an independent legal framework when they have not received what they should have. It is important not only that the state recognizes all persons as right holders, but also that persons see themselves equally and know how to act accordingly. Thus, a rights-based approach is a key tool in achieving an appropriate level of public health.

The human rights-based approach to food security suggests new ways to identify, analyze and combat the causes of hunger and poverty, as well as an alternative method of promoting development. Approaching development from the perspective of the right to food and other inherent human rights is not only necessary for human survival; it is a new way to meet the millennium development goals.

\section{CONCLUSION}

Food security and nutrition are central to the individual and fundamental factors to the whole of society in respect of human rights. Food security is a component and guarantor of the realization of the right to health. All other components of the right to health depend on its proper condition. Therefore, studying the requirements that provide the conditions for maintaining and improving healthy, sufficient, nutritious, safe human nutrition is essential. An adequate level of food security must be ensured by individual governments and the international community through the development, approval, or implementation of an appropriate regulatory framework, as well as through the establishment of a political and institutional framework.

States should enshrine the right to food security in their domestic legislation and, if possible, in their Constitutions. Equally important is the adoption of a framework law on food security or the creation of appropriate sectoral legislation.

States should provide mechanisms that offer adequate, effective, and timely remedies in cases of violations of the right to food security.

\section{REFERENCES}

1. Ayala A., Mason Meier B. Public Health Reviews. 2017; 38:10. Available from: https://d-nb.info/1128938391/34

2. Kurman T., Kurman 0., Tuieva 0 . The legal foundations of food safety as a means of providing public health in globalization Wiad Lek. 2019;12:2626-2630. Available from: https://pubmed.ncbi.nlm.nih. gov/32124797/

3. FAO. Right to food making it happen. 2011. Available from: http://www. fao.org/3/i2250e/i2250e.pdf

4. FAO. How to feed the world in 2050. Available from: http://www.fao. org/fileadmin/templates/wsfs/docs/expert_paper/How_to_Feed_ the_World_in_2050.pdf

5. Bekele D. A review on the relationship between nutrition and health condition in humans. Archives of nutrition and public health. 2020;3.

6. Constitution of the World Health Organization. 1946. Available from: http://apps.who.int/gb/bd/PDF/bd47/EN/constitution-en.pdf?ua=1

7. Alston P. Conjuring up new human rights: a proposal for quality control. American Journal of International Law. 1984; 3:607 - 621.

8. ICESCR. Resolution 2200A. 1966. UNGA. Available from: https://www. ohchr.org/en/professionalinterest/pages/cescr.aspx

9. Coniglio M. Food and nutrition: matters of public health. Journal of food, nutrition and population health. 2016. Available from: https://www. imedpub.com/articles/food-and-nutrition-matters-of-public health. php?aid $=17545$

10. Nutrition. WHO. Available from: https://www.who.int/health-topics/ nutrition

11. FA0. The state of food insecurity in the world. 2015. Available from: http://www.fa0.org/3/a-i4646e.pdf

12. Derevyanko B., Nikolenko L., Syrmamiik I. at al. Assessment of financial and economic security of the region (based on the relevant statistics of the Donetsk region. Investment Management and Financial Innovations. 2016. 15(4): 283-295. 
13. Ayala A. and Meier B. A human rights approach to the health implications of food and nutrition insecurity. Public Health Rev. 2017; 38: 10.

14. Sanchez-Villegas A., Toledo E., de Irala, J. et al. Fast-food and commercial baked goods consumption and the risk of depression. Public Health Nutrition. 2012; 15(3): 424-432.

15. Gutorova N., Batyhina 0., Trotska M. Legal protection of publichealth through control over genetically modified food. Wiad Lek. 2018; 2:366-370.

16. Pashkov V., Trotska M. Natural environment as component of public health: some aspects of its legal regulation. Wiad Lek. 2019; 2: 261-267.

17. Vitalii M. Pashkov, Maryna V. Trotska, Andrii 0. Harkusha The theoretical and legal basis for environmental risk as a possible measurement of harm to the environment and human health. Wiad Lek.2020; 11: 2523-2527.

18. Olena M. Batyhina, Bogdan V. Derevyanko, Vitaliy V. Kadala Recreational lands as a component of health care: some aspects of legal regulation. Wiad Lek. 2020;12:2860-2864. doi: 10.36740/WLek202012226

19. Universal Declaration of Human Rights. General Assembly resolution 217 A. 1948. Available from: https://www.un.org/en/about-us/universaldeclaration-of-human-rights

20. ICESCR. United Nations. Available from: https://www.ohchr.org/en/ professionalinterest/pages/cescr.aspx

21. CEDAW.United Nations Human right. New York, 18December 1979. Available from: https://www.ohchr.org/en/professionalinterest/pages/cedaw.aspx

22. UNCRC. General Assembly resolution 44/25. 1989. United Nations Human right. Available from: https://www.ohchr.org/en/professionalinterest/ pages/crc.aspx

23. Committee on World Food Security. About CFS. Available from: http:// www.fao.org/cfs/ru/

24. FA0. Trade reforms and food security. 2003. Available from: http://www. fao.org/3/a-y4671e.pdf

25. Framework law on the right to food and food sovereignty. Latin American and Caribbean Parliament. Panama City, 2018. Available from: http:// parlatino.org/wp-content/uploads/2017/09/derecho-alimentacionsoberania-ing.pdf

26. FA0. Report of the World Food Summit. 1996. Available from: http:// www.fa0.org/docrep/003/w3548e/w3548e00.htm.

27. FA0. Food security information for action practical guides. 2008. Available from: http://www.fao.org/3/al936e/al936e.pdf

28. World Summit on Food Security. Draft declaration of the world summit on food security. Rome. 2009. Available from: http://www.fao.org/ fileadmin/templates/wsfs/Summit/Docs/Declaration/WSFS09_Draft_ Declaration.pdf

29. Regulation (EC) 178/2002 of the EP and of the Council. 2002. Available from: https://eur-lex.europa.eu/legal-content/EN/ ALL/?uri=celex\%3A32002R0178

30. Food safety. European Parliament. Available from: https://www.europarl. europa.eu/RegData/etudes/fiches_techniques/2013/050505/04A_ FT\%282013\%29050505_EN.pdf

31. Vidar M., Kim Y. and Cruz L. Legal developments in the progressive realization of the right to adequate food thematic. Development Law Branch. FAO Legal Office. 2014. Available from: http://www.fao.org/3/ i3892e/i3892e.pdf

32. Knuth L, Vidar M. Constitutional and legal protection of the right to food around the world. 2011. Available from: http://www.oda-alc.org/ documentos/1340937409.pdf

33. Constitution of the people's republic of Bangladesh. 1972. Available from: http://bdlaws.minlaw.gov.bd/act-367.html

34. Niger's Constitution of 2010 Available from: https://www. constituteproject.org/constitution/Niger_2017.pdf?lang=en
35. Maldives's Constitution of 2008 Available from: http://extwprlegs1.fao. org/docs/pdf/mdv136135.pdf

36. Bolivia's Constitution of 2009. Available from: https://www. constituteproject.org/constitution/Bolivia_2009.pdf

37. Constitution of the Republic of Ecuador, 1998. Available from: https://ihl-databases.icrc.org/applic/ihl/ihlnat.nsf/0/ BAOABF52718D79D6C1256AA80031580

38. Basic Law for the Federal Republic of Germany. Available from: https:// www.btg-bestellservice.de/pdf/80201000.pdf

39. Global food security act. Senate of the United States. April 13, 2016. Available from: https://www.congress.gov/bill/114th-congress/housebill/1567/text

40. Golay Christophe. The right to food and access to justice: examples at the national, regional and international levels. Rome, 2009. Available from: https://www.geneva-academy.ch/joomlatools-files/docman-files/ The\%20right\%20to\%20food\%20and\%20access\%20to\%20Justice.pdf

41. Khosa and others vs. Minister of Social Development, South Africa, Constitutional Court, 2004 (6) SA 505 (CC). Available from: https:// dullahomarinstitute.org.za/childrens-rights/legal-resources/audit-ofchildrens-rights-cases/other-welfare-protection-family-law-issuescustody-support-grant-and-access/khosa-and-others-v-minister-ofsocial-development-and-others-mahlaule-and-others-v-minister-ofsocial-development-and-others-2004-6-sa-505-cc

42. Fons Coomans. The Ogoni vs. the African Commission on Human and Peoples' Rights. International and Comparative Law Quarterly. 2003;52:749-760. Available from: http://www.righttoenvironment. org/ip/uploads/downloads/OgoniCaseProf.Coomans.

43. Kenneth George vs. Minister of Environmental Affairs \& Tourism, The Supreme Court of appeal of South Africa. 2007. Available from: http:// www.saflii.org/za/cases/ZASCA/2006/57.html

44. Inter-American Court of Human Rights. Case of the Sawhoyamaxa Indigenous Community v. Paraguay. 2006. Available from: https://www. corteidh.or.cr/docs/casos/articulos/seriec_146_ing.pdf

\section{ORCID and contributionship:}

Olena M. Batyhina: 0000-0002-7245-9369 A, B, D, E, F Bogdan V. Derevyanko: 0000-0001-7408-8285 A, B, D, F Tetiana V. Khailova: 0000-0001-6106-2027 A, C, E, $F$

\section{Conflict of interest:}

The Authors declare no conflict of interest.

\section{CORRESPONDING AUTHOR}

\section{Olena Batyhina}

Poltava Law Institute of Yaroslav Mudryi National

Law University, Poltava, Ukraine

$+380509089321$

e-mail: elenabatyhina@gmail.com

Received: 29.06 .2021

Accepted: 15.10 .2021

A - Work concept and design, B - Data collection and analysis, C - Responsibility for statistical analysis,

D-Writing the article, $\mathbf{E}$-Critical review, $\mathbf{F}$ - Final approval of the article 


\title{
LEGAL ASPECTS OF USING NATURAL RESOURCES FOR HEALTH AND RECREATIONAL PURPOSES TO ENSURE HUMAN RIGHT TO HEALTH CARE
}

DOI: 10.36740/WLek202111237

\author{
Alla K. Sokolova, Maryna K. Cherkashyna \\ YAROSLAV MUDRYI NATIONAL LAW UNIVERSITY KHARKIV, UKRAINE
}

\begin{abstract}
The aim: Is to conduct a comparative legal analysis of the use of natural resources for health and recreation purposes in Ukraine, the European Union, and other countries to improve the scientific theoretical basis of the legal regulation for the use, protection, and conservation of such natural resources.

Materials and methods: The national and international legal instruments regulating the rights to health and the right to use natural resources for health and recreational purposes were examined by analyzing practices of foreign states in the field of these legal relations, in particular, the comparative-legal, complex, formal, and logical, structural and functional methods along with analytical and empirical research tools.

Conclusions: The legislation of Ukraine does not fully disclose the concepts, features, classification of natural healing and recreational resources, and therefore many aspects of their use, protection, and conservation remain uncertain and unsecured provisions of regulations. The article features approaches to improving the current ecological legislation promoting proper legal regulation of using natural resources for health and recreational purposes, thereby creating the necessary conditions to ensure the right to health care.
\end{abstract}

KEY WORDS: the concept of sustainable development, natural resources, the right to use nature, the right to health care, legal regulation of using natural resources for health and recreational purposes

Wiad Lek. 2021;74(11 p.2):3077-3084

\section{INTRODUCTION}

The Rio Declaration on Environment and Development (1992) states that caring for people is essential to sustainable development. People have the right to a healthy and fruitful life in harmony with nature. The goals of sustainable development cannot be achieved in terms of widespread debilitating diseases, so countries urgently need to address the causes of ill health, including environmental causes, and their implications for development. The Plan of Implementation of the World Summit on Sustainable Development (2002) provides the need for countries to strengthen health system capacity ensuring the effective and accessible provision of basic health services to all towards disease prevention and control and the reduction of environmental threats to human rights and fundamental freedoms, according to the national laws and cultural and religious values, as well as to the reports of relevant United Nations conferences and summits and special sessions of the General Assembly (VI, $\$ 54$ ).

Thus, in today's world, the realization and protection of the human right to health care is the main issue at both the international and national levels. Having numerous reports on the concept of health, in the scientific literature the opinion is expressed that health is associated with the corresponding human condition, which is characterized by several components such as 1) physical condition; 2) state of mind; 3) social welfare; 4) the absence of diseases and physical disability. A person is healthy when these elements interact with each other in a certain balance, complementing each other. Accordingly, public health focuses on the study of health concepts based on different layers, among which environmental state including the natural environment, is not the last [1]. There is a direct link between human health and the environment, namely, the state of health and the threat to human life depends on the natural objects state, the degree of their pollution, and exhaustion. The right to health care is one of the most important human rights. One of the guarantees of this right is a safe natural environment, which, on the one hand, allows maintaining health at the appropriate level without deteriorating it, and on the other - improving and preventing negative consequences in this regard [2].

Natural resources affect human health, because not only they are part of the human environment and so it must be safe, but also because natural resources can be used by a human directly as a means of preservation, maintenance, restoration of the basic vital forces and health by the realization of the right of nature use. Moreover, ensuring this right, defined in the system of environmental rights, is a prerequisite for the realization of the human right to health care. Therefore, the purpose of this article is to improve the scientific basis for the use, protection, and conservation of 
health and recreational natural resources, as well as the formulation of proposals and recommendations for improving the legal regulation of relevant environmental relations.

\section{THE AIM}

Of this article is to conduct a comparative legal analysis of the use of natural resources for health and recreation purposes in Ukraine, the European Union, and other countries to improve the scientific theoretical basis of the legal regulation for the use, protection, and conservation of such natural resources.

\section{MATERIALS AND METHODS}

The study is based on empirical and analytical data taken from the reports of UN conferences, the National Report "Sustainable Development Goals. Ukraine", the European Convention on Human Rights, the legal doctrine of environmental law, regulations of the Verkhovna Rada of Ukraine, the Cabinet of Ministers of Ukraine and other state executive bodies, as well as international documents, regulations of the European Union and some foreign countries, special scientific literature and scientific and practical comments on the environmental legislation of Ukraine. The national and international legal instruments regulating the rights to health and the right to use natural resources for health and recreational purposes were examined by analyzing practices of foreign states in the field of these legal relations, in particular, the comparative-legal, complex, formal, and logical, structural and functional methods along with analytical and empirical research tools.

\section{REVIEW AND DISCUSSION}

Right to Use Natural Resources as the Main Condition to Ensure Human Right to Health Care under the Concept of Sustainable Development

It is well known that the term sustainable development was introduced into widespread use by the World Commission on Environment and Development (WCED) under the leadership of Gro Harlem Brundtland in 1987. The Commission's task was to develop basic principles, indicators of sustainable development, and a global long-term environmental and economic action program for the next decade. As the result the report "Our common future" [3] was presented, where a clear definition of the term "sustainable development" in its modern sense was formulated and a new concept of sustainable development as an alternative to development based on unlimited economic growth was put forward for the first time. This development involves solving economic, social, and environmental problems, interconnectedness and interdependence, and ensuring the human right to a healthy and productive life in harmony with nature which is one of the central problems in the concept of sustainable development that needs to be addressed. The main elements of the concept of sustainable development were developed and consolidated at the conference in Rio de Janeiro (1992). Also at the World Summit on Sustainable Development in Johannesburg, member countries agreed on the Johannesburg Declaration on Sustainable Development (2002) [4] and the Plan of Implementation of the World Summit on Sustainable Development (2002).

The principles of the state environmental policy of Ukraine are: achieving the Sustainable Development Goals, which were approved at the United Nations Summit on Sustainable Development (2015) [5] - in particular, to ensure a healthy lifestyle and promote well-being for all at all ages [6]. Supporting the global goals of sustainable development until 2030 proclaimed by the UN General Assembly resolution 2015 and the results of their adaptation, the President of Ukraine decided to ensure compliance with the Sustainable Development Goals of Ukraine until 2030 [7], set out in the National Report [8] taking into account the specifics of Ukraine's development.

The Constitution of Ukraine proclaims that a person, his or her life and health, honor and dignity, inviolability, and security are recognized in Ukraine as the highest social value (Article 3). According to Article 50, everyone has the right to a safe environment for life and health and to compensation for damages caused by violating this right [9]. One of the basic provisions of Ukraine's legislation on this issue is Article 6 of the Law "Bases of the Legislation of Ukraine on Health Care" [10], which stipulates that every citizen of Ukraine has the right to health care, which provides, in particular, a safe environment for life and health; safe and healthy working, study, living and recreation conditions, confirming a connection between the right to health care and the realization of the right of citizens to rest and restoration of basic vitality (Article 45 of the Constitution of Ukraine). According to Article 26 of the Law "Bases of the Legislation of Ukraine on Health Care", the state provides environmental protection as an important prerequisite for human life and health by protecting living and inanimate nature, protecting people from negative environmental impacts, by achieving harmonious interaction of a human, society, and nature, rational use and reproduction of natural resources.

The country's responsibility to the Ukrainian citizens for violating the legislation on environmental safety and protection of the right to a safe environment for life and health is confirmed by the European Court of Human Rights in numerous cases of Ukrainian citizens against Ukraine and other citizens against their countries on the life and health protection of the environment [11, p. 77], which is associated with the right to respect private and family life, officially recognized in Article 8 of the Convention on Protection of Human Rights and Fundamental Freedoms [12].

Health care as an inalienable natural right of citizens is regulated by almost all areas of national law, among which the rules of environmental law play an important role. The environmental legislation of Ukraine enshrines a key provision that state health and human life are subject to state protection against the adverse effects of environ- 
mental conditions (Article 5 of the Law of Ukraine "On Environmental Protection") [13].

According to the legislation of Ukraine, citizens can use natural resources (wildlife, natural plant resources, forests, water bodies, etc.) for health and recreational purposes on the right of general and special use. The legal basis for the implementation of such rights in Ukraine is the Land Code [14], the Water Code [15], the Forest Code [16], the Subsoil Code [17] and the Laws "About Flora" [18], "About Fauna" [19], "About Natural and Reserved Fund of Ukraine" [20], etc.

When carrying out economic and other activities, primarily related to the use of natural resources and complexes, the requirements of environmental protection should be observed and the environmental rights of others should not be violated. The need to protect and rationally use the natural resource base of economic and social development is due to the fact that human activities are increasingly affecting the integrity of ecosystems that provide essential resources and services in the interests of human well-being and economic activity. The National Security and Defense Council of Ukraine, taking into account the high level of risks to natural ecosystems and public health, has appropriately established priority measures to neutralize them [21].

Given that the state of natural objects depends entirely on the environmental conditions of their location, climate change is important for natural resources used for health and recreational purposes. Such situations force countries, including Ukraine, to focus their policies on solving problems in the context of adaptation of natural health and recreational resources to climate change, as this direction will further ensure citizens their right to health care through the implementation of useful nature management.

The above is well-founded, as there is a direct link between the state of human health and the environment, the state of environmental safety of industrial and other facilities, and the level of a real threat of man-made incidents dangerous to human life and health [22]. Therefore, the definition of the characteristics of such concepts as environmental safety, the states of the environment, and others have been in scientists' focus.

A.D. Shakirov notes that without such basic conditions as air, water, food, and a habitable climate, people cannot survive on this planet. Thus, a favorable environment is necessary to fundamental rights guaranteed by international human rights treaties [23]. Thus, the deterioration of the environment has both direct and indirect negative consequences for the effective realization of human rights and freedoms. And the natural environment, namely its state in general and individual natural objects in particular, is one of the elements that both directly and indirectly affect human health [1], and international law provides for this dependence at the legislative level [24].

Legal Aspects of Using Natural Resources for Health and Recreational Purposes in Ukraine

Legislation of Ukraine regarding the legal regulation of the use of natural resources for health and recreational purposes is currently not represented by a separate special legal act. Analysis of the resources of environmental law shows that attention to natural objects with these features is only briefly given as general laws in this area of public relations, and resource-based legislation. Thus, one of the main laws is the Law of Ukraine "On Environmental Protection" which establishes the basic provision that natural resources, intended to meet vital needs (including health and recreation), are used according to general natural resource use (Article 38) [13]. This procedure stipulates that these natural objects are guaranteed to be used by all citizens free of charge, without obtaining special permits, and without assigning these resources to individuals.

The next important provision established by the Law of Ukraine "On Environmental Protection" is referring natural resources used for health and recreational purposes to objects of special protection. The need for such protection is due to the fact that such natural areas and objects have great ecological value as unique and typical natural complexes, to preserve favorable environmental conditions, prevent and stabilize negative natural processes and phenomena (section 1 Article 60).

According to Article 62 section 1 resort, health, and recreation areas are recognized as areas that have natural healing factors: mineral springs, climatic and other conditions conducive to the treatment and rehabilitation of people. Recreational areas, in turn, are areas of land and water space intended for organized mass recreation and tourism (Article 63) [25]. In addition to the above characteristics of these areas, the criterion for delimitation may also be the subject composition, authorized to establish the nature management regime for such resources (section 3 Article 63, Section 4 Article 63).

The Law of Ukraine "About Natural and Reserved Fund of Ukraine" [20] is a resource law that to some extent regulates the use of natural resources for recreational and health purposes. In particular, among all the objects of the nature reserve fund, the norms of the Law are devoted to the categories of those that can be used for health and other recreational purposes. Such objects are national nature parks and parks-monuments of landscape art. Separately, the Law considers recreational activities within such natural areas as the zone of anthropogenic landscapes, regulated recreation, regional landscape parks, dendrological, zoological parks.

This legal act also does not define recreational or health resources, but some conclusions can be drawn about their purpose. Thus, when considering the recreational purpose of a certain area, the Law implies, among other things, the purpose of organized, effective tourism and recreation, visitor service, preservation in the natural state of typical or unique natural complexes and objects, and in some cases health improvement (zone of regulated recreation of national nature parks).

Thus, as noted by A.H. Bobkova, the main features of recreational resources are their suitability for use in the organization and recreation of the population, confirmation of such suitability in the manner prescribed by law, making appropriate decisions by the authorities to declare 
such areas recreational, determining their boundaries and regimes of use and protection and some other features related to the natural properties of the respective lands and objects located there [26, p. 52].

The legislation does not fully disclose the concept of "recreational natural resources" or "natural resources used for recreational purposes", but the analysis of many rules of law shows that at present the legislator does not own certain objects of nature health or recreational qualities regulating this area of public relations. This conclusion clearly illustrates the difference between such legal regulation and the legal regime of natural healing resources [27], as the latter is clearly defined by the legislator as having special properties.

All the above are listed in a number of other special laws, emphasizing the possibility of using certain resources for recreational or health purposes. For instance, according to section 1 Article 64 of the Water Code of Ukraine [15] using water for health, recreational and sports purposes is carried out in the order of general and special water use. Article 39 of the Forest Code of Ukraine contains the division of forests by ecological and socio-economic significance, among which a separate group consists of recreational and health forests having mainly recreational, sanitary, hygienic, and health functions [16]. One of the types of subsoil use according to Article 14 of the Subsoil Code of Ukraine is the creation of geological territories and objects that have important scientific, cultural, sanitary, and health significance [17]. According to Article 14 of the Law "About Flora" the use of natural plant resources, subject to compliance with the established requirements may be carried out, in particular, for health and recreational purposes [18]. And Article 16 of the Law "About Fauna" guarantees citizens the right to free general use of wildlife to meet vital needs (aesthetic, health, recreational, etc.) [19]. Thus, the legislation of Ukraine enshrines only the basic provisions on the possibility of using natural resources for health and recreational purposes, in particular, in the general or special use, and in certain cases implementation of property rights, determining their status, guarantees of their protection and preservation. It should be noted the lack of law that fully discloses the concepts, features, classification of health and recreational natural resources, and therefore many aspects of their use, protection, and conservation remain uncertain and unsecured provisions of regulations.

For the conceptual disclosure of the topic of using natural resources for recreational purposes, sectoral subordinate legislation partially regulating this issue can be a model. Such an act is the Order of the former Ministry of Environmental Protection of Ukraine "On Approval of the Regulations on recreational activities within the territories and objects of the nature reserve fund of Ukraine" [28]. Thus, section 1 having general provisions defines, in particular, that recreational resources are objects of natural and historical-cultural environment that can be used for recreational activities. Recreational activities, in turn, are activities aimed at restoring the mental, spiritual, and physical strength of a human through health and cultural and cognitive recreation, tourism, spa treatment, recreational and sport fishing, hunting, and more. Thus, this normative act to some extent provides answers to questions concerning the regulation of the use of natural recreational resources, but the legal status of such objects, which are outside the nature reserve fund, remains unclear.

O.M. Shmyhova determines that the right to use recreational nature in the subjective sense is a system of legal opportunities for a human to use natural resources (complexes) to meet the vital needs of traditional forms of recreation and sports within recreational areas and other areas, using which for these purposes are not prohibited or restricted by law, without harming human life and health and the environment. The author proposes the adoption of the Law "On recreational areas and recreational nature" [29].

In the science of environmental law, some scientists have developed a theory of dividing the right of recreational nature or recreational law into a separate institution. L.A. Samusenko substantiates the allocation of recreational law by the fact that recreational (sanatorium, health, sports, mass, tourist) purposes of using natural resources have significant differences from other types of nature rights [30]. This point of view has its positive aspect, as division into a separate category of recreational nature will result in the implementation of state and legal measures to regulate it, which will ensure and guarantee more effective and targeted protection and conservation of recreational natural resources. This theory is also supported by O.M. Tkachenko, focusing attention on the objects of natural and recreational law [31]. Thus, the formation of proper legal regulation of relations for the entire system of natural recreational resources will allow a more detailed and high-quality approach to the conservation and protection of clearly defined natural resources.

A.M. Orlov in his dissertation singled out the definition of health and recreational properties through the prism of their territorial location [32]. According to many theorists, recreation is an organized activity, primarily related to recreation in favorable conditions. Rehabilitation is usually characterized by belonging to specific natural or artificial objects or phenomena that have the appropriate properties and are often part of a resort or recreational area.

This understanding of the health purpose of natural resources is also reflected in certain legislation. According to Article 47 of the Land Code of Ukraine, health and recreational lands include lands that have natural healing properties, which are used or can be used for disease prevention and treatment of people [14]. However, the legislation and legal literature state that the healing properties are not the lands themselves, but the natural healing resources located on them, suitable for treatment, medical rehabilitation, and prevention of diseases [33, $\mathrm{p}$. 145-146]. Also, the legislator, dividing the categories of "medical" and "health" goals, does not name the criteria for their delimitation and often combines these properties for a single natural resource within a single legal regime of 
its protection and use. Therefore, given the scientific views on the clear delineation of the purpose of rehabilitation, recreation, and treatment, they should also be taken into account at the legislative level, as in this way the legal protection of relevant natural resources will be more effective and targeted.

Therefore, based on the above, we consider it appropriate to include in the Law of Ukraine "On Environmental Protection" a special section where concepts, features, lists of natural health and recreational resources, as well as basic environmental requirements for their use, protection, preservation, and playback, will be written.

Foreign States Experience on Legal Regulation of Natural Resources Using for Health and Recreational Purposes

The approach to understanding the various purposes of using natural resources are borrowed from the practice of the international tourism industry of European countries. Thus, along with the above categories of spa tourism and wellness tourism, a separate type of activity is clearly defined - medical tourism. English-language literature uses different concepts of this phenomenon: "medical tourism", "health tourism", "trade in health services". However, its main essence is a person's trip abroad in order to receive specialized medical care in a tourist complex with special infrastructure, which often takes place within a particular resort [34, p. 11].

Regarding this issue, attention is drawn to the views of foreign authors, who have developed their own understanding of activities in the field of recreation, health, and treatment based on studies of European practices. In particular, medical tourism considers medical intervention outside the country of a person's residence where the medical element is central to such activities [35, p. 268]. Recreational activities are aimed at resting or healing the human body through mainly water treatments, such as mineral or thermal pools, steam rooms, and saunas. The emphasis here is usually on recovery, rehabilitation, or recreation [36, p. 85]. As for health tourism, it is mostly not considered as an independent activity, but defined in comparison with the above categories: as an autonomous phenomenon along with medical tourism, which includes recreation [35]; as a generic category for medical tourism [37, p. 7]; as an intermediate link between recreation and treatment [36].

Recreational and health activities in Central Europe are regulated at the state level by laws, regulations, and orders of the Ministries of Sport and Tourism, the Ministries of Health, the Ministries of Foreign Affairs, Transport and Regional Development, and the National Health Funds [38, p. 132]. Thus, in such countries as Poland, Germany, Austria, the Czech Republic, Slovakia, the criteria for identifying resort and recreational areas are clearly defined, as well as the institutional principles of the resort as an area with a significant concentration of health and recreational resources [39, p. 13].

For instance, in the Czech Republic and Slovakia, recreational and health activities are considered separate phe- nomena. In particular, health activities fall entirely under the category of healing purposes and are the responsibility of the Ministry of Health, and are regulated according to health legislation. Recreation, in turn, involves spa tourism and includes stays in appropriate health facilities, but not directly related to treatment. Today, the recreational and health sphere in these countries is represented, first of all, by the most significant natural objects: Karlovy Vary in the Czech Republic and Piestany in Slovakia, which are known for their health effects. For instance, the Czech resorts of Karlovy Vary and Marianske Lazne are based mainly on natural healing resources, which consist of mineral and thermal waters, peloids (humus, peat, and mud), natural gases, and climate. Most Slovak resorts also operate on the basis of natural healing resources (mineral, thermal, and radon waters, peloids, and gases). Currently, Slovakia has about 1.500 natural sources of mineral water (springs, wells) with healing properties [ 40 , p. 113-122]. Thus, these countries have a large complex of natural resources with health and healing properties, actively use them for recreational purposes as the basis of some of the most visited resorts in the world.

The experience of Bulgaria is noteworthy, as this country has a relatively wide range of natural and anthropogenic, and recreational resources, and the similarity of climate, recreational resources, socio-economic factors of their development make this country a good example for Ukraine. Thus, Bulgaria has adopted the practice of dividing its territory into tourist areas. For instance, one of such tourist areas is the area of the Rose Valley (Kazanlak), which the main specialization is health and cultural and recreational tourism (spa and wellness tourism, adventure and ecotourism, mountain hiking, and recreational tourism, etc.).

The legal basis for such state measures was the Bulgarian Law on Tourism, according to which a tourist area is a natural and social system with a stable spatial infrastructure and a high degree of concentration of natural resources, within which a competitive and effective tourism policy is implemented. In addition, the Law contains a definition of "medical services", meaning services that involve using natural healing resources like mineral waters or mud, procedures that promote human body recovery [41]. Thus, Bulgarian law does not explicitly define natural or health resources, but this country is an example in which the legal regulation of using such natural objects is fully covered by tourism.

As it is known, Hungary has the highest potential in the world to use thermal springs for health purposes. The largest thermal health resort in Europe is located in Budapest. In this regard, the country has developed a "Plan of Szechenyi" (a program document that defines the economic development of Hungary until 2020), which was approved in 2011 [42, p. 282]. In particular, the document provides for investment of funds from the state budget and entrepreneurs (large resort operators) regarding the construction of new and modernization of existing resort infrastructure in the field of spa tourism [43, p. 154].

Among the Poland laws regulating the use of natural resources for health and recreational purposes, there is the 
Law “On Tourist Services" of August 29, 1997 [44]. However, the sectoral Law of the Republic of Poland "On Nature Protection" [45] contains many rules aimed at protecting natural objects and areas used for recreational purposes (Article 113, Article 127, Article 293).

It should be noted that the largest number of recreational resources, which are additionally often used for health purposes, is concentrated in European countries. That is because mainly each European country has favorable natural, geographical, climatic features, various historical and architectural monuments of different eras, and the highest recreational attractiveness due to highly developed accommodation and recreational infrastructure. For that reason, these countries have a fairly extensive system of management and regulation of recreational activities at both local and national levels. Such experience is indicative for Ukraine, as our country does not have a clearly formed and legally regulated system of governance in this area [46, p. 60-61].

Therefore, special state organizations and associations play an important role in regulating the use of natural resources for health and recreational purposes in European countries. For instance, in Poland there is the Association of Spa Communes, in the Czech Republic - the Union of Health Resorts of the Czech Republic and the Czech Tourist Information Center, in Slovakia - the Association of Spa Resorts.

Thus, the law of foreign countries on nature protection is not focused on a detailed conceptual aspect, so it is difficult to speak of a high scientific level of general provisions of resource regulations, which would contain the definition or purpose of natural recreational and health resources. European practice is based on a different approach: using nature is mainly viewed through the prism of tourism and resorts, many countries successfully use them by combining within one policy issues of tourist attractiveness of prominent sites and protection of health and recreational resources. Therefore, the role of the tourism and recreation industry is growing within Ukraine's integration into the world economic space.

Its development will contribute to solving the problems of forming a positive international image of the country, overcoming the balance of payments deficit, employment, and gradual reconstruction of regional natural complexes [47, p. 94].

\section{CONCLUSIONS}

Ukraine has a well-developed system of tools to achieve a high-level efficient use of natural resources for health and recreational purposes. In particular, the emergence and development of health and medical tourism in our country contribute to the unique natural, recreational resources and a network of various health facilities that can meet a wide range of needs of tourists for recreation and health. However, this area of public relations in Ukraine has still been developing, so it is important to identify features of legal regulation of using these natural resources based on the example of European countries, as well as proposing measures to improve the national legal system on this issue.
So, first of all, we propose to comprehensively revise the Law of Ukraine "On Environmental Protection", which provides for appropriate legal terms, concepts (with the definition of their content), features, lists of natural resources related to health and recreation; to establish general ecological requirements for their use, protection, preservation, and reproduction as objects of special state protection. The regime of protection, preservation, and use of certain health and recreational natural resources must be determined by special legal norms. Relevant legal relations regarding health and recreational natural resources are mostly not regulated by the differentiated ecological legislation of Ukraine. Considering this, such relations should be regulated by relevant environmental codes and laws. Therefore, when developing the Land Code of Ukraine, the Forest Code of Ukraine, the Water Code of Ukraine, the Subsoil Code and the Laws of Ukraine: "About Flora", "About Fauna", "About Atmospheric Air Protection", "About Natural and Reserved Fund of Ukraine", "About the Ecological Network of Ukraine", etc., should find their place in the form of relevant sections in specific provisions for regulating the use of natural resources for health and recreational purposes, as well as their protection, conservation, and reproduction, given their special legal status.

Nowadays in Ukraine, the legal regulation of using natural resources in health or recreational areas is actually based on information or extracts from various natural cadastres (State Land Cadastre, State Forest Cadastre, State Water Cadastre, State Cadastre of Mineral Resources, State Cadastre of Minerals and Manifestations, etc). We consider it expedient to adopt a bylaw providing a special cadastre for health and recreational natural resources. This cadastre will be a system of information on the quantity, quality, and other characteristics of all health and recreational natural resources identified and calculated in Ukraine (their volume, environmental value, protection, and use). It would be appropriate to establish a Department within the Ministry of Environmental Protection and Natural Resources of Ukraine, which will be responsible for monitoring the efficient and rational use of such resources in the complex.

Therefore, it is important to improve the current environmental legislation of Ukraine (defining general provisions and their specification in special laws and codes) as well as reduce or eliminate environmental threats to nature and human health. Thus, solving these problems will contribute to the proper legal regulation of using natural resources for health and recreational purposes, creating necessary conditions guaranteeing the right to health and its protection.

\section{REFERENCES}

1. Pashkov VM, Trotska MV. Natural environment as component of public health: some aspects of its legal regulation. Wiad lek. 2019; 72(2):261-6.

2. Bobkova MH, Trotska MV. Safe natural environments as guarantee of exercising the right to health. Wiad lek. 2019; 72(8): 1571-5.

3. United Nations General Assembly. Our Common Future. Report of theWorld Commission on Environment and Development[Internet]. Nairobi; 1987 June 16 [cited 2021 July 23]. Available from: https://sustainabledevelopment. un.org/content/documents/5987our-common-future.pdf. 
4. World Health Organization. Johannesburg Declaration on Health and Sustainable Development. Meeting of Senior Officials and Ministers of Health [Internet]. Johannesburg, South Africa; 2002 Jan. 19-22 [cited 2021 July 23]. Available from: https://www.who.int/mediacentre/ events/HSD_Plaq_02.8_def1.pdf.

5. United Nations General Assembly. Transforming our world: the 2030 Agenda for Sustainable Development [Internet], Resolution 70/1 (Sept. 25, 2015) [cited 2021 July 23]. Available from: https://www.un.org/ en/development/desa/population/migration/generalassembly/docs/ globalcompact/A_RES_70_1_E.pdf.

6. Ukrajina. Pro Osnovni zasady (strateghiji) derzhavnoji ekologhichnoji polityky Ukrajiny na period do 2030 roku, Zakon No 2697-VIII (Ljut. 28, 2019) [About the Basic principles (strategy) of the state environmental policy of Ukraine for the period till 2030, Law No 2697-VIII (Febr. 28, 2019)]. VVR. 2019; 16: art. 70. (in Ukrainian).

7. Prezydent Ukrajiny. Pro cili stalogho rozvytku Ukrajiny na period do 2030 roku, Ukaz No 722/2019 (Veres. 30, 2019) [On Sustainable Development Goals of Ukraine for the period till 2030, Decree No 722/2019 (Sept. 30, 2019)]. OG. 2019; 79: art. 2712. (in Ukrainian).

8. Ministry of Economic Development and Trade of Ukraine. Sustainable Development Goals: Ukraine. National Baseline Report [Internet]. Kyjiv: Minekonomiky; 2017 [cited 2021 July 23]. Available from: https:// ukraine.un.org/sites/default/files/2020-06/SDGs_NationalReportEN_ Web.pdf.

9. Konstytucija Ukrajiny, № 254k/96-BP (Cherv. 28, 1996) [Constitution of Ukraine, No 254k/96-BP (June 28, 1996)].VVR. 1996; 30: art. 141 (in Ukrainian).

10. Ukrajina. Osnovy zakonodavstva Ukrajiny pro okhoronu zdorov'ja, Zakon No 2801-XII (Lystop. 19, 1992) [Bases of the Legislation of Ukraine on Health Care, Law No 2801-XII (Nov. 19, 1992)]. VVR. 1993; 4: art. 19 (in Ukrainian).

11. Nosik VV. Problemy dostupu do pravosuddja u zakhysti prava na bezpechne dlja zhyttja i zdorov'ja dovkillja v Ukrajini [Problems of access to justice in protecting rights to environmental safety for life and health in Ukraine]. In: Kovalenko NV, Rybachuk Al, Kravchuk VM, Pyvovar IV, eds. Judicial protection of the natural environment and environmental rights. International Judicial Forum; 2019 Nov 7; Kyjiv: Verkhovny Sud; 2019. p. 76-82 (in Ukrainian).

12. European Court of Human Rights. The European Convention on Human Rights. As Amended by Protocols Nos. 11 and 14. Supplemented by Protocols Nos. 1, 4, 6, 7, 12, 13 and 16 [Internet]. Strasbourg: ECHR, 2013 [cited 2021 July 23]. Available from: https://www.echr.coe.int/ documents/convention_eng.pdf.

13. Ukrajina. Pro okhoronu navkolyshnjogho pryrodnogho seredovyshha, Zakon No 1264-XII (Cherv. 25, 1991) [On Environmental Protection, Law No 1264-XII (June 25, 1991)]. VVR. 1991; 41: art. 546. (in Ukrainian).

14. Zemeljnyj kodeks Ukrajiny, № 2768-III (Zhovt. 25, 2001) [Land Code of Ukraine, No 2768-III (0ct. 25, 2001)]. VVR. 2002; 3-4: art. 27. (in Ukrainian).

15. Vodnyj kodeks Ukrajiny, No 213/95-BP (Cherv. 6, 1995) [Water Code of Ukraine, No 213/95-BP (June 6, 1995)]. VVR. 1995; 24: art. 189. (in Ukrainian).

16. Lisovyj kodeks Ukrajiny, No 3852-XII (Sich. 21, 1994) [Forest Code of Ukraine, No 3852-XII (Jan. 21, 1994)]. VVR. 1994; 17: art. 99. (in Ukrainian).

17. Kodeks Ukrajiny pro nadra, No 132/94-BP (Lyp. 27, 1994) [Code of Ukraine About Subsoil, No 132/94-BP (July 27, 1994)]. VVR. 1994; 36: art. 3401. (in Ukrainian).
18. Ukrajina. Pro roslynnij svit, Zakon No 2026-III (Zhovt. 5, 2000) [About Flora, Law No 2026-III (Oct. 5, 2000)]. VVR. 2000; 50: art. 435. (in Ukrainian).

19. Ukrajina. Pro tvarynnyj svit, Zakon No 2894-III (Ghrud. 12, 2001) [About Fauna, Law No 2894-III (Dec. 12, 2001)]. VVR. 2001; 14: art. 97. (in Ukrainian).

20. Ukrajina. Pro pryrodno-zapovidnyj fond Ukrajiny, Zakon No 2456-XII (Cherv. 16, 1992) [About Natural and Reserved Fund of Ukraine, Law No 2456-XII (June 16, 1992)]. VVR. 1992; 34: art. 502. (in Ukrainian).

21. Rada nacionaljnoji bezpeky i oborony Ukrajiny. Pro vyklyky i zaghrozy nacionaljnij bezpeci Ukrajiny u ekologhichnij sferi ta pershocherghovi zakhody shhodo jikh nejtralizaciji, Rishennja (Berez. 23, 2021) [0n challenges and threats to Ukraine's national security in the environmental sphere and priority measures to neutralize them, Decision (March 23, 2021)]. 0G. 2021; 26: art. 1249. (in Ukrainian).

22. Sokolova AK, Vilchyk TB, Cherkashyna MK. Ensuring the environmental rights as a prerequisite for the rights to health in Ukraine and the European Union. Wiad lek. 2019; 72(12-2): 2489-95. doi: 10.36740/ WLek201912216.

23. Shakirov AD. Zashchita ekologicheskih prav cheloveka v celyah dostizheniya ustojchivogo razvitiya [Protection of environmental human rights to achieve sustainable development]. Vestnik of Volzhsky University after V.N. Tatischev. 2013; 2(78): 161-71. (Ru).

24. European Parliament, Council of the European Union. Laying Down the Sixth Community Environment Action Programme, Decision No 1600/2002/EC (July 22, 2002) [Internet]. 0J. 2002 [cited 2021 July 23]; L 242: 1-15. Available from: http://www.fao.org/faolex/results/details/ en/c/LEX-FAOC034551.

25. Malysheva NR, Jerofejev MI. Науково-практичний коментар до Закону України "Про охорону навколишнього природного середовища" [Scientific and Practical Commentary to the Law of Ukraine "On Environmental Protection"]. Kharkiv: Pravo; 2017. (in Ukrainian).

26. Bobkova AGh. Pro ponjattja pryrodnykh rekreacijnykh resursiv [0n the concept of natural recreational resources]. Law of Ukraine. 2000; 5:51-4. (in Ukrainian).

27. Sokolova A, Cherkashyna M. The Legal Regulation of the Use of Natural Healing Resources: The Theory and Practice of Disputes Resolution. Access to Justice in Eastern Europe. 2021; 2(10): 144-63. doi: 10.33327/ AJEE-18-4.2-n000065.

28. Ministerstvo okhorony navkolyshnjogho seredovyshha Ukrajiny. Pro zatverdzhennja Polozhennja pro rekreacijnu dijaljnistj u mezhakh terytorij ta ob'jektiv pryrodno-zapovidnogho fondu Ukrajiny, Nakaz No 330 (Cherv. 22, 2009) [0n Approval of the Regulations on recreational activities within the territories and objects of the nature reserve fund of Ukraine, Order No 330 (June 22, 2009)]. OG. 2009; 57: art. 1997. (in Ukrainian).

29. Shmyghova 0M. Pravove reghuljuvannja rekreacijnogho pryrodokorystuvannja v Ukrajini ta inshykh derzhavakh [Legal Regulation of Recreational Nature Use in Ukraine and Other Countries] [Abstract Candidate's dissertation]. Kyiv: Taras Shevchenko National University of Kyiv; 2010. (in Ukrainian).

30. Samusenko LA. Pravo rekreacionnogo prirodopolzovaniya [Recreational Use of Natural Resources] [Abstract Candidate's dissertation]. Minsk: Belarusian State University; 2013. (in Russian).

31. Tkachenko EN. Ob"ekty prava pol'zovaniya lechebno-rekreacionnym fondom [Objects of the Right to Use Medical and Recreational Fund]. Problems of Legality. 1998; 34: 151-4. (in Russian). 
32. Orlov AM. Pravovi problemy pryrodokorystuvannja j okhorony navkolyshnjogho seredovyshha ozdorovchykh ta rekreacijnykh miscevostej (na materialakh Avtonomnoji Respubliky Krym) [Legal problems of nature use and environmental protection of health and recreational areas (based on the materials of the Autonomous Republic of (rimea)] [Candidate's dissertation]. Kyiv: Institute of State and Law. V.M. Koretsky National Academy of Sciences of Ukraine; 2005. (in Ukrainian).

33. Novosad AS, Momot Al. Pravove reghuljuvannja zemelj ozdorovchogho pryznachennja [Legal Regulation of Lands of Health-Improving]. Legal Novels. 2018; 4: 142-8. (in Ukrainian).

34. Letunovska N, Kwilinski A, Kaminska B. Scientific Research in The Health Tourism Market: A Systematic Literature Review. Health Economics and Management Review. 2020; 1: 8-19.

35. Tressider R. Health and medical tourism. In: Robinson P, Heitmann $S$, Dieke $P$, eds. Research Themes for Tourism. Wallingford: $C A B$ International; 2011.

36. Smith M, Puczkó L, eds. Health and Wellness Tourism. Amsterdam: Elsevier Butterworth-Heinemann; 2009.

37. Cook PS. What is health and medical tourism? In: The Annual Conference of the Australian Sociological Association; 2008 Dec 2-5 [Internet]. Victoria: University of Melbourne; 2008 [cited 2021 July 23]. Available from: http://utas.academia.edu/PetaCook/Papers/225976/What_is_ Health_and_Medical_Tourism.

38. Parfinenko AJu, Volkova II, Shherbyna VI. Problemy ta perspektyvy rozvytku likuvaljno-ozdorovchogho turyzmu v Ukrajini (u porivnjanni z krajinamy (entraljnoji Jevropy) [Problems and Prospects of Spa Tourism Development in Ukraine (in Comparison with Central European Countries)]. The Journal of V.N. Karazin Kharkiv National University. Series «International Relations. Economics. Country Studies. Tourism». 2018; 7: 130-5. (in Ukrainian).

39. GhumenjukVV. Derzhavne reghuljuvannja kurortno-rekreacijnoji sfery [State regulation of the resort and recreational sphere]. Kyiv: Kyiv National University of Trade and Economics; 2016. (Ua).

40. Routledge. Health and Wellness Tourism: A Focus on the Global Spa Experience [Internet]. Taylor and Francis Group; 2014 [cited 2021 July 23]. Available from: https://www.routledge.com/rsc/downloads/ Health Wellness Tourism FB final.pdf.

41. Republic of Bulgaria. Tourism Act (March 12, 2013) [Internet]. DV. 2013 [cited 2021 July 23]; 30. Available from: https://www.tourism. government.bg/en/kategorii/zakoni/tourism-act.

42. Zakharkevych NP. Dosvid krajin Jevropejsjkogho Sojuzu u formuvanni osnov «zelenoji» ekonomiky [The Experience of the European Union in Formation of Foundations of the Green Economy]. University Scientific Notes. 2013; 2(46): 278-85, (Ua).

43. Subota MV. Ekonomichne reghuljuvannja i socialjne sprjamuvannja rozvytku kurortnoji dijaljnosti [Economic Regulation and Social Direction of Resort Activity Development] [Candidate's dissertation]. Kam'janecjPodiljsjkyj: The State Agrarian and Engineering University in Podilia; 2015. (in Ukrainian).
44. Rzeczpospolita Polska. 0 usługach turystycznych, Ustawa (Sierp. 29, 1997) [Internet]. DzU. 2006 [cited 2021 July 23]; 220: art. 1600. Available from: http://isap.sejm.gov.pl/isap.nsf/download.xsp/ WDU20042232268/U/D20042268Lj.pdf.

45. Rzeczpospolita Polska. Prawo ochrony środowiska, Ustawa (Kwiec. 27, 2001) [Internet]. DzU. 2001 [cited 2021 July 23]; 62: art. 627. Available from: https://isap.sejm.gov.pl/isap.nsf/download.xsp/ WDU20010620627/T/D20010627L.pdf.

46. Levcov SV. Orghanizacija nadannja rekreacijnykh poslugh orghanamy miscevogho samovrjaduvannja u stolychnomu reghioni [Organization of Recreational Services Provided by Local Governments in the Capital Region] [Candidate's dissertation]. Kyjiv: National Academy for Public Administration under the President of Ukraine; 2017 (in Ukrainian).

47. Voloshenko VM. Udoskonalennja mekhanizmiv derzhavnogho upravlinnja rozvytkom rynku rekreacijnykh poslugh: ukrajinsjki realiji v konteksti jevropejsjkoji integhraciji [Improvement of Mechanisms of State Control Development of the Market of Recreational Services: the Ukrainian Realities in the Context of European Integration]. Bulletin of the National Academy of Public Administration under the President of Ukraine. 2016; 2: 93-9. (in Ukrainian).

\section{ORCID and contributionship:}

Alla K. Sokolova: 0000-0002-1840-6290

Maryna K. Cherkashyna: 0000-0002-8892-5440

\section{Conflict of interest:}

The Authors declare no conflict of interest.

\author{
CORRESPONDING AUTHOR \\ Maryna K. Cherkashyna \\ Yaroslav Mudryi National Law University \\ Kharkiv, Ukraine \\ tel.: +38067724-91-20 \\ e-mail:m.k.cherkashyna@nlu.edu.ua
}

Received: 31.06 .2021

Accepted: 11.10 .2021

A - Work concept and design, B - Data collection and analysis, C - Responsibility for statistical analysis, D-Writing the article, $\mathbf{E}$-Critical review, $\mathbf{F}$ - Final approval of the article 


\title{
DIVULGENCE OF CONFIDENTIALITY OF ADOPTION: CRIMINAL LEGAL AND MEDICAL ASPECTS
}

DOI: 10.36740/WLek202111238

\author{
Viktoriia V. Haltsova', Sergiy 0. Kharytonov' ${ }^{1}$, Oleksii 0. Bondarenko ${ }^{2}$ \\ 'YAROSLAV MUDRYI NATIONAL LAW UNIVERSITY, KHARKIV, UKRAINE \\ ${ }^{2}$ V. N. KARAZIN KHARKIV NATIONAL UNIVERSITY, KHARKIV, UKRAINE
}

\begin{abstract}
The aim: Identify the problems that arise in connection with the violation of confidentiality of adoption, and on the analysis basis of public danger of violation of confidentiality of adoption to justify the feasibility of criminal liability for such an act.

Materials and methods: The authors used the system-structural method in the study of confidentiality of adoption as a legal phenomenon. Also, the comparative method of research was useful in comparing the criminal law of foreign countries on criminal liability for violation of confidentiality of adoption.

Using the dialectical method, the problem of the confidentiality of adoption (adoption) was studied in terms of the relationship and interaction of the main categories used in the work on the violation of confidentiality of adoption. In addition, the method of statistical processing of analytical data and the results of the questionnaire were used in this research. Conclusion: The authors state that adoption allows realizing the inalienable right to family upbringing, which is proclaimed in many international acts in the field of human rights protection. It is noted that in most cases, adoptive parents want to keep the confidentiality of adoption. The negative impact of violation of confidentiality of adoption on both the child and his / her family members has been proved. It is concluded that the public danger and severity of violation consequences of confidentiality of adoption are sufficient for the expediency of its criminal prohibition.
\end{abstract}

KEY WORDS: orphanhood, the child's right to family upbringing, family relations

Wiad Lek. 2021;74(11 p.2):3085-3091

\section{INTRODUCTION}

Most countries worldwide have an increased interest in the comprehensive protection of the rights of minors, especially in the problems of orphanhood and settlement of such children in the family. Undoubtedly, orphanhood is a serious social problem in many countries, which, unfortunately, tends to deepen, in particular, during wars and armed conflicts, pandemics, man-made and natural disasters that occur in many countries. That is why orphanhood as a negative social phenomenon requires an extraordinary solution to this problem by the world community in the context of compliance with international instruments in the field of children's protection of rights and interests. Based on this, the legal protection of children and protection of their rights is an independent institution that is part of the system of international protection of human and civil rights and freedoms and is provided by international, constitutional, civil, family, criminal, and others branches of legislation.

In particular, in such international instruments like the Convention on the Rights of the Child, the Universal Declaration of Human Rights of 1948, the International Covenants on Civil and Political Rights, the Economic, Social and Cultural Rights of 1966, and the European Convention on Human Rights and fundamental freedoms in
1950, the Hague Convention on the Adoption of Children (1967), the Convention on the Protection of Children and Co-operation in Respect of Intercountry Adoption (1993), and others. not only the rights of the child are fixed, but also the organizational and legal mechanisms of adoption as one of the priority forms of protection of children's rights are defined.

Adoption, according to experts, is a special form of raising orphans or children whose parents are deprived of parental rights, which allows them to have a family, and for adoptive parents is a kind of realization of the natural need for motherhood and fatherhood, which allows them to make family life more meaningful. If a child does not have a family, he/she does not receive the necessary parental love, care, emotional contact, sense of security, resilience, and harmony, which often leads to mental and personality pathology and can cause many negative hobbies: smoking, alcohol and drugs, manifestation of aggression, committing immoral offenses, and even criminal offenses [1, p. 139].

It is believed that children's right to be raised in a family is one of their fundamental rights. Considering the family role and family upbringing in a child's life, not only their social but also their psychological function is noted, because it is in the family that all those qualities that have value for society are formed. According to many sociologists 
and psychiatrists, the family absence in a child that would ensure his/her upbringing and formation as a person leads to their loneliness and limits social contacts. In addition, self-limitation in communication due to lack of family is the cause of serious personality disorders. Therefore, the absence of a child's family also indicates that his/her right to family upbringing, which is enshrined in Art 20 of the UN Convention on the Rights of the Child, according to which "a child who is temporarily or permanently deprived of a parental environment has the right to special protection and assistance of the state". If the child does not have a family and parents, it is possible to realize his / her right to an upbringing through adoption, which allows achieving the best positive results in the upbringing of the child. After all, the family acts as a natural environment for the physical, mental, spiritual development of the child, his/ her material support.

Therefore, it is fair to say that adoption gives the child a sense of security, provides him/her with natural (family) conditions for development. In addition, it allows the child to avoid mental, physical, and social delay, gives a chance for their complete development, forms a common norm of behavior in society, and gives parents the pleasure of parenthood and a full family, strengthens marriage, and eliminates loneliness [2, p. 208].

Thus, adoption can be recognized as a special family form of raising an orphan or a child deprived of parental care, and the relationship between adoptive parents and a child is the same as the relationship between family blood members, referred to in Art 8 of the Convention for the Protection of Human Rights and Fundamental Freedoms.

Adoption taking into account the importance of this institution for the child's interests has the character of a large-scale sphere of activity and requires not only its regulation by international, family, civil, and other regulatory areas of law, but also criminal protection of these social relations [3, p. 10].

Considering that adoption has the purpose of creating a real family environment for a child, establishing a strong family relationship, so in most cases, the adoptive parents want to keep the confidentiality of adoption. Based on this, we note that in fact, each state at its discretion forms a block of confidential information about family relations, including in the field of adoption, which arises in connection with the confidentiality of adoption. Therefore, the existence of the institution of confidentiality of adoption and its criminal protection is one of the guarantees of the state to protect the family from unlawful encroachments and ensure the proper upbringing of orphans [3, p. 26].

That is why the criminal legislation of many countries around the world establishes criminal liability for encroachment on public relations in the field of adoption in order to preserve its confidentiality. For example, the responsibility for disclosing the confidentiality of adoption is established in Art. 177 of the Criminal Code of Belarus; Art. 155 of the Criminal Code of the Russian Federation; Art. 175 of the Criminal Code of the Republic of Azerbaijan; Art. 169 of the Criminal Code of Latvia; Art. 135 of the Criminal Code of Kazakhstan; Art. 125 of the Criminal Code of Uzbekistan; Art. 169 of the Criminal Code of Armenia; Art. 204 of the Criminal Code of Moldova; Art. 173 of the Criminal Code of Tajikistan; Art. 145 P. 2 of the Criminal Code of Bulgaria; Art. 168 of the Criminal Code of Ukraine and others.

It should be noted that some of the Criminal Code of other foreign countries also establish criminal liability for "Criminal acts against confidentiality", and some for "Divulgence of confidentiality". For example, the Criminal Code of Argentina in Art. 157/2 of the Criminal Code "Divulgence of confidentiality" provides for the responsibility of a person for the issuance of personal information, confidentiality, which he/she must keep in accordance with the law. Criminal liability for divulgence of confidentiality is contained in the Criminal Code: Spain (Articles 197-205) Book 2, Section X, $\$ 144$ of Norway, Art. 198 of the Criminal Code Book 2 Chapter 2, Chapter 5 of Turkey, Part 2, ch. 14 st. 134 Japan, Art. 272 book 2 Chapter XVII of Holland, art. 266 of the Criminal Code of Poland. Thus, in these cases, it is a matter of divulgence the confidentiality of adoption, which in some countries is considered professional confidentiality, in others - as a personal, family confidentiality.

\section{THE AIM}

Investigate the problems of expediency of the existence of criminal liability for disclosing the confidentiality of adoption in criminal law. Justify the need for criminal law prohibition of divulgence of the confidentiality of adoption based on analysis of the social danger of the act and the severity of consequences it leads to. To this end, explore the views of psychologists, educators, and other professionals that the divulgence of the confidentiality of adoption poses a real threat or may cause significant harm not only to social relations in the field of family relations, but also relations that ensure normal physical and mental development of minors also violates the child's right to family upbringing. Based on this, determine whether it is appropriate to prohibit the divulgence of confidentiality of adoption.

\section{MATERIALS AND METHODS}

The authors used the system-structural method in the study of confidentiality of adoption as a legal phenomenon. Also, the comparative method of research was useful in comparing the criminal law of foreign countries on criminal liability for violation of confidentiality of adoption.

Using the dialectical method, the problem of the confidentiality of adoption (adoption) was studied in terms of the relationship and interaction of the main categories used in the work on the violation of confidentiality of adoption. In addition, the method of statistical processing of analytical data and the results of the questionnaire were used in this research.

In addition, the method of statistical processing of analytical data of the Family for a Child Program was used, 
which was conducted jointly with the State Institute for Family and Youth Development in a survey of 29 adoptive families from Ivano-Frankivsk, Rivne, Kharkiv, Odesa, Cherkasy regions and Kyiv, in which 32 adopted children in Ukraine are brought up (2006); it also contains statistics from the first national survey of families among 365 adoptive families, which was conducted in 18 oblasts of Ukraine together with the State Institute for Family and Youth Development (2007); used data from a survey of 2011 respondents to the national representative survey "Study of public opinion on the implementation of the right of orphans and children deprived of parental care to family upbringing" (2008), conducted in all regions of Ukraine at the request of the State Department for Adoption and Rights by "Ipsos Ukraine" with the technical support of the Family for a Child Program. Also with the help of this method the views of the International Association of Adopted People and NGOs of Ukraine: All-Ukrainian NGO "Women's Consortium of Ukraine", Partnership "Every Child", Human Rights Center "Postup", Sumy Regional Youth NGO Gender Agency for Consultations and Information", Kharkiv Regional Foundation "Public Alternative", which were aimed at studying public opinion on adoption and the expediency of observance of the confidentiality of adoptions.

\section{REVIEW AND DISCUSSION}

Article 13 of the Declaration on Social and Legal Principles Concerning the Protection and Welfare of Children, Especially in the Case of the Transfer of Children for Adoption and Adoption at the National and International Levels of December 3, 1986, states that the main purpose of adoption is to provide a permanent family for a child, the care of which can not be shown by his/her parents.

No less important is the provision of Art. 11 of the European Convention on Adoption of Children, that as a result of adoption the child becomes a full member of the family of adoptive parents and has the same rights and responsibilities as blood children of adoptive parents. In addition, in Art. 20 of the European Convention on Adoption of Children (1967) and Art. 31 of the Convention on the Protection of Children and Co-operation in Respect of Intercountry Adoption (1993) states that, if necessary, at the adoptive parents' request, the confidentiality of adoption may be maintained. If a child is adopted, his or her blood ties are severed. These provisions were also indicated in the Resolution of the Supreme Court of Ukraine (Civil Court of Cassation) № 627/9098/15-ts of 12.08.2020 [4].

It should be noted that in countries such as the United States, Canada, and some others, adoption takes place in the so-called "open" way when adopted children know their origins and are informed who their blood parents are. In Italy, adoptive parents must inform the minor of the adopted child's status in the "most adequate" and "most appropriate" form. In addition, after the age of twenty-five, adoptees have the right to access information about their background and information about their biological par- ents. Access to this information may also be allowed after reaching the age of majority if there are proven reasons that it may affect the psychological and physical condition of a young person [5].

In the UK, the confidentiality of adoption is aimed at the complete separation of any ties with the child's blood family. However, after the child reaches the age of 18, only the child has the right to receive information from the blood parents, but they do not have the right to search for the child after his / her adoption [5].

It should be noted that the International Association of Adopted People does not support "closed" adoption, believing that it harms the psychological well-being of the adopted child [6, p. 144]. They agree with them in Ukraine, in particular, such NGOs as the All-Ukrainian NGO "Women's Consortium of Ukraine", Partnership "Every Child", Human Rights Center "Progress", Sumy Regional Youth NGO "Gender Agency for Consultation and Information", Kharkiv Regional Foundation "Public Alternative", which believe that it is necessary to abolish the confidentiality of adoption in Ukraine, as it violates the rights of the child, in particular the origin of the child [7]. Violations of this child's right are also pointed out by foreign researchers that information about the child's origin is the main element of children's identity, which is recognition of the fact of its existence and includes not only the child's family ties, name, and citizenship as well as racial, sexual and religious affiliation [8, p. 149].

The United Nations Children's Fund (UNICEF) also considers it necessary to abolish the confidentiality of adoption in Ukraine, arguing that the latter contradicts international acts, in particular, Art. 7 of the UN Convention on the Rights of the Child that "a child, as far as possible, has the right to know his/her parents and the right to care for them" and Art. 8 that "States Parties undertake to respect the right of the child to preserve his or her identity, including nationality, name and family ties, as required by law, without prejudice to unlawful interference." In addition to the provisions of the Convention, the child's right to information about his/her origin is enshrined in many documents, for example, in Art. 22 of the European Convention on Adoption, that an adopted child must have access to information available to the competent authorities regarding his or her origin. In addition, under the UN Convention on the Rights of the Child and the Hague Convention on the Adoption of Children (1967), the Convention on the Protection of Children and Co-operation in Respect of Intercountry Adoption (1993), adopted children have the right to information about his/her real family, to know the history of his/her generation, but under special supervision [9]. In addition, some researchers believe that information about the child's origin performs not only a social function as a tool for the child's adaptation to society through his family, his parents but also the protection of the child's interests, for example, when such information is needed to identify a child's predisposition. to diseases that can be inherited from parents, genetic features of the child's body, etc. [10, p. 194]. 
Proponents of the benefits of "open" adoption without maintaining the confidentiality of adoption (adoption) are not only a reference to international conventions on the child's rights, that every child should have the right to know what his/her roots are, who his/her biological parents are. They point out that ignorance of this information interferes with the attitude of the individual as such, and is unfair to their right to know their history, the desire to connect with the biological family [11].

However, there are opposing views of experts that, on the contrary, ensuring the confidentiality of adoption is the key to a successful relationship between the adopted child and adoptive parents and allows protecting the child [12, p. 110]. In addition, the confidentiality of adoption avoids confrontation and protects biological parents who have given their child up for adoption and have already built their lives and often constantly feel ashamed of their actions [11].

Thus, for more than a decade, there has been a dispute in society between supporters and opponents of the confidentiality of adoption. Some believe that such confidentiality is necessary because it helps protect the adopted child and his/her parents from talk and gossip, interference in family life, while others believe that it violates the child's rights and prevents social services from fully controlling the upbringing of such children. After analyzing international acts, we show that there is a certain conflict over the confidentiality of adoption. On the one hand, it is a guarantee of protection of the child's rights to a family upbringing and interference in the sphere of private (family) life, on the other hand, it restricts the child's right to information about his/her origin and the right to know his/her parents.

Given the above, before the law, scientists believe, there should be a balance of interests between the rights of the child and his biological, social parents, and their relatives [10, p. 198].

In this regard, the European Court of Human Rights considers it possible to restrict a child's right to access information about his or her origin if such a restriction has a legitimate aim. For example, if the goal is to protect and preserve the health of the child [13, p. 176]

Thus, the European Court of Human Rights in its decision of October 30, 2018, in the case "S.S. v. Slovenia" (application no. 40938/16) stated that Art. 8 of the Convention for the Protection of Human Rights and Fundamental Freedoms does not require national authorities to make endless attempts to reunite the family. Public authorities are only required to take all necessary measures that can reasonably promote the reunification of the child and their parents. At the same time, after a considerable period of time has elapsed since the child was in custody, the child's interest in not changing his or her actual marital status may outweigh the parent's interest in returning to the family. Given that the prospects for reunification of the biological family, in this case, were insignificant (the biological mother was deprived of parental rights, and the child was adopted). The court considered that the child's interests in full integration with her actual family outweighed the applicant's desire to maintain legal ties with her. Therefore, the choice of such a mechanism is limited by the need to reach a possible consensus - maintaining the balance of interests of the child (ensuring its right to information), biological parents (exercising the right to anonymity), and third parties whose rights and interests may be violated relatives of biological parents [14].

Psychologists' claims about the expediency of the confidentiality of adoption also differ. Some believe that the secret of adoption has a destructive effect on the child's development, in addition, putting the family in a situation of constant tension and fear of its possible divulgence [15, p. 258]. Others, on the contrary, point out that adoption is perceived by its participants as an act of forming a fullfledged family, it is these relationships that respondents assess as joyful, those that allow them to feel the fullness of life [15, p. 258-259].

In addition, psychologists note that the divulgence of the secret of adoption leads to strong psychological experiences of children, which may be accompanied by accusations of dishonesty and lies. Studies have shown that in such situations there were facts: running away from home, regressive and protest behavior of the child, refusal to live in the adoptive family, trying to find their blood parents, getting into an antisocial environment after running away from foster parents. When children hear that they are not related, they review all the previous years of their life in the family, criticizing the whole spectrum of adult behavior. Analyzed stories of revealing the secret of adoption show that it often led to severe psychological experiences, bullying among their adolescents and neighbors, suicide. In addition, not all children express a desire to learn about the history of their origin. Some still insist on never knowing this fact, that the ties between them and their parents are so strong that no one can ever question their veracity $[15, \mathrm{p} .262]$.

So, to the question "When I found out that I had been adopted," $45 \%$ of the adopted children said that they suddenly showed aggression towards their parents, hatred for them, and resentment for the lies, which caused a long period of mistrust and resentment. Some children (28\%) disagreed and did not accept the fact of their adoption, and insisted that adults confirm that they were "their relatives". In addition, parents hide the fact of adoption from their loved ones and explain this by the fact that they want their children to be loved equally [15, p. 262].

We believe that the divulgence of the secret of adoption causes psychological trauma not only to the child but also to the adoptive parents and this, in turn, can weaken the stability of the family as an important social institution [19, p. 2900]. Therefore, the legislation of many countries, including Poland, recognizes adoption as a private matter in which it is tactless to interfere, so most adopters (adoptive parents) keep the secret of adoption, primarily for the interests of the child. They argue that the need to live in a family is a biological and psychological need of the child; it inspires confidence that others think and perceive such a child as a native and allows to isolate him from the negative environment, helps to better convey to the child the tradi- 


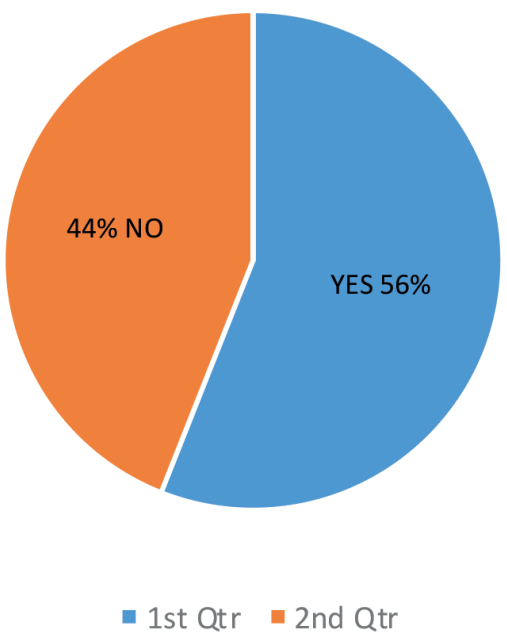

Fig. 1. Survey respondents, do you think it is necessary to keep the confidentiality of adoption at all?

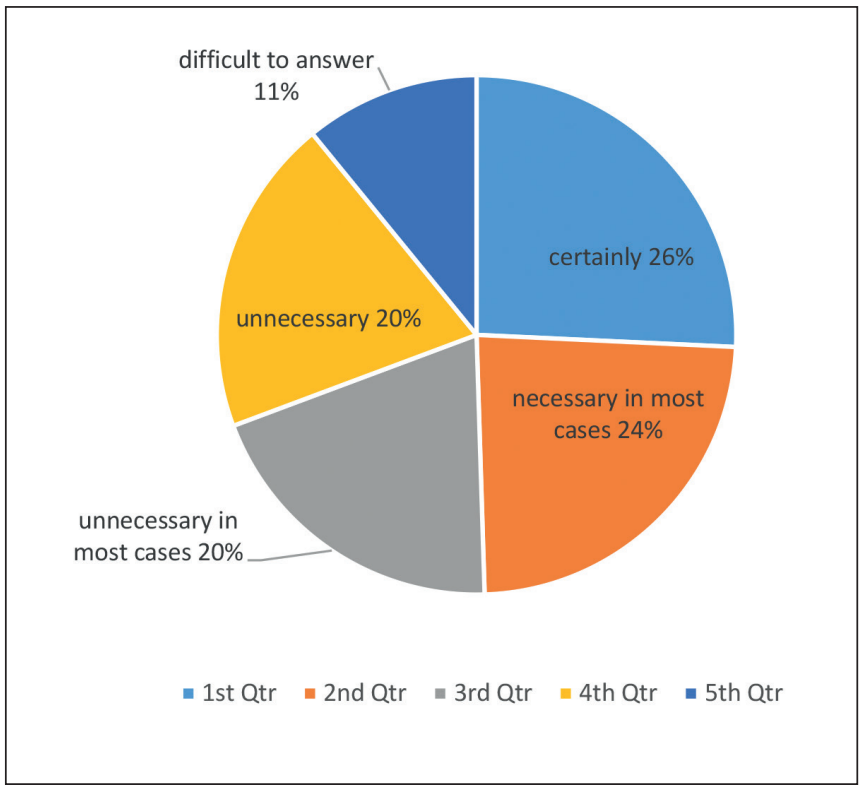

Fig. 3. Survey respondents, is it necessary to keep the confidentiality of adoption from family friends?

tions of his/her own family, and others. Parents believe that a child, knowing the truth about his/her origin, will find himself in a difficult psychological situation, because there will be doubts because he is not a biological child, so he does not deserve parental love. Too often, adoptive parents do not want a child who has learned the confidentiality of adoption to lose self-confidence because they will think that they are less able, intelligent, agile, smart, or healthy than their own children, lose interest in learning and lead to drug use, substances or alcohol, as he/she may justify his/her antisocial behavior by the fact that their blood parents were uneducated or socially maladapted. In addition, adopted children often feel discomfort and are ashamed of

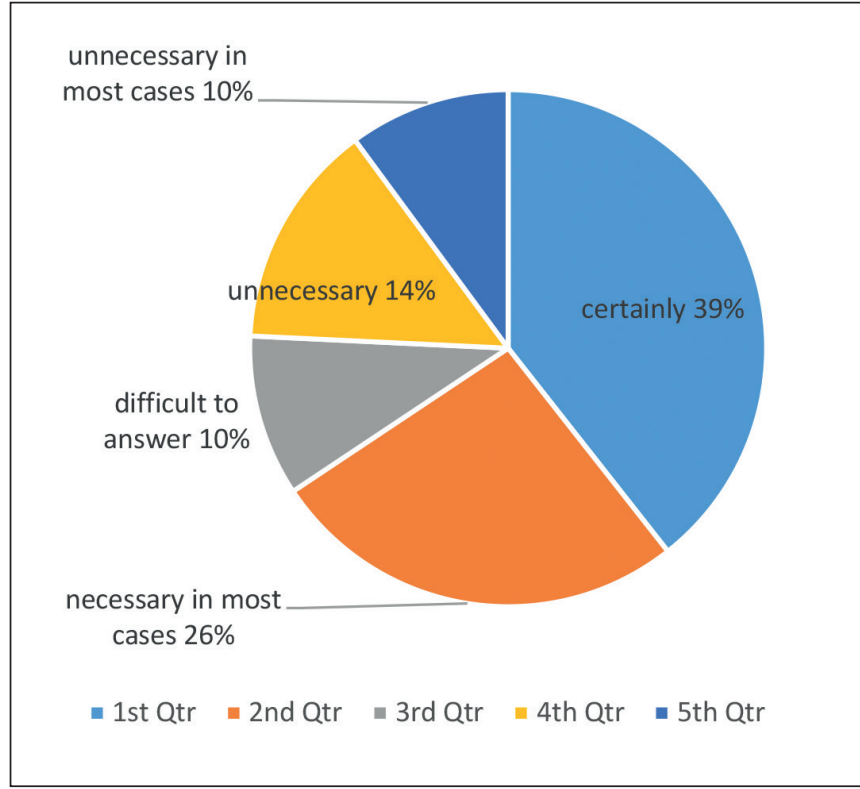

Fig. 2. Is it necessary to keep the confidentiality of adoption from other people?

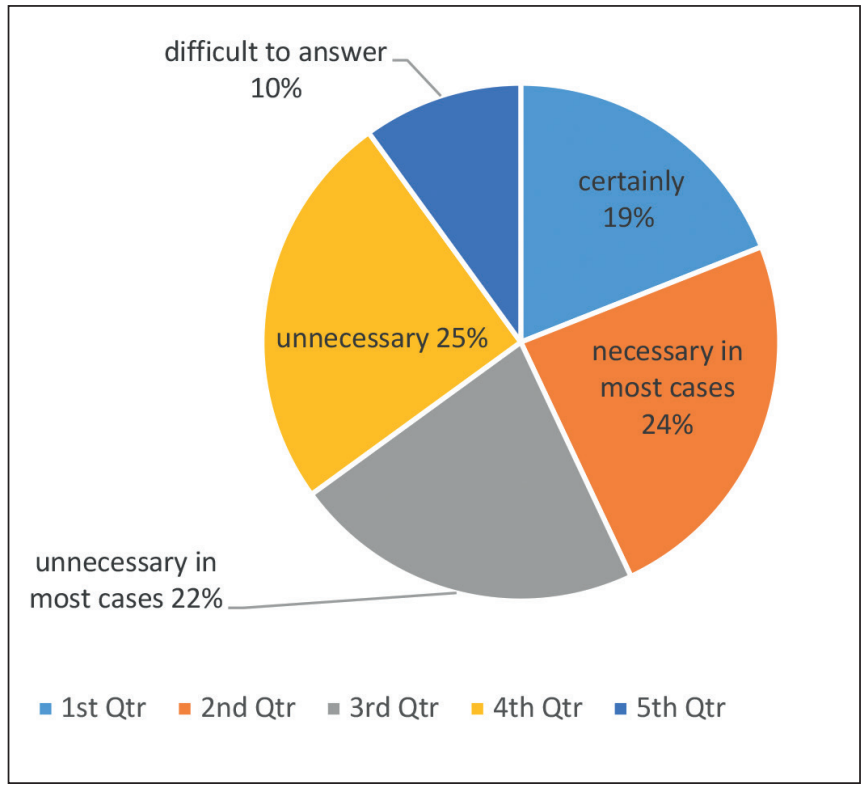

Fig. 4. Is it necessary to keep the confidentiality of adoption from close relatives of the family?

their origin, they have a "split personality", which provokes exacerbation of psychological and social problems, symptoms of mental disorders, feelings of inferiority, anxiety, depression, etc. [16, p. 137-139].

Despite some rethinking of the role and place of the confidentiality of adoption in society, the divulgence of family secrets can be no less destructive than their concealment [17].

This is evidenced by the results of a survey of respondents [18, p. 127] (Figure 1-5).

As can be seen, according to many experts, the secret of adoption contributes to the formation of a real family relationship between parents and adopted children and their 


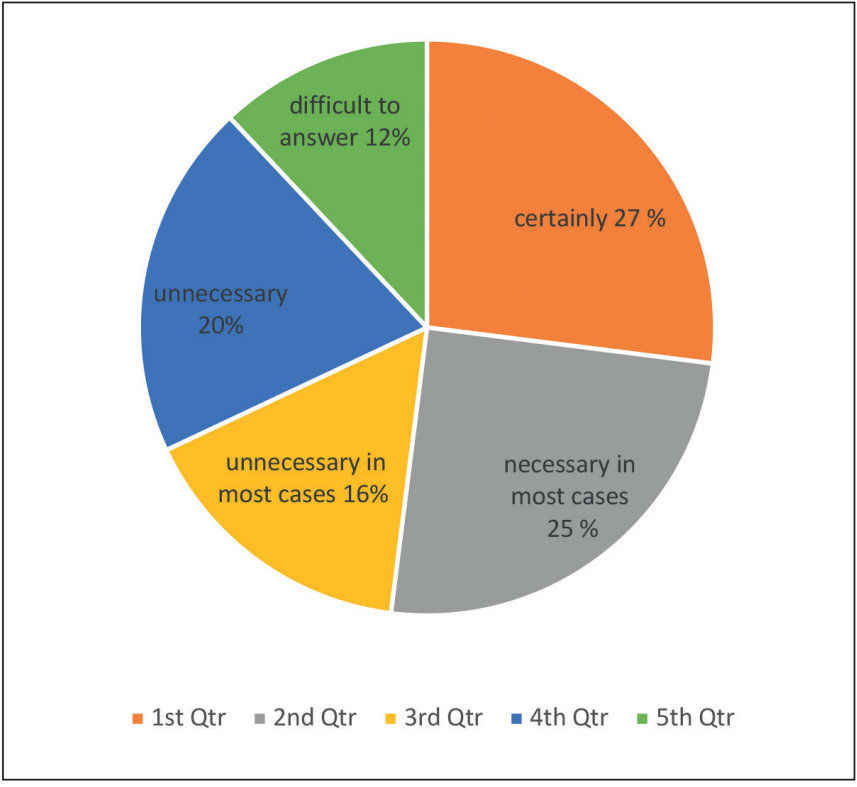

Fig. 5. Respondents' opinions on keeping the adoption confidentiality from the child

upbringing. The survey of respondents allowed to determine that the secret of adoption is kept by more than half (56\%) of the surveyed parents. Among them, $24 \%$ decided never to reveal to a child the secret that he/she is not a native. Other parents are determined by the time when it is possible to reveal to the child the secret of his/her adoption. 50\% of those who keep the confidentiality of adoption have not yet decided at what age it is best to do so, one in five (14\%) believe that it is better to provide information to a child when he or he/she reaches adulthood when he/she can make decisions on his or her own. Significantly fewer parents (4\%) do not consider it necessary to postpone the disclosure of information about adoption until adulthood, and plan to do so when the child turns 10 or older [18, p. 46].

$44 \%$ of families do not keep the confidentiality of adoption. Regarding the age at which the child learned that he/ she was not native, $58 \%$ of parents who do not keep the confidentiality of adoption, to the question "If you do not keep the confidentiality of adoption, at what age did the child learn that he/she was adopted?" gave the following answers: at the age of 2 to 6 years - 29\%; at the age of 7 to 10 years - 19\%; age from 11 to 16 years $-10 \%$. Some parents answered this question in such a way that it is impossible to determine the age of children "immediately" - $6 \%$. In the vast majority of cases (51\%) information about the adoption of the child was provided by parents themselves: $37 \%$ - both parents, $12 \%$ - a mother, $2 \%$ - a father. $3 \%$ indicated that the adoption was provided by the child's grandparents, $1 \%$ by neighbors, and $14 \%$ by other persons, of whom $7 \%$ acknowledged that the child was adopted at a conscious age, so there was no secret of adoption for her. Parents also indicate that the children learned that they are not relatives, from the following sources: "said in the orphanage", "social worker", "brothers and sisters", "adopted child - the child of acquaintances" [18, p. 47].

\section{CONCLUSIONS}

Adoption is one of the best and priority forms of placement of a child without a family because due to this, he/she simultaneously receives parents as a child and other family members, as well as a minor, realizes his/her inalienable right to family upbringing, which is proclaimed in many international acts in the field of human rights protection.

Because adoption is in the best interests of the child and aims to provide the child with a real family environment, to establish a strong family relationship, so in most cases, adoptive parents want to keep the adoption a secret. Therefore, the latter can be considered one of the components of information security, which protects both the rights and interests of the child and adoptive parents, family, family relationships from socially dangerous encroachments. It is the will of the adoptive parents and in some cases the child's will that determines the limits of the illegal behavior of disclosing the secret of adoption.

We believe that if the adoptive parents do not want to keep the adoption confidentiality from the child, it should not be devulgenced, because it belongs to the family's internal life, can not be public property because it can lead to difficulties in communicating with peers or others threat to the normal functioning of family relations.

Thus, the disclosure of confidentiality of adoption is a socially dangerous act that encroaches on a very important area for society - adoption, here suffer as the interests of children and their adoptive parents, which can cause severe psychological trauma or mental illness, undermine the family as part of society, to cause the child indifference to parents, others and themselves, to cause family conflicts and family breakups, to cause feelings of alienation of adolescent, to complicate the process of raising a child, harassment by others, lead to vagrancy, alcohol or drugs, and, even to the suicide of both adopted child and adoptive parents.

Therefore, the social danger and severity of consequences of disclosing the confidentiality of adoption as a result of which can cause significant harm not only to the rights and interests of minors but also to the lives and health of children and their parents. a well-founded decision of the legislator on the criminal law protection of family law relations in the field of adoption acts as a means of ensuring the effectiveness of international, constitutional, civil, and family law on the placement of orphans from criminal encroachments.

\section{REFERENCES}

1. Cy 'mbalyuk I. Osobly 'vosti vply 'vu simejnogo vy xovannya na pedagogichno zanedbany`x narkoty' chno zalezhny'x pidlitkiv u konteksti problemy' zapobigannya torgivli lyud 'my' [Features of the impact of family upbringing on pedagogically neglected drugaddicted adolescents in the context of the problem of preventing human trafficking]. Problemy` osvity. № 40. Kyiv. 2004. S. 131-139 (in Ukrainian).

2. Skiepko M., Brągoszewska J. Zaburzenia psychiczne u dzieci adoptowanych Psychiatric disorders inadopted children. PSYCHIATR. PSYCHOL. KLIN. 2009;9 (3):207-213. 
3. Gal'czova V.V. Kry`minal'na vidpovidal'nist' za rozgoloshennya tayemny ci usy' novlennya (udocherinnya) ta nezakonni diyi shhodo usy'novlennya (udocherinnya) [Criminal liability for disclosing the confidentiality of adoption (adoption) and illegal actions related to adoption (adoption)]. Kharkiv : Pravo. 2015, p. 248 (in Ukrainian).

4. Postanova Verkhovnoho Sudu Ukrainy (Kasatsiinyi tsyvilnyi sud) № $627 / 9098 / 15$-ts vid 12.08.2020. Pro nadannia prava na pobachennia z dytynoiu. Yedynyi derzhavnyi reiestr sudovykh rishen u formi vidkrytykh danykh. Available from : http://od.reyestr.court.gov.ua/files/45/ c8420170730ec4ce369c75545053a980.rtf [reviewed 2021.27.07] (in Ukrainian).

5. Eldridzh Sherri. Voprosyi, kotoryie zadayut usyinovlennyie deti [Questions asked by adopted children]. Kyiv. 2010. p. 232. (in Russian).

6. Jagannath Pati. Adoption: Right to Information Versus Right to Confidentiality / Jagannath Pati // Child Safety, Welfare and Well-being / Jagannath Pati. New Delhi : Springer, 2016;141-157.

7. Taiemnytsia vsynovlennia: pozytsiia hromadskykh orhanizatsii [The confidentiality of adoption: the position of public organizations]. Available from : https://gurt.org.ua/articles/15322/ [reviewed 2021.27.07] (in Ukrainian).

8. Dzheraldina van Biuren. Mizhnarodne pravo haluzi prav dytyny. Pereklad $\mathrm{z}$ anhliiskoi. [International law in the field of children's rights]. Odesa: A0 BAKhVA. 2006. p. 524 (in Ukrainian).

9. Dytiachyi fond 00N (luNISEF) pidtrymuie skasuvannia taiemnytsi vsynovlennia v Ukraini [The United Nations Children's Fund (UNICEF) supports the abolition of the confidentiality of adoption in Ukraine]. Ukraina bez syrit. Available from: http://www.unicef.org/ukraine/ukr/ media_20680.html [reviewed 2021.20.07] (in Ukrainian).

10. Lefterova 0. I. Mizhnarodno-pravove zabezpechennia realizatsii prava dytyny na informatsiiu pro vlasne pokhodzhennia [International legal support for the realization of the child's right to information about their own origin]. Pravova derzhava. 2019; 33: 194-199 (Ua).

11. Adopted Child's Right to Information as to Biological Parents. Available from:https://www.stimmellaw.com/en/articles/adopted-childs-rightinformation-biological-parents. [reviewed 2021.18.06]

12. Milimko L.V., Yaroshenko T.S. Teoretyko-pravovi aspekty ta etychni pytannia taiemnytsi usynovlennia (tochky dotyku) [Theoretical and legal aspects and ethical issues of the mystery of adoption (points of contact)]. Derzhava i pravo. 2020;88:108-116 (in Ukrainian).

13. Fulei T.I.Zastosuvannia praktyky Yevropeiskoho sudu z prav liudyny pry zdiisnenni pravosuddia [Application of the case law of the European Court of Human Rights in the administration of justice: Scientific and methodological guide for judges]: Naukovo-metodychnyi posibnyk dlia suddiv. Kyiv. 2015. p.208 (in Ukrainian).

14. Sprava «S.S. proty Slovenii» (Pres-reliz) [Case"S.S. AgainstSlovenia"(Press Release)]. Available from:https://www.echr.com.ua/translation/spravas-s-proti-sloveniii-pres-reliz/ [reviewed 2021.20.07] (in Ukrainian).

15. MelnychukT.I.Stavlennia batkiv ta ditei usimiakh usynovyteliv/udocheryteliv do «taiemnytsi» nekrovnoho pokhodzhennia pryiniatoi v simiu dytyny [The attitude of parents and children in the families of adoptive parents to the "confidentiality» of non-blood origin adopted into the child's family]. Problemy suchasnoi psykholohii. 2014;25:255-267 (in Ukrainian).
16. Antonina Sebesta Jawność adopcji jako problem etyczny i kulturowy w Polsce. Annales Academiae Paedagogicae Cracoviensis Folia 10 Studia Philosophica I, 2002; 135-142.

17. Myzynova A.V .Simeina taiemnytsia: vidobrazhennia zmistu sekretu v roboti z psykholohom [Family confidentiality: reflecting the content of the confidentiality in working with a psychologist]. Zhurnal prykladnoi psykholohii ta psykhoanalizu. 2012. № 4. Available from: https:// changeonelife.ua/ua/news/simejna-tayemnicya-vidobrazhennyazmistu-sekretu-v. [reviewed 2021.20.07] (in Ukrainian).

18. Usynovlennia: realii ta tendentsii. Rezultaty sotsiolohichnykh doslidzhen (Za rezultatamy opytuvannia simei-usynovyteliv v Ukraini (chastyna 1). Za rezultatamy sotsiolohichnoho doslidzhennia «Vyvchennia hromadskoi dumky shchodo realizatsii prava dytyny-syroty ta dytyny, pozbavlenoi batkivskoho pikluvannia, na simeine vykhovannia» (chastyna 2)) [Adoption: realities and trends. The results of sociological research. According to the results of the survey of adoptive families in Ukraine (part 1). According to the results of a sociological study «Study of public opinion on the implementation of the right of an orphan and a child deprived of parental care to family upbringing» (part 2)]. Kyiv : Feniks. 2015. 160 s. (in Ukrainian).

19. Volodina, 0.0., Haltsova, V.V., Kharytonov, S.O. Social danger of domestic violence and the need for rehabilitation of its victims. Wiad lek. 2020;12:2895-2901.

\section{ORCID and contributioship:}

Viktoriia V. Haltsova: 0000-0002-0700-427X ${ }^{A, B, D}$

Sergiy O. Kharytonov: 0000-0002-8947-8734 A,E,F

Oleksii O. Bondarenko: 0000-0001-6901-7298 ${ }^{A, E, F}$

\section{Conflict of interest:}

The Authors declare no conflict of interest.

\section{CORRESPONDING AUTHOR Sergiy $\mathbf{0}$. Kharytonov}

Yaroslav Mudryi National Law University Kharkiv, Ukraine tel. +380503233980

e-mail:kharitonovs@ukr.net

Received: 01.07.2021

Accepted: 12.10.2021

A - Work concept and design, B - Data collection and analysis, C - Responsibility for statistical analysis, D-Writing the article, $\mathbf{E}$ - Critical review, $\mathbf{F}$ - Final approval of the article 


\title{
DOPING AS A GLOBAL PROBLEM OF THE $21^{\text {ST }}$ CENTURY ON ACCOUNT OF ITS ILLEGAL INFLUENCE ON THE RESULTS OF OFFICIAL SPORTS COMPETITIONS
}

DOI: 10.36740/WLek202111239

\author{
Volodymyr V. Shablystyi, Dmytro 0. Anisimov \\ DNIPROPETROVSK STATE UNIVERSITY OF INTERNAL AFFAIRS, DNIPRO, UKRAINE
}

\begin{abstract}
The aim: The study of international and domestic practices of Ukraine concerning the legal regulation of liability for exerting illegal influence on the results of official sports competitions within the context of such means of its commission as the use of doping for the purpose of obtaining additional arguments to emphasize the benefit / the inexpedience of criminalization of such acts as quasi-corruption fraudulent activities.

Materials and methods: The article implements doctrinal provisions of domestic and foreign scientific developments in relation to the liability for illegal influence on the results of official sports competitions by means of the use of doping as well as national and foreign criminal legislation, established law enforcement practices, and results of the sociological survey. For such purpose, the authors utilized the methods of analysis and synthesis, a comparative legal method, methods of survey and generalization of viewpoints, research findings.

Conclusions: Authors have established the absence of necessity for the introduction of the criminal prohibition in respect of athletes for the use of doping for an entire span of their professional career as well as for the use of doping as the means for exerting illegal influence on the results of official sports competitions. The expedience of further studies has been ascertained by drawing from the experience of the EU, Australia, Canada, USA, and other countries concerning the legal regulation of liability for exerting illegal influence on the results of official sports competitions, legal consequences of the use of doping and corresponding law enforcement practices within the context of grounds and principles of criminalization of socially dangerous acts elaborated by the criminal law studies.
\end{abstract}

KEY WORDS: human health, doping, liability, results of official sporting events

Wiad Lek. 2021;74(11 p.2):3092-3097

\section{INTRODUCTION}

Doping is indeed a global problem of the $21^{\text {st }}$ century due to its illegal influence on the results of official sports competitions. Criminalization of illegal influence on the results of official sports competitions is predominantly characteristic of the post-soviet countries, while in the criminal codes of the majority of European and other foreign countries such acts are being qualified as fraud or instances of bribery. It has been established that the use of doping as the means of illegal influence on the results of official sports competitions remains outside the scope of the criminal law.

\section{THE AIM}

To study international and domestic practices of Ukraine with regard to the legal regulation of liability for exerting illegal influence on the results of official sports competitions within the context of such means of its commission as the use of doping for the purpose of obtaining additional arguments to emphasize the benefit / the inexpedience of criminalization of such acts as quasi-corruption fraudulent activities.

\section{MATERIALS AND METHODS}

The article implements doctrinal provisions of domestic and foreign scientific developments in relation to the liability for illegal influence on the results of official sports competitions by means of the use of doping as well as national and foreign criminal legislation, established law enforcement practices, and results of the sociological survey. For such purpose, the authors utilized the methods of analysis and synthesis, a comparative legal method, methods of survey and generalization of viewpoints, research findings.

\section{REVIEW AND DISCUSSION}

"Citius, Altius, Fortius - Communiter» or «Faster, Higher, Stronger - Together» - for the first time since 1894 the International Olympic Committee has changed the traditional motto of the Olympic Games by adding the word «together» to it. Joint effort always brings about faster and better results than individual work. Such a decision marks an important stage in development and sends a clear message - particular attention should be paid to solidarity [1]. Indeed, the Olympic Games, any other international 
or national sports competitions represent a joint effort to demonstrate which country places greater emphasis on the health of its citizens - the better the sports results are, the more developed in economic and social terms the country is. In case particular attempts to exert illegal influence on the results of official sports competitions by means of using banned performance-enhancing substances (doping) do occur this may even call into question the image of the country in the international arena or bring an end to the sporting career of individual athletes. Incidentally, in the 2020 Summer Olympics held in Tokyo namely, the Ukrainian female athlete became the first to have been tested positive for doping [2]. It is furthermore evident that victory or prize places in prestigious international competitions are always related to considerable earnings therefore the use of doping with the purpose of obtaining said earning must entail corresponding consequences.

Contemporary sport is an enormous superprofit-generating industry with the annual income of its members estimated by hundreds of billions of US dollars. In the view of scholars, particularly significant cashflows pass through international organizations such as the International Federation of Association Football (FIFA, from French) and the International Olympic Committee (IOC) [3, p. 121]. The issue of illegal influence on the results of official sports competitions has acquired particular relevance during the 2020 UEFA European Football Championship (UEFA Euro 2020). Sport has long shifted away from a perfect concept by Pierre de Coubertin with the governing principle of the rule of sportsmanship (Fair Play).

It is therefore the authors have conducted research into international and domestic practices of Ukraine on the legal regulation of liability for exerting illegal influence on the results of official sports competitions within the context of such means of its commission as use of doping and have obtained further arguments in favor of improvements to the Article 369-3 of the Criminal Code of Ukraine.

According to historical studies, the competitions date back well before the beginning of the Common Era. The earliest account of competitions may be found during the reign of Ramesses II (1279-1213 BC). In those days, competitions were held in wrestling and club fencing against Nubians, Libyans, and other ethnicities with results of such competitions evaluated by judges [4, c. 24]. Long before the Common Era, when written rules had not yet been developed, the regulation of competitions was conducted with the help of judging. The first official sports competitions are traditionally considered to be the Olympic Games.

Presently, the majority of European countries ratified international normative legal acts that regulate the anti-corruption efforts in general and, in particular, in the sphere of sports.

For instance, on January 27th, 1999 the Criminal Law Convention on Corruption was adopted, on October 31st, 2003 the United Nations Convention against Corruption was negotiated, on May 16th, 2005 the Council of Europe Convention on Laundering, Search, Seizure and Confiscation of the Proceeds from Crime and on the Financing of Terrorism were initiated, on September 18th, 2014 the Council of Europe Convention on the Manipulation of Sports Competitions was concluded, etc.

Doping may be referred to as a stand-alone form of corruption in the sphere of sports. High-performance sport indeed depends directly on the use of doping. From the beginning of the 19th century, there were known instances of administering cocaine to racehorses on par with strychnine to improve endurance. Even at that time athletes used to resort to match-fixing of competitions with their opponents with the purpose of obtaining illegal income. Presently, the problem of doping as an illegal influence on the results of official sports competitions brings about its own realities into the international arena. It jeopardizes the principles of ethics, sportsmanship, and health of athletes [5, c. 5-6]. It is therefore the issue of the use of doping during the participation in official competitions is being regulated by a range of normative legal acts.

Specifically, on November 16th, 1989 the Anti-Doping Convention was adopted, on November 18th, 2005 the International Convention against Doping in Sport 19 October 2005 was signed, the World Anti-Doping Code entered into force in 2003, etc. However, despite the prohibition against the use of doping when participating in official sports competitions there occur numerous instances of its violation. The authors deem it necessary to provide a cursory review of such violations by Ukrainian athletes on the international Olympic stage.

Following the results of the 2004 Summer Olympics in Athens, the International Olympic Committee stripped a Ukrainian rower Olena Olefirenko of her bronze medal for the use of Instenon, a shot putter Yuriy Bilonoh - of his gold medal for the use of Oxandrolone. In the wake of the 2008 Summer Olympics in Beijing, the International Olympic Committee ruled to strip a Ukrainian wrestler Vasyl Fedoryshyn of his silver medal for the use of Turinabol, Olha Korobka - of her silver medal in weightlifting for the use of Turinabol, Lyudmyla Blonska - of her silver medal in athletics for the use of Methyltestosterone, Nataliya Davydova - of her bronze medal in weightlifting for the use of Turinabol, Denys Yurchenko - of his bronze medal in athletics for the use of Turinabol, Victoria Tereshchuk - of her bronze medal in modern pentathlon for the use of Turinabol. According to the results of the 2012 Summer Olympics in London, the International Olympic Committee stripped the Ukrainian javelin thrower Oleksandr Pyatnytsya of his silver medal for the use of Turinabol, Yuliya Shymechko - of her bronze medal in weightlifting for the use of Turinabol, Oleksiy Torokhtiy - of his gold medal in weightlifting for the use of Turinabol. Thuswise, the International Olympic Committee overall has imposed sanctions against 11 Ukrainian athletes for the use of doping ${ }^{1}$.

Nonetheless, the issue of illegal influence on the results of official sports competitions by means of the use of doping concerns not only Ukraine and Ukrainian athletes. For instance, a bronze medalist in long jumping at the 2008 Summer Olympics in Beijing Blessing Okagbare was 
suspended for the 2020 Olympic Games on suspicion of violation of anti-doping rules. On July 30th, 2021 in Tokyo, she made the semifinals in a $100 \mathrm{~m}$ short sprint by winning her qualifying round. However, on a day preceding the semifinals the Athletics Integrity Unit (AIU) informed that the drug test of a Nigerian athlete as of July 19th, 2021 turned out to be positive for human growth hormone [2].

Alongside such developments, during the participation in the 2020 Summer Olympics sanctions were also imposed against a Georgian athlete. As reported by the media relations service of the International Testing Agency (ITA) a Georgian shot putter Benik Abrahamyan was suspended from participation in the 2020 Summer Olympics in Tokyo for violation of anti-doping rules. The A-sample from the doping test that Abrahamyan took on July 31st, 2021 indicated the presence of banned substances ${ }^{2}$.

According to the Law of Ukraine "On Anti-Doping Control in Sport» as of 07.02.2017 № 1835-VIII, doping in sport is the case of violation of anti-doping rules, and a drug test is any biological material which is collected for the purposes of doping control [6].

Initially, doping was understood as the use of substances that artificially enhance performance in competitions. The most comprehensive definition of doping was provided by the International Sports Medicine Congress (Strasbourg, 1965): «Doping is an injection in the body of a person, made in any possible way, of a substance, alien to this body, of some physiological ingredient in abnormal quantity or some other substance in an unnatural way, so that to artificially and unfairly improve athlete's results in the course of participation in a competition» [7, p. 57].

The primary effect of Turinabol, as a substance widely used among professional athletes, is the enhancement of metabolic and substance-generating processes necessary for the production of organic tissues. It is therefore they are often called growth hormones [8, p. 53]. Upon entering the body, synthetic testosterone derivatives affect the hypothalamus and the pituitary gland, inhibiting their production of hormones as well as causing a halt in testosterone production. They may furthermore lead to disorders of the cardiovascular system, liver damage, mental disorders, male infertility, premature stunting and growth impairment among children and teenagers, development of malignant tumors. Upon elimination of synthetic steroids from the system natural functions of the body may not restore [9, p. 43]. According to the Prohibited List by the World Anti-Doping Agency (WADA), during both in- and out-of-competition period the following substances and methods are prohibited at all times: anabolic agents; peptide hormones, growth factors, related substances and mimetics; Beta-2 agonists; hormone and metabolic modulators; diuretics and masking agents; prohibited methods: manipulation of blood and blood components, chemical and physical manipulation; gene and cell doping; prohibited substances: stimulants, cannabinoids, glucocorticoids, narcotics; substances prohibited in particular sports: beta-blockers [10].

Particular attention must be paid to a pharmaceutical drug «Meldonium» which was not included on the World Anti-Doping Agency Prohibited List until January 1st.
2016. Meldonium or mildronate is a metabolic substance aimed at increasing performance, in particular, endurance, improved rehabilitation (recovery), prevention of overloading of the central nervous system, etc. This, in WADA's viewpoint, qualifies as a violation of the rule of sportsmanship (Fair Play) since the utilization of meldonium provides an advantage to athletes who use it [11, p. 167].

This issue is further emphasized by such scholars as Christian Görgens, Sven Guddat, Josef Dib, Hans Geyer, Wilhelm Schänzer, Mario Thevis - the use of meldonium has tremendous potential for its misuse in elite sports [12, p. 973]. Some scholars (Giusepee Lippi and Camilla Mattiuzzi) generally stressed the fact that its use may jeopardize the life and health of athletes who employ it for artificial performance enhancements [13, pp. 50-51]. However, all of this does not prevent individual athletes from using meldonium in their sporting careers.

As an instance, after the official ban on meldonium, the mass media disclosed the names of several Russian athletes revealed to have used said prohibited substance, among them: a biathlete Eduard Latypov, a road bicycle racer Eduard Vorganov, an ice dancer Ekaterina Bobrova, a tennis player Maria Sharapova, a speed skater Pavel Kulizhnikov, short track speed skaters Semion Elistratov and Ekaterina Konstantinova, a volleyball player Aleksandr Markin [14].

The hormone surge is also unofficially classified as the form of doping. In particular, it can be used by female athletes. In a determined period before the competition, the athlete becomes pregnant thus stimulating her hormone output which, in its turn, considerably impacts her athletic performance. In some cases, female athletes even resort to abortions. For male athletes, on the contrary, it is recommended to practice sexual abstinence to increase hormone levels. Numerous instances of using such form of doping were acknowledged with cases reported during the 1980 Summer Olympics.

Nevertheless, as may be seen, the prohibition of the aforementioned substances applies solely to the in-competition period. Cocaine is used by athletes to relieve the pain syndrome, accelerate muscle growth, and enhance endurance. Upon the review of mass media, the following world-renowned athletes may be identified as having used cocaine. Among them are football players Diego Maradona, Adrian Mutu, Paul Gascoigne; tennis players Martina Hingis, Dan Evans, Richard Gasquet; professional boxers Mike Tyson and Tyson Fury. That list is far from exhaustive [5, p. 6]. It must be further stressed that the use of doping during participation in official sports competitions in the majority of cases is conducted under the influence of the coach and in collusion with the physician that accompanies the athletes in the course of his sporting career. The issue of doping may furthermore escalate to a national level when backed by top political officials.

As an instance, in 2019 sanctions were imposed against the Russian Federation on the decision by the World Anti-Doping Agency for doping violations on the part of Russian authorities aimed at tampering with the database of the Moscow anti-doping laboratory. According to the 
report by the Canadian professor Richard McLaren, who carried out an investigation on the subversion of drug testing results, based on the testimony of the head of Moscow anti-doping laboratory Grigory Rodchenkov it was indicated that members of special forces of the Russian Federation conducted unsanctioned substitution of drug test results on a regular basis, in particular at the 2014 Winter Olympics.

As a result of sanctions, Russia is banned for a period of four years from participating in large-scale international competitions, such as the Olympic Games and world championships. Furthermore, prohibition is imposed with regard to organizing and conducting international competitions in the territory of the country, using the Russian flag and hymn during competitions. It must be further noted that mentioned bans also affected Russian athletes who were not convicted of using doping - they were allowed to participate in competitions only under a neutral flag. The latest news in this doping scandal as of late has been the approval of a fragment from Pyotr Tchaikovsky's The Piano Concerto No. 1 instead of the hymn of the Russian Federation during medal ceremonies.

Taking into consideration the above-stated issues, the majority of European countries, which ratified corresponding international legal acts on anti-corruption in the sphere of sports, have further enforced normative legal acts at the national level. Specifically, on November 3rd, 2015 the Verkhovna Rada of Ukraine adopted the Law of Ukraine «On prevention of influence of corruption offenses on the results of official sports competitions» under № 743-VIII aimed at preventing the impact of corruption offenses and other offenses related to corruption in the sphere of sports on the results of official sports competitions and which further defines the principles, specific features of subjects and measures for prevention and identification of corresponding offenses and elimination of their consequences as well as liability for such offenses.

Resulting from this, corresponding changes were implemented into criminal and administrative legislation in relation to liability for illegal influence on the results of official sports competitions of the Article 369-3 of the Criminal Code of Ukraine (hereinafter - the CC of Ukraine) and the Article 72-9-1 of the Code of Ukraine on administrative offenses.

However, it is worth noting that in a number of countries, studied by the authors, the criminal liability for illegal influence on the results of official sports competitions is not established. This specifically concerns Australia, Austria, Argentina, Belgium, Bulgaria, Denmark, Estonia, Spain, Iran, Kazakhstan, Kyrgyzstan, China, Korea, Lithuania, the Netherlands, Germany, Norway, Poland, Thailand, Turkey, Turkmenistan, Uzbekistan, France, Switzerland, Sweden, and Japan. Nonetheless, individuals that conduct said actions in certain cases may be held criminally responsible for bribery or fraud.
It is furthermore established that a special regulation that provides for criminal liability for illegal influence on the results of official sports competitions exists in the criminal legislation of Azerbaijan, Belarus, Ukraine, Georgia, Israel, Latvia, Moldova, Russia, Tajikistan, and the state of Texas. In the Criminal Code of San Marino, an illegal influence on the results of official sports competitions is a qualifying element of fraud.

In this way, out of 36 countries under study, 61\% (26 countries) do not implement criminal liability for illegal influence on the results of official sports competitions. $39 \%$ (10 countries) implement criminal liability for illegal influence on the results of official sports competitions. At the same time, none of the studied Criminal Codes provide for the liability for use of doping as the means of exerting illegal influence on the results of official sports competitions

Turning to judicial practice in the application of Article 369-3 of the CC of Ukraine, it can be observed that according to the country-wide Unified report on criminal offenses by the Office of the Prosecutor General of Ukraine, between 2015 and May 2021 a total of 8 criminal proceedings were registered and 2 individuals were served a notice of suspicion.

Within the framework of the presented study on the criminal liability for illegal influence on the results of official sports competitions the authors have surveyed investigators and operatives of the National Police of Ukraine, who took advanced training courses in the Dnipropetrovsk State University of Internal Affairs during August 2020 June 2021 and overall represent all regions of Ukraine (230 respondents), and it was established that presently there exists an extra-high level of latent criminal activity under the Article 369-3 of the CC of Ukraine (indicated by 190 respondents which constitute $83 \%$ of the total number of the surveyed), while almost $100 \%$ of respondents replied negatively to the criminalization of such acts as quasi-corruption fraudulent activities.

Turning to the Unified register of pre-trial investigations, several court orders on the adoption of specific procedural decisions may be found therein, even though these decisions concern other types of illegal influence on the results of official sports competitions which, in contrast to the use of doping, are criminalized. However, while proving the use of doping is reduced to the analysis of biological materials resulting in the identification of the presence of the prohibited substances in the athlete's blood, proving the illegal influence on the results of official sports competitions under Article 369-3 of the CC of Ukraine implies numerous impediments. This is attested by the absence of guilty verdicts throughout the entire span of existence of this criminal prohibition.

For instance, on May 1st, 2018 unknown persons attempted to influence the results of official sports competitions by subornation, instigation, and attempts to 
collude with the goalkeeper of the FC Karpaty Lviv U-19, offering the latter the cash funds in the amount of 10.000 US dollars to help fix the result of the match between the FC Karpaty Lviv and the FC Shakhtar Donetsk by arranging the loss of the match by his team [15]. As a further instance, on May 23rd, 2018, during the examination of the mobile phone device iPhone 7 Plus with the SIM-card HOMEP_1 which belonged to the FC Hoverla Uzhhorod footballer, the information was discovered to evidence that the latter exerted illegal influence on the results of official sports competitions with the purpose of obtaining illegal proceeds, in particular his electronic correspondence with third persons related to performing football game, information on his possession of accounts on the website of the international bookmaker company that conducts its activity in the domain of accepting and placing bets on the results of sports matches, photocopies of documents of other individuals about whom the prosecution possesses comprehensive information with regard to their complicity in criminal activity, etc. [16]. This way, since 2018 and until present there have been no criminal proceedings instituted against the indicated persons.

\section{CONCLUSIONS}

Therefore, doping is indeed a global concern of the 21 st century due to its illegal influence on the results of official sports competitions. Taking into account the study of doctrinal provisions of domestic and foreign scientific developments about the liability for illegal influence on the results of official sports competitions by means of the use of doping as well as national and foreign criminal legislation, established law enforcement practices and results of the sociological survey, it has been corroborated that presently there exists no necessity for the establishment of criminal prohibition in respect of athletes for the use of doping for an entire span of their professional career. The study of international and national practices of legal regulation of liability for exerting illegal influence on the results of official sports competitions within the context of such means of its commission as the use of doping allowed to ascertain the inexpedience of criminalization of such acts as quasi-corruption fraudulent activities. At the same time, the regulation on criminal liability for illegal influence on the results of official sports competitions has its own right of existence, however with a pressing need for its improvement. Therefore, the authors will further undertake to study foreign experience in the legal regulation of liability for illegal influence on the results of official sports competitions and corresponding law enforcement practices within the context of grounds and principles of criminalization of socially dangerous acts elaborated by the criminal law studies.

\section{REFERENCES}

1. Vpershe $v$ istoriyi zminyly deviz Olimpiys'kykh ihor [For the first time in history, the motto of the Olympic Games was changed]. Available from: https://www.pravda.com.ua/news/2021/07/20/7301111/ (in Ukrainian).
2. Pretendentka na medal v Tokio poimana na dopinge [Tokyo Medal Applicant Caught Doping]. Available from: https://skeptik.com.ua/ pretendentka-na-medal-v-tokio-pojmana-na-dopinge/ (in Russian).

3. Pavlinov A.V. Korruptsiya v sfere mezhdunarodnogo i rossiyskogo sporta (retsenziya na stat'yu S.V. Maksimova «Nuzhna li kriminalizatsiya zloupotrebleniy v sfere mezhdunarodnogo sporta?» [Corruption in the field of international and Russian sports (review of the article by S.V. Maksimov «ls it necessary to criminalize abuse in the field of international sports?»]. Rossiyskiy zhurnal pravovykh issledovaniy. 2019; Tom. 6. 4 (21): 121-128 (in Ukrainian).

4. Istoriya fizicheskoy kul'tury i sporta [History of physical culture and sports] : ucheb.-metod. kompleks dlya stud. spets. 1-030201 / sost. i obshchaya red. V.YU. Dyatlova. Novopolotsk : U0 «PGU», 2005, 1-244 p. (in Russian).

5. Anisimov D.0. Aktual'ni pytannya vykorystannya dopinhu ta narkotychnykh rechovyn u sferi sportu [Current issues in the use of doping and drugs in sports]. Narkobiznes: suchasni hlobalizatsiyni protsesy : mater. Rehional. nauk.-prakt. seminar. (28 lyutoho 2020 r., m. Dnipro). Dnipro : Vydavets' Bila K.0., 2020: 5-7 (in Ukrainian).

6. Pro antydopinhovyy kontrol' u sporti [On anti-doping control in sports]: Закон України від 07.02.2017 № 1835-VIII. URL: https://zakon.rada. gov.ua/laws/show/1835-19 (in Ukrainian).

7. Volikov H.0. Analiz praktyky zastosuvannya statti 323-yi Kryminal'noho kodeksu Ukrayiny «Sponukannya nepovnolitnikh do zastosuvannya dopinhu»: deyaki aspekty [Analysis of the practice of application of Article 323 of the Criminal Code of Ukraine «Encouragement of minors to use doping»: some aspects]. Visnyk Odes'koyi advokatury. 2016.3: $57-64$ (in Ukrainian).

8. Svistil'nikov A.B., Rudnev S.M. Protivodeystviye nezakonnomu oborotu sil'nodeystvuyushchikh veshchestv i biologicheskikh aktivnykh dobavok: problemy i puti resheniye [Counteraction to illicit trafficking in potent substances and biological active additives: problems and solutions]. Problemy pravookhranitel'noy deyatel'nosti. 2013. 1: 52-57 (in Russian).

9. Gunina L. Anabolicheskiye agenty v sporte: mekhanizm dopingovogo deystviya i pobochnyye effekty [Anabolic Agents in Sports: Doping Mechanism and Side Effects]. Nauka v olimpiyskom sporte. 2015. 4: 39-48 (in Russian).

10. Zaboronenyy spysok (sichen' 2020): Mizhnarodnyy standart/Vsesvitnye antydopinhove ahent-stvo. Natsional'nyy antydopinhovyy tsentr [Prohibited List (January 2020): International Standard / World AntiDoping Agency. National Anti-Doping Center]. Available from: https:// nadc.org.ua/wp-content/uploads/2019/10/PL_2020.pdf(in Ukrainian).

11. H. Karl Greenblatt, David J. Greenblatt Meldonium (Mildronate): A Performance-Enhancing Drug? Clinical Pharmacology in Drug Development. Volume 5, Issue 3: 167-169. D0I: 10.1002/cpdd.264.

12. Christian Görgens, Sven Guddat, Josef Dib, Hans Geyer, Wilhelm Schänzer, Mario Thevis Mildronate (Meldonium) in professional sports - monitoring doping control urine samples using hydrophilic interaction liquid chromatography - high resolution/high accuracy mass spectrometry. Drug Test. Analysis, 2015.7:973-979. DOI: 10.1002/ dta. 1788.

13. Giusepee Lippi, Camilla Mattiuzzi. Misuse of the metabolic modulator meldonium in sports. Journal of Sport and Health Science. 2017. 6: 49-51. D0l: 10.1016/j.jshs.2016.06.008.

14. WADA ob"yasnilo, pochemu zapretili mel'doniy [WADA explains why Meldonium was banned]. URL: https://newdaynews.ru/sports/560472. html (in Russian). 
15. Materialy Yedynoho derzhavnoho reyestru sudovykh rishen' [Materials of the Unified State Register of Court Decisions]. Available from: http:// reyestr.court.gov.ua/Review/73748686 (in Ukrainian).

16. Materialy Yedynoho derzhavnoho reyestru sudovykh rishen' [Materials of the Unified State Register of Court Decisions]. Available from http:// reyestr.court.gov.ua/Review/77778637 (in Ukrainian).

\section{ORCID and contributionship:}

Volodymyr V. Shablystyi: 0000-0003-0210-1772 B, D, E, F

Dmytro O. Anisimov: 0000-0003-2893-8343 ${ }^{A, D, E, F}$

\section{Conflict of interest:}

The Authors declare no conflict of interest.

\section{CORRESPONDING AUTHOR}

Volodymyr V. Shablystyi

Dnipropetrovsk State University of Internal Affairs

Dnipro, Ukraine

tel: +380975757831

e-mail:vo-1_shablisty@ukr.net

Received: 02.07.2021

Accepted: 14.10 .2021

A - Work concept and design, B - Data collection and analysis, C - Responsibility for statistical analysis,

D - Writing the article, $\mathbf{E}$-Critical review, $\mathbf{F}$ - Final approval of the article 


\title{
THE EXPERIENCE OF LEGAL AND ORGANISATIONAL ARRANGEMENTS FOR MILITARY MEDICAL ACTIVITIES IN THE DEFENCE FORCES (USING FRANCE, GERMANY AND UKRAINE AS EXAMPLES)
}

DOI: 10.36740/WLek202111240

\author{
Yana 0. Hryhorenko' Oleksandr G. Kushnirenko², Oleksandr I. Shkuropatskyi \\ 'V. N. KARAZIN KHARKIV NÁTIONAL UNIVERSITY, KHARKIV, UKRAINE \\ ${ }^{2} Y A R O S L A V$ MUDRYI NATIONAL LAW UNIVERSITY, KHARKIV, UKRAINE
}

\begin{abstract}
The aim: To identify and establish the basics of organizational and legal support for military medical activities performed by the Defense Forces of France, Germany, and Ukraine, to make a comparative legal analysis of these principles in order to select the best practices that could be adopted by the forces of modern states.

Materials and methods: This study is based on regulatory instruments of England, France, Germany, the United States, and Ukraine. The following methods are used in the article: comparative-legal, comprehensive and analytical ones.

Conclusions: The study confirmed the importance of the legal and organizational framework of military medical activities to ensure the proper medical support of the troops. It includes 1) legal principles as key imperative requirements imposed on the operation of the military health services system; 2) legal foundations for the activities of the military medical services; 3 ) institutional arrangement.
\end{abstract}

KEY WORDS: rights of armed forces personnel, military medical activities, medical support of the troops, social protection

Wiad Lek. 2021;74(11 p.2):3098-3103

\section{INTRODUCTION}

The relevance of the present review stems primarily from the ambition of any modern country to develop a capable defense force to ensure its sovereign status. Ensuring the life and health of the armed force personnel, which is entrusted to the system of military medical services, plays an essential role in the functioning of the defense forces. However, the organizational and legal support for military medical activities within the legal doctrine remains understudied. Given this, the experience that has developed in this area in various states would be useful in establishing a conceptual legal model that could form the basis for the reform of the relevant systems in developed states.

\section{THE AIM}

To identify and establish the basics of organizational and legal support for military medical activities performed by the defense forces of France, Germany, and Ukraine, to make a comparative legal analysis of these principles to select the best practices that could be adopted by the forces of modern states.

\section{MATERIALS AND METHODS}

This study is based on regulatory instruments of England, France, Germany, the United States, and Ukraine, ex- pert opinion, and doctrinal references. Both general and special methods of scientific knowledge are used in the article. In particular, these include the system structural, comparative-legal, formal dogmatic, comprehensive, and analytical ones.

\section{REVIEW AND DISCUSSION}

The French Constitution has a specific section on sovereignty, which is further detailed in the French Code of Defence, according to which the army of the Republic is in the service to the Nation and its main task is to prepare and provide by force of arms for the defense of the Motherland and the supreme interest of the Nation (Article L4111-1). Articles 24 and 26 of the Basic Law for the Federal Republic of Germany determine the defense essence of German military policy, while the Constitution of Ukraine emphasizes the need for the Ukrainian Armed Forces and other military formations to ensure their sovereign status (Article 17). When performing such tasks, these institutions should at the same time be guided by key constitutional priorities related to ensuring human rights, including those of armed forces personnel. One of the main concerns in this context is to ensure the life and health of armed forces personnel, including by guaranteeing the right to health and medical care. 
V. Bilyi, V. Zhakhovskyi, V. Livinskyi, studying military medical activities, have aptly noted that another key factor determining the army's combat efficiency and preparedness, along with its technical equipment, is the soldiers' health status, which depends on the system of medical support [1]. COVID-19 pandemic makes the exercise of this right all the more important, both regarding the life and health of armed forces personnel and concerning national security. Scholars from various countries, including Peter Na, J. Tsai, I. Pietrzak, and others, have made significant contributions to the development of this scientific issue concerning servicemen [2]. It is no coincidence that there have been many recent publications on measures to improve the health of armed forces personnel precisely for the purpose of increasing defense capabilities and national security considering the challenges of today. Therefore, a special institutional mechanism shall be developed aimed at fulfilling a range of military medical activities in order to provide medical services to the troops. These activities are analyzed according to legal requirements by comparing the main approaches of France, Germany, and Ukraine using a comparative legal approach. The reason lies in the similarity of the legal systems, as well as the tendency of Ukraine to adopt the best practices of effective legal models. Given the above, the importance of the military-medical activity that can be observed within the defense sector of these states should be emphasized. As the key figure in its divisions is a serviceman, who acquires his status because there are quite stringent requirements related to the state of health. McManus J., Mehta SG, McClinton AR, De Lorenzo RA, Baskin TW specify that the military service as a type of special public service in any state provides for the recruitment of people who are fit both by age and health [3]. Furthermore, attention should also be paid to the fact that, according to Morrison C., Horwitz I., Carrick M., Morrison C., military medical services, unlike similar civilian services, are crisis-oriented, which means that medical services can be provided in extraordinary situations [4]. It is, in particular, about their activities in a combat situation. The Federal Republic of Germany, for example, has legally established priorities for the officership of the operational support sanitary services. These include not just the simple readiness of personnel and equipment to perform appropriate activities and provide medical services, but also the ability to be rapidly deployed to prevent crises and conflicts. All the above shows the unique organization of such services and special training of doctors (who are required to possess not only medical knowledge and skills but also strictly military skills) [5] and special tasks regarding health monitoring of both potential recruits and those who are already in service.

As a result, there are special health requirements for those fulfilling military service, as the tasks assigned to servicemen are of considerable physical and mental strain. To ensure the complete fulfillment of such tasks, one shall be in good health. This aspect is addressed primarily within the framework of sector-specific laws dealing with the organization of the armed forces as part of the Defence Forces.
Thus, Article L4123-19 of the French Defence Code states that, while in service, the armed forces personnel shall be provided with hygienic and safe conditions to protect their health and physical integrity, following the procedure prescribed by the Decree of the Council of State.

As noted by I. Holovanova, O. Krasnova, and O. Krasnov in their study of medical support for troops under conditions of anti-terrorist operations, the medical service is specifically challenged in wartime by the timely provision of medical care to the wounded. This can be achieved with a set of measures in the medical evacuation system, namely the establishment of a medical service team to respond to the specific situation, etc. It must be stated that preserving the life and health of armed forces personnel is the responsibility of all those involved in military management in order to keep all units of the defense forces up to standard. There is an approach in this respect related, firstly, to the fact that the defense forces should include persons who have an adequate level of health to perform tasks as members of the armed forces. And secondly, an appropriate state of health must be retained in the best possible way, taking into account substantial physical and mental strain [7] as well as significant risks to life and health (e.g. while engaged in combat operations). These factors determine the specific nature of military medical law and require the formation of an organizational and legal framework for the activities of those who perform military medical activities and create the conditions for the medical support of the troops.

The review resulted in the identification of three interrelated blocks in the structure of the organizational and legal framework for the provision of military medical activities in the defense forces of France, Germany, and Ukraine, each of which, complementing each other, has an independent significance in the system of medical support for the troops. The first block includes principles that make military medical activities to achieve the basic constitutional priorities for the defense forces of modern states. Such priorities take into account the humanist orientation of state activities. In this case, the unity of principles correlates with the unity of military medical services existing in France, Germany, and Ukraine. The second block is the system of regulations and other sources of law, which together regulate military medical activities. Such a system consists of both a set of various laws and regulations with different legal forces (Germany, Ukraine) and a codified act that regulates defense issues as a whole, including the military medical services (France). The third block is the system of entities that carry out military medical activities following both the principles of such activities and the system of regulations and other sources of law.

When researching issues related to the organizational and legal principles of military medical activities, it is worth defining a framework that will cover such fundamentals. Referring to the achievements of legal doctrine, in the context of which the issue to identify the organizational and legal foundations in various spheres of public activity arose, scholars have proposed several different approaches in this regard. 
P. Shahanenko described organizational and legal support as a set of not just legal and regulatory, but also logistical, financial, personnel, informational, and even operational measures [8]. However, according to D. Pryimachenko and R. Ihonin, organizational and legal support is a set of administrative, organizational, financial, informational, logistical, and technical measures [9]. Thus, legal and organizational support involves the implementation of a wide range of impacts, both legal and organizational, on the activities of the relevant public authorities and other authorities to ensure their lawful and effective functioning.

A comprehensive description of the legal and organizational framework for military medical activities in the countries analyzed shall be started with the basic principles. As the analyzed activity has two interrelated components, namely the military and the medical, such principles shall be divided into two groups. Principles relating to military medical activities, which are integrated into the military organization and are military in nature, shall form the first group. The second group shall consist of principles reflecting its medical nature. The principles that constitute the first group and are general military principles in nature include those provided for in national legislation. Thus, among the above principles relating to military medical activities the following shall be mentioned: the principle of taking all measures to protect and defend the national territory, adapting to NATO standards, the principle of loyalty to constitutional duty and the military oath; the principle of humanity, transparency, and publicity for democratic civilian control; the principle of constant operational preparedness; the principle of ensuring state social protection for armed forces personnel. The latter principle means that the French Republic, as a State, its authorities, and institutions, can contribute to the financing of additional guarantees of social protection for armed forces personnel (Article L4123-3(1) of the French Code of Defence). In Ukraine, this principle is reflected in the Constitution (Article 17(5) of the Fundamental Law of Ukraine). The difference in approaches is since Ukraine, compared to France and Germany, is a transit country, a factor that harms the social security of armed forces personnel. Another important aspect regarding military service and medical care is Paragraph 3 of Germany's Law on the Legal Status of Military Personnel, describing the basic principles according to which a soldier's state of health and related guarantees are the ground for his appointment and the performance of demanding tasks.

The above principles are fundamental not only for all members of the Defence Forces but also for the military medical services. The principle of humanism and social protection of armed forces personnel is certainly decisive among them, which, as we have already noted, includes medical support. Nevertheless, other principles also play an important role. According to T. Blashchuk, patients shall be entitled to receive quality health care, taking into account the principles of humanity and dignity in relations between the patient and the medical service provider [10]. Thus, the system that functions effectively cannot be built without humanism, including in the medical support of the troops.

As for the second group of principles, they are special and reveal the essence of military medical activity. The following principles can be included: the equality of the armed forces personnel concerning medical care; focus on up-to-date standards for medical support; the principle of a joint medical service (in all three countries); the preventive and precautionary nature of the medical activity; arranging of the medical support for the troops under the standards on medical care (medical standards), clinical protocols and military medical standards; the principle of expert knowledge of military medical personnel (Article R3232-11 of the French Code of Defence) and others. The legal framework for military medical activities represents the second block regarding characteristics of the organizational and legal framework for the medical support for the troops. The analysis of the current military legislation of France, Germany, and Ukraine demonstrates that the following levels can be distinguished in the structure of this legislation regarding the regulation of issues related to military medical activities: the first level is the level representing the foundations of the constitutional (state) system and the level at which the relevant provisions relating to the right to health and medical care are incorporated in the provisions of the Constitution. It shall be noted that, first of all, there is a strong constitutional basis for the medical services (military-medical activity), which relates to the tasks entrusted to the army (according to Article L4111-1 (2) of the French Code of Defence, military service requires a spirit of sacrifice, which may include the supreme sacrifice, discipline, availability, loyalty, and neutrality), on the one hand, and the necessity to provide the serviceman with the rights and social guarantees, on the other hand (the French Code of Defence states that the performance of military duties merits both the respect of citizens and the establishment of appropriate guarantees.). Due to this, the legal basis for the further detailed legal regulation of issues related to ensuring the life and health of armed forces personnel, including by guaranteeing the right to health care and medical assistance, has been established. A different approach prevails in Ukraine, given the transient nature of the state. The right to health care for members of the armed forces is established in Article 17(5) and Article 49 of the Constitution, that is, at the highest level. The second level is conceptual. It refers to the formation of key directions for the development of military medical activities. The conceptualization of the medical support for the troops and its further comprehensive development shall be referred to the military medical doctrine, which assumes that an important component and resource of national security is the health of the citizens, in particular the armed forces personnel. Even though this regulatory act has been adopted as a government decree, it forms the ideological and normative basis for further legislative regulation of these issues. The third level aims to make the constitutional and conceptual provisions more specific by regulating military medical activities in the area of conscription and enlistment into the armed forces through 
legislation. It involves the organizational and legal regulation of conscription and enlistment in terms of the implementation of health-related requirements for intended armed forces personnel. All these measures are aimed at developing defense force personnel who will be capable of serving in the armed forces. According to the current law of the Federal Republic of Germany (Paragraph 3 of Germany's Law on the Legal Status of Military Personnel), it is clearly stipulated that members of the armed forces are to be commissioned and serve if their physical health, amongst other things, is appropriate. Paragraph 71 of the Law, in turn, requires a medical examination for applicants to determine if they are fit to perform the duties of military service. The fourth level of legislative support involves the specification of constitutional and conceptual provisions regarding the legal regulation of medical support in the area of military service. It is about establishing appropriate guarantees of the right to health and medical care for active armed forces personnel and members of their families. One of the guarantees in the Federal Republic of Germany, for example, is that the official website of the Bundeswehr is constantly updated and a relevant map is filed, allowing servicemen who fall ill to promptly find their army doctor [11]. The right of armed forces personnel to health care is also guaranteed at this level through the legal regulation of medical supervision and medical examinations of the servicemen. Such an approach certifies the specific character of military service and the status of military personnel in comparison to non-military service. For the vast majority of civilians (excluding children, disabled people, and certain other persons), the right to health and medical care is legally established and is known to be exercised at the initiative of the individual. This means that a person is in control of his or her own health and, if there are any complaints, he or she can exercise his or her constitutional right by consulting doctors and medical institutions. But the situation is unique for armed forces personnel. In addition to the fact that they can also contact the relevant institutions and officials on their own initiative, exercising their rights, but the state establishes the duties of the relevant officials to constantly monitor the health status of the personnel. The reason is that there is an urgent need to ensure constant combat and mobilization readiness of all units, and this can only be achieved if the health of all the personnel is adequate. Furthermore, an organizational and legal framework for preventive measures in this area is being developed. This includes measures to improve the health and physical development of armed forces personnel and to prevent injuries and poisoning, by controlling the quality of food and water, among other things. Thus, according to Article R3232-11 of the French Code of Defence, the Health Service of the Armed Forces prescribes sanitary and preventive measures and is involved in their implementation and monitoring [12]. All this is due to the fact that the State, represented by the medical services, is responsible for the conscripts, taking them on full support. The most explicit reference is made to Bundeswehr's Health Service Command, which points out that it is professionally responsible for the health care of the entire Bundeswehr. This responsibility is implemented, among other things, through the obligation of state supervision (control), which is exercised Proprio motu under the applicable law [13]. In Ukraine, such responsibility is legally imposed on all medical service officials. For example, following Article 18 of the Charter of Garrison and Security Services of the Armed Forces of Ukraine, the chief medical officer of the garrison is responsible for arranging and carrying out preventive and anti-epidemic measures, and monitoring the implementation of sanitary regulations in the garrison.

The third block of the legal and organizational framework for military medical activities covers the level of institutional medical support for the troops. It involves the establishment and operation of relevant institutions, services, and individuals whose activities are aimed at ensuring the health and medical care for members of the armed forces and their families. The institutional components can include the medical services (military medical units, military health care institutions, and health care management authorities). The main structure of the military medical services in Ukraine and the responsibilities of officials are set out in the Charters of the Armed Forces. Regarding the Federal Republic of Germany, the current legislation governing the Bundeswehr's medical service consists of the following acts: 1. The Law on the Legal Status of Military Personnel, which establishes the legal status of armed forces personnel, including the medical service. 2. The Defence and Disciplinary Code, which contains provisions for the disciplinary responsibility of armed forces personnel, including those in medical service positions [14]. 3. The Decree on the Careers of Armed Forces Personnel (Section 2 (Paragraphs 28-32)), sets out the employment requirements, conditions for the promotion, and transfer of medical officers [15]. Today, the Bundeswehr medical service controls hospitals of the armed forces, medical care departments, and regional medical service management [16]. In France, the duties and framework of the institutional mechanism of the army health service are regulated by articles R3232-11 to R323232-14.

It shall be emphasized that the institutional mechanism for the implementation of military medical activities can also include public, community health care institutions, which, at the expense of the defense forces, must provide medical care to armed forces personnel, in certain cases. This is due to the need to combine the capabilities and efforts of all medical services (military and civilian) to form an integrated medical space. For instance, the Bundeswehr of the Federal Republic of Germany focuses on the medical care activities of the Medical Service Command in the framework of civil-military cooperation [17]. In France, according to articles R6147-112 to R6147-120 of the French Code of Public Health, the military medical service is authorized to provide medical care to persons who are not directly related to the army [18]. All medical services are integrated and their tasks, including those related to national security and defense, are carried out. 


\section{CONCLUSIONS}

The study confirmed that the legal and organizational framework for military medical activities is important for the proper medical support of the troops. These principles constitute, firstly, legal principles as key imperative requirements imposed on the operation of the military health services system. Secondly, the legal basis for such activities. Given the importance of military medical activities in terms of ensuring sovereignty and defense capacity, the current national legislation contains such provisions in acts of supreme legal force, constitutions (in particular Ukraine), or codified acts (in the French Republic these issues are regulated by the Code of Defence, and by-laws and codified acts in Germany). Thirdly, the institutional arrangement, which may generally have its national specificity, focuses predominantly on a single functional area. For example, the military medical service in France, Germany, and Ukraine is the only one serving all army units. In France, this service also operates in the Gendarmerie. However, there is a tendency in all the countries mentioned to integrate civilian and military medical facilities.

\section{REFERENCES}

1. Bilij V, ZHahovs'kij V, Livins'kij V. Voenno-medichna doktrina Ukraïni yak osnova medichnoï skladovoï nacional'noï bezpeki derzhavi.[ The military medical doctrine of Ukraine as the basis of the medical component of the national security of the state] Nauka i oborona. 2018;4:8-12 (in Ukrainian).

2. Peter $\mathrm{Na}$, J. Tsai, I. Harpaz-Rotem, R. Pietrzak Mental health and suicidal ideation in US military veterans with histories of COVID-19 infection. BMJ Mil Health first published as 10.1136/bmjmilitary-2021-001846 on 25 May 2021. doi: 10.1136/bmjmilitary-2021-001846.

3. McManus J., Mehta SG, McClinton AR, De Lorenzo RA, Baskin TW. Informed consent and ethical issues in military medical research. Emerg Med. 2005;12(11):1120-6. doi: 10.1197/j.aem.2005.05.037.

4. Morrison C., Horwitz IB, Carrick MM. Morrison CA, et al.J Ethical and legal issues in emergency research: barriers to conducting prospective randomized trials in an emergency setting. Surg Res. 2009;157(1):11522. doi: 10.1016/j.jss.2009.03.051.

5. The American bar association Legal guide for military families: first edition. Random house. New York.2013:372.

6. Golovanova I, Krasnova 0, Krasnov 0. Medichne zabezpechennya vijs'kovih chastin Zbrojnih Sil Ukraïni. [Medical support of military units of the Armed Forces of Ukraine] Ukraïna. Zdorov'ya naciï. 2016;4/1(41):33-36. (in Ukrainian).

7. RAIN LIIVOJA BIOMEDICAL ENHANCEMENT OF WARFIGHTERS AND THE LEGAL PROTECTION OF MILITARY MEDICAL PERSONNEL IN ARMED CONFLICT.Medical Law Review 2021;26(3):421-448.

8. Shaganenko P. Ponyattya organizacijnogo zabezpechennya diyal'nosti organiv prokuraturi.[The concept of organizational support for the activities of the prosecutor's office] Chasopis kiïvs'kogo universitetu prava. 2015; 4:144-147 (in Ukrainian).

9. Prijmachenko D., Igonin R. Spivvidnoshennya ponyat' «organizacijne zabezpechennya sudiv», «organizacijne upravlinnya v sudah» ta «sudove upravlinnya». [Correlation of the concepts of "organizational support of courts"," organizational management in courts", and "judicial management"] Slovo Nacional'noï shkoli suddiv Ukraïni. 2013;1:57-66 (in Ukrainian).

10. BlashchukT. Pravo na medichnu dopomogu ta jogo realizaciya v umovah pandemiï (COVID-19). [The right to health care and its implementation in a pandemic(COVID-19)]. Pidpriemstvo, gospodarstvo i pravo. 2020;11:5-11. (in Ukrainian)
11. Nachrichten aus dem Kommandobereich. Available from: https:// www.bundeswehr.de/de/organisation/sanitaetsdienst/kommandound-organisation-sanitaetsdienst/kommando-sanitaetsdienstlicheeinsatzunterstuetzung [reviewed 2021.08.06].

12. Code de la défense:Section 2: Leservice de santé des armées (Articles R323211 à R3232-14)Code dela défense:Section 2: Leservice de santédes armées (Articles R3232-11 à R3232-14). Available from: https://www.legifrance. gouv.fr/codes/id/LEGISCTA000034589799/[reviewed 2021.08.06].

13. Nachrichten aus dem Kommando Sanitätsdienst Available from: https:// www.bundeswehr.de/de/organisation/sanitaetsdienst/kommandound organisation-sanitaetsdienst/kommando-sanitaetsdienst [reviewed 2021.08.07].

14. Wehrdisziplinarordnung (WD0). Available from: https://www. gesetze-im-internet.de/wdo_2002/BJNR209310001.html. [reviewed 2021.08.07]

15. Verordnung über die Laufbahnen der Soldatinnen und Soldaten (Soldatenlaufbahnverordnung - SLV). Soldatenlaufbahnverordnung vom 28. Mai 2021 (BGBI. I S. 1228)" Available from: http://www.gesetze-im-internet.de/slv_2021/ BJNR122810021.html [reviewed 2021.08.07].

16. International study of the stem function of vyskovo-medical forces (dosvid France, Germany and the USA) Available from: http://euinfocenter.rada. gov.ua/uploads/documents/29451.pdf [reviewed 2021.08.15].

17. Kommando Sanitätsdienstliche Einsatzunterstützung Available from: https://www.bundeswehr.de/de/organisation/sanitaetsdienst/ kommando-und-organisation-sanitaetsdienst/kommandosanitaetsdienstliche-einsatzunterstuetzung [reviewed 2021.08.15].

18. Code de la santé publique: Section 7 : Relations entre le service de santé des armées et les autres acteurs du système de santCode de la santé publique : Section 7 : Relations entre le service de santé des armées et les autres acteurs du système de santé. Available from: https://www. legifrance.gouv.fr/codes/article_Ic/LEGIARTI000038443982/[reviewed 2021.07.15].

\section{ORCID and contributionship:}

Yana O. Hryhorenko: 0000-0001-8670-6669 A,B,D

Oleksandr G. Kushnirenko: 0000-0003-1836-5043 C, E

Oleksandr I. Shkuropatskyi: 0000-0002-4679-7292 E,F

\section{Conflict of interest:}

The Authors declare no conflict of interest.

\section{CORRESPONDING AUTHOR Yana 0. Hryhorenko \\ V. N. Karazin Kharkiv National University \\ Kharkiv, Ukraine \\ tel: +380955043040 \\ e-mail: grigorenko@karazin.ua}

Received: 31.06 .2021

Accepted: 12.10 .2021

A - Work concept and design, B - Data collection and analysis, C - Responsibility for statistical analysis,

D-Writing the article, $\mathbf{E}$-Critical review, $\mathbf{F}$ - Final approval of the article 


\title{
RESEARCH STUDY OF MEDICINES USING THE HUMAN BODY AFTER HIS/HER DEATH
}

DOl: 10.36740/WLek202111241

\author{
Olena I. Antoniuk', Ivan I. Vyshnyvetskyy² \\ ${ }^{1}$ MINISTRY OF JUSTICE OF UKRAINE, KYIV, UKRAINE, UKRAINIAN ASSOCIATION FOR CLINICAL RESEARCH, KYIV, UKRAINE \\ ${ }^{2}$ BOGOMOLETS NATIONAL MEDICAL UNIVERSITY, UKRAINIAN ASSOCIATION FOR CLINICAL RESEARCH, KYIV, UKRAINE
}

\begin{abstract}
The aim of this paper is to determine the legal nature and basis for the research of medicines using the human body after establishing the fact of his/her biological death. Materials and methods: This research study is based on an analysis of the norms of international law and legislation of some states on the admissibility of the research of medicines using the human body after establishing the fact of his/her biological death. The research was carried out using the methods of dialectical and formal logic, general scientific and special legal research methods.

Conclusions: The possibility of organizing and conducting research using the human body after ascertaining the fact of his/her biological death as a scientific study distinguishes such studies from related types of medicines research, proposed standardization of these studies within the preclinical research of medicines, and examination of materials funds.
\end{abstract}

KEY WORDS: scientific research of medicines, clinical trials, preclinical trials, human body, statement of death

Wiad Lek. 2021;74(11 p.2):3103-3107

\section{INTRODUCTION}

The study of the effect of new medicines on the human body is carried out within the medicines' clinical trials, which are preceded by preclinical studies, during which the information necessary to address the possibility of continuing and study features of the medicines in humans.

However, the importance of preclinical studies, mainly in cell cultures and animals, for predicting the safety and efficacy of therapy in human trials remains limited. Attempts to improve the predictability of human test results with animal data are not accompanied by a reduction in a high incidence of clinical medicines failure. In addition, poor interpretation of information obtained in animal studies for use in clinical trials of medicines in humans leads to a significant loss of resources $[1 ; 2]$.

One of the most common errors observed in preclinical studies concerns dose determination for humans (phase I trials) based on animal studies. There is a misleading trend regarding linear transposition based on a simple conversion of the dose calculation used in small animals $(\mathrm{mg} /$ $\mathrm{kg}$ ) extrapolated to a patient with average body weight [3].

Approximately $12 \%$ of medicines that undergo preclinical studies are subsequently placed in human clinical trials. Only $60 \%$ of them successfully complete the first phase of testing. Overall, almost $89 \%$ of the medicines studied are unsuccessful in human clinical trials, and about half of these failures are due to unforeseen human toxicity [2].

Carrying out preclinical studies in animals poses many challenges in terms of their ability to ensure the safety of clinical trials in humans. Therefore, proposals are made to reduce them through using other, potentially more reliable methods. More often scientific organizations and government regulators are recognizing that alternative methods can replace animal testing and improve the safety of new therapeutic medicines for human use [4]. For example, the US FDA published in 2006 "Guidance for Industry, Investigators, and Reviewers: Exploratory IND Studies", which called for greater use of the so-called Phase 0 clinical trials [5]. The time and cost savings for the development of new therapeutic medicines can be significant if the safety of preclinical trials without the involvement of animals is proven [4].

In research of alternatives for some pharmaceutical companies for certain medicines, there is interest in their preclinical study using the human body after establishing the fact of his/her death.

Studies of medicines using the human body with artificially supported life support systems after establishing the fact of his/her death (hereinafter - the Research), as well as clinical trials of such medicines, could provide data on the effects on the human body of the study medicines but would have an undeniable advantage because the data are obtained in the human body, but without safety risks using in healthy volunteers or patients.

As stated in the preambular paragraph of Regulation (EC) №536 / 2014 [6], the safety risk of the subject of clinical trials is based mainly on two sources: investigational medicinal product and maneuver. 
Because of the use of the deceased's body in the Research, the functioning of which is maintained artificially, such a study is safer than a clinical trial and does not contain risks of adverse effects on humans. In this context, the Latin expression "mortui vivos docent" (dead teach the living) is relevant.

It should be noted that in medical education (in particular, surgical training) the corpse has always been used for the purpose of direct study of the human body, surgical practice, and new scientific methods [7].

At the same time, the Research is closer to a clinical trial, compared to other common types of preclinical studies performed with animals.

Thus carrying out Research does not replace clinical trials, and allows solving a question of expediency of carrying out a clinical trial of medicines.

During the organization and conducting of Research, first of all, the question of the legitimacy of such activities arises. It should be noted that the relevant legal relations have not found special regulation, they are regulated in fragments at the level of various normative acts. In addition, these issues have not been addressed in research. The issues of medicines trials have been studied mainly in the context of medical trials in general and clinical trials in particular.

This state of regulation and scientific development, of course, negatively affects the legal relations that arise during such activities and necessitates a separate scientific study of the organization and conduct of Research.

\section{THE AIM}

This paper aims to determine the legal nature and research basis of medicines using the human body after establishing the fact of his/her biological death.

\section{MATERIALS AND METHODS}

To achieve the research's objectives the features of normative regulation, different types of medicines' research in different countries, including considered international regulations, as well as regulations of some states on the research topic are analyzed.

The methods of theoretical analysis and synthesis were used during the study of the legal norms' content and concepts contained in normative legal acts and ethical norms. The method of systematic analysis was used, in particular, in clarifying the legal nature of the research. Formal-legal analysis of regulations on the use of the deceased's body allowed to conclude on the research legitimacy and to formulate proposals for their regulation in the preclinical medicines' research study. The comparative legal method was used in the analysis of the peculiarities of the regulation in different states of the use of the body of a deceased person in scientific research. Methods such as formal-logical (to highlight the differences between the research and clinical trials, clinical trials of tissue and cell grafts) and some others were also used in solving the problems of the study.

\section{REVIEW AND DISCUSSION}

To clarify the legal basis for conducting research using the human body, it is first necessary to establish the relationship between the study and clinical medicines 'trials. A clinical trial of medicine is defined as research conducted on a human being as a research's subject, designed to evaluate the efficacy and safety of medicinal products (Part 2 of Article 2 of Regulation (EC) №536 / 2014, paragraph 1.12 of ICH GCP E6 (R2) [ 8]).

Analysis of the legal provisions for clinical trials allows us to conclude that the latter are conducted: 1) in order to establish or confirm the effectiveness and safety of the drug; 2) after mandatory assessments and official approval. In this case, the decision on clinical trials is made in the presence of positive conclusions of examination of the materials of the preclinical study on the effectiveness of medicines and their safety; convincing evidence that the risk of medicines side effects will be significantly lower than the expected positive effect.

These requirements are due to the fact that clinical trials of medicinal products are performed on humans (paragraphs 14, 15 of the preamble, paragraph 1 of part 2 of Article 2 of Regulation (EC) №536 / 2014) - both on a patient and a healthy volunteer (paragraph 17 of part two) Article 2 of Regulation (EU) №536 / 2014). Human research is referred to in Article 16 of the Convention for the Protection of Human Rights and Dignity of Biology and Medicine: Convention on Human Rights and Biomedicine [9]. At the same time, one of the conditions for conducting human research is the absence of an alternative whose effectiveness would be similar to the effectiveness of human research (paragraph 16 of Article 16 of the Convention and Article 5 of the Additional Protocol to the Convention on Human Rights and Biomedicine in Biomedical Research) № 195) [10]).

According to paragraph 1.57 of the ICH GCP E6 (R2), the research's subject is defined as a person who participates in a clinical trial in the group receiving the test product or in the control group.

It should be noted that the term "person" is used to denote a physical party as a participant in a legal relationship. In this case, the person's death terminates his existence as a participant in legal relations.

The above provisions have legal significance and indicate that the terms "a person", "physical party", "law subject", "research subject", "a patient", "a healthy volunteer" are the terms used to denote a living person.

These features are reflected in the terminology used, in particular, in the legislation on transplantation of anatomical materials to humans, which distinguishes between the concepts of "living donor" and "corpse donor" ("dead person").

For example, the Additional Protocol to the Convention on Human Rights and Biomedicine on Transplantation of Human Organs and Tissues (ETS № 186) [11] separately regulates the removal of organs and tissues from a living person - a living donor (Chapter III) and a deceased person (Chapter IV). It is stipulated that doctors who testify 
to the person's death may not be those persons who are directly involved in the removal of organs or tissues from the deceased body or in subsequent transplant procedures or are responsible for potential recipients of organs or tissues (part two of Article 16 specified Additional Protocol).

Participation in the research of human medicines (living person) is a qualifying feature of medicines' clinical trial and one of the conditions. However, this is not a shortcoming of legal techniques and does not mean that there is a gap that must be eliminated by analogy with the law, applying to the Research conducted on the dead bodies, regulations on clinical trials, because it corresponds to a well-established international approach to understanding the nature of clinical trials.

The use of the body in the Study will take place after the person's death, i.e. after the termination of a person's right to life. Obviously, the deceased body cannot be examined by the patient and have the status of a research subject. In this case, it is the research object.

These findings and the content of clinical trial regulations indicate that they regulate only those researches that are performed on living people (including patients who are in critical and emergency conditions) but do not regulate the medicines' research on the deceased bodies.

Thus, the Research cannot be considered to be conducted with the participation of patients or healthy volunteers, and therefore, it does not belong to medicines' clinical trials.

Given the above, it can also be argued that the recording of information necessary for the Research of manipulation and test results should not be done using the patient's primary medical records used in medicines' clinical trials, as the last subject (patient or healthy volunteer) is no longer available due to death.

In addition, the procedure for obtaining permission from the regulatory body to conduct medicines' clinical trial, control over its conduct, its suspension's bases are aimed primarily at ensuring the protection of the rights, safety, and well-being of patients. This is stated in particular in the provision of ICH GCP E6 (R2), which is defined as an international ethical and scientific standard for planning and conducting research involving $\boldsymbol{a}$ human as a subject, as well as documenting and presenting the results of such research.

However, since the Research of medicines is administered exclusively to the deceased body, which does not meet the definition of a patient (healthy volunteer), there is no need to assess the potential risk of the study for the subject in relation to his/her benefits.

This means that the legislative provisions determining the procedure for organizing, approving, conducting medicines clinical trials of drugs do not apply to the Research, because the latter does not meet the qualifying feature of the clinical trial, namely - has no subject, but will be conducted on the corpse, which is no longer a subject of legal relations, but is an object, but with a special legal regime, unless otherwise expressly provided.

For example, Guide 11 "Collection, storage and use of biological materials and related data" contained in the
International Ethics Guidelines for Human Health Research, developed by CIOMS in collaboration with WHO, provides that the person whose biological materials and relevant data are used in the Research is the research participant and the ethical guidelines that apply to the study participants are applied in this situation. In addition, it indicates the use of samples and data of deceased bodies in the research $[12$, p. 42].

Thus, these International Ethical Guidelines distinguish between two types of research - with human participation and with the samples' and the corpse' data using.

The Research does not apply to the regulations on clinical trials of tissue and cell transplants (including cord (stem) cord blood stem cells) and examination of clinical trial materials. The last type of research is also carried out with the participation of a person and during its conduct, the use of the deceased as a body of the deceased is not regulated. In such studies, the deceased may only be a donor of anatomical material for transplantation or manufacture of bioimplants.

It is also necessary to dwell on the comparison of research and medicines' preclinical studies. Standards for the planning and conduct of preclinical studies of medicinal products in the EU are set out in Guidance EMA / CPMP / ICH / 286/1995 (ICH M3 (R2)) [13].

Medicines' preclinical Research is a set of chemical, physical, biological, microbiological, pharmacological, toxicological, and other scientific studies that are conducted before the start of clinical trials. Preclinical studies of the medicinal product include laboratory preclinical studies and/or experiments on laboratory animals to determine the specific activity and safety of the medicinal product.

Animal models as well as ex vivo and in vitro preparations can be used as test systems in preclinical studies of drug safety pharmacology. Ex vivo and in vitro systems may include but are not limited to, such systems as isolated organs and tissues, cell cultures, cell fragments, subcellular organelles, receptors, ion channels, transporters, and enzymes [14, p. 11].

Thus, pre-clinical researches under current regulations do not cover studies performed on deceased bodies.

However, the Research has the same purpose as a preclinical study, namely: to predict the human response to the medicine and to minimize the risk of adverse reactions in humans to such medicines.

Normative prescriptions for preclinical research can be extended to research conducted on the deceased bodies only by standardizing the specifics of their organization and conduct.

Differences between these types of medicines' research do not mean that the study should be prohibited as different from other types of Research, the order of which is standardized.

Research is a type of scientific study in the field of health care, so it is subject to legal regulation of scientific research in general and scientific research in the field of health care in particular, including conducted by scientific, educational 
institutions, or scientists. The Research is aimed at obtaining new scientific knowledge about the studied medicine, which will be recorded in documentary form.

However, the Research is possible only if the legality of using the corpse after his/her death.

In some countries, the relevant issues are regulated by law, which enshrines the right of an individual to order the transfer after his death of not only organs and other anatomical materials, but also bodies in general to scientific, medical, or educational institutions. Thus, these regulations create a legal basis for research using the deceased body by the relevant institutions.

However, like any medicines' study, the Research has its own specifics and the relevant features require a separate regulatory framework, as insufficient regulation of the use of the deceased body in research can cause not only legal but also ethical and psychological problems related, in particular, concerning the deceased.

For example, the Civil Code of the French Republic was supplemented by provisions on the inviolability of the human body by the Law of 29 July 1994 on the Inviolability of the Human Body. Thus, it was provided that the human body is inviolable and cannot be the subject of property law (Articles 16-1). In addition, it is provided that any agreements aimed at giving the human body property value are null and void (Article 16-5) [15, p. 24-25].

These regulations meet the requirements of Article 21 of the Convention for the Protection of Human Rights and Dignity of Biology and Medicine: the Convention on Human Rights and Biomedicine, according to which the human body and its parts as such should not be a source of financial gain.

The Trans-European Pedagogical Research Group on Anatomical Sciences has highlighted the fact that in Europe there are significant differences in legal and ethical requirements for using the body for anatomical research. Such differences reflect cultural and religious differences, as well as different legal and constitutional boundaries. There are different views on "ownership" of the body and on the need to develop special legislation in this regard. In addition, there are differing views on the acceptability of using unclaimed bodies by persons who have not given informed consent. For example, in the Italian Republic, according to the law, an unclaimed body can be transferred for educational purposes and research. In this case, the voluntary consent of the deceased is not required. In addition, the question of the possibility of ordering a person to transfer his/her body for scientific purposes is not regulated by law. However, there is no legal prohibition in this regard, so a person can use the tools by which the last will of the person, in particular, the will, to make such an order [7].

In the Netherlands, a person can transfer his/her body for use by the anatomical institute in medical science. To do this, it is necessary to write and sign a declaration by own hand that the person wants his/her body to be transferred to medical science after his/her death. The declaration is stored in the institute's documents, and copies are issued to the person and his/her family doctor. If a person is registered as a donor, priority is given to donation [16].
The current state of normative regulation of relevant issues, characterized by insufficient attention in the legislation of many states to the conditions and procedure of disposal of a human body in case of death, violates the principle of legal certainty and puts in uncertain legal position participants in such Researches, significantly reducing the protection of their rights and does not provide an adequate level of protection for the data obtained from such Researches.

Of course, it should be agreed that a person should be able to order the transfer of his/her body for research or educational purposes, as well as to limit the examination and dissection of the body [7], with certain statutory exceptions (for example, to determine the cause of death) law enforcement agencies).

It is considered that the right to consent to the use of the body after death should be granted only to an able-bodied adult without the use of the institution of informed consent of the legal representative used in clinical trials of medicinal products.

In this case, Researches on the content and purpose are close to the medicines' pre-clinical study, given that, in the process of regulatory regulation of their conduct may also take into account the normative developments in this type of medicines research.

\section{CONCLUSIONS}

Research using the human body (after establishing the fact of his/her biological death) can be organized and conducted as a scientific study, in particular by scientific institutions, educational institutions, or with the participation of individual scientists. The study is subject to regulations governing scientific activities, including in the field of health care.

Provisions using the human body are not subject to the provisions of the legislation on:1) medicines' clinical trials, 2) preclinical study of medicines and examination of materials of a preclinical study of medicines; 3 ) clinical trials of tissue and cell grafts and examination of relevant materials.

The state of normative regulation of medicines' research using the deceased body is unsatisfactory, because apart from the general norms on the scientific activity there are no special normative regulations, while other types of research of medical measures are sufficiently regulated at the legislative level.

However, given the nature and purpose of this research, which aims to obtain data on the medicines' effectiveness and safety, it is close to preclinical studies of such medicines, so the regulation of the latter can be supplemented by provisions on organization and conduct of medicines' research using of the corpse.

Normative regulation requires resolving the following issues: 1) granting a person for life, as well as revoking his/her consent to use his/her body after death in medical examinations (determination of the entity entitled to such an order or consent to a deceased person, form of order, circumstances that exclude the use of the body in medical 
research); 2) the possibility of a relevant order from the close relatives of the deceased, if it does not contradict his/ her order; 3 ) the right of the said persons to give appropriate consent to receive information regarding the use of the body in research; 4) approval of the Research by the ethics committee of the institution in which it will be conducted, and further ethical supervision of the Research; 5) prohibition of participation in the fact statement of the person's death of medical specialists who will carry out Research on a deceased body; 6) confidentiality of information on the use of the deceased body in the Research; 7) the subsequent corpse's fate after the Research's end.

\section{REFERENCES}

1. Seyhan AA. Lost in translation: the valley of death across preclinical and clinical divide - identification of problems and overcoming obstacles. Translational Medicine Communications. 2019;4(18). doi.org/10.1186/ s41231-019-0050-7.

2. Gail AVan. Norman Limitations of Animal Studies for Predicting Toxicity in Clinical Trials: Is it Time to Rethink Our Current Approach? JACC: Basic to Translational Science 2019;4(7):845-854. doi.org/10.1016/j. jacbts.2019.10.008.

3.. Andrade E.L, Bento A.F, Cavalli J et al. Calixto Non-clinical studies in the process of new medicines development - Part II: Good laboratory practice, metabolism, pharmacokinetics, safety and dose translation to clinical studies. Braz. J. Med. Biol. Res. 2016;49(12). doi. org/10.1590/1414-431X20165646.

4. Dirven H, Vist GE, Bandhakavi S et al. Performance of preclinical models in predicting medicines-induced liver injury in humans: a systematic review. Sci Rep. 2021;11(6403). doi.org/10.1038/s41598-021-85708-2.

5. Gawai AA, Shaikh F, Gadekar M et al. A Review on: Phase ' 0 ' Clinical Trials or Exploratory Investigational New Medicines. Turk J Pharm Sci. 2017;14(1):84-89. doi:10.4274/tjps.63935.

6. Regulation (EU) № 536/2014 of the European Parliament and of the Council of April 16, 2014. Available from: http://pharmadvisor.ru/ documents/ss3680/ss3680.html.

7. Bin P, Delbon P, Piras M, Paternoster M et al. Donation of the body for scientific purposes in Italy: ethical and medico-legal considerations Open Med (Wars). 2016;11(1):316-320. doi: 10.1515/med-2016-0060.

8. Guideline for good clinical practice E6(R2) of June 11, 2015. European Medicines Agency. 2015. https://www.ema.europa.eu/en/documents/ scientific-guideline/guideline-good-clinical-practice-e6r2-4-step2b_en.pdf.

9. Convention for the Protection of Human Rights and Dignity of the Human Being with regard to the Application of Biology and Medicine: Convention on Human Rights and Biomedicine, 04.04.1997. https:// rm.coe.int/168007cf98.

10. Additional Protocol to the Convention on Human Rights and Biomedicine, concerning Biomedical Research (ETS № 195), 25.01.2005. https://rm.coe.int/168008371a.
11. Additional Protocol to the Convention on Human Rights and Biomedicine concerning Transplantation of Organs and Tissues of Human Origin (ETS № 186), 22.01.2002 https://rm.coe.int/1680081562.

12. International Ethical Guidelines for Health-related Research Involving Humans, Fourth Edition. Geneva. Council for International Organizations of Medical Sciences (CIOMS);2016, 122 p. https://cioms.ch/wp-content/ uploads/2017/01/WEB-CIOMS-EthicalGuidelines.pdf.

13. EMA/CPMP/ICH/286/1995 (ICH M3(R2)) «Non-clinical safety studies for the conduct of human clinical trials and marketing authorisation for pharmaceuticals». https://www.ema.europa.eu/en/ich-m3-r2-nonclinical-safety-studies-conduct-human-clinical-trials-pharmaceuticals.

14. Metodychni rekomendatsii Derzhavnoho pidpryiemstva «Derzhavnyi ekspertnyi tsentr MOZ Ukrainy» "Doklinichni doslidzhennia farmakolohii bezpeky likarskykh zasobiv» [Methodological Recommendations of the State Enterprise «State Expert Centre of the Ministry of Health of Ukraine» «Preclinical Studies of Pharmacological Safety of Medicines»]. 2011.Kyiv.22. https:// dec.gov.ua/?ZG93bmxvYWQ=L3dwLWNvbnRIbnQvdXBsb2Fkcy 9zaXRIL2ZpbGVfdXBsb2Fkcy91YS9kX3YvbXJmYi5kb2M=.

15. Grazhdanskiy kodeks Frantsii (Kodeks Napoleona) [The French Civil Code (the Napoleonic Code)]/ Per. s frants. V. Zahvataev / Otv. red. A. Dovgert. Kiev: Istina, 2006: 1008. (in Russian)

16. How do I donate my body to medical science after my death? https:// www.government.nl/topics/organ-tissue-donation/question-andanswer/donation-body.

\section{ORCID and contribuionship:}

Olena I. Antoniuk: 0000-0003-1825-3981 $1^{A, B, C, D, E, F}$

Ivan I. Vyshnyvetskyy: 0000-0001-7228-3052 ${ }^{B, D, E, F}$

\section{Conflict of interest:}

The Authors declare no conflict of interest.

\section{CORRESPONDING AUTHOR Olena I. Antoniuk \\ Ministry of Justice of Ukraine \\ Kyiv, Ukraine \\ tel. +380502798954 \\ e-mail: e.antonuk@ukr.net}

Received: 15.06 .2021

Accepted: 13.10 .2021

A - Work concept and design, B - Data collection and analysis, C - Responsibility for statistical analysis, D-Writing the article, $\mathbf{E}$-Critical review, $\mathbf{F}-$ Final approval of the article 


\title{
THE RIGHT TO LIFE FROM THE POINT OF VIEW OF PERSONAL AUTONOMY IN DECISION-MAKING ON EUTHANASIA (REVIEW OF THE ECHR PRACTICE AND THE LEGISLATION OF SELECTED COUNTRIES)
}

DOI: 10.36740/WLek202111242

\author{
Nataliia M. Akhtyrska', Yuriy V. Grodetskiy² \\ 'INSTITUTE OF LAW, TARAS SHEVCHENKO NATIONAL UNIVERSITY OF KYIV, UKRAINE \\ ${ }^{2} Y A R O S L A V$ MUDRYI NATIONAL LAW UNIVERSITY, KHARKIV, UKRAINE
}

\begin{abstract}
The aim: To analyze law enforcement practice on the basis of the national legislation of foreign states to single out features of legal regulation of the right to euthanasia realization and to outline the Ukrainian prospects of euthanasia legalization.

Materials and methods: The empirical basis of the research is the legislation of some European countries (Belgium, Spain, Italy, Portugal, and the Netherlands) and Canada; decisions of the European Court of Human Rights on the right to voluntary death and the obligations of states; the results of a survey of 750 respondents conducted by the authors. The methodological basis of the study were philosophical views on life, death, and the right to certainty, formal-logical method (analysis, synthesis, induction, deduction, etc.), comparative, analytical, statistical, sociological methods of cognition, as well as a synergetic approach.

Conclusions: The issue of legal regulation of euthanasia is multifactorial, socially conditioned, and requires a positive action of the state both in terms of regulation and/or prohibition, and the proper provision of citizens with health care. Legislative support for the human right to a "dignified death" is dictated, to some extent, by society's demand, which must be finally resulted in the draft law.

As for Ukraine, the adoption of such a law is obviously premature. Although according to a survey of citizens on euthanasia and the feasibility of introducing such a law in Ukraine, $57 \%$ are positive about the experience of other countries, and $41 \%$ were in favor of adopting a law in Ukraine, it is not possible to assess their opinion due to ignorance of legislation where euthanasia is allowed.
\end{abstract}

KEY WORDS: palliative care, quality of life, euthanasia, human rights, the right to a dignified death

Wiad Lek. 2021;74(11 p.2):3108-3112

\section{INTRODUCTION}

The right to life must be guaranteed by the rule of law. Due to the implementation of European standards-oriented justice reform and implementation of the Strategy for Reform of the Judiciary, Judiciary and Related Legal Institutions for 2015-2020, approved by the Decree of the President of Ukraine of May 20, 2015, № 276, the overall indicator of Ukraine in the Rule of Law Index) from 2011 to 2020 increased by $16 \%$. However, Ukraine ranks only 72 nd out of 128 countries, ahead of Turkey (107th), but behind Bulgaria (55th), Poland (28th), the Czech Republic (18th), and Estonia (10th).

In recent years, in most countries of the world, there has been a decrease in the Rule of Law Index, which indicates a persistent negative trend towards the weakening of the rule of law in the world. According to the Index, Ukraine's weaknesses remain a high level of political interference, failure to ensure the inevitability of punishment for offenses, and corruption. Regulators are inefficient and non-transparent (100th out of 128), high level of corruption (110th out of 128). The country's strengths are the protection of funda- mental freedoms and the low level of violent crime (52nd out of 128). According to the Index, the key problems in ensuring the rule of law in Ukraine are systemic corruption, unfair judiciary, and weak law enforcement. Ukraine is also in the TOP-3 countries in the number of appeals to the European Court of Human Rights in 2019 and the TOP5 countries in the number of decisions of the European Court of Human Rights in violation of Ukraine at least one article of the European Convention on Human Rights and fundamental freedoms throughout its existence [1].

With regard to ensuring the human right to health care, the National Strategy for Human Rights, approved by the Decree of the President of Ukraine on March 24, 2021, defines one of the strategic goals, which is aimed at achieving equal access for everyone in Ukraine to quality health care and medical care. At the same time, among the issues that need to be addressed in this document is the provision of training to medical staff on human rights in health care, including access to quality health care, patient autonomy, the right to privacy, respect for dignity, and the right to information in an accessible form, free choice of 
service provider, choice of treatment options or refusal of treatment, dignified death, etc. [2]. Based on this, we can conclude that in fact, we are talking about the possibility of using euthanasia in Ukraine. With this in mind, it is advisable to analyze the legislation of other countries, the practice of the ECHR and identifies problems and possible ways to minimize risks.

\section{THE AIM}

To analyze law enforcement practice on the basis of the national legislation of foreign states to single out features of legal regulation of the right to euthanasia realization and to outline the Ukrainian prospects of euthanasia legalization.

\section{MATERIALS AND METHODS}

The study is based on an analysis of the legislation of some European countries (Belgium, Spain, Italy, Portugal, the Netherlands) and Canada. The criteria for assessing legal positions were the decisions of the European Court of Human Rights, namely "Lambert and others v. France", "Pretty v. The United Kingdom", "Gheorghe and Gheorghe Stoicescu v. Romania", "Gross Aldo v. Switzerland", "Gard v. The United Kingdom"', Havlik v. Liechtenstein”, as well as the interpretation of Article 2 of the Convention for the Protection of Human Rights and Fundamental Freedoms, provided by the ECHR on 31.08.2021 (Guide on Article 2 of the European Convention on Human Rights. Right to life, Updates on 31 August. 2021).

Taking into account the practical direction of the study and addressing the socio-legal issue of expediency and timeliness of euthanasia in Ukraine, a survey of 750 people (of different ages, genders, social status, place of residence) was conducted. The analysis and generalization of the obtained results were adjusted taking into account the awareness of persons about the phenomenon of euthanasia. The methodological basis of scientific intelligence has become philosophical-ideological views on life, death and the right to certainty, formal-logical method (analysis, synthesis, induction, deduction, etc.), comparative, analytical, statistical, sociological methods of cognition, as well as a synergetic approach.

\section{REVIEW AND DISCUSSION}

UN General Assembly Resolution 37/189, adopted at the 111th plenary session of 18 December 1982 on "Human Rights and Scientific and Technological Progress", states that governments have a responsibility to preserve civilization and ensure that everyone enjoys his or her inalienable right to life. [3]. Part 1 of Art. 6 of the International Covenant on Civil and Political Rights emphasizes that the right to life is an inalienable right of everyone. This right is protected by law. No one can be arbitrarily deprived of life [4]. The Universal Declaration of Human Rights also enshrines the right of everyone to life, liberty, and security of person (art. 3) [5]. Article 2 of the Convention for the
Protection of Human Rights and Fundamental Freedoms states that everyone's right to life is protected by law. Thus, according to international human rights instruments, the right to life creates both negative and positive obligations of the state, i.e. the state must not only refrain from actions that violate the right to life but also act positively to create the necessary conditions to protect this right.

At the same time, in several countries, issues of not only life but also the right to euthanasia have been resolved at the legislative level. Even though the question of euthanasia in medicine was first raised by the English scientist Francis Bacon in the XVI century, to date there is no unanimity in the regulatory solution to this problem.

Switzerland has had a law since 1942 that allows doctor-assisted euthanasia. In the United States, California, the law on the human right to a dignified death was passed in the 70s of the last century. In Belgium, the law was passed in 2002, which states that the euthanasia process can be accompanied only by a doctor who treats the patient for a long time. At the same time, the person's condition must be hopeless, and the patient undergoes physical and moral sufferings, which cannot be facilitated. If the patient is aware that his/her condition may worsen (coma, paralysis), he/she can record their will in writing, so that he/she is not connected to the life support system and do not try in any other way to prolong their life [7]. In 2014, the Belgian parliament passed a law allowing euthanasia to be performed on critically ill patients of any age, i.e. child euthanasia was legalized. By the way, doctors and public figures opposed this [8].

In Germany, in 2009, citizens were given the right to write a statement in advance stating that they refused to support life. Since 2002, the euthanasia of children with disabilities has been allowed in the Netherlands. In New Zealand, the decision on the legal regulation of euthanasia was made as a result of a referendum (65\% of citizens voted in favor). Similarly, voluntary euthanasia is legalized in the Netherlands, Belgium, Luxembourg, Colombia, and several US states, where the "Decent Death Act" has been passed, allowing doctors to prescribe lethal medications that patients take on their own.

In Spain, euthanasia and assisted suicide has been legalized since March 2021, but this decision is currently being challenged in parliament by the Constitutional Court. Spain, by establishing a law legalizing euthanasia, has become the fourth country in Europe to allow people to make such a decision under certain circumstances. The law, which came into force on June 25, 2021, allows adults with serious and incurable diseases that cause unbearable suffering, to choose the end of their lives [10]. Before the establishment of law, helping anyone to death was punishable by up to 10 years in prison. Thus, as of 2021 , there are eight countries in the world where euthanasia is legalized, after the Netherlands, Belgium, Luxembourg, Canada, Colombia, New Zealand, and some US states. It should be noted that this law justifies the new right to a "dignified death" by other constitutional rights, such as the right to life, the right to physical integrity, the right to human dignity, and the right to autonomy. 
There are two forms of euthanasia - active and passive, different countries have different perceptions of the legitimacy of all forms. Thus, some states recognize all types (forms) of euthanasia (Belgium, the Netherlands, Luxembourg), passive euthanasia is legalized in France, Israel, Spain, and South Korea; Active euthanasia is possible in six US states (Vermont, California, Montana, Oregon, Washington, and Colorado). In other states, it is prohibited by law, but different models of passive euthanasia are used, based on general law and case law.

In Ukraine in 2019, there was an attempt to introduce a bill on euthanasia for consideration in the Verkhovna Rada of Ukraine, but it was never registered. Ruslan Stefanchuk, First Deputy Speaker of the Verkhovna Rada, also expressed his position in favor of legalizing euthanasia and associated suicide. However, it is seen that the decision to prepare such a bill is influenced by the lack of sufficient research, justification, study of the opinion of citizens and professionals (doctors, social workers, lawyers).

The authors conducted a survey of 750 citizens regarding their attitude to euthanasia and the feasibility of introducing such a law in Ukraine, showing that $57 \%$ of respondents are positive about the experience of other countries, and $41 \%$ were in favor of law adoption in Ukraine. At the same time, the age distribution of answers is interesting: $100 \%$ of people over 60 categorically support the prohibition of the right to euthanasia, assess it as "pressure on the elderly", as "recognition of statelessness", as evidence of the government's helplessness to ensure a decent old age and treatment who gave their lives to the state", people at the age from 35 between 60 perceive the discussion on the introduction of euthanasia more moderately (32\% allow the adoption of the law, consider such a mechanism humane; $46 \%$ did not think about the feasibility of such a legislative step; $22 \%$ categorically deny and condemn such discussions, considering them propaganda of suicide); among people under the age of $35,43 \%$ allow the adoption of such a law in Ukraine and evaluate this step positively. The main criterion of a categorical negative attitude to euthanasia is religious beliefs.

It should be noted that the majority of respondents are not familiar with the peculiarities of the countries' legislation where euthanasia is legal, which does not allow assessing the opinion of the population on this issue. At the same time, it turned out that the vast majority of respondents are unaware of some issues, for example, regarding palliative care and its scale in Ukraine; the number of suicides caused by suffering from incurable diseases in Ukraine; the number of persons convicted of illegal drug acquisition to relieve pain (for personal use or by relatives).

Regarding the risks of legalizing euthanasia, respondents expressed concerns about the quality of treatment and the objectivity of doctors' conclusions about the diagnosis, as well as distrust of judicial authorities, which may declare a person incapable of deciding on euthanasia.

According to $99 \%$ of respondents, military action in eastern Ukraine leads to an increase in the number of people with physical and mental disabilities, and therefore the state must first improve the system of health care, palliative care, social adaptation, and material security, cultivate a culture of a healthy lifestyle and its appreciation.

The French writer and philosopher A. Camus wrote in his work "Stranger": "No one chooses the time of his arrival in this world, so he can at least decide when to leave it." In another work by A. Camus, "Happy Death", the hero suffers from an injury (lack of legs), so he is convinced that "it is impossible to pollute the world with crippled kisses." Life, the right to die, the cause of suicide, the integrity and quality of life, the perception form of the absurdity of events and psychological stability, understanding, trying to be happy despite the disease, psychological and physical stability, patience, vulnerability this is the subject of writers, philosophers, psychologists, psychiatrists, and more recently - lawyers, lawmakers, who must find an answer to the question: whether the right to a "good death" without suffering should be standardized, whether a person has the right to life at all, or to a life of appropriate quality, what is a quality life, what should be the mechanism for making such decisions?

The European Court of Human Rights conditionally divides the issues related to the end of life into two groups: 1) euthanasia; 2) cessation of treatment. The Court considers that it is not possible to deduce from Article 2 of the Convention the right to die both at the hands of a third party and with the assistance of a public authority. All the cases before the Court emphasized the State's obligation to protect life (Pretty v. The United Kingdom, §39).

In Haas v. Switzerland, which concerned the refusal of the authorities to grant access to drugs that would allow a mentally ill patient to commit suicide, the Court concluded that the State had an obligation to prevent a person from shortening his or her life if that decision had not been made adopted voluntarily and with full awareness of the case (\$54) [12].

In Lambert and Others v. France, [13] concerning decisions by public authorities to discontinue artificial nutrition and hydration on which the patient's survival depended, the Court found that there was no consensus among the member States of the Council of Europe on authorization to discontinue treatment that artificially sustains life, even though most states still allow it. In this connection, the Court noted that, although the formalities accompanying treatment discontinuation varied from one State to another, there was a consensus on the decisive role of the patient's will in the decision, whatever the method of expression.

Therefore, the Court considers that in matters concerning the end of life, as well as to the beginning of life, States should be given the opportunity to consider not only the authorization or prohibition of cessation of treatment, which artificially supports life and related formalities but also on how to balance the protection of the patient's right to life and the right to respect for his/her private life and personal autonomy ( $\$ \$ 147-148)$.

When examining the provision or termination of medical care, the Court takes into account the following factors:

1) the existence in domestic law and practice of the regulatory framework in accordance with Article 2; 
2) take into account the wishes previously expressed by the applicant and his/her relatives, as well as the opinions of other medical professionals;

3) the possibility of judicial appeal in case of doubt as to the optimal decision to be made in the interests of the patient (Gard and Others v. The United Kingdom, \$83) [14].

Here are some examples from case law. On February 26, 2020, the Second Senate of the Constitutional Court of Germany ruled on euthanasia, citing the presumption of personal autonomy (paragraph 1 of Article 1 of the German Civil Code), which may be expressed in the exercise of the right to die. As a criterion for the legitimacy of such a conscious decision, the court recognizes the understanding of the quality of life and the expediency in a particular situation to stop it.

The Human Rights Committee, which monitors the implementation of the International Covenant on Civil and Political Rights, has expressed concern in its conclusions about the states that allow euthanasia. In particular, the Committee, concerned about the scale of euthanasia and suicide assistance in the Netherlands, called for a review of legislation in this area in the light of the recognition of the human right to life. The Parliamentary Assembly of the Council of Europe recommends that citizens respect and protect the dignity of the terminally ill and the dying in all respects. At the same time, bioethics experts expressed support for the establishment of the right to a dignified death. The UNESCO Universal Declaration of Bioethics and Human Rights (UDBHR) codifies both the principles of autonomy and dignity (Articles 5 and 10), with some scholars relying on one or both of these principles to protect the right to a dignified death [15].

Since 2016, Canada has allowed medical care in the exercise of the right to die, both physician-assisted suicide and voluntary euthanasia for patients whose natural death is "reasonably predictable." The law was in response to a ruling by the Supreme Court of Canada that the existing ban on third-party suicide and voluntary euthanasia violated the Canadian Charter of Rights and Freedoms. The people of the country supported the law, but at the same time consider it quite restrictive. In a case opened in Quebec in 2019, the provincial Supreme Court found that restricting death assistance to patients whose natural death was presumed violates the Charter of Rights and Freedoms $[16 ; 17]$. Given the court's legal position, the Canadian Parliament has made some amendments. Although patients whose natural death is reasonably foreseeable are entitled to death assistance, requests from them should be subject to additional screening for 90 days. During this time, the patient is consulted; the issue of improving palliative care is resolved, which can improve his/her condition [18]. The 2016 law required a revision in five years, taking into account an analysis of its application. In particular, the question arose as to the appropriateness of taking into account the previous requests of patients in the early stages of dementia, when individuals still have the ability to enjoy life, do not want to live to reach a certain limit when this ability is lost. The issue of euthanasia for people with mental illness was also controversial. Such situations will become more relevant over time as the population ages.

From a legal point of view, there is a problem of bringing doctors to justice for helping in death. The Supreme Court of the Netherlands has ruled that physicians cannot be held liable for euthanasia of patients who consent in advance and then lose that ability. Canadian legislation in 2021 excludes mental illness as the sole basis for receiving death benefits, but this exclusion is automatically revoked after two years [18]. This two-year period is given to parliament to decide on the need to provide the necessary measures to alleviate the suffering of the mentally ill who seek death assistance.

In Belgium and the Netherlands, the presence of mental illness is a reason for euthanasia. According to Peter Singer, a professor of bioethics at Princeton University, the question remains as to the reliability of psychiatric assessments of whether a patient's mental illness is incurable and whether it will be long-lasting.

According to the Bureau of the World Health Organization, about 1 billion people in the world live with mental disorders, of which 8 million in Ukraine. As Ukrinform reported, in 2019 about 302 thousand citizens applied for psychiatric care. At the same time, it was during that period that psychiatric hospitals received the largest funding shortfall and found themselves on the verge of closure. This is especially true of specialized psychiatric hospitals that treat patients with chronic mental illness. There are about 22,000 of them [21]. The Japanese writer Kobo Abe in the book "Man-box", referring to the report of the Nagoya City Court, warned that the main reason for the decision to give up life is not physical but psychological and psychiatric suffering, but this area does not penetrate of the law" [22].

In general, it should be noted that in Ukraine there are significant problems with access to medical services, especially palliative care. According to the Ministry of Health of Ukraine, more than 1.5 million people need palliative care every year [23]. Added to this is the lack of a sufficient supply of painkillers, as not every doctor can prescribe such drugs, and not every pharmacy is licensed to sell drugs. In some regions of Ukraine, there are 3-4 pharmacies that have the right to release these drugs, and this is not enough to provide all patients with the necessary means, which leads to their suffering.

\section{CONCLUSIONS}

Given the above, it is undoubtedly appropriate to recognize that the issue of legal regulation of euthanasia is multifactorial, socially conditioned, requiring positive action of the state in terms of regulation and/or prohibition, and proper provision of citizens with health care. Legislative support for the human right to a "dignified death" is dictated, to some extent, by society's demand, so dialogue with it must precede the draft law.

As for Ukraine, the adoption of such a law is premature. Although according to a survey of citizens on euthanasia and the feasibility of introducing such a law in Ukraine, 
$57 \%$ are positive about the experience of other countries, and $41 \%$ were in favor of adopting a law in Ukraine, it is not possible to assess their opinion due to ignorance of legislation where euthanasia is allowed.

\section{REFERENCES}

1. National economic strategy for the period up to 2030, approved by the resolution of the Cabinet of Ministers of Ukraine of March 3, 2021 № 179/ Available from: https://www.kmu.gov.ua/npas/pro-zatverdzhennyanacionalnoyi-eko-a179 (in Ukrainian).

2. National Strategy in the Sphere of Human Rights, approved by the Decree of the President of Ukraine of March 24, 2021 № 119/2021/ Available from: https://zakon.rada.gov.ua/laws/show/119/2021\#Text (in Ukrainian).

3. UN General Assembly Resolution №37 / 189, adopted at the 111th plenary session of 18 December 1982"Human rights and scientific and technological progress". Available from: https://www.un.org/ru/ga/37/ docs/37res.shtml (in Russian).

4. International Covenant on Civil and Political Rights of 16.12.1966. Available from: https://zakon.rada.gov.ua/laws/show/995_043\#Text (in Ukrainian).

5. Universal Declaration of Human Rights, adopted and promulgated by UN General Assembly Resolution 217 A (III) of 10 December 1948 (in Ukrainian).

6. Convention for the Protection of Human Rights and Fundamental Freedoms of November 4, 1950/ Available from: https://zakon.rada. gov.ua/laws/show/995_004/card2\#Card (in Ukrainian).

7. Kasper Raus, BertVanderhaegen, Sigrid Sterckx, Euthanasia in Belgium: Shortcomings of the Law and Its Application and of the Monitoring of Practice. The Journal of Medicine and Philosophy: A Forum for Bioethics and Philosophy of Medicine. Vol. 46, Issue 1, February 2021, P. 80-107. Available from: https://doi.org/10.1093/jmp/jhaa031

8. Kim SY, De Vries RG, Peteet JR. Euthanasia and Assisted Suicide of Patients With Psychiatric Disorders in the Netherlands 2011 to 2014. JAMA Psychiatry. 2016 Apr; 73(4):362-8. doi: 10.1001/ jamapsychiatry.2015.2887.

9. Euthanasia \& Physician-Assisted Suicide (PAS) around the World. Legal Status in 28 Countries from Australia to Uruguay. Available from: https:// euthanasia.procon.org/euthanasia-physician-assisted-suicide-pasaround-the-world/ [reviewed 2021.07.14].

10. Spain passes law allowing euthanasia. Available from: https://www. bbc.com/news/world-europe-56446631 [reviewed 2021.07.14].

11. CASE OF PRETTY v. THE UNITED KINGDOM (Application no. 2346/02) JUDGMENT.29 April 2002. FINAL. 29/07/2002. Available from: https:// www.bailii.org/eu/cases/ECHR/2002/427.html [reviewed 2021.07.14].

12. Haas v. Switzerland case. Judgment of the ECtHR of 20 January 0 , 2011. Available from: http://base.garant.ru/12182620/ [reviewed 2021.07.14].

13. Judgment of the ECtHR of 05.06.2015 «Case» Lambert and Others v. France». Available from: https://www.coe.int/ru/web/portal/-/ echr-hearing-in-the-case-lambert-and-others-v-france [reviewed 2021.07.14].

14. Gard and Others v. The United Kingdom. Available from: https:// www.echr.coe.int/Documents/Guide_Art_2_RUS.pdf. [reviewed 2021.07.14].

15. Leticia Mora Rebecca. Reingold An International Human Right to Die With Dignity? Available from: https://oneill.law.georgetown.edu/aninternational-human-right-to-die-with-dignity/ December 13, 2019. [reviewed 2021.08.11].
16. Quebec judge overturns parts of federal, provincial laws on medically assisted dying. Available from: https://www.cbc.ca/ news/canada/montreal/medically-assisted-dying-law-overturnedquebec-1.5279067 [reviewed 2021.08.11].

17. Downie J., Schuklenk U. Social determinants of health and slippery slopes in assisted dying debates: lessons from Canada. Journal of Medical Ethics. 2021; 47:662-669. doi:10.1136/medethics-2021-107493.

18. Medical assistance in dying. Available from: https://www.canada.ca/ en/health-canada/services/medical-assistance-dying.html [reviewed 2021.08.11].

19. Eva C.A. Asscher, Suzanne van de Vathorst Supreme Court rules on the first prosecution of a Dutch doctor since the euthanasia act. Journal of Medical Ethics. April 28, 2020. Available from: https://blogs.bmj. com/medical-ethics/2020/04/28/supreme-court-rules-on-the-firstprosecution-of-a-dutch-doctor-since-the-euthanasia-act-2/ [reviewed 2021.08.11].

20. Peter Singer Extending the Right to Die. Available from: https://www. project-syndicate.org/commentary/extending-the-right-to-assistedsuicide-voluntary-euthanasia-by-peter-singer-2021-04 [reviewed 2021.08.11]/

21. In Ukraine, 8 million people live with mental disorders - WHO. Available from: https://www.ukrinform.ua/rubric-society/3115748-v-ukraini-8miljoniv-gromadan-zivut-z-psihicnimi-rozladami-vooz.html [reviewed 2021.07.11] (in Ukrainian).

22. Kobo Abe. The Box Man. New York: Vintage International. 2001.

23. Paliatyvna dopomoha: $v$ Ukraini budut stvoreni Tsentry medychnoi reabilitatsii ta paliatyvnoi dopomohy ditiam [Palliative care: Centers for medical rehabilitation and palliative care for children will be established in Ukraine]. Available from: https://moz.gov.ua/article/health/ paliativna-dopomoga-v-ukraini-budut-stvoreni-centri-medichnoireabilitacii-ta-paliativnoi-dopomogi-ditjam [reviewed 2021.08.11] (in Ukrainian).

\section{ORCID and contributionship:}

Nataliia M. Akhtyrska: 0000-0003-3357-7722 ${ }^{A, B, D, F}$

Yuriy V. Grodetskiy: 0000-0002-7103-7316 ${ }^{B, E}$

\section{Conflict of interest:}

The Authors declare no conflict of interest

\section{CORRESPONDING AUTHOR \\ Nataliia M. Akhtyrska}

Institute of Law of Taras Shevchenko

National University of Kyiv, Ukraine

tel: +380676129978

e-mail: Akhtyrska.n@gmail.com

Received: 12.06 .2021

Accepted: 15.10 .2021

A - Work concept and design, B - Data collection and analysis, C - Responsibility for statistical analysis,

D-Writing the article, $\mathbf{E}$-Critical review, $\mathbf{F}$ - Final approval of the article 